

\section{DISCLAIMER}

This report was prepared as an account of work sponsored by an agency of the United States Government. Neither the United States Government nor any agency Thereof, nor any of their employees, makes any warranty, express or implied, or assumes any legal liability or responsibility for the accuracy, completeness, or usefulness of any information, apparatus, product, or process disclosed, or represents that its use would not infringe privately owned rights. Reference herein to any specific commercial product, process, or service by trade name, trademark, manufacturer, or otherwise does not necessarily constitute or imply its endorsement, recommendation, or favoring by the United States Government or any agency thereof. The views and opinions of authors expressed herein do not necessarily state or reflect those of the United States Government or any agency thereof. 


\section{DISCLAIMER}

Portions of this document may be illegible in electronic image products. Images are produced from the best available original document. 


\section{DISCLAIMER}

"This book was prepared as an account of work sponsored by an agency of the United States Government. Neither the United States Government nor any agency thereof, nor any of their employees, makes any warranty, express or implied, or assumes any legal liability or responsibility for the accuracy, completeness, or usefulness of any information, apparatus, product, or process disclosed, or represents that its use would not infringe privately owned rights. Reference herein to any specific commercial product, process, or service by trade name, trademark, manufacturer, or otherwise, does not necessarily constitute or imply its endorsement, recommendation, or favoring by the United States Government or any agency thereof. The views and opinions of authors expressed herein do not necessarily state or reflect those of the United States Government or any agency thereof."

This report has been reproduced directly from the best available copy.

Available from the National Technical Information Service, U.S. Department of Commerce, Springfield, Virginia 22161.

Price: Printed Copy A16

Microfiche A01 


\author{
SEMI-ANNUAL REPORT \\ FOR THE \\ UNCONVENTIONAL GAS RECOVERY \\ PROGRAM
}

Period Ending September 30, 1980

R. D. Manilla, Editor

November 1980

U. S. Department of Energy

MORGANTOWN ENERGY TECHNOLOGY CENTER

Morgantown, West Virginia 


\section{ACKNOWLEDGMENTS}

This document is the fifth semi-annual report describing the technical progress of the U. S. Department of Energy's (DOE) projects directed at gas recovery from unconventional sources. Currently the program includes:

- Methane Recovery from Coalbeds Project (MRCP)

- Eastern Gas Shales Project (EGSP)

- Western Gas Sands Project (WGSP)

- Geopressured Aquifers Project (GAP)

The Energy Technology activities in Western Tight Gas Sands, Eastern Gas Shales, and Coalbed Methane Projects are under the direction of the Fossil Energy Director of Fossil Fuel Extraction. The Geopressured Aquifer activities are under the Solar-Geothermal Director of Geothermal Energy. For each of the gas resources, the program implementation is accomplished by DOE field offices. The Western Tight Gas Sands, Eastern Gas Shales, and Coalbed Methane projects are being implemented by the Morgantown Energy Technology Center with technical support from the Bartlesville Energy Technology Center and Pittsburgh Mining Operations. The Geopressured Aquifers Project is being implemented by the Houston Office of Geothermal Energy.

This report is divided into five parts: a summary (Section 1), and a section devoted to each resource (Sections 2 through 5). Each resource section presents information which serves as an introduction to that project. Technical progress and status of the activities for each project's primary elements are presented in the following paragraphs.

Italic print used throughout this semi-annual denotes changes and/or progress since March 31, 1980. A statement to that effect will appear at the top of each page where changes/progress are described.

This report covers the period of April 1, 1980 through September 30, 1980. 


\section{CONTENTS}

1.0 Executive Summary

\section{Page}

1.1 Methane Recovery from Coalbeds Project 1

1.2 Eastern Gas Shales Project 4

1.3 Western Gas Sands Project 9

1.4 Geopressured Aquifers Project 14

2.0 Methane Recovery from Coalbeds Project 2-1 - 2-136

Table of Contents 2-2

List of Figures $2-3$

List of Tables 2-3

3.0 Eastern Gas Shales Project 3-i - 3-61

Table of Contents 3-ij

List of Tables 3-iji

List of Figures 3-iii

4.0 Western Gas Sands Project 4-i

Table of Contents 4-i

List of Figures 4-iii - 4-vii

List of Tables 4-viij

5.0 Methane from Geopressured Acquifers 5-1

Table of Contents 5-2 


\subsection{EXECUTIVE SUMMARY}




\subsection{METHANE RECOVERY FROM COALBEDS $P R O J E C T$}

During this reporting period, the Department of Energy continued its heavy activity schedule in execution of the Methane Recovery from Coalbeds Project. To properly emphasize the major areas of activity, the project was restructured within the Morgantown Energy Technology Center. This report reflects the new project structure and hence, is divided into achievements for the project elements as follows:

- Evaluation - which assesses the results and accomplishments of the other project elements, integrates the efforts of project participants, identifies future project needs, provides information management and technology transfer, and provides discretionary support as needed.

- Resource and Site Characterization - which acquire the necessary resource data from selected target sites

- Research, Instrumentation, and Model Development - which is directed at mitigating long-range and near-term technology gaps

- Production Technology Development - which is aimed at identifying and selecting potentially feasible field systems for development, demonstration, and economic data collection and analysis

\section{1 .1 EVALUA T I O N}

MRCP participated in the joint DOE/SPE Unconventional Gas Recovery Symposium, held in Pittsburgh, Pennsylvania in May. Sixteen papers directly applicable to the coalbed methane technology were presented; six others concerned issues and problems associated with coalbed methane, as well as with the other unconventional gases.

To assist in the storage and retrieved of coalbed methane well test data, TRW prepared specifications for the development of a data base that will use DOE systems and personnel for administration. The target date for the initial version is late winter 1980; the expanded version, which will include data from type III tests and production technology projects, is scheduled for summer 1981.

Intercomp has prepared and published its final report, "Evaluation of Data Gathered from Unminable Coal Seams," under Contract No. DE-AC21-79MC10641. The report has been condensed by Intercomp and included in Section 2.2.3, Resource Analys is and Assessment. It contains an accounting of the work performed in test planning assistance, 
test site production potential evaluation, resource assessment, and technology transfer.

Under its Engineering Assistance task of Contract DE-AC21-78MC08089, TRW provided support in project planning, documentation, and evaluation of candidate research projects. In addition, TRW directs the efforts of four educational institutions providing support to MRCP: Virginia Polytechnic Institute and State University, Colorado School of Mines, Pennsylvania State University, and the University of New Mexico. Other TRW tasks involve resource and site characterization; research, instrumentation and model development; and production technology development.

1.1.2 RESOURCE AN D S I T E

C H A R A C TER I Z A T I O N

In spite of the heavy exploration season in the oil and conventional gas industries, cooperative drilling with MRCP progressed rapidly. During the April 1 - September 30 period, nine cooperative wells were spudded and/or tested, in the following target areas of interest; eleven others have been firmly arranged, and will have been tested by the end of the drilling season.

$\begin{array}{ll}\text { Greater Green River } & 1 \\ \text { Illinois } & 2 \\ \text { Piceance } & 2 \\ \text { Powder River } & 3 \\ \text { San Juan } & 1\end{array}$

Under its Resource Engineering task, Contract No. DE-AC21-78MC08089, TRW submitted well test data packages to the MRCP Open File at METC. Findings from the field and laboratory tests are summarized in Section 2.3. In addition, TRW published the following basin reports, which are also in the MRCP Open File:

San Juan Basin
Greater Green River Coal Region
Western Washington Coal Region
Arkoma Basin

1.1.3 RESEARCH, INSTRUMENTATION AND MODEL DEVELOPMENT

Sandia Laboratories, in association with the University of Missouri at Rolla, has prepared plans for the Field Testing of a system subassembly of the water jet drilling system. The field tests are scheduled 
for October and November 1980, and test results will be summarized in the next UGR Semi-Annual Report.

Dames and Moore has been awarded a contract to develop and evaluate near mine stimulation techniques for coalbed degasification. The project will involve drilling six pairs of boreholes, stimulating each using various techniques, and assessing the effect of the fractures on mining.

The University of New Mexico has been awarded a contract to validate the "chip desorption". procedure, and to study the effects of pore structure on methane drainage. If valid, the chip desorption method will lessen the desorption period, as well as reduce the need for full coring.

1.1.4 PRODUCTION TECHNOLOGY DEVELOPMENT

The Westinghouse project to demonstrate the technical feasibility of onsite power generation using a methane-fueled turbine generator was moved to the Bethlehem Steel Marianna Mine No. 58 site, connected to a shaft venting methane from horizontal boreholes, and is currently in operation. Demonstration of the system will continue through December 1980.

At Waynesburg College in southwestern Pennsylvania, a single well draining three coal zones was dewatered. The surface equipment has been installed and the Equitable Gas Company intends to complete hookup in late November.

At the Occidental Research Corporation/Island Creek Coal Mine project sites marked improvement in horizontal drilling techniques has been noted, between the first trial borehole and the most recent production hole. Boreholes are being drilled concurrently with minimum interference, which is one of the research objectives of this project.

The issue of minable versus unminable coal, which was opened last fall, continues to be unresolved. Both the Piceance Basin Production Technology Test Project (Intercomp. Inc./Coseka Resources) and the Book Cliffs Coal Field Production Test Project (Mountain Fuel Supply Company) have been affected by the denial of permits to apply stimulation treatments to the coal horizons. 
The following is a summary of significant EGSP accomplishments from Apri1 1, 1980 through September 30, 1980.

\begin{tabular}{l} 
RESOOURCE CHARACTERIZATION AND \\
\hline INVENTORY
\end{tabular}

Radioactive shale isopachs for New York and ohio were completed and published, along with cross-sections for ohio. Studies in Tennessee were completed, with a report on the stratigraphy of the Chattanooga Shale.

The previous Semi-Annual Report (METC-SP/80/12) presented the results of basin analyses for the Appalachian Basin. During this reporting period, geologic and geochemical studies of the Illinois Basin were completed. These studies indicated that the New Albany Shale Group in Illinois can be divided roughly into three geographical regions:

a) A major depositional center in southeastern Illinois, with a maximum thickness of 460 feet, consisting predominantly of laminated black shale.

b) A second depositional center in southeastern Iowa and west central Illinois with a maximum thickness of over 300 feet, consisting mostly of olive-gray and greenish-gray shale.

c) A northeast-southwest trending area of thin shale separating the two depocenters.

The New Albany apparently was deposited in a deep-water, stratified, anoxic basin centered in southeastern Illinois and adjacent western Kentucky. Fossiliferous carbonates were deposited in a very restricted aerobic zone. Bioturbated greenish-gray shales and indistinctly bedded shales were deposited in a transitional dysaerobic zone. Laminated brownish-black shales were deposited in the anaerobic zone. Anerobic conditions persisted throughout most of New Albany deposition in southeastern Illinois whereas dysaerobic conditions predominated in western Illinois. The area of thin New Albany between the main depocenters is characterized by the interbedding of dysaerobic and anaerobic shales.

Linear features on satellite images and air photographs proved to be related to glacial landforms. Few bedrock structures were detected by remote sensing. The best potential for shale gas production in the Illinois Basin lies in a nineteen county area in southeastern Illinois, corresponding to the main depocenter of the New Albany Shale. 
(Italics denote changes since March 31, 1980)

Geological data integration is systematically underway to determine areas within the Appalachian, Illinois, and Michigan Basins wherein exploration activity might likely be warranted for shale gas production ventures. Tetra Tech, Mound, SAI, the Illinois Geological Survey, and the Morgantown Energy Technology Center have jointly participated in a team effort to publish geologic screening reports for the various states having Eastern Gas Shale prospects. These are expected to be completed, published, and distributed by the end of the year.

EXTRACTION TECHNOLOGY R\&D

Finite element models for vertical hydraulic fracturing in Devonian shale have been developed, including the effects of in situ stress and multi-layering.

Testing of five tailored-pulse-loading concepts in the NTS mineback have shown that multiple fractures can be created from a borehole while avoiding the formation of a stress cage by using an appropriately designed technique. One of the concepts tested (full bore, progressively burning propellant with air pad) produced a large permeability increase. Results are being evaluated to determine if and when a field trial may be warranted.

A two-dimensional gas simulator for Devonian shale production has been completed, based on the radial one-dimensional model previously developed. The radial model has been used to aid in site selection and test design for the offset Well Test program. The recommended site is a well in Meigs County, Ohio.

The offset well test activity is a shift in project strategy (Figure 1-1) to acquire data from producing reservoirs through downhole measurements. The need for basic reservoir data on gas production and storage mechanisms reflects the project maturity that has evolved through research in the laboratory as well as gas production in the field. Another key factor in the project is that evaluation of the effectiveness of various stimulation techniques is severely restricted by limited observation capabilities. Accordingly, detailed plans, schedules, and tests have been developed to conduct so called mineback experiments in a shale mine of Eastern Ohio. Negotiation for installation of this underground laboratory is expected in the next six months.

TECHNOLOGY TESTING AND VERIFICATION

Five wells in Ohio were stimulated with foam, as part of a program to test an exploration rationale relating gas production to the depositional environment. Although high fracture density and drilling 


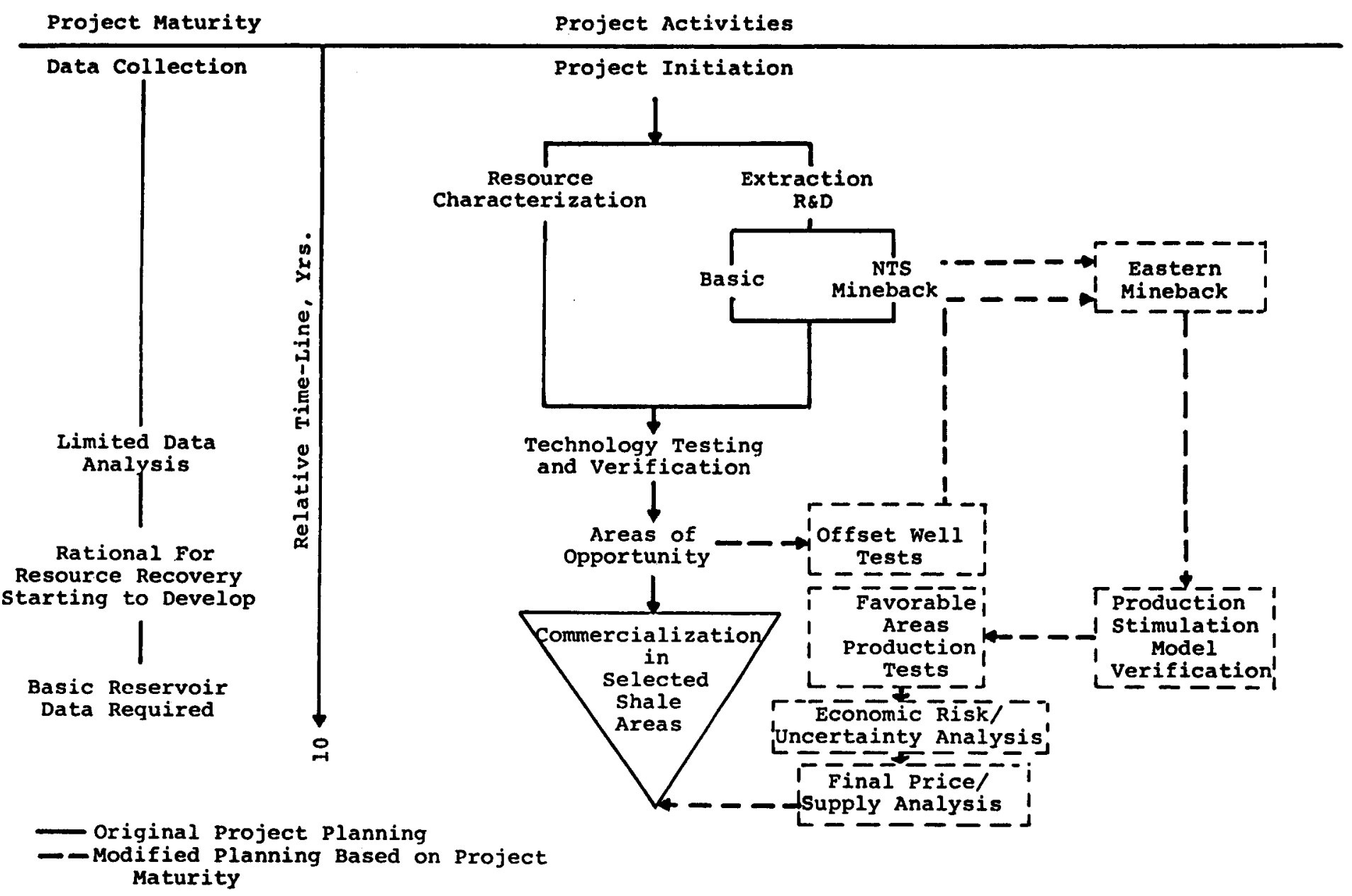

Figure 1-1 Eastern Gas Shales Project Development 
(Italics denote changes since March 31, 1980)

gas shows proved out the exploration rationale, no significant gas flows were obtained after stimulation due to the presence of salt water.

Five wells (one in Ohio, four in New york) were drilled under two contracts, using exploration rationales based on seismic analysis. Two of these wells have been stimulated with foam, but the results are not yet available.

Seven other stimulation tests were performed during this reporting period to test recompletion and other shale development rationales. Three wells in Trumbull County, OH, are being cleaned up after stimulation with foam. No measurable gas volume was evident either before or after treatment. Two other wells in Trumbull county were attempts to use a Gearhart owens liquid explosive as the stimulation process. These were operational disasters and resulted in abandoned wells. An isolated foam treatment in knox County, OH, was unsuccessful in producing gas while another foam treatment in Preston county, WV, produced encouraging results (150-200 MCFD).

Figure 1-2 shows EGSP test sites for FY80 and FY81. 


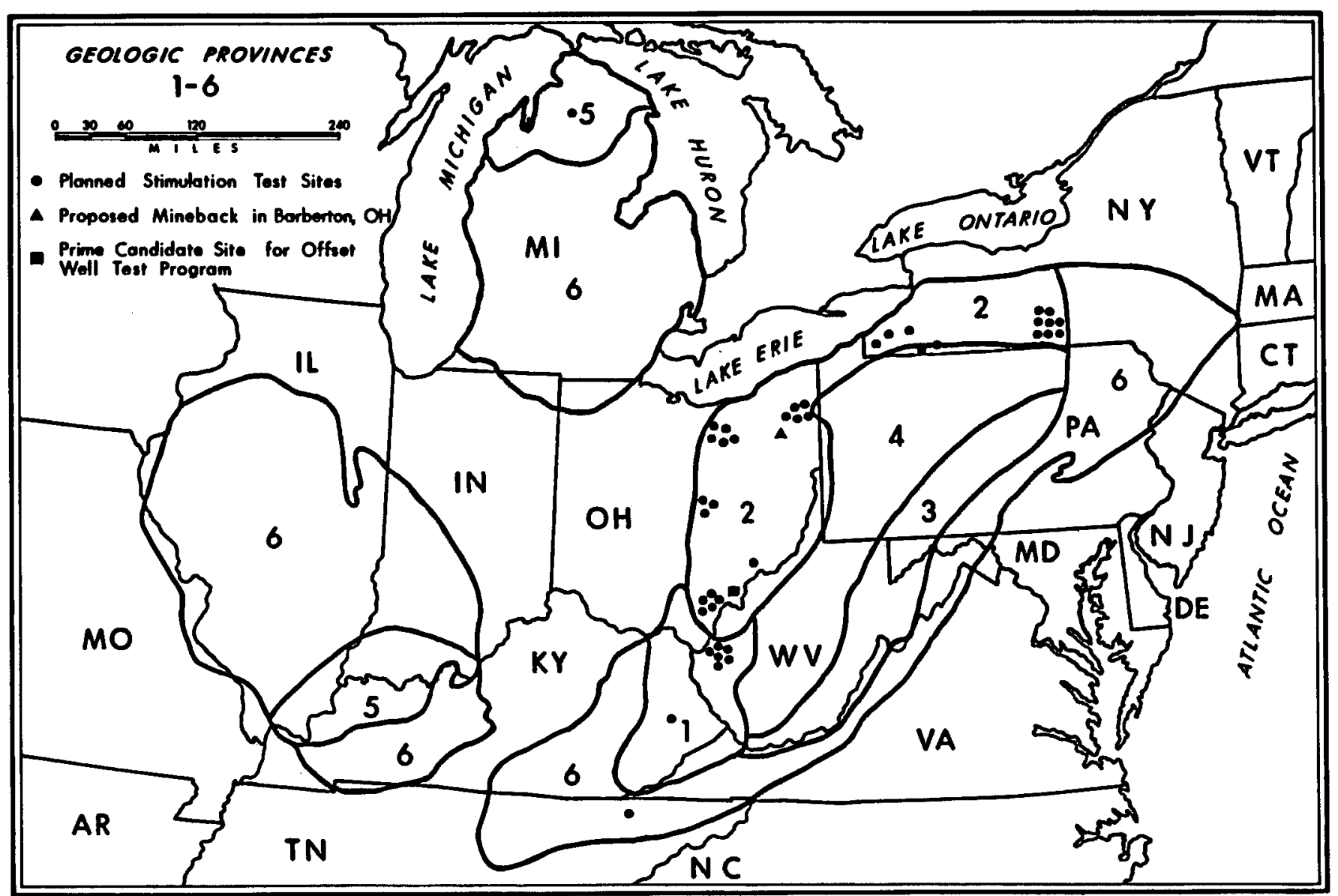

Figure 1-2 EGSP Test Sites, FY80-FY81 
1.3 WESTERN GAS SANDS

The following is a brief summary of significant WGSP accomplishments during the period April 1, 1980, through September 30, 1980.

\author{
1.3.1 RESOURCE ASSESSMENT
}

U. S. GEOLOGICAL SURVEY

During the reporting period 11 reports were published. Four maps were completed.

USGS activities in the areas of interest are as follows:

- Greater Green River Basin

Stratigraphic analysis of the Greater Green River Basin continued. Core analysis was completed on Rainbow Resources No. 1-3 Pacific Creek Federal well. Core was sampled and described from the Champlin No. 221 Amoco $C$ well.

- Northern Great Plains Province

$X$-ray analysis of clays from drill-cuttings from Rainbow Resources Pacific Creek Federal No. 1-34 well was completed. Scomples from Belco (Inexco) WASP No. A-1 well were submitted for complete geochemical analyses. Studies of authigenic carbonates in the Gommon Shale from Montana and North and South Dakota began.

- Vinta-Piceance Basins

Paleonotologic data from Price River Canyon was compiled. Core was examined from Mapco RBU No. 11-17F well in the Uinta Basin. Stratigraphic and reservoir analysis continued of the Uinta and Piceance Basins. Surface exposures of Wasatch Formation units along Yellow Creek between Meeker and Rangely Fields in the Piceance Basin were examined. 
Coastal oil and Gas Corporation was contacted in regard to coring, logging, testing and fracturing a well with WGSP support in the Natural Buttes area of the Uinta Basin. Several other operators were contacted concerning possible coring operations. In the Piceance Basin contacts included CSG Exploration, Adolph Coors Company, Teton Energy, Dome Petroleim, Texas Eastern and Bow Valley Exploration. Others were Cotton Petroleum (Uinta Basin), Pacific Transmission Supply Company (Uinta Basin), Mountain Fuel Supply Company (Greater Green River Basin) and Falcon Oil and Gas Company (Northern Great Plains Province).

\section{SURVEY OF BASIN ACTIVITIES}

Production figures from horizons of interest and the number of newly staked and completed wells are listed in Table 4-3.
1.3.2 RESEARCH
A N D
DE V E L O

\section{BARTLESVILLE ENERGY TECHNOLOGY CENTER}

The measurement of formation characteristics of cores from Mapco RBU No. 11-17F well and CIGE NBU No. 21 well were completed. Laboratory testing of the second generation Sandia core bits demonstrated excellent coring capabilities. Work began on the measurement of anisotropy in western tight gas sands. The permeability system calibration by Lawrence Livermore Laboratories was campleted.

A semi-cutomated method for cation exchange capacity (CEC) determination was developed.

Sonic, neutron and density logging studies of low permeability gas sands continued. Carbonate content of core from the CIGE NBU No. 21 well was measured and the effect of the carbonate on matrix density determined.

Core samples from the Mitchell Energy Muse-Duke No. 1 well and Pacific Transmission Supply Company No. 24-19 Federal well were utilized for sonic travel time analysis.

Settling velocities of sand particles in aqueous slumies of hydroxypropyl guar were conducted for proppant transport studies. 
(Italics denote changes since March 31, 1980.)

\section{GAS RESEARCH INSTITUTE}

A matrix or information model to identify the state-of-the-art in tight gas sands technology is being developed.

Literature reviews and background studies were conducted on the Arkoma Basin/Ouachita Mountains Province of Oklahoma and Arkansas, Raton Basin of New Mexico and Colorado, Anadarko Basin of OkZahoma and Texas, and the Wind River and Big Horn Basins of Wyoming.

A data base for over 900 gas wells in the Uinta, Greater Green River, Piceance and Denver (Wattenberg Field) Basins was campiled for the development and application of an economic analysis methodology. Gas production data are being used to measure well performance.

\section{LAWRENCE LIVERMORE NATIONAL LABORATORY}

To evaluate hydraulic fracture penetration across a frictional interface a set of calculations has been utilized to calculate the strain energy density at the fracture tip and directly across the interface as a pressurized fracture approaches the interface.

Analyses were completed of a pressure driven fracture intersecting a frictional interface with a varying coefficient of friction along the interface.

Work continued on the apparatus for simultaneous ultrasonic velocity measurements in multiple directions.

Exploration continued of the use of polycarbonate to study fluid flow in cracks and experiments were begun to study the effect of a nonuniform stress field on crack growth.

\section{LOS ALAMOS NATIONAL LABORATORY}

Measurement of water in the pore space of solid porous samples continued using magnetic resonance techniques and the inverse geometry instrument. Aruclear spin-lattice and spin relaxation time measurements for water were determined in several somples.

A new NMR spectrometer permits 1800 pulsing measures at shorter times with improved signal-to-noise ratios. This instmment will allow more accurate NMR characterization of rock scmples and ultimately result in better calibration of the downhole tool. 
(Italics denote changes since March 31, 1980.)

SANDIA NATIONAL LABORATORIES

A parametric study was completed using the recently developed one dimensional solution. The study revealed the sensitivity of probe measurements (potentials or equivalent opparent resistivities) to variations in the radial extent of the invaded zone, as well as to the structure and location of the transition region where this region is moved to several different radial positions.

The two dimensional finite element solution to borehole resistivity become operational in June. The code was tested on a radially stratified resistivity profile which could then be compared with the previously developed one dimensional model.

1.3.3 FIELD TESTS AND DEMONSTRATIONS

MULTI-WELL EXPERIMENT

Site negotiations for $M W X-1$ continued. Sandia-CER budget requirements were revised and broken down by wells and fiscal year. Design of a tool to measure the dip and strike of bedding, fractures and joints during the field processing of core was approved. Design of the core ganma apparatus was revised.

\section{COLORADO INTERSTATE GAS COMPANY}

Measurement of bottomhole pressure at the Miller No. 1 and Sprague No. 1 wells was conpleted. The pressure data on the Sprague No. 1 well indicated some improvement in formation permeability.

\section{DOE WELL TEST FACILITY}

In support of the joint DOE/CIG dry gas injection experiment, the DOE Well Test Facility was on site at Miller No. 1 in the Wattenberg Field, Colorado, during April. Preliminary results derived from linear flow analysis indicated substantial improvement of the zone surrounding the fracture.

To enhance the ability to analyze well test data from the trailer, development began of a three dimensional single phase reservoir simuZator. 
(Italics denote changes since March 31, 1980.)

SANDIA LABORATORIES - MINEBACK

A feasibility study has been conducted in tuff at the G tunnel (NTS) to determine the state-of-stress from time-dependent strain relaxation of overcored specimens. Two techniques were used: a strain gauge rosette on the surface of the core and disc gauges attached to the circumference of the core. Both techniques produced similar results which suggests that the orientation of the principal strain is identical for the instantaneous elastic strain and the time-dependent relaxation strain. This study suggests that both techniques for strain-relaxation measurements of oriented core at depth may indicate the orientation of subsequent hydraulic fractures.

\subsubsection{PROJECT MANAGEMENT}

Project status reports for the months of April, May, June, July and August, 1980, were published. During the reporting period, the Western Gas Sands Project Quarterly Basin Activities Report. January 1-March 31, 1980 and the Western Gas Sands Project Quarterly Basin Activities Report, April 1 - June 30, 1980, were released. The WGSP financial supplements for the months of March, April, May, June, July and August, 1980, were released to a limited distribution. The Project Plan Document for FY 1981 and WGSP Logging Report were released. The DOE Well Test Facility Manual was updated as equipment was added or modified. 


GEOPRESSURED AQUIFERS

The following is a summary of significant activities in this program through September 30, 1980.

\title{
RESOURCE ASSESSMENT
}

Current resource assessment activity is focused on the onshore portion of the Texas-Louisiana Gulf Coast. In Texas, the primary areas of study have been in the Frio, Wilcox, and Vicksburg formations. Initial work resulted in choosing the optimum test well site for the first designed well in Brazoria County, Texas. Further work has delineated five more sites in the Frio and four sites in the Wilcox Fairways.

Continuing work in Louisiana has resulted in the selection of the following five prospect areas on which a new test well can be drilled:

\author{
Atchafalaya Bay \\ Lafourche Crossing \\ Southeast Pecan Island \\ Johnson Bayou \\ Rockefeller Refuge
}

Five additional areas are in the process of being defined.

\section{SUPPORTING RESEARCH}

Methane solubility studies are continuing at Idaho State University. Equipment has been assembled and is being tested. Laboratory aquifer simulation studies at the University of Southern California have been completed, and final reports are in preparation. The assembly of high-temperature, high-pressure viscometer at the Institute of Gas Technology has been terminated due to insurmountable technical difficulties.

The objective of legal and institutional research being supported by DOE is to identify legal and institutional barriers that may exist which may tend to delay or preclude geopressured resource production. A study by the Law Center of the Louisiana State University has been completed and a report entitled "Legal Problems Inherent in the Development of Geopressured and Geothermal Resources in Louisiana" has been issued. Work continues on keeping the public and government entities informed of geopressured aquifer development. To this end, two workshoptype meetings have been held in Alvin, Texas, to apprise all interested 
parties of the developments in Brazoria County, Texas (first designed well geopressured aquifer test), and to plan for growth should the pace of exploration accelerate.

\section{FIELD TESTS AND DEMONSTRATIONS}

The first well specifically designed to test geopressured aquifers over a long period was started in Brazoria County, Texas. After encountering mechanical difficulties, the original hole was plugged back and a new well was drilled and completed 500 feet southeast of the initial attempt. The well is presently undergoing tests. The plugged-back hole is being used as a disposal well. Two additional wells have been designed and contracted for in Louisiana. One well, Sweet Lake, project is presently being drilled and the PARC perdue project is scheduled to commence in January 1981.

\section{TECHNOLOGY TRANSFER}

The DOE/Industry geopressured geothermal forums have provided a good mechanism for informing all interested parties regarding the diverse research being carried out in the geopressured aquifer field. Meetings have been held with excellent response from various industry participants.

The fifth U.S. Gulf Coast Geopressured Geothermal Energy Conference will be in October 1981 at LSU. 


\subsection{METHANE RECOVERY FROM COALBEDS}

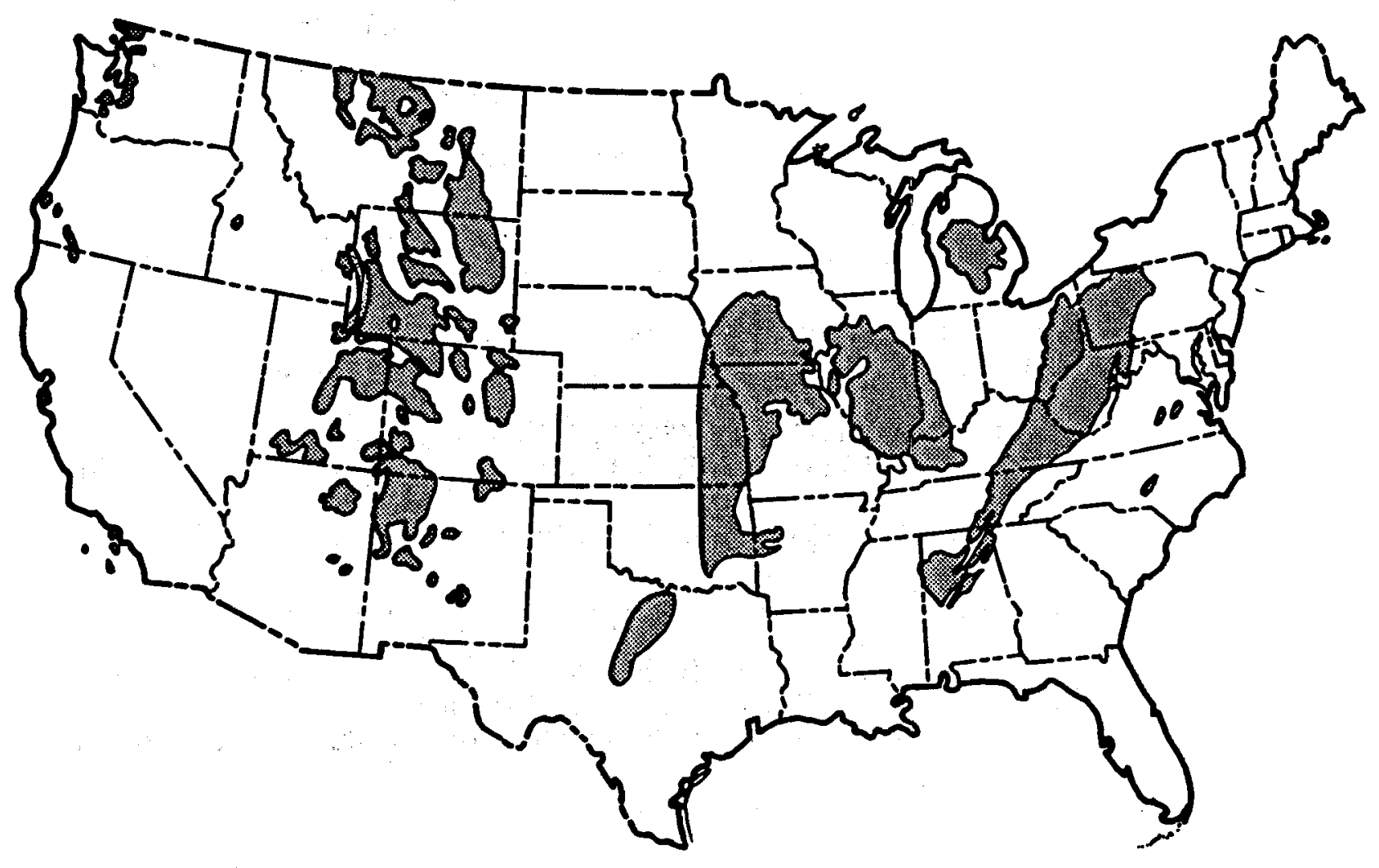


Section

Page

2. METHANE RECOVERY FROM COALBEDS .......... 2-1

2.1 INTRODUCTION ....................... 2-5

2.1 .1 BACKGROUND ................ 2-5

2.1 .2 PROJECT GOALS AND OBJECTIVES $\ldots$ 2-... 2-6

2.2 EVALUATION ................ 2-8

2.2.1 PROJECT DIRECTION, INTEGRATION,

AND SUPPORT $\ldots . \cdots 2-8$

2.2.2 INFORMATION MANAGEMENT AND TECHNOLOGY

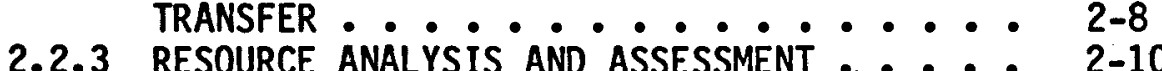

2.3 RESOURCE AND SITE CHARACTERIZATION .... 2-19

2.3.1 BACKGROUND ........... 2-19

2.3.2 WELL TESTING .............. 2-19

2.4 RESEARCH, INSTRUMENTATION AND MODEL

DEVELOPMENT ............ 2- 2-89

2.4.1 EXTRACTION TECHNOLOGY R\&D ...... 2-89

2.4.2 PREPARATION TECHNOLOGY R\&D ...... 2-101

2.5 PRODUCTION TECHNOLOGY DEVELOPMENT . . . . 2-102

2.5.1 GENERAL ........... 2- 2-102

2.5.2 PRODUCTION TECHNOLOGY PROJECTS
ASSOCIATED WITH MINING . . . . . 2-102

2.5.3 PRODUCTION TECHNOLOGY DEVELOPMENT
PROJECTS NOT ASSOCIATED WITH MINING • • $\quad$ 2-124 
Figure

$\underline{\text { Page }}$

2-1 MRCP Areas of Primary Interest for

2-2 Arkoma Basin, Target Area, and Well Sites..... 2-25

2-3 Greater Green River Coal Region, Target

Area, and Well sites .............. 2-31

2-4 Illinois Basin, Redefined Target Area, and Well sites ..................... 2-42

2-5 Northern Appalachian Basin, Target Area, and Well Sites .................. 2-50

2-6 Piceance Basin, Target Area, and Well Sites .... 2-54

2-7 Powder River Basin, Target Area, and Well Sites ... 2-70

2-8 San Juan Basin, Target Area, and Well Sites .... 2-78

2-9 Southern Appalachian/Warrior Basin Target

Area and Well Site ................ 2-83

2-10 Western Washington Coal Region, Target Areas, and Well Site .................... 2-86

2-11 Production Technology Development Project Sites . . 2-105

2-12 Total Gas Production from 17 Producing Wells .... 2-118

\section{LIST OF TABLES}

Table Page

2-1 Current Major MRCP Participants ........ 2-9

2-2 Current Areas of MRCP Exploration .......... 2-21

2-3 Wells Tested by MRCP through this Reporting Period .. 2-22

2-4 Sumary of Coal and Gas Findings for Each Well Tested ....................... 2-23

2-5 Production Technology Development Projects .... 2-107 


\subsubsection{B ACK GROUND}

Methane, the major component of natural gas, is generated during the natural process of coal formation. Frequently, because of the low permeability of strata associated with coalbeds, it is trapped in the coal and surrounding areas. The total magnitude of the coalbed methane resource in the U.S. has been estimated at approximately 700 trillion cubic feet (Tcf). Given current and conservatively projected economic and technological factors, the recovery of some 300 trillion cubic feet of this resource appears to be feasible.

During mining operations in an underground mine, the removal of coal provides space into which the methane can migrate and mix with air to form a flammable or explosive mixture. The federal government and some mining companies have been investigating techniques for draining methane from coalbeds to prevent gas migration into mine working areas. The techniques investigated include drilling vertical or directional wells into virgin coalbeds in advance of the working faces and drilling horizontal boreholes into virgin coalbeds from a central shaft or heading. These drainage methods produce natural gas comparable to that from other gas reservoirs. Previously mined (gob) areas may be drained through vertical wells which provide gas diluted with air; mixtures range from 25 to 90 percent methane. The most widespread method of controlling methane concentrations to safe levels is dilution with ventilating air to sweep the methane from the mine into the atmosphere. These techniques are aimed at reducing gas concentrations to a safe level and at the same time improving mining productivity by reducing downtime caused by hazardous gas levels.

It has been estimated that mines in the Pittsburgh coal seam are currently venting over 100 million cubic feet (MMcf) of methane per day. The expansion of coal mining over the next 10 years, together with extensive adoption of predraining and gob mining draining techniques, will increase this rate considerably. At present, little commercial use is being made of this potential resource--the gas is wasted. The serious gas shortages and curtailment of industrial activity during recent winters emphasize the importance of utilizing this gas.

Preliminary studies indicate that profitable recovery and utilization of this resource is feasible. The variations in quality, available quantities, and geographic locations make it clear that no single solution is appropriate for all cases. The studies indicate a high probability of economic gas utilization for several applications including: direct pipeline injection; liquefied natural gas (LNG) 
production; onsite power generation; heating applications; and petrochemical feedstock production. Much of the technology necessary to use this valuable resource exists today, although some modification may be required to accommodate the requirements of specific applications.

\subsubsection{PROJECT GOALS AND OBJECTIVES}

To curb the waste of coalbed methane and to encourage its recovery and utilization, the U.S. Department of Energy initiated the Methane Recovery from Coalbeds Project (MRCP) in fiscal year 1978. The project is oriented toward locating and estimating the resource, estimating the recoverable reserves, developing economical recovery systems and methods, and utilizing the methane in appropriate ways.

Many project activities have been ongoing since the project was formally organized in October 1977. To properly emphasize the major areas of activity, and to facilitate the integration of MRCP technologies into the Unconventional Gas Recovery Program, the task areas were restructured during the past reporting period. The four areas of activity are:
- Evaluation
- Resource and Site Characterization
- Research, Instrumentation, and Model Development
- Production Technology Development

\section{EVALUATION}

The objectives of this activity are to: (1) assess the results of the other activities, (2) continue the development of the coalbed methane data base, (3) assess recent technological developments and related industry activities, (4) update estimates of the potential of the resource, and (5) develop and monitor project plans that reflect the integration of the technical, geologic, economic, and other types of data that result from the project. The intent of the activity is to ensure that DOE efforts complement industry R\&D activities and that project activities directly support the goals of the Fossil Energy Gas Resources RD\&D Program.

This activity currently is composed of the following task areas:

- Project direction, integration, and support

- Project information management and technology transfer

0 Resource analysis and assessment

Evaluation activities are discussed in Section 2.2. 
The primary objective of this activity is to acquire the necessary resource data from specific sites in the target reservoir areas to provide the basis for assessing the resource, guiding modeling efforts, and selecting potential sites for production technology development projects.

This activity covers the following tasks:

- Acquisition of reservoir geologic data

o Coring, logging, and testing wells of opportunity.

Activities currently being performed under this task are discussed in Section 2.3.

RESEARCH, INSTRUMENTATION, AND MODEL DEVELOPMENT

The objectives of this activity are to improve existing diagnostic techniques or develop new diagnostic techniques, to improve or develop new stimulation approaches, and to improve the ability to accurately predict and measure reservoir response to stimulation techniques. Fulfilling these objectives requires basic and applied R\&D in the laboratory and the field and the development of models. The models will serve as the repository of knowledge gained from the R\&D. They will describe the present understanding of the stimulation processes, gas flow from coalbed reservoirs, and economic parameters related to fracturing and production. Models and instrumentation will be evaluated and refined based on tests conducted in the field, in conjunction with Production Technology Development projects.

The following are ongoing tasks, or tasks that will be initiated later under this activity:

- Drilling techniques and equipment

- Coalbed stimulation techniques

- Preparation techniques and equipment

Research, instrumentation, and model development activities are discussed in Section 2.4 .

PRODUCTION TECHNOLOGY DEVELOPMENT

The objectives of this activity are to: (1) design, operate, and field test coalbed methane integrated systems; (2) investigate and resolve problems that may be encountered under operational conditions; and (3) evaluate the systems, subsystems, and operating methods tested for technical and economic feasibility and readiness for commercial ventures. 
Tasks in this area of activity encompass the following:

- Recovery/utilization projects associated with mining

- Recovery/utilization projects not associated with mining.

The activities are discussed in Section 2.5 . 
As noted earlier, the Methane Recovery from Coalbeds Project was restructured during this reporting period to facilitate integration with the other Unconventional Gas Recovery projects. Specific activities included under this element are:

- Project direction, integration, and support

- Information management and technology transfer

- Resource analysis and assessment.

2.2.1 PROJECT DIRECTION, INTEGRATION, $A N D$ S U P P ORT

During this reporting period, in addition to the planning and coordination required for the project, several site visits and reviews were conducted. Visits were made to the Waynesburg College, Emerald Mines, Marianna No. 58, Occidental Research/Island Creek Coal, Clinchfield Coal, and U.S. Steel projects to evaluate progress. In addition, an in-depth project review was conducted by the Manager of the Fossil Energy Office of $0 i 1$, Gas and Shale Technology in September.

As of the end of the reporting period, 24 federal, state, and contractor organizations were participating in the Methane Recovery from Coalbeds Project. The participants are listed alphabetically in Table 2-1. Other members of the oil and gas industry supporting the project as suppliers of goods and services include equipment and supplies manufacturers, drillers, well service companies, and consultants.

2.2.2 INFORMATION MANAGEMENT AND TECHNOLOGY TRANSFER

MRCP participated in the joint SPE/UGR symposium held in Pittsburgh, Pennsylvania, in May. Sixteen papers directly applicable to the technology were presented; six others concerned associated problems and issues.

In addition, during this reporting period MRCP participants presented papers at the 1980 Symposium on the Geology of Rocky Mountain Coal and the American Association of Petroleum Geologists Annual Convention.

MRCP was invited to discuss the project, its purpose, scope, and progress at a meeting of the National Petroleum Council.

To assist in the storage and retrieval of coalbed methane well test data, MRCP has begun work on a computerized data base that will be 


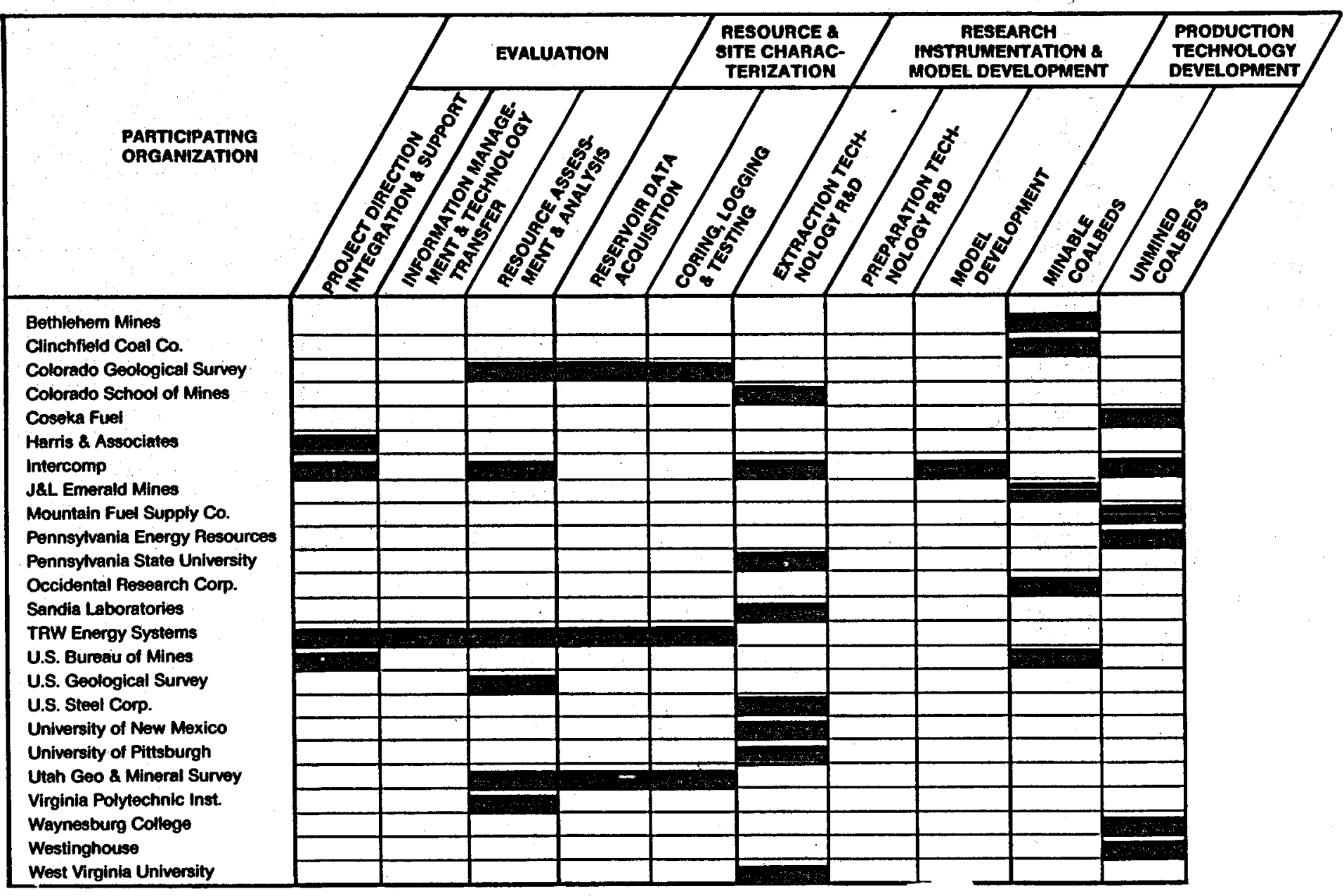


structured and administered by METC. When developed, MRCP participants will be informed of its availability and capability. The target date for the first phase, which will cover methane content (Type I) tests, is late winter 1980. The target date for the second phase, which will include producibility (Type III) tests and production data, is summer 1981.

\section{2. 3 RESOURCE ANALYSIS AND A S S E S S MENT}

During the reporting period, four contractors were involved in resource analysis and assessment, complementing the efforts of DOE/ METC and TRW Energy Systems Planning Division. Progress reports for each contractor comprise the remainder of this section. 


\subsubsection{EVALUATION OF DATA FROM UNMINED COAL SEAMS}

Intercomp, Inc.

Status:

Houston, Texas

Active

Contract:

DE-AC21-79MC10641

Contract Date:

March 31, 1978

Anticipated Completion Date:

April 30, 1981

Principal Investigator:

H. S. Price

DOE Technical Project Officer:

H. D. Shoemaker

\section{OBJECTIVE}

To reduce uncertainties in the critical parameters related to methane recovery from unmined U.S. coalbeds.

SCOPE OF WORK

Contract DE-AC21-79MC10641 with Intercomp, Inc. provides for identifying critical parameters and reducing uncertainties related to methane extraction from unmined coalbeds. An earlier contract (EM-78-C-21-8352), partially implemented in 1978 and early 1979, specified an optimized test program. These contracts crosscut resource and site characterization projects and assist in characterizing unmined coalbeds by emphasizing methane producibility.

\section{BACKGROUND}

A simulation model was used to develop a comprehensive test program to characterize the potential of methane production from "unmined" coalbeds in the United States. The study identified those parameters most important to the production of methane from coal:
- Coalbed thickness
o Coalbed permeability
- Initial pressure
o Initial gas content
- Relative permeability
o Hydraulic fracture length
- Hydraulic fracture conductivity.

The range of values over which each of those independent variables may vary was estimated together with the frequency distribution with in the range. A sensitivity study was made that varied the independent variables over their ranges and calculated a characterization parameter, 
(Italics denote changes since March 31, 1980.)

$\phi$. The definition of $\phi$ is the cumulative discounted gas production deliverability for ten years at a discount rate of 15 percent per year.

The measurement methods and test sequences were established together with costs of the various tests. Through regression analysis and consideration of the distribution and ranges of the independent variables, it was established that a total of sixty survey-type test modules were required with specific spatial consideration as to the location of the modules.

During previous reporting periods, test site analyses have been performed on the Kinloch Development Company Murdock No. 1 well in Greene County, Pennsylvania and on three wells producing from the Pittsburgh coal near the Cumberland Mine of U.S. Steel Corporation in Greene County, Pennsylvania. A sensitivity study was performed to assist in the design of a test sequence in the Arkoma Basin. The study of the seventeen-well pattern of the U.S. Steel Corporation Oak Grove degasification project in Jefferson County, Al abama was also begun.

Low gas concentrations indicated in other test data received caused the resource assessment study to be temporarily suspended until more complete data were available, and the resources of this contract were available, and the resources of this contract were applied to sitespecific analyses.

\section{PROGRESS THIS REPORTING PERIOD}

The final report on Evaluation of Data Gathered from Unminable Coal Seams, was prepared and published in August. The report covers activities in test planning assistance, estimation of test site production potential, assistance in on-site test monitoring, resource engineering, and technology transfer activities.

Two simulations were performed using the Intercomp "Implicit Gas-Water Model With Absorbed Gas Option". For the first simulation, the Oak Grove Well Patterm data were used. Conclusions of the pattern analysis were:

a. Pressure interference between coal gasification wells is an important factor in gas production.

b. Gas can be recovered from coalbeds that can materially affect the gas content of coal ahead of mining. Further, this rate is sufficient for a gas supply.

c. If economic gas production is the purpose of coal degasification, a larger well spacing is desirable. 
(Italics denote changes since March 31, 1980.)

d. If degasification of a specific coal area for the purpose of mining is the major objective, a smaller well spacing is desirable.

The second simulation performed used data from Well 22 of the U.S. Steel degasification pattern. The Single Well Analysis was, in fact, a reevaluation of a simulation performed earlier, necessitated by the discovery that data supplied earlier was erroneously interpreted. The rerun simulation indicates that Well 22 is producing at a low rate, not because of the low deliverability of the coal, as previously surmised, but because of the large supply of water in close proximity to the well.

The report has been submitted to the METC Open File for reference by MRCP participants.

In addition, Intercomp participated in the SPE/DOE Symposium on Unconventional Gas Recovery by preparing and presenting a paper, "Analysis of the Coalbed Degasification Process at a Seventeen Well Patterm in the Warrior Basin of Alabama" by K. L. Ancell, S. Lambert, and F.S. Johnson. 


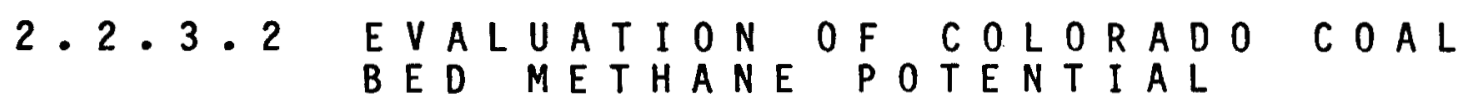

Colorado Geological Survey

Status:

Denver, Colorado

Contract:

DE-FG21-80MC14256

Contract Date:

Apri1 1, 1978

Anticipated Completion Date: March 31, 1981

Principal Investigator: L. R. Ladwig

DOE Technical Project Officer: H. D. Shoemaker

OBJECTIVE

To provide technical assistance and support for resource delineation activities in Colorado and the Rocky Mountain area.

SCOPE OF WORK

The Colorado Geological Survey, under Grant DE-FG21-80MC14256, provides support in characterization of coalbeds, primarily those in the state of Colorado and the Rocky Mountain area. This work includes the following activities:

- Selecting, evaluating, and recommending favorable drill and test sites

- Synthesizing and summarizing pertinent geological information

- Monitoring industry activity and determining the potential for cooperative agreements for core sampling/methane desorption/ flow testing

- Performing well-site geologic supervision

- Performing methane desorption of samples.

\section{BACKGROUND}

Colorado Geological Survey geologists have gathered mine emission data from coal mines throughout Colorado. To date, 187 samples have been desorbed and tested by ultimate, proximate, trace element, and petrographic analyses. Adsorption isotherms have been run on several samples, and carbon isotope analyses have been run on desorbed gas. The data have been combined with structure and isopach maps to provide estimates of gas content of the areas of highest potential in the Piceance, San Juan, and Raton Basins. 
(Italics denote changes since March 31, 1980.)

PROGRESS THIS REPORTING PERIOD

Preliminary estimates of the gas-in-place in selected Colorado coal secoms are as follows:

\begin{tabular}{llc} 
Basin & Seam & Gas Volume (Tcf) \\
\hline Piceance & Mesaverde & 31 \\
San Juan & Fruitiand & 7 \\
Raton & Vermejo & 2
\end{tabular}

Gas contents in the individual coalbeds have ranged from 0 to 514 cubic feet per ton of coal, with heating values ranging from 388 to 397 Btu per cubic foot of gas. 

$2 \cdot 2 \cdot 3 \cdot 3$
E V A L U A T I O N OF UTA H
C $O A L B E D$

METHANE POTENT I A L

\begin{tabular}{|c|c|}
\hline $\begin{array}{l}\text { Utah Geological and Mineral Survey } \\
\text { Salt Lake City, Utah }\end{array}$ & $\begin{array}{l}\text { Status: } \\
\text { Active }\end{array}$ \\
\hline $\begin{array}{l}\text { Contract: } \\
\text { Contract Date: } \\
\text { Anticipated Completion Date: }\end{array}$ & $\begin{array}{l}\text { DE-FG-21-79MC11729 } \\
\text { June } 1,1979 \\
\text { May } 31,1981\end{array}$ \\
\hline $\begin{array}{l}\text { Principal Investigator: } \\
\text { DOE Technical Project Officer: }\end{array}$ & $\begin{array}{l}\text { A. D. Smith } \\
\text { H. D. Showmaker }\end{array}$ \\
\hline
\end{tabular}

\section{OBJECTIVE}

To provide technical assistance and support for resource delineation activities in the state of Utah.

SCOPE OF WORK

The Utah Geological and Mineral Survey MRCP activities involve collection of available coal core samples for desorption of methane by the direct method and for proximate and ultimate analyses. In addition, a new Utah coal map will be prepared to show the rank of coal as defined by more up-to-date data. All available information to support the findings will be recorded; i.e., depth, formation, interval, coal zone or bed, location, and coal description.

\section{BACKGROUND}

Prior to April 1, 1980, 266 coal core samples were collected and the gas content determined by the direct method. Samples have been obtained from the following coal fields:

\section{Coalfield}

Alton

Book Cliffs

Emery

Henry Mountains

Kaiparowits Plateau

Sego

Wasatch Plateau
No. of Samples

3
111
60
1
12
33
46

Gas content values were generally low (less than $64 \mathrm{cf} / \mathrm{ton}$ ) in all coalfields except Book Cliffs. Values observed for Book Cliffs ranged up to a high of $406 \mathrm{cf} / \mathrm{ton}$ for a sample of unnamed coal collected at a depth of 2,056 feet. The Book Cliffs coalfield, particularly that 
(Italics denote changes since March 31, 1980.)

area east of a line running from Helper to Sunnyside, Utah, was delineated as having the highest methane gas potential.

Underground detailed mapping and sample collection were completed in the Sunnyside coalbed to investigate the variable gas enission rates observed in underground mining operations. Final conclusions will be formulated upon completion of analytical tests.

PROGRESS THIS REPORTING PERIOD

During the reporting period, two samples were obtained from the Book Cliffs field and 17 from the Wasatch Plateau field. Gas content of these samples was low, ranging from 0 to 18 cubic feet per ton. 
(Italics denote changes since March 31, 1980.)

2.2.3.4 EVALUATION OF SOUTHERN C OALFI ELDS

Virginia Polytechnic Institute Status: \& State University Active

Bl acksburg, Virginia

Contract:

Contract Date:

DE-AC21-78MC08089

Anticipated Completion Date:

June 1,1979

Principal Investigator:

DOE Technical Project Officer:

December 31, 1980

C. T. Rightmire (TRW)

H. D. Shoemaker

\section{OBJECTIVE}

To determine the methane production potential of Southern coalfields. SCOPE OF WORK

This effort consists of an evaluation of promising coal areas, basins, and seams in the Southern coalfields with emphasis on coal seams that are currentiy uninined, unlikely to be mined in the near future, or currently unminable.

BACKGROUND

A bibliography of the Richmond Basin, containing approximately 60 references, has been compiled. In addition, field mapping has been performed by the Virginia Division of Mineral Resources under a subcontract with VPI.

PROGRESS THIS REPORTING PERIOD

A preliminary draft of the characterization of the Richmond Basin has been prepared and submitted to TRW for review and comment. The comments have been received and are being incorporated; a final draft will be published during the next reporting period. 


\section{3.1 B ACK GROUND}

One of the primary objectives of MRCP is to acquire the necessary resource data from specific sites in target reservoir areas so that the information can be used to assess the magnitude and recoverability of the resource, to guide modeling efforts, and for planning production technology development projects. The work in resource and site characterization is primarily performed by TRW Energy Systems Planning Division under Task 2 of Contract No. DE-AC21-78MC08089. To provide the proper framework, a Resource Delineation Plan was pub1 ished and implemented in early 1979. Figure 2-1 shows the target areas of primary interest, which covers approximately 80,000 square miles of coal-bearing terrain. Within those areas, approximately 80 wells will be tested by MRCP using, to the fullest extent possible, cooperative agreements with other agencies and with the oil and gas industry in order to optimize cost effectiveness.

Target areas are continuously being redefined. The present areas of MRCP exploration are listed in Table 2-2. Basically, within the redefined target areas sampling density is maintained at one well per 1,000 square miles.

\section{3 .2 WELL TESTING}

Prior to this reporting period, 28 wells had been drilled and either completely or partially tested. During this reporting period, seven more wells were in various stages of testing. The seemingly low rate of drilling during this period is primarily due to the unavailability of rigs to support drilling for MRCP participants because of an extremely heavy demand from the conventional oil and gas industry.

Table 2-3 is a list of the wells tested by MRCP with cooperating companies or agencies and the geological basin involved. Documentation for the tests have been assembled, cataloged, and summarized as Well Test Data Packages and are now available in the MRCP Open File at the Morgantown Energy Technology Center for review and analysis. Five wells earlier classified "confidential" in accordance with agreements made with the cooperator have been declassified and the test data released to the MRCP Open File during this reporting period.;

Table 2-4 summarizes the coal and gas findings of each of the tested wells. "Gas content" includes "lost" gas, as calculated by curve fitting; desorption by the direct method; and residual gas, calculated from coal analyses.

The well testing material has been organized according to geological basin to provide a convenient vehicle for reporting and evaluation 
$\stackrel{n}{\tilde{\alpha}}$

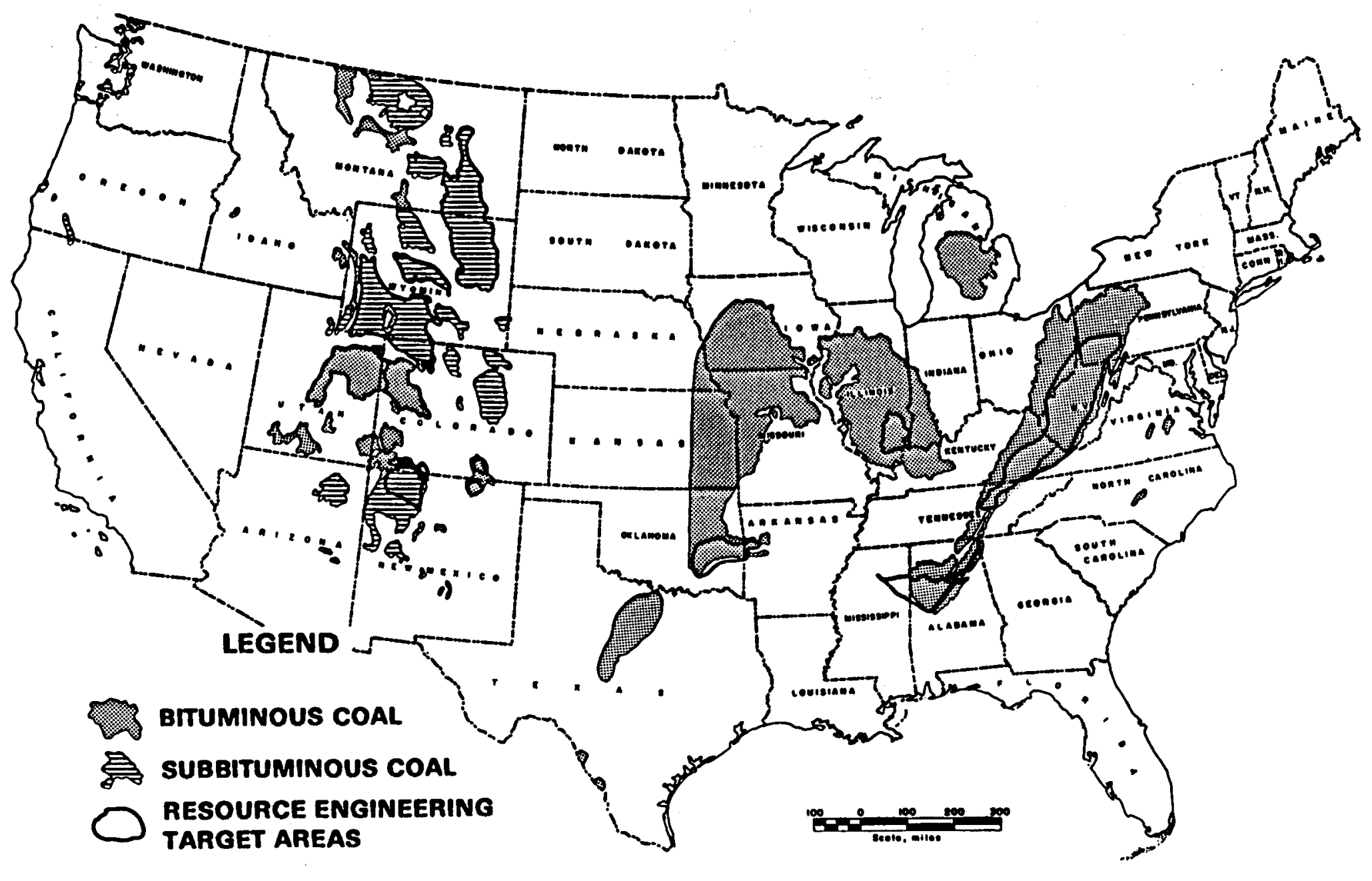

Figure 2-1. MRCP Areas of Primacy Interest for Resource Delineation Activities 
Table 2-2. Current Areas of MRCP Exploration

\begin{tabular}{|l|c|c|c|}
\hline \multicolumn{1}{|c|}{ COAL REGION } & \multicolumn{3}{|c|}{ AREA (SQUARE MILES) } \\
\cline { 2 - 4 } & TOTAL & TARGET & GEOLOGIC \\
\hline EASINS
\end{tabular}

Area redefined this year.

purposes. The remainder of section 2.3.2 presents specific findings of each basin and each well in a highly condensed form. Additional information may be found in the Well Test Data Packages, the TRW Monthly Progress Reports, and Basin Reports for the Illinois Basin, Powder River Basin, San Juan Basin, Greater Green River Coal Region, Western Washington Coal Region, and the Arkoma Basin that have been compiled and submitted under DOE Contract No. DE-AC21-78MC08089, and which are available in the MRCP Open Files. 
Table 2-3. Wells Tested By MRCP through this Reporting Period

\begin{tabular}{|c|c|c|}
\hline BASIN & $\begin{array}{l}\text { WELL SITE } \\
\text { DESIGNATION }\end{array}$ & $\begin{array}{l}\text { COOPERATING COMPANY/AGENCY } \\
\text { AND WELL IDENTIFICATION }\end{array}$ \\
\hline ARKOMA & $\begin{array}{l}\text { EAA } \\
\text { EAB } \\
\text { EAC } \\
\text { EAD }\end{array}$ & $\begin{array}{l}\text { Arkla Exploration, Brown \#1-2 } \\
\text { Mustang Production. Barringer \#1-11 } \\
\text { Mustang Production, Day \#1-4 } \\
\text { U.S. Burec, \#DH-A17 }\end{array}$ \\
\hline \multirow[t]{2}{*}{ GREEN RIVER } & GAA & $\begin{array}{l}\text { Energy Reserves Group, } \\
\text { Robert A. Van Dorn } \# 1\end{array}$ \\
\hline & $\begin{array}{l}\text { GAB } \\
\text { GAC* }\end{array}$ & $\begin{array}{l}\text { Belco Petroleum, S-29-27 } \\
\text { Kemmerer Coal Co., } \\
\text { Barrel Springs Unit } 29-2\end{array}$ \\
\hline \multirow[t]{2}{*}{ ILLINOIS } & $\begin{array}{l}\text { DAA } \\
\text { DAB }\end{array}$ & $\begin{array}{l}\text { Hagen Oil Company. Henderson \#2 } \\
\text { GeoWest Inc., VIICA } 711-1 \mathrm{CD}\end{array}$ \\
\hline & $\begin{array}{l}\text { DAC } \\
\text { DAD } \\
\text { DAE }\end{array}$ & $\begin{array}{l}\text { Indiana Geological Survey, SDH-301 } \\
\text { Indiana Geological Survey. SDH-302 } \\
\text { R. W. Beeson Oil Producer, Coy Vandygriff }\end{array}$ \\
\hline NORTHERN APPALACHIAN & $\begin{array}{l}\text { AAA } \\
\text { AAB }\end{array}$ & $\begin{array}{l}\text { Kinloch Development, Murdock \#1 } \\
\text { Waynesburg College. Thayer Hall Tract \#1 }\end{array}$ \\
\hline PICEANCE & $\begin{array}{l}\text { FAA } \\
\text { FAB } \\
\text { FAC } \\
\text { FAD } \\
\text { FAE } \\
\text { FAF } \\
\text { FAG } \\
\text { FAH } \\
\text { FAl* } \\
\text { FAJ" }\end{array}$ & $\begin{array}{l}\text { Fuelco. Cathedral 0-28-3-101-S } \\
\text { Twin Arrow, C\&K Well \#1-13 } \\
\text { Twin Arrow, C\&K Well } \# 4-14 \\
\text { Western Fuels, No. 310136-2 } \\
\text { Western Fuels. No. 21011-5 } \\
\text { Western Fuels, No. 310129-4 } \\
\text { Western Fuels, No. 310135-4 } \\
\text { Fuelco, D-26-3-101-S } \\
\text { Confidential Well No. } 6 \\
\text { Adolph Coors, Nichols \#1-24 }\end{array}$ \\
\hline POWDER RIVER & $\begin{array}{l}\text { IAA } \\
\text { IAB } \\
\text { IAC } \\
\text { IAD: } \\
\text { IAE: } \\
\text { IAF. }\end{array}$ & $\begin{array}{l}\text { USGS, 79BR6 } \\
\text { Montana BMG, No. US-7735 } \\
\text { Montana BMG, No. US-7746 } \\
\text { USGS, No. 80-AU-14 } \\
\text { USGS, No. 80-AU-16 } \\
\text { USGS. No. 80-AU-7 }\end{array}$ \\
\hline SAN JUAN & $\begin{array}{l}\text { HAA } \\
\text { HAB }\end{array}$ & $\begin{array}{l}\text { Western Coal Company, Corehole P-70 } \\
\text { Navajo Nation Minerals Dept. \& } \\
\text { USGS/Coal Branch. K-3 Well }\end{array}$ \\
\hline $\begin{array}{l}\text { SOUTHERN APPALACHIAN/ } \\
\text { WARRIOR }\end{array}$ & CAA & $\begin{array}{l}\text { Grace Petroleum Corporation. } \\
\text { No. 1. Grimsley } 35-15\end{array}$ \\
\hline WESTERN WASHINGTON & LAA & Sandia'Lawrence Livermore Labs, DOE 7 \\
\hline
\end{tabular}

-Implementation of these tests began in this reporting period. 


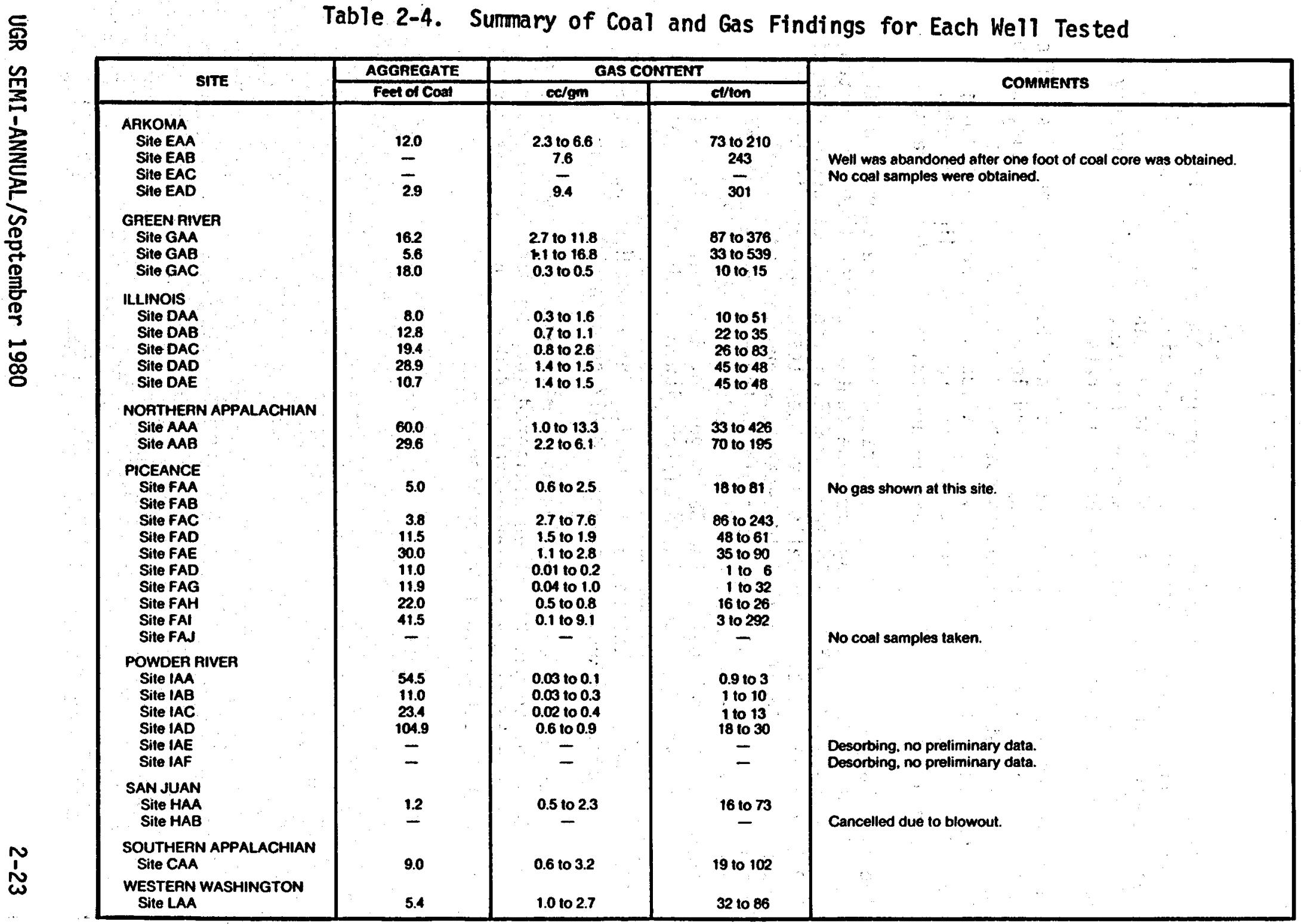



$2 \cdot 3 \cdot 2 \cdot 1$
A R KOM A
B A S I N
A N D ARKANSAS)

The Arkoma Basin encompasses approximately 5,300 square miles in Arkansas and OKlahoma (Figure 2-2). It contains extensive bituminous coal reserves in the Desmoinesian (Pennsylvanian) age rocks. Some minor coals occur in the Atokan Series of rocks, which lie directly below the Desmoinesian age coal-bearing strata.

Coals in the Arkoma Basin were deposited in deltaic environments. The gassiest coals are found in the upper and lower Hartshorne beds, which are 3 to 7 feet thick and contain estimated resources of about 5 billion tons. Individual 3- to 4-foot-thick seams are preserved in synclinal basins as narrow belts parallel to steeply dipping beds. Overburden is less than 3,000 feet in approximately 610 square miles.

The U.S. Bureau of Mines has investigated the methane content of the Hartshorne coals. The average methane content ranges from $211 \mathrm{cf} / \mathrm{ton}$ with an overburden of 0 to 50 feet to $672 \mathrm{cf} / \mathrm{ton}$ with an overburden of 2,000 to 3,000 feet. Four wells have been tested by MRCP in the Arkoma basin. The Type I field tests have provided additional desorption data for some of the coals in the western part of the Arkoma Basin. Upper Booch coal contained approximately $240 \mathrm{cf}$ of methane per ton of coal in the Barringer No. 1-11 well. Tentatively identified Hartshorne coal is $73 \mathrm{cf} / \mathrm{ton}$, lower Booch coal is approximately $211 \mathrm{cf} / \mathrm{ton}$, and the McAlester coal contains approximately 130 cf/ton in the Brown Estate No. 1-2 well. The lower Hartshorne coal from the Bureau of Reclamation well DH-Al7 contains $300 \mathrm{cf} / \mathrm{ton}$.

Based on these limited desorption data, minimum and maximum ranges for expected in-place gas have been estimated for the Hartshorne coals. Assuming an average gas content of 200 to $450 \mathrm{cf} /$ ton, the Hartshorne coals contain $1,600-3,600$ Bcf methane. 


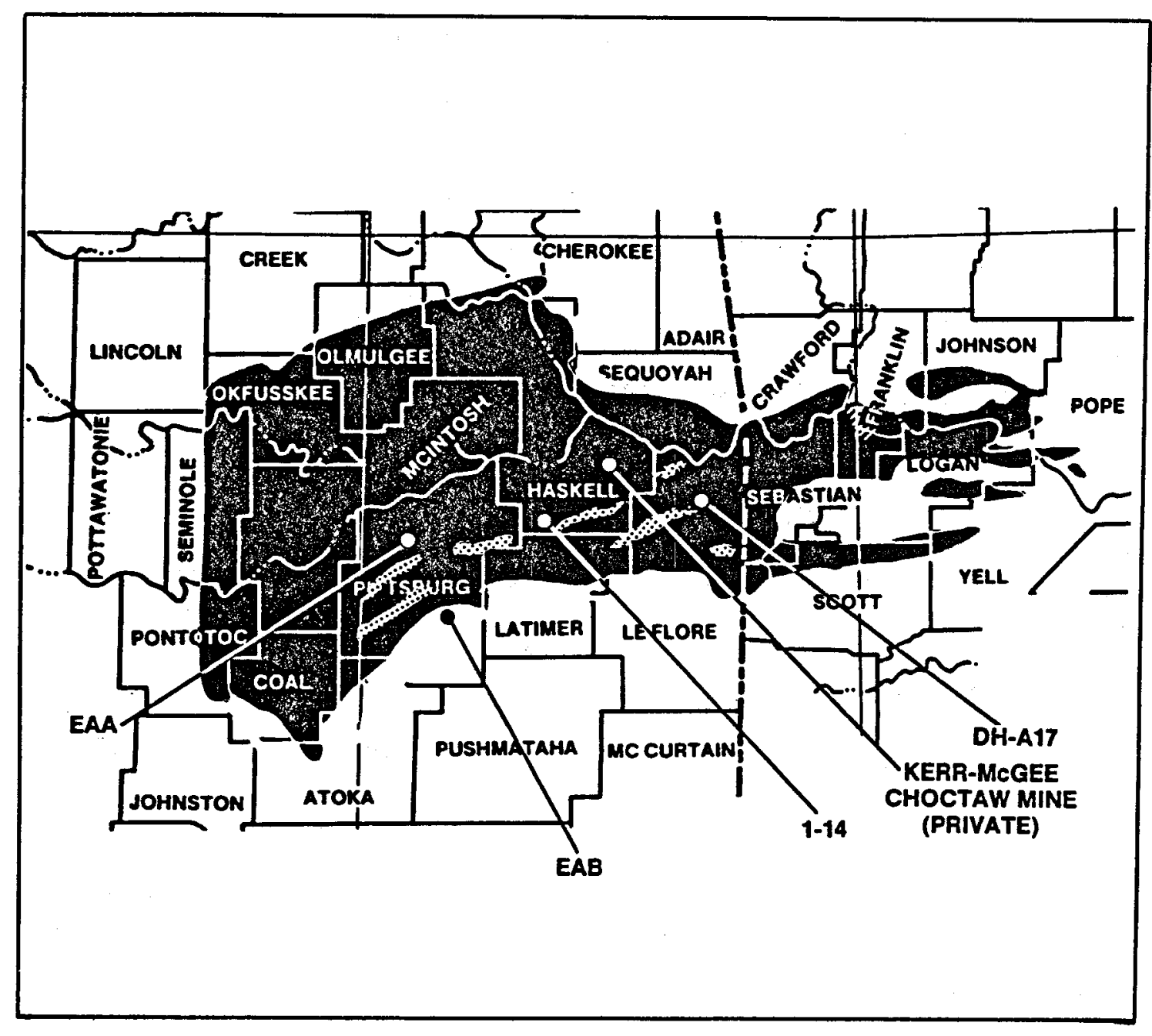

Figure 2-2. Arkoma Basin, Target Area, and Well Sites 
Cooperator: Arkla Exploration Company, Shrevesport, Louisiana

Location: Pittsburg County, Oklahoma (Section 2, Township 6N, Range. 13E)

Company's Well Name: Brown \#1-2

Field Operation Dates: October 9-11, 1978

Tests Performed

- Logging: Induction laterolog, neutron density, sonic

- Sidewall coring

- Drill stem testing (2700 to 2740 feet)

Summary of Test Results

- Results taken from sidewall cores

\begin{tabular}{ccccc} 
Lithology & $\begin{array}{c}\text { Sample } \\
\text { Depth (ft) }\end{array}$ & & $\begin{array}{c}\text { Total Gas Per } \\
\text { Unit cc/gm }\end{array}$ & cf/ton \\
\cline { 2 - 2 } Coal & 1904 & & 4.1 & 131 \\
Coal & 2128 & 6.6 & 211 \\
Coal & 2730 & & 2.3 & 73
\end{tabular}

- Initial Shut-in Pressure: 716 psig

- Water flow: $9.0 \mathrm{bbl} / \mathrm{day}$

- Average Permeability: $4.5 \mathrm{md}$ 
Cooperator: Mustang Production Company, Oklahoma City, Oklahoma Well Location: Pittsburg County, Oklahoma (Section 11, Township 4N, Range 15E)

Company's Well Name: Barringer \#1-11

Field Operation Dates: July 4-July 26, 1979-February 11-13, 1980

Tests Performed

o Coring:

Intervals cored: 3650 to 3662 feet, 4435 to 4458 feet, and 4580 to 4593 feet. Coalbeds encountered include:

Middle Booch, 3651.5 to 3652.5 ;

Upper Hartshorne, 4410 to 4417 ;

Lower Hartshorne, 4627 to 4632.

- Logging: Electric, gamma-ray, spectralog, compensated density, caliper

- Computer analysis: Rank, thickness, moisture, mineral, ash content

- Desorption

Summary of Test Results

\begin{tabular}{|c|c|c|c|}
\hline 01 ogy & Depth (ft) & $\begin{array}{l}\text { Thickness } \\
\text { (ft) }\end{array}$ & $\frac{\text { Total Gas Per Unit }}{\mathrm{cc} / \mathrm{gm} \text { cf } / \text { ton }}$ \\
\hline $\mathrm{Cc}$ & 3651 & 1.0 & 243 \\
\hline
\end{tabular}

\begin{tabular}{|c|c|c|c|c|}
\hline Lithology & $\begin{array}{c}\text { Porosity } \\
(\%)\end{array}$ & $\begin{array}{c}\text { Permeability } \\
\text { (md) }\end{array}$ & $\begin{array}{c}\text { Bulk } \\
\text { Density }\end{array}$ & $\begin{array}{c}\text { Compressive } \\
\text { Strength } \\
\text { (psi) }\end{array}$ \\
\hline Silt & 3.5 & 0.02 & 2.61 & -- \\
\hline $\begin{array}{l}\text { Siltstone/ } \\
\text { floor rock }\end{array}$ & 5.1 & 0.06 & 2.53 & 15,769 \\
\hline
\end{tabular}


Cooperator: Mustang Production Company, Oklahoma City, OKlahoma

Well Location: Haskell County, Oklahoma (Section 14, Township 7N, Range 20E)

Company's Well Name: Day Well \#1-14

Field Operation Dates: July 4-26, 1979

Logs and Tests Performed

- Borehole geophysical logging: electric, gamma-ray, spectralog, compensated density, neutron, caliper

o Coring Intervals: $1615-1643$ feet; $2585-2613$ feet

\section{Test Results}

- No coal recovered in coring operation 
Cooperator: U.S. Bureau of Reclamation, Amarillo, Texas

Well Location: LeFlore County, Oklahoma (Section 14, Township 8N, Range 26E)

Company's Well Name: Well \#DH-A17

Field Operation Dates: September 6-14, 1979

Logs and Tests Performed

- Borehole geophysical logs run: gamma-ray, caliper, and electric

- Conventional coring: $10 \mathrm{ft}$ of core. Coal at 191.6 to 194.5 feet

- Desorption of coal sample

- Laboratory analysis of coal sample complete

Summary of Test Results

Desorption data from conventional cores:

Sample Sample Desorbed Residual Lost Total Gas

Depth Weight Gas Gas Gas Per Unit

(ft) Lithology $(\mathrm{gm}) \quad(\mathrm{cc} / \mathrm{gm})(\mathrm{cc} / \mathrm{gm})(\mathrm{cc} / \mathrm{gm}) \overline{(\mathrm{cc} / \mathrm{gm})(\mathrm{cf} / \mathrm{ton})}$

$\begin{array}{llllllll}192 & \text { Coal } & 1363 & 8.4 & 0.9 & 0.1 & 9.4 & 300\end{array}$ 
The Greater Green River Coal Region, shown in Figure 2-3, occupies approximately 21,000 square miles in southwestern Wyoming and northwestern Colorado and includes the following structural units: the Western Wyoming Thrust Belt, the Green River Basin, the Rock Springs Uplift, the Great Divide Basin, and the Washakie Basin. This region contains significant quantities of both bituminous and subbituminous coal; the total original in-place resource is estimated at more than 80 billion short tons. This coal is found in both Upper Cretaceous and Tertiary units that crop out on the flanks of the surrounding uplifts and dip into the basinal areas. Very little is known about the quantity and stratigraphic distribution of coals in the deeper part of the basins. Therefore, the estimate of the total quantity of coal in this region is believed to be conservative. The following is a sumary of the geology, coal resources, and potential coalbed methane resource in the various structural units that make up this region.

The area in the western Wyoming Thrust Belt that contains coal outcrops is called the Hams Fork coal region. This is the fifth largest coal-producing area in Wyoming. Because of its location in the western Wyoming Thrust Belt, this region's structure is extremely complex. The major coal-bearing units include the Upper Cretaceous Frontier and Adaville Formations. Other formations containing coal are the Lower Cretaceous Bear River, the Upper Cretaceous Blind Bul1, and the Paleocene Evanston. Coals in this area range from about 3 to 118 feet thick and are subbituminous to high volatile $C$ bituminous in rank. The total estimated original in-place coal resource, both bituminous and subbituminous, in the Hams Fork coal region is approximately 5 billion short tons. The estimated potential coalbed methane resource from this area ranges from approximately 9.3 billion to 1.9 trillion cubic feet.

The Green River Basin, located in southwestern Wyoming between the western Wyoming Thrust Belt and the Rock Springs Uplift, is a broad synclinal area of about 10,000 square miles. Only minor coals outcrop in the basin, but it is probable that substantial coal resources are present in the subsurface. However, very little is presently known about the quantity and stratigraphic distribution of coals in the subsurface; therefore, any estimate of the potential methane resource would probably be extremely conservative. Upper Cretaceous Mesaverde group coal from one well in this basin was sampled for desorption and yielded between 420 and 524 cubic feet of methane per ton of coal.

The Rock Springs Uplift is a north-south trending anticlinal feature of Laramide age, located in the center of Sweetwater County, Wyoming. The principal coal-bearing units in the Rock Springs Uplift area 


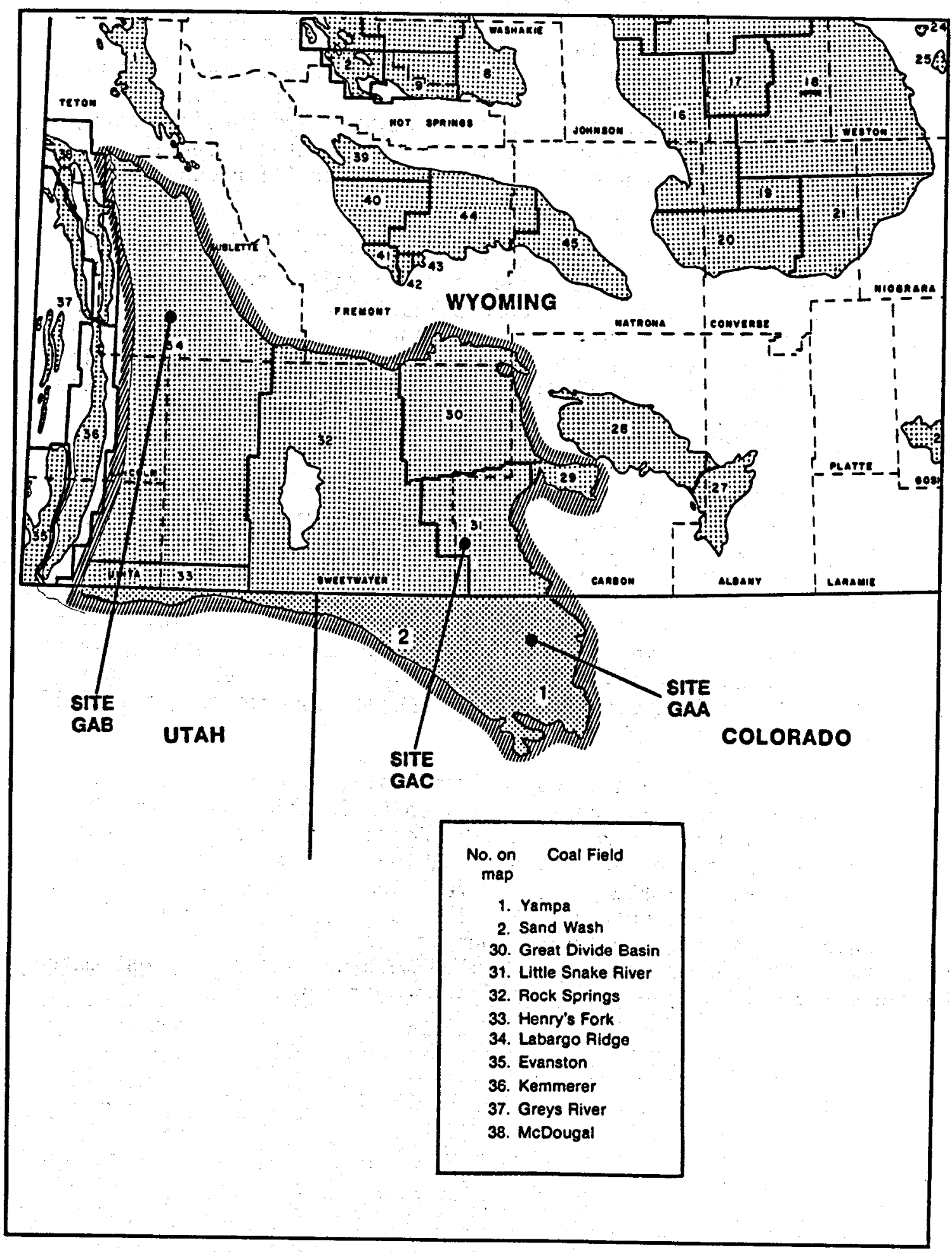

Figure 2-3. Greater Green River Coal Region, Target Area, and Well Sites 
include the Upper Cretaceous Rock Springs and Almond Formations of the Mesaverde group, the Upper Cretaceous Lance Formation, and the Paleocene Fort Union Formation. Coals from these formations are generally subbituminous $B$ to high volatile $C$ bituminous in rank and average about 5 to 6 feet thick. The estimated total original inplace coal resource of this area, both bituminous and subbituminous, is approximately 13 billion short tons. The estimated potential methane resource is betweeen 29 billion and 5.5 trillion cubic feet.

The Great Divide Basin, located in the northeastern part of Sweetwater County, Wyoming, is a large synclinal basin modified by broad shallow folds and widespread small-scale faults. The major coal-bearing unit in the Great Divide Basin is the Eocene Wasatch Formation. Coals in this formation are best developed in the southeastern and central parts of the basin, where it is estimated that there are approximately 1.6 billion short tons of subbituminous coal within 3,000 feet of the surface. The estimated potential coalbed methane resource of this basin ranges up to 160 billion cubic feet.

The Washakie Basin is a broad syncline that covers approximately 3000 square miles in south central Wyoming and northwestern Colorado. In the primary Washakie Basin, the major coal-bearing units are the Upper Cretaceous Mesaverde Group and the Eocene Wasatch Formation. These coals range in thickness from about 3 to 32 feet and are lignite to high volatile $C$ bituminous in rank. The estimated total original in-place coal resource in this basin is approximately 23 million short tons of bituminous coal and 119 billion short tons of subbituminous coal. The estimated potential coalbed methane resource ranges from 67 million to 200 billion cubic feet.

The Sand Wash Basin is a southeasterly trending synclinal prong of the Washakie Basin. The major coal-bearing units in this basin are the Upper Cretaceous Williams Fork and Iles Formations of the Mesaverde group and the Paleocene Fort Union Formation. These coals range in thickness from approximately 2 to 20 feet and are subbituminous $B$ to high volatile $C$ bituminous in rank. The total estimated original in-place coal resource from this group is approximately 58 billion short tons. The potential total coalbed methane resource is estimated to range from 116 billion to 23 trillion cubic feet. 
At the end of this reporting period four wells had been tested in the area:

$\begin{array}{ll}\text { Test Well } & \text { Status } \\ \begin{array}{l}\text { Site GAA (Type I Test) } \\ \text { Cooperating Company } \\ \text { Confidential }\end{array} & \begin{array}{l}\text { Well test data } \\ \text { package complete }\end{array} \\ \begin{array}{ll}\text { Site GAA (Type III Test) } \\ \text { Cooperating Company }\end{array} & \begin{array}{l}\text { Pre-frac testing } \\ \text { Confidential }\end{array} \\ \begin{array}{l}\text { Site GAB } \\ \text { Belco Petroleum Company }\end{array} \\ \begin{array}{l}\text { Site GAC } \\ \text { Kemmerer Coal Company }\end{array}\end{array}$

These tests are described in detail in the following section. 
Cooperator: Energy Reserves Group, Casper, Wyoming

Well Location: Moffat County, Colorado (Section 29, Township 7N, Range 90W)

Company's Well Name: Robert A. Van Dorn \#1

Field Operations Dates: November 1978 - December 1979 (Type I)

Logs and Tests Performed

- Conventional coring: 139 feet of core, coal at 3652 to $3652.6,3674$ to $3676.1,3923$ to $3924.1,3937$ to 3937.2 , 3947.9 to $3948.2,4649$ to $4659.8,4660.8$ to 4661 , and 4704.4 to 4706 feet

- Borehole geophysical logging: Compensated neutron/formation density, borehole compensated sonic, dual induction-SFL, natural gamma, and caliper

- Sidewall coring: 26 cores obtained; sample depth, 3683 to 4988 feet

- Drill stem tests: Intervals tested--3700 to 3800,4634 to 4714 feet

- Coal core desorption

- Proximate/ultimate analysis

- Coal structural/strength testing at Colorado School of Mines 
Summary of Test Results

Conventional core samples

\begin{tabular}{|c|c|c|c|c|}
\hline Lithology & $\begin{array}{c}\text { Sample } \\
\text { Depth } \\
(\mathrm{ft}) \\
\end{array}$ & $\begin{array}{c}\text { Thickness } \\
(\mathrm{ft}) \\
\end{array}$ & $\frac{\text { Total Gas }}{\text { (cc/gm) }}$ & $\begin{array}{l}\text { Per Unit } \\
\text { (cf/ton) }\end{array}$ \\
\hline $\begin{array}{l}\text { HVB Bituminous } \\
\text { HVB Bituminous } \\
\text { Shale } \\
\text { HVB Bituminous } \\
\text { HVB Bituminous } \\
\text { HVB Bituminous } \\
\text { HVB Bituminous } \\
\text { HVB Bituminous } \\
\text { HVB Bituminous } \\
\text { HVB Bituminous } \\
\text { HVB Bituminous }\end{array}$ & $\begin{array}{l}3675 \\
3922 \\
3930 \\
3948 \\
4654 \\
4655 \\
4656 \\
4657 \\
4658 \\
4659 \\
4708\end{array}$ & $\begin{array}{r}1.4 \\
1.1 \\
0.2 \\
0.3 \\
10.8 \\
10.8 \\
10.8 \\
10.8 \\
10.8 \\
10.8 \\
7.2\end{array}$ & $\begin{array}{r}8.0 \\
3.8 \\
3.9 \\
2.7 \\
9.0 \\
8.4 \\
9.3 \\
9.4 \\
8.6 \\
10.1 \\
11.8\end{array}$ & $\begin{array}{r}256 \\
121 \\
124 \\
87 \\
288 \\
270 \\
296 \\
301 \\
274 \\
323 \\
376\end{array}$ \\
\hline
\end{tabular}

Sidewall core samples:

Depth
4984
4982
4980
4978
4976
4872
4868
4864
4986
4814
4720
4666

Lithology

Coal

Very carbonaceous shale

Coal with shale

Coal

Coal

Coal

Coal

Coal

Coal

Coal

Coal

Coal
Gas in Place

(cf/ton)

144

90

157

158

142

179

157

210

133

190

136

179 
Cooperator: Energy Reserves Group, Casper, Wyoming

Well Location: Moffat County Colorado (Section 29, Township 7N, Range 9W)

Company's Well Name: Robert A. Van Dorn \#1

Field Operation Dates: December 1979 - February 1980 (Type III)

Logs and Tests Performed

- Initial post-frac flow: Producing 3-10 Mcf gas/day, 3-4 bbl water/day

- Present post-frac flow: Producing less than 1 Mcf gas/day

Summary of Test Results

- Produced gas sample analysis: $48.8 \% \mathrm{CH}_{4}, 31.7 \% \mathrm{~N}_{2}, 18.1 \% \mathrm{CO}_{2}$, and $1 \%$ ethane

- Bottomhole pressure determined from pressure fall-off test is 2080 psi; average effective radial permeability is $1.6 \mathrm{md}$

Comments/Additional Data

- See initial series for Type I test results 
Cooperator: Belco Petroleum Corporation, Lakewood, Colorado

Well Location: Sublette County, Wyoming (Section 28, Township 30N, Range 113W)

Company's Well Name: S-29-27

Field Operation Dates: January 2-14, 1979

Logs and Tests Performed

- Conventional coring: 90 feet of core. Coal at 3479.1 to 3481.4 feet, 3494.8 to 3496.5 feet, 3526.6 to 3528.1 feet

- Borehole geophysical logging: Borehole compensated sonic/garma ray dual induction - SFL, compensated neutron/formation density, caliper

- Sidewall coring: 18 cores obtained

Sample depths: $3498-3500$ feet 3484 - 3487 feet 3438 - 3440 feet

- Coal core desorption

- Proximate/ultimate analysis

\begin{tabular}{|c|c|c|c|c|}
\hline Lithology & $\begin{array}{l}\text { Sample } \\
\text { Depth } \\
\text { (ft) } \\
\end{array}$ & $\begin{array}{c}\text { Thickness } \\
\text { (ft) }\end{array}$ & $\begin{array}{l}\text { Total Gas } \\
\frac{(\mathrm{cc} / \mathrm{gm})}{\left({ }^{2}\right.}\end{array}$ & $\begin{array}{l}\text { Per Unit } \\
\text { (cf/ton) }\end{array}$ \\
\hline $\begin{array}{l}\text { Coal } \\
\text { Coal } \\
\text { Coal } \\
\text { Coal } \\
\text { Coal }\end{array}$ & $\begin{array}{l}3479 \\
3480 \\
3481 \\
3495 \\
3496\end{array}$ & $\begin{array}{l}2.3 \\
2.3 \\
2.3 \\
1.7 \\
1.7\end{array}$ & $\begin{array}{l}15.1 \\
15.2 \\
13.6 \\
16.8 \\
16.8\end{array}$ & $\begin{array}{l}485 \\
485 \\
435 \\
539 \\
539\end{array}$ \\
\hline $\begin{array}{l}\text { Dk. gray } \\
\text { Carbonaceous shale } \\
\text { Dk. gray }\end{array}$ & 3507 & 1.9 & 6.6 & 210 \\
\hline $\begin{array}{l}\text { Carbonaceous shale } \\
\text { Coal } \\
\text { Coal }\end{array}$ & $\begin{array}{l}3520 \\
3527 \\
3528\end{array}$ & $\begin{array}{l}1.4 \\
1.6 \\
1.6\end{array}$ & $\begin{array}{r}1.1 \\
14.6 \\
16.0\end{array}$ & $\begin{array}{r}33 \\
466 \\
513\end{array}$ \\
\hline
\end{tabular}


Summary of Test Results

Sidewall core samples:

Sample Depth Range (ft) Lithology (cf/ton)

3438.5

Coal

214

$3440.0-3485.5$

Carbonaceous shale

$98-212$

$3498.0-3499.5$

Coal

$215-350$ 
(Italics denote changes or progress since March 31, 1980)

\section{MRCP WELL SITE GAC}

Cooperator: Kemmerer Coal Company, Denver, Colorado

Well Location: Carbon County, Wyoming (SE 1/4, Section 29, Township $16 \mathrm{~N}$, Range 93W)

Company's Well Name: Barrel Springs Unit 29-2

Field Operation Dates: June 24-30, 1980

Logs and Tests Performed

- Mud logging: 1500 feet of the Fort Union Formation (mud gas analysis from chromatograph and lithological description)

- Drill chip collection: foum samples from two coalbeds (4638 to 4646,4976 to 4986 feet)

- Borehole geophysical logging will be performed at a later date

- Desorption of coal chips: after desorption is complete, chips will be sent to laboratory for residual gas determination and proximate/ultimate analysis

Sumary of Test Results

Preliminary desorption from coal chips:

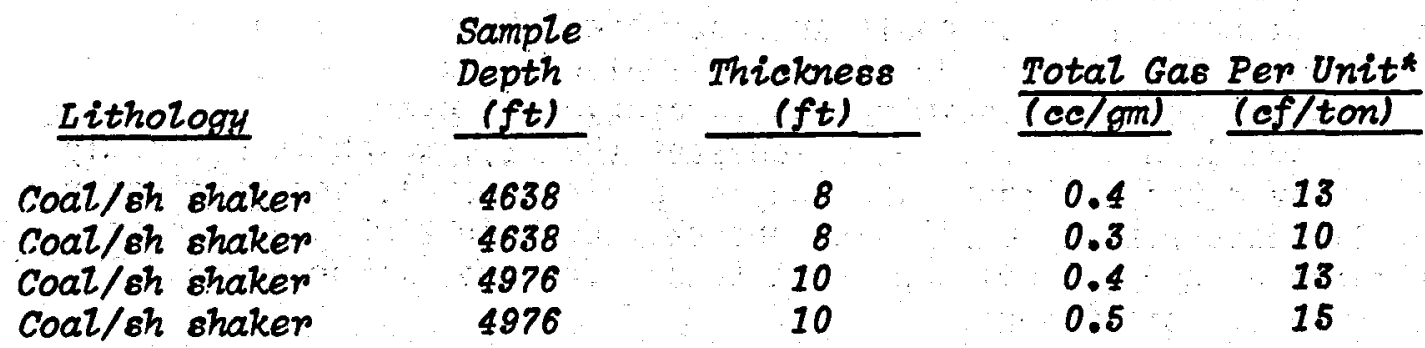

* Does not inclide lost or residual gas 


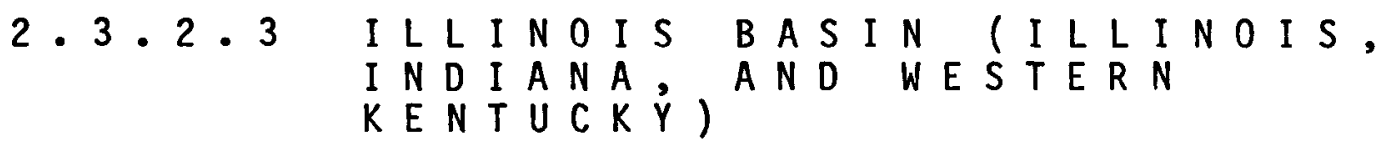

The Illinois Basin encompasses approximately 53,000 square miles in the east-central United States, covering a large portion of Illinois and extending into southwestern Indiana and western Kentucky. This basin contains extensive bituminous coal reserves in Pennsylvanian age rocks.

The U.S. Geological Survey has estimated that the total coal resource of the Illinois Basin might be 365 billion tons. More than 75 individual coal seams have been identified in this area, 20 of which are mined. The majority of the coals are not continuous and do not maintain constant thicknesses. Individual seam thickness ranges from a few inches to 15 feet over large areas. The coals outcrop at the periphery of the basin and dip gently towards the deeper central portion in southeastern Illinois and western Kentucky. Lower and upper Pennsylvanian coals are thin and discontinuous while the middle coals are thick, generally continuous, and provide the major reserves of the basin. The lower and upper coals have not been studied in as much detail and are not as well correlated as the thicker coalbeds of the Middle Pennsylvanian. The greatest cumulative thickness of coal seams presumably occurs in the southeastern portion of the basin (near the tri-state boundary) where the thickest Pennsylvanian section occurs. All Illinois Basin coal seams are covered by less than 3,000 feet of overburden, and the major coals are within 1,500 feet of the surface.

The Springfield-Harrisburg (No. 5) coals in Illinois and their correlatives, Springfield $V$ in Indiana and No. 9-coals in Kentucky, are the most extensive and uniformly thick coals in the Illinois Basin; reserves of these coals are estimated at more than 67 billion short tons. The Herrin (No. 6) coal is also thick and extensive in Illinois and contains estimated coal reserves of over 77 billion short tons. Some deeper coals, the Colchester (No. 2), which is uniformly present over the entire basin, and the Davis (No. 6), and Mannington (No. 4), occurring primarily in Kentucky, contain combined reserves estimated at over 39 billion short tons. The coal is predominantly high volatile bituminous.

The recent investigation of gas desorption data indicates that the gas content of coals in the Illinois Basin is generally low, ranging from less than 40 up to 150 cubic feet per ton. Based on limited available desorption data, minimum and maximum ranges for expected in-place gas have been made from the Danville, Herrin, Springfield-Harrisburg, and their equivalent coals. The Danville coals are anticipated to have a minimum of approximately 0.5 trillion and a maximum of nearly 1.7 trillion cubic feet of in-place gas. Likewise, the estimated range 
for Herrin coal is 2.5 to 3.4 trillion cubic feet of gas; and the Springfield-Harrisburg, 2.2 to 9.9 trillion cubic feet of gas. The minimum total in-place gas resource for these three seams totals over 5 trillion cubic feet. It is assumed that the methane contained in major deeper coals (Colchester, Davis, etc.) could add significantly to this figure. Although the specific gas content of coals in the Illinois Basin is quite low, the magnitude of the coal resource produces large in-place gas resource estimates.

The gas content of coals in the Illinois Basin is thought to be higher towards the southeastern portion of the basin, and this is the initial target area defined by the MRCP for early coalbed methane delineation. Recently, the coals having the greatest probability for early commercial gas production were redefined, and the primary MRCP target in the Illinois Basin now consists of two areas totalling approximately 4,300 square miles, as shown in Figure 2-4. The initial MRCP target area in the Illinois Basin was approximately 9,111 square miles. Target Area A, located in western Kentucky, contains a thick section of deep coals in a highly disturbed structural belt. Target Area B, in southeastern IIlinois and southwestern Indiana, retains part of the initial target area and contains previously reported gassy coals and thick coal sections at considerable depths.

At the end of this reporting period the status of well tests was as follows:

Test Well

Site DAA

Hagen $0 i 1$ Company

Site DAB

Geowest, Inc.

Site DAC

Indiana Geological Survey

Site DAD

Indiana Geological Survey

Site DAE

R. W. Beeson $0 i l$ Producer
Status

Well test data package is complete

Well test data package is complete

Well test data package is complete

Well test data package is complete

Well test data package is complete 


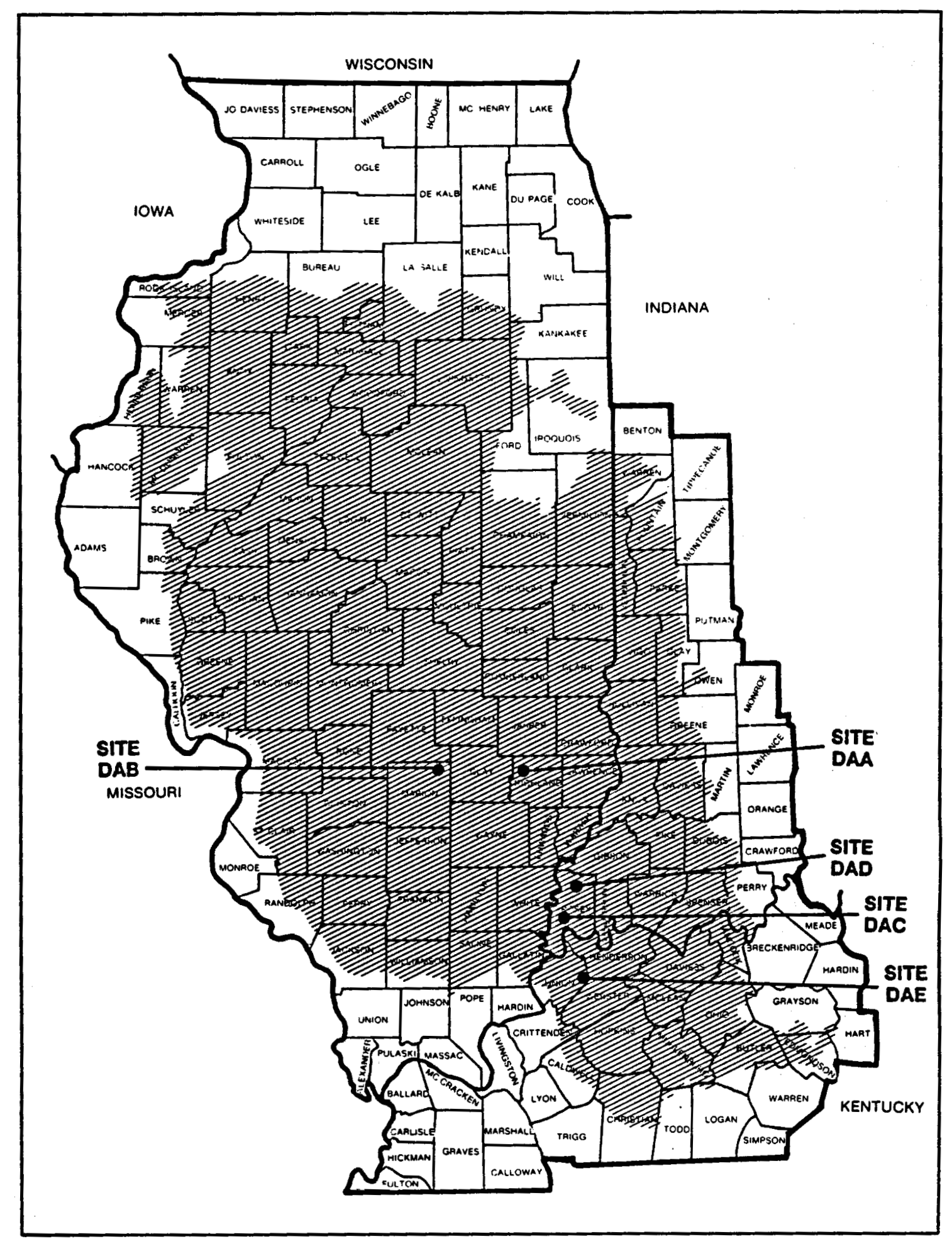

Figure 2-4. I17inois Basin, Redefined Target Areas, and Well Sites 
Cooperator: Hagen $0 i 1$ Company, Clay City, Illinois

Well Location: Clay City, Illinois (Section 19, Township 3N, Range 8E)

Company's Well Name: Henderson \#2 We11

Field Operation Dates: October 25-28, 1978

\section{Logs and Tests Performed}

- Conventional coring: 194 feet of core. Coal at 994 to 997 , 1035 to 1037,1077 to 1078,1089 to 1091 , and 1352 to 1352.5 feet

o Drill stem tests: Tests at 1342 to 1354,1071 to 1083, and 1026 to 1038 feet

- Borehole geophysical logging: Induction-laterolog, porosity, density, sonic, fracture identification

- Sidewall cores: Very little coal recovered

- Desorption of coal

- Laboratory analyses

Summary of Test Results

- Gas desorbed from conventional coring

\begin{tabular}{|c|c|c|c|c|}
\hline Lithology & $\begin{array}{l}\text { Sample } \\
\text { Depth } \\
\text { (ft) }\end{array}$ & $\begin{array}{c}\text { Thickness } \\
(\mathrm{ft})\end{array}$ & $\frac{\text { Total Gas }}{(\mathrm{cc} / \mathrm{gm})}$ & $\begin{array}{l}\text { Per Unit } \\
\text { (cf/ton) }\end{array}$ \\
\hline $\begin{array}{l}\text { HVB Bituminous } \\
\text { HVB Bituminous } \\
\text { HVB Bituminous } \\
\text { HVB Bituminous } \\
\text { Shale } \\
\text { HVB Bituminous } \\
\text { HVB Bituminous } \\
\text { HVB Bituminous }\end{array}$ & $\begin{array}{r}994 \\
995 \\
1035 \\
1036 \\
1034 \\
1077 \\
1090 \\
1352\end{array}$ & $\begin{array}{l}2.75 \\
2.75 \\
2.00 \\
2.00 \\
2.00 \\
1.25 \\
1.50 \\
0.50\end{array}$ & $\begin{array}{l}1.4 \\
1.3 \\
1.0 \\
1.1 \\
0.3 \\
1.0 \\
1.1 \\
1.6\end{array}$ & $\begin{array}{l}45 \\
42 \\
32 \\
35 \\
10 \\
32 \\
35 \\
51\end{array}$ \\
\hline
\end{tabular}


- Drill Stem Test Results:

Coalbed

Seelyville

Briar Hil1 (5A)

Herrin (6)
Shut-in Pressure

479-466 psig 239-176 psig Misrun due to plugged tool
Flow

No significant flow

No significant flow

- Porosity estimated to be between $3 \%$ and $7 \%$; permeability less than $0.1 \mathrm{md}$. 
Cooperator: GeoWest Incorporated, Billings, Montana

Well Location: Marion County, Illinois (Section 7, Township 2N, Range 2E)

Field Operation Dates: May 12-17, 1979

Logs and Tests Performed

- Conventional coring

- Borehole geophysical logging: electric, gamma-ray, gamma-gamma density, and caliper

- Drill stem test: aborted because of hole sloughing

- Desorption of coal samples

- Laboratory analyses of coal samples

Summary of Test Results

Sample
Depth

Lithology

HVB Bituminous

HVB Bituminous

HVB Bituminous

HVB Bituminous

HVB Bituminous

HVB Bituminous

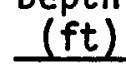

665

698

727

736

733

732
Thickness

(ft)

2.8

5.1

0.9

4.0

4.0

4.0
Total Gas Per Unit

(cc/gm) (cf/ton)

0.8

1.1

0.7

0.9

0.9

0.8

25

35

23

29

29

26
Sample

Harrisburg (\#5) Roof Briarhill (\#5a) Roof Danville (\#7) Roof Harrisburg (\#5) Floor Briarhill ( $\# 5$ a) Floor Herrin (\#6) Floor Danville (\#7) Floor

\section{Permeability}

(md)

0.04

4.8

0.23

*

*

*

*
Porosity

(\%)

8.5

16.9

9.5

*

*

*

*
Density

2.14

2.47

2.41

2.45

2.50

2.44

2.36

*Unsuitable for permeability and porosity measurement 
Cooperator: Indiana Geological Survey, Bloomington, Indiana

Well Location: Posey County, Illinois (Section 33, Township 65, Range 13W)

Field Operation Dates: October 3 - November 16, 1979

Logs and Tests Performed

- Borehole geophysical logging: gamma-ray, SP, resistivity

- Desorption of coal samples

- Laboratory analyses of coal samples

Summary of Test Results

\begin{tabular}{|c|c|c|c|c|}
\hline Lithology & $\begin{array}{l}\text { Sample } \\
\text { Depth } \\
\text { (ft) }\end{array}$ & $\begin{array}{c}\text { Thickness } \\
(\mathrm{ft})\end{array}$ & $\begin{array}{l}\text { Total Gas } \\
\text { (cc/gm) }\end{array}$ & $\begin{array}{l}\text { Per Unit } \\
\text { (cf/ton) }\end{array}$ \\
\hline $\begin{array}{l}\text { HVB Bituminous } \\
\text { Coal } \\
\text { Coal } \\
\text { HVB Bituminous } \\
\text { HVB Bituminous } \\
\text { HVB Bituminous } \\
\text { HVB Bituminous }\end{array}$ & $\begin{array}{l}467 \\
518 \\
616 \\
728 \\
787 \\
879 \\
889\end{array}$ & $\begin{array}{l}2.0 \\
3.7 \\
3.5 \\
2.2 \\
1.3 \\
1.7 \\
5.0\end{array}$ & $\begin{array}{l}1.1 \\
\star \\
0.8 \\
1.8 \\
2.1 \\
0.8 \\
2.6\end{array}$ & $\begin{array}{l}35 \\
\star \\
26 \\
58 \\
67 \\
26 \\
83\end{array}$ \\
\hline
\end{tabular}

* Canister leaked 
(Italics denote changes or progress since March 31, 1980)

\section{MRCP WELL SITE DAD}

Cooperator: Indiana Geological Survey, Bloomington, Indiana

Well Location: Posey County, Illinois (Section 26, Township 45, Range 13W)

Field Operation Dates: November 26, 1979 - May 22, 1980

Logs and Tests Performed

- Borehole geophysical logging: gamma-ray, SP, resistivity

- Desorption of coal samples

- Laboratory analyses of coal samples

Summary of Test Results

\begin{tabular}{|c|c|c|c|c|}
\hline Lithologu & $\begin{array}{c}\text { Sample } \\
\text { Depth } \\
\text { (ft) } \\
\end{array}$ & $\begin{array}{c}\text { Thickness } \\
(f t)\end{array}$ & $\frac{\text { Total Gas }}{(\mathrm{co} / \mathrm{gm})}$ & $\frac{\text { Per Unit }}{\text { (cf/ton) }}$ \\
\hline Coal (VII) & 605 & 3.0 & 2.2 & 70 \\
\hline Coal (Herrin) & 562 & 4.9 & - & - \\
\hline Coal (V) & 665 & 4.1 & 1.4 & 4.5 \\
\hline Coal (IVa) & 772 & 2.2 & 2.4 & 77 \\
\hline Coat (IV) & 827 & 2.5 & - & - \\
\hline Coal (IIIa) & 993 & 9.5 & - & - \\
\hline Coal (III) & 995 & 9.5 & - & - \\
\hline Coal (III) & 667 & 4.4 & - & - \\
\hline Coal (V) & 669 & 4.4 & - & - \\
\hline
\end{tabular}

- Gas composition of two samples averaged 60 percent $\mathrm{CH}_{4}$ due to air trapped in dead space of sample canister. Isotopic analysis of hydrocarbons indicated $13 C=-61.3$. 
Cooperator: R. W. Beeson Dil Producer, Evansville, Indiana

Well Location: Webster County, Kentucky

Field Operation Dates: January 18-22, 1980

\section{Logs and Tests Performed}

- Geophysical logs run: Induction electric Log, density and neutron borehole compensated logs, 3-D velocity log, and COM-PRO LOG (computer processed coal log)

- Drill stem testing indicated both coalbeds to be very tight (low permeability). Each coal horizon was found to have a small amount of formation pressure

- Desorption of coal samples

- Lab analysis of coal, roof, and floor rocks

Summary of Test Results

\begin{tabular}{|c|c|c|c|c|c|}
\hline \multicolumn{2}{|c|}{ Lithology } & $\begin{array}{l}\text { Sample } \\
\text { Depth } \\
(\mathrm{ft}) \\
\end{array}$ & $\begin{array}{c}\text { Thickness } \\
(\mathrm{ft})\end{array}$ & $\begin{array}{l}\text { Total Gas } \\
\frac{(\mathrm{cc} / \mathrm{gm})}{}\end{array}$ & $\begin{array}{l}\text { Per Unit } \\
\text { (cf/ton) }\end{array}$ \\
\hline \multicolumn{2}{|c|}{$\begin{array}{l}\text { HVA Bituminous } \\
\text { HVA Bituminous } \\
\text { HVA Bituminous } \\
\text { HVA Bituminous }\end{array}$} & $\begin{array}{l}1200 \\
1204 \\
1305 \\
1308\end{array}$ & $\begin{array}{l}5.7 \\
5.7 \\
5.0 \\
5.0\end{array}$ & $\begin{array}{l}1.4 \\
1.4 \\
1.4 \\
1.4\end{array}$ & $\begin{array}{l}45 \\
45 \\
45 \\
45\end{array}$ \\
\hline 0 & $\begin{array}{l}\text { Mechanica } \\
\text { coalbed \# }\end{array}$ & $\begin{array}{l}\text { perties } \\
\text { e deter }\end{array}$ & $\begin{array}{l}\text { roof and } f \\
d \text { : }\end{array}$ & rock sample & es from \\
\hline
\end{tabular}




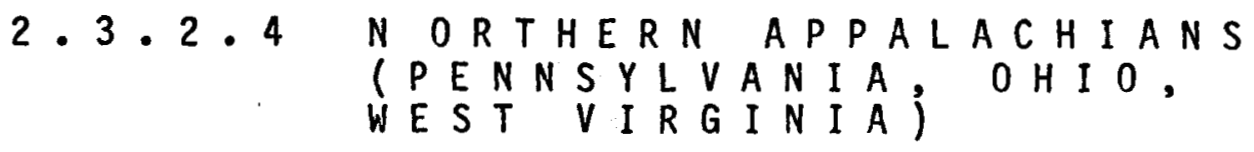

Coal in the northern Appalachians is found in Permian Dunkard Group rocks and the Pennsylvanian Conemaugh, Allegheny, and Pottsville Group strata. These rock units contain approximately 198 billion tons of coal reserves in about 90 minable coal seams. The total coal thickness varies from 20 to 60 feet. The individual seams are generally thin, less than 10 feet thick, but continuous over large areas. The coal is low to high volatile bituminous in rank and is known to have methane production potential. Gas emission data exist for mines in at least 15 different seams. The beds in the area range from gently to tightly folded and faulted in the east to nearly horizontal in the west. Most of the coal is covered by less than 3,000 feet of overburden.

The MRCP testing program has provided methane data at two sites in the Northern Appalachians. The gas concentrations from sidewall coring of the \#1 Murdoch Well provide a range of 33 to 426 cubic feet per ton with the higher values representing samples of the lower perforated coals. At the Waynesburg well, the methane content ranges from 70 to 195 cubic feet per ton.

The current target area of interest within the Northern Appalachian Basin is shown in Figure 2-5. At the end of this reporting period, the status of well tests was as follows:

Test Well

Site AAA

Kinloch Development Company

Site $A A B$ Waynesburg College
Status

Wel! test data package complete

Well test data package complete 


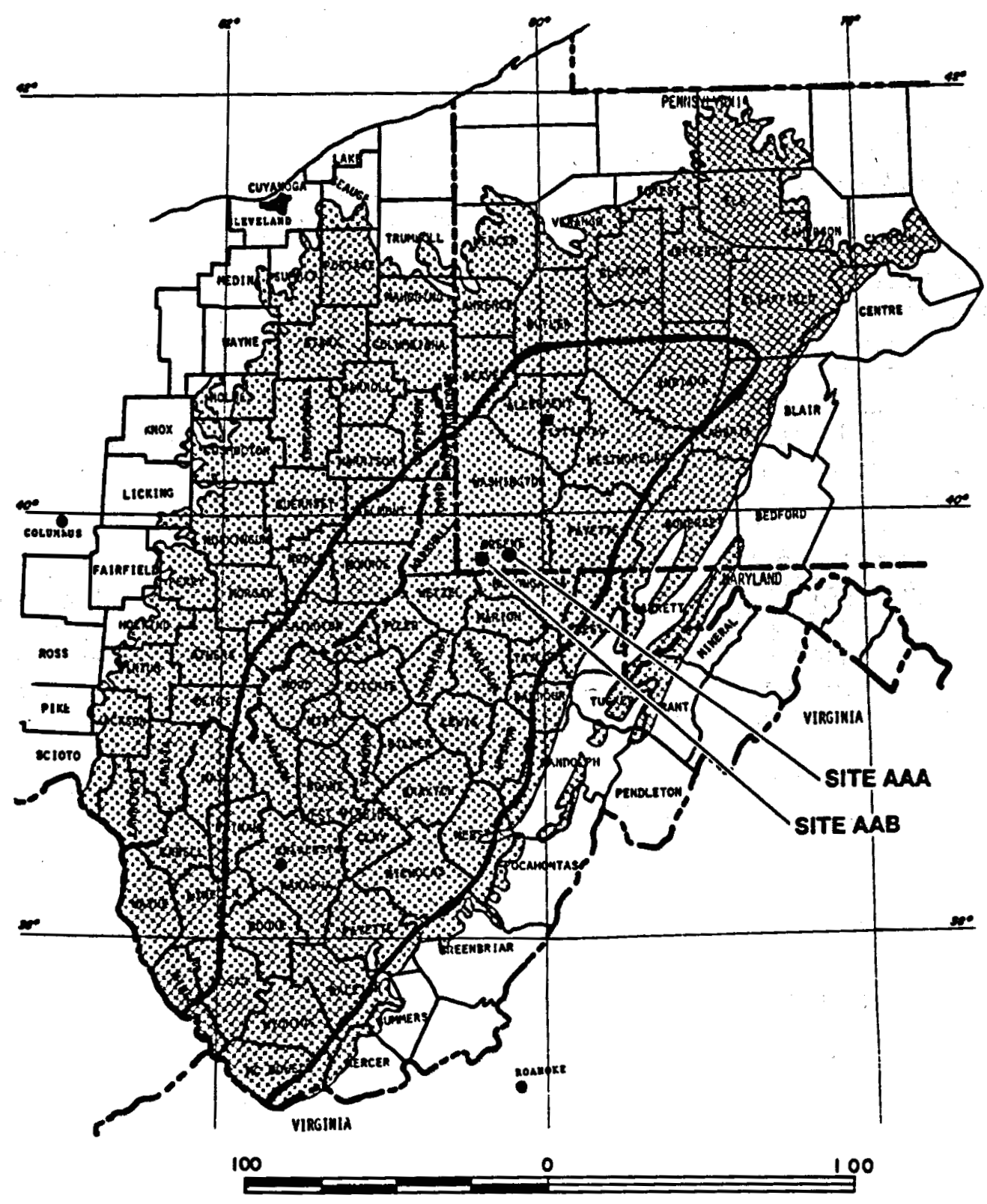

Figure 2-5. Northern Appalachian Basin, Target Area, Well Sites 
Cooperator: Kinloch Development Company, Waynesburg, Pennsylvania Well Location: Greene County, Pennsylvania (Whiteley township, 1 mile north of Fordyce along Frosty Run)

Company's Well Name: \#1 Murdock Well

Field Operation Dates: April 3 - June 23, 1978

\section{Logs and Tests Performed}

- Borehole geophysical logging: neutron, compensated density, induction, gamma-ray, caliper, and graphic lithologic

- Fracture treatment: Three-stage frac at 800 to 3900 psi (well above design) introduced $1533 \mathrm{bbl}$ of water containing 18,480 pounds of 80 to 100 mesh sand and 15,750 pounds of 20 to 40 mesh sand

- Acidized before stimulation with 1,000 gallons of 15 percent acid

- Sidewall coring

Summary of Test Results

- Prior to stimulation, permeabilities of 0.5 to $1.0 \mathrm{md}$ were measured

- After frac, well flowed 80 bbl water per day with show of gas

- Total Gas Content

\begin{tabular}{|c|c|c|c|}
\hline $\begin{array}{l}\text { Coalbeds } \\
\text { Tested }\end{array}$ & $\begin{array}{l}\text { Thickness } \\
(\mathrm{ft})\end{array}$ & $\begin{array}{l}\text { Depth } \\
\text { (ft) }\end{array}$ & $\begin{array}{l}\text { No. of } \\
\text { Shots }\end{array}$ \\
\hline $\begin{array}{l}\text { Upper Kittanning } \\
\text { Middle Kittanning } \\
\text { Lower Kittanning } \\
\text { Brookville (Clarion) }\end{array}$ & $\begin{array}{l}5 \\
5-1 / 2 \\
7 \\
4\end{array}$ & $\begin{array}{l}1338 \\
1396 \\
1421 \\
1485\end{array}$ & $\begin{array}{l}3 \\
6 \\
6 \\
4\end{array}$ \\
\hline
\end{tabular}


Cooperator: Waynesburg College, Waynesburg, Pennsylvania

Well Location: Greene County, Pennsylvania (Purman Run Tract on college campus North of Waynesburg)

Field Operation Dates: October-December, 1979

Logs and Tests Performed

- Geophysical testing: Dual induction, compensated density, and sonic $\log$

Summary of Test Results

Sample

No.

41

42

43

44

45

46

$\mathrm{J}-\mathrm{L}-1$

155

$\mathrm{J}-\mathrm{L}-2$

47

156

48

142
Coal

Waynesburg

Waynesburg

Sewickley

Sewickley

Pittsburgh

Pittsburgh

(Rider)

Bakerstown

Upper Freeport

Upper Kittanning

(Predom. Shale)

Middle Kittanning

Clarion
Depth

(ft)

149

153

371

486

489

491

483

888

1085

1187

1188

1238

1292
Total Gas $\mathrm{cc} / \mathrm{gm} \quad \mathrm{cf} / \mathrm{ton}$

$2.8 \quad 90$

$2.2 \quad 70$

$4.7 \quad 150$

$4.6 \quad 147$

$4.1 \quad 131$

$5.6 \quad 180$

$4.2 \quad 134$

$4.4 \quad 141$

$3.6 \quad 115$

$4.8 \quad 154$

$6.1 \quad 195$

$3.1 \quad 99$

4.4141

Note: This well has been completed and stimulated under the MRCP Production Technology Development effort; additional information is in Section 2.5.3.1. 
Coals in the Piceance Basin are found within the sandstones and shales of the Mesaverde group of Late Cretaceous age. There are approximately 18 seams in the Mesaverde with an aggregate thickness of 30 to 80 feet. The individual seams range from lenticular and discontinuous to thick and continuous, with lateral extent in excess of 2,000 square miles. The coal resource is estimated at approximately 60 billion tons. Individual beds range from a few feet to 20 feet thick, but average about 10 feet thick. The coal is of subbituminous to anthracite rank. Mine emission data indicate that 13 seams have methane production potential. The coal is found in a geologic basin with steep dips at the margin and nearly horizontal beds in the center. Coal is found at depths of more than 3,000 feet a very short distance from the outcrop. The coal has been observed in oil tests at depths of approximately 6,700 feet.

Recent MRCP Type I field tests have provided additional desorption data for some of the coals in the Piceance Basin. Preliminary test results show that gas content ranges from 1 to 339 cubic feet per ton.

The current MRCP target area of interest within the Piceance Basin is shown in Figure 2-6.

At the end of this reporting period the status of well tests is as follows:

Test Well

Site FAA

Fuel Resources Development Co.

Site $F A B$

Twin Arrow Drilling Co.

Site FAC

Twin Arrow Drilling Co.

Site FAD

Western Fuels Co.

Site FAE

Western Fuels Co.

Site FAF

Western Fuels Co.

\section{$\underline{\text { Status }}$}

Well test data package is complete

Well test data package is complete

Well test data package is complete

Well test data package is complete

Well test data package is complete

Well test data package is complete 


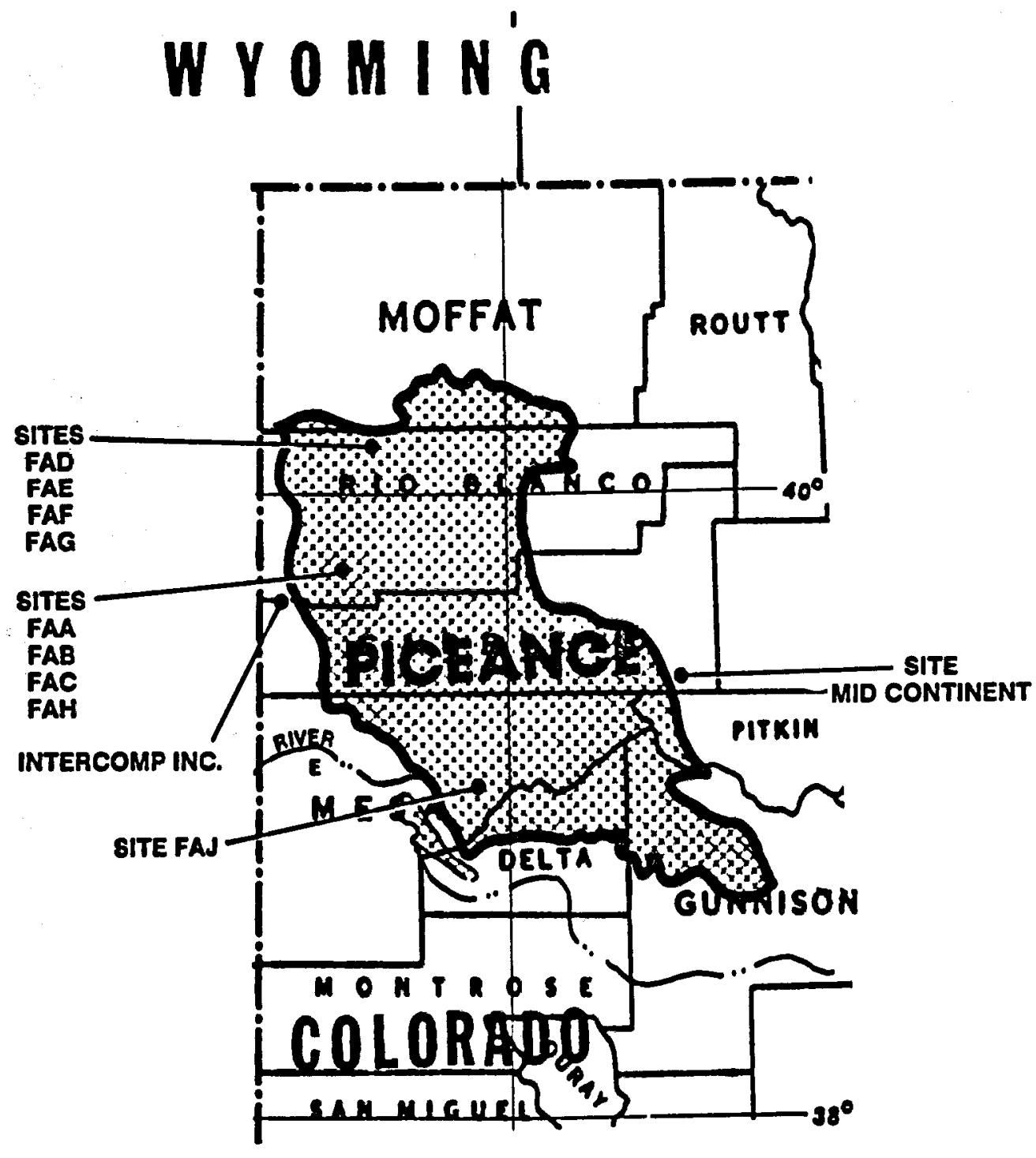

SITE FAI Not Shown (Confldential Data)

Figure 2-6. Piceance Basin, Target Area, and Well Sites 
Site FAG

Western Fuels Co.

Site FAH

Fuel Resources Development Co.

Site FAI

Cooperating Company Confidential

Site FAJ
Well test data package is complete

Well test data package is complete

Field operations complete; analyses in progress

Field operations complete; analyses in progress

These tests are described in detail in the following sections. 


\section{MRCP WELL SITE FAA}

Cooperator: Fuel Resources Development Company, Denver, Colorado Well Location: Rio Blanco County, Colorado (Section 28, Township 3S, Range 101W)

Company's Well Name: Cathedral D-28-3-101-S

Field Operation Dates: September 9-10, 1978

Logs and Tests Performed

- Borehole geophysical logging - Compensated neutron formation density and dual induction laterolog

- Conventional coring - 142 feet of core, coal samples taken at 1584 to 1586 and 1603 to 1604 feet

- Coal core desorption

- Proximate/ultimate analysis

Summary of Test Results

- Results from conventional coring

Lithology $\quad \begin{array}{r}\text { Sampl } \\ \text { Depth } \\ (\mathrm{ft})\end{array}$

Sample
Depth

HVB Bituminous

1585

HVB Bituminous

1603

Thickness

(ft)

2.0

1.0
Total Gas Per Unit (cc/gm) (cf/ton)

0.6

2.5
18

81 
Cooperator: Twin Arrow Drilling Company, Rangely, Colorado

Well Location: Rio Blanco County, Colorado (Section 13, Township 3S, Range 101W)

Company's Well Name: C\&K Well \#1-13

Field Operation Dates: October 3-7, 1978

Logs and Tests Performed

- Borehole geophysical logging - Compensated density, induction electric, and cement bond $\log$

- No coring or desorption testing conducted

Summary of Test Results

o Zones tested--573-581, 627-665, 726-736, 801-810 feet

- Testing Sequence, All Zones Results/Comments

Pressure and flow tests No pressure, no flow

Squeeze cemented 320 to 1050 feet

Cement bond $\log \quad 100$ to 883 feet

Perforated 1 shot per foot

Acid treated $7.5 \% \mathrm{HF}$

Swabbed Dry

Pressure and flow tests No pressure, no flow

- No gas show in coals. Drilling site is on mesa with valley floor lower than intervals tested. It is possible that any original gas in place was lost to the atmosphere. 
Cooperator: Twin Arrow Drilling Company, Rangely, Colorado

Well Location: Rio Blanco County, Colorado (Section 14, Township 3S, Range 101W)

Company's Well Name: C\&K Well \#4-14

Field Operation Dates: November-December 1978

Logs and Tests Performed

- Borehole geophysical loggging - Run on adjacent hole \#4-14x, includes dual induction, compensated densilog, acoustilog, spectralog, dual laterlog, micro-laterlog, and compensated densilog-compensated neutron

- Conventional coring - 150 feet of core. Coal desorption samples at 685.2 to $685.6,698.1$ to $698.45,770.9$ to 771.6 , 772.5 to $773.8,759.2$ to $760.0,801.9$ to $802.6,804.4$ to $805.0,809.4$ to 809.7 , and 986.5 to 987.3 feet

Summary of Test Results

\begin{tabular}{|c|c|c|c|c|}
\hline Lithology & $\begin{array}{l}\text { Sample } \\
\text { Depth } \\
\text { (ft) }\end{array}$ & $\begin{array}{c}\text { Thickness } \\
(\mathrm{ft})\end{array}$ & $\frac{\text { Total Gas }}{(\mathrm{cc} / \mathrm{gm})}$ & $\frac{\text { Per Unit }}{\text { (cf/ton) }}$ \\
\hline $\begin{array}{l}\text { Carbonaceous Shale } \\
\text { Carbonaceous Shale } \\
\text { Carbonaceous Shale } \\
\text { Carbonaceous Shale } \\
\text { HVB Bituminous } \\
\text { HVB Bituminous } \\
\text { HVB Bituminous } \\
\text { HVB Bituminous } \\
\text { HVB Bituminous }\end{array}$ & $\begin{array}{l}685 \\
698 \\
772 \\
771 \\
759 \\
809 \\
802 \\
804 \\
986\end{array}$ & $\begin{array}{r}0.6 \\
11.0 \\
14.6 \\
14.6 \\
0.9 \\
3.2 \\
3.2 \\
3.2 \\
7.8\end{array}$ & $\begin{array}{l}3.6 \\
6.7 \\
1.4 \\
0.8 \\
2.7 \\
7.6 \\
2.7 \\
1.4 \\
3.5\end{array}$ & $\begin{array}{r}115 \\
214 \\
46 \\
24 \\
86 \\
243 \\
88 \\
46 \\
111\end{array}$ \\
\hline
\end{tabular}


Cooperator: Western Fuels Association, Lakewood, Colorado

Well Location: Rio Blanco County, Colorado (Section 36, Township 3N, Range 101W)

Company's Well Name: Well \#310136-2

Field Operation Dates: June 11-20, 1979

Logs and Tests Performed

- Borehole geophysical logging: Electric, gamma-ray, gamma-garma density, and caliper

- Conventional coring: 43 feet of core. Coal at 1324.7 to $1325.9,1325.9$ to $1327.1,1330.65$ to $1338.8,1351.2$ to 1352.1 feet

- Desorption of coal samples

- Laboratory analysis of coal samples

Summary of Test Results

- Results from conventional coring:

\begin{tabular}{|c|c|c|c|c|}
\hline Lithology & $\begin{array}{l}\text { Sample } \\
\text { Depth } \\
\text { (ft) }\end{array}$ & $\begin{array}{c}\text { Thickness } \\
(\mathrm{ft})\end{array}$ & $\begin{array}{l}\text { Total Gas } \\
\frac{(\mathrm{cc} / \mathrm{gm})}{(\mathrm{c})}\end{array}$ & $\frac{\text { Per Unit }}{\text { (cf)ton) }}$ \\
\hline $\begin{array}{l}\text { Coal } \\
\text { Coal } \\
\text { Coal } \\
\text { Coa1 } \\
\text { Coal }\end{array}$ & $\begin{array}{l}1325 \\
1331 \\
1333 \\
1336 \\
1351\end{array}$ & $\begin{array}{l}2.4 \\
8.2 \\
8.2 \\
8.2 \\
0.9\end{array}$ & $\begin{array}{l}1.9 \\
1.9 \\
1.7 \\
1.5 \\
1.5\end{array}$ & $\begin{array}{l}61 \\
61 \\
54 \\
48 \\
48\end{array}$ \\
\hline
\end{tabular}


Cooperator: Western Fuels Association, Lakewood, Colorado

Well Location: Rio Blanco County, Colorado (Section 1, Township 2N, Range 101W)

Company's Well Name: Well \#21011-5

Field Operation Dates: June 26 - July 1, 1979

Logs and Tests Performed

- Borehole geophysical logging: Electric, gamma-ray, gamma-gamma density and caliper

- Conventional coring: 79 feet of core. Coal at 741.75 to $748.18,758.71$ to $761.01,764.92$ to $770.0,770.0$ to 772.5 , 794.65 to $796.8,797.5$ to $801.5,805.6$ to 810.97 feet. Eight samples placed in canisters for desorption

- Desorption of coal samples

- Laboratory analysis of coal samples

Summary of Test Results

o Results from conventional coring:

\begin{tabular}{|c|c|c|c|c|}
\hline Lithology & $\begin{array}{l}\text { Sample } \\
\text { Depth } \\
\text { (ft) }\end{array}$ & $\begin{array}{c}\text { Thickness } \\
\text { (ft) }\end{array}$ & $\frac{\text { Total Ga }}{(\mathrm{cc} / \mathrm{gm})}$ & $\frac{\text { Per Unit }}{\text { (cf/ton) }}$ \\
\hline $\begin{array}{l}\text { Coal } \\
\text { Coal } \\
\text { Coal } \\
\text { Coal } \\
\text { Coal } \\
\text { Coal } \\
\text { Coal } \\
\text { Coal }\end{array}$ & $\begin{array}{l}741 \\
744 \\
759 \\
765 \\
772 \\
795 \\
797 \\
809\end{array}$ & $\begin{array}{l}6.43 \\
6.43 \\
2.30 \\
7.58 \\
7.58 \\
2.15 \\
4.0 \\
5.37\end{array}$ & $\begin{array}{l}0.5 \\
2.1 \\
1.7 \\
2.2 \\
2.8 \\
1.9 \\
1.9 \\
1.1\end{array}$ & $\begin{array}{l}16{ }^{\star} \\
69 \\
54 \\
70 \\
90 \\
64 \\
61 \\
35\end{array}$ \\
\hline
\end{tabular}

*Possible canister leak 
Cooperator: Western Fuels Association, Lakewood, Colorado

Well Location: Rio Blanco County, Colorado (Section 29, Township 3N, Range 101W)

Company's Well Name: Well \# 310129-4

Field Operation Dates: August 23-31, 1979

\section{Logs and Tests Performed}

- Borehole geophysical logging: Electric, gamma-ray, gamma-garma density, and caliper

- Conventional coring: 45 feet of core. Coal at 879.2 to 882.5 feet, 904.3 to 912.0 feet

- Desorption of coal samples

- Laboratory analysis of coal samples

\section{Summary of Test Results}

\begin{tabular}{|c|c|c|c|}
\hline Lithology & $\begin{array}{l}\text { Sample } \\
\text { Depth } \\
\text { (ft) } \\
\end{array}$ & $\begin{array}{l}\text { Thickness } \\
(\mathrm{ft}) \\
\end{array}$ & $\begin{array}{l}\text { Total Gas Per Unit } \\
\text { (cc/gm) } \frac{(\mathrm{cf} / \text { ton })}{}\end{array}$ \\
\hline $\begin{array}{l}\text { Coal } \\
\text { Siltstone } \\
\text { Coal }\end{array}$ & $\begin{array}{l}880 \\
905 \\
911\end{array}$ & $\begin{array}{c}3.3 \\
30 \\
7.7\end{array}$ & $\begin{array}{l}0.2 \\
0.1 \\
0.01\end{array}$ \\
\hline
\end{tabular}

*Does not include lost gas 
Cooperator: Western Fuels Association, Lakewood, Colorado

Well Location: Rio Blanco County, Colorado (Section 35, Township 3N, Range 101W)

Company's Well Name: Well \# 310135-4

Field Operation Dates: August 23-31, 1979

Logs and Tests Performed

- Borehole geophysical logging: Electric, gamma-ray, gamma-gamma density, and caliper

- Conventional coring: 28.9 feet of core. Coal at 1187.46 to 1190.96 feet, 1198.35 to 1206.75 feet

- Desorption of coal samples

- Laboratory analysis of coal samples in progress

Summary of Test Results

- Results from conventional coring

\begin{tabular}{|c|c|c|c|}
\hline Lithology & $\begin{array}{l}\text { Sample } \\
\text { Depth } \\
\text { (ft) } \\
\end{array}$ & $\begin{array}{c}\text { Thickness } \\
(\mathrm{ft}) \\
\end{array}$ & $\begin{array}{l}\text { Total Gas Per Unit } \\
\text { (cc/gm) }(\text { (cf/ton) }\end{array}$ \\
\hline $\begin{array}{l}\text { Siltstone floor } \\
\text { rock } \\
\text { Coal }\end{array}$ & $\begin{array}{l}1191 \\
1206\end{array}$ & $\begin{array}{l}3.5 \\
8.4\end{array}$ & $\begin{array}{l}0.04 \\
1.0\end{array}$ \\
\hline
\end{tabular}

*Does not include lost gas 
Cooperator: Fuel Resources Development Company (Fuelco), Denver, Colorado

Well Location: Rio Blanco County, Colorado (Section 26, Township 3S, Range 101W)

Company's Well Name: D-26-3-101-S

Field Operation Dates: August 12-17, 1979

Logs and Tests Performed

- Borehole geophysical logging: Electric, gamma-ray, compensated density, and caliper

- Conventional coring: 96 feet of core. Coal at 1148.9 to $1151.9,1154.0$ to $1159.0,1183.2$ to $1185.7,1205.7$ to 1206.5 , 1209.1 to $1217.8,1223.0$ to 1225.0

- Laboratory analysis of roof and floor rocks complete; data not yet available

- Desoprtion of coal samples

Summary of Test Results

o Results from conventional coring:

\begin{tabular}{|c|c|c|c|c|}
\hline Lithology & $\begin{array}{l}\text { Sample } \\
\text { Depth } \\
\text { (ft) }\end{array}$ & $\begin{array}{c}\text { Thickness } \\
(\mathrm{ft}) \\
\end{array}$ & $\begin{array}{l}\text { Total Gas } \\
\frac{(\mathrm{cc} / \mathrm{gm})}{}\end{array}$ & $\begin{array}{l}\text { Per Unit } \\
\text { (cf/ton) }\end{array}$ \\
\hline $\begin{array}{l}\text { Coal } \\
\text { Coal } \\
\text { Coal }\end{array}$ & $\begin{array}{l}1210 \\
1211 \\
1223\end{array}$ & $\begin{array}{l}8.7 \\
8.7 \\
2.0\end{array}$ & $\begin{array}{l}0.5 \\
0.8 \\
0.6\end{array}$ & $\begin{array}{l}16 \\
26 \\
19\end{array}$ \\
\hline
\end{tabular}


(Italics denote changes or progress since March 31, 1980)

MRCP WELL SITE FAI

Cooperator: Confidential

Well Location: Piceance Basin (specific location confidential)

Company's Well Name: (Confidential Well No. 6)

Field Operation Dates: April 18-30, 1980

Logs and Tests Performed

- Borehole geophysical logs

- Completed coring of 68 feet

- A total of about 42 feet of coal was encountered at the following depths:

Core Intervals (ft)

$4682-4696$ (14 feet)

4726-4759 (33 feet)

4798-4819 (21 feet)

Core Composition

41.5 feet of coal

5.0 feet of carhonaceous shale

21.5 feet of sandstone

Core recovery of shale + sandstone - $100 \%$

Core recovery of coal - $25 \%$

- Desorption of coal core and some cuttings is in progress (16 samples)

- Lab analysis of coal samples to be conducted on completion of desorption 
(Italics denote changes or progress since March 31, 1980)

Stomamy of Test Results

\begin{tabular}{|c|c|c|c|c|}
\hline Lithologu & $\begin{array}{l}\text { Sample } \\
\text { Depth } \\
\text { (ft) } \\
\end{array}$ & $\begin{array}{c}\text { Thickness } \\
(f t) \\
\end{array}$ & $\frac{\text { Total Gas }}{\text { (cc/gm) }}$ & $\frac{\text { Per Unit }}{\text { (cf/ton) }}$ \\
\hline Coal & With \#1 core & - & 1.3 & 41 \\
\hline Non-Carb. shate & With \#1 core & - & 0.1 & 3 \\
\hline Coal/shale shaker & With \#2 core & 41.5 of coal & 4.1 & 131 \\
\hline Coal/shale shaker & With \#2 core & 41.5 of coal & 5.0 & 160 \\
\hline Coal & 4756 & $\begin{array}{l}5.0 \text { of carbon- } \\
\text { aceous shale }\end{array}$ & 5.5 & 176 \\
\hline Coat & 4731 & $\begin{array}{l}5.0 \text { of carbon- } \\
\text { aceous shate }\end{array}$ & 3.3 & 105 \\
\hline Carbonaceous shate & 4735 & $\begin{array}{l}5.0 \text { of carbon- } \\
\text { aceous shate }\end{array}$ & 0.2 & 7 \\
\hline Coar & 4726 & $\begin{array}{l}5.0 \text { of carbon- } \\
\text { aceous shate }\end{array}$ & 1.0 & 32 \\
\hline Coar & 4755 & $\begin{array}{l}5.0 \text { of carbon- } \\
\text { aceous shate }\end{array}$ & 9.1 & 292 \\
\hline Coat & 4753 & $\begin{array}{l}4.0 \text { of carbon- } \\
\text { aceous shate }\end{array}$ & 5.8 & 185 \\
\hline Coal/shale shaker & With \#3 core & $\begin{array}{l}5.0 \text { of carbon- } \\
\text { aceous shate }\end{array}$ & 4.7 & 150 \\
\hline Coar & 4804 & $\begin{array}{l}5.0 \text { of carbon- } \\
\text { aceous shate }\end{array}$ & 8.9 & 284 \\
\hline Coat & 4801 & $\begin{array}{l}5.0 \text { of carbon- } \\
\text { aceous shale }\end{array}$ & 8.3 & 267 \\
\hline Coal & 4798 & $\begin{array}{l}5.0 \text { of carbon- } \\
\text { aceous shale }\end{array}$ & 8.8 & 283 \\
\hline Rolling sandstone & $?$ & $\begin{array}{l}21.5 \text { of } \\
\text { sandstone }\end{array}$ & 5.8 & 186 \\
\hline Coal & $?$ & $\begin{array}{l}21.5 \text { of } \\
\text { sandetone }\end{array}$ & 2.5 & 79 \\
\hline
\end{tabular}


(Italics denote changes or progress since March 31, 1980)

\section{MRCP WELL SITE FAJ}

Cooperator: Adol ph Coors, Golden, Colorado

Well Location: Mesa County, Colorado (Section 24, Township 105W, Range 97W)

Company's Well Name: Nichols \#1-24

Field Operation Dates: April 18-June 25, 1980

Logs and Tests Performed (Type III)

- The well was fractured during the stimulation treatment performed in May 1880

- A subsequent infectivity test was performed on Jume 24 and 25 to evaluate the results of the fracture

- Water samples taken during swabbing operations prior to the injectivity test are being analyzed by Dowell and a water testing zaboratory

Sumamy of Test Results

- Average post-fracture permeability was $19 \mathrm{md}$ in the fractured formation

- Initial reservoir pressure in the perforated zone (2625 to 2633 feet) was 1079 psia

- Hydrautic Stimulation:

- After flowing back well and swabbing frac fluid and nitrogen, well failed to produce methane in any production size rate. Small quantities of gas were observed, but flow fell off to zero in 5 to 10 minutes

o Injectivity Test:

- Data obtained in the injectivity test cannot be used to verify that the Cameo coal seam itself was fractured. The only conclusion that can be drawn from the test is that a formation previously stimulated accepted fluids during the injectivity test. Additional testing in the form of a differential temperature survey could indicate where produced fluids are coming from. 
- If it were known that the cameo coal seam definitely contained producible quantities of gas, the absence of post-frac gas production would mean that the coalbed itself was not fractured and that the fracture proceeded elsewhere. It can be inferred from the test results that the coalhed is within the drainage area if the well contains insufficient gas to make it producible. This is based on the estimated average permeability to liquid being relatively'high for a coalbed (about $19 \mathrm{md}$ ). The effective permeability to gas should be considerably higher provided the formation is dewatered, which would be the oase with a permeability to water of $19 \mathrm{md}$.

- It is possible that the injected fluids entered an adjacent formation by channeling behind the casing for some distance up to the down well and/or through fractures created by the previous stimulation treatment. However, according to Coors Energy Division personnel, a cement bond log was rum previously in the well as part of the original well completion procedures and indicated competent bonding between the casing string and cement sheath at that time. 
$\begin{array}{ll}2.3 .2 .6 & P O W D E R \quad R I V E R \quad B A S I N \\ & (W Y O M I N G \quad A N D \quad M O N T A N A)\end{array}$

The Powder River Basin contains the nation's largest coal resources. Most of the thick coalbeds occur in the upper member--the Tongue River Member--of the Fort Union Formation, and the overlying Wasatch

Formation. Coalbeds do occur in the lower members of the Fort Union Formation, as well as the Lance and Mesaverde Formations, but generally they are thinner and less continuous. Some of these older coalbeds crop out in the southwestern portion of the Powder River Basin, near Glenrock and Douglas, Wyoming.

The coal resource of the Powder River Basin has been calculated from subsurface data to be 1.3 trillion tons. Most of it is in thick beds that are relatively near-surface--with most of the coal at a depth less than 2,500 feet, even in the basin center. Powder River Basin coal ranges in rank from lignite $A$ through subbituminous $A$. Generally, Powder River Basin coals are low in sulfur with low to moderate ash content, although ash content can vary considerably. Commonly, the coals have an as-received moisture content of 20 to 30 percent, and volatile matter and fixed carbon contents of 30 to 40 percent.

The total number of coalbeds in the Powder River Basin is difficult to determine because the beds split, coalesce, and are sometimes discontinuous, with beds pinching out and new beds appearing. Some correlations between the beds of various fields have been made, but much remains to be done. In the Sheridan County area of Wyoming, as many as 11 persistent coalbeds occur in the Wasatch Formation. In other areas, as many as 12 to 18 coalbeds occur, most of them within the Fort Union Formation. Most of the Wasatch beds occur under less than 200 feet of overburden. However, the Wasatch and Fort Union Formations together attain a maximum thickness of 3,970 feet in the Buffalo area.

Two of the largest coalbeds in the basin are the Wyodak-Anderson and the Lake De Smet beds. The Wyodak-Anderson coalbed crops out over a north-south distance of 120 miles in the Gillette Coal Field. It, and the beds correlative to it, persist downdip to the deepest part of the Powder River Basin. The Wyodak-Anderson bed is locally up to 150 feet thick, but averages 50 to 100 feet in thickness. Based on these figures, the bed contains at least 100 billion tons of coal to a depth of 2,000 feet. This is the largest tonnage in a single continuous coalbed anywhere in the U.S.

The Lake De Smet bed, in the Buffalo Coal Field, is thought to be the thickest coalbed in the U.S. and second thickest in the world. It is 15 miles long, 70 to 220 feet thick, and one-half to two miles wide. 
All data collected to date indicate that the Powder River Basin should provide several favorable target areas for recovery of methane gas from coalbeds using shallow wells.

The area considered to be the prime methane exploration target within the Powder River Basin is illustrated in Figure 2-7. It encompasses portions of Campbel1, Sheridan, and Johnson Counties in Wyoming, and Big Horn and Powder River Counties in Montana. Factors used in delineating the target boundaries include:

- Restricting the area to lands underlain by the Tongue River Member of the Fort Union Formation, and additionaliy to:

- Areas in which shallow drill holes are known to flow anomalously large amounts of methane

- Areas in which flowing artesian wells are concentrated

- Areas in which three or more individually thick coalbeds are coalesced together into a single superbed.

At the end of this reporting period, the status of well tests was as follows:

Test Well

Site IAA

USGS

Site IAB

Montana Bureau of

Mines and Geology

Site IAC

Montana Bureau of

Mines and Geology

Site IAD

USGS

Site IAE

USGS

Site IAF

USGS $\underline{\text { Status }}$

Well test data package complete

Well test data package complete

Well test data package complete

Field operations complete; analyses in progress

Field operations complete; analyses in progress

Field operations complete; analyses in progress

These tests are described in detail in the following sections. 


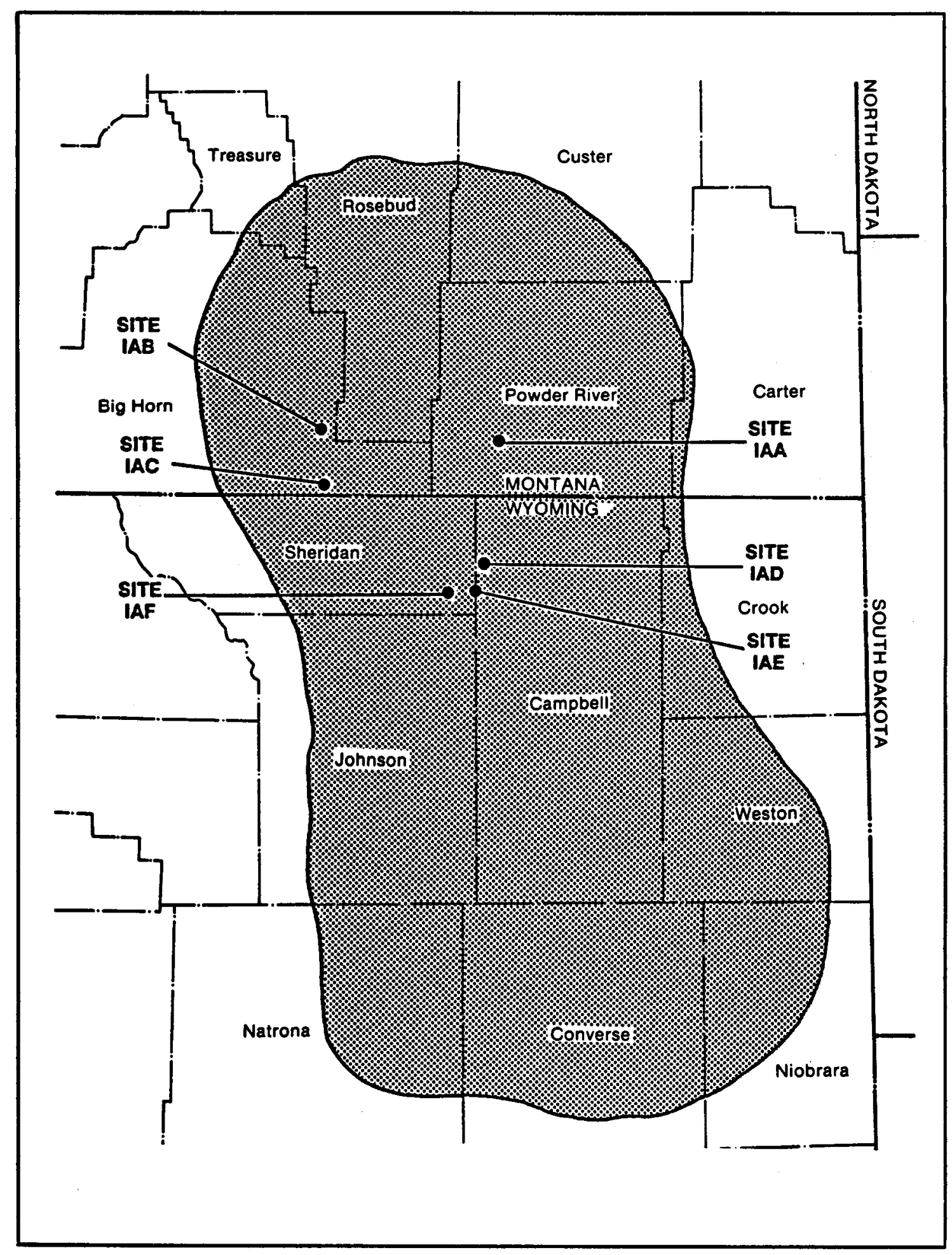

Figure 2-7. Powder River Basin, Target Area, and Well Sites 
Cooperator: U.S. Geological Survey, Coal Branch, Denver, Colorado Well Location: Powder River County, Montana (Section 22, Township 8S, Range 47E)

Company's Well Name: USGS Well 79-BR-6

Field Operation Dates: August 28-31, 1979

Logs and Tests Performed

- Borehole geophysical logging: Gamma-ray, caliper, density, S.P., and resistivity

- Drilling and coring completed

- Conventional coring started at 236.5 feet

- Anderson seam top at 243.2 feet; seam 52.6 feet thick

- Canyon A-B (Dietz) seam top at 377.0 feet; seam 24.5 feet thick

- Desorption of coal samples

- Laboratory analysis of coal samples and roof and floor rock to be completed

Summary of Test Results

Lithology

Lignite A

Lignite A

Subbituminous $C$

Subbituminous $B$

Subbituminous $B$

Subbituminous $B$
Sample Depth

(ft)

248

266

291

378

385

401
Thickness

(ft)

52.6

52.6

52.6

24.5

24.5

24.5
Total Gas Per Unit

(cc/gm) (cf/ton)

0.06

0.05

0.03

0.10

0.04

0.10

2
2
1
3
1
3


Cooperator: Montana Bureau of Mines and Geology, Butte, Montana Well Location: Big Horn County, Montana (Section 5, Township 7S, Range 40E)

Company's Well Name: Site I: Well \# US-7735

Field Operation Dates: September 6-9, 1979

Logs and Tests Performed

- Conventional coring: 1114.6 feet of core. Coal at 121 to $145.5,347$ to $352.5,390.3$ to $402.8,620$ to 673.5 feet

- Borehole geophysical logging: Gamma-gamma density, SP, resistivity, gama-ray

- Drill stem testing: Tool plugged resulting in limited success. Formation pressure is 51 psig

- Desorption of coal samples

- Physical properties analysis of overburden, interburden, and underburden

Summary of Test Results

\begin{tabular}{|c|c|c|c|c|}
\hline Lithology & $\begin{array}{l}\text { Sample } \\
\text { Depth } \\
\text { (ft) }\end{array}$ & $\begin{array}{c}\text { Thickness } \\
(\mathrm{ft})\end{array}$ & $\begin{array}{l}\text { Total Gas } \\
(\mathrm{cc} / \mathrm{gm})\end{array}$ & $\begin{array}{l}\text { Per Unit } \\
\text { (cf/ton) }\end{array}$ \\
\hline $\begin{array}{l}\text { HVC Bituminous } \\
\text { Subbituminous } B \\
\text { Subbituminous } \\
\text { Subbituminous } \\
\text { Subbituminous } \\
\text { B } \\
\text { Subbituminous } \\
\text { Subbituminous } \\
\text { Subbituminous A } \\
\text { Subbituminous A } \\
\text { Subbituminous A }\end{array}$ & $\begin{array}{l}121 \\
134 \\
144 \\
348 \\
390 \\
401 \\
621 \\
631 \\
657 \\
672\end{array}$ & $\begin{array}{r}24.5 \\
24.5 \\
24.5 \\
5.5 \\
12.7 \\
12.7 \\
20.0 \\
20.0 \\
6.5 \\
5.0\end{array}$ & $\begin{array}{l}0.1 \\
0.2 \\
0.2 \\
0.04 \\
0.03 \\
0.03 \\
0.04 \\
0.2 \\
0.2 \\
0.3\end{array}$ & $\begin{array}{r}3 \\
3 \\
6 \\
1 \\
1 \\
1 \\
1 \\
6 \\
6 \\
10\end{array}$ \\
\hline
\end{tabular}


Cooperator: Montana Bureau of Mines and Geology, Butte, Montana

Well Location: Big Horn County, Montana (Section 7, Township 9S, Range 40E)

Company's Well Name: Site II, Well \# US-7746

Field Operation Dates: September 10-12, 1979

\section{Logs and Tests Performed}

- Borehole geophysical logging: Gamma-gamma density, SP, resistivity log, gamma-ray

- Conventional coring: 157 feet of core. Coal at 154.7 to $169.4,171$ to $172.7,172.9$ to $173.3,173.5$ to $174.5,424.0$ to $503.4,538.8$ to $603.0,742.7$ to $762.2,762.5$ to 769.7 feet

- Desorption of coal samples

- Physical properties analysis of overburden, interburden, and underburden

\section{Summary of Test Results}

\begin{tabular}{|c|c|c|c|c|}
\hline Lithology & $\begin{array}{l}\text { Sample } \\
\text { Depth } \\
\text { (ft) }\end{array}$ & $\begin{array}{c}\text { Thickness } \\
(\mathrm{ft})\end{array}$ & $\begin{array}{l}\text { Total Gas } \\
\text { (cc/gm) }\end{array}$ & $\begin{array}{l}\text { Per Unit } \\
\text { (cf/ton) }\end{array}$ \\
\hline $\begin{array}{l}\text { Subbituminous B } \\
\text { Subbituminous B } \\
\text { HVC Bituminous } \\
\text { Subbituminous B } \\
\text { HVC Bituminous } \\
\text { Subbituminous A } \\
\text { Subbituminous A } \\
\text { Subbituminous A } \\
\text { HVC Bituminous } \\
\text { Subbituminous A }\end{array}$ & $\begin{array}{l}168 \\
173 \\
448 \\
456 \\
479 \\
491 \\
502 \\
602 \\
755 \\
769\end{array}$ & $\begin{array}{r}4.9 \\
0.4 \\
77.4 \\
77.4 \\
77.4 \\
77.4 \\
77.4 \\
9.2 \\
9.7 \\
7.2\end{array}$ & $\begin{array}{l}0.04 \\
0.05 \\
0.10 \\
0.10 \\
0.15 \\
0.04 \\
0.02 \\
0.20 \\
0.25 \\
0.4\end{array}$ & $\begin{array}{r}1 \\
2 \\
3 \\
3 \\
5 \\
1 \\
1 \\
7 \\
8 \\
13\end{array}$ \\
\hline
\end{tabular}


(Italics denote changes since March 31, 1980.)

MRCP WELL SITE IAD

Cooperator: U.S. Geological Survey, Coal Branch, Denver, Colorado

We11 Location: Campbell County, Wyoming (Section 20, Township 55N, Range 75W)

Company's Well Name: USGS Well 80-AU-14

Field Operation Dates: July 15-22, 1980

Loge and Tests Performed

- Borehole geophysical logging: Gamma-ray, density, resistivity and caliper

- Conventional coring - 126.2 feet cored, recovered 1137 feet Coalbeds cored:

Smith bed at 294.8 to 329.8 feet

Anderson/Conyon bed at 680.6 to 755.0 feet

- Desorption of coal samples

- Proximate and ultimate analyses of coal samples

Summary of Test Results

\begin{tabular}{|c|c|c|c|c|c|}
\hline ithology & & $\begin{array}{l}\text { Sample } \\
\text { Depth } \\
\text { (ft) } \\
\end{array}$ & $\begin{array}{c}\text { Thickness } \\
(f t)\end{array}$ & $\begin{array}{l}\text { Total Gas } \\
(\mathrm{cc} / \mathrm{gm})\end{array}$ & $\begin{array}{l}\text { Per Init* } \\
\text { (of/ton) }\end{array}$ \\
\hline $\begin{array}{l}\text { Coal/Anderson } \\
\text { Coal/Anderson } \\
\text { Coal/Anderson } \\
\text { Coal/Anderson }\end{array}$ & $\begin{array}{l}\text { Canyon } \\
\text { Canyon } \\
\text { Canyon } \\
\text { Canyon }\end{array}$ & $\begin{array}{l}742 \\
738 \\
685 \\
723\end{array}$ & $\begin{array}{l}74.4 \\
74.4 \\
74.4 \\
74.4\end{array}$ & $\begin{array}{l}0.8 \\
0.6 \\
0.7 \\
0.9\end{array}$ & $\begin{array}{l}26 \\
18 \\
21 \\
30\end{array}$ \\
\hline
\end{tabular}

*Does not inclule residual gas 
(Italics denote changes since March 31, 1980.)

\section{MRCP WELL SITE IAE}

Cooperator: U.S. Geological Survey, Coal Branch, Denver, Colorado

Well Location: Sheridan County, Wyoming (Section 5, Township 54N, Range 76W)

Company's Well Name: USGS Well 80-AU-16

Field Operation Dates: July 29 - August 2, 1980

\section{Loge and Tests Performed}

- Geophysical logging - Gamma, density, resistivity, and caliper

- Conventional coring - Arvada, Smith, and Anderson seams

- Desorption of coal samples

- Proximate and ultimate analyses of coal samples

\section{Sumary of Test Resulte}

Preliminary desorption data from conventional cores:

\begin{tabular}{|c|c|c|}
\hline $\begin{array}{l}\text { Lithologyl } \\
\text { Coal Horizon }\end{array}$ & $\begin{array}{l}\text { Sample } \\
\text { Depth } \\
(f t)\end{array}$ & $\begin{array}{l}\text { Total Gas Per Unit } \\
\text { (cc/gm) (of/ton) }\end{array}$ \\
\hline $\begin{array}{l}\text { Coal/Arvada } \\
\text { Coal/Smith } \\
\text { Coal/Smith } \\
\text { Coal/Anderson } \\
\text { Coal/Anderson } \\
\text { Coal/Anderson }\end{array}$ & $\begin{array}{r}73 \\
271 \\
312 \\
619 \\
625 \\
635\end{array}$ & $\begin{array}{l}\text { In desorption } \\
\text { In desorption } \\
\text { In desorption } \\
\text { In desorption } \\
\text { In desorption } \\
\text { In desorption }\end{array}$ \\
\hline
\end{tabular}


(Italics denote changes since March 31, 1980.)

\section{MRCP WELL SITE IAF}

Cooperators: U.S. Geological Survey, Coal Branch, Denver, Colorado

Well Location: Sheridan County, Wyoming (Section 3, Township 54N, Range $77 \mathrm{~W}$ )

Company's Well Name: USGS Well 80-AU-7

Field Operation Dates: July 29 - August 2, 1980

Logs and Tests Performed

- Geophysical logging - Gama, density, resistivity, and caliper

- Conventional coring - Smith and Anderson seams

- Desorption of coal samples

- Proximate and ultimate analyses and coal samples

Sumnary of Test Results

Preliminary desorption data from conventional cores:

\begin{tabular}{|c|c|c|c|}
\hline $\begin{array}{c}\text { Lithology/ } \\
\text { Coal Horizon } \\
\end{array}$ & $\begin{array}{l}\text { Sample } \\
\text { Depth } \\
\text { (ft) } \\
\end{array}$ & $\begin{array}{l}\text { Total Gas } \\
(\mathrm{co} / \mathrm{gm})\end{array}$ & $\begin{array}{l}\text { Per Unit } \\
\text { (cf/ton) }\end{array}$ \\
\hline $\begin{array}{l}\text { Coal/Smith } \\
\text { Coal/Smith } \\
\text { Coal/Anderson } \\
\text { Coal/Anderson }\end{array}$ & $\begin{array}{l}206 \\
300 \\
594 \\
604\end{array}$ & $\begin{array}{l}\text { In deso } \\
\text { In deso } \\
\text { In deso } \\
\text { In deso }\end{array}$ & $\begin{array}{l}\text { rption } \\
\text { rption } \\
\text { rption } \\
\text { rption }\end{array}$ \\
\hline
\end{tabular}




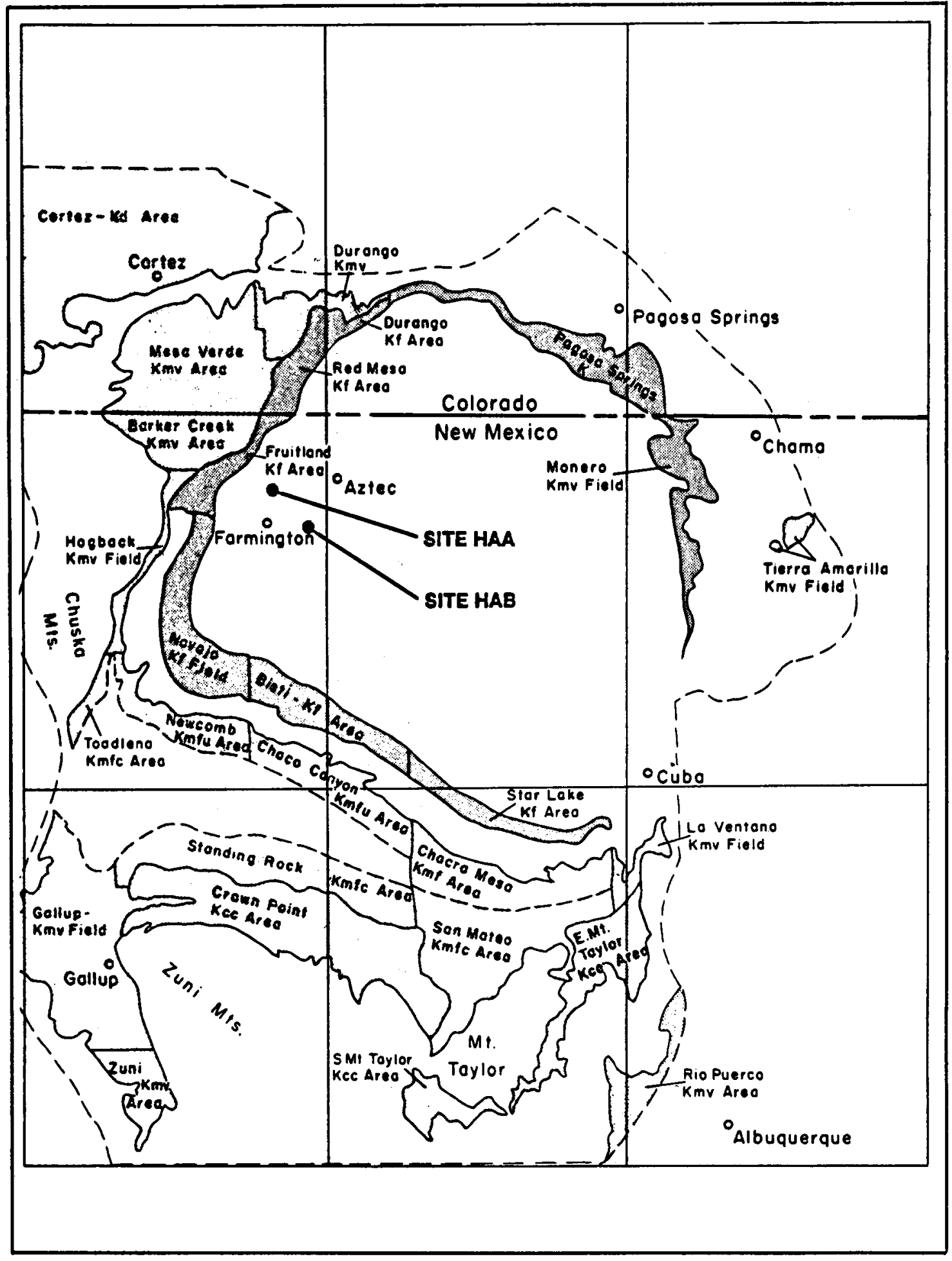

Figure 2-8. San Juan Basin, Target Area, and Well Sites 
The status of test wells in this basin during this reporting period is as follows:

Test Well

Site HAA

Western Coal Co.

Site $H A B$

Navajo Nations

Mineral Dept.

\section{Status}

Well test data package is complete

Well test data package is complete

These tests are described in detail in the following sections. 
Cooperator: Western Coal Company, Albuquerque, New Mexico

Well Location: San Juan County, New Mexico (Section 22, Township 30N, Range 15W)

Field Operation Dates: June 16-17, 1978

Logs and Tests Performed

- Conventional coring: 43.5 feet of core cut between 370 and 413.5 feet encountering cumulative coal thickness of 12.2 feet

- Coal core desorption

- Proximate/ultimate analysis

- No borehole geophysical log runs

Summary of Test Results

\begin{tabular}{|c|c|c|c|c|}
\hline Lithology & $\begin{array}{l}\text { Sample } \\
\text { Depth } \\
\text { (ft) } \\
\end{array}$ & $\begin{array}{c}\text { Thickness } \\
(\mathrm{ft})\end{array}$ & $\begin{array}{l}\text { Total Gas } \\
\text { (cc/gm) }\end{array}$ & $\begin{array}{l}\text { Per Unit } \\
\text { (cf/ton) }\end{array}$ \\
\hline $\begin{array}{l}\text { VA Bitum } \\
\text { VB Bitum }\end{array}$ & $\begin{array}{l}398 \\
399\end{array}$ & $\begin{array}{l}8.2 \\
8.2\end{array}$ & $\begin{array}{l}2.3 \\
0.5\end{array}$ & $\begin{array}{l}73 \\
16\end{array}$ \\
\hline
\end{tabular}


(Italics denote changes since March 31, 1980.)

\section{MRCP WELL SITE HAB}

Cooperator: Navajo Nation Minerals Department, Window Rock, Arizona USGS Coal Branch, Denver, Colorado

Well Location: San Juan County, New Mexico (Section 18, Township 18N, Range 14W)

Company's Well Name: K-3 well

Field Operation Dates: Apri1 26-30, 1980

\section{Logs and Tests Performed}

- Conventional coring: Cancelled due to blowout

- Drill chip collection: Coal chips were collected from a coalbed at 815 to 835 feet

- Rorehole geophysical logging: Cancelled due to blowout

- Drill chip decorption

- sample of gas taken duming blowout sent to lab for analysis

\section{Sumary of Test Results}

- Desorption of coal chips in progress; initial indication of low gas content 
Coal resources in the southern Appalachians, shown in Figure 2-9, are found in sequences of shale, siltstone, sandstone, and conglomerate in the Pottsville group of Pennsylvanian age. There are approximately 25 minable coal seams with total thickness ranging from 15 to 50 feet. The estimated coal resource for the area is approximately 40 billion tons. Individual seams range in thickness from a few inches to 7 feet, average three to five feet, and are continuous over fairly large areas. The coal rank is from low to high volatile bituminous. Mine emission data suggest that at least four seams contain significant quantities of methane. The coal seams and their adjacent formations are nearly horizontal within the Warrior Basin proper, but are gently to tightly folded and faulted along the basin's eastern margin. Overburden thickness varies from 0 to greater than 6,000 feet with all current mining less than 3,000 feet deep.

The MRCP testing in the Warrior Basin has evaluated the methane content of four coal seams from the No. 1 Grimsley 35-15 well. The methane content is low with values ranging from 16 to 102 cubic feet per ton. 


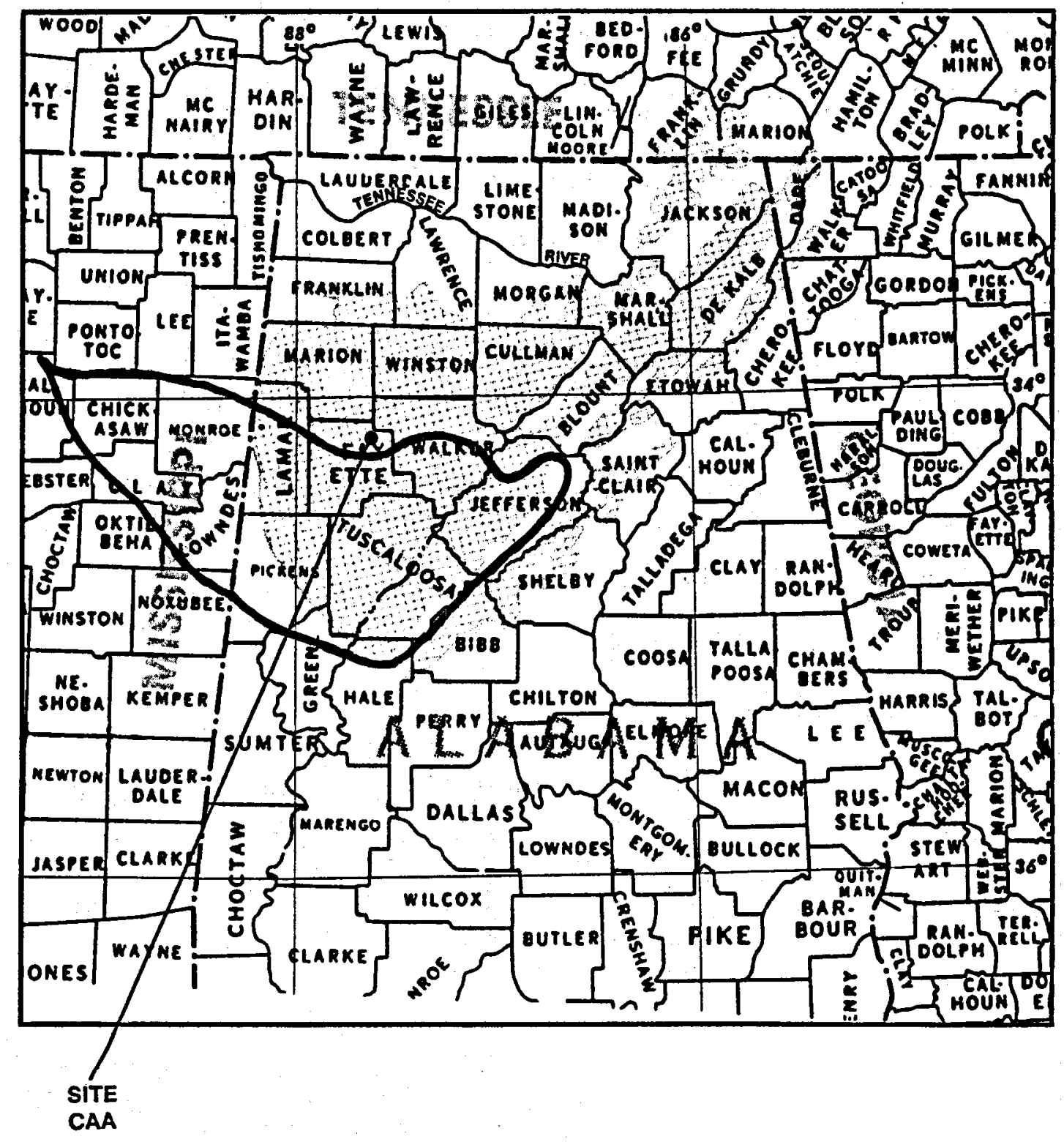

SCALE: $\quad 1: 2,500,000$

$100 \quad$ SCALE $\quad 0^{2,500,000} 100$

Figure 2-9. Southern Appalachian/Warrior Basin Target Area and Well Site 
Cooperator: Grace Petroleum Corporation, Jackson, Mississippi

Well Location: Fayette County, Alabama, Davis Chapel Field, (Section 34, Township 14S Range 11W)

Company's Well Name: Well No. 1-Grimsley 35-15

Field Operation Dates: July 6-23, 1979

Logs and Tests Performed

- Borehole geophysical logging: Dual induction (DISF), formation density, compensated neutron, microlog and borehole compensated sonic log

o Conventional coring: 80 feet of core. Coal at 593 to 597, 1100 to 1102,1675 to 1676,1879 to 1882 feet

- Desorption of coal samples

- Laboratory analyses of coal samples

Summary of Test Results

\begin{tabular}{|c|c|c|c|c|}
\hline Lithology & $\begin{array}{l}\text { Sample } \\
\text { Depth } \\
(\mathrm{ft})\end{array}$ & $\begin{array}{c}\text { Thickness } \\
(\mathrm{ft}) \\
\end{array}$ & $\begin{array}{l}\text { Total Gas } \\
\text { (cc/gm) }\end{array}$ & $\begin{array}{l}\text { Per Unit } \\
\text { (cf/ton) }\end{array}$ \\
\hline $\begin{array}{l}\text { HVB Bituminous } \\
\text { Lignite } \\
\text { HVB Bituminous } \\
\text { HVA Bituminous }\end{array}$ & $\begin{array}{r}593 \\
1102 \\
1675 \\
1880\end{array}$ & $\begin{array}{l}2.5 \\
2.0 \\
2.5 \\
3.0\end{array}$ & $\begin{array}{l}2.8 \\
3.2 \\
0.6 \\
2.2\end{array}$ & $\begin{array}{r}90 \\
102 \\
19 \\
70\end{array}$ \\
\hline
\end{tabular}


The Western Washington Basin, shown in Figure 2-10, encompasses three regions with an area of approximately 7,500 square miles. Though principally Eocene in age, coal deposits in this basin range from Paleocene to early 01igocene. The deposits formed on a broad low-lying coastal plain in a tropical forest and swamp environment that existed along the eastern shorel ine of a north-trending, paleo-sedimentary basin. They al so interfinger with and grade into, marine coal-bearing rocks to the west. All coal-bearing areas have been structurally deformed since their formation by folding and faulting, and deformation in many of the areas has been intense. Overlying the coal-bearing rocks in most areas of Western Washington is a thick mantle of glacial deposits of Pleistocene age. Deposits from at least four separate glacial advances are over 3,000 feet thick in parts of the Puget Lowl ands.

Knowledge of coal geology in the basin has been gained almost entirely from mining operations in the Bellingham, Green River, WilkesonCarbonado, Centralia-Chehalis and Roslyn fields. In the Bellingham field, coal occurs in more than 10 beds that range in thickness from a few inches to 15 feet. Coal in the Green River district ranges in thickness from 3 to 40 feet in intensely faulted and deformed beds. The Wilkeson-Carbonado field is a source of coking coal and contains from 15 to 20 beds with a thickness of 2 to 8 feet. The CentraliaChehal is is the largest field containing at least 12 beds averaging in thickness from 6 to 8 feet with individual beds up to 40 feet thick with partings. The Rosiyn field contains at least eight beds with thickness ranging from 2 to 21 feet. The total coal resource in the basin is estimated to be 60 billion tons, principally high to medium volatile bituminous.

Knowledge of methane concentration in this basin and is 1 imited and based on methane-related mining accidents, water wells producing methane, oil and gas exploration, and coal core desorption from the Centralia-Chehal is district (four cores). The average value desorbed from these cores is 65 cubic feet per ton.

Since these four cores were from coal at the low end of the subbituminous $C$ rank, a value of 65 cubic feet per ton is thought to be a reasonable minimum value for in-place methane resource. It is assumed that the higher-rank bituminous coals would have greater methane content, and al so that prime target areas would have even higher concentrations of methane. Therefore, 400 cubic feet of methane per ton of coal is a reasonable estimate for the maximum in-place methane resource. Using these figures, coalbed methane resource contained in Western Washington is estimated for the known 


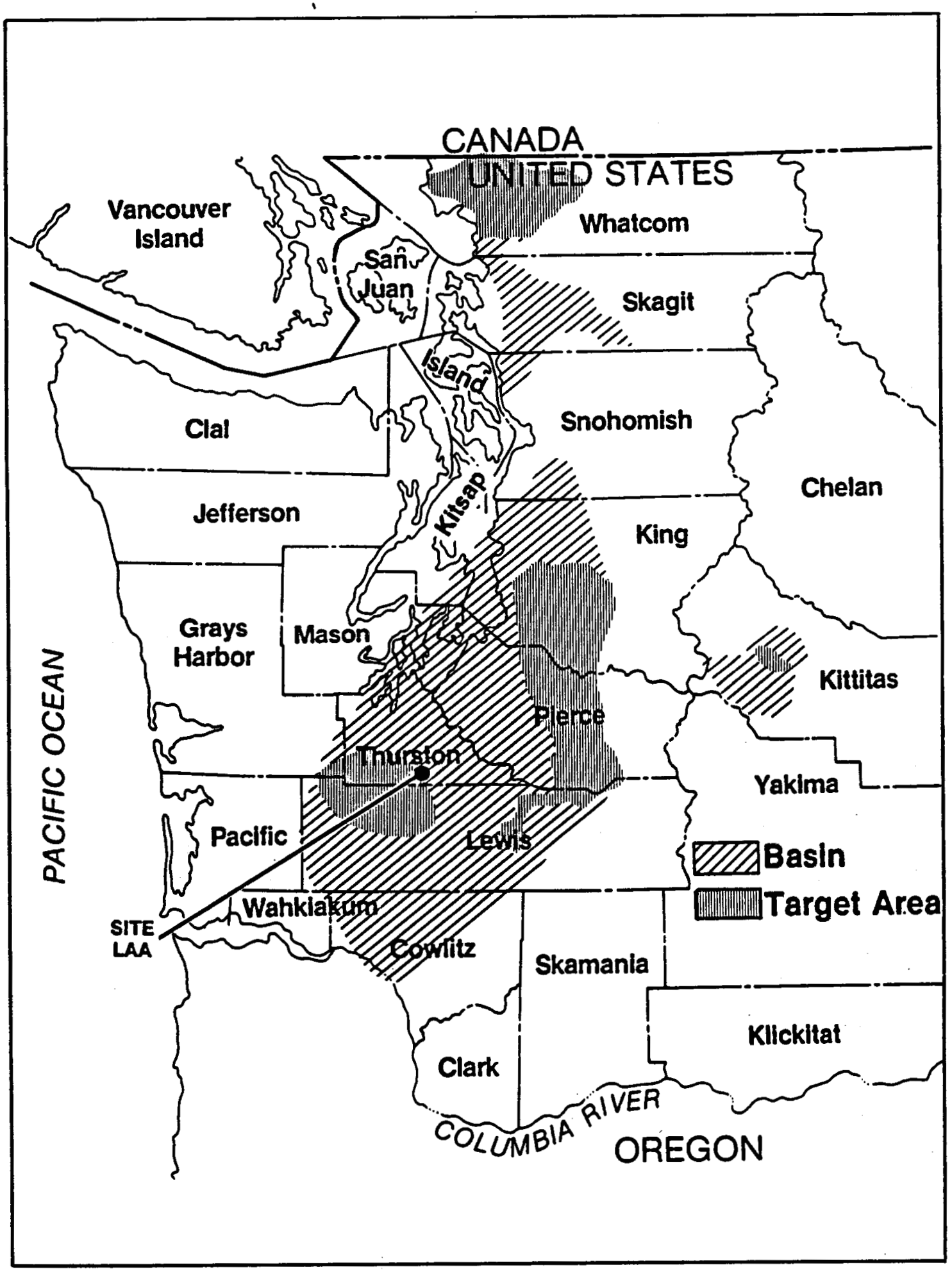

Figure 2-10. Western Washington Coal Region, Target Areas, and Well Site 
coal reserves to range from 0.4 to 3.6 trillion cubic feet, and for the total potential coal resource to range from 2.6 to 24 trillion cubic feet.

The currently defined methane recovery target areas in this basin are shown in Figure 2-10.

The status of test wells in this basin during this reporting period is as follows:

Test Well

Site LAA

DOE $\underline{\text { Status }}$

Well test data package

is complete.

This test is described in detail in the following section. 
Cooperator: Sandia/Lawrence Livermore Labs, Albuquerque, New Mexico Well Location: Thurston County, Washington (Section 21, Township 15N, Range 1W)

Field Operation Dates: October 29-November 7, 1979

\section{$\underline{\text { Logs and Tests Performed }}$}

- Desorption samples were taken from the "Big Dirty" Coalbed at the intervals listed below:

Sample No.

$$
\begin{aligned}
& 1 \\
& 2 \\
& 3 \\
& 4
\end{aligned}
$$

Depth (ft)

$$
\begin{aligned}
& 602.8-603.8 \\
& 610.0-611.0 \\
& 617.9-618.9 \\
& 623.2-623.9
\end{aligned}
$$

- Rock property testing of roof and floor rock samples

\begin{tabular}{|c|c|c|c|c|}
\hline Lithology & $\begin{array}{l}\text { Sample } \\
\text { Depth } \\
\text { (ft) }\end{array}$ & $\begin{array}{c}\text { Thickness } \\
(\mathrm{ft})\end{array}$ & $\begin{array}{l}\text { Total Ga } \\
(\mathrm{cc} / \mathrm{gm})\end{array}$ & $\begin{array}{r}\text { Per Unit* } \\
\text { (cf/ton) }\end{array}$ \\
\hline $\begin{array}{l}\text { Coal } \\
\text { Coal } \\
\text { Coal } \\
\text { Coal }\end{array}$ & $\begin{array}{l}603 \\
610 \\
618 \\
623\end{array}$ & $\begin{array}{l}21.7 \\
21.7 \\
21.7 \\
21.7\end{array}$ & $\begin{array}{l}2.7 \\
2.4 \\
1.0 \\
1.0\end{array}$ & $\begin{array}{l}86 \\
77 \\
32 \\
32\end{array}$ \\
\hline
\end{tabular}

- Proximate/ultimate analyses of coal samples upon completion of desorption

- Borehole geophysical logs were not run

\section{Summary of Test Results}


2. 4 RESEARCH, INSTRUMENTATION, AND MODEL DEVELOPMENT

The MRCP resource and site characterization and production technology development work elements are complemented by research, instrumentation and model development activities to the degree necessary to develop the technologies. Activities within this element are divided into the following two categories:

- Extraction technology R\&D

- Preparation technology R\&D

2.4.1 EXTRACTION TECHNOLOGY R\&D

Extraction technology R\&D efforts currentiy include drilling technology development, stimulation technology development, and model development. The present participants are:

- Sandia Laboratories, Water Jet Drilling

- Pennsylvania State University, Reservoir Fracturing and Mining Through Fractured Areas

- Colorado School of Mines, Effect of Predrainage Stimulation Techniques on Coal Recovery

- West Virginia University; Fracture Mechanics

- Dames and Moore, Development of Near Mine Stimulation Techniques for Coalbed Degasification

- University of New Mexico, Investigation of Pore Structure Effects in Methane Released from Coal

- University of Pittsburgh, Carbon Dioxide for Methane Production Enhancement.

These studies are discussed in sections 2.4.1.1 through 2.4.1.4. 
2. 4.1.1 WA TER JE T DR I L L I N G

Sandia National Laboratories

Albuquerque, NM

Contract:

Contract Date:

Anticipated Completion Date:

Principal Investigator:

DOE Technical Project Officer:
Status: Active

M-11098

Apri1 9, 1979

December 31, 1981

K. M. Timmerman

H. D. Shoemaker

\section{OBJECTIVE}

To develop the technology for deep horizontal penetration of coal seams from vertical boreholes using water jet drilling techniques.

SCOPE OF WORK

The work includes defining drill system requirements; evaluation of design alternatives; design, fabrication, and testing of prototypes; and field demonstration of the system. The requirements include drilling multiple horizontal holes in a coal seam from a single vertical borehole. These holes can be used for draining methane from the coal or for linking underground coal conversion wells. Phase I of the project consists of initial evaluation and design. Phase II consists of fabrication and testing of models and system components (drilling head, drill string, "round-the corner" device). The complete system will be assembled, field tested, and demonstrated in Phase III.

\section{BACKGROUND}

Work began on this project in March 1979. Preliminary studies and designs were completed by August. Laboratory and field tests of a prototype drilling head were completed in November 1979 by the University of Missouri - Rolla. The tests showed that, with certain improvements, the water jet drill could make acceptable holes in coal. Concurrently, a scale model of the articulated drill string and a device to maneuver it from vertical to horizontal in the coal seam was built and used to study that design problem. Specifications and requests for quotes for a coal seam boundary sensor were issued. The sensor is required to ensure deeping the drill in the coal seam. No acceptable proposals were received. 
(Italics denote changes since March 31, 1980.)

PROGRESS THIS REPORTING PERIOD

Plans were prepared to conduct field tests of a system subassembly consisting of an improved drilling head, a length of drill string, the drill directional control and instrumentation system, and elements of the "round-the-cormer" device. This equipment has been designed, fabricated, anl laboratory tested. The field tests are scheduled for October and November 1980. 
(Italics denote changes since March 31, 1980.)
$2 \cdot 4 \cdot 1 \cdot 2$
R E S E R VOIR
FRACTURING
$A N D$
MINING THROUGH FRACTURED
A R E A S

Pennsylvania State University

State College, Pennsylvania

Contract:

Contract Date:

Anticipated Completion Date:

Principal Investigator:

DOE Technical Project Officer:
Status: Active

DE -AC21 -78MC08089

June 1,1979

December 31,1980

C. T. Rightmire (TRW)

H. D. Shoemaker

\section{OBJECTIVE}

To evaluate the recovery of methane from fractured coal deposits and the impact of fracture stimulation on the subsequent mining of coal. SCOPE OF WORK

This study concerns reservoir modeling, fracturing, and mining through fractured areas. Planned activities include:

- Development of a rational scientific concept or methodology for determining the best method(s) for fracturing a bed

- Actual in-mine investigations and mapping of stimulation results

- Actual onsite validation of successfur scientific and 1 aboratory-developed techniques for fracturing coal seams. Assistance in implementing the validation tests and independent analysis of test results

- Evaluation of the impact of coal seam degasification on mine ventilation cost

PROGRESS THIS REPORTING PERIOD

Additional data on the effects of hydraulically fracturing coalbeds before mining have been compiled by actual in-mine investigations of the cumberland coal company mine in the vicinity of Well No. CNG 1034. Gas and water flow observations are being taken from Wells no. CNG 1035 and CNG 1036, which had been earlier drilled and stimulated for methane drainage. 


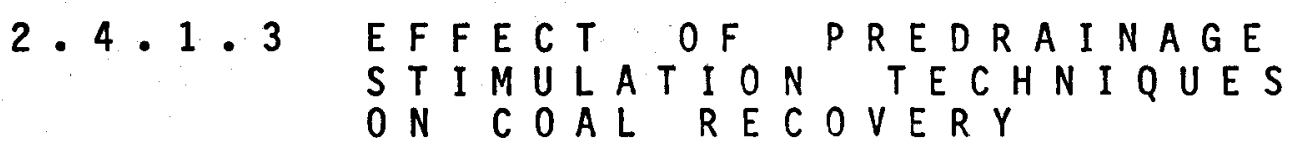

Colorado School of Mines Golden, Colorado

Contract:

Contract Date:

Anticipated Completion Date:

Principal Investigator:

DOE Technical Project Officer:
Status: Active

DE-AC21-78MC08089

November 28, 1978

December 31, 1980

C. T. Rightmire (TRW)

H. D. Shoemaker

OBJECTIVE

To evaluate the effect of premining methane drainage stimulation techniques on later coal recovery operations.

SCOPE OF WORK

The effect of premining methane drainage stimulation techniques on later coal recovery by conventional (room-and-pillar, shortwall, and longwa11) mining techniques is being evaluated through an extensive literature review and by using structural, analytical, and finite element models. The following activities are being conducted:

- Review, summarize, and evaluate previous experience and proposed techniques for degasifying coalbeds before mining, with particular attention paid to those factors that would affect mine stability.

- Review major coal-producing areas in the U.S. and categorize these areas with respect to methane content. Summarize the geological and structural data for the most important high-gas content areas.

- Summarize the mining methods, layouts, roof control, and stability problems for the major mines in each area.

0 Identify and describe the types of existing and artificially induced structural features that might be affected by: removing the gas, and (2) the process of gas removal.

- Prepare structural, analytical, ana finite element models for use in simulating the mining of typical high-gas content formations. These models are used to evaluate the sensitivity of opening and mine stability under a variety of natural and degasification conditions. 
(Italics denote changes since March 31, 1980.)

- Apply the stability models to actual mines presently using degasification techniques. Compare predicted and the actual results.

- Recommend procedures and techniques for evaluating stability changes caused by degasification.

\section{PROGRESS THIS REPORTING PERIOD}

During the period, five reports were compiled and submitted to TRW and DOE-METC for review and comment.

2. Collin R. Fay, "Hydraulic Fracture Propagation-Direction As Related To Premining Methane Drainage."

2. George B. Clark, "Basic Theories and Mechanisms of Hydrofracturing State-Of-The-Art."

3. F. J. Samaniego, "Design and Construction of The New Triaxial Testing Machine In The Edgar Mine."

4. Laertes Bigarella, "Potential Methane Drainage Using Hydrofracturing, Carbondale Coal Field, Pitkin County, Colorado."

5. Laertes Bigarella, Geomechanical Properties of Coal Measure Rocks - A Review. 
2.4.1.4 FRACTURE MECHAN ICS

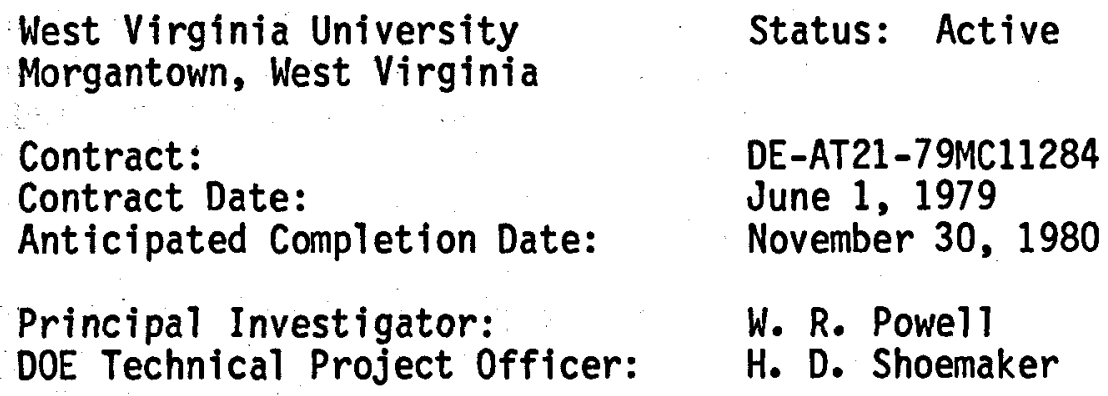

OBJECTIVE

To acquire fundamental knowledge of the mechanisms controlling fracture initiation and growth in coal.

SCOPE OF WORK

Work is planned to provide for the acquisition of more fundamental knowledge of the mechanisms that control fracture initiation and growth in coal. This knowledge will lead to improved predictions, and possible control, of the fracture patterns and an understanding of when fractures cross stratigraphic features such as bedding planes, fault cleats, and other fractures. This work includes the following tasks:

1. Quantifying the fracture toughness of coal

2. Identifying directions of natural weakness in these materials (e.g., butt cleats, face cleats) and determining their relative strengths

3. Experimentally measuring the interactions of stresses, directions of weakness, and fracture orientation

4. Determining the influence of liquid flow rates, viscosity, and stimulated tectonic stresses on the propagation of hydraulically induced fractures

5. Developing models for the mechanical behavior of coal that can be used to predict fracture patterns in the field

6. Experimentally examining the ability, under various stress states, of cracks in these materials to propagate across joints, other fractures, and across boundaries into surrounding rocks

7. Comparison of fracture properties of coal with those of the more thoroughly studied limestone and Berea Sandstone 
(Italics denote changes since March 31, 1980.)

BACKGROUND

Design and fabrication of the testing equipment was completed during the first 10 months of the contract. Twenty one fracture toughness tests were conducted on Pittsburgh coal specimens at various loading rates and in various orientations. The equipment for producing hydraulic fracturing was completed.

\section{PROGRESS THIS REPORTING PERIOD}

- Nineteen additional tests were performed to quantify the fracture toughness of Pittsburgh coal. Twelve tests were conducted on Redstone coal and five on Waynesburgh coal.

- Fifty-five fracture toughnese tests were conducted with the notch cut at various angles $10^{\circ}, 15^{\circ}, 30^{\circ}, 45^{\circ}, 60^{\circ}, 75^{\circ}$, and $\left.90^{\circ}\right)$ to the bedding plane. For all angles between $15^{\circ}$ and $75^{\circ}$ more than 75 percent of the fractures changed direction to follow the bedding planes. In the absence of confining stressists, it is not possible to propagate fractures oblique (by more than $15^{\circ}$ ) to the bedding plane.

- Ten successful hydraulic fracture tests were performed on $5-1 / 2 \times 5-1 / 2 \times 5-1 / 2$ inch cubes at various confining pressures. The testing rate has been slower than anticipated because of minor equipment fail ures, and repeated failures of the flat jacks used to api? results are listed below; the minimum confining stress acts on the butt cleat.

\begin{tabular}{|l|c|c|c|c|}
\hline \multirow{2}{*}{$\begin{array}{c}\text { SPECIMEN } \\
\text { NUMBER }\end{array}$} & \multicolumn{3}{|c|}{ CONFINING PRESSURES (PSI) } & $\begin{array}{c}\text { FRACTURE } \\
\text { PRESSURE }\end{array}$ \\
\cline { 2 - 5 } & VERTICAL & $\begin{array}{c}\text { MIN. } \\
\text { HORIZON. } \\
\text { HORIZONTAL }\end{array}$ & 210 \\
80072301 & 500 & 300 & 200 & 240 \\
80072801 & 800 & 400 & 200 & 392 \\
80081101 & 800 & 600 & 400 & 200 \\
60081501 & 0 & 0 & 0 & 370 \\
80081502 & 0 & 0 & 0 & 100 \\
80091705 (a) & 0 & 0 & 0 & 195 \\
(b) & 250 & 200 & 100 & 345 \\
80091702 (a) & 250 & 250 & 250 & 645 \\
(b) & 1200 & 900 & 400 & 915 \\
\hline
\end{tabular}


(Italics denote changes since March 31, 1980.)

- A computer simulation of hydraulic fracture is being modified to try to predict the behavior of these tests.

- The fracture toughness of coal as an anisotropic material was repeated using a maximun stress rather than maximum strain energy density opiterion for crack propagation. This theory does predict the variations in $K_{l_{c}}$ with orientation that were measured in Task 1. Applying the theory requires knowledge of the ultimate strength in tension. Thirteen tests were performed to measure ultimate strength.

- Fracture toughness tests were performed on 23 specimens of Berea sandstone having different widths, and eighteen tests were performed on Columbus limestone. 


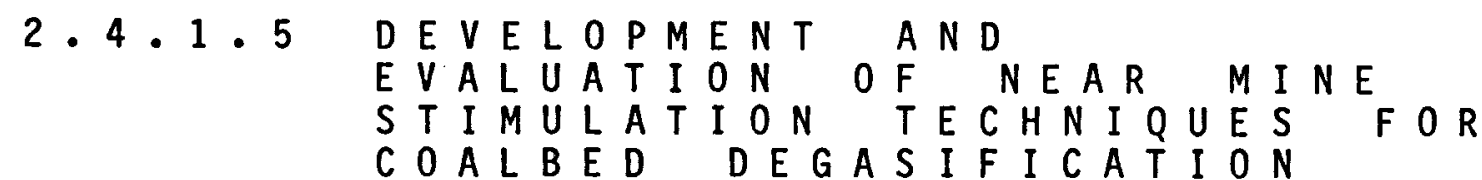

Dames and Moore

Cincinnati, Ohio

Contract:

Contract Date:

Anticipated Completion Date:

Principle Investigator:

DOE Technical Project Officer:
Status: Active (New)

DE-AC01-80-ET14205

September 29, 1980

December 29, 1982

D.J. Steele

M.A. Trevits (USBM)

\section{OBJECTIVE}

The major objective of this effort is to gather information pertaining to the hydraulic stimulation process and thereby supply the mining industry with a sound basis from which mine planning decisions can be made. Specific objectives for accomplishing this include: underground measurement and inspection of the areas affected by stimulation treatment, determination of changes in mine roof integrity, and refinement of the stimulation treatment designs.

BACKGROUND

A total of twelve vertical boreholes will be drilled and completed, two boreholes each within six separate coal horizons, representing a cross-section of the major bituminous coal producing areas within the conterminous United States. The work will be conducted in four discrete phases beginning with site selection followed by ground investigations. Various hydraulic stimulation treatments will be designed and implemented at the borehole locations to determine the most efficient stimulation fluid. Upon completion of stimulation activities, the boreholes will be abandoned and intercepted by mining. The areas affected by the stimulation treatment will be mapped, measured, and photographed and the overall impact on the mine advancement will be determined.

Ongoing activities of this project will be discussed in future reports. 
(Italics denote changes since March 31, 1980.)

\begin{tabular}{|c|c|c|c|}
\hline $2 \cdot 4 \cdot 1 \cdot 6$ & $\begin{array}{lllllllll}I & N & V & E & S & T & I & G & A \\
S & T & R & U & C & T & U & R & E \\
M & E & T & H & A & N & E & & \\
C & 0 & A & L & & & \end{array}$ & 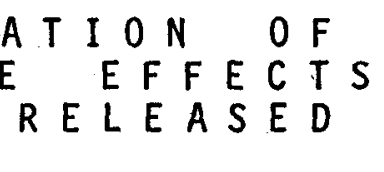 & $\begin{array}{llll}P & 0 & R & E \\
& I & N \\
F & R & 0 & M\end{array}$ \\
\hline
\end{tabular}

University of New Mexico

Status: Active (New)

Albuquerque, New Mexico

DE -AC21-78MC08089

Contract:

June 13, 1980

Contract Date:

December 31, 1982

Principal Investigator:

C. T. Rightmire (TRW)

DOE. Technical Project Officer:

H. D. Shoemaker

\section{OBJECTIVE}

Field and laboratory studies will be undertaken to determine the validity of the "chip desorption" technique and to investigate the effects of pore structure in methane released from coal.

SCOPE OF WORK

Project investigators from the University of New Mexico (UNM) will obtain chip samples from drilling operations arranged by TRW. The coal chips will be collected from rotary drill and core drill mud and desorbed to determine the metindur content of the coal. The methane

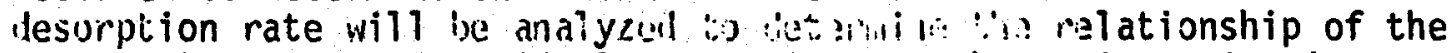
rate to lost gas and residual gas estimates. Later investigations will be directed toward physical characterization of coal samples and chromatic determination of micropore and macropore diffusion coefficients. The contract option al so provides for the development of a combined tiffusion-crack flow model.

PROGRESS THIS REPORTING PERIOD

Plans have been made for UNM geologists to obtain cuttings from wells being drilied in the San Juan Basin under a cooperative agreement between TRW and Northwest Pipeline. 
(Italics denote changes since March 31, 1980.)
$2 \cdot 4 \cdot 1 \cdot 7$
C A R B O N
D I $0 \times 1 D$ I
$\mathrm{F} O \mathrm{R}$
METHANE PRODUCTION
ENHANCEMENT

$\begin{array}{ll}\text { University of Pittsburgh } & \text { Status: } \\ \text { Pittsburgh, Pennsylvania } & \text { Active } \\ \text { Contract: } & \text { DE-FG21-80MC14262 } \\ \text { Contract Date: } & \text { March 1, 1980 } \\ \text { Anticipated Completion Date: } & \text { October 31, } 1980 \\ \begin{array}{l}\text { Principal Investigator: } \\ \text { DOE Technical Project Officer: }\end{array} & \text { A. A. Reznik } \\ \text { H. D. Shoemaker }\end{array}$

\section{OBJECTIVE}

To determine the feasibility of using carbon dioxide to optimize in situ production of methane from coal.

SCOPE OF WORK

The purpose of this study is to determine the feasibility of enhancing the production of in situ methane from gaseous coals by carbon dioxide injection. Feasibility is to be measured in terms of rate and ultimate recovery of methane versus carbon dioxide adsorption (consumption) and product gas quality. Performance parameters will include injection pressure, water saturation, and continuity of injection. Enhanced performance will be evaluated in relation to natural desorption.

BACKGROUND

The current project is an extension of the work of two earlier contracts: EW-78-X-21-0813 and DE-FG21-79MC10831. These earlier contracts established that the pressence of water in coal greatly reduced methane production during both natural and carbon dioxideenhancced production processes. It was al so established that intermittent injection (adsorption)/producition (desorption) was superior to any continuous injection process. Injection pressures were limited to 200 psig. All tests were performed on Pittsburgh seam coal.

PROGRESS THIS REPORTING PERIOD

Since the project was started in May, four special pressure vessels were obtained. These high-pressure vessels are now in use and a gas chromatograph has been installed. A series of runs in which the water satumation is at maximum, the in situ methane is adsorbed at $200 \mathrm{psig}$, and the rums are parametric only in the value of the carbon dioxide injection pressure have been made. Experiments with carbon dioxide 
(Italics denote changes since March 31, 1980.)

injection pressures of 200, 300, 400, 560, and 800 psig have been completed or are in progress. All coal samples are large 13-1/2 inches in diameter), integral pieces of Pittsburgh seam coal.

Preliminary results indicate the following:

1. Approximately 40 percent of the in situ methane is recovered by natural desorption at atmospheric pressure.

2. Three carbon dioxide injections produce an additional 30 to 35 percent of the original in situ methane.

3. Recovery appears to be independent of carbon dioxide injection pressure.

4. The quality of the product gas decreases with successive carbon dioxide injections and averages about 30 methane.

5. 100 SCF of carbon dioxide is lost (adsorbed) per 15 SCF of enhanced methane production. Recovery, in this respect, favors the higher carbon dioxide injection pressures.

6. The produsion (desorption) isotherms, both natural and enhanced, appear to fit the copreination:

$$
V(t)=V_{\infty}\left(1-\exp \left(-\alpha t^{\beta}\right)\right)
$$

for constant values of $\alpha$ and $\beta$, where $V(t)=$ total gas desorped to time $t$, and $V_{\infty}$ represents the maximum value of prouised gas, i.e., as $t+\infty$.
2. 4. 2
P R
P A R A T I O N
TECHNOLOGY
$R$ \& D

At the present time no R\&D efforts are being conducted in Preparation Technology development. Some studies have been conducted in association with Production Technology Development projects. Reports of this activity will be discussed in future Semi-Annual Reports. 
2.5 PRODUCTION TECHNOLOG Y DEVELOPMENT

2.5.1 GENERAL

The MRCP production technology development element is aimed at testing the technical and economic feasibility of systems and subsystems proposed for recovery, processing, and utilization of coalbed methane. In view of the variability of methane quantity and quality, a single recovery/processing/utilization system cannot be designed and developed, as with other natural resources. Instead, technology development must be oriented toward degasification in advance of mining (predrainage), concurrently with mining, after mining (gob gas removai) and divorced from mining. Table 2-5 shows the various combinations of well design, stimulation techniques, and utilization applications of the ten MRCP Production Technology Development Projects. Figure 2-11 shows the locations of the projects.

Transportation is a major cost of gas distribution. Transporting coalbed methane over a long distance is economical only if pipelines exist in the vicinity that can be used to commingle the unconventional gas with conventional gas. While this situation exists in many parts of the country, other more economical means of using or converting the energy may be available. Thus, MRCP processing/utilization technology will also assess the feasibility of using the gas for chemical feedstock, liquefied natural gas, propane, etc.
$2 \cdot 5 \cdot 2$
$P R O J E C T S$
A S S OC I A T E D
W I T H
$M I N I N G$

Many of the production technology development projects concerning methane drainage in association with mining were originally funded by the U.S. Bureau of Mines (USBM) in conjunction with the mine safety program. Generally, they are aimed at quickly removing large quantities of gas in order to enhance mining. Vertical, horizontal, and directional drilling techniques are currently being investigated under MRCP auspices. The projects representing this element are as follows:

2.5 .2 .1

2.5 .2 .2
Space Heating Project (Westmoreland County, Pennsylvania)

-- Westinghouse Electric Corporation

Onsite Power Generation Project (Washington County, Pennsylvania) -- Westinghouse Electric Corporation 
2.5 .2 .3

2.5.2.4

2.5.2.5

2.5.2.6
Long Horizontal Holes/Active Mine Project (Buchanan County, Virginia)

-- Occidental Research Corporation/Island Creek Coal Company

Multiple Vertical Borehole Degasification Project (Jefferson County, Alabama)

-- United States Steel Corporation

Directional Drilling for Degasification of the Pittsburgh Coalbed Project

(Green County, Pennsylvania)

-- H. F. Scott

Vertical Drilling to Degasify the Jawbone Coalbed Project

(Dickensen County, Virginia)

-- Clinchfield Coar Company 
Table 2-5. Production Technology Development Projects

\begin{tabular}{|c|c|c|c|c|c|}
\hline \multirow{2}{*}{ PROJECT } & \multirow{2}{*}{$\begin{array}{l}\text { GAS } \\
\text { SOURCE }\end{array}$} & \multicolumn{2}{|c|}{ EXTRACTION METHODS } & \multirow{2}{*}{ UTILIZATION } & \multirow{2}{*}{$\begin{array}{l}\text { SITE } \\
\text { LOCATION }\end{array}$} \\
\hline & & WELL & STIMULATION & & \\
\hline \multicolumn{6}{|l|}{ MINEABLE COAL } \\
\hline $\begin{array}{l}\text { Westinghouse - } \\
\text { Space Heat }\end{array}$ & Predrain & $\begin{array}{l}\text { Muitiple Vertical } \\
\text { Wells }\end{array}$ & Hydraulic & Space Heating & Pennsylvania \\
\hline $\begin{array}{l}\text { Westinghouse - } \\
\text { Power Generation }\end{array}$ & Predrain & \begin{tabular}{|c|}
$\begin{array}{c}\text { Multiple Horizonial } \\
\text { Holes }\end{array}$ \\
\end{tabular} & None & Turbine Generator & Pennsylvania \\
\hline $\begin{array}{l}\text { Occidental/Island Creek - } \\
\text { Horizontal Hole Drainage }\end{array}$ & Predrain & $\begin{array}{c}\text { Multiple Horizontal } \\
\text { Holes }\end{array}$ & None & Coal Dryer Fuel & Virginla \\
\hline $\begin{array}{l}\text { U.S. Steel - } \\
\text { Vertical Drainage }\end{array}$ & Predrain & $\begin{array}{l}\text { Multiple Vertical } \\
\text { Holes }\end{array}$ & Various & None & Alabama \\
\hline $\begin{array}{l}\text { Emeraid Mines - } \\
\text { Slant Hole Drainage } \\
\end{array}$ & Predrain & \begin{tabular}{|c|}
$\begin{array}{c}\text { Multiple Horizontal } \\
\text { Holes from One } \\
\text { Slant Hole }\end{array}$ \\
\end{tabular} & None & None & Pennsylvania \\
\hline $\begin{array}{l}\text { Clinchfield Coal - } \\
\text { Vertical Drainage } \\
\end{array}$ & Predrain & $\begin{array}{c}\text { Multiple Vertical } \\
\text { Wells }\end{array}$ & Foam & None & Virginia \\
\hline \multicolumn{6}{|l|}{ UNMINED COAL } \\
\hline $\begin{array}{c}\text { Waynesburg College - } \\
\text { Multiple Completion } \\
\end{array}$ & $\begin{array}{c}\text { Urban } \\
\text { Area }\end{array}$ & $\begin{array}{c}\text { Single Vertical } \\
\text { Wells }\end{array}$ & Hydraullc & $\begin{array}{l}\text { Campus } \\
\text { Pipeline }\end{array}$ & Pennsylvania \\
\hline $\begin{array}{l}\text { Pennsylvania Energy Resources - } \\
\text { Anthracite Production Econ. }\end{array}$ & $\begin{array}{c}\text { Flooded } \\
\text { Area }\end{array}$ & \begin{tabular}{|c} 
Multiple Vertical \\
Wetls
\end{tabular} & Various & Pipeline & Pennsylvania \\
\hline $\begin{array}{l}\text { Mountain Fuels - } \\
\text { Production Economics }\end{array}$ & $\begin{array}{l}\text { Deep } \\
\text { Coal }\end{array}$ & $\begin{array}{l}\text { Multiple Vertical } \\
\text { Wells }\end{array}$ & Hydraulle & Pipeline & Utah \\
\hline $\begin{array}{l}\text { Coseka Fuels - } \\
\text { Production Economics }\end{array}$ & $\begin{array}{l}\text { Deep } \\
\text { Coal }\end{array}$ & $\begin{array}{c}\text { Muftiple Vertical } \\
\text { Wells }\end{array}$ & Hydraulic & Plpeline & Colorado \\
\hline
\end{tabular}




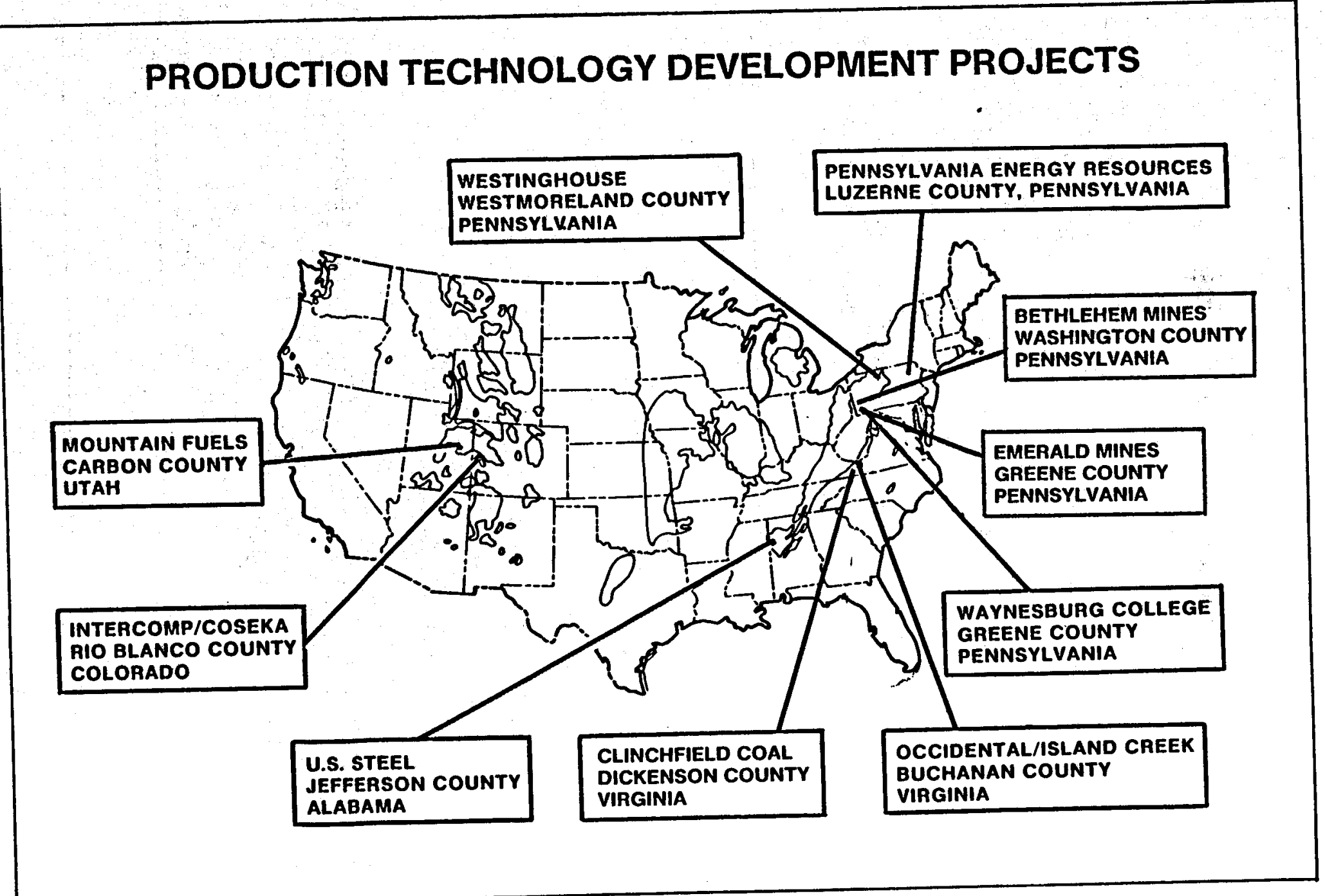


2.5.2.1 SPACE HEATING TEST PROJECT

Westinghouse Electric Corporation

Pittsburgh, Pennsylvania

Contract:

Contract Date:

Anticipated Completion Date:

Principal Investigator:

DOE Technical Project Officer:
Status: Active

DE-AC21-78MC08332

May 12, 1978

July 12, 1981

C. L. Sturgill

J. R. Duda.

\section{OBJECTIVE}

To develop techniques for extraction of methane from coalbeds and to determine the suitability of the gas for process heat generation.

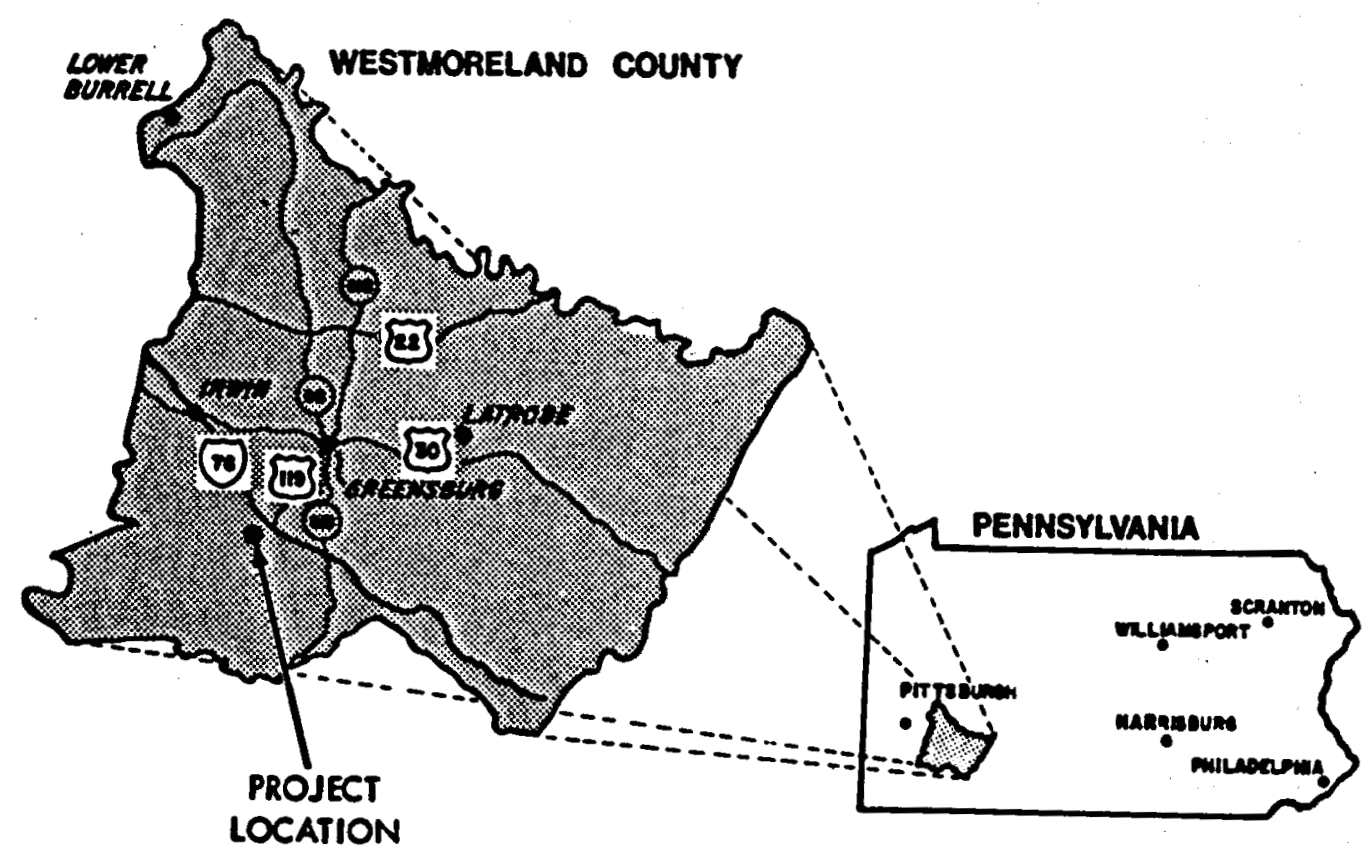


SCOPE OF WORK

This cooperative agreement between DOE and Westinghouse consists of a methane drainage and utilization project at the Westinghouse Waltz Mill site in Westmoreland County, Pennsylvania. The project objective is to determine and demonstrate effective extraction and stimulation techniques for drainage of methane from 850 acres of virgin coal and to use the methane for process heat generation (steam, hot water, and space heating). The data obtained will be used to assist in determining optimum well spacing for methane drainage operations. Drainage will be accomplished with multiple vertically drilled boreholes penetrating 11 coal seams of the Allegheny and Pottsville Groups with an aggregate thickness of 26.5 feet. Stimulation will be accomplished by multiple hydraulic fracturing treatments in four zones. The project is being implemented in three sequential phases:

o Phase I - System preliminary design, development, and analysis

- Phase II - Detailed design and analysis

- Phase III - Site preparation and operation

Two wells were planned for Phase I: a production well and an observation well. Phase II consists of evaluating the work performed during Phase I and planning for Phase III. Phase III consists of drilling and stimulating a sufficient number of production wells to drain the entire 850-acre tract.

Phases I and II are each planned to last six months. Phase III (not yet contracted) is planned to run 26 months. The stimulation treatment (four zones) for the Phase I production well (No. 4) was designed by Intercomp. It was planned to core and log this well both before and after casing. The purpose of the observation well (No. 5) is to monitor water and pressure levels during gas production.

BACKGROUND

Phase I production well (No. 4) was completed in December 1978 in four zones using a Kiel fracture. An electric downhole pump was used to dewater the well. The frac water was recovered, but the well continued to produce a large amount of water. The water has an acceptable pH value, but because of salt concentration it is hauled away for disposal. Free gas flow over four or five days was 32 to $33 \mathrm{Mcfd}$ initially and the shut-in pressure ranged from 12 to 25 psi. This low production was consistent with the low $37 \mathrm{cf} /$ ton average methane content of the coal. 
(Italics denote changes since March 31, 1980.)

PROGRESS THIS REPORTING PERIOD

As of the end of the reporting period, the Westinghouse Well No. 4 was still in production and continued to supply about one half of the facility's gas needs. 
2.5.2.2 ONSITE POWER GENERATION TEST PROJECT

Westinghouse Electric Corporation Pittsburgh, Pennsylvania

Contract:

Contract Date:

Anticipated Completion Date:

Principal Investigator:

DOE Technical Project Officer:
Status: Active

DE-AC21-77ET13133

September 1, 1977

February 1, 1981

C. L. Sturgill

J. R. Duda

\section{OBJECTIVE}

To demonstrate the technical feasibility of using coalbed methane for generating electrical power for local usage.

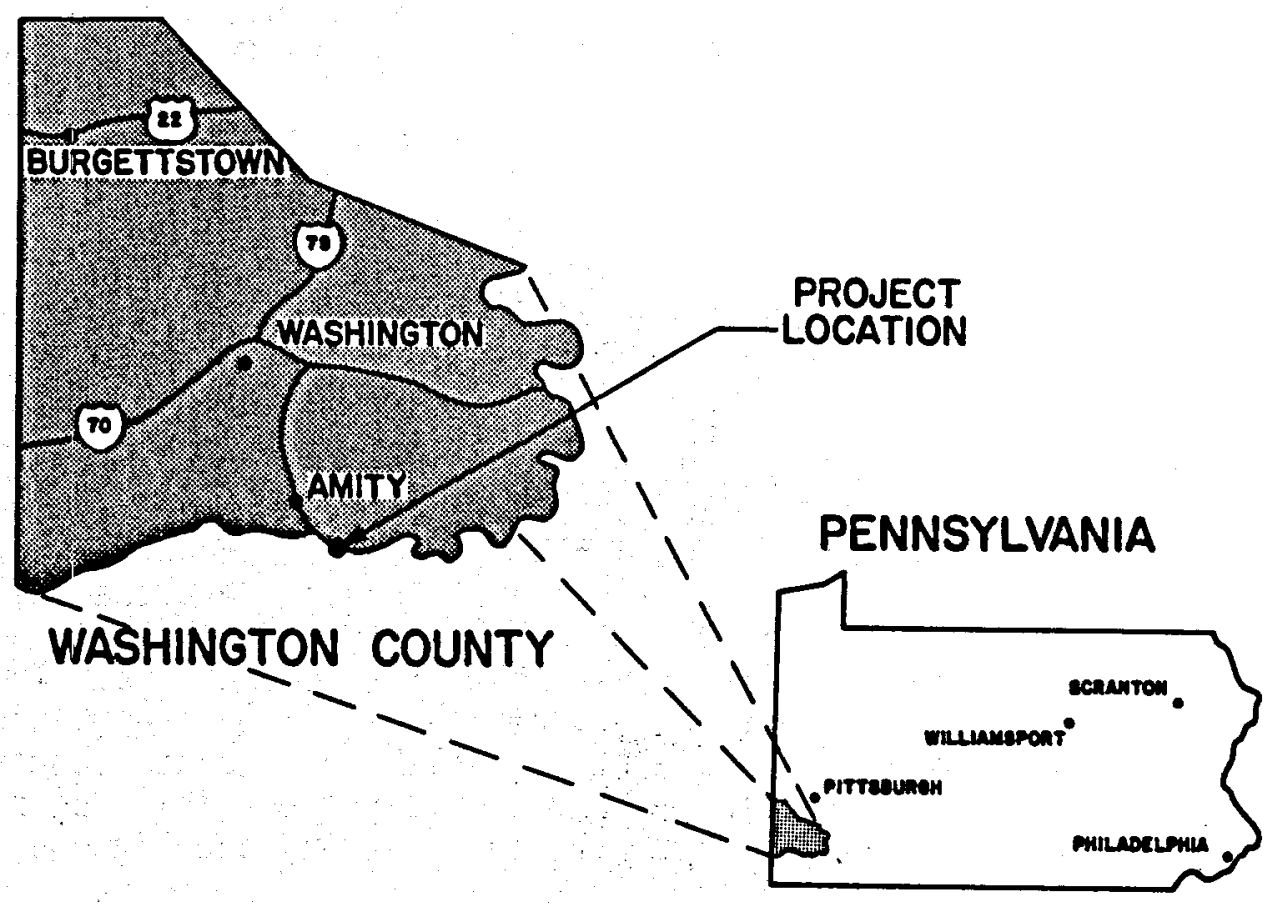


This contract, which involves DOE, Westinghouse, and the Commonwealth of Pennsylvania, is being conducted in cooperation with the Bethlehem Mines Corporation at the Mariana No. 58 mine near Washington, Pennsylvania.

A specific objective of the project is to demonstrate the operation of a gas turbine using coalbed methane as the fuel source.

A goal of this project is to provide wells with gas production rates sufficient to sustain operation of a turbine that could supply power directly to the local mine power grid. The design gas flow rate to be achieved is $300 \mathrm{Mcfd}$, which would drive the turbine at its rated net power output of $625 \mathrm{~kW}$ (five percent of the total mine power requirement). However, the turbine can be run at lower output in the event well production is less than estimated. The turbine is owned by the U.S. Army.

The contract is being implemented in three sequential phases:

- Phase I - Fuel analysis, well selection, and interface equipment design

- Phase II - Fuel availability, interface equipment installation, and turbine installation

- Phase III - Turbine operation, data collection and analysis. BACKGROUND

Initially, the demonstration project was to operate a turbine generator with gob gas from a degasification borehole at Bethlehem Mines Corporation's Cambria Division in Ebensburg, Pennsylvania. However, a mine fire affected this gob fuel source and subsequently a vertical borehole (\#32-13) was drilled into virgin coal seams and developed to replace the defunct gob source. Borehole \#32-13 produced only about $40 \mathrm{Mcfd}$, which is considerably less than acceptable. Hence, the demonstration project was transferred to Bethlehem Mine Corporation's Marianna No. 58 Mine, in Washington County, Pennsylvania, to utilize an existing degasification network. The network consists of four horizontal boreholes in a coal seam, underground collection piping, and a vertical stack to evacuate about 240 Mcfd to the surface for venting into the atmosphere. This degasification network, known as the Waychoff borehole, has been in operation since late 1978. 
(Italics denote changes since March 31, 1980.)

PROGRESS THIS REPORTING PERTOD

The demonstration project was transferred from Ebensburg to the Marianna No. 58 Mine in May 1980. Actual site construction, pipeline installation, and equipment deliveries started late May, 1980 and were completed by mid-August 1980. The initial operation of the turbine generator on coalbed methane was conducted on August 21, 1980. Shakedown operations continued until early september and the demonstration project became fully operational on september 10, 1980. The weekly period of operation throughout september is between midnight sronday through 8:00 a.m. Saturday. The system is taken off-line each saturday moming to permit equipment maintenance and inspections and other mining functions to be performed.

All surface electrical loads at the Sabol Shaft are electrically powered by the turbine generator output. These loads consist of a 300 HP ventilation fan, $150 \mathrm{HP}$ methane gas compressor, $100 \mathrm{HP}$ air compressor, and surface utilities. The average electrical load is about $400 \mathrm{~kW}$ and the corresponding fuel consumption is 205 Mcfd.

The initial phases of the project were completed by the transfer of operations from Ebensburg and initial start-up at Marianna No. 58 Mine. Phase III started when full operational status was achieved on September 10, 1980. Phase III data and analysis will be presented in the next report. 


$$
\begin{aligned}
& \text { 2.5.2.3 LONG HOR IZONTAL HOLES, } \\
& \text { ACT IVE MINE TEST PROJECT } \\
& \text { BUCHANAN COUNTY, VIRGINIA }
\end{aligned}
$$

Occidental Research Corp.

Irvine, California

Contract:

Contract Date:

Completion Date:

Principal Investigator:

DOE Technical Project Officer:
Status: Active

DE-AC21-78MC08089

April 1, 1979

July 1, 1981

N. F. McGinnis (TRW)

H. D. Shoemaker

\section{OBJECTIVE}

To develop a technique for recovery of methane from long horizontal holes drilled from within the mine and use the gas in an appropriate application.

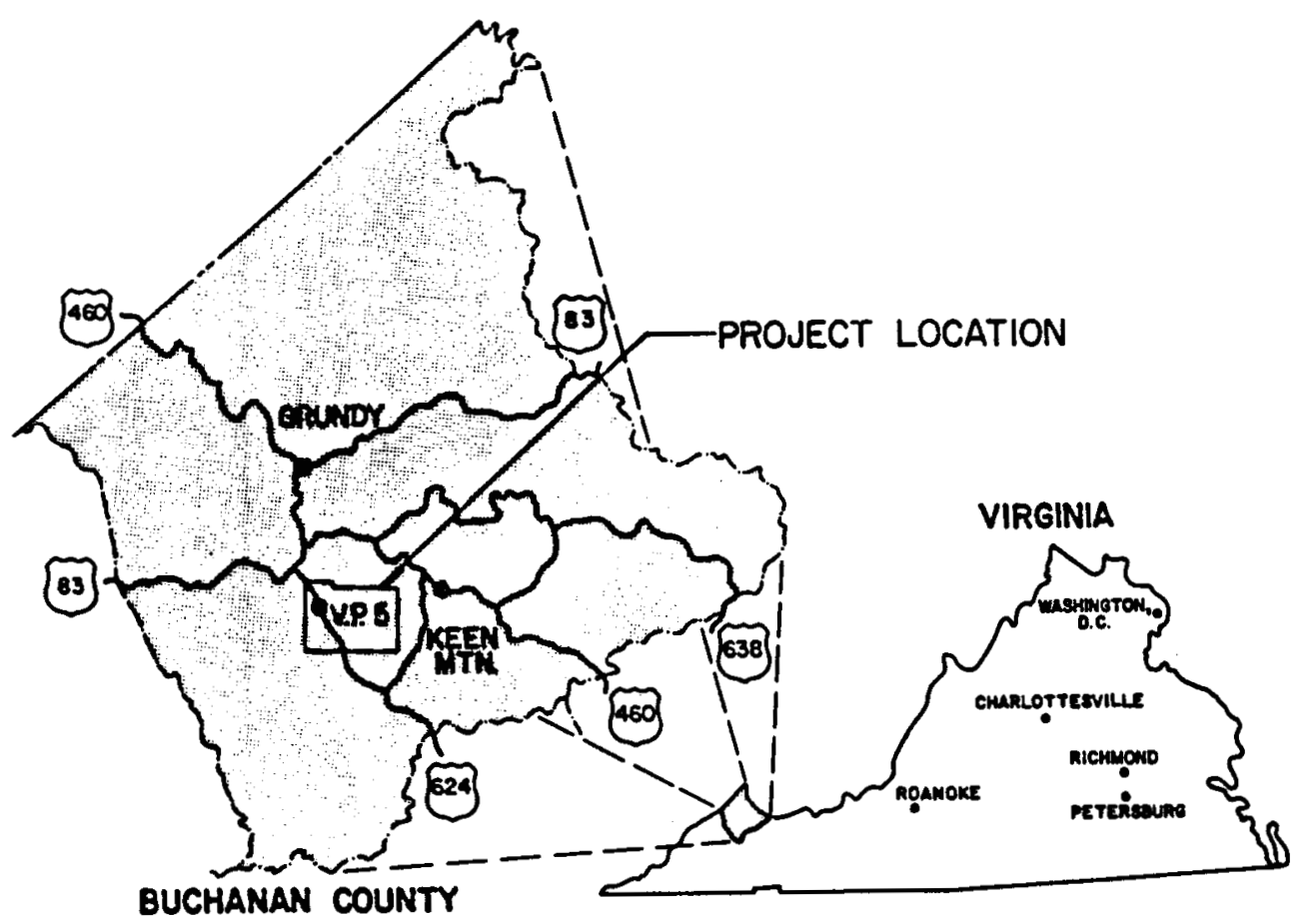


This project is concerned with methane drainage using multiple horizontal boreholes in a mine under development. The technique was proposed by a team consisting of Occidental Research Corporation (ORC) and Island Creek Coal. It includes several technology improvements including the development of a drilling technique for long horizontal boreholes (greater than 2000 feet) to drain the entire length of a longwall panel and development of a bit guidance technique to keep the borehole within the coal seam.

The project also includes the development of an in-mine piping network with an integrated safety system. Plastic pipe is used to reduce costs. During the design and validation effort, a small vertical vent to the surface will be used for testing. Assuming success, a large vent shaft will be installed in advance of its need for mining to provide a passageway for the mine-to-surface piping. The gas drained during the design verification phase may be used to produce LNG in a unit under development by a separate venture of Island Creek Coal. This unit, located at an adjacent mine, is being developed to operate at low gas feed volumes. Other options under consideration include fuel for Coal Dryer or gas pipeline injection.

\section{BACKGROUND}

This project was initiated by ORC prior to entering the cost-sharing agreement with the government effective April 1979. ORC purchased a new in-mine dri11, the "Big John" model from Acker Drill Company, Scranton, Pennsylvania, and installed the drill in the mine. The drill was checked out by drilling several short holes. The methane produced during these shakedown operations was piped to a vent using a polyethylene piping system equipped with safety equipment approved by MSHA.

To date, the project has been able to improve techniques in guidance and control of the drill within the coal seam, obtain a better understanding of the mine stratigraphy, and more fully understand the gasiness of the coal seams. The ability to drain an overlaying seam from within the mine has been suecessfully tested. Drilling of several holes targeted to 2,000 feet has been held up because of excessive gas production in a restricted in-mine pipeline network. Because of this, a larger capacity surface vacuum pump is being procured to increase the vent rate.

PROGRESS THE REPORTING PERIOD

During this reporting period, considerable progress was made in the implementation phase. A second horizontal drilling, modified appropriately, has been purchased from the Acker Drill Company, tested, and moved into the mine. Hole No. 9, which was started in March, was 
(Italics denote changes since March 31, 1980.)

drilled to a length of 900 feet at which point the well was abandoned due to a sloughing borehole which stuck the drill string.

Unfortrmately, Hole No. 10 was also not completed, and was abandoned after 400 feet because of coal instability and sloughing caused by nearby mining. Hole \#11 was spudded in approximately 920 feet away from No. 10 and drilled to a length of 1200 feet, grouted, and is currently producing 434 Mefd. Drilling had to be terminated before the target 2000 foot length was reached because the resultant gas exceeded the ventilation capacity. The drilling was completed in seven working shifts, which marks a considerable improvement in the drilling techniques.

As of the end of August 1980, flow rates from the boreholes in existence were as follows:

\section{Borehole No.}

Oxy \#5

$0 x y \# 6$

Oxy \#?

$0 x y \# 8$

Oxy \#9

$0 x y \# 10$

oxy \#11
Flow Rate (Mrefd)

111.1

398.2

19.9

37.7

75.9

64.1

434.0

Total $1,129.9$

During the latter portion of the reporting period, a decision was made by ORC to use some of the gas to fuel its coal-drying facility. The equipment for the conversion has been ordered. The results of the application as well as the economic conalyses of evaluation utilization subsystems will be included in a future semi-annual report. 
2.5.2:4 MULTIPLE VERTICAL BOREHOLE DEGASIFICATION TEST PROJECT, JEFFERSON COUNTY, ALABAMA

United States Steel Corporation

Contract:

Contract Date:

Completion Date:

Principal Investigator:

DOE Technical Project Officer:
Status: Field Work Completed

ET-75-C-01-9027

June 1975

August 1980

J. S. Wallace

S. W. Lambert (CMTC)

\section{OBJECTIVE}

To develop the capability of removing coalbed gas using a pattern of vertical boreholes, and to demonstrate this method's compatibility with the process of mining coal.

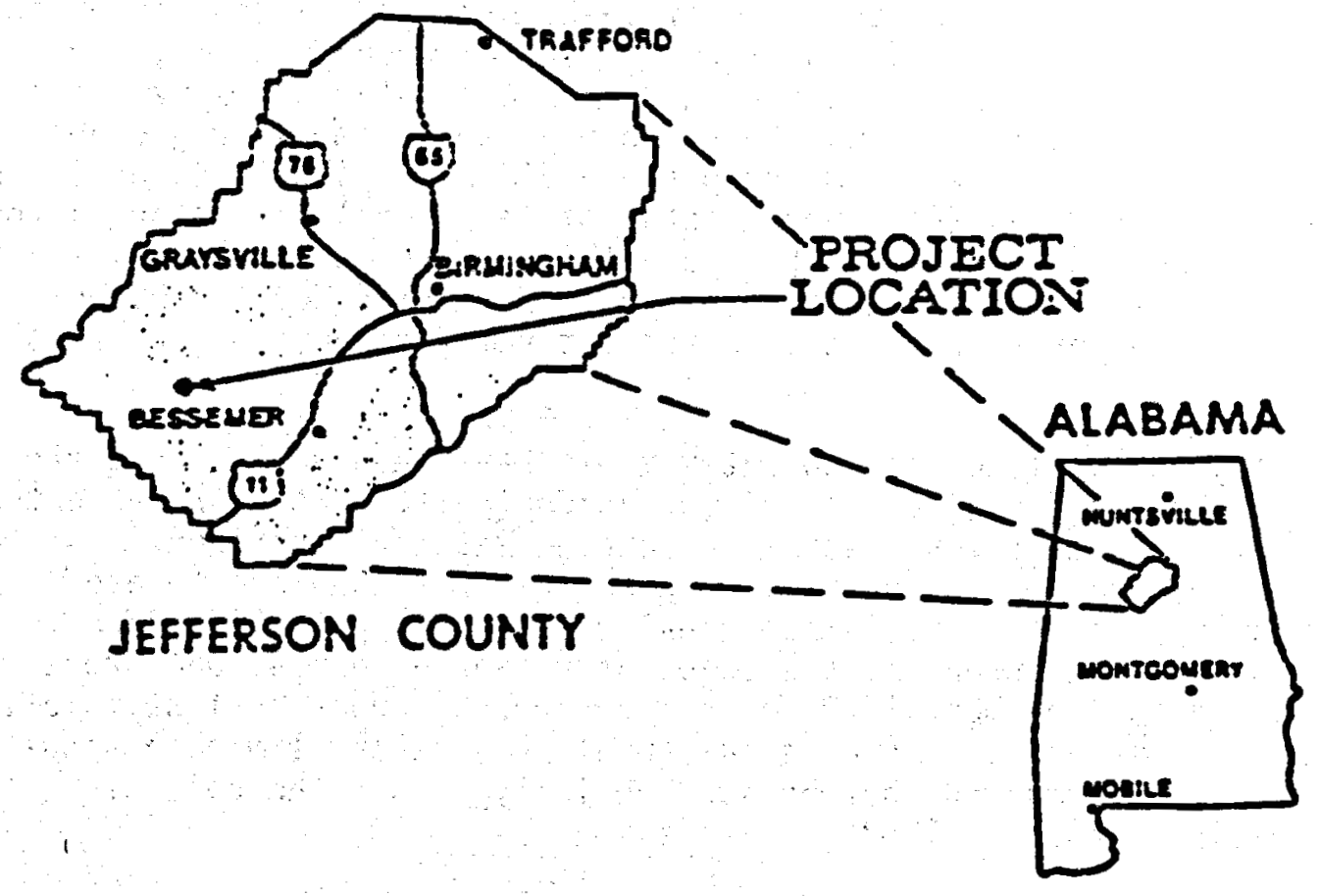


Under this contract between the DOE and U.S. Steel Corporation, 28 vertical boreholes near the U.S. Steel Oak Grove Mine, Jefferson County, Alabama will be tested. Twenty-three of these boreholes are to be placed on a grid pattern located approximately five years ahead of active mining, while the remaining five boreholes will be placed less than 1,000 feet from the underground mine operations. A11 28 boreholes will be completed into the Mary Lee coalbed, stimulated, produced, and mined through. The goal of this project is to provide increased coal output and decreased mine ventilation costs using large-scale application of vertical borehole methane drainage techniques designed to be minimally disruptive to the coal mining process.

BACKGROUND

A total of 21 boreholes had been completed at Oak Grove before April 1979. Four of these were placed near the mine and have since been mined through. Seventeen boreholes were completed in the test area located five years ahead of mining. These boreholes are placed on a 3 by 5 grid pattern of 21.5-acre spacings with two adjacent but outlying boreholes.

The number of actively producing wells on the grid pattern fluctuates greatly because of mechanical difficulties caused by unprecedented high and sudden coalbed gas flows. Despite these problems, approximately 12 boreholes were draining gas on a regular basis by October 1978. Total gas flow from the pattern at that time averaged about 600 Mcf daily. Gas flows from the pattern did not change much until the beginning of March 1979 when a total of 16 boreholes were put into production. On March 15 total gas flow rose to approximately 1.2 Mcf with individual borehole gas flows ranging from 5 Mcf to 200 Mcf daily. The entire pattern of boreholes removed about 400 barrels of water daily.

Although stabilized gas and water flows have been achieved at the 17-borehole pattern test site, operational difficulties related to the influx of stimulation treatment propping material continue. As the boreholes are pumped, sufficient quantities of sand accumulate in the downhole pumping mechanism to greatly reduce pumping efficiency. Because of this problem, the scope of research work at Oak Grove was expanded in September 1979 to include several additional stimulation experiments which, if successful, would reduce or el iminate sandrelated problems and thereby substantially reduce the cost of operating future coalbed gas wells. 
(Italics denote changes since March 31, 1980.)

Seven additional boreholes were to be completed under this modification. Six of the boreholes were to be added to the 17-hole pattern while the one reinaining borehole had been already completed near the mine.

The near-mine test borehole, provided under the expanded work program, was completed approximately 1,600 feet ahead of a projected six-entry mining section. The coalbed was treated with 53,000 gallons of 75 percent quality foam at an average injection rate of 4.7 barrels per minute, using no proppant. The well, referred to as TW5, was allowed to produce for 147 days before underground interception.

The total amount of gas produced from TW5 was 9,000,000 cubic feet for an average daily rate of more than 61,000 cubic feet. The results gathered underground after borehole mine-through indicated that the stimulation of TW5 caused no significant fracturing of mine roof or floor. Detailed reports of all the U.S. Steel near-mine borehole tests, including the TW5 test, have been published in three separate Reports of Investigation that are available through METC or CMTC.

\section{PROGRESS THIS REPORTING PERIOD}

The total amount of gas produced from the test pattern at oak Grove is 750 million cubic feet with 10,829 well operating days logged, the per well average gas flow is 69,217 scfd. Gas and water flow rates from the patterm since August 5, 1977 (day one of well operation from the first borehole put into production) are shown in Figure 2-12. Large increases in gas production in the first several months were caused by the increasing number of wells put into production during that period. smaller fluctuations in gas production reflect the number and condition of wells actially operating during any given month. There is still no evidence to suggest individual or overall decline in gas production even though rates have been relatively low for the past few months. Tresion for these low flows is directly related to the completion and stimulation of the sic ne:v wells that were recently completed on the test grid. Several of the wells were shut in during a period before and after stimulation of the six new wells in order to test for possible commication. Routine maintenance procedures, essential for maintaining high flow rates, were also delayed because of the stimulation treatments. 

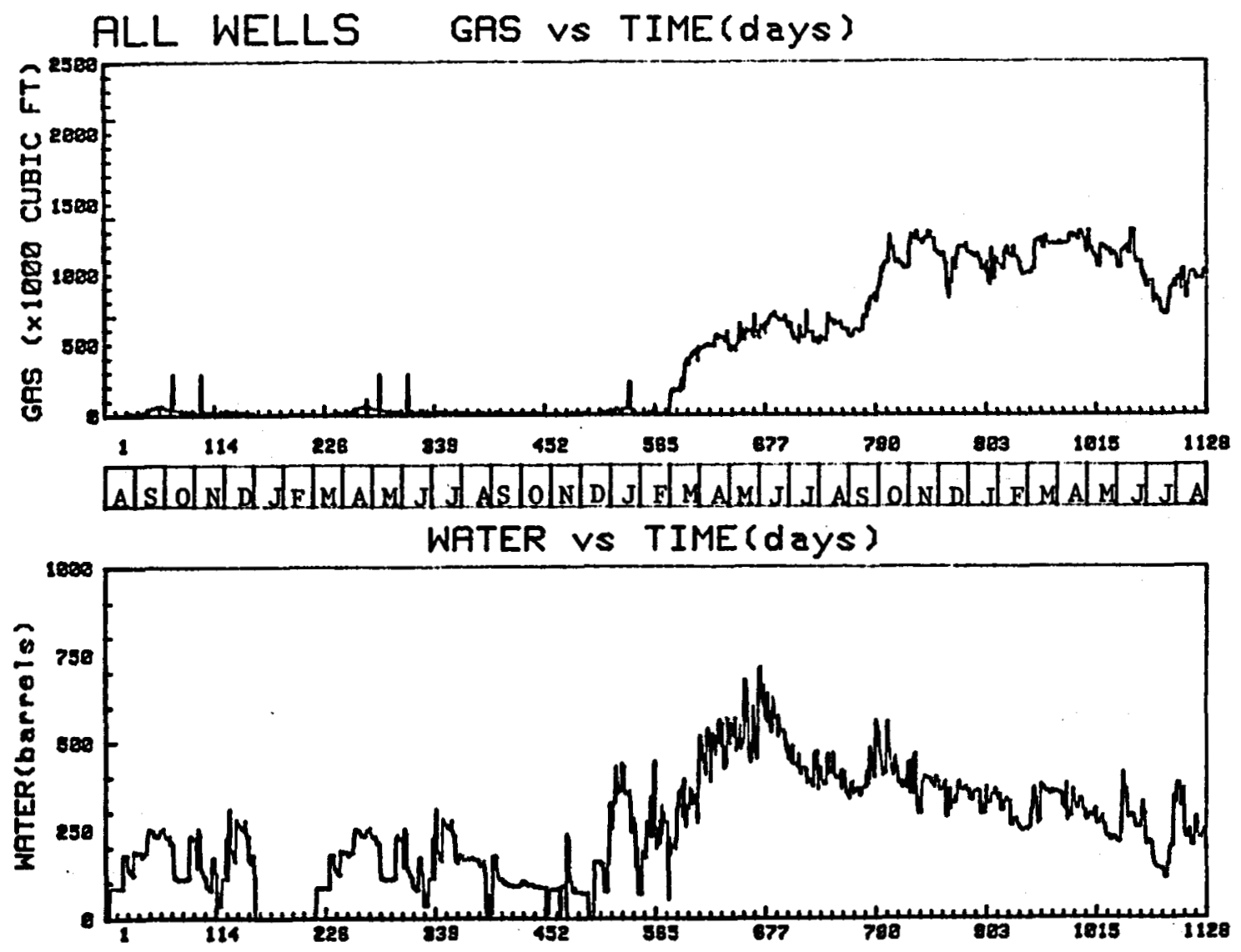

Figure 2-12. Total Gas Production from 17 Producing Wells

Figure 2-12. Total Gas Production from 17 Producing Wells 


$$
\begin{aligned}
& \text { 2.5.2.5 DIRECTIONAL DRILLING FOR } \\
& \text { DEGASIF I CATION OF THE } \\
& \text { PITTSBURGH COALBED, } \\
& \text { GREENE CO., PENNSYLVAN I A }
\end{aligned}
$$

Harold F. Scott, Contractor Bridgeville, Pennsylvania

Contract:

Contract Date:

Anticipated Completion Date:

DOE Technical Project Officer: W.P. Diamond (USBM)
Status: Active

ET-77-C-01-8891

September 27, 1977

May 26, 1983

\section{OBJECTIVE}

To demonstrate the capability of using directional drilling techniques to drill long, horizontal methane drainage holes in coalbeds from a surface location to reduce the explosion hazard of methane/air mixtures.

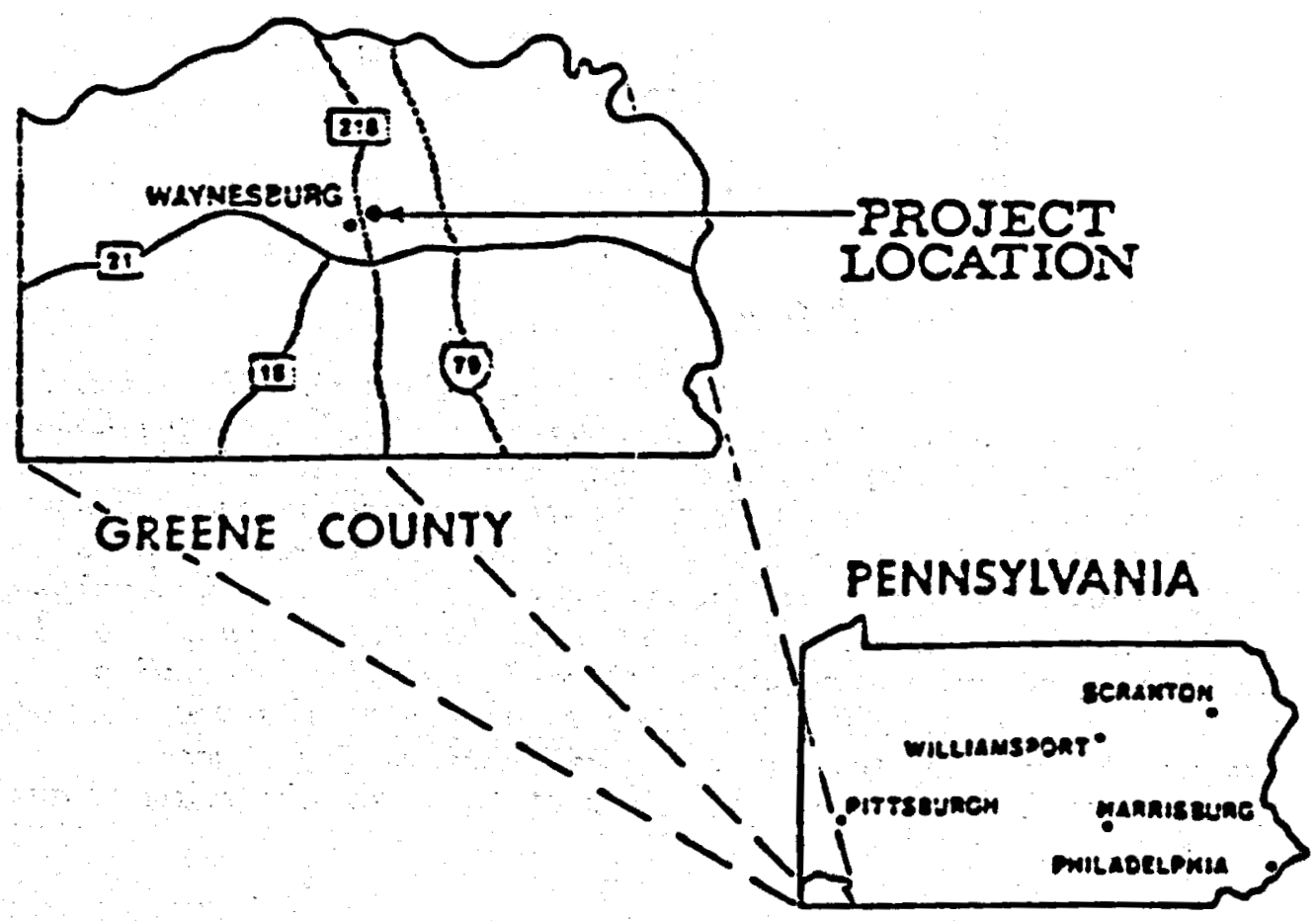


SCOPE OF WORK

This contract is a continuation of research initiated by the U.S. Bureau of Mines to determine the adaptability of directional drilling for draining methane from coalbeds in advance of mining. A directional borehole is first drilled to intercept the Pittsburgh coalbed horizontally at a depth of 1,000 feet below the surface. Multiple long, horizontal methane drainage holes are then drilled into the coalbed in a "birdfoot" pattern originating at the bottom of the directional borehole. A vertical borehole located near the initial coalbed intercept is designed to remove water from the coal to facilitate methane drainage. Seven vertical monitoring boreholes are located within the project area to continually monitor the progress and extent of methane drainage.

\section{BACKGROUND}

Five horizontal methane drainage holes have been drilled into the coalbed in a "birdfoot" pattern originating at the bottom of the directional borehole. A sumary of the drilling results of the horizontal holes is presented in the following table:

$\begin{array}{ccc}\begin{array}{c}\text { Hole } \\ \text { No. }\end{array} & \begin{array}{c}\text { Total length } \\ (\mathrm{ft})\end{array} & \begin{array}{c}\text { Length in } \\ \text { coal }(\%)\end{array} \\ \text { H1 } & 1,767 & 62 \\ \text { H2 } & 3,207 & 84 \\ \text { H3 } & 2,993 & 92 \\ \text { H4 } & 870 & 62 \\ \text { H5 } & 707 & 85\end{array}$

PROGRESS IN THIS REPORTING PERIOD

Production of water and gas has been initiated from the directional methane drainage system. Water production from the dewatering hole has declined from a high of $100 \mathrm{bpd}$ (pump capacity) to $20 \mathrm{bpd}$. As dewatering proceeds, production from the directional borehole has increased to 8,000 cfd and production from the dewatering hole is $17,000 \mathrm{cfd}$. Cumulative gas production from the directional borehole is 550 Mef and 2.132 Mef from the dewatering borehole. . Data from the seven vertical monitoring boreholes indicate that the dewatering process is gradually reducing the coalbed reservoir pressure, but at a rate that is slower than expected. Specifications for remedial drilling activities to increase the flow of gas from the coalbed are in preparation. 
Clinchfield Coal Company McClure, Virginia

\section{Contract:}

Contract Date:

Anticipated Completion Date:

Principal Investigator:

DOE Technical Project Officer:
Status: Active

ET-77-C-01-9151

September 28, 1977

September 28, 1982

T. Wallace

M. A. Trevits (USBM)

\section{OBJECTIVE}

To determine the feasibility of using vertical boreholes to drain methane gas from the Jawbone coalbed and to evaluate the relationship of borehole spacing on gas drainage rates.

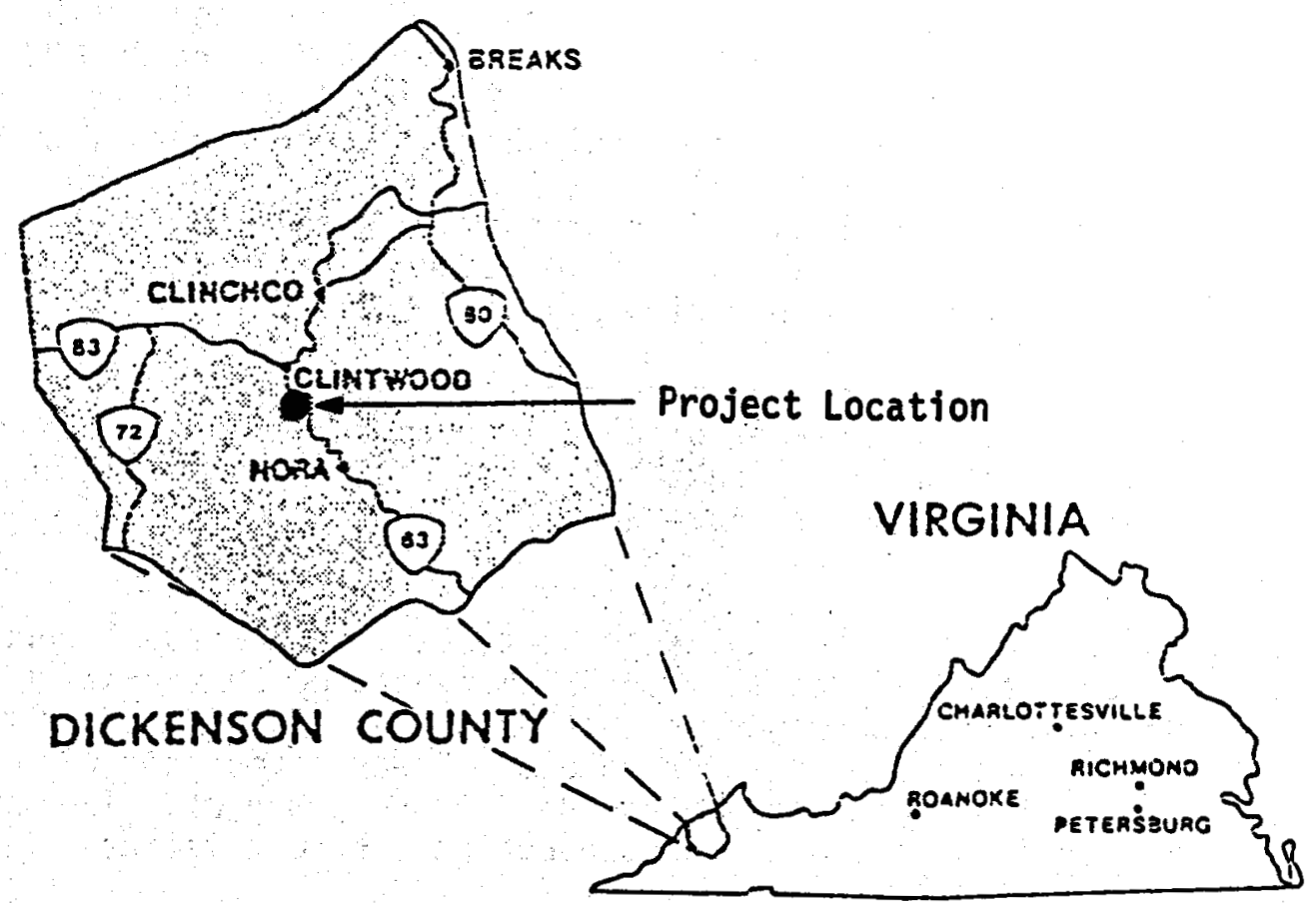


Under this contract, a minimum of five vertical boreholes near Clinchfield's McClure No. 1 mine will be tested. Work is to be conducted in two phases. The first phase consists of drilling and completing five boreholes into the Jawbone coalbed at appropriate spacings. Borehole DG-1A has been located close to mining operations while the remaining boreholes, $D G-2 C, 3 B, 4$, and $5 D$, have been positioned in a four-spot pattern located two years ahead of active mining. When the first phase of this project has been completed, the results will be evaluated.

The second phase will commence upon mutual agreement that a marketable volume of pipeline quality coalbed gas can be produced. The second phase will consist of 20 boreholes completed as in the first phase. Gas produced from these test boreholes will be transported through a pipeline and delivered to a point of utilization or to a commercial gas transmission line for sale.

\section{BACKGROUND}

Drilling operations for the first Jawbone coalbed degasification borehole began on May 30, 1978. Direct method desorption tests performed on two cores recovered from this borehole indicated an in-place gas content of approximately 280 cubic feet per ton of coal. The borehole was subsequently stimulated on June 6,1978 using 30,000 gallons of nitrogen-generated foam and 27,000 pounds of 20- to 40 -mesh sand proppant. Gas production from this borehole has ranged from a high of 43.5 Mcfd in December 1978 to a low of 16 Mcfd in March 1980. Underground mining operations had progressed to within 500 feet of the borehole by March 1980; total cumulative gas production as of the end of September 1980 total led approximately 11.6 MMcf.

Drilling operations at the four-spot pattern began in July 1979. Foam stimulation treatments were performed at boreholes $4 D$ and $5 \mathrm{D}$ upon completion of drilling operations. Average treatment utilized 30,000 gallons of nitrogen-generated foam and 15,700 pounds of 20 - to 40 -mesh sand proppant.

The last two of the five boreholes to be tested under Phase I were drilled and completed by December 1979. Borehole DG-5D was stimulated with 24,400 gallons of nitrogen-generated foam and 14,200 pounds of 20- to 40-mesh sand proppant. Borehole DG-2C was stimulated with 26,200 gallons of nitrogen generated foam and no proppant. The treatment was designed to determine the production characteristics of a no-proppant stimulation treatment.

All boreholes in the four-spot pattern have been outfitted for coalbed water removal. Methane-fueled engines were installed to operate the surface pumping facilities because of the high cost of equipping the 
(Italics denote changes since March 31, 1980.)

pattern with electric power. Borehole 50 was not produced because of a delay in delivery of the methane-fueled engine.

PROGRESS THIS REPORTING PERIOD

Underground mining operations intercepted borehole IA on May 12, 1980. Representatives of the Clinchfield Coal Co. reported that the induced sractures were totally contained within the coalbed, and did not damage the adjacent roof strata. Total cumulative gas production from this borehole duming its 18-month production history was 12 MMcf.

Gas production from boreholes in the foum-spot pattern has been severely limited because of carburetor and alternator problems in the methane-fueled engines. Several attempts have been made to correct the problems, but the engines began to malfunction after only a few days of production. The problem has become 60 acute that the coal company is considering installing electric power despite the high cost. .

The methane-fueled engine for borehole 5D was delivered. Intermittent production from the pattern has averaged 20 Mefd per hole. 
2.5.3 PRODUCTION TECHNOLOGY DEVELOPMENT PROJECTS NOT ASSOCIATED W I TH M I N I N G

Most of the coal in the United States cannot be economically mined with current technology because: (1) the coal horizons are too deep, (2) the seams are too thin, or unstable, and (3) the coal reservoirs are in developed or unaccessable areas.

Many of the thick coal seams existing in the western United States cannot economically be mined because of the amount of overburden, as well as the steeply dipping nature of the coalbeds. Such coal horizons, as well as those underlying urban communities, will possibly not be mined. The methane associated with the coalbeds, however, may be technically and economically recoverable and thus, may contribute to the energy supply.

The projects oriented toward recovery, processing, and utilization of methane from unmined coal seams are relatively new. Four projects, described in the remainder of this section, are in this category.

$\begin{array}{ll}\text { 2.5.3.1 } & \begin{array}{l}\text { Multiple Completion/Single Well Project } \\ \text { (Greene County, Pennsylvania) } \\ \text {-- Waynesburg College }\end{array} \\ \text { 2.5.3.2 } & \begin{array}{l}\text { Anthracite Coal Draingae Project } \\ \text { (Luzerne County, Pennsylvania) } \\ \text {-- Pennsylvania Energy Resources, } \\ \text { Incorporated }\end{array} \\ & \text { Book Cliffs Coal Field Production } \\ & \text { Test Project } \\ & \text { (Carbon County, Utah) } \\ & \text {-- Mountain Fuel Supply Company } \\ & \text { Piceance Basin Production Test Project } \\ & \text { (Rio Blanco County, Colorado) } \\ & -- \text { Intercomp, Inc./Coseka Resources }\end{array}$


2.5.3.1 MULTIPLE COMPLETION DEVELOPMENT TEST PROJECT, GREENE COUNTY, PENNSYLVANIA

Waynesburg College

Waynesburg, Pennsylvania

Contract:

Contract Date:

Completion Date:

Principal Investigator:

DOE Technical Project Officer:
Status: Active

DE-AC21 -78MC08089

July 1979

October 1980

N. F. McGinnis (TRW)

H. D. Shoemaker

\section{OBJECTIVE}

To develop and demonstrate a multiple completion technique system, considering a variable need for dewatering each zone, and utilizing the recovered methane in a local distribution pipeline.

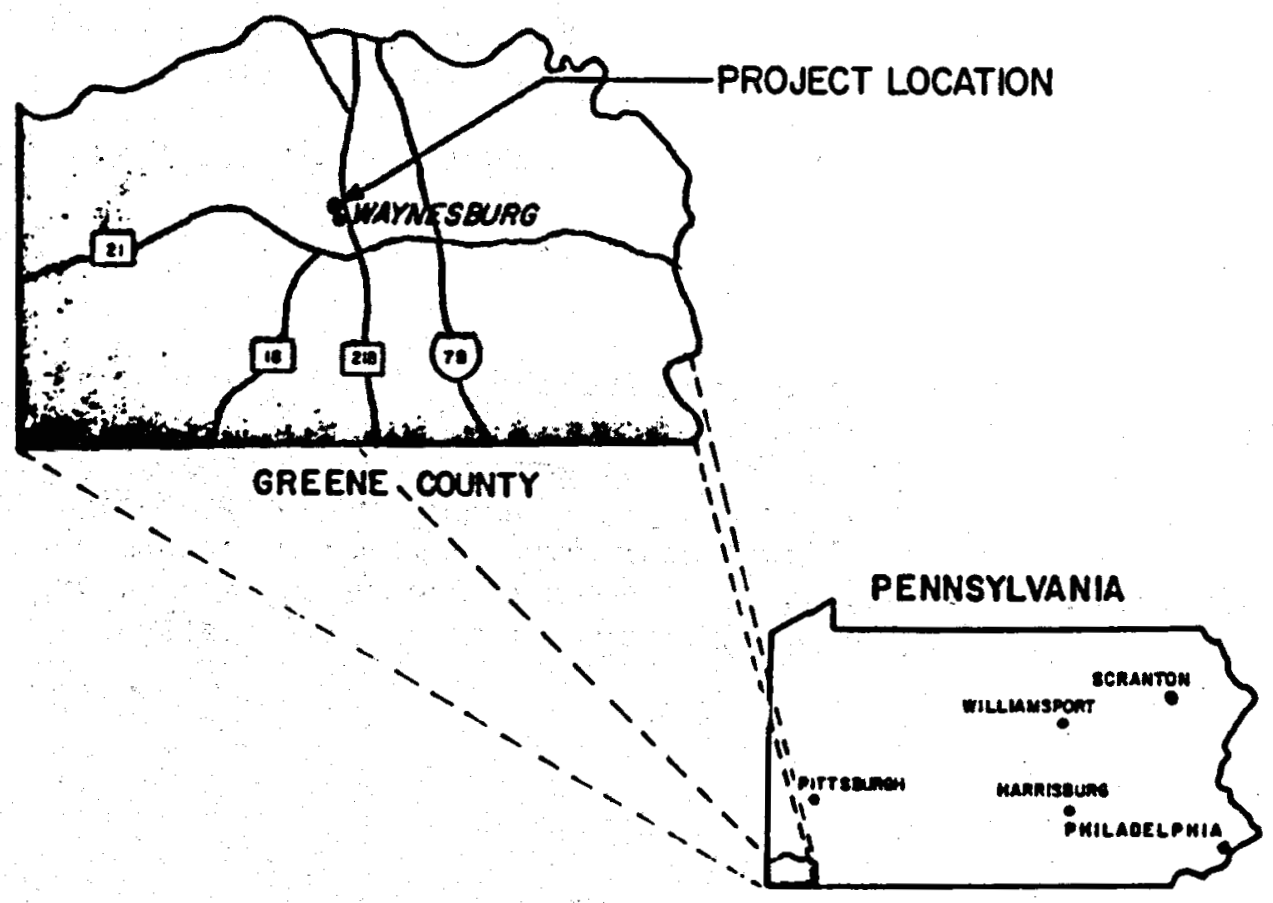


(Italics denote changes since March 31, 1980.)

SCOPE OF WORK

The development of multiple methane production zones in a single well is the objective of this $\mathrm{planned}$ project. The coal is not being mined because it underlies extensively developed surface areas. The site selected for this project is on land owned by Waynesburg College, the Purman Run tract on the college campus college in Waynesburg, Pennsylvania. The proposed utilization of the gas is to supplement the existing natural gas supply to the college.

A method will be developed to perform multiple completion in a single well considering the requirements to isolate the production zones and dewater the production intervals. The development of a multiple completion technique will increase the cost of an individual well but will lower the overall cost of recovering gas from multiple coal seams. The major issue is to develop a technique that will isolate the methane production intervals, as in standard oil field practice, but still provide for the removal of water produced in methane drainage.

BACKGROUND

Under this cost-sharing contract, Waynesburg College is involved in deternining the sechnological and economic feasibility of draining multiple coal horizons through a single well. The well has been drilled on the college campus and the production zones have been identified, isolated, and foam fractured using 20/40 mesh sand as the proppant. During the frac, an unrecorded abandoned well situated approximately 100 yards away from the production well blew out.

A complete description of this project is contained in the Semi-Annual Report for March 1980.

\section{PROGRESS DURING THIS REPORTING PERIOD}

Because of the rainy season and the lack of availability of a workover rig, the old well could not be plugged until late sumer. Difficulties in completely dewatering the well were also experienced, caused by pump failure, pump motor fail ure, gas locks, and accumulation of paraffin in the pump. In late August and early September the surface processing equipinent, consisting of a separator and a dehydrator, was instrlled in readiness for hookup into the commecial pipeline. 
(Italics denote changes since March 31, 1980.)

During late September, Equitable Gas Company analyzed the gas and conveyed its interest in purchasing the coalbed methane for injection into the local pipeline. While not completely devoid of frac nitrogen, the gas composition read as follows:

$\begin{array}{lr}\mathrm{CH}_{4} & 93.8 \% \\ \mathrm{C}_{2} \mathrm{H}_{6} & 0.5 \% \\ \mathrm{~N}_{2} & 3.8 \% \\ \mathrm{CO}_{2} & 1.9 \% \\ \mathrm{O}_{2} & --. * \\ \text { 'Lese than } 0.1 \% & \end{array}$

Final arrangements between Equitable Gas and Waynesburg College are expected to be completed in November 1980 . 
2.5.3.2 ANTHRACITE COAL DRA INAGE TEST PROJECT, LUZERNE

C OUNTY, PENNSYLVANIA

Pennsylvania Energy

Resources Inc. (PERI)

Wilkes-Barre, Pennsylvania

Contract:

Contract Date:

Completion Date:

Principal Investigator:

DOE Technical Project Officer:
Status: Deferred

DE-AC21-78MC08089

To be determined

To be determined

N. F. MCGinnis (TRW)

H. D. Shoemaker

\section{OBJECTIVE}

To develop and demonstrate a system for the recovery of methane from anthracite coal using multiple stimulated wells, and utilizing the gas by injection into a local pipeline.

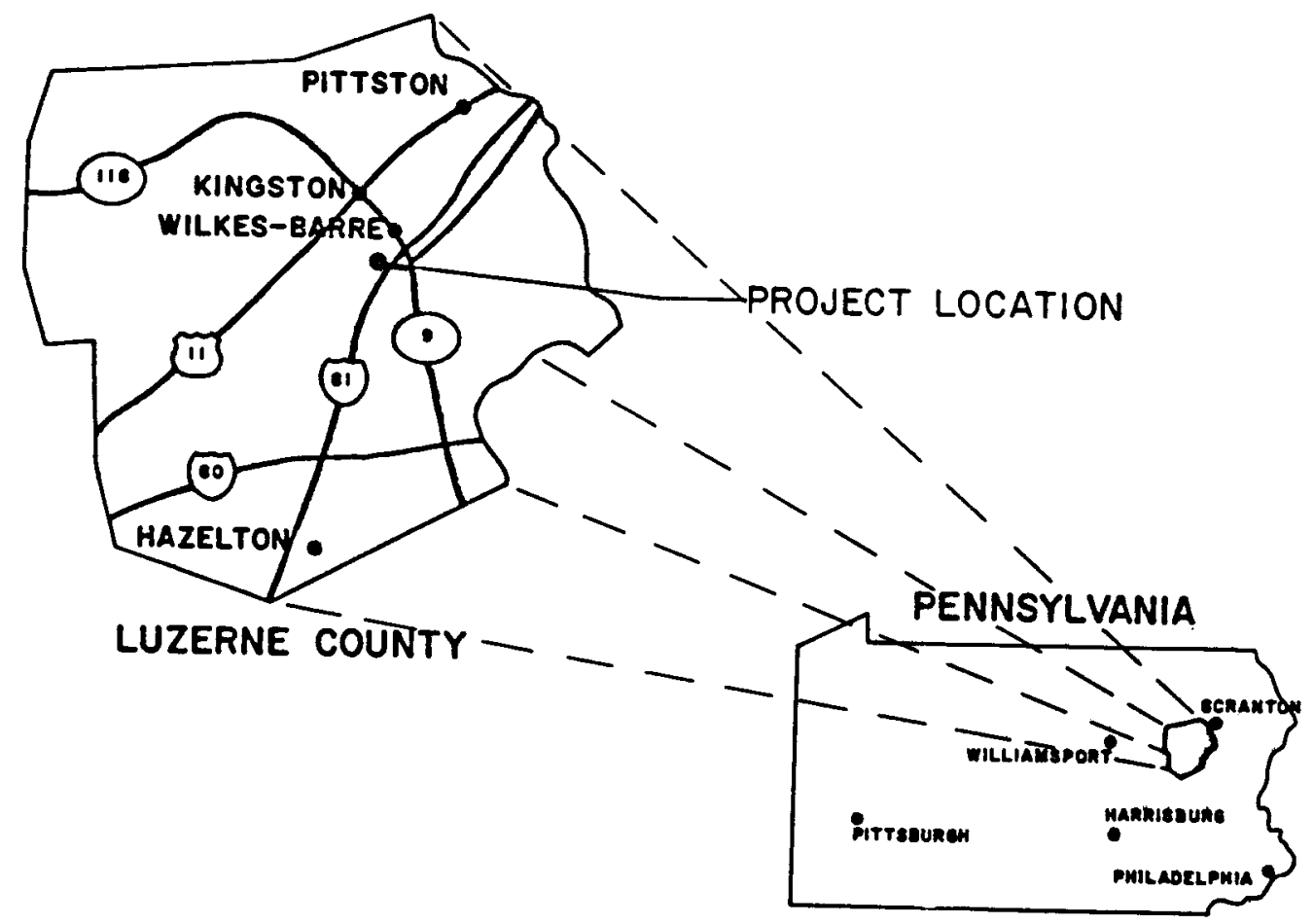


(Italics denote changes since March 31, 1980.)

SCOPE OF WORK

The proposed project was conceived by PERI to develop a technique for economically extracting and using methane from the Red Ash veins of the Northern Anthracite fields, in the area northwest of Wilkes-Barre. The coal is in an area where deep mining was halted because of flooding after a major cave-in. The veins are under zones containing water obviously communicating with the nearby Susquehanna River. Surface or pit mining is not practical because of the depth of the coal $(2,000$ feet). The contract provides for the geological characterization of the test area, the selection of stimulation techniques, an! the drilling and completion of three production wells. Various completion and stimulation techniques will be used. The proposed utilization is to tie the wells into a local pipeline owned by the Pennsylvania Gas and Water Company, a company associated with PERI.

\section{BACKGROUND}

PERI has prepared a conceptual design, obtained gas rights to the leased land, selected sites for four wells, and obtained coal samples. In addition, A draft of the Environmental Assessment for this project has been completed.

PROGRESS THIS REPORTING PERIOD

Budgetary constraints precluded implementation of this project during FY 1980; however, arrangements are being made to resime work in early FY 1981 . 
2.5.3.3 B $00 K$ CLIFFS COALFIELD PRODUCTION TEST PROJECT

Mountain Fuel Supply Company

Salt Lake City, Utah

Contract:

Contract Date:

Completion Date:

Principal Investigator:

DOE Technical Project Manager:
Status: Active

DE-AC21-78MC10734

January 11, 1979

April 11, 1982

R. L. Coates

H. D. Shoemaker

\section{OBJECTIVE}

To determine effective extraction techniques for recovery and utilization of coalbed methane from deep horizons.

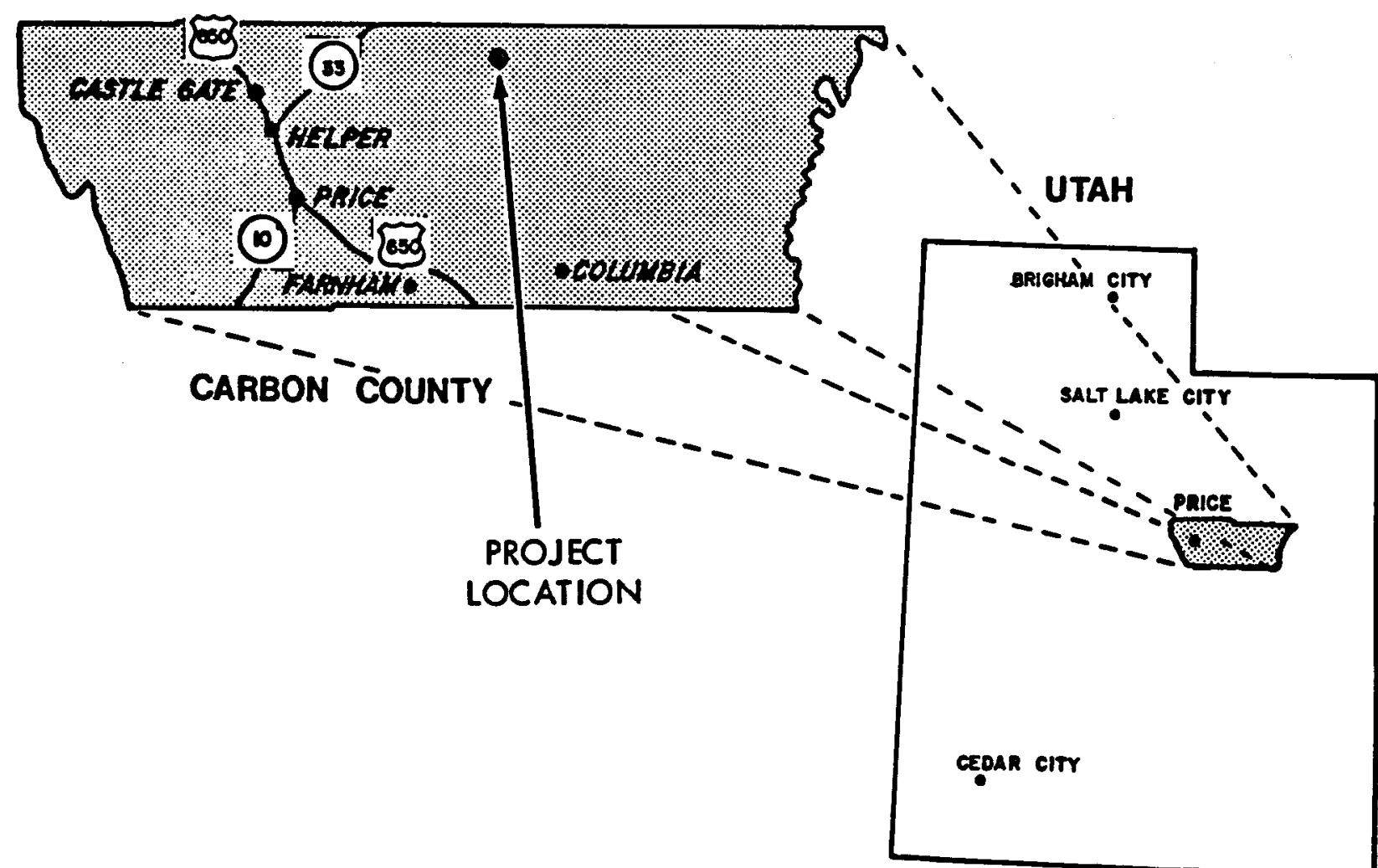


This project is intended to demonstrate methane production from deep coal seams of the Book Cliffs Coal Field in central Utah. An objective of the project is to determine effective extraction techniques leading to gas recovery for pipeline injection into an interstate facility owned by MFSC. The project consists of three sequential phases:

- Phase I - System preliminary design, development and

- Phase II - Detailed design and analysis ( 6 months)

- Phase III - Site preparation and operation (27 months).

Three vertical wells will be drilled and completed using fracture techniques similar to those successfully used by USBM in shallower eastern coals. One or more seams will be stimulated in each well depending on drilling and coring test data. Following an initial production test period of up to three months, during which the coalbed will be dewatered, facilities will be installed to gather, compress, dehydrate, and inject the gas into a nearby transmission line. An extended production test of up to 15 months would then be conducted. The entire project will be completed over a 36-month period.

BACKGROUND

Three recovery well site locations have been selected based on favorable coal depth, high methane content of the coal, access for drilling, proximity to an existing natural gas pipeline, and favorable coal, oil, and gas lease ownerships. Wells No. 1 and No. 2 are located in the Whitmore Park area of the Book Cliffs region (Section 34, T12S, R12E, Carbon County, Utah). Well No. 3 is located in Mathis Canyon in the Castle Gate area of the Book Cliffs region (Section 15, T12S, R10E, Carbon County), about 12 miles west of Wells No. 1 and No. 2 .

Phases I and II were completed and Phase III was initiated in September 1979. Well site plans for all three wells were prepared, and USGS and State of Utah approvals to drill were received for the Whitmore Park Wells No. 1 and No. 2. USGS denied the drilling permit application for the Mathis Canyon Well No. 3 because of questions concerning gas ownership and "minability" of the coal. Concern was expressed about potential damage to the coal/overburden rock by fracture treatment that might adversely affect subsequent mining operations. The application was resubmitted in September without hydraulic stimulation, and an appeal of the original application, including hydraulic stimulation, was made soon thereafter. 
(Italics denote changes since March 31, 1980.)

The Whitmore Park Well No. I was drilled and cored in October 1979. The coal seam depths and thicknesses are:

\begin{tabular}{lcccc} 
Coal Seam & Projected Depth & & Actual Depth & Actual Thickness \\
\cline { 2 - 3 } Sunnyside & 2666 & & 2881 & 12 \\
Rock Canyon & 2836 & & 3033 & 5 \\
Fish Creek & 2856 & & 3055 & 4 \\
Gil son & 2874 & 3097 & 14 \\
Kenilworth & 2937 & 3160 &
\end{tabular}

Permeability calculated for the Gibson coal ranges from $20 \mathrm{md}$ at an injection rate of 0.47 BPM, to $200 \mathrm{md}$ at a rate of 1.5 BPM. Methane content ranges from approximately 97 to 98.5 percent.

The Whitmore Park Well No. 2 was drilled and cored in November 1979. Methane content ranges from 95 to 98 percent. Heavier hydrocarbons do not appear to be present in significant concentrations.

Desorption data from the Whitmore Park well coal samples indicate maximum gas content of $395 \mathrm{cf} / \mathrm{t}$ on of coal, excluding residual gas. After each sample has completely desorbed, it will be crushed and the residual gas content will be measured. The desorption samples taken by the UGMS measured less gas desorbed than the Mountain Fuel Supply and IGT samples. Gas content from the UGMS samples ranges from 58 $\mathrm{cf} /$ ton to $215 \mathrm{cf} /$ ton to $395 \mathrm{cf} / \mathrm{ton}$. The reason for the apparent difference is unknown, but several pusibilities are being investigated.

PROGRESS THIS REPORTING PERIOD

Prestimulation pumping has been initiated on the. Whitmore Well No. 1. Water production rates ( $43 \mathrm{bpd})$ indicate communication with a fractured sand zone above the Gilson coalbed. A casing liner has been rum and cemented in place, but the consensus from MSFC. IGT, and Halliburton experts indicates the zone cannot be fractured without reopening the water zone. Hence, Whitmore No. 1 will not be used as a production well.

Prestimulation dewatering of the Whitmore No. 2 well continued until the weli was stimulated during september. The treatment will be 
(Italics denote changes since March 31, 1980.)

designed and applied by Halliburton. Critical parameters of the stimulation plan are:

Hydraulic pad volume, gallons of water Total volime, gallons of foam

Foam Quality, percent N2

Sand, $2 b$.

Promping Rate, bbl/min

Formation Pressure, psi

Formation Temperature, ${ }^{\circ} F$

BHTP, pei

Casing, inches

5,000

50,000

75

60,000

KCL Concentration, percent in water 15

1,050

90

2,940

5.5

Foaming Agent, gailons/gallon water

$5 / 1,000$ 
2.5.3.4 PICEANCE BASIN PRODUCTION TEST PROJECT

Intercomp, Inc.

Houston, Texas

Contract:

Contract Date:

Completion Date:

Principal Investigator:

DOE Technical Project Officer:
Status: Delayed Awaiting DOI Decision

$78 \mathrm{ET} 12408$

September 29, 1978

December 31, 1980

K. L. Ancell

H. D. Shoemaker

\section{OBJECTIVE}

To demonstrate effective extraction technology for ultimate recovery and utilization of methane from coalbeds located in Rio Blanco County, Colorado.

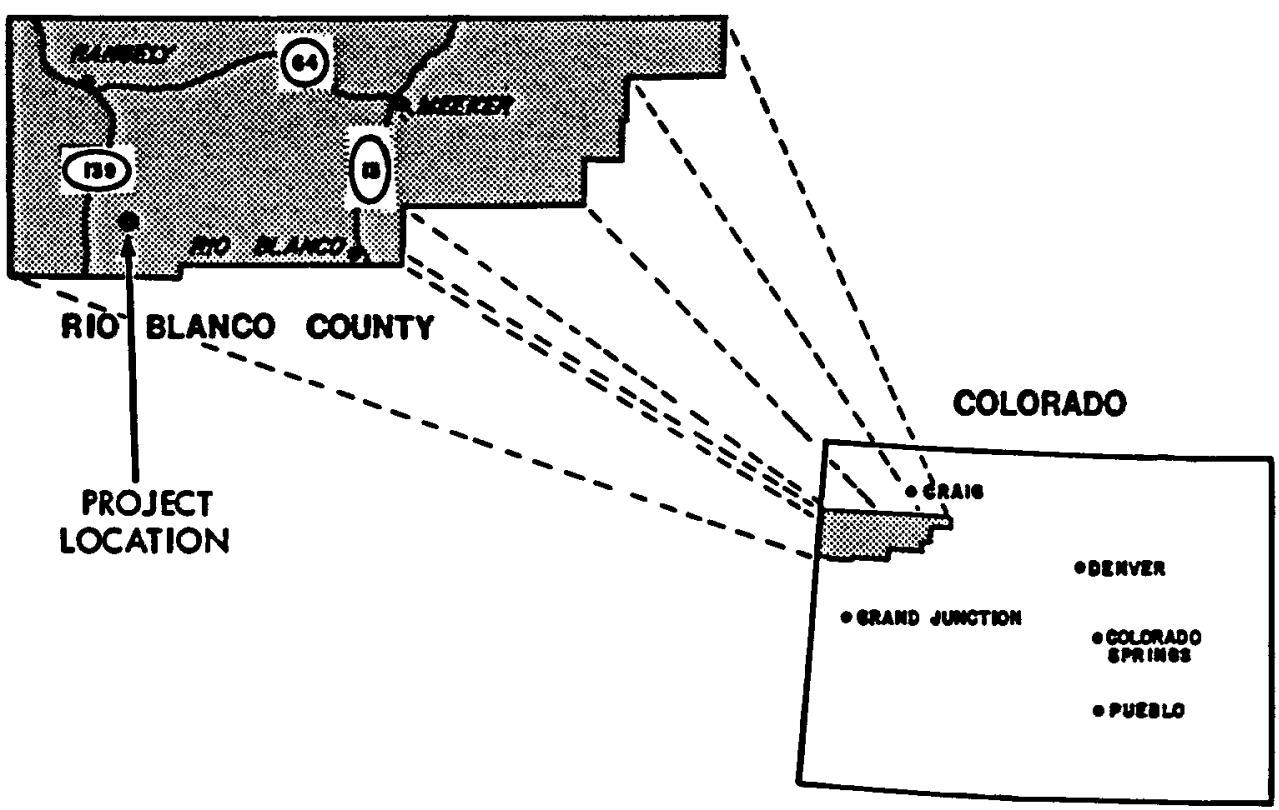


This contract, a cooperative agreement between DOE and Intercomp/ Coseka Resources, consists of a project at a Coseka-leased site in Rio $B$ lanco County, Colorado involving an existing Coseka well, Federal 1-16, which has demonstrated approximately 10 Mcfd production. The project objective is to determine effective extraction techniques leading to methane production from coalbeds underlying the site, for injection into an 80-psi pipeline located nearby. Methane extraction will be accomplished by vertically drilled wells involving multiple hydraulic fracture treatments. The project consists of three sequential phases:

o Phase I - System preliminary design, development and analyses ( 6 months)

- Phase II - Detailed design and analysis (3 months)

o Phase III - Site preparation and operation (9 months).

Phase I consists of a multi-well program involving the current Coseka Federal 1-16 well for observation and at least one other offset production well that will be drilled, cored, logged, stimulated, and thoroughly tested. The production well will be drilled 2,000 feet north of the Federal 1-16 well to a depth of 1,500 feet; both water and gas production will be monitored, and samples will be collected and analyzed. Four to 12 weeks of production data will be collected. Data collected from the various well tests will be analyzed mathematically using the Intercomp reservoir model. Model results will be used in the design of appropriate hydraul ic fracture treatments. After stimulation work has been completed, a complete evaluation of well performance will be made.

Phase II will use the Phase I results for detailed design and analysis of the methane production system for Phase III. Phase III will consist of the implementation of the pilot-scale methane production system including wells, gas-gathering systems, compressor station, etc. Arrangements will be made for prerelease and sales agreements before introducing the gas into the pipeline system.

BACKGROUND

Field activities were started in the fall of 1978 , but were not possible during the winter months because of adverse weather conditions. The well remained shut-in all winter and well site activity was resumed in Apri1 1979. It was swabbed in May and an adequate gas flow was observed. As a result, it was decided that an injection test to determine permeability of coal seam would not be performed. 
(Italics denote changes since March 31, 1980.)

A pumping jack was installed and a 75-day gas production test was started on June 8,1979 . The initial gas production measured 10 Mcfd gas flow with 11 psi on the casing side.

Well 1-16 was shut down in August. During the 75-day production period, the well produced a total of 686 Mcf of gas and 642 barrels of water. The average calculated rates are 9.2 Mcfd of gas and $8.6 \mathrm{bpd}$ of water. Drilling plans have been prepared for a second well, Federal 12-15. However, approval has not been granted by the USGS and DOI to drill and fracture this well as planned. Questions were raised concerning gas ownership and "whether or not the oil and gas lessee has the right to recover gas associated with coal deposits".* This could preclude fracture treatment, which is probably required to provide accceptable gas production. Fracture treatment planning continued pending resolution of this "potential resource conflict".*

PROGRESS THIS REPORTING PERIOD

Field activity on this contract has been temporarily suspended pending approval of the sundry notice to drill and fracture Federal 12-15 by the USGS and DDI. Although the DOE is pursuing this issue, no decision had been made by the end of this reporting period.

Contract Modification No. M004 was received, changing the contract number from DE-AC21-80ET12408 to DE-AC21-78ET12408 and modifying some of the reporting addresses. A request to extend the contract completion date from December 31, 1980 to December 31, 1981 has been submitted.

* Quoted from well permit denial. 


\subsection{EASTERN GAS SHALES}

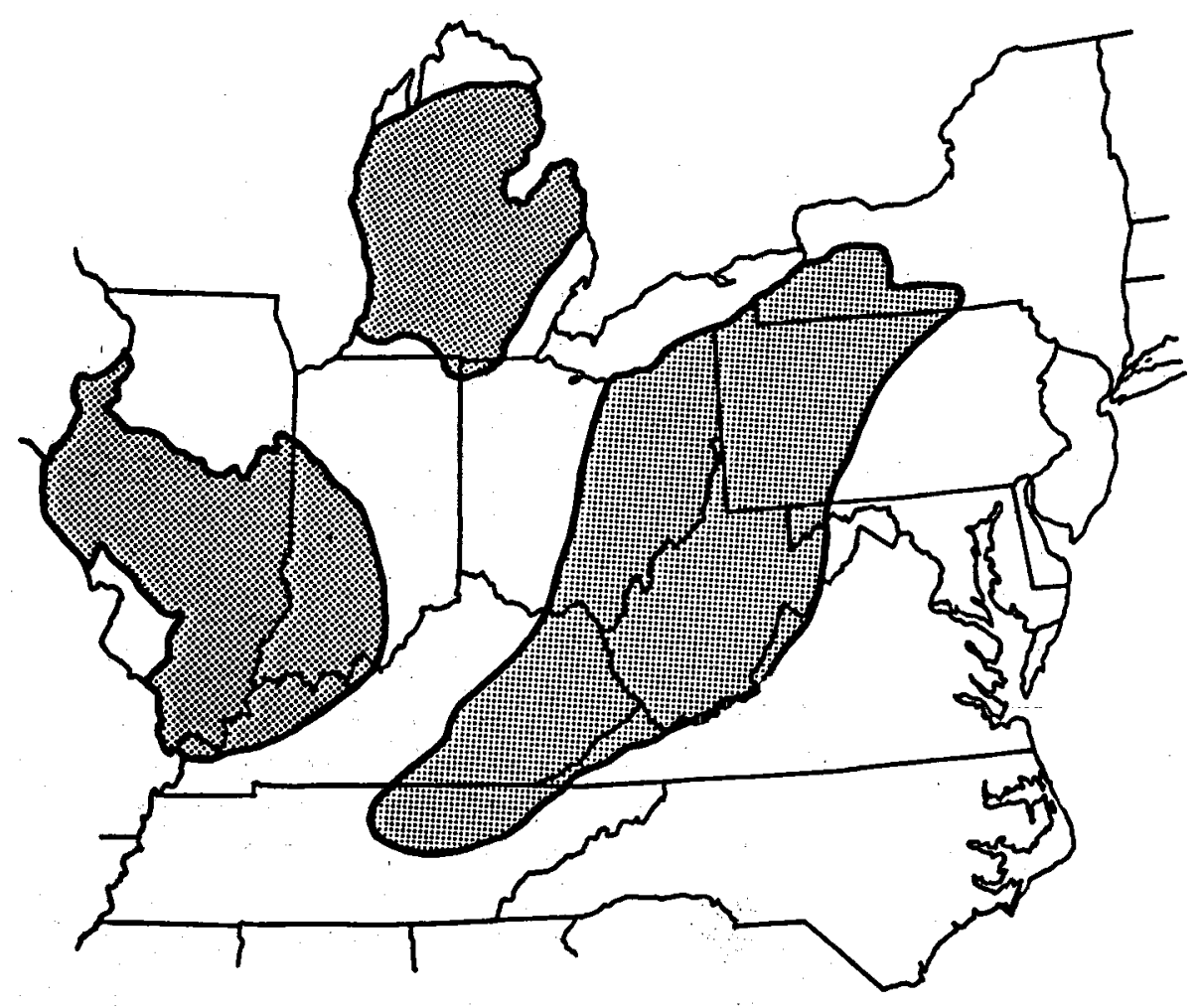


3.1 Introduction.................................. 3-1

3.1.1 Project Description......................... 3-1

3.1 .2 Contractors............................... 3-5

3.2 Resource Characterization and Inventory.............. 3-7

3.2.1 Introduction................................ 3-7

3.2.2 Appalachian Basin............................ 3-7

3.2.3 Illinois Basin............................... 3-26

3.2.4 Michigan Basin............................... 3-34

3.3 Extraction Technology R \& D....................... 3-35

3.3.1 Introduction................................ 3-35

3.3.2 Fracture Mechanics............................ 3-35

3.3.3 Production Enhancement........................ 3-35

3.3.4 Reservoir Performance.......................... 3-36

3.3.5 Technical Support............................. 3-36

3.4 Technology Testing and Verification................... 3-48

3.4.1 Introduction................................ 3-48

3.4.2 Exploration Rationale......................... 3-48

3.4.3 Exploitation Rationale........................ 3-48

3.5 Project Integration............................... 3-60

3.5.1 General.................................... 3-60

3.5.2 Environmental Activities....................... 3-60

3.5.3 Project Data Base Management System.............. 3-60

3.5.4 Economic Evaluation........................... 3-60

3.5.5 Technology Transfer.......................... 3-61 


\section{LIST OF TABLES}

Page

Table 3-1 EGSP Contractors/Work Packages................ 3-6

Table 3-2 Cliffs Minerals, Inc. Data Collection on EGSP

Cores..................................... 3-9

Table 3-3 Mound Facility EGSP Core Analyses.............. 3-14

Table 3-4 Summary of Data on Wells Shot with EL836 Water

Gel Explosive............................... 3-43

Table 3-5 Drilling and Logging Information for Ten Wells

Under Columbia Gas Contract.................. 3-54

Table 3-6 Columbia Gas 10-Well MHF Program Summary as of

$8 / 31 / 80$.

\section{LIST OF FIGURES}

Figure 3-1 Location of Eastern Gas Shales Geologic Provinces. 3-2

Figure 3-2 Eastern Gas Shales Project Description........... 3-3

Figure 3-3 ERIM Study Area in Western Kentucky............ 3-10

Figure 3-4 Location of Gruy Federal, Inc. Activities During

Second Half of FY80......................... 3-12

Figure 3-5 Location of Erie County, PA, Wel1............. 3-13

Figure 3-6 Location of Eight NX Wireline Core Holes........ 3-17

Figure 3-7 Gas Production Potential and Known Gas Shows in 111 inois............................... 3-32

Figure 3-8 Schematic of Gruy Federal, Inc. Surface Facilities for Eastern Devonian Shale Gas Testing Program.... 3-45.

Figure 3-9 Location of Donohue, Anstey \& Morrill Test Wells and Radioactive Shale Isopach of West Falls

Formation............................... 


\subsection{N TRODUCTION}

\subsubsection{PROJECT DESCRIPTION}

The Eastern Gas Shales Project (EGSP) is one of several unconventional gas resource projects currently being funded by the Department of Energy (DOE) to enhance the nation's gas supply posture. EGSP efforts during the first four years of the ten-year project have been directed at determining the geologic character and magnitude of the Devonian shale gas resource and toward increasing production of natural gas from this resource base. Almost all of the planned formation characterization work required to update the resource knowledge base has been completed. Geological evaluations are essentially complete to ascertain basin limits and stratigraphic targets as potential gas sources. With these developments, large areas of the Devonian shale have evolved as geologic provinces (Figure 3-1) exhibiting certain characteristics that require particular technological developments for gas extraction. Integration of geologic data to determine prospects for shale production testing is in progress.

EGSP research has identified the nature of producible gas containment to be micro- and macro-fractures in the shale formation. Knowledge of these fractures, their directionality, and their density has enabled the development and testing of effective techniques to connect the gas-bearing natural fractures to the borehole. Tests of stimulation techniques in light of the geologic environment in the respective gas provinces have permitted the development of a rationale for stimulation strategy. The results of these pilot tests are undergoing systematic evaluation to permit refinement of R\&D objectives. Initial economic analyses of Devonian shale stimulation ventures have been encouraging and indicate that shale gas production should be technically and economically viable in some geologic provinces.

The EGSP activities are organized into the following four functional categories, or project Elements:

- Resource Characterization and Inventory

- Extraction Technology Research and Development

- Production Development

- Project Integration

The interrelationships between these Elements are shown in Figure 3-2. The goals and objectives of these thements are described below. 
í

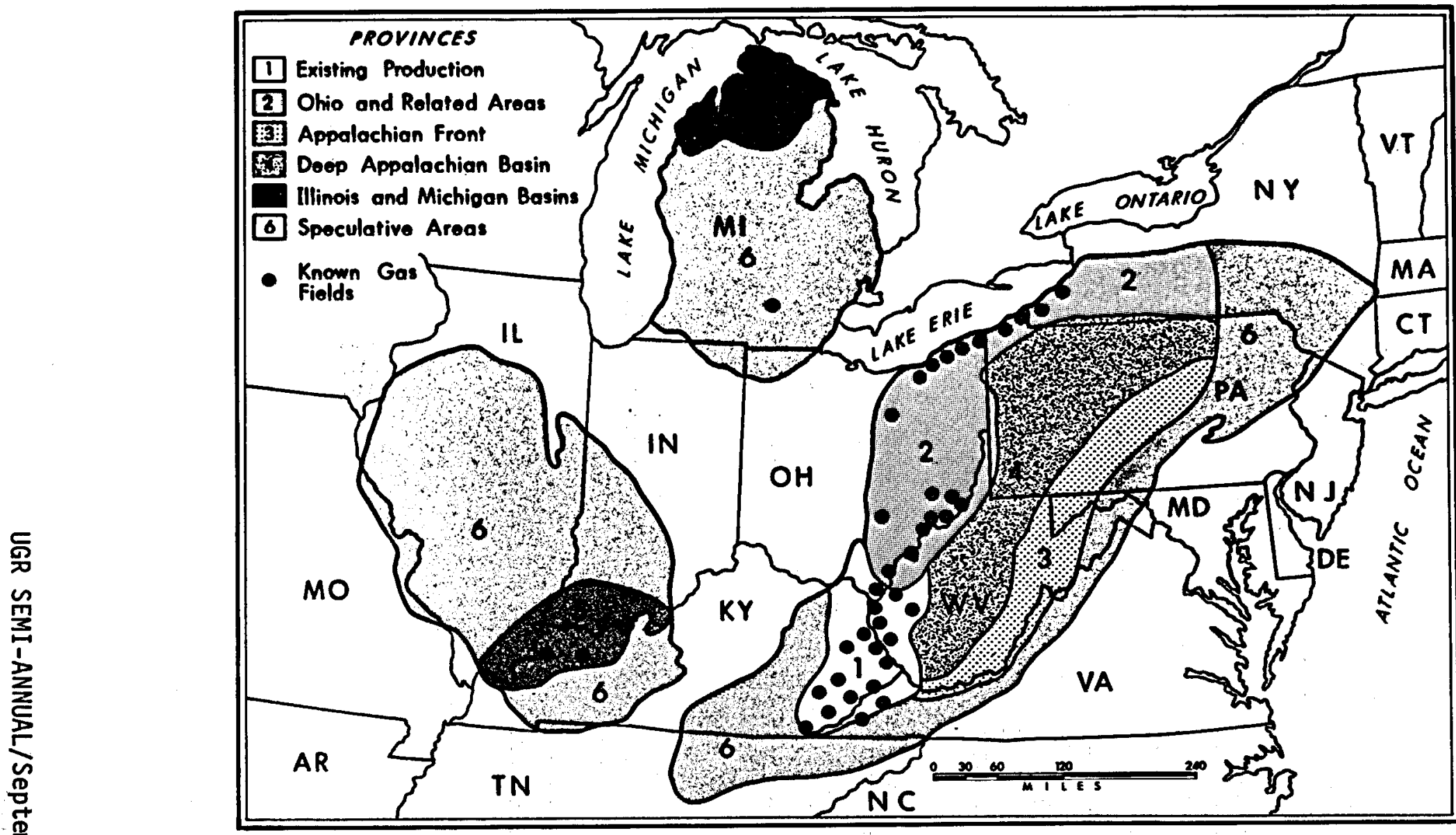

Figure 3-1 Location of Eastern Gas Shales Geologic Provinces 


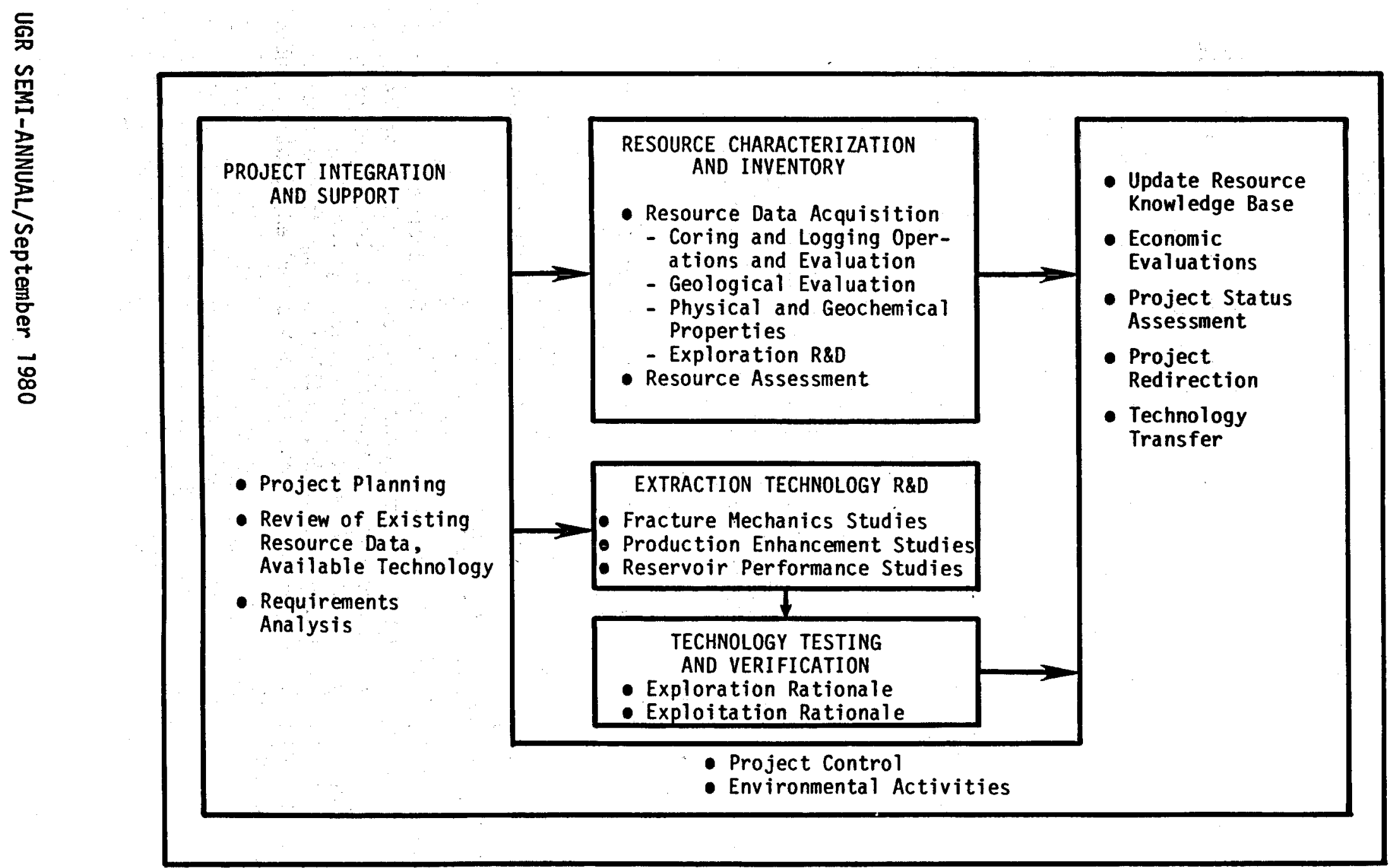


The goals of this Element are to determine the geologic, physical, and geochemical characteristics of the Devonian shales in order to develop methods of quantifying the amount of available gas, and methods of locating high potential areas of gas production.

The objectives are to:

- Generate stratigraphic, structural, and sedimentological data in order to characterize the geologic setting of the Devonian shale in the Appalachian, Illinois, and Michigan Basins.

- Physically and chemically characterize rocks of Devonian age within their geologic framework.

- Estimate the total gas resource and producible reserves of the Devonian Shale.

- Identify analogs to known fracture systems and production areas and to utilize geological, geophysical, and geochemical methods to locate fracture systems in the Devonian shale.

\section{EXTRACTION TECHNOLOGY RESEARCH AND DEVELOPMENT}

The goals of this Element are to: undertake laboratory, theoretical, and/or field-based R\&D studies aimed at identifying promising ways to recover substantial amounts of new gas from the Devonian shale reservoirs that have been located by particular exploration rationales.

The objectives are to:

- Develop a comprehensive understanding of the factors affecting gas production from reservoirs in various geologic regions.

- Develop a forecasting capability by which reservoir response to stimulation will be indicated for various geologic conditions.

\section{TECHNOLOGY TESTING AND VERIFICATION}

The goals of this Element are to: test, evaluate, and document exploration techniques used to locate natural fracture systems in the Devonian shale; verify and document various extraction techniques used to maximize the recovery of natural gas; and establish feasible economic options for various exploration, drilling, completion, and stimulation techniques in view of current and projected exploration and extraction technologies. 
The objectives are to:

- Utilize various exploration techniques to locate target wells and to perform subsequent well stimulation, well testing, and reservoir evaluation to verify these techniques.

- Verify by field testing, various drilling and completion techniques developed through the Extraction Technology R\&D Element.

- Demonstrate the cost-effectiveness of the various exploration and exploitation techniques tested.

PROJECT INTEGRATION

The goal of this Element is to provide direction and guidance for meeting project goals and objectives, from an overall systems perspective.

The objectives of this Element are to:

- Plan, coordinate, and evaluate the project.

- Establish the technical requirements for the other project Elements and determine if they are met.

- Establish economic options for gas production based on current and projected drilling, completion, and stimulation technologies.

- Identify and coordinate all project environmental activities.

- Implement transfer to the private sector of the technology developed and utilized in the EGSP.

\section{1 .2 C ONTRACTORS}

The contractors active in the EGSP during this reporting period are identified in Table 3-1. 
Table 3-1 EGSP Contractors/Work Packages

\begin{tabular}{|c|c|c|c|c|c|c|c|}
\hline \multirow[b]{2}{*}{ EGSP Contractors } & \multicolumn{3}{|c|}{$\begin{array}{l}\text { RESOURCE } \\
\text { CHARACTERI ZATION } \\
\text { AND INVENTORY }\end{array}$} & \multicolumn{2}{|c|}{$\begin{array}{l}\text { EXTRACTION } \\
\text { TECHNOLOGY } \\
\text { R\&D }\end{array}$} & \multicolumn{2}{|c|}{$\begin{array}{l}\text { TECHNOLOGY } \\
\text { TESTING AND } \\
\text { VERIFICATION }\end{array}$} \\
\hline & 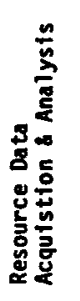 & 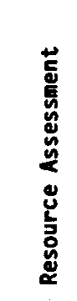 & 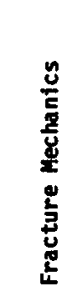 & 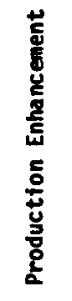 & 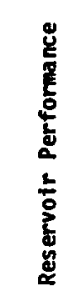 & 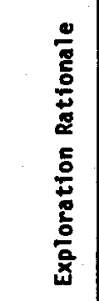 & 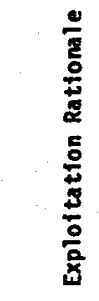 \\
\hline Cliffs Minerals, Inc. & $x$ & & & & & & \\
\hline Columbia Gas System Service Corp. & & & & & & & $x$ \\
\hline Donohue, Anstey \& Morrill (2) & & & & & & $x$ & \\
\hline E. I. DuPont DeNemours \& Co. & & & & $x$ & & & \\
\hline $\begin{array}{l}\text { Environmental Research Inst itute } \\
\text { of Michigan }\end{array}$ & $x$ & & & & & & \\
\hline Gruy Federal, Inc. (2) & $x$ & & & & $x$ & & \\
\hline Houghton College & & & & & & & $\bar{x}$ \\
\hline Illinots Geological Survey (2) & $\underline{x}$ & & & & & & \\
\hline Indiana Geological Survey & $x$ & & & & & & \\
\hline Juniata College & $x$ & & & & $x$ & & \\
\hline Lawrence Livermore Laboratory & & & $x$ & & & & \\
\hline Mitchell Energy Corporation (2) & & & & & & $x$ & $x$ \\
\hline Mound Facility & $x$ & & & & & & \\
\hline Ohio Geological Survey & $x$ & & & & & & \\
\hline Ohio State University & & & $x$ & & & & \\
\hline Sandia Laboratories & & & $x$ & & & & \\
\hline Science Applications, Inc. & $\bar{x}$ & $x$ & $x$ & & $x$ & & \\
\hline Stanford Research Institute (2) & & & $x$ & & & & \\
\hline Tennessee Geological Survey & $x$ & & & & & & \\
\hline Terra Tek, Inc. (2) & & & $x$ & & & & \\
\hline Tetra Tech, Inc. & $x$ & & & & & & \\
\hline United States Geological Survey & & $x$ & & & & & \\
\hline University of Kentucky RF & $x$ & & & & & & \\
\hline University of Maryland & & & $x$ & & & & \\
\hline J. T. Waggoner & & & & & & & $x$ \\
\hline Thurlow Heed Associates & & & & & & & $x$ \\
\hline $\begin{array}{l}\text { West Virginia Geological } \\
\text { Economic Survey }\end{array}$ & $\underline{x}$ & & & & & & \\
\hline West Virginia University (3) & $x$ & & $x$ & & & & \\
\hline
\end{tabular}




\subsubsection{N TR O D U C T I O N}

This part of the EGSP includes the acquisition and analysis of geological, physical, and geochemical data. During this reporting period, the data collection phase was essentially completed. Emphasis now is on development and testing of exploration rationales to identify favorable areas for gas production, and refining resource estimates.

\subsubsection{APPALACHIAN BAS IN}

The Appalachian Basin extends for over 1500 miles from southern New York to northern Alabama and Georgia. All of the State of West Virginia and portions of New York, Pennsylvania, Ohio, Maryland, Virginia, Kentucky, Tennessee, North Carolina, South Carolina, Georgia, and Alabama are included. The EGSP study area in the Appalachian Basin includes over 90,000 square miles of Devonian shale formations, or all of the State of West Virginia and portions of New York, Pennsyivania, Ohio, Maryland, Virginia, Kentucky, and Tennessee (see Figure 3-1).

The rock formations of the Devonian geologic period were deposited in inland seas over 350 million years ago. The Devonian shales outcrop in the eastern, northern, and western portions of the Basin and reach a thickness of over 3000 feet in south-central West Virginia. The rock facies become coarser-grained and thicken to the east of this area.

A summary of the work performed in Resource Characterization during this reporting period follows.

Collection, Description, and Logging of EGSP Devonian Shale Cores Cliffs Minerals, Inc. Contract Number: DE-AC21-78MC08199

The objective is to collect data on Devonian shale cores and to describe the lithology, fractures, and physical properties of the cores for comparison with logs.

sampling and laboratory procedures are almost completed for all wells to date except for wells PA\# 1, PA\#3, PA\#4, PA\#5, and MI\#2. Phase I reports are completed except for newly acquired wells - reports are in progress. Phase II reports are completed or in preparation except for those wells requiring sampling and laboratory measurements. Phase III 
(Italics denote changes since March 31, 1980)

reports have been started on several wells, but only one well (WV\#5) is near completion. A display of the work accomplished during this reporting period and the present status of this contract is given in Table 3-2.

Remote Sensing Applied to the Increase of Natural Gas Reserves in the Devonian Shale

Environmental Research Institute of Michigan

Contract Number: DE-AC05-77ET12137

The objective is to evaluate remote sensing as an exploration technique for natural gas from the Devonian shales of the Appalachian, Illinois, and Michigan Basins. In an area selected for lineament enhancement, selected imagery will be processed and interpreted, and a final report will evaluate the current status of remote sensing, lineamentenhancement research, and its future potential.

Completely digitized seasat imagery (100 km width) has been received in both tapes and transparencies. Transparencies are being enlarged to a $1: 250,000$ scale.

Gradient filtering was performed on test site III on Landsat band ${ }_{4}^{6}$ utilizing a $3 \times 3$ and $9 \times 9$ smoothing with a passband at $N E-S W \pm 20^{\circ}$. The purpose was lineament enhancement. However, the enhancement was not much of an improvement over unenhanced color-composited imagery. An algorithm obtained from USGS has indicated better interpretive characteristics in other regions and is now being tested on the test site imagery. The algorithm uses a 101 by 101 difference filtering system to destrip the Landsat image. The filter image is then combined with the unfiltered image.

Figure 3-3 shows the ERIM study area in western Kentucky.

Organization and Collection of Data from EGSP Drilling, Coring, and Logging Operations

Gruy Federal, Inc.

Contract Number: DE-AC05-78MC08382

The objective is to obtain core material and data from up to 22 new EGSP wells. All field activities connected with the coring, logging, completion, and testing of the EGSP core wells will be reported. 


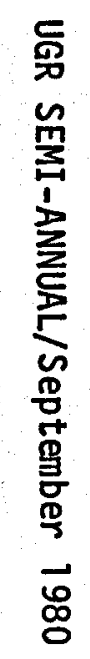

Table 3-2 Cliffs Minerals, Inc. Data Collection on EGSP Cores

\begin{tabular}{|c|c|c|c|c|c|c|c|c|c|c|c|c|c|c|c|c|c|c|c|c|c|c|c|c|c|c|}
\hline & in & $\begin{array}{ll}\mathrm{w} \\
\mathrm{k}\end{array}$ & $\begin{array}{l}w \\
7 \\
\end{array}$ & $\begin{array}{l}\mathrm{kY} \\
14 \\
\end{array}$ & $\begin{array}{l}\mathrm{MI} \\
n\end{array}$ & $\begin{array}{l}\mathrm{MI} \\
12\end{array}$ & \begin{tabular}{|l|l|}
$M y$ \\
$n$ \\
1
\end{tabular} & $\frac{14}{12}$ & $\begin{array}{ll}\mathrm{MY} \\
3\end{array}$ & 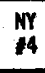 & $\begin{array}{ll}\text { OH } \\
13\end{array}$ & \begin{tabular}{l|l} 
OH \\
-4
\end{tabular} & $\begin{array}{l}\mathrm{OH} \\
15 \\
\end{array}$ & $\begin{array}{ll}\mathrm{OH} \\
\text { H6-1 } \\
\end{array}$ & \begin{tabular}{l|}
$\mathrm{OH}$ \\
$6-2$ \\
40
\end{tabular} & $\begin{array}{ll}\mathrm{OH} \\
16-3 \\
\end{array}$ & \begin{tabular}{|l|}
$\mathrm{OH}$ \\
$6-4$ \\
\end{tabular} & $\begin{array}{l}\text { OH } \\
\text { 16-5 }\end{array}$ & $\begin{array}{ll}\text { OH } \\
\text { H }\end{array}$ & $\begin{array}{l}\mathrm{OH} \\
\mathrm{OH}\end{array}$ & $\begin{array}{l}\mathrm{PA} \\
\mathrm{A}\end{array}$ & $\begin{array}{l}\mathrm{PA} \\
72 \\
\end{array}$ & $\begin{array}{ll}\mathrm{PA} \\
\mathrm{B} \\
\end{array}$ & $\begin{array}{l}\mathrm{PA} \\
\mathrm{PA}\end{array}$ & $\begin{array}{l}\mathrm{PA} \\
\$ 5\end{array}$ & TM \\
\hline Layout \& Assembly & 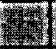 & 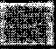 & 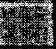 & & $x$ & $x$ & met & & $x$ & $x$ & 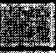 & & 1 & Fin & 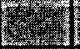 & Hes & (5) & S & $x$ & $x$ & & Pes: & $x$ & $x$ & $x$ & $x$ \\
\hline $\begin{array}{l}\text { Mark 0.1-foot } \\
\text { Intervals }\end{array}$ & 15 & 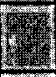 & $8=$ & 2 & $x$ & & 10 & & $x$ & $x$ & & 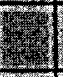 & 5 & 45 & 20 & 5 & 1. & (2) & $x$ & $x$ & & 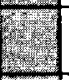 & $x$ & & $x$ & $x$ \\
\hline $\begin{array}{l}\text { Mark Ortentation } \\
\text { Lines }\end{array}$ & 4 & (7) & 3 & 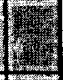 & $x$ & & 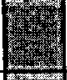 & & $x$ & $x$ & 部 & 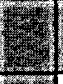 & S & 20 & 21: & 19: & 1 & $3^{2}$ & $x$ & $x$ & & Se & $x$ & & & $x$ \\
\hline $\begin{array}{l}\text { Lithologic } \\
\text { Description }\end{array}$ & 5 & 4 & 8 & 17. & $x$ & & 2 & & $x$ & $x$ & 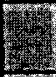 & 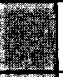 & $x$ & 10 & 11: & 196. & (2) & 10 & $x$ & $x$ & & 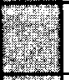 & & & & $x$ \\
\hline $\begin{array}{l}\text { Fractographic } \\
\text { Analysis }\end{array}$ & 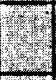 & 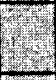 & 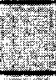 & - & $x$ & & t5 & & $x$ & $x$ & 4 & 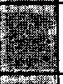 & $x$ & (7) & (5) & W & . & Din & $x$ & $x$ & \begin{tabular}{|c|}
0 \\
$\vdots$ \\
$\vdots$ \\
\hdashline \\
\end{tabular} & be & $x$ & & & $x$ \\
\hline Photographic Log & 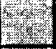 & 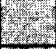 & $\sqrt{2}$ & 1) & & & F & & .. & & Ta & $\sqrt{2}$ & $x$ & Es & (1) & $L^{2}$ & 1. & J. & $x$ & $x$ & ह & . & & & & $x$ \\
\hline Sonic Samples & 5 & Sy & 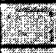 & +2 & $x$ & & 26- & & $x$ & $x$ & De & Fint & $x$ & $F=$ & E. & 5 & 1 & $x$ & $x$ & $x$ & 8 & $x$ & & & & $x$ \\
\hline DTS \& PL Samples & The & 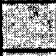 & 4 & Den & $x$ & & 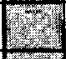 & z & $x$ & $x$. & 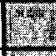 & 5 & $x$ & 5 & 5 & 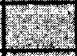 & S & $x$ & $x$ & $x$ & $\Xi$ & $x$ & & & & $x$ \\
\hline USGS Samples & int & 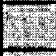 & 5 & 1 & $x$ & & ? & 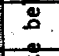 & $x$ & $x$ & Ist & $m$ & $x$ & $\sqrt{50}$ & 28 & ? & I. & $x$ & $x$ & $x$ & $\Xi$ & & & & w & $x$ \\
\hline Misc. Samples & 5 & sin & 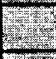 & 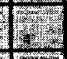 & $x$ & & is: & 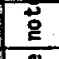 & & & 5 & $=$ & $x$ & $x$ & $x$ & $x$ & $x$ & $x$ & $x$ & $x$ & $\frac{\mathscr{s}}{6}$ & & & & & $x$ \\
\hline $\begin{array}{l}\text { Other Contractors' } \\
\text { Inspect. \& Sampl ing }\end{array}$ & $\sqrt{51}$ & (2) & S & I. & $x$ & 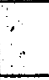 & W & 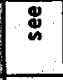 & & & 1 & 5 & $x$ & $x$ & $x$ & $x$ & $x$ & $x$ & $x$ & $x$ & 营 & & & & & $x$ \\
\hline Phase I Report & 8 & 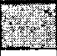 & 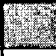 & (1) & $x$ & * & Th & & $*$ & $*$ & 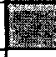 & 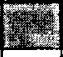 & 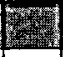 & 5 & 2 & Bes & 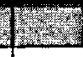 & $x$ & 18 & $x$ & & 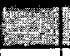 & & & $x$ & 3 \\
\hline Phase II Report & $=$ & $x$ & 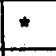 & $x$ & $*$ & & $x$ & & $*$ & $*$ & $x$ & $x$ & $x$ & $x$ & $x$ & $x$ & $x$ & $x$ & $*$ & $*$ & & * & & & & $\star$ \\
\hline Phase III Report & $*$ & $*$ & & $*$ & & & * & & & & $\star$ & $*$ & $*$ & & & & & & & & & & & & & $*$ \\
\hline Archived & $x^{k} a^{9}$ & Ty & 12 & $x$ & & & $5 y$ & & & & 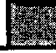 & & $x$ & $x$ & $x$ & $x$ & $x$ & $x$ & & & & $x$ & & & & $x$ \\
\hline
\end{tabular}

Mote: DOE participation in EGSP well MYł2 (Hellsville, NY) was cancelled due to problems encountered getting core barrel down well.

Legend

国 - Work completed prior to this reporting period

$x$ - Hork completed during this reporting period

- Phase reports in preparation 


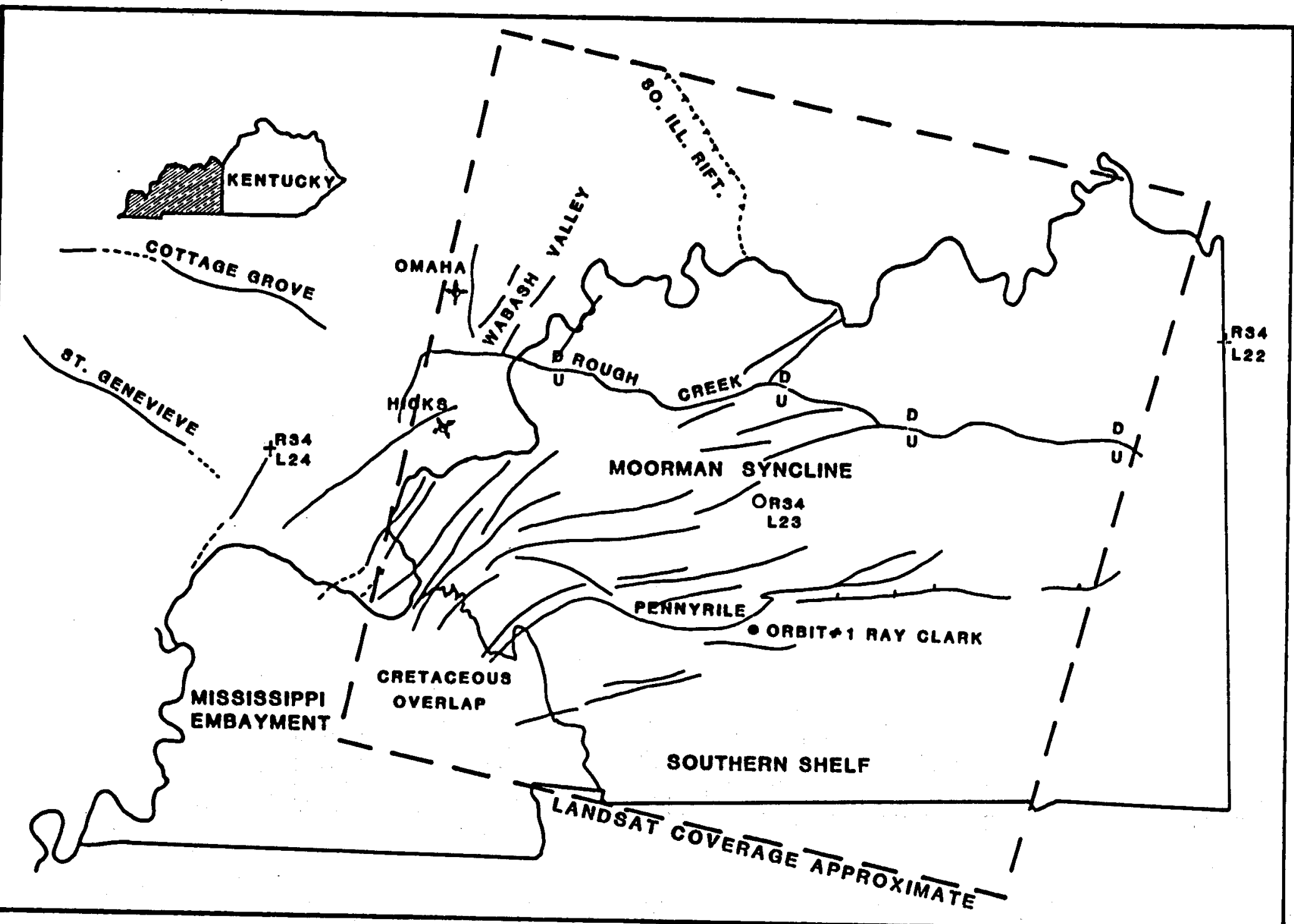

Figure 3-3 ERIM Study Area in Western Kentucky 
(Italics denote changes since March 31, 1980)

The EGSP Michigan No. 2 well in Ostego County was cored, logged, and stimulated. Post stimulation work was performed and evaluated and the well flowed at 156 MSCFD with $94 \mathrm{~B} / \mathrm{D}$ water and a 12/64 inch choke. The flowing wellhead pressure was 240 psi with a $18 / 64$ inch choke. The gas flow rate was 264 MSCFD with $205 \mathrm{~B} / \mathrm{D}$ water and the flowing wellhead pressure was 170 psi.

The EGSP Pennsylvania No. 5 well in Lawrence County, PA, was completed on september 5, 1980. This was the first well in the Devonian shale Coring and Logging program in which DOE also cooperated in the stimulation of the Devonian shale. The well tested at 133 MSCFD with a rock pressure of 1350 psig.

As a follow-up test of an exploration rationale, on June 7,1980 , the EGSP Tennessee No. 9 Grainger County, Tennessee well was acidized. on June 8,1980 the well was fractured with 50,000 gallons of 75 percent quality foam, 10,000 pounds of 80/100 mesh sand and 50,000 pounds of 20/40 mesh sand. The well was flowed back shortly after the job using progressively increasing choke sizes, starting with 12/64 inch. The well was shut-in on June 20,1980 following flow rates from 43,000 to 12,000 SCFD. Formation water with a salinity of $120,000 \mathrm{ppm}$ to 150,000 ppm was coming into the hole.

Figure 3-4 shows the location of Gruy Federal, Inc activities during this reporting period.

Interaction Between Gases and Shale of the Eastern U.S. Juniata College

Contract Number: DE-AS05-76MC05197.

The objectives are to measure the amount and composition of shale gas as a function of the presence of foreign gases, and to determine gas diffusion constants, total adsorptive capacity, and the permeabiljty of shale samples. All these data will be evaluated as a function of particle size and various degassed states as induced by elevated temperatures. All data will be interpreted in terms of their implications for well productivity.

Comparison studies of high versus low pressure data are continuing with graphing of the low pressure runs.: Degasability data collection has been undertaken on samples which were run on both the low and high pressure apparatus. Anomalies are beling studied to determine possible origins. Degasibility data show no "strong" dependence on pressure, but degassing rates may be a function of mesh size as evidenced in some high pressure data. Consequently, a cell was designed to permit degassing data to be recorded on cut slabs. 
$\frac{\omega}{N}$

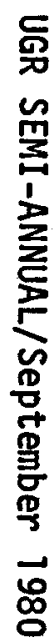

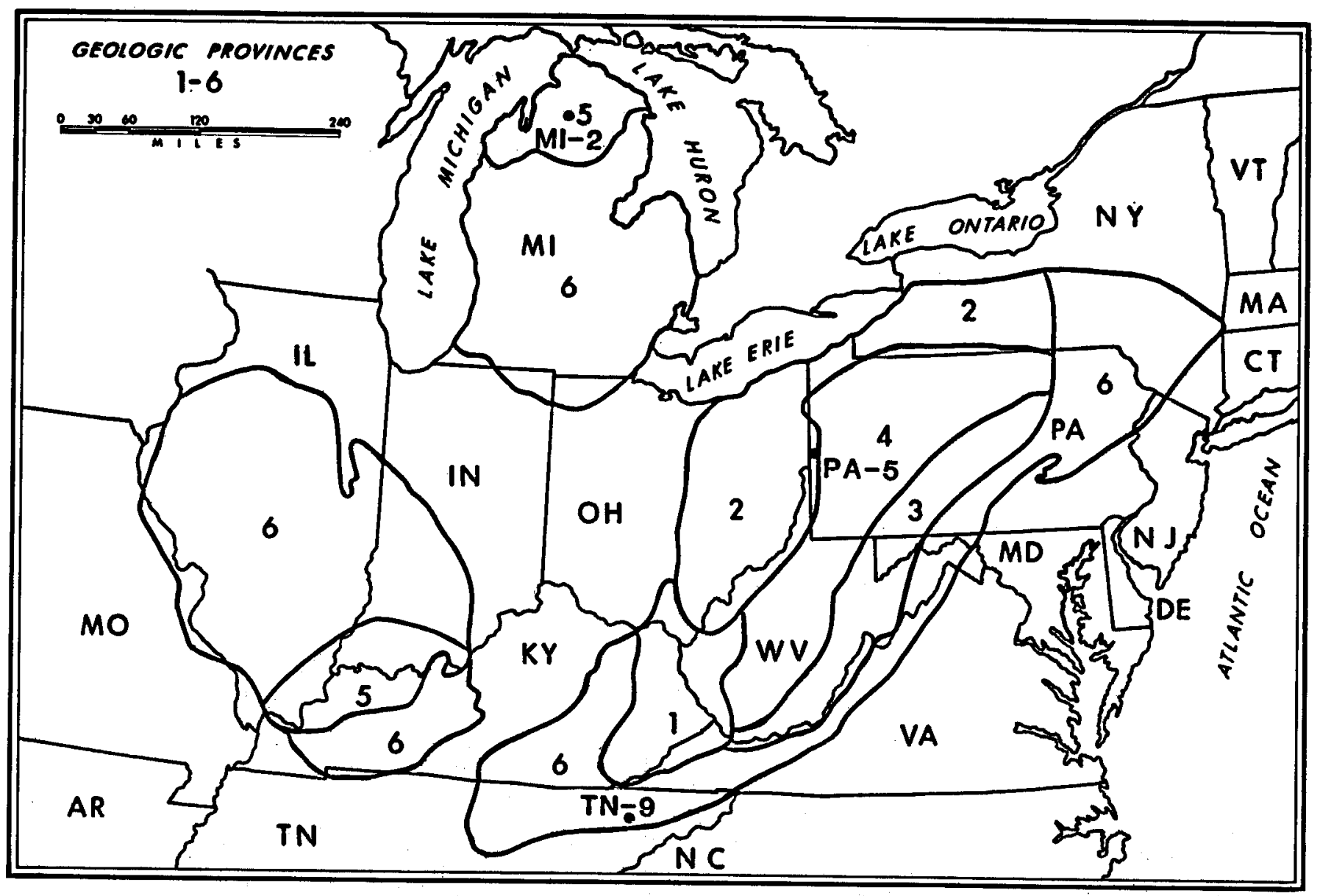

Figure 3-4 Location of Gruy Federal, Inc. Activities During Second Half of FY80 
Physical and Chemical Characterization of Devonian Shale Gas Mound Facility

Contract Number: DE-AC04-76DP00053

The objective is to perform detailed chemical, geochemical, physicochemical, and biostratigraphic analyses and lithologic descriptions for EGSP cores. In addition, a statistical analysis of all data will be provided, and an interpretation of regional and stratigraphic variations of the different component variables will be performed.

Work for this reporting period dealt primarily with ohio and Pennsylvania wells. A tabular sumary of work partially or totally completed during this period is given in Table 3-3.

Testing of the well drilled and cored by Mound in Pennsylvania was completed by Gruy Federal during this reporting period.

Presque Isle State Park Well No. I

This well, located in Exie County, Pennsylvania, was arilled to a total depth of 1276 feet (see Figure 3-5).

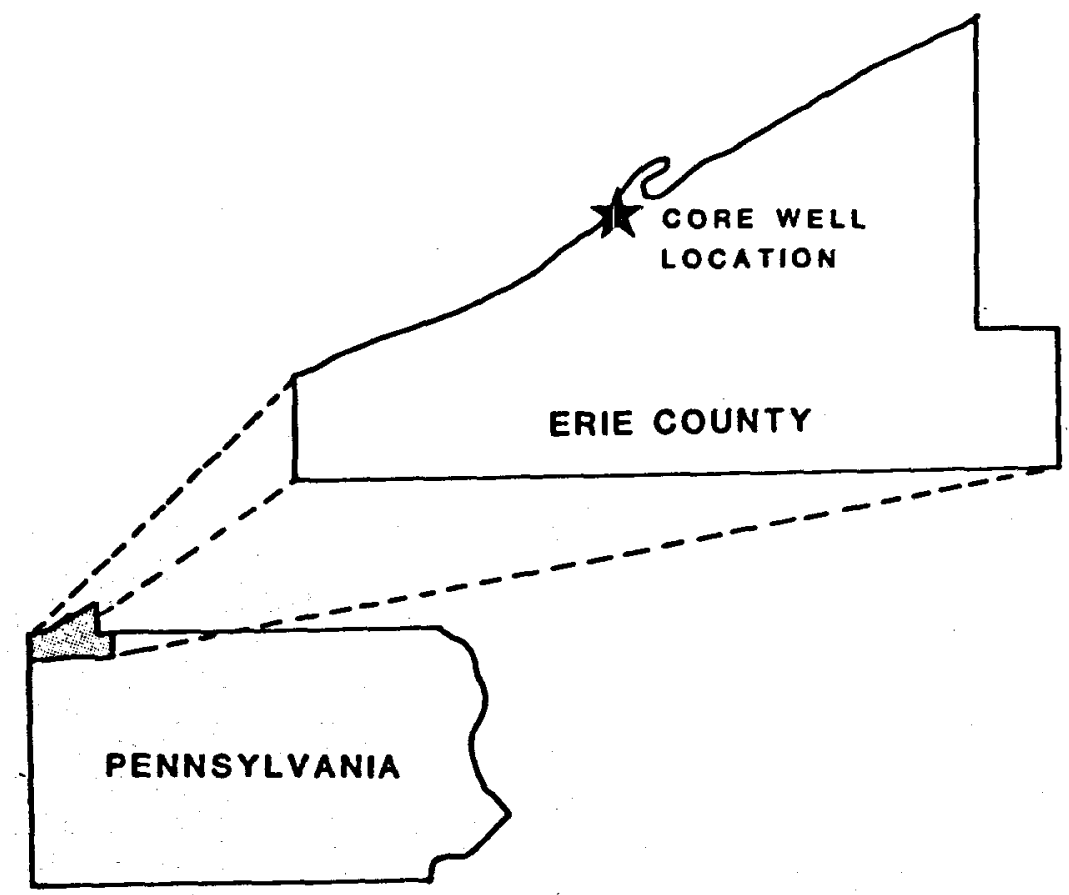

Figure 3-5 Location of Erie County, PA Well 


\begin{tabular}{|c|c|c|c|c|c|c|c|c|c|c|c|c|c|c|c|}
\hline & $\mathrm{OH}-3$ & $\mathrm{OH}-4$ & $\mathrm{OH}-5$ & $\mathrm{OH}-6-1$ & $\mathrm{OH}-6-2$ & $\mathrm{OH}-6-3$ & OH-6-4 & $\mathrm{OH}-6-5$ & $\mathrm{OH}-7$ & PA-1 & $\mathrm{PA}-3$ & $P A-4$ & $K Y-4$ & ILL-5 & MI-1 \\
\hline $\begin{array}{l}\text { Vitrinite } \\
\text { Reflectance }\end{array}$ & & $x$ & & $x$ & $x$ & $x$ & & $x$ & $x$ & & $x$ & & & $x$ & \\
\hline $\begin{array}{l}\text { Bitumen } \\
\text { Extract })\end{array}$ & & & & & & & & & & & $x$ & & & & \\
\hline Pyrolysis-GC & & & & & & & & & & & $x$ & & & & \\
\hline Biostratigraphy & & $x$ & & & & & & & & & $x$ & & & & \\
\hline$c_{1}-c_{7}$ & & & & $\bar{x}$ & $\bar{x}$ & $x$ & $x$ & $x$ & $x$ & & & $x$ & & $x$ & $x$ \\
\hline Bulk Density & & & & $x$ & $x$ & $x$ & $x$ & $x$ & $x$ & & & $x$ & & $x$ & $x$ \\
\hline $\begin{array}{l}\text { Total Organic } \\
\text { Carbon (TOC) }\end{array}$ & & & $x$ & $x$ & $x$ & $x$ & $x$ & $x$ & $x$ & & & $x$ & & $x$ & $x$ \\
\hline Visual Kerogen & & & & $x$ & $x$ & $x$ & $x$ & $x$ & $x$ & & & $x$ & & $x$ & \\
\hline $\begin{array}{l}\text { Kerogen Elemental } \\
\text { Analysis }\end{array}$ & & & & $x$ & $x$ & $x$ & & $x$ & & & & & & & \\
\hline Permeability & & $x$ & & & & & & & & & $x$ & & $x$ & & \\
\hline Dilatometry & & $x$ & & & & & & & & $x$ & & & & & \\
\hline $\begin{array}{l}\text { Adsorption/ } \\
\text { Desorption } \\
\text { Studies }\end{array}$ & $x$ & $x$ & & & & & & & & & $x$ & & & & \\
\hline Lithology & & & & $x$ & $x$ & $x$ & $x$ & $x$ & $x$ & & & $x$ & & $x$ & $x$ \\
\hline $\begin{array}{l}\text { Well Identi- } \\
\text { fication }\end{array}$ & & & & $x$ & $x$ & $x$ & $x$ & $x$ & $x$ & & & $x$ & & $x$ & $x$ \\
\hline Sample Depth & & & & $x$ & $x$ & $x$ & $x$ & $x$ & $x$ & & & $x$ & & $x$ & $\bar{x}$ \\
\hline
\end{tabular}

$x$ - signifies work partially or totally completed during this reporting period

象 
(Italics denote changes since March 31, 1980)

The well flowed at 15 MCFD for four days and was shut-in to monitor buildup. It is difficult to quantify the net productive footage in this well, which mag lie in the range of 32 to 255 feet. Using these two limits, the corresponding average permeability values are estimated to be .39 and $.05 \mathrm{md}$ respectively.

Analysis of the transient test data on the Presque Isle state Park No. 1 Well led to the following conclusions:

- The well is located in an area of extensive natural fractures, which makes it a good natural producer.

- Turbulence effects were negligible.

- Wellbore storage effects were negligible.

- Well performance is very sensitive to the skin factor.

Eastern Gas Shales Project Study of the Upper Devonian Shale in Ohio Ohio Department of Natural Resources

Contract Number: DE-AS05-76MC05200

The objective is to perform geological evaluation of the Devonian shales in Ohio. This includes construction of a well data file, a computer data base, interlocking cross sections, isopach, lithofacies, and structure maps; and lineament analyses and mineralogic and petrographic analyses of EGSP and OHGS cores and drill cuttings. GaS detectors will be used to monitor gas shows encountered in the drilling of new wells, and these data will be correlated with samples of cores and cuttings.

The series of detailed, interlocking stratigraphic cross sections within the state of ohio was completed.

Regional structure maps on the top and base of the Devonian shale sequence in ohio were completed. Structure contour mapping of the "Big Lime" was completed and revised. Work is progressing on the Berea structure maps.

The series of isopach maps of the radioactive shales within the Devonian system was completed. During this reporting period, additional isopach mapping was also completed on the Chagrin and Huron units within the Devonian shale sequence. Radioactive versus non-radioactive shales were calculated on these two units. The Lower olentangy, upper Olentangy, and Cleveland Shale isopach, percent radioactive shale lithofacies maps are cartographic production-ready. 
(Italics denote changes since March 31, 1980)

Transfer of Landsat lineaments to 1:250,000 scale base maps is completed. Fracture density contouring was begun on a 5,000 meter grid instead of the previous 10,000 meter square area to better define regional nature and more realistically represent existing Devonian shale and Clinton sandstone oil and gas fields. Generated first and second degree trend surface and computed residual maps were obtained for eastern ohio at a 1:250,000 scale. Photolinears were contoured at a 1:250,000 scale, utilizing a 2,500 meter grid system. Producing (both present and past) oil and gas wells have been plotted for overlay usage over the raw data contour maps, computer generated second degree residual maps, and Landsat density and distribution maps.

Anal ytical data collection is complete. Manuscripts of findings and conclusions are in preparation for the mineralogy and petrology and the geochemistry shale characterization tasks. Six additional wells were monitored for gas shows and profiles were made, bringing the total number to 72 wells.

Evaluation of the Chattanooga Shale in the Tennessee Valley and Ridge for Natural Gas and Uranium

Tennessee Department of Conservation

Contract Number: DE-AC05-76ET12126

The objectives are to drill and core eight stratigraphic exploration wells in the Chattanooga Shale and to analyze the cores obtained. These core data will be used to document the regional stratigraphy and structure in the Tennessee Valley and Ridge and to locate the Chattanooga Member which is a potential gas producing zone. A regional seismic survey will be conducted in order to identify the location of tectonically fractured Chattanooga shale formations.

A final report with three plates has been submitted. The report deals with the "Stratigraphy of the Chattanooga. Shale in the Newman Ridge and Clinch Mountain Areas, Tennessee". Eight NX wireline diamond drill core holes were drilled in northeastern Tennessee (Figure 3-6). The majority of the final report includes detailed lithologic logs of each hole. In addition, temperature, caliper, natural gama, gama gamma density, and neutron porosity logs were run. The Chattanooga shale was subdivided, based on the logging information, into four stratigraphic units: $A, B, C$, and $D$. Units $A$ and $C$ are primarily silty gray to greenish gray shale units whereas $B$ and $D$ are predominantly dark gray to black shale units. The three plates illustrate: (1) the Chattanooga Shale stratigraphy along the Newman Ridge; (2) the Chattanooga shale stratigraphy along clinch Mountain; and (3) structural profiles, thickness, and isolith maps of the Chatanooga shale in northeastern rennessee. Paleontology, regional correlations, and geochemical aspects of this area will be completed by the U.S.G.S. 


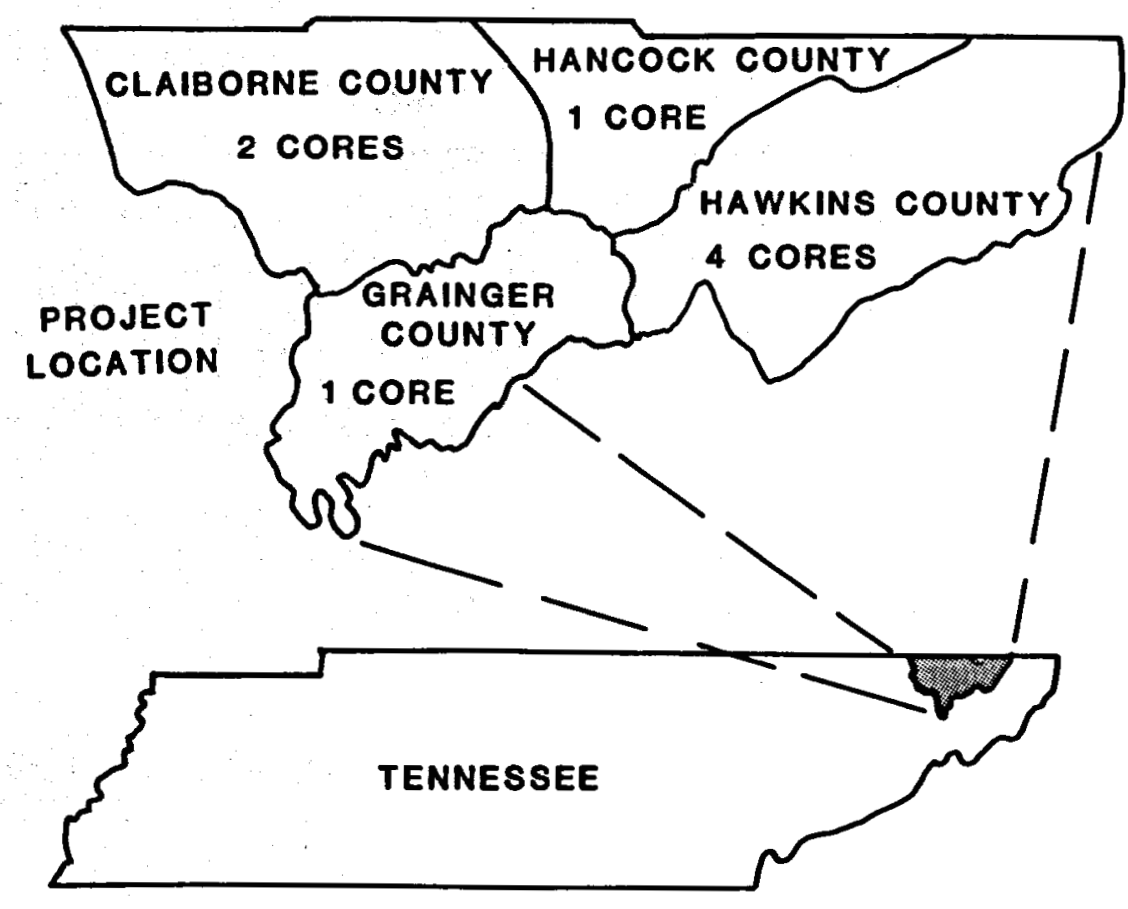

Figure 3-6 Location of Eight NX Wireline Core Holes

Assessment of Shale Production in Dual Completed Wells

Tetra Tech, Inc.

Contract Number: DE-AC21-78MC10389

The objective is to determine the productive potential of the Devonian shale in the northern portion of the Appalachian Basin. This includes data acquisition and evaluation, map preparation, and project identification and classification.

Emphasis this reporting period was focused on the coordination of work in geologic data integration prepared by the team assembled by DOE/METC. Representatives of METC, Tetra Tech, Mound, SAI, and the Illinois Geological survey gathered data generated for individual states in the Appalachian, Illinois, and Michigan Basins. As part of this effort, data were synthesized into individual geologic screening reports for New York, Pennsylvania, Ohio, Kentucky, West Virginia, Indiana, Illinois, and Michigan. Completion of the reports is scheduled for late fall of 1980 and is expected to guide industry exploration activity in the shale. 
Black Shale Study in Kentucky

University of Kentucky Research Foundation

Contract Number: DE-AC21-76MC05202

The objective is to collect, compile, and analyze available drillhole and outcrop data on Devonian shales of eastern Kentucky. The sedimentary history and stratigraphic framework of the Devonian shale in the area will be determined. Detailed lithologic and geochemical analyses of core material will be performed. Core taken by DOE contract from wells in Kentucky will be archived, and a data bank of geologic and reservoir data will be provided.

A final report was submitted in July 1980. Conclusions from the "Final Report, Black Shale studies in Kentucky" follow.

SECTION I - STRATIGRAPHIC STUDIES

Section I consisted of a summary of results for three substudies. A condensed version follows:

\section{Petrographic Studies}

- Seven major stratification types and numerous microscopic sedimentary structures were identified.

- Three major lithologies were identified based on organic content.

- Five microfacies were defined by variations in abundance of minerals, organic constituents, and nature of laminations.

- Microstratigraphic correlations were conducted between cores.

\section{Stratigraphic Studies}

Internal stratigraphy of the seemingly homogeneous black-shales in eastern Kentucky resulted in:

- Six lithostratigraphic and two biostratigraphic units were reported.

- Six of the seven subsurface radioactive units defined by Provo were found to correlate along the outcrop length. Five were recognized consistantly, and the two lower units (6\&7) were found to pinch out before reaching the outcrop belt.

- The radioactive units were found to overlap each other and thin towards the Cincinnati Arch with only the upper three units 
(Italics denote changes since March 31, 1980)

present at the arch zenith. This suggests a transgressive black-shale sea with a positive Cincinnati Arch at that time.

- Where the Bedford shale is not present, a division between the Devonian and Mississippian black shales was defined by more radioactivity in the Mississippian sequence.

- With respect to stratigraphic cross sections through the Appalachian Basin, three cross sections were constructed. These sections include a section through the southern part of the Appalachian Basin, the Rome Trough section, and the Eastern longitudinal section. The first section is published, the latter two are in press.

Characterization of subsurface stratigraphy included:

- Generation of four radioactive isopach maps, eight isopach maps, and eight structure contour maps.

- Total shale thickness ranges from $7.3 \mathrm{~m}$ (24 feet) on the crest of the Cincinnati Arch to $556.2 \mathrm{~m}$ (1825 feet) in eastern Pike county.

- A greater clastic content close to West Virginia clastic sources dilutes radioactivity within the black shale sequence, which is reflected on gamma-ray logs as a weaker positive signature.

- A hinge line, which runs nearly north-south from western Lewis County to eastern Bell county, separates a broad area of relatively thin black shale from an area of rapidly thickening black shale to the east.

- Distinct thickening and thinning trends are apparent on isopach maps and often represent local synclinal and anticlinal structures, which can be identified on county structure maps in Kentucky.

- Structures like the Rockcastle River Uplift and Rome Trough were apparently active both during and after black-shale deposition. others like the paint creek oplift, were only active after black-shale deposition.

- Structure contour maps indicate that the Devonian axis of the Cincinnati Arch was 10 to $12 \mathrm{~km}$ east of the ordovician axis in Lincoln, Casey, and northern Russell counties.

- The greatest thickness of highly radioactive shale occurs in northern Floyd, Johnson, and northern Martin Counties. Although black-shale thicknesses increase even more to the east, the amount of highly radioactive black shale decreases in an eastward direction due to clastic dilution. 
- A depositional model for the entire black shale sequence was developed, relating black-shale deposition to tectonic and climatic factors interaction.

- Deposition occurred during a time of cratonic subsidence and transgression in a nearly enclosed, equatorial, epicontinental, and progressively deepening sea.

- A pycnocline developed, forming anaerobic conditions in the deeper waters, preserving the organic matter from oxidation.

- The subsiding peripheral basin (Appalachian Basin) west of the Acadian Mountains acted as a collecter confiner of coarser clastics.

- An extensive bibliography (over 1200 entries) of black shale paleontology and paleoecology was compiled as well as an atlas of common black-shale fossils.

SECTION II - GEOCHEMICAL STUDIES

Section II consisted of five reports. These are summarized below. Local Chemical Variability of Black Shales

Although the black shales may look homogeneous, chemical variability does exist over short intervals. $x$-ray fluorescence spectrometry was performed on thirty-three samples taken from two separate locations. At each site, three vertical columns of samples spaced at $1 \mathrm{~m}$ intervals were collected with a sample spacing within each column of $10 \mathrm{~cm}$. It would seem that sample sizes on the order of 0.5 to 1 cubic meters are required to delineate the local variance between small samples.

Areal and Straigraphic Geochemistry

The report focuses on chemical variance and in particular, those elements which act independently, have economic potential, have a bearing on depositional modeling, and have environmental implications. Data are presented in two ways:

- Average value maps for each sampling locality which although misrepresenting local variability, do show overall, regional, and geochemical trends.

- Fence diagrams which show both stratigraphic and lateral chemical variability.

Chemical elements studied include: organic carbon, chromium, copper, molybdenum, nichel, phosphorous, sulfur, uranium, and vanadium. A summary of each element's variability is incorporated in the report. 
(Italics denote changes since March 31, 1980)

Kerogen Discrimination

Kerogen in black shales derived from differing organic debris should differ chemically and in natural gas yields. The purpose of the study was to establish criteria for the distinction of kerogeneous material from different precursors on the basis of its inorganic chemical content.

The Chemical Analysis of Black Shale Materials by X-ray Fluorescence Spectrometry

The methodology for determining major, minor, and trace elements on a Philips PW1410/70 vacuum spectrometer coupled to a General Electric $x$-ray generator is given. Information covered includes calibration, sample preparation, instrument settings, and precision and accuracy tables. Also included is an appendix on gamma-ray spectrometric determination of Uranium and Thorium.

Statistical Analysis of the Geochemistry of the Devonian Shales in Kentucky

Based on correlation coefficients, it was found that major and trace elements could be grouped into associations based on high positive correlations between particular elements and low to negative correlations between these elements and those of other associations. A listing of associations and included elements is given below.

Association

Elements

Clastic

$\mathrm{Si}, \mathrm{Ti}, \mathrm{Al}, \mathrm{K}, \mathrm{Na}, \mathrm{Rb}$

Pyrite $\mathrm{Fe}, \mathrm{Pb}, \mathrm{Cd}, \mathrm{Co}, \mathrm{Cr}, \mathrm{Nb}, \mathrm{Ga}, \mathrm{Ni}, \mathrm{Zn}$

Carbonate

$\mathrm{Ca}, \mathrm{Mg}, \mathrm{Mn}, \mathrm{Cu}, \mathrm{Cd}, \mathrm{S}$

Phosphate

$\mathrm{Pb}, \mathrm{Co}, \mathrm{Cu}, \mathrm{Y}, \mathrm{Zn}$

organic

$U, V$, MO

Characterization and Evaluation of the Devonian Shales in West Virginia West Virginia Geological and Economic Survey

Contract Number: DE-AC05-76ET12130

The objective is to collect, compile, and analyze all available drillhole and outcrop data on the Devonian shales in West Virginia. The sedimentary history and stratigraphic framework of the Devonian shale in the area will be determined. Detailed lithologic and geochemical analyses of core material will be performed.

The coding of Boone county data consistent with the WVGES database format has been completed. Also completed and in the drafting stage are the computer-drawn production potential maps. Gas shows maps were al so completed. 
(Italics denote changes since March 31, 1980)

Twenty-one wells were drilled as Devonian shale tests in 14 counties of West Virginia. Twenty-two wells with shale gas pays were completed, based on first quarter 1980 drilling reports. Thus, 80 to 85 shale wells will have been drilled or completed during 1980 .

Several topical reports were completed during this reporting period:

1. "The Subsurface Stratigraphy of the Middle and Upper Devonian Clastic Sequence in Northwestern West Virginia." Dowse, Mary E., WVGS, May 1980, 175 p. plus 7 plates (UGR No. 358).

The Middle and Upper Devonian clastic sequence in northwestern West Virginia was broken into members similar to those exposed in New York and ohio. Classification was based primarily on recognition of black shale markers. Isopachs and cross sections were constructed to show the areal distribution and stratigraphic relationships of each unit. Both Devonian sequences thicken to the east with the black shales thickening to the west. For gas production, the Rhinestreet Shale Member of the West Falls Formation and the Huron Nember of the Ohio shale are the most promising, especially where fracturing has occurred.

2. "Petrology of the Upper Devonian Clastic Sequence in IIncoln and Jackson Counties, West Virginia, and Wise county, Virginia." WVGS, June 1980,80 p. (UGR NO. 359).

The fabric, or manner in which rock components are put together to form a resultant rock, was studied based on $x$-ray and thin section analyses. Four lithic types were found: (1) sharply-banded shale, (2) thinly laminated shale, (3) lenticularly-laminated shale, and (4) non-banded shale. The most favorable shales for gas production appear to be thinly-laminated and organic-rich lenticularly laminated shales.

High-angle and inclined fractures only partially mineralized correlate with gas shows. Low-angle slickensides, microscopic fractures, and tightly mineralized fractures correlate with low or no gas shows.

3. "Stratigraphic Description of DOE/EGSP Core 41 (W.V. 5) Point Pleasant, WV." Rhoades, Stewart, Brian Easterday, Mike Vickers, George R. Clarkson, Keith Hallorhan, and Steve Gerrard, WVGS, June $1980,12$ p. (UGR No. 360$)$.

4. "Inorganic Geochemistry of Devonian Shales in West Virginia: Final Report." Hohn, Michael Ed., WVGS, June 1980, 89 p. (UGR No. 361).

Elemental analysis of well cuttings in western and southern West Virginia were analyzed for trends through factor analysis and trend surface analysis. 
(Italics denote changes since March 31, 1980)

The trends appeared to be consistent with a model of a delta complex in the areas.

Elemental percentages do not appear to indicate regions of high production potential beyond the correlation of sulfur with black shale. Sulfur may be used to measure the presence and quantity of "organic facies".

5. "Devonian Conodont Blostratigraphy in the Subsurface of Mason County, West Virginia." Clarkson, George Roy, Thesis, WVGS, June 1980,82 p. (UGR No. 362 ).

Extracted conodonts from the Mason County, West Virginia, core indicate the onondaga Limestone ranges in age from the Polygnathus Costatus patulus - zone to the P.C. Costatus zone. The overlying shales range in age from probable Middle Devonian (Eifelian) to the Scaphignathus Velifere - Zone (Fammemian).

6. "The Occurrence of 011 and Gas in Devonian Shales and Equivalents in West Virginia," Schwietering, Joseph F., WVGS, preliminary report, 38 p. plus 18 plates (UGR No. 419 ).

Analysis of Structural Geological Parameters that Influence Gas Production from the Devonian Shale of the Appalachian Basin West Virginia University

Contract Number: DE-AC21-76ET12138

The objective is to analys is regional and local geologic structures within eastern Kentucky and West Virginia in order to determine how these structures affect Devonian shale gas production. Techniques and rationales for enhanced gas recovery and exploration will be developed.

Hand contouring of geochemical data for the lower Huron, Middle Huron, Upper Huron, Three Lick Bed, and Berea/Bedford has been completed on all 180 maps. Drafting has been completed on approximately 50 percent of these maps. Negotiations continue with Kentucky-West Virginia Gas Company to drill, core, and $l 0 g$ a well in a high gas producing location of the Big sandy Field.

The Bison system is operational, but wW is awaiting parts for a second, better compressor. Most of the software for the ray-trace modeling has been completed. This software will be tested on the Bison system.

The completion date for manuscripts concerning surface structural studies in the fold belt and subsurface structural studies in the eastern Kentucky shale gas field is tentatively set for the end of September, 1980. 
(Italics denote changes since March 31, 1980)

The EGSP study brought international acclaim from papers presented at the International Geological Congress in Paris, France. Field trips allowed for comparative studies between Alpine and Appalachian structure and tectonics.

Geological, Geochemical, and Geophysical Appraisal of Energy Resources of the Devonian Black Shale in the Appalachian Basin

United States Geological Survey Contract Number: DE-AI01-76ET10136

The objective is to characterize the gas-productive and potentially gas-productive black and brown carbonaceous shales and related rocks of Middle and Late Devonian age in the Appalachian Basin. A comprehensive paleogeographic model of the basin of accumulation and the environment of deposition for the Devonian black shales will be developed. A data system capable of storing the data generated by EGSP contractors in the Appalachian Basin will be developed. A detailed appraisal of the resource potential of the shale sequence will be made, with particular emphasis placed on the natural gas resource.

A suite of slim-hole cores in Lewis and Fleming Counties, $K Y$, of the Devonian shale sequence and associated beds has been logged, permitting greater correlation detail with Johnson and Martin Counties, KY. Two maps, showing stratigraphic cross sections and core-drill hole locations, have been published (EGSP Series 1400). A report on the "Lithologic Description of Cores and Exposures of Devonian Shale and Associated Strata in Ohio Along Lake Erie," has been released (USGS Open File Report \#80-719; UGR No. 270). Work has been received on Devonian and Mississippian stratigraphic correlations in Kentucky, Indiana, Ohio, and Tennessee for AAPG's COSUNA-LOBAR correlation charts to match EGSP correlations. EGSP large-sized graphics for areas in Ohio, Kentucky, and Virginia were reviewed. A short report was prepared correlating the driller's "Tully" of Pennsylvania to the Tully limestone of central New York.

The project's geophysics final report is ready for peer review. An open file report \#80-707 (UGR No. 368) was prepared on "Defining organic-Rich Facies in the Devonian Shale in the Western Part of the Appalachian Basin." An organic-facies based on two percent by volume organic content was preferred over organic-facies boundaries based on shale color or gama-ray intensity. The two percent boundary corresponds with an accepted division between hydrocarbon-source and nonsource rocks of 1.7 percent of volume. Laboratory analyses of canned samples show a relationship between moveable-gas content and organic content at approximately 2 to 3 percent organic content by vol ume. 
(Italics denote changes since March 31, 1980)

Approximately 50 simples from well PA\#4 were submitted for o $C^{13}$ carbonate and $\sigma 0^{18}$ oxygen determinations. Work has begun on the final report for the source bed geochemistry study. open file report \#80-810 entitled "Organic Carbon Content of Devonian Shale sequence Sampled in Drill Cuttings From Twenty Wells in Southwestern New York," was released in August 1980. This report gives the depth intervals sampled, stratigraphic unit, Munsell color, and organic carbon content $(w t \%)$.

Work has been progressing on joint studies in northern West Virginia and contiguous Pennsylvania. A map indicating the relationship of joint patterns in several different rock types in the clarksburg $2^{\circ}$ quadrangle has been released as USGS open-file \#80-897.

Conodont studies of drillers "Tully" from the Presque Isle well at Erie, $P A$ indicate this unit is older than the central New York Tully limestone. This unit includes rocks in the Tichenor Limestone to the Centerfield Limestone interval from the middle of the Hamilton Group.

Work is continuing on the relationship of uranium to specific types of kerogen, through the use of fission trace maps and microprobe studies. A comparative study on the geochemistry of Devonian shale cores from Mason, Monongalia, and Upshur Counties, WV; Clark County, IN; Tazewell County, IL; and Sanilac County, MI has been completed as open file report \#80-938 (UGR \#446). Trace elements (U, V, Mo, Hg, As, Co, Ca, 2n) were studied. A comparison of analytical trace element data with percent organic carbon and sulfur showed no differences between sedimentary basins. Trace elements fluctuated as did organic carbon and sulfur percentages. No obvious changes were seen in the volatiles (Hg, As, S) with deep burial and heating and resultant oil and gas generation because the volatiles may be in pyrite which is not greatly affected by heating in a non-oxidizing environment.

Bulk and clay mineralogy $x$-ray analysis has been completed on samples from Johnson County, $K Y$, Erie and McKean Counties, $P A$; and Gallia and Lorain Counties, OH. Bulk mineralogy has been completed on samples from pocahontas and Raleigh counties, WV. Open file report \#80-660 (UGR NO. 282) titled "Munsell Color Value as Related to Organic Carbon in the Devonian Shale of the Appalachian Basin" was completed during this reporting period. A final report is in preparation.

Munsell color values above 3 to 3.5 can be used to determine the weight percent of organic carbon when samples are prepared as dry

pressed-power wafers and compared to the power curve contained in the report. The presence of more than five percent calcite darkens the color of the shale without an increase in organic carbon.

The selection of a geochemical and geophysical data base and play areas are underway for the Appalachian Basin resource appraisal. A paper was presented at the UGR symposium in Pittsburgh, $P A$, but is not yet published, entitled "Application of Exploration Play - Analys is Technigues to the Assessment of Conventional and Unconventional Petroleum Resources." 
(Italics denote changes since March 31, 1980)

\subsubsection{L L I N O I S B A S I N}

The Illinois Basin encompasses portions of the States of Illinois, Indiana, Kentucky, Wisconsin, Iowa, and Missouri. The EGSP study area in the Illinois Basin includes over 24,000 square miles of Devonian shale formations in Illinois, Indiana, and Kentucky (see Figure 3-1).

The Devonian shales outcrop in the northern and eastern portions of the Basin, and reach a thickness of over 450 feet in southeastern IIlinois.

A summary of the work of three contractors on Resource Characterization of this Basin follows.

Geologic and Geochemical Studies of the New Albany Group (Devonian Black Shale) in Illinois to Evaluate its Characteristics as a Source of Hydrocarbons

Ill inois State Geological Survey

Contract Number: DE-AC21-76ET12142

The objective is to discover the potential of the New Albany Group in Illinois as a hydrocarbon source, particularly natural gas. The following characterization, evaluation, and analysis activities will be provided for the Illinois Basin: geological evaluation; mineralogic petrographic, physical, and geochemical characterization; trace element, mode of occurrence and relative distribution; isotopic, and adsorption/desorption analyses.

The project Final Report titled "Geologic and Geochemical studies of the New Albany Shale Group (Devonian-Mississippian) in Illinois was completed on June 30, 1980. This report consists of three major subheadings: geology, geochemistry, and gas production. Findings from individual segments within these major subheadings are described below.

GEOLOGY

The New Albany Shale Group in Illinois can roughly be divided into three regions:

1. The major depositional center in southeastern Illinois, where the New Albany reaches a maximum thickness of 460 feet ( 140 $m)$, is predominantly laminated black shale, and is composed primarily of the Blocher, Selmier, and Grassy Creek shales.

2. A second depositional center in southeastern Iowa and west central Illinois, where the New Albany is more than 300 feet $(90 \mathrm{~m})$ thick, is mostly bioturbated olive-gray and 
(Italics denote changes since March 31, 1980)

greenish-gray shale; it contains the Sweetland Creek shale, Grassy Creek Shale, Saverton Shale, Louisiana Limestone, Horton Creek Formation, and Hannibal Shale.

3. A northeast-southwest trending area of thin New Albany Shale separating the two depocenters. This area of thin shale consists of interfingering gray and black shales. The Sweetland Creek, Grassy Creek, Saverton, and Hannibal Shales are the dominant formations.

The New Albany Group is middle Devonian at the base (Blocher Shale) and is early Mississippian (Kinderhookian) at the top (Hannibal Shale).

The main lithologic characteristics of the New Albany formations are as follows:

- The Blocher shale is a brownish-black to grayish-black, finely laminated, carbonaceous, calcareous and dolomitic shale.

- The Sylamore Sandstone is a thin, time transgressive sandstone or sandy zone at the base of the New Albany.

- The selmier shale contains alternating beds of laminated brownish-black to grayish-black shale and bioturbated olive-gray to olive-black shale.

- The sweetland Creek shale consists of alternating beds of dark and light greenish-gray, indistinctly bedded, bioturbated shale.

- The Grassy Creek shale is a dominantly brownish-black to grayish-black, laminated, pyritic, carbonaceous shale.

- The saverton Shale consists of interbedded greenish-gray, dark greenish-gray, and olive-gray bioturbated shale.

- The Louisiana Limestone is a micritic carbonate present only at places in western Illinois.

- The Horton Creek Formation contains limestone (including the Hamburg Oolite Bed), siltstone, sandstone, and shale at places in western Illinois.

- The Hannibal Shale consists of greenish-gray, olive-green, and dusky yellow-green bioturbated mudstone and shale.

The New Albany apparently was deposited in a deep-water, stratified, anoxic basin centered in southeastern Illinois and adjacent western Kentucky. Fossiliferous carbonates were deposited in a very restricted aeroblc zone. Bioturbated greenish-gray shales and indistinctly bedded shales were deposited in transitional dysaerobic zone. Laminated brownish-black shales were deposited in the anaerobic zone. Anerobic conditions persisted throughout most of New Albany deposition in 
(Italics denote changes since March 31, 1980)

southeastern Illinois whereas dysaerobic conditions predominated in western Illinois. The area of thin New Albany between the main depocenters is characterized by the interbedding of dysaerobic and anaerobic shales.

Linear features on satellite images and air photographs proved to be related to glacial landforms. Few bedrock structures were detected by remote sensing.

Extensive fracturing and faulting occurs in southern and southeastern Illinois.

Petrographic studies have identified and characterized five major 1ithofacies in the New Albany Shale: (1) limestones and dolomites; (2) highly bioturbated mudstones; (3) indistinctly bedded shales; (4) thickly laminated shales; and (5) finely laminated shales.

The distribution of shale lithofacies was determined by the depositional environment of the shale, especially wave energy, bottom oxygenation, and bottom topography (water depth).

The mineralogy of the New Albany Shale is relatively uniform. The predominant silt-sized constituents are quartz, feldspar, and muscovite. Dolomite and pyrite are minor components of most samples. The predominant clay constituent is illite, with minor chlorite and mixed-layer illite-smectite in virtually all beds.

Reflected light studies of kerogen indicate that the organic matter in the brownish-black shales is predominantly Type II kerogen (oil-prone), whereas the organic matter in the greenish-gray shales is Type III kerogen (gas-prone). The differences in kerogen types are believed to be due to selective preservation rather than to variations in the type of organic matter deposited.

Vitrinite reflectance and liptinite fluorescence studies reveal increasing thermal maturation of organic matter to the southeast which can be related to the structure of the basin.

Studies of the amount and type of organic matter, thermal maturation, and the occurrence of solid hydrocarbons strongly suggest that active petroleum generation and expulsion occurred in southern and southeastern Illinois and western Kentucky. Nowhere in the Illinois Basin is the shale known to have reached the principal zone of gas generation.

Preferred weakness (planes) in shale cores was not found with use of acoustic compressional wave velocity determinations, nor were weakness directions found by $x$-ray particle orientation techniques.

Mechanical testing by the point-load method proved to be a good way of showing the preferred plane of weakness in cores; these directions of weakness matched results shown by indirect tensile strength testing at $30^{\circ}$ intervals of azimuth. 
No single method or combination of methods used to isolate organic matter from black shale yielded an ash-free organic fraction. The most successful method proved to be a series of acid treatments with dilute $H \mathrm{NO}_{3}, \mathrm{HF}$, and HCL. Ash contents of the isolated organic fractions ranged from 0.15 to 4.09 percent.

The zonal centrifuge techniques using aqueous sucrose densities were ineffective for separating small amounts of finely disseminated organic matter from the mineral matrix of whole shales.

Residual mineral matter in the isolated organic fraction prevented conclusive assignment of trace elements to the organic or inorganic phases. However, data for $\mathrm{Ni}, \mathrm{U}, \mathrm{Se}, \mathrm{Sb}, \mathrm{Mo}$, and $\mathrm{V}$ indicate that at least a portion of their concentrations in the isolated organic fraction is due to their association with the organic matter.

The elements $U, M o, S b$, and $\mathrm{Cs}$ in the organic fraction show a positive correlation with the gas content of the whole shale; however, there is no significant difference in their enrichments between the gas-bearing and non-gas-bearing shales examined.

The amount of gas released from core samples correlated closely with gamma-ray intensity determined from borehole logs.

Combined pyrolysis-gas chromatography provides a simple, direct method for qualitatively characterizing the non-volatile organic matter contained in the shale. The composition of the pyrolysis products is influenced by both the pyrolysis temperatures and the organic content of the shale.

Degradation of the organic matter takes place at temperatures above $500^{\circ} \mathrm{C}$.

The quantity of non-condensable gases produced by pyrolysis of shale increased with increasing organic content of the shale and with increasing temperature. The increase in yield of gas was not linear, even for shale samples from the same core. Both saturated and unsaturated paraffins were produced.

The oxygen content of the atmosphere within the retort affects the composition of the pyrolysis products.

Results of pyrolysis studies may have important implications for the design of in situ retoring of shale for gas production.

organic compounds evolved by heating shale are dependent on the pyrolysis temperature and on the organic content of the shale. volatile indigenous compounds are evolved at low temperatures. These compounds can also be extracted by benzene-methanol solvent. The 
(Italics denote changes since March 31, 1980)

organic matter is degraded to highly volatile hydrocarbons by moderately high (about $550^{\circ} \mathrm{C}$ ) pyrolysis temperatures.

Pyrolysis of the asphaltene fraction of the organic matter extracted from shale gives results similar to those obtained for the whole shale. Pyrolysis of shales of widely different stages of maturation yields results that are unique for each shale. The temperature of the initial fragmentation can be related to the interactions of the molecules or to the strength of the bonds in the large molecules making up the organic matter in the shale.

Isotopic fractionation occurs during outgassing of a core. Experiments show that with proper sampling techniques, the fractionation is probably not sufficient to cause errors in interpretations based on analysis of offgases.

Gases analyzed in this study all appear to be of low-grade thermal origin, with no significant contribution of bacterial gas.

Gases obtained from core $02 I L$ have chemical and isotopic compositions similar to solution gases from oil deposits directly beneath the shale. The data suggest a common origin for the gas in the shale and for the gas in the oil. Caution is advised when interpreting the gas content of Devonian shales in the immediate vicinity of oil reservoirs.

The isotopic composition of methane appears to correlate with the vitrinite reflectance value of the shale. The methane is isotopically lighter, however, than would be predicted by the gas-source rock pairs reported by stahl (1977).

Porosity of a shale depends upon three major factors--depth of burial, carbonate content, and organic content.

Shales can hold appreciably more methane at their burial depths than is typically found in gas-bearing cores.

Methane not only occupies pore space but is also pressure-solubilized in the organic portion of the matrix in the more deeply buried shales of high-organic content.

Shales with molecular sieve characteristics are produced with increasing depth of burial combined with increasing organic content. Much of the total pore volume is associated with ultramicropores, or passageways, with diameters less than 5 angstrom units.

The release rate of methane from shale is a function of the degree of ultra-microporosity present in the shale, and is also a function of shale "particle" size and orientation.

The two desirable factors which apparently contribute the most to methane generation-increased burial depth (for thermal degradation) and increased organic content--also produce a very low-permeability structure that is detrimental to rapid gas release. 
(Italics denote changes since March 31, 1980)

NATURAL GAS PRODUCTION

The best potential for gas production was determined to lie in a 19-county area in southeastern Illino is corresponding to the main depocenter of the New Albany (Figure 3-7). In this area the New Albany is thickest, and contains the greatest percentage of brownish-black, organic-rich shale. This area also corresponds to the area of deepest burial and greatest thermal maturity of organic matter in the shale. Adjacent parts of Indiana and Kentucky may also be included in this area of highest potential.

Coordination of Study of the Devonian Black Shale in Illinois Basin III inois State Geological Survey

Contract Number: DE-AS21-78MC08214

The objective is to summarize the data being generated by EGSP

contractors in the Illinois Basin. Resource and reserve estimates for the Illinois Basin will be prepared. A basin-wide data base that can be used to integrate analytical results with structure, stratigraphy, and production/show information will be developed. Core and log data will be collected for a well in Wayne County, Illinois.

Reports from the three-state area (Illinois, Kentucky, and Indiana) in the Illinois Basin are being integrated and should be completed by October 30,1980 .

Data developed by Mound Laboratory and Battelle Institute on cores in the Illinois Basin are being incorporated with existing data in the MINERS data system. The ILLIMAP computer mapping system is largely completed with Indiana and Illinois on-line and Kentucky nearly completed. ILLIMAP will be provided as part of the MINERS package.

A report "User's Manual for the Mineral Resources Evaluation System (MINERS)", compiled by L. H. VanDyke, J. P. Hoeflinger, and W. $D$. Brigham, was submitted on June 30,1980 . MINERS is a batch mode data base system that was developed to:

- Create and maintain hierarchical data files.

- Retrieve and work with large masses of data.

- Manage several data bases of varying size.

- Display processed or unprocessed data in many ways, including the drawing of base maps and displaying data thereon. 


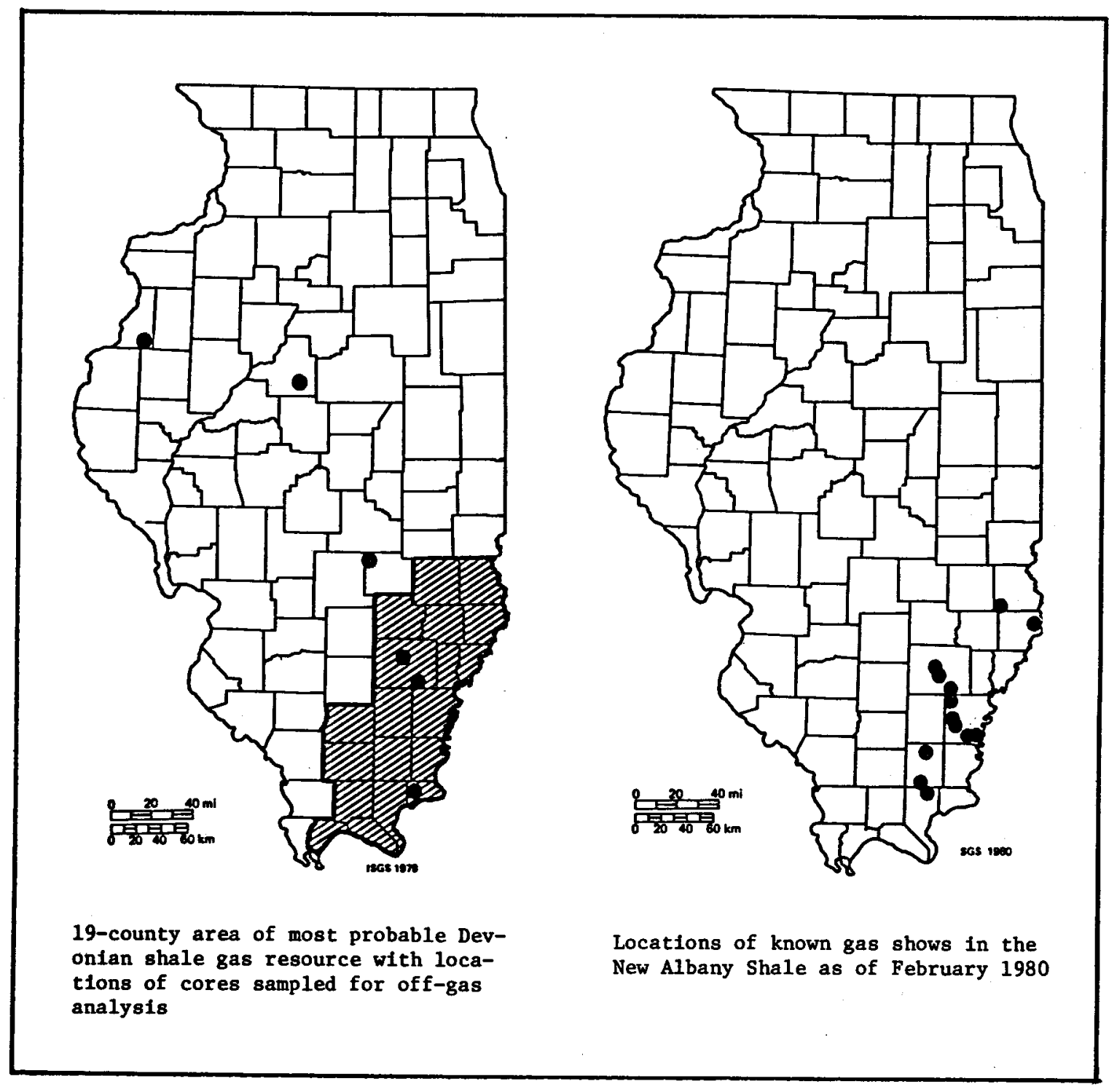

Figure 3-7 Gas Production Potential and Known Gas Shows in Illinois 
Eastern Gas Shale Project Study of the New Albany Shale in Indiana Indiana Geological Survey

Contract Number: DE-AC21-76MC05204

The objective is to collect, compile, and analyze all available drillhole and outcrop data on the New Albany Group in Indiana. The sedimentary history and stratigraphic framework of the Devonian shale in the area will be determined and detailed cross sections, and isopach, lithofacies, lineament, and regional structure maps will be constructed. Detailed physical, mineralogical, and chemical analyses of the core material will be performed. Target areas where commercial volumes of natural gas are likely to be present will be delineated, and specific production stimulation techniques that are most likely to succeed will be suggested.

A final report was submitted in July 1980. Stratigraphic cross sections, strugture maps, isopach maps, and oil and gas shows maps were constructed of the New Albany Shale in the Illinois and Michigan Basins in Indiana. Four units were recognized and mapped in the New Albany in the subsurface in the Illinois Basin in Indiana. In acendIng order, these are the Blocher, Selmier, Morgan Trail-Camp RunClegg Creek Interval, and the Ellsworth. The Antrim, Ellsworth, and Sunbury Shales, which are together equivalent to the New Albany Shale, were mapped in the Michigan Basin in Indiana.

Petrographic and lithologic descriptions or cores from Martin, Jackson, Clark, and Sullivan Counties showed that the New Albany Shale can be characterized in the Illinois Basin into three lithotypes: a hard brownish-black organic-rich shale, a softer greenish-gray organiapoor shale, and a shale intermediate in hardness and organic content that is olive brownish-black.

oil yields in the New Albany Shale were found to be directly proportional to organic contents producing approximate yields of $1 \mathrm{gal} /$ tn $/ \%$ carbon at $500^{\circ} \mathrm{C}$ under a helium atmosphere. Gas yields were not found to significantly correlate to organic content.

Ten gas fields are known in the Illinois Basin in Indiana which have or could have produced New Albany Shale gas: seven in Harrison County, one in Martin County, and two in Daviess County. The bulk of the production has been from Harrison County, with total shale gas production estimated at 5 billion cubic feet. Gas production appeared to be related more to structural highs than lineament alignment. Based on probable thermal maturity of the shale and the extent of fractures, southwest corner of the state in the Illinois Basin. 
The Michigan Basin is a subcircular feature which lies northwest of the Appalachian Basin and north of the Illinois Basin. The Basin encompasses all of the State of Michigan and portions of Indiana, Ohio, Wisconsin, and the Province of Ontario. The EGSP study area in the Michigan Basin includes over 32,000 square miles of Devonian shale formations in Michigan and Indiana (see Figure 3-1).

The Devonian shales outcrop around the rim of the Basin and reach a thickness of over 660 feet near the central part of the Basin.

EGSP activities have included coring of the Devonian shale, and will include the development of suitable exploration rationales applicable to the geologic characteristics of the area. A second oriented Devonian shale core was taken from a well in Otsego County, Michigan (north portion of the Basin), during this reporting period. The well was al so stimulated with a final open flow of 264 MSCFD. This substantiates the production rate of 350 MCFD obtained from a foam fractured Ostego County well three years ago. 


\subsubsection{NTRODUCTION}

The goal of this Element is to undertake laboratory, theoretical, and/or field-based R\&D studies aimed at identifying promising ways to recover substantial amounts of new gas from the Devonian shale reservoirs that have been located by particular exploration rationales.

The two main areas of work involve stimulation modeling and reservoir modeling. Models are being developed to predict the effects of both explosive and hydraulic stimulation treatments. These models are being validated with laboratory studies, in situ tests, and mineback experiments. They will then be used to identify new treatments and to optimize existing treatments. Specific theoretical and experimental efforts are being made to study and evaluate the effects of hydraulic fracturing and its mechanics, proppant displacement, and tailoredpulse-loading. Attempts are being made to predict permeabilities for fracture control in explosive stimulation. In addition, a tool to measure in situ stresses has been designed, and will be developed.

A reservoir model for Devonian Shale gas has been developed, and was used in the site selection and test design of an Offset Well Test Program. The development and verification of a two-dimensional model was completed during this reporting period. After being validated, the reservoir model will be combined with stimulation models in order to develop cost-effective recovery methods, and in order to predict the economically recoverable gas.

Other current efforts in this Element are aimed at developing tailored-pulse-loading explosive concepts for stimulation.

\subsubsection{FRACTURE MECHANICS}

Ten contracts, including two national laboratories, are currently active in this Work Package of the EGSP. A summary of these activities is presented in the following pages.

\subsubsection{PRODUCTION ENHANCEMENT}

The surmary of one contract in this Work Package of the EGSP is presented in the following pages. 


\subsubsection{RESER VOIR PERFORMANCE}

A summary of efforts in this Work Package of the EGSP is presented in the following pages.

\subsubsection{TECHNICAL SUPPORT}

There is one technical and management support contractor specifically for the EGSP (Science Applications, Inc.). A summary of this work is presented in the following pages.

Gas Stimulation Project

Lawrence Livermore National Laboratory

The objective is to provide research and development support to the EGSP. This support will include two- and three-dimensional modeling of hydraulic fracturing; small-scale laboratory modeling; basic rock mechanics measurements; reservoir analyses; conventional log evaluations; dry-hole sonic log development and application; and environmental reports.

Modeling efforts have shown that frictional slippage along an interface tends first to draw a fracture toward the interface, and then to stop the fracture. Experimentally it was shown that a minimum frictional stress was required before the hydraulic fracture would cross the interface, and the theoretical result that variation of friction along an interface can result in a step-like change in the fracture path was confirmed. This has been postulated as an explanation for the abrupt step found in certain places during mineback of hydraulic fractures at NTS.

Further theoretical studies to quantify this effect have indicated that there are large shear stresses in the regions where the friction changes abruptly, and high tensile strains in the material across the interface from the fracture. These high tensile strains would result in a fracture propagating perpendicular to the maximum tensile strain. 
Hydraulic Fracture and Associated Stress Modeling for the EGSP Ohio State University Contract Number: DE-AC21-79MC010514

The objective of this study is to use finite-element numerical modeling simulations to study the role of in situ stresses, pore pressure, and shale material and geometric properties in terms of fracture treatment selection. Formulae will be developed for predicting the width, height, length, and orientation of hydraulic fractures in terms of structural, fracture mechanics, and fluid response behavior.

Finite element models for vertical hydraulic fracturing in Devonian shale have been developed. This model includes the effects of in situ stress and multi-layering. The model provides a predictive capability for width, height, and length estimates. Supporting rationales for foam and dendritic fracturing have also been developed. Selected laboratory experimental results and field data obtained on ongoing EGSP programs have been anal yzed.

In Situ Testing of Well Shooting Concepts Sandia Laboratories

The objective of this study is to conduct modeling efforts for specific tests and for tailored-pulse stimulation in general. The purpose is to improve well-shooting technology for stimulating Devonian shale reservoirs with dynamic fracturing techniques that are aimed at producing multiple fractures radiating from a wellbore.

The mineback has been completed but full details are not yet defined. Preliminary indications show that the information collected on fracture morphology tends to confirm previous permeability enhancement measurements which were presented at the UGR Symposium at Pittsburgh, $P A$, in Nay 1980, and in the previous semi-Annual report.

Small Scale Field Test of Explosive Experiments

Stanford Research Institute, International

Contract Number: DE-AC21-79MC11577

The objective of this study is to evaluate tailored-pulse-loading through laboratory and computational efforts. The laboratory measurements will determine the material properties and inherent flaw characteristics required for calculational simulation. Laboratory 
springing experiments will determine the phenomenology in explosive/propellant borehole loading of selected geological materials and the NAG-FRAG fracture parameters of these materials. Calculations will be made to predict tensile and shear fracturing, and permeability enhancement will be made to determine the range in pulse shapes that most enhances permeability for comparison with the field experiments.

Calculational simulations of laboratory springing experiments were performed to evaluate the effects of some modifications to the NAG-FRAG model, and to derive fracture parameters. Three earlier (1978) gasfrac field experiments in tuff were simulated to test the fracture parameters derived from the laboratory experiments. The results indicate that the simulation methodology, the NAG-FRAG model, and the laboratory derived fracture parameters can be applied to small-scale field experiments.

Fracturing in two (Kinefrac and Dynafrac) of the multi-frac small-scale field experiments in tuff was also computationally simulated (using preshot idealized pressure histories since measured values were not available at the time). The results show that both the input pulse shape and material property variations influence the fractures created.

The same two pressure histories were used to simulate fracturing in Devonian shale. In general:

- Larger fracture densities are likely in Devonian shale than in tuff for the same stimulation technique, although the individual crack lengths may be smaller.

- Crack coalescence may be a more important phenomenon in Devonian shale than in tuff, and thus permeability enhancement is not strictly comparable to fracture enhancement.

- Because Devonian shale has lower porosity than tuff, less borehole compaction is expected. Hence, effective permeabilities in Devonian shale may be larger than in tuff, because the presence of a compacted zone around the borehole in tuff is likely to cause closure of fractures and prevent fluid flow.

Proppant Fracture Mechanics Interaction Study of the Flow Treatment Process

Stanford Research Institute, International

Contract Number: DE-AC21-79MC11597

The objective is to use a small-scale laboratory hydraulic fracture pressure chamber to study fluid penetration and crack propagation characteristics in simulated rock media as functions of fluid viscosity 
(Italics denote changes since March 31, 1980)

and pumping rate. Experiments will be conducted in which proppants have been added so as to provide cases in which proppant motion is dominated by simulated gravitational settling.

Methods were developed for measuring fracture width and pressure distribution in the fracture. This experimental technigue was improved by eliminating the large pressure drop associated with the initial fracture by starting the experiment with a prefractured specimen, using epoxy as a fracturing fluid to preserve the fracture shape, and producing guasistatic fracture growth (without stepping) by using a highly viscous fluid. When water is used as a fracturing fluid, the fracture propagated in steps and the pressure distribution in the fracture was effectively uniform, except for the short time when the fracture propagated. When the fracture was arrested in the chloroform welded interface between the two layers of PMMA, the fracture width was nonzero.

Design of a Wireline Tool for In Situ Stress Measurements

Terra Tek, Inc.

Contract Number: DE-AC21-79MC11047

The objective is to design a a wireline stress measuring tool that can determine in situ stress levels by means of mini-hydraulic fracturing tests.

The tool design is in the final stages and will be completed and submitted by late fall 1980. The tool design utilized standard off-the-shelf components wherever possible and incorporates a completely digital control system. Fracture orientation detection will utilize a radial differential temperature logging tool developed by EXXON, this tool was identified as being the most successful commercially available logging tool for locating fractures in both cased and open wellbores.

Fracture Mechanics Tests on Selected Shale Cores

Terra Tek, Inc.

Contract Number: DE-AC21-80MC12093

The objective is to determine the the compatibility of hydraulic fracturing fluids with Devonian shale from specific regions in the Appalachian Basin. Two fluids, foam and liquid carbon dioxide, will be evaluated with respect to the amount of formation damage caused by each. 
(Italics denote changes since March 31, 1980)

All the tests associated with the Eastern Gas Shale Project (EGSP) OH\# 3 well have been completed, and a final report will be available by mid-November 1980. Tests concerning the other five wells are in progress and the data will be made available at a later date.

Fracture Control for Utilization in Shale Gas Stimulation University of Maryland Contract Number: DE-AC21-78MC12010

The objective of this study is to conduct laboratory tests using dynamic photoelasticity, high speed photography, and dynamic holography. Models mode of Homalite 100 and plexiglass (birefringent polymers) as well as certain types of rock (limestone and granite) will be used. These tests will be followed by large scale bench- and block-tests in a nearby quarry site to verify results obtained from the laboratory model tests. The purpose of these tests is to understand and predict the possibilities for fracture control in the explosive/propellant stimulation of shale wells.

Good agreement was obtained between fracture propagation distance in laboratory models and predictions from the HEMP computer code. Stem initiated fractures were found to be the dominant mechanism for fracturing in air-filled boreholes even for the case where the ratio of length of open hole above charge to charge length was as low as 1.67 . Very little influence of confining stress or direction of crack propagation was observed at borehole peak pressure to in situ compressive stress ratios ranging from 10 to 100. successful propagation of a pressurized crack across naturally occurring joint sets in a limestone boulder has been demonstrated. The radial direction of propagation was always reestablished after a limited amount of propagation had occurred along joint planes. only preliminary results are currently available for the optimum pressure pulse needed for maximum propagation distance.

Development of Ultrasonic Techniques for Measuring In Situ Stresses West Virginia University Contract Number: DE-AC21-77MC08087

The objective of this study is to determine the the feasibility of an ultrasonic technique as a method of measuring in situ stresses under both uniaxial and biaxial compression. The relationships between stress and $P$-wave velocity for core specimens will be established. Data obtained will be interpreted mathematically and correlated to measurements done on the core specimens in order to predict both the 
direction and magnitude of the applied stresses. The effect of transverse anisotropic properties will al so be studied. Phase II of this contract will be field study where field measurements will be made using a special P-wave velocity measuring device.

A final report was prepared and sent to METC in June 1980. The principal stress was determined by using the least squares method to fit a theoretical curve to the distribution of P-wave velocity ( $v$ ) around a borehole. The parameters of this equation can be written in terms of the principal stress and known variables, so the principal stress can be determined.

This procedure was carried out for sandstone and shaly sandstone blocks, under both uniaxial and biaxial compression. There was reasonable agreement for most values of applied stress between actual and predicted values.

Thus the ultrasonic technique can be used for measuring both the magnitude and duration of the principal in situ stresses, although there are some problems that need to be solved.

In Situ Stress Determination Based on Fracture Responses Associated with Coring Operations

West Virginia University

Contract Number: DE-AT21-78MC11284

The objective is to apply elasticity and fracture mechanics concepts to drilled out cores in order to evaluate the magnitude of in situ stresses. Three point bending tests will be conducted on Devonian shales to find critical mode 1 stress intensity factors required for mapping the fracture propagation paths developed due to in situ stress relief during coring. In order to find anisotropic material properties, uniaxial compression, tests, split cylinder tests, and simple shear tests will be conducted. All of these units will be incorporated in predictive models. to simulate the repetitive fracture patterns observed in Devonian shales and to establish in situ stress magnitudes.

Stress-strain relations, tensile strengths, compressive strengths, and mode-1 critical-stress intensity factors (KIC) have been establ ished experimentally for different directions of loading in representative Devonian shale core. The shales appear to be anisotropic, and in general tensile strength increases with depth while KIC decreases with depth indicating some inverse relationship. The stress-strain curves have been used to predict the depth of the sample, and stress differences have been related to differences in tectonic stresses. The experimentally determined properties have been used in a finite element model to predict a set of unique tectonic stresses. 
(Italics denote changes since March 31, 1980)

The range of measured values for compressive strength, Young's Modulus, and Poisson's Ratio from samples of a shale core in ohio were:

$$
\begin{array}{ll}
\text { Compressive strength } & 8451 \mathrm{psi} \text { to } 11,300 \mathrm{psi} \\
\text { Young's Modulus } & 2.0 \times 10^{6} \mathrm{psi} \text { to } 3.03 \times 10^{6} \mathrm{psi} \\
\text { Poisson's Ratio } & .206 \text { to } .264
\end{array}
$$

Study of Explosive Stimulation in Devonian Shale Gas Wells

E. I. DuPont DeNemours and Company

Contract Number: DE-AC21-78MC11843

The objective is to achieve a direct comparison between conventional explosive stimulation and a novel gas well stimulation technique in a fractured shale reservoir. Thirteen wells in Putnam County, West Virginia will be stimulated. Eight of the above wells will be stimulated with DuPont's EL-835 explosive and the other five will be stimulated by conventional explosives.

Six Devonian shale gas wells in Putnam County, West Virginia, have been treated with explosives to compare conventional five-inch diameter, 80 percent gelatin dynamite with a high-energy, high-density water-gelled explosive designed to totally fill the borehole. Final open flow measurements indicate substantially large flow rates when increased explosive loads per foot of borehole were employed. Details for five of the wells are given in Table 3-4. Due to public reaction on road and environmental grounds, the project has been stopped at six wells, and final results are being evaluated.

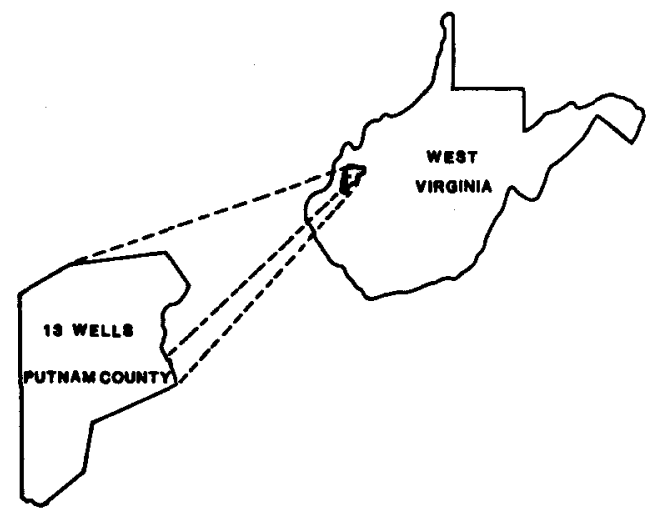




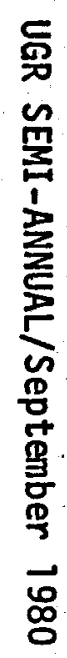

Table 3-4 Summary of Data on Wells Shot With EL836 Water Gel Explosive

(Open hole diameter 6-1/4 inches)

\begin{tabular}{|l|l|l|l|l|l|l|l|l|}
\hline $\begin{array}{l}\text { Wel1 } \\
\text { Number }\end{array}$ & $\begin{array}{l}\text { Depth } \\
\mathrm{ft}\end{array}$ & $\begin{array}{l}\text { Casing } \\
\text { Depth } \\
\mathrm{ft}\end{array}$ & $\begin{array}{l}\text { El836 } \\
\text { 1bs }\end{array}$ & $\begin{array}{l}\text { Loading } \\
\text { Density } \\
\text { 1b/ft }\end{array}$ & $\begin{array}{l}\text { Loading } \\
\text { Time } \\
\text { hrs. }\end{array}$ & $\begin{array}{l}\text { Date } \\
\text { Fired }\end{array}$ & $\begin{array}{l}\text { Initial } \\
\text { Open } \\
\text { Flow } \\
\text { (MCFD) }\end{array}$ & $\begin{array}{l}\text { Final } \\
\text { Open } \\
\text { Flow } \\
\text { (MCFD) }\end{array}$ \\
\hline McClean A-31 & 4503 & 2775 & 12,000 & 18.7 & $12-1 / 2$ & $6 / 17 / 80$ & $<1$ \\
McClean A-24 & 4594 & 2779 & 12,000 & 16.1 & $9-1 / 2$ & $7 / 2 / 80$ & $<1$ \\
McClean A-25 & 4538 & 2755 & 12,000 & 17.9 & 8 & $7 / 24 / 80$ & $<1$ \\
McClean A-26 & 4533 & 2727 & 37,500 & 73 & 23 & $8 / 9 / 80$ & $<1$ \\
McClean A-45 & 4488 & 2748 & 12,000 & 19 & 8 & $8 / 24 / 80$ & $<1$ \\
\hline
\end{tabular}


Gas Well Testing and Analysis Service in the Devonian Shale Gruy Federal, Inc.

Contract Number: DE-AC21-78MC08096

The objective is to develop uniform gas well testing procedures. Phase I will be a six month program to test five wells in order to develop an orderly procedure by which Devonian shale wells can be tested and the transient pressure analyzed. Phase II will apply the technology developed to test approximately 20 wells on an as-needed basis. The well tests and analyses are intended to permit evaluation of the effectiveness of various hydraulic and explosive stimulation techniques conducted under the EGSP.

During this reporting period, well test results for Presque Isle state Park No. I well (EGSP-PA\#3), Houghton College Fee No. 1, and Columbia Gas Transmission Corp. Well No. 20613 well were analyzed.

The results for the Presque Isle well are presented under the Mound Facility contract, and the results of the Houghton well are presented under the Houghton College contract. The Columbia well results are presented below.

A schematic of the surface facilities used in the testing procedure is shown in Figure 3-8.

Columbia Gas Transmission Corp. Well No. 20613

The well located in Iawrence county, Ohio was drilled to a total depth of 2,553 feet and perforated. The well was fracture using $480 \mathrm{bbl}$ water and 606,600 scf nitrogen. The fracture was propped with 56,700 pounds of 20/40 mesh sand and 56,700 pounds of $80 / 100$ mesh sand.

The well initially flowed at 25 MCFD but declined after 48 hours. The well was shut-in after three days of production to monitor buildup. The fracture volume was estimated to be $917.73 \mathrm{cu}$ ft from frac data.

The estimation of matrix permeability and fracture half length from conventional analysis are shown in the following table.

Permeability Fracture half-length*

First Drawdown $\quad 0.008 \mathrm{md} \quad 10 \mathrm{ft}$

$\begin{array}{lll}\text { Buildup } & 0.006 & 14\end{array}$

$\begin{array}{lll}\text { Second Drawdown } & 0.007 & 10\end{array}$

$\begin{array}{lll}\text { Arithmetic mean } & 0.007 & 11\end{array}$

$0.007 \mathrm{md}$.

* Calculations are based on an average permeability value of 


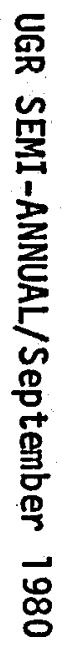

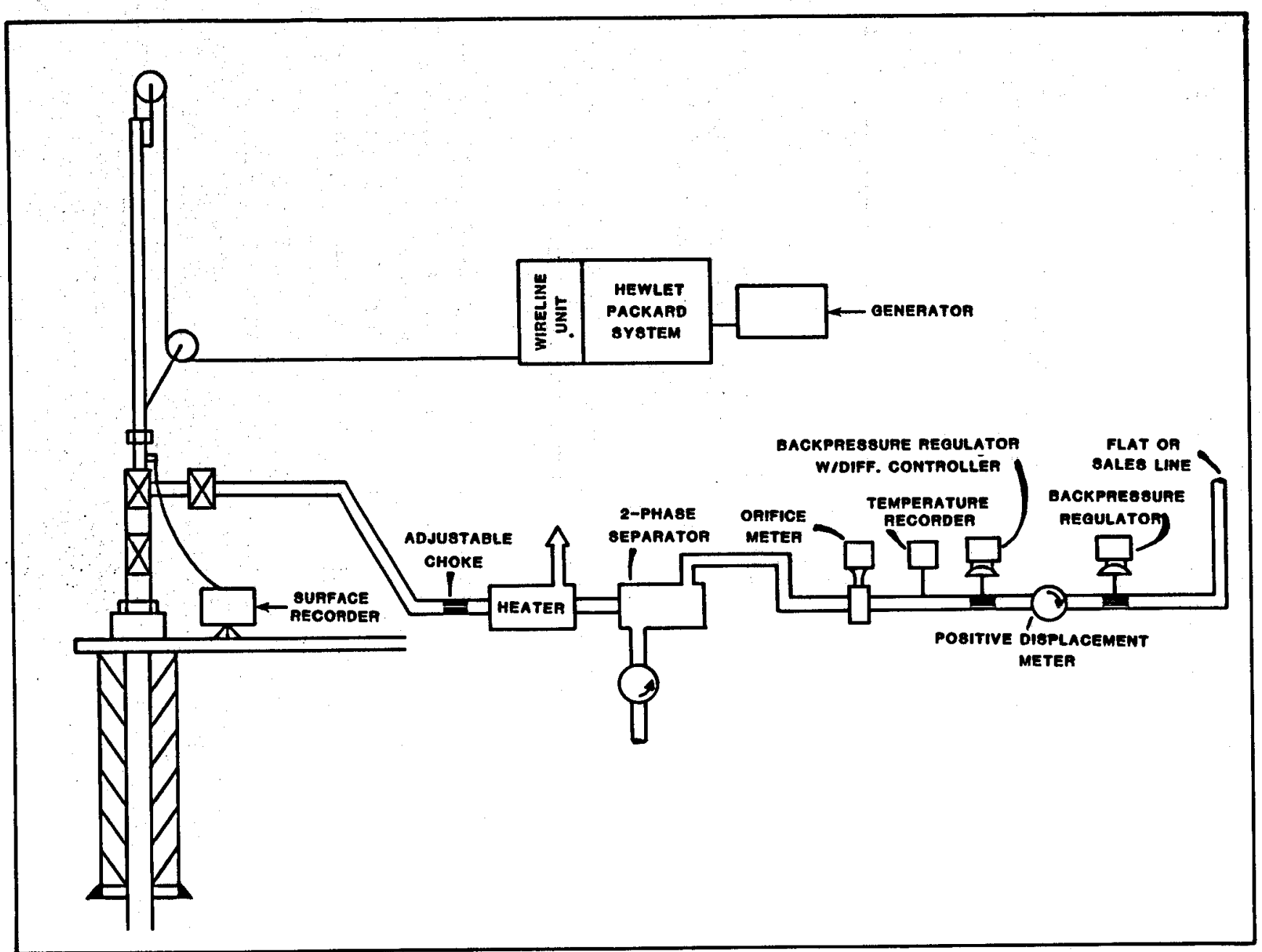

$\underset{1}{\infty}$

Figure 3-8 Schematic of Gruy Federal, Inc., Surface Facilities for Eastern Devonian Shale Gas Gas Testing Program 
Analysis of the transient test data on the columbia Gas Transmission Corporation No. 20613 led to the following conclusions.

- The well is located in an area of low permeability which makes it a poor producer.

- The stimulation treatment created a very small fracture in the perforated interval.

- Turbulence effects were negligible.

- Type curve techniques could not be used because of variable flow rates during drawdown and short shut-in periods during buildup.

Technical and Management Support Services

Science Applications, Inc.

Contract Number: DE-AT21-78MC08216

The objective is to provide technical and management support to the EGSP including planning assistance, analytical studies, technical fact finding and evaluation, and engineering services.

In addition to providing general support to METC in all Elements of the EGSP, SAI also undertook specific tasks. Progress on these is sumarized below.

1. Twenty-three wells in the Appalachian Basin and seven wells from the Illinois Basin are being used in a study of outgas volume, total carbon, organic carbon, vitrinite reflectance, and gamma ray intensity. The data have been tabulated for all wells where data were available, and strip chart logs have been prepared for each well.

Geologic descriptions have been written for each site. Sites have been located on a structural geology map. Isochemical maps have been prepared for each stratigraphic unit using gas volume, total carbon, and organic carbon as variables, resulting in a total of 42 maps. Vitrinite reflectance intensity maps have been prepared for both basins. Trend surface analysis to the first and second order have been prepared for all isochemical maps.

2. The total recoverable resource of Devonian shale gas in the Appalachian Basin, using shot wells and current well spacings was estimated as 20.2 Tcf. This study is described more fully under Section 3.5.4 (Economic Evaluation). 
(Italics denote changes since March 31, 1980)

3. A two-dimensional gas simulator for Devonian shale production has been completed, and the User's Manual describing the detailed listing was submitted during this reporting period. During the previous reporting period, both a mathematical model describing gas flow through Devonian shales and the software for a radial one-dimensional numerical model for single well performance were completed and placed into operation. This one-dimensional model was extended to two-dimensions, maintaining its full capability regarding Klinkenberg effects, desorption, and shale matrix parameters. The two-dimensional model has been tested for a wide variety of conditions, including multiple wells with constant rate and/or constant pressure production, variable formation thickness, and reservoir anistropy.

4. The radial flow model has been used to aid in site selection and test design for the offset Well Test program, by history matching and the use of simulated pressure transient tests.

A well in Meigs county, Ohio, was recomended for the offset Well Test. The matching parameters for this well are:

$\begin{array}{ll}\text { fracture permeability } & .018 \mathrm{md} \\ \text { fracture porosity } & .010 \\ \text { matrix porosity } & .058 \\ \text { matrix permeability } & 1.0 \times 10^{-6} \mathrm{md} \\ \text { fracture spacing } & 450 \mathrm{~cm}\end{array}$

5. A report has been submitted on the results of a workshop on stimulation of naturally fractured formations. The results of static and dynamic laboratory tests on NTS tuff and Devonian shale have been incorporated in submitted reports which also review and compare existing material property data for both rocks. Reports on the calculations for pre-test modeling of the NTS mineback experiments and the evaluation of DuPont EL836 explosive stimulation treatments have been submitted. Calculations have been completed for the stimulation treatments of the offset wells of the multi-well testing program and for the parameter sensitivity study of tailored-pulse-loading treatments. 


\section{4 \begin{tabular}{l} 
TECHNOLOG Y TES T ING AND \\
\hline VERIFICATION
\end{tabular}}

\section{4 .1 I N T R O D U C T I O N}

Economic Devonian shale gas production is dependent on both exploration and exploitation rationales and techniques. While it is difficult to completely separate the contributions of exploration and exploitation for individual wells, core analysis and well testing does allow individual evaluation of exploration and exploitation rationales. of the eight contracts in this Element, three are designed primarily to test exploration rationales, and the other five to test stimulation techniques.

Two exploration rationales are currently being tested. The first rationale is based on seismic velocity analysis. The other rationale is based on the theory that the development of natural fracture systems is related to the structure at the time of deposition. Five wells were drilled in Ohio to support the theory of the relationship of hydrocarbon distribution to depositional environment. Evidence collected to date from drilling, coring, sampling, and logging data supported the theory since natural fractures and gas shows were present in all five wells. Stimulation tests, however, did not produce any significant gas flows.

The stimulation treatments to be tested under the other five contracts are primarily foam, as previous EGSP research has indicated that this is the most promising technique for further development.

\subsubsection{EXPLORATION RAT I O N A L E}

Three contractors are currently active in this Work Package of the EGSP. A summary of their work appears on the following pages.

\subsubsection{EXPLOITATION RATIONALE}

A summary of the work of the five contractors in this Work Package of the EGSP follows. 
New Exploration Concept for Locating Fracture Zones in the Devonian Shale Donohue, Anstey and Morrill

Contract Number: DE-AC21-78MC08339

The objective is to drill two or three wells through the Devonian shale in Ohio to test the exploration rationale that zones of natural fracture intensity in the shale can be identified through measurement of seismic velocity. The technique will be used in the siting of the well, which wili then be drilled, logged, and stimulated. Standard sonic logging techniques will be supplemented by check shooting for seismic velocity before and after stimulation in the wells.

One well was drilled and stimulated with foam in Nobel County, OH, during this reporting period.

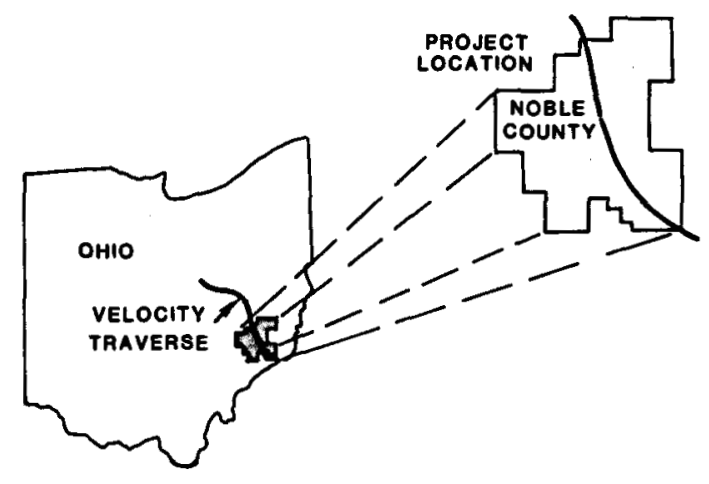

Shale Test Wells in Southern Tier Counties of New York Donohue, Anstey and Morrill

Contract Number: DE-AC21-79MC12697

The objective is to test the production potential of the

Rhinestreet/Marcellus facies of the Devonian shale by drilling ten wells in the Southern Tier Counties of New York. The wells will be drilled, cored, logged, tested, stimulated, and retested. The wells will be sited using seismic and geologic exploration techniques. A complete core of the Upper Devonian shale will be obtained from the first well for detailed resource and reservoir characterization work. The decision to continue drilling up to ten wells will be based upon the results of the stimulation and testing of the initial wells.

Four of these wells (Phase 1) were drilled during this reporting period: The Erwin Prospect - Dann \#1, North Corning Prospect - Scudder \#1, Dannsville Prospect - Meter, Kennedy, Howe \#1, and the Rathbone Prospect - Valley Vista View \#1. 
(Italics denote changes since March 31, 1980)

- The Dann \# 1 well in Steuben County, $N Y$, was drilled to the planned total depth of 1400 feet. There was a good show of gas at the predicted depth of 1074 feet. The well is to be stimulated with foam.

- The Scudder \#I well in Steuben County, NY, was drilled, cored, and logged. There were only insignificant gas shows and the well is shut-in pending investigation of the fractured zone. The stimulation of this well has been postponed until the results of Dann \#1 are analyzed.

- The Meter, Kennedy, Howe \#I well in Livingston County, NY, was drilled, logged, and is to be stimulated with foam.

- The Valley Vista View \# 1 well in Steuben County, $N Y$, was drilled, cored, and logged. A large gas show of 1300 MCFD was found at 680 feet, but tapered off in a few days. The well will be stimulated with foam in two stages.

The location of these wells is shown in Figure 3-9.

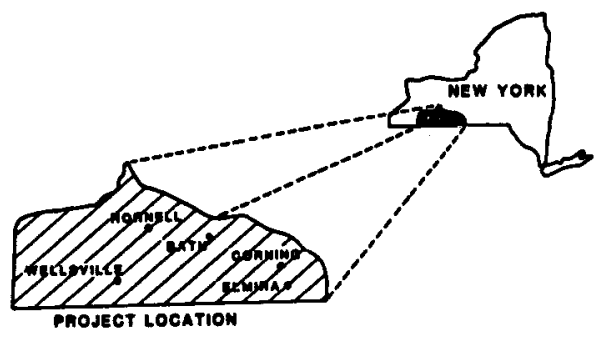

Support Development of an Unconventional Exploration Technique to Selectively Locate Natural Fracture Systems in the Devonian-Ohio Shale Mitchell Energy Corporation Contract Number: DE-AC21-78MC08387

The objective is to test the theory that the development of natural fracture systems is related to the structure at the time of deposition. Five wells will be drilled, selectively cored, logged, and selectively stimulated in order to evaluate the concept through standard and experimental analyses. These results will be verified by drilling, logging, and stimulating six additional wells and comparing results. A program for large scale, economical development of the Ohio Devonian shale reserves will be recommended based on a final analys is of results. 


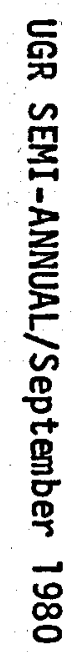

CONTOUR INTERVAL 100'

STUDY AREA DWEW YORK TEST WELLS

ABANDONED SHALE-GAS FIELDS

- TOWNS AND CITIES

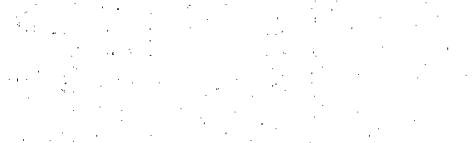

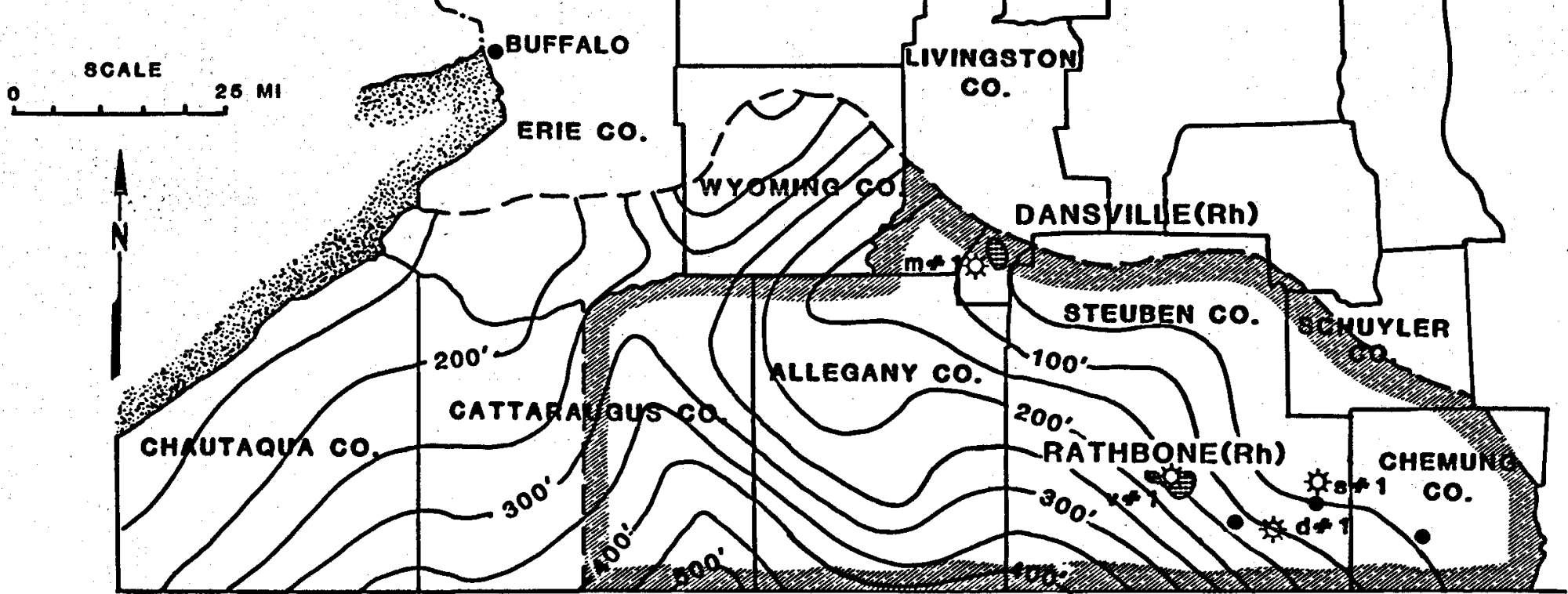

Figure 3-9 Location of Donohue, Anstey \& Morrill Test Wells and Radioactive Shale Isopach of West Falls Formation

d 1 DANN + 1 WELL

$m+1$ METER, KENNEDY, HOWE \& 1 WELL

8*1 SCUDDER + 1 WELL

Y 1 VALLEY VISTA VIEW + 1 WELL

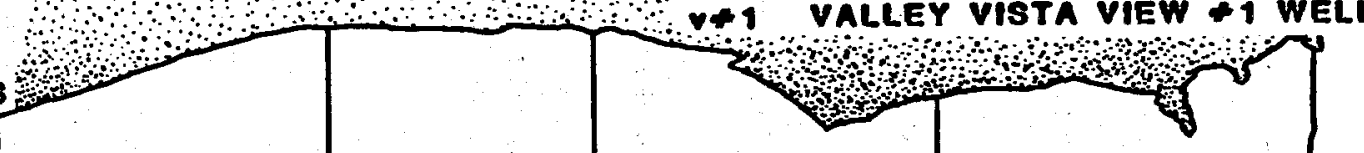


(Italics denote changes since March 31, 1980)

The predicted presence of extensive natural fracturing demonstrates the exploration rationale. However, the established presence of saltwater in the fracture system along with possible gas drainage out of the test area precluded gas production after stimulation.

Fluid samples are being analyzed to determine the source of the large volumes of water being recovered from the Phase $I$ wells. The completion work and testing of the lower shale zone in the Phase I wells indicated the following: $(1)$ in order to test the vertical extent of the fluid, the upper shale zone must be completed in the structurally highest well; and (2) in order to obtain comparable results, fluid recovery operations should not be suspended until all of the following conditions are met.

- Total fluid recovered after stimulation is at least $100 \mathrm{bbl}$ over that used in the frac plus that lost in the shale during drilling.

- Chloride content of the fluid recovered is greater than 100,000 $\mathrm{mg} / 1$ (or has at least stabilized).

- No significant shows of hydrocarbons have been encountered.

As a result, fluid recovery operations were suspended for the lower shale zones in four wells, while one well in the upper zone and one in the lower zone continue to be pumped. Discussions are being held on closing out the contract.

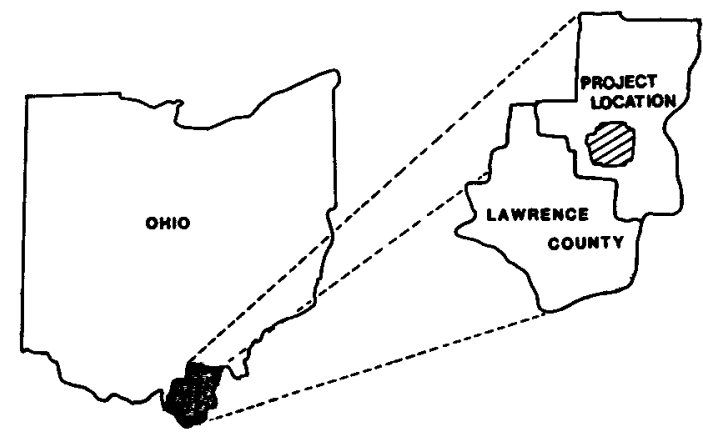

Assessment of the Economic Potential of Devonian Shale Gas Production Columbia Gas System Service Corporation Contract Number DE-AC21-78MC08385

The objective is to assess the production potential of the Devonian shales in Ohio. Ten wells will be drilled, logged, and stimulated in Trumbull and Lorain Counties, Ohio, and two of these wells will be cored. The selection of a stimulation technique will be made based on geological conditions in the areas. An evaluation of the results of 
(Italics denote changes since March 31, 1980)

these activities will be made including a determination of the reserves, economics, and the most efficient program for the development of Devonian shale gas in these areas.

September 1979 marked the initiation of field work on this program. By the end of November 1979, Columbia had drilled, cored, logged, and cased all ten project wells.

significant gas shows occurred in wells \#20150 and \#20152 in Lorain County, and well \#20144 in Trumbull county. Table 3-5 1 ists the important arilling and logging information.

As of February 20, all the work on the program was suspended until all of the participants could agree upon a completion strategy.

All the work on the project was resumed since the written agreement on future technical direction was reached on April 11, 1980. Gas Research Institute gave Columbia written notification of their intent to fund five additional stimulations under this contract of June 10, 1980.

During this reporting period, Columbia perforated and acidized the lower zones of the five Trumbull county wells, and stimulated well No. 20144 (Ware-Trumbull county). As of the August reporting period, the lower zones of wells No. 20145 (Gordon-Trumbull) and No. 20143 (Meleski-Trumbull) were fractured with foam, and the stimulation of well No. 20146 (Allman-Trumbull) was prepared using displaced GOEX 1 iquid explosives. There was insufficient gas flow in the Trumbull wells to justify a long-term pre frac test. post-frac cleanup efforts are continuing on wells No. 20143, No. 20144 and No. 20145. Two wells were subjected to the displaced liquid explosive technique designed by Gearhart-Owens. Both stimulation attempts encountered premature detonations and caused well abandonment. As such, the treatments were operational disasters.

Table 3-6 presents an outline of progress to August 31, 1980, and illustrates the activities completed since the project began.

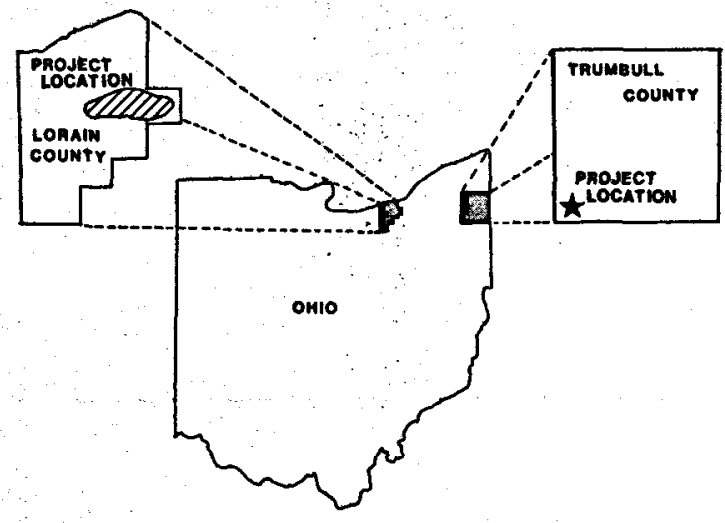


Table 3-5 Drilling and Logging Information for Ten Wells Under Columbia Gas Contract

\begin{tabular}{|c|c|c|c|c|c|c|c|}
\hline Well Number & County & $\begin{array}{l}\text { Top of } \\
\text { Share }\end{array}$ & $\begin{array}{l}\text { Base of } \\
\text { Shale }\end{array}$ & $\begin{array}{l}\text { Feet } \\
\text { Cored }\end{array}$ & $\begin{array}{l}\text { Temp./Sibil. } \\
\text { Events at: }\end{array}$ & $\begin{array}{l}\text { Gas } \\
\text { Show at: }\end{array}$ & $\begin{array}{l}\text { Open } \\
\text { Flow }\end{array}$ \\
\hline 20143 & Trumbul1 & 263 & 2701 & 1187 & -- & $\begin{array}{l}\text { trip gas } 1616 \\
\text { Conn. gas } 1792 \text {, } \\
\text { 1906, 2198, } \\
2256,2316 \text {, } \\
2434,2552\end{array}$ & TSTR" \\
\hline 20144 & Trumbull & 228 & 2593 & -- & 614 & $\begin{array}{l}\text { Bariod } \\
1913-2102 \\
\text { o1500 to } 2000 \\
\text { units }\end{array}$ & $\begin{array}{l}\text { Estimated at } \\
90-100 \mathrm{MCF}\end{array}$ \\
\hline 20145 & Trumbull & 240 & 2610 & -- & -- & -- & TSTM \\
\hline 20146 & Trumbul1 & 229 & 2629 & -- & -- & -- & TSTM \\
\hline 20147 & Trumbul1 & 226 & 2593 & -- & -- & -- & $\begin{array}{l}1 \text { MCF before } \\
\text { logging }\end{array}$ \\
\hline 20148 & Lorain & 252 & 1246 & -- & $\begin{array}{l}345-347,405-428, \\
514-525,572-576 \\
610-624 ; 650-669 \\
1239-1286\end{array}$ & $\begin{array}{l}398,642,656, \\
664,980\end{array}$ & 4 MCF \\
\hline 20149 & Lorain & 293 & 1273 & 879 & $\begin{array}{l}\text { 465-475, } 538-543, \\
558-628,729-732, \\
756-758,790-797, \\
1274-1290, \\
1302-1308\end{array}$ & -- & $8 \mathrm{MCF}$ \\
\hline 20150 & Lorain & 230 & 1253 & -- & $\begin{array}{l}650-745 \\
1092-1124\end{array}$ & $603-653$ & $38 \mathrm{MCF}$ \\
\hline 20151 & Lorain & 247 & 1292 & -- & $1200,1270,1224$ & -- & TSTM \\
\hline 20152 & Lorain & 296 & 1277 & -- & $\begin{array}{l}300-400,476 \\
648-652\end{array}$ & 527,760 & 35 MCF \\
\hline
\end{tabular}

«Too Small To Measure 


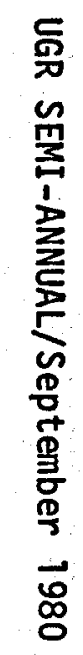

Table 3-6 Columbia Gas 10-Well MHF Program Summary as of 8/31/80

\begin{tabular}{|c|c|c|c|c|c|c|c|c|c|c|}
\hline Area & $\begin{array}{l}\text { Well } \\
\text { No. }\end{array}$ & $\begin{array}{r}\text { Site } \\
\quad A \\
\text { EIA }\end{array}$ & $\begin{array}{l}\text { Select } \\
\text { Archeo } \\
\text { Survey }\end{array}$ & $\begin{array}{l}\text { tion } \\
\text { Site } \\
\text { Prep }\end{array}$ & $\begin{array}{c}\text { Drilling } \\
\& \\
\text { Coring }\end{array}$ & Logging & $\begin{array}{c}\text { Perf. } \\
\& \\
\text { Brkdn. }\end{array}$ & $\begin{array}{l}\text { Pre- } \\
\text { frac } \\
\text { Test }\end{array}$ & $\begin{array}{l}\text { Stimu- } \\
\text { lation }\end{array}$ & $\begin{array}{c}\text { Clean } \\
\text { up }\end{array}$ \\
\hline \multirow{5}{*}{$\begin{array}{l}\text { AREA } 1 \\
\text { Trumbull } \\
\text { County, } \\
\text { Ohio }\end{array}$} & $\begin{array}{l}\text { Well } 1 \\
20143\end{array}$ & $x$ & $x$ & $x$ & $x$ & $x$ & $X$ & $x$ & $\begin{array}{l}\text { 1st } \\
\text { Zone }\end{array}$ & Cont. \\
\hline & $\begin{array}{l}\text { Wel1 } 2 \\
20144\end{array}$ & $\underline{x}$ & $x$ & $\underline{X}$ & $X$ & $x$ & $X$ & $x$ & $x$ & Cont. \\
\hline & $\begin{array}{l}\text { Well } 3 \\
20145\end{array}$ & $x$ & $X$ & $X$ & $X$ & $x$ & $x$ & $x$ & $\begin{array}{l}\text { Ist } \\
\text { Zone }\end{array}$ & Cont. \\
\hline & $\begin{array}{l}\text { Well } 4 \\
20146 \\
\end{array}$ & $x$ & $x$ & $x$ & $x$ & $x$ & $X$ & $x$ & $x$ & Aband. \\
\hline & $\begin{array}{l}\text { Wel1 } 5 \\
20147\end{array}$ & $x$ & $x$ & $X$ & $x$ & $x$ & $x$ & $x$ & $x$ & Aband. \\
\hline \multirow{5}{*}{$\begin{array}{l}\text { AREA } 2 \\
\text { Lorain } \\
\text { County, } \\
\text { Ohio }\end{array}$} & $\begin{array}{l}\text { We11 } 1 \\
20148\end{array}$ & $\underline{x}$ & $x$ & $x$ & $x$ & $x$ & & & & \\
\hline & $\begin{array}{l}\text { Well } 2 \\
20149 \\
\end{array}$ & $x$ & $x$ & $X$ & $x$ & $x$ & & & & . \\
\hline & $\begin{array}{l}\text { We11 } 3 \\
20150\end{array}$ & $x$ & $x$ & $x$ & $x$ & $x$ & & & & \\
\hline & \begin{tabular}{|l|} 
Wel1 4 \\
20151 \\
\end{tabular} & $x$ & $x$ & $x$ & $x$ & $\underline{x}$ & & & & \\
\hline & $\begin{array}{l}\text { We115 } \\
20152\end{array}$ & $x$ & $x$ & $x$ & $x$ & $x$ & & & & \\
\hline
\end{tabular}

ún 
Devonian Shale Test Well/Houghton College Area of New York Houghton College

Contract Number: DE-AC21-79MC10640

The objective is to evaluate the production potential of the Devonian shale in Allegany County, NY. One well will be drilled and logged through the Devonian shale formation in Allegany County, New York. A foam fracture treatment will be designed for the well; the well will be stimulated with this treatment; and post-frac testing will be performed.

The Houghton College \# 1 well was drilled, logged, and cased in August 1979. The well was drilled to a total depth of 2332 feet. Cuttings from the well were studied and a description completed.

During september 1979, the well was stimulated using a 50,000-gallon foam frac treatment. The formation breakdown pressure was 3000 psi with an average treating pressure of $2810 \mathrm{psi}$. The well gauged a flow of 300 MCFD at $130 \mathrm{psi}$ on a 18/64 choke. After flowback of frac fluids, the well was shut-in and tested by Gruy Federal Inc.

since it could not be determined from test results whether the induced fractures were vertical or horizontal, both analyses are given in the following table.

ESTIMATION OF SYSTEM PERMEABILITY

AND FRACTURE HALF-LENGTH FROM CONVENTIONAL ANALYSES

VERTICAL FRACTURE

Permeability, Half-Length

$m d$

0.064

ft

86 *

$93^{*}$

36

72

0.061

0.066

0.064

*

HORIZONTAL FRACTURE

Permeability, Fracture Radius

Drawdown

md

ft

Buildup

Type Curve

$(72$

$$
0.064
$$

$77 * *$

Arithmetic Mean

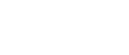
* Based on an average permeability value of 0.064 md from conventional techniques.

* Based on a vertical permeability value of 0.0088 . 
(Italics denote changes since March 31, 1980)

The analysis of the transient test data on the Houghton College No. 1 well using a reservoir simulator led to the following conclusions.

- The well is located in an extensive natural fracture system which makes it a good producer.

- The effective fracture half-length in the perforated interval is only about 18 feet.

- Storage effects are minimal.

- Linear flow lasted only a short time and radial flow was attained.

- Turbulence effects were negligible.

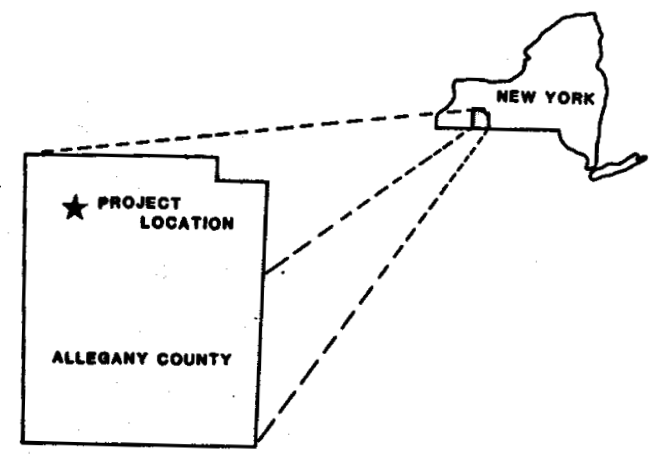

Assessment of Devonian Shale Potential in Carroll County, Ohio Mitchell Energy Corporation

Contract Number: DE-AC21-78MC12537

The objective is to assess the production potential of the Devonian shale in this area by recompleting a currently temporarily abandoned well drilled to the Clinton Sand. The Marcellus Shale, and optionally the Burkett Shale, is scheduled for stimulation.

A 50,000 gallon foam frac, displacing 60,000 pounds of sand at 30 BPM into a fracture at a depth of 2800 to 3500 feet, was used to stimulate the primary test interval. Following the fracture fluid recovery, the gas flow rates were too small to measure, indicating the test site is unfavorable for development. A decision is pending on whether to frac the upper zone. 


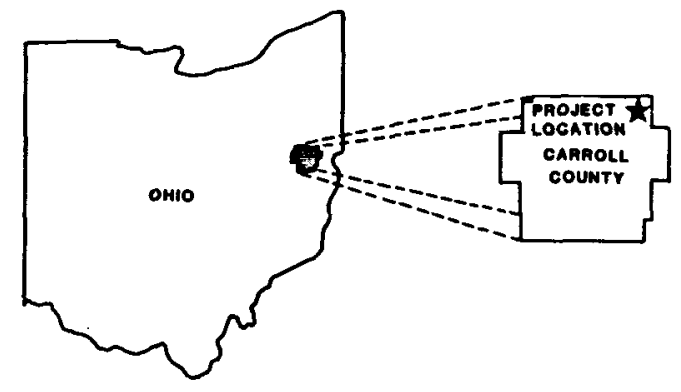

Assessment of Devonian Potential in Preston County, West Virginia J. T. Waggoner

Contract Number: DE-AC21-79MC010515

The objective is to assess the production potential of the Devonian shale in this area by recompleting a currently temporarily abandoned well drilled to the Oriskany sandstone. The Marcellus Shale is scheduled for stimulation with a gel/ $\mathrm{CO}_{2}$ treatment.

The Marcellus Shale was stimulated in April 1980. Preliminary results indicate a flow of 150 to 200 MCFD. However, the well is in a remote area and will probably not be commercialized. It is presently shut-in.

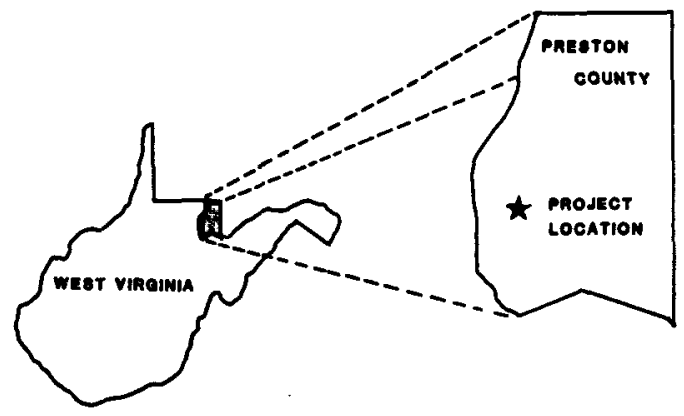

Testing Program for Shale Gas Production Potential

Thurlow Weed and Associates, Inc.

Contract Number: DE-AC21-78MC08386

The objective is to test the production potential of the Devonian shale in knox County, Ohio. One new well will be drilled, cored, and logged in the Devonian shale of Ohio; four existing wells will be logged; and stimulation treatments will be performed on the new well and three existing wells. The stimulation treatments will be designed for site-specific geologic conditions, and data will be acquired on the commercial potential of the various stimulation techniques used. In 
(Italics denote changes since March 31, 1980)

order to evaluate methods of determining stimulation selection, characteristics of the existing wells plus characteristics of the new test well will be studied in light of resulting production.

The Everett Black No. 1 well was stimulated during the previous reporting period. It was blown back and tested for pressure and flow rates for two days after the frac.

Natural fracture analysis in the boreholes of all four project wells was carried out using the downhole video system.

Core from one of the wells is being analyzed to determine which fracturing fluids are more suitable for the other three project wells.

In December 1979, a 1000 barrel foam frac of the No. I Beckholt well provided discouraging initial results.

There are two additional stimulations to be performed and the contract has been extended to December 1980 .

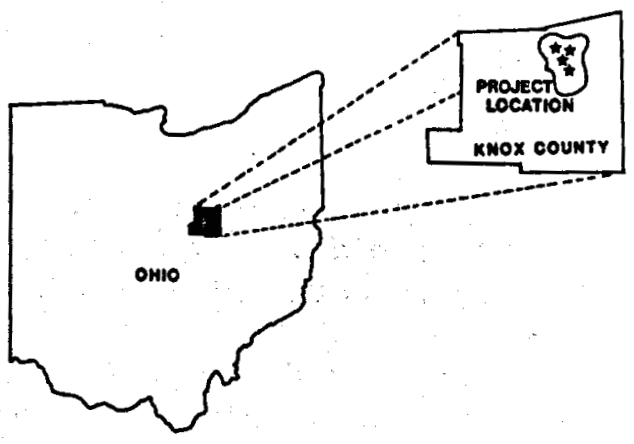




\subsection{PROJECT INTEGRATION}

\subsubsection{GENERA L}

As well as planning, coordinating, and evaluating the Resource Characterization and Inventory, Extraction Technology R\&D, and Technology Testing and Verification activities, this Element of the EGSP includes environmental studies, a project data base management system, economic analysis, and technology transfer.

\subsubsection{EN V I RONMENTAL ACTIVITIES}

An environmental impact statement for the offset Well project is in progress, and should be completed early in FY 81 .

\subsubsection{PROJECT DATA BASE MANAGEMENT S Y S T E M}

The EGSP subfile data base is being enhanced. The definition has been changed to incorporate numeric fields. All of the data were reloaded to put the new definition into effect. At the same time, several data errors were corrected in the system. This process of correcting errors is still taking place along with modification to the load programs so that updates can be added to the data base. The bottom half of the WHCS data base was loaded onto a mountable disk pack from tape. This procedure makes on-line retrievals possible for the entire whCS file.

\subsubsection{E C O NOMIC E V ALUATION}

A study to determine the economically recoverable gas from Devonian Shale in the Appalachian Basin was initiated in September 1979 and is expected to be completed by October 1980 .

Historical production data have been compiled. The data are mostly confined to proven fields such as the Big sandy and Cottageville. Quantitative analyses will first be performed on the recoverable resource and associated geological factors of these and other regions where production data are available.

Cluster analyses have been performed to obtain different clusters or groupings with distinct geological features for the Basin. The clusters are based on geological factors such as radioactive shale thickness, thermal maturity, and stress-ratios. 
(Italics denote changes since March 31, 1980)

The results of the cluster analysis will be used in attempts at extrapolation from training to target areas for obtaining statistical distributions of the recoverable resource.

An analysis of counties with production data shows that the recoverable resource on a well-by-well basis has a statistically skewed distribution which appears to be lognormal. An aggregation of these probabilistic distributions, given suitable well spacings and success-ratios of wells, has been made to obtain interval estimates of the recoverable resource. Using traditional "shooting" technology, an expected value $(\mu)$ of 20.2 TCF, with a standard deviation $(\sigma)$ of 1.6 TCF, based on a 160 acre well spacing has, been obtained for the basin. preparation of a final report has been initiated.

\subsubsection{TECHNOLOGY TRANSFER}

A joint SPE/DOE UGR Conference was held in Pittsburgh, PA in May 1980. Forty-three papers were presented at this meeting. The papers are available from SPE aS SPE/8921 through SPE/8972. The Conference Proceedings are also available from METC as UGR File NO. S357. A 28 1/2-minute film on the UGR Program was produced and shown at this meeting. The film is available for loan from METC (UGR File No. 424).

The UGR Information File Document has been published by METC (METC/80/1). This document includes accession 1 ists, cross-reference indexes, lists of UGR-related symposia papers, and current UGR contractors. The UGR' Information File now contains over 440 documents and logs and 110 maps in the accession lists. AlI EGSP contractor quarterly and annual reports, final reports, topical reports, and maps are in the UGR File. Copies of individual reports or maps can be obtained upon request to METC. Logs are available as open-file viewing only.

Maps printed as EGSP series during this reporting period included the following:

- EGSP Series 105 through 110 - Isopach maps of specific black shale units in New York state

- EGSP Series 300 through 303 - Isopach maps of specific black shale units in ohio

- EGSP Series 304 through 309 - Cross sections through the Devonian shale in Ohio

- EGSP Series 1400 - Location of cross sections within the Appalachian Basin 


\subsection{WESTERN GAS SANDS}

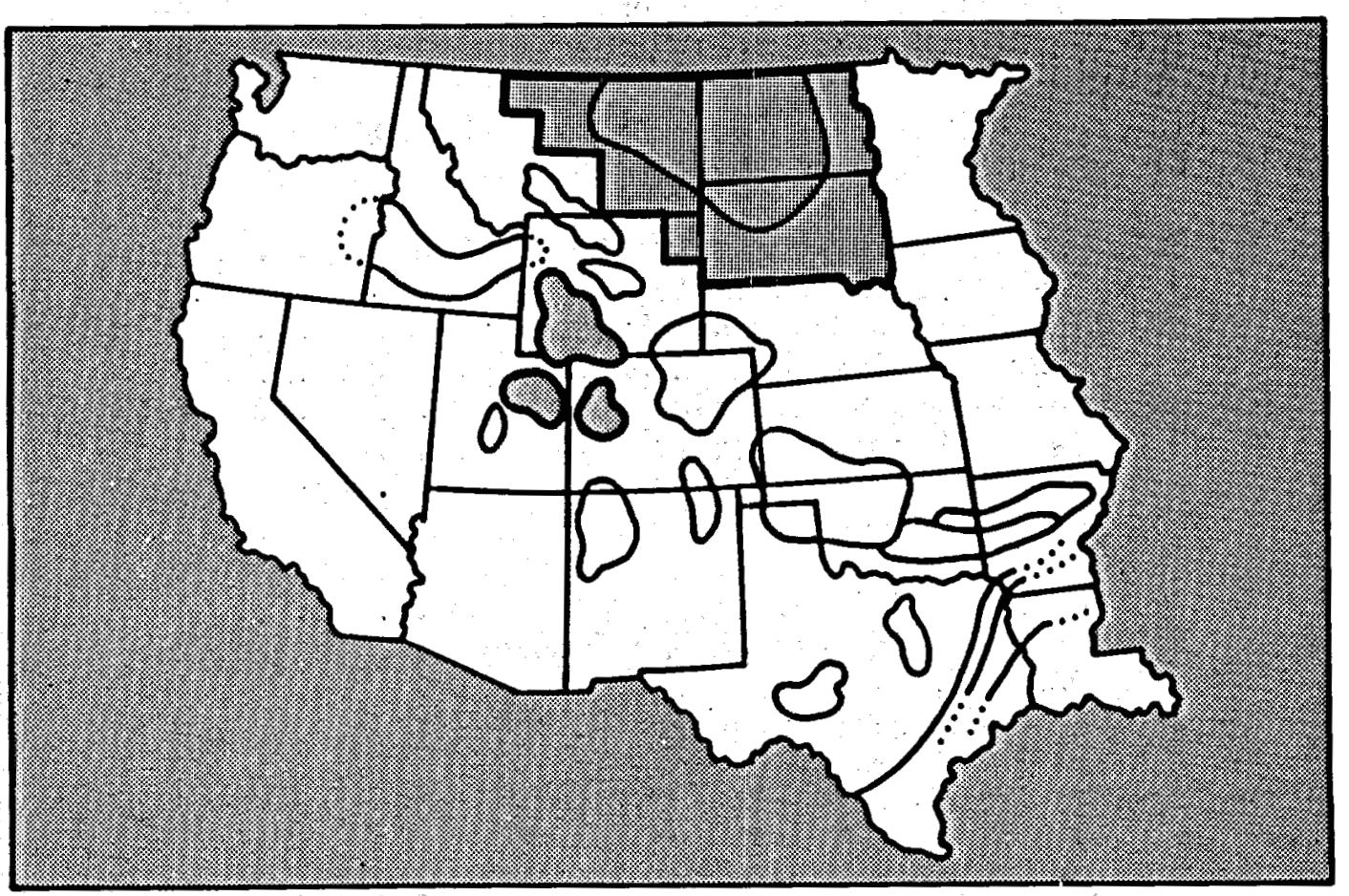


4. WESTERN GAS SANDS PAGE

4.1 Introduction. ............... . 4-1

4.1.1 Background ............... 4-1

4.1.2 Western Gas Sands Project. . . . . . . 4-3

4.2 Resource Assessment . . . . . . . . . . . 4-4

4.2.1 U.S. Geological Survey Activities. . . . . 4-4

4.2.2 Core Program ............ 4-5

4.2.3 CK GeoEnergy Corporation ........ 4-5

4.2.4 Survey of Basin Activities ....... 4-6

4.3 Research and Development by Energy Technology

Centers and National Laboratories ....... 4-7

4.3.1 Bartlesville Energy Technology Center. . . 4-7

4.3.2 Gas Research Institute ......... 4-44

4.3.3 TRW Western Gas Sands Support. . . . . 4-45

4.3.4 Lawrence Livermore Laboratory. . . . . . . 4-46

4.3.5 Los Alamos Scientific Laboratory .... . 4-59

4.3.6 Sandia Laboratories. . . . . . . . 4-60

4.4 Field Tests and Demonstrations. . . . . . 4-78

4.4.1 Background . . . . . . . . 4-78

4.4.2 Colorado Interstate Gas Company. . . . . 4-84

4.4.3 DOE Well Test Facility ....... . . 4-87

4.4.4 Gas Producing Enterprises, Inc.. . . . . . 4-89

4.4.5 Mitchell Energy Corporation. . . . . 4-94

4.4.6 Sandia Laboratories - Stimulation Research . 4-96

4.5 Project Management. . . . . . . . . . . 4-100 
FIGURES

PAGE

Figure 4-1 Map of Western U.S., Showing Areas

of Interest. . . . . . . . . 4-1

Figure 4-2 Effect of Net Confining Pressure on

Gas STippage at Core Depth 8,243.3 Ft. . . . 4-8

Figure 4-3 Reduction in Gas Permeability Due to

Net Confining Pressure . . . . . . . 4-9

Figure 4-4 Reduction in Extrapolated Gas Permea-

bility Due to Net Confining Pressure . . . . 4-9

Figure 4-5 Comparison of Klinkenberg Permeability

and Liquid Permeability. . . . . . . . 4-10

Figure 4-6 Comparison of Extrapolated Kl inkenberg

Permeability and Liquid Permeability . . . . 4-12

Figure 4-7 Matrix Density vs Percent Carbonate,

CIGE No. 20............. 4-13

Figure 4-8 Log Section from CIGE NBU No. $21 \ldots$. . . 4-16

Figure 4-9 Matrix Density vs Percent Carbonate,

CIGE NBU No. 21............. 4-16

Figure 4-10 Bulk Density vs Laboratory Derived

Porosity, Mlapco BBU No. 11-17F . . . . . . 4-18

Figure 4-11 Neutron Log Porosity vs Laboratory

Derived Porosity, Mapco RBU No. 11-17F . . . 4-19

Figure 4-12 Porosity from Sonic Log vs Laboratory

Derived Porosity, Mapco RBU No. 11-17F . . . 4-20

Figure 4-13 Sonic Log Travel Times, Mapco RBU No.

11-17F ................ 4-21

Figure 4-14 Calculated Matrix Travel Times, Mapco

RBU No. 11-17F ......... . . . 4-21

Figure 4-15 Fracture Closure vs Proppant Coverage

Using 12/20 Mesh Sintered Bauxite and

Grey Berea . . . . . . . . . 4-28

Figure 4-16 Theoretical Comparison of Porous with

Hollow Spheres, 20/40 Mesh . . . . . . . 4-31 
Figure 4-17 Fracture Closure vs Closure Pressure with Various Fractions of Monolayer Coverage Using 12/20 Mesh Sintered Bauxite Proppant Between Smooth and Fractured Berea Blocks. ......... 4-32

Figure 4-18 Production Forecast .......... 4-35

Figure 4-19 Effect of Fracture Skin on Drawdown wi th 0.1 md Permeability. ......... 4-36

Figure 4-20 Effect of Fracture Skin on Build-up with 0.1 md Permeability. ........ 4-36

Figure 4-21 Effect of Wellbore Storage on Drawdown with Fracture Skin $0.1 \mathrm{md}$ and $0.1 \mathrm{md}$ Permeability. ............ . . 4-37

Figure 4-22 Effect of Wellbore Storage on Build-up with Fracture Skin of $0.1 \mathrm{md}$ and $0.1 \mathrm{md}$ Permeability. ........... 4- 4-37

Figure 4-23 Effect of Wellbore Storage on Drawdown with Skin Factor of $0.1 \mathrm{md}$ and $0.05 \mathrm{md}$ Permeability. . . . . . . . . 4-39

Figure 4-24 Effect of Wellbore Storage on Build-up with Skin Factor of $0.1 \mathrm{md}$ and $0.05 \mathrm{md}$ Permeability. ............. 4-39

Figure 4-25 Comparison of Production Forecasts. . . . . 4-41

Figure 4-26 Comparison of Production Forecasts. . . . . . 4-41

Figure 4-27 Comparison of Production Forecasts. . . . . 4-42

Figure 4-28 Drawdown Curves for Three Fracture Geometrics. . . . . . . . . . 4-42

Figure 4-29 Build-up Curves for Three Fracture Geometrics. . . . . . . . . 4-43

Figure 4-30 Production Forecasts for Three Fracture Geometrics. ............. 4-. . 43

Figure 4-31 Normalized Strain Energy Density at the Crack Tip as a Function of Distance from the Interface for Several Values of $B$. 
Figure 4-32 Normalized Strain Energy Density as

a Function of $B$ in the Material Across

the Interface from the crack. ....... 4-49

Figure 4-33 Fracture Geometry ............ 4-51

Figure 4-34 Normalized Strain Energy Density,

$\mathrm{Ke}$, as a Function of Frictional

Sheer Stress, Ie. ........... 4-52

Figure 4-35 Frictional Prob. Geometry ........ 4-53

Figure 4-36 Parallel Strain Across Interface

from Pressurized Fracture as a

Function of Position Along Interface. . . . . 4-53

Figure 4-37 Parallel Strain Across Interface

from Pressurized Fracture as a

Function of Position Along Interface. . . . . 4-54

Figure 4-38 Parallel Strain Across Interface

from Pressurized Fracture as a

Function of Position Along Interface. . . . 4-54

Figure 4-39 Parallel Strain Across Interface

from Pressurized Fracture as a

Function of Position Along Interface. . . . 4-55

Figure 4-40 Experimental Arrangement to Study

Effect of Non-uniform Stress Field

as Crack Growth ........... . . 4-58

Figure 4-41 Shell Big Mineral Creek Breakdown

Seismic Signals, February 26, 1980. . . . . 4-62

Figure 4-42 Shell Big Mineral Creek Breakdown

Signals, February 16, 1980. . . . . . . 4-62

Figure 4-43 Shell Big Mineral Creek SEPS Electrical

Direction, February 17, 1980. ...... . 4-64

Figure 4-44. Conductivity Profile. . . . . . . . 4-65

Figure 4-45 Predicted Apparent Resistivities at

Probe.............. 4-66

Figure 4-46 Comparison of Potentials and Apparent

Resistivities from One and Two

Dimensional Models. . . . . . . . 4-68 
Figure 4-47 Comparison of 1-D and 2-D Mode1

Calculations. ............... 4-69

Figure 4-48 Digitization of Sample No. 4403.8

from CIGE No. 21 Core . . . . . . . . . 4-71

Figure 4-49 Computer Analys is of Digitized Sample

No. 4403.8. . . . . . . . . . . 4-71

Figure 4-50 Principal Pore Axis Angles. . . . . . . . . 4-72

Figure 4-51 Depth Model of Soft Thick Sand

Lense in a Silty Background

Underlain by a $50 \mathrm{Ft}$ Thick Sand Bed . . . . . . 4-74

Figure 4-52 60-140 $\mathrm{Hz}$ Wavelet Record Section of

Depth Model ............ 4-74

Figure 4-53 Two Dimensional Record Section Taken

at Brysen Canyon Site . . . . . . . . 4-75

Figure 4-54 Three Dimensional Time Slice at

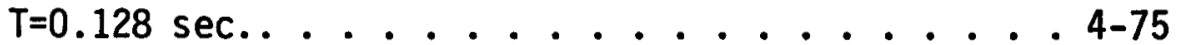

Figure 4-55 Map Showing Projected Trends of

Channels A, B and C, Projected

Outcrop and Positions of Mapped

Outcropping Channels in Area.

Figure 4-56 Production and Injection Volumes

and Associated Pressures of CIGE

Miller No. 1 and Sprague No. 11 Wells . . . . 4-85

Figure 4-57 Natural Buttes No. 9 Well Flow Rate . . . . . . 4-90

Figure 4-58 Natural Buttes No. 14 Well Flow Rate. . . . . . 4-90

Figure 4-59 Natural Buttes No. 18 Well Flow Rate. . . . . . 4-91

Figure 4-60 Natural Buttes No. 19 Well Flow Rate. . . . . . 4-91

Figure 4-61 Natural Buttes No. 20 Well Flow Rate. . . . . . 4-92

Figure 4-62 Natural Buttes No. 22 Well Flow Rate. . . . . . 4-92

Figure 4-63 Width of Fracture Through Section A-A

(Mineback Data) ........... 4-96

Figure 4-64 Geometrical Relationships Between

Crack and Interface . . . . . . . . . 4-101 
Figure 4-65 Variation in Stress Intensity Factor as a Crack Approaches an Interface. ..... 4-102

Figure 4-66 Tensile Stress as a Function of Distance from Crack Tip . . . . . . . 4-102 


\section{TABLES}

Table 4-1 Principal Study Areas and Resource

Base Estimates. . . . . . . . . . . 4-2

Table 4-2 Summary of Drilling Activities from

April 1980 through July 1980. . . . . . . . 4-6

Table 4-3 Slope and Intercept Values as a

Function of Net Confining Pressure. . . . . . . 4-8

Table 4-4 Porosity Results Measured with Matrix

Volume Cap. ............. 4-14

Table 4-5 Laboratory Measured Densities . . . . . . . . 4-15

Table 4-6 Mean Single Particle Settling Times,

secs................... 4-26

Table 4-7 Mean Single Particle Settling Rates,

cm/secs.. . . . . . . . . . . 4-26

Table 4-8 Mean Single Particle Settling Times,

secs.................. 4-27

Table 4-9 Mean Single Particle Settling Rates,

$\mathrm{cm} / \mathrm{sec}$. . . . . . . . . . . . 4-27

Table 4-10 Comparison of Seismic and Outcrop

Descriptions of Channel Sandstones. . . . . . . 4-77

Table 4-11 MHF Contract Location and Frac Data . . . . . . 4-80 


\subsection{INTRODUCTION}

$4: 1.1$ B ACKGROUND

Geologic studies indicate that an immense resource of natural gas exists in low permeability reservoirs in a number of geologic basins scattered throughout the western United States (Figure 4-1). Potentially gas productive sands within these intervals thousands of feet thick might number a hundred or more and may range in thickness from a few feet to more than $100 \mathrm{ft}$. In addition, the lateral extent of these sands is quite variable, and they may be "blanket" type deposits of large areal extent, or be lenticular of 1 imited but unknown size.

Studies by the Federal Power Commiss ion in 1973, supplemented by the United States Geological Survey and by Lewin \& Associates in 1978 have identifled four areas which are large in areal extent, contain a large number of known low permeabllity reservoirs, and have a sizable existing data base (Table 4-1). The Lewin study also evaluated nine other basins which were estimated to contain an additional 190 trillion cubic feet of gas in low permeability reservoirs.

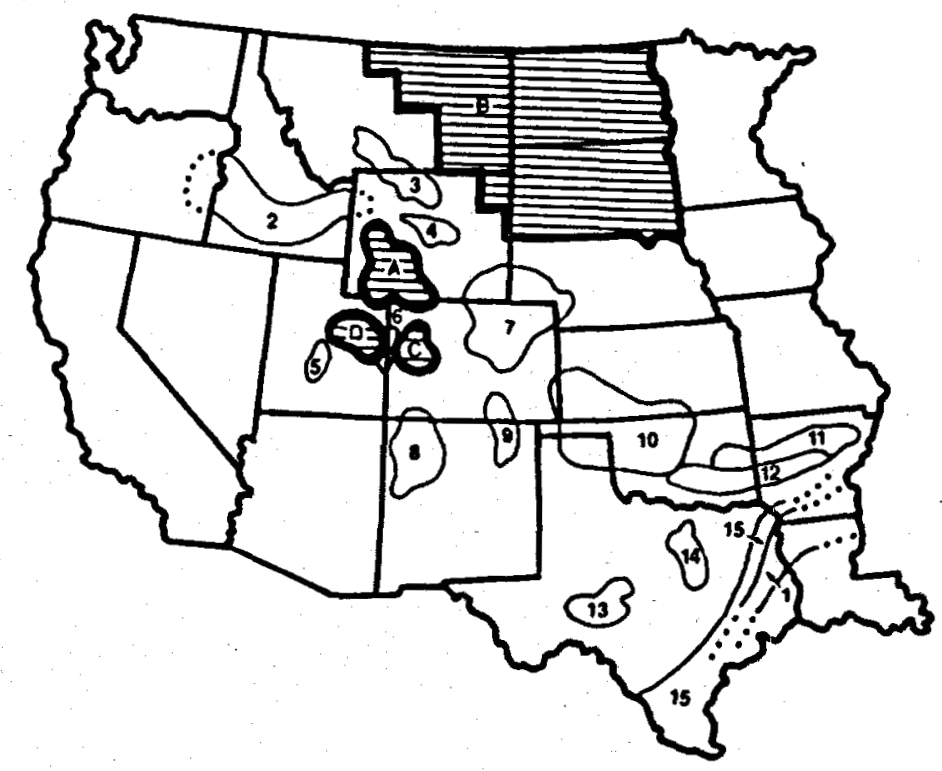

PRIMARY STUDY AREAS
A. Greater Green River Basin
B. Northem Great Plains Province
C. Piceance Basin
D. Uinta Basin

ADDITIONAL LOW PERMEABILITY SANDSTONE AREAS

1. Cotton Valley Trend

2. Snake River Downwarp

3. Big Hom Basin

4. Wind River Basin

5. Wasatch Plateau

6. Douglas Creek Arch

7. Denver Basin

8. San Juan Basin

9. Raton Basin

10. Anadarko Basin

11. Arkoma Basin

12. Ouachita Mountains Province

13. Val Verde Basin

14. Fort Worth Basin

15. Westem Gulf Basin

Figure 4-1 Map of Western U.S., Showing Areas of Interest 
Table 4-1 Principal Study Areas and Resource Base Estimates

\section{Estimated Resource (TCF)*}

\begin{tabular}{lccc}
\multicolumn{1}{c}{ Area } & State & FPC \& USGS Est. & Lewin \& \\
\hline Greater Green River & WY & 240 & 91 \\
Northern Great Plains Province & MT, WY, & 130 & 53 \\
& SD, ND & & \\
Piceance Basin & CO & 210 & 36 \\
Uinta Basin & UT & 150 & 50 \\
\cline { 2 - 4 } & Totals & 730 & 230 \\
\hline
\end{tabular}

- Trillion Cubic Feet

* "Does not include presently commercial or "speculative" areas 
The Western Gas Sands Project (WGSP) is part of a U.S. Department of Energy program to accelerate the development of domestic energy resources. It is directed toward the development of new and improved techniques for recovering gas from low-permeability reservoirs that currently cannot be economically produced. The purpose of the project is to encourage and supplement industrial efforts in developing technology to demonstrate the feasibility of economically producing natural gas from these reservoirs.

The project objectives are:

- to accurately define the resource base,

- to develop and implement techniques for determining physical and chemical properties of the reservoirs,

- to determine appropriate stimulation technology, and

- to assess potential gas reserves and demonstrate economic productivity to encourage industrial development of the resource.

Achieving these objectives will require:

- utilization of updated drilling and geological information to determine optimum drilling sites for resource confirmation and production research activities,

- cost-sharing field tests with industry to characterize the reservoirs and to test and refine production stimulation technologies, particularly massive hydraulic fracturing,

- maintaining an effective research program in government, industry and academic institution laboratories oriented toward improving diagnostic tools and methods and increasing the effectiveness of gas stimulation techniques,

- incorporating and building upon the R\&D results, and

- economic analyses and technology transfer.

Project progress achieved from April 1 through September 30, 1980, will be noted in italics. 
(Italics denote changes since March 31, 1980.)

4.2 RESOURCE ASSESSMENT

4.2.1 U.S. GEOLOGICAL SURVEY

A C T I V I T I E S

UINTA-PICEANCE BASINS

During this reporting period paleontologic data from Price River Canyon was compiled. Small samples of core from Mapco RBU No. 11-17F well in the Uinta Basin were excomined. Core from a Twin Arrow C\&K well, Westwater Canyon in the Bookcliffs (Uinta Basin), is being examined to determine suitability for reservoir property studies. Initial analysis indicated that almost all of the Mesaverde cores have been extensively altered by near surface weathering conditions, making them unsuitable for direct rock-property and mineralogic comparisons to the deep subsurface at Natural Buttes.

Stratigraphic and reservoir analysis continued of the Uinta and Piceance Basins. Pressure data is being compiled in the Piceance Basin. A paper was prepared on the relations between diagenesis and porosity in Mesaverde core from the Uinta Basin.

The compilation of a mop continued relating water and/or hydrocarbon recoveries for all Mesaverde Group tests in the Piceance Basin. The data is derived from analysis of completion zones and drill stem tests.

Surface exposures of Wasatch Formation units along Yellow Creek between Meeker and Rangely Fields in the Piceance Basin were examined. In this area, the Wasatch contains many rocks that were formed in a lacustrine depositional setting; these rocks contain organic matter and are probable sources of gas and/or oil in deeply buried units.

Lithologies of cored units in the Uinta Basin were plotted against geophysical log curves. This related log response to rock properties determined from SEM, petrographic and sedimentologic studies. Surface exposures of Upper Cretaceous Mesaverde Group sandstones in the south central part of the Uinta Basin were described.

\section{GREATER GREEN RIVER BASIN}

Gas desorption and analyses were completed on core from Rainbow Resources No. 1-3 Pacific Creek Federal well. Core from the Champlin No. 221 Amoco C well in Sec. 19, T18N, R95W, Sweetwater County, Wyoming, was sampled and described. 
(Italics denote changes since March 31, 1980.)

A map was submitted for review: "Preliminary chart showing electric log correlation section $J-J '$ ' of some Upper Cretaceous and Tertiary rocks, Washakie Basin, Wyoming," by T.F. TyZer, J.R. Peterson and H.E. Bucurel.

A paper was presented entitied "Evaluation of organic matter and subsurface temperature and pressure with regard to gas generation in lowpermeability Upper Cretaceous and Zower Tertiary sandstones in Pacific Creek area, sublette County, Wyoming," B.E. Lrow, C.W. Spencer and N.H. Bostick, at the National AAPG-SEPM-EMD Convention.

Core is being solicited from operators in the Bowdoin Dome area in northcentral Montana and West Shore Pine Bills field in northwestern South Dakota.

\section{NORTHERN GREAT PLAINS PROVINCE}

Scmples from Belco (Inexco) WASP No. A-1 well were submitted for complete geochemical analyses. X-ray analysis of clays from drill-cuttings from Rainbow Resources Pacific Creek Federal No. 1-34 well were completed. The report on stratigrophic correlations of Upper Cretaceous rocks in the Rock Springs Uplift and northern Green River Basin has been temporarily suspended until additional field work is completed. Field and laboratory studies began of cuthigenic carbonates in the Gammon Shale from Montana and North and South Dakota.

\section{2 .2 CORE PROGRAM}

Discussions were held with Coastal oil and Gas Corporation concerning coring, logging, testing and fracturing a well with WGSP support in the Natural Buttes area in the Uinta Basin.

Several operators were contacted concerning possible coring operations. In the Piceance Basin, contacts included CSG Exploration, Adolph Coors Company, Teton Energy, Dome Petrolezm, Texas Eastern and Bow Valley Exploration. Others were Cotton Petroleum (Uinta Basin), Pacific Transmission Supply Company (Uinta Basin), and Mountain Fuel Supply Company (Greater Green River Basin) and Falcon Oil \& Gas Company (Northern Great Plains Provincel.

\subsubsection{CK GEOENERGY CORPORATION}

The final report is being prepared on the Green River/Wind River Studies, under contract NO. DE-AC08-79BC10005, Techniques for Optimizing Selection and Completion of Western Tight Gas Sands. $C K$ GeoEnergy and Schlumberger reviewed the interpretation of the DOE-GC-1 corehole Zogs. 
(Italics denote changes since March 31, 1980.)

\section{2 .4 S URVEY OF BAS I N A C T I V I T I ES}

The monitoring of basin activities is an important part of resource assessment and promotes cooperation between industry and goverment. Certain areas in each study area have been recommended by the USGS for obtaining core. Operators active in these specific areas are located by monitoring new activity in each area and are contacted to negotiate contracts for a joint industry/goverment coring operation.

Drilling information is campiled primarily from The Rocky Mountain Region Report, published daily by Petroleum Information Corporation. Additional sources used are the Montana Oil and Gas Journal, The Oil and Gas Journal and the Western oil Reporter.

Table 4-2 is a summary of the drilling activities in the four areas of interest during the reporting period.

Table 4-2 Summary of Drilling Activities from April, 1980 through July, 1980

\begin{tabular}{|c|c|c|c|c|}
\hline & $\begin{array}{l}\text { Greater } \\
\text { Green } \\
\text { River }\end{array}$ & $\begin{array}{l}\text { Northern } \\
\text { Great Plains } \\
\text { Province }\end{array}$ & $\begin{array}{c}\text { Piceance } \\
\text { Basin }\end{array}$ & $\begin{array}{l}\text { Uinta } \\
\text { Basin }\end{array}$ \\
\hline $\begin{array}{l}\text { Development } \\
\text { Producers } \\
\text { Shut-Ins } \\
\text { D\&A }\end{array}$ & $\begin{array}{r}26 \\
1 \\
6\end{array}$ & $\begin{array}{l}44 \\
25 \\
18\end{array}$ & $\begin{array}{r}23 \\
1 \\
4\end{array}$ & $\begin{array}{r}13 \\
2 \\
5\end{array}$ \\
\hline $\begin{array}{l}\text { Wildcats } \\
\text { Discoveries } \\
\text { Shut-Ins } \\
\text { D\&A }\end{array}$ & $\begin{array}{r}5 \\
0 \\
10\end{array}$ & $\begin{array}{r}9 \\
4 \\
21\end{array}$ & $\begin{array}{l}1 \\
0 \\
1\end{array}$ & $\begin{array}{l}2 \\
0 \\
0\end{array}$ \\
\hline $\begin{array}{l}\text { New Locations } \\
\text { Development } \\
\text { Wildcats }\end{array}$ & $\begin{array}{l}73 \\
47\end{array}$ & $\begin{array}{r}102 \\
39\end{array}$ & $\begin{array}{l}55 \\
17\end{array}$ & $\begin{array}{l}29 \\
12\end{array}$ \\
\hline \multirow[t]{2}{*}{ IPF (MCFD) } & 29,536 & 17,000 & 11,156 & 18,316 \\
\hline & \multicolumn{3}{|c|}{ Total IPF (MCFD) 76,008} & \\
\hline
\end{tabular}


(Italics denote changes since March 31, 1980.)

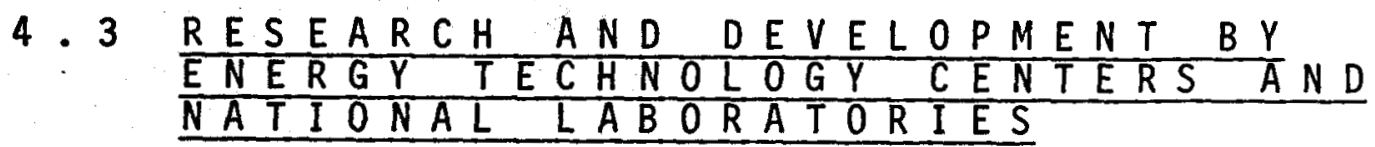

4.3.1. BARTLESVILLE ENERGY TECHNOLOGY C E N T E R

IN SITU PERMEABILITY

Measurement of Formation Characteristics for Western Tight Sands Institute of Gas Technology

Measurements on core samples from the Mapco RBU No. 11-17F well, Sec. 17, T10S, R2OE, Uinta County, confirmed earlier observations that the slope of the Klinkenberg plot decreases as net confining pressure increases. The gas permeability of cores from $8,243.3 \mathrm{ft}$ decreased considerably as a result of increasing net confining pressure. $A$ Klinkenberg plot for the core is shown in Figure 4-2. With increased net confining pressure, the slope of the lines and the extrapolated permeability values at infinite mean pore pressure decreased sharply. The slope and intercept values are shown in Table 4-3 as a function of net confining pressure.

Figures $4-3$ and 4-4 show the reduction of gas permeabilities (measured at a mean pore pressure of 34.7 psial and extropolated permeabilities as a function of net confining stress. The reduction in permeability of these cores is more pronounced than other core samples studied from the same well.

Liquid permeabilities for Core No. 6475.5 from the CIGE NBU No. 21 well, Uinta Basin, were measured. A 2 percent $\mathrm{KCl} / 2$ percent $\mathrm{NaCl}$ brine was used as the flowing fluid. Differential pressures were maintained at approximately 80 psi. These permeability values were compared with the Klinkenberg permeabilities determined by gas flow measurements. The results are shown in Figure $4-5$ as a plot of permeability versus net confining pressure. The figure shows that the liquid permeability values are consistently lower than the corresponding Klinkenberg at each net confining pressure. The ratio of the values remained approximately constant. Porosity was measured to be 0.102 .

Pore volume compressibility of the core was measured by monitoring the amount of water displaced from the core as confining pressure increased. The decrease in pore volume was only 3.3 percent of initial pore volume when confining pressure increased to opproximately in situ values (20.7 MPa or 3,000 psi). Pore volume compressibility (expressed as change in 


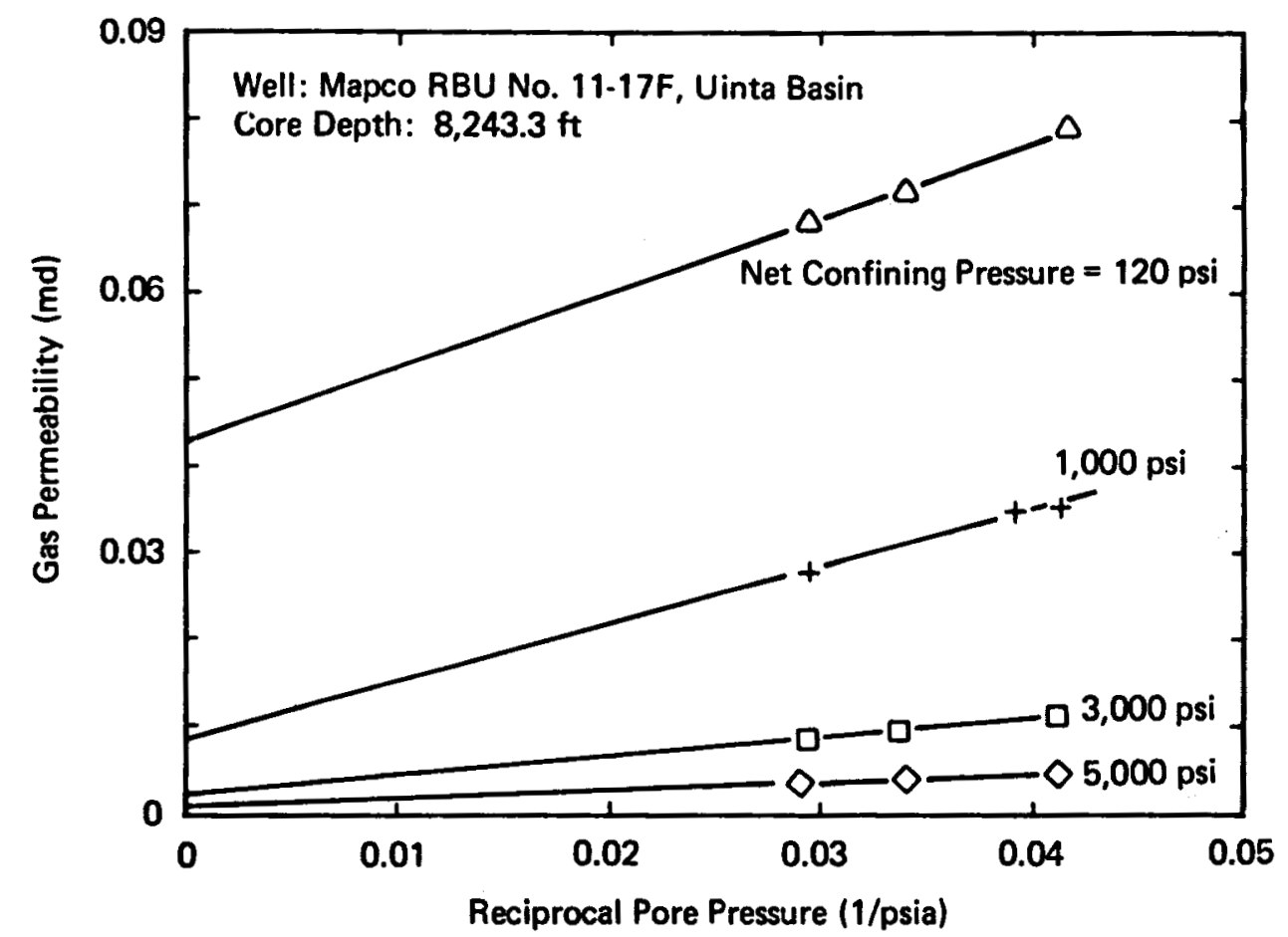

Figure 4-2 Effect of Net Confining Pressure on Gas Slippage at Core Depth 8,243.3 Ft

Table 4-3 Slope and Intercept Values as a Function of Net Confining Pressure

\begin{tabular}{ccc}
\hline $\begin{array}{c}\text { Net Confining } \\
\text { Pressure, psi }\end{array}$ & $\begin{array}{c}\text { Slope of } \\
\text { Klinkenberg Plot, } \\
\text { md psi }\end{array}$ & $\begin{array}{r}\text { Intercept } \\
\text { Ko, }_{\text {md }}\end{array}$ \\
\hline Core Depth: 8,243.3 ft & & \\
120 & 0.9040 & 0.04200 \\
1,000 & 0.6850 & 0.00810 \\
3,000 & 0.2230 & 0.00220 \\
5,000 & 0.1190 & 0.00049
\end{tabular}

Core Depth: $8,298.4 \mathrm{ft}$

$\begin{array}{rrr}120 & 1.6150 & 0.10500 \\ 1,000 & 0.4680 & 0.02200 \\ 3,000 & 0.0450 & 0.00046\end{array}$

Core Depth: $8,234.9 \mathrm{ft}$ 


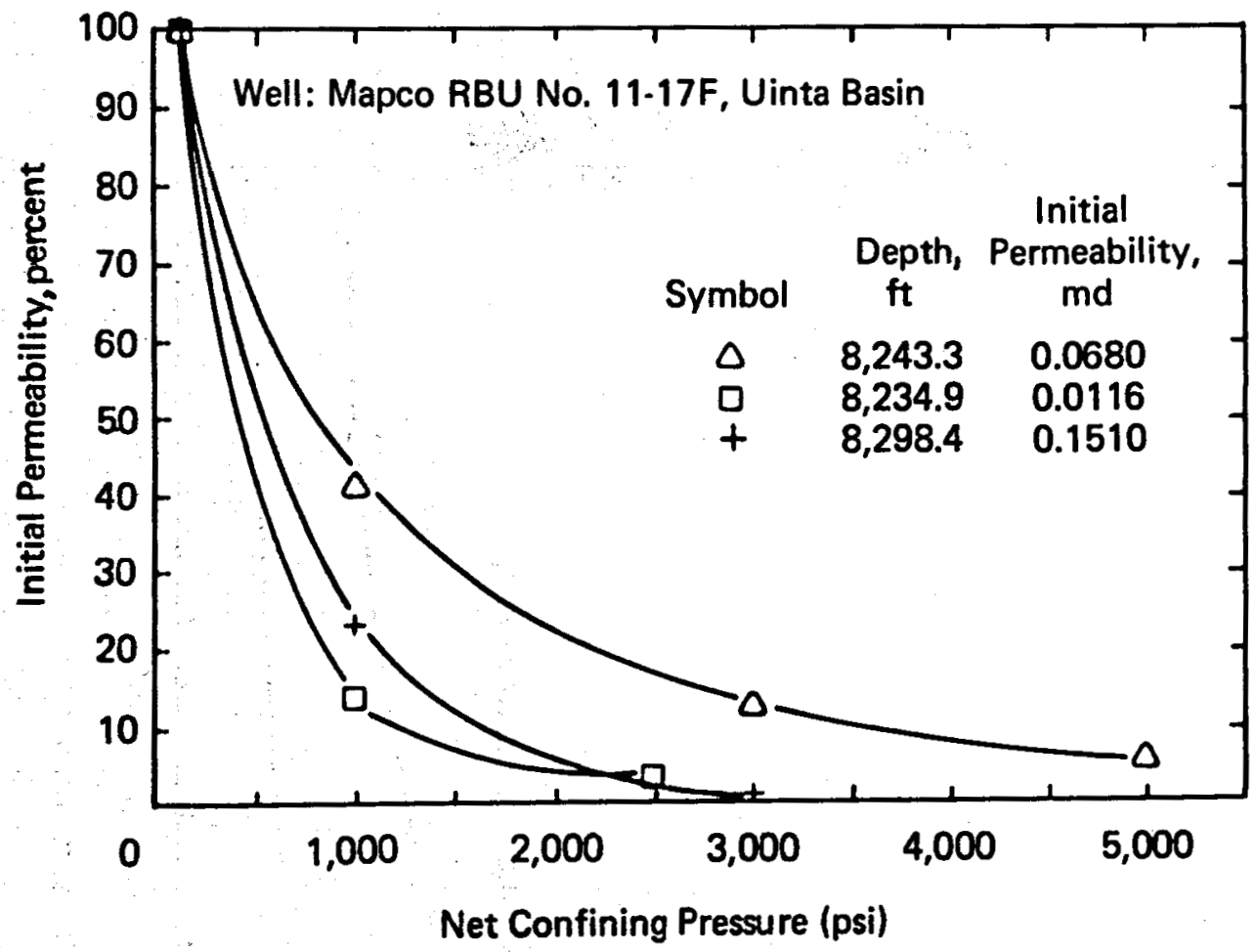

Figure 4-3 Reduction in Gas Permeability Due to Net Confining Pressure

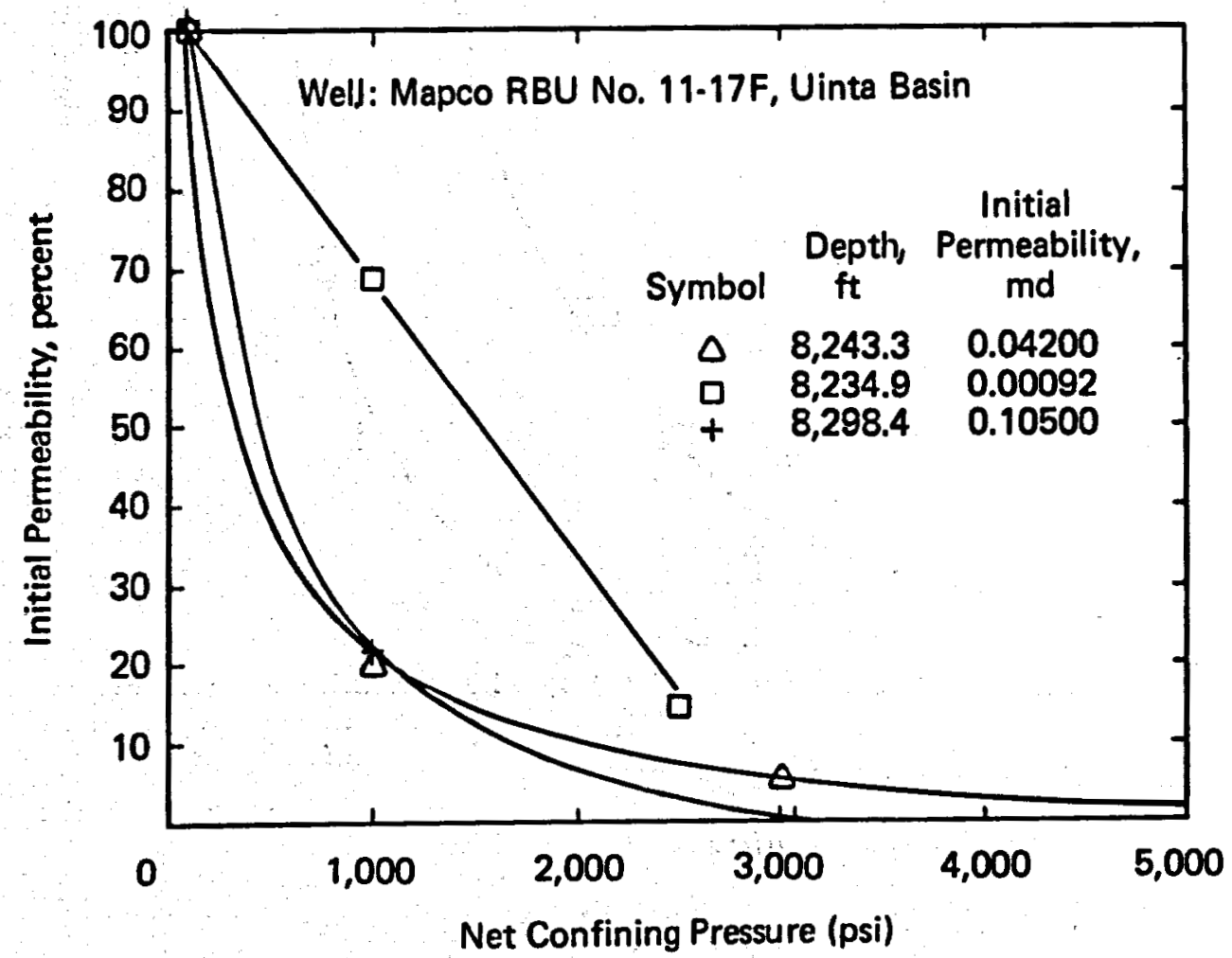

Figure 4-4 Reduction in Extrapolated Gas Permeability Due to Net Confining Pressure 


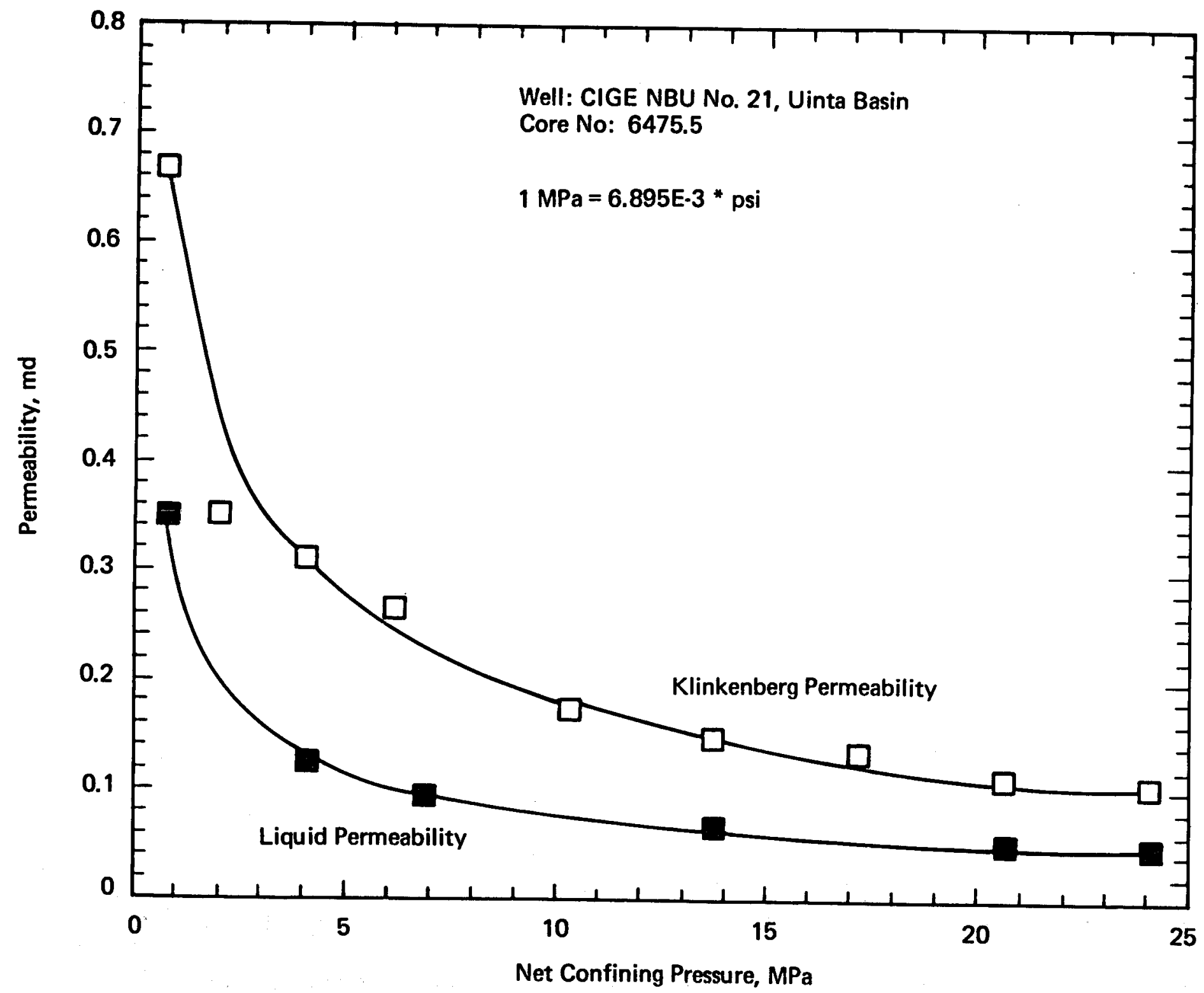

Figure 4-5 Comparison of K1 inkenberg Permeability and Liquid Permeability 
(Italics denote changes since March 31, 1980.)

pore volume per unit pore volume per megapascal) was $1.64 \times 10^{-3}(\mathrm{MPa})^{-1}$. Porosity, determined by saturation, was 0.102.

These observations indicate that while permeability is a strong function of net confining pressure, porosity for the core investigated is not greatiy affected.

Liquid and gas permeability measurements were conducted on Core No. 7427.5 from the CIGE NBU No. 21 well, Uinta Basin. Liquid permeabilities were consistently lower than Klinkenberg permeabilities. The results are shown in Figure 4-6. It was noted that at high net confining pressure, the ratio of the two permeabilities remained approximately constant. It oppears that the initial drop in permeability (i.e., at low net confining pressures) may be attributed to the effects of brine-rock interaction. SEM and thin section studies indicate the absence of water-sensitive or swelling clays, and the discrepancy in permeability values may be due to the reabsorption of water molecules on clays which were dehydrated when the core plugs were dried. The difference in permeability may also be due to the effect of clay or fine movement and blockage of pores by the scme as a result of the high differential pressure $0.058 \mathrm{MPa}$ (85 psi) used to maintain flow. It is to be noted that the permeability of this core [initial gas permeability of $0.028 \mathrm{md}$ at a net confining pressure of $0.827 \mathrm{MPa}$ (120 psi), and mean pore pressure of $0.24 \mathrm{MPa}(34.7 \mathrm{psi})]$ was significantly lower than the initial gas permeability of core No. 6475.5 , which was $0.997 \mathrm{md}$ under the some conditions of net confining pressure and mean pore pressure.

Pore volume compressibility for this core was determined to be $5.58 x$ $10^{-4} \mathrm{pV} / \mathrm{pV} / \mathrm{MPa}$. The sample had a porosity of 0.07 .

\section{Permeability of Interbedding Material of Tight Western Gas Sands - Lawrence Livermore Laboratory}

Four samples were prepared and loaded into the pressure vessel. An external furnace for the pressure vessel was fabricated in June and installed in July. A parometer study was performed to evaluate the permeability measurement technique.

Work began on the meaning and measurement of anisotropy in western tight sands. True anisotropical conditions are confirmed when lab and/or field measurements indicate that permeability has the form of the symmetric second-rank tensor, $k_{i j}=k_{j i}$.

The permeability system calibration was campleted and the first four samples were loaded into the pressure vessel and pressurized. A literature search was begun to determine the compressibility and viscosity of the pore fluid (Argon) at pressure (1-50 MPa) and temperature $\left(20-3500^{\circ} \mathrm{C}\right)$. 
(Italics denote changes since March 31, 1980.)

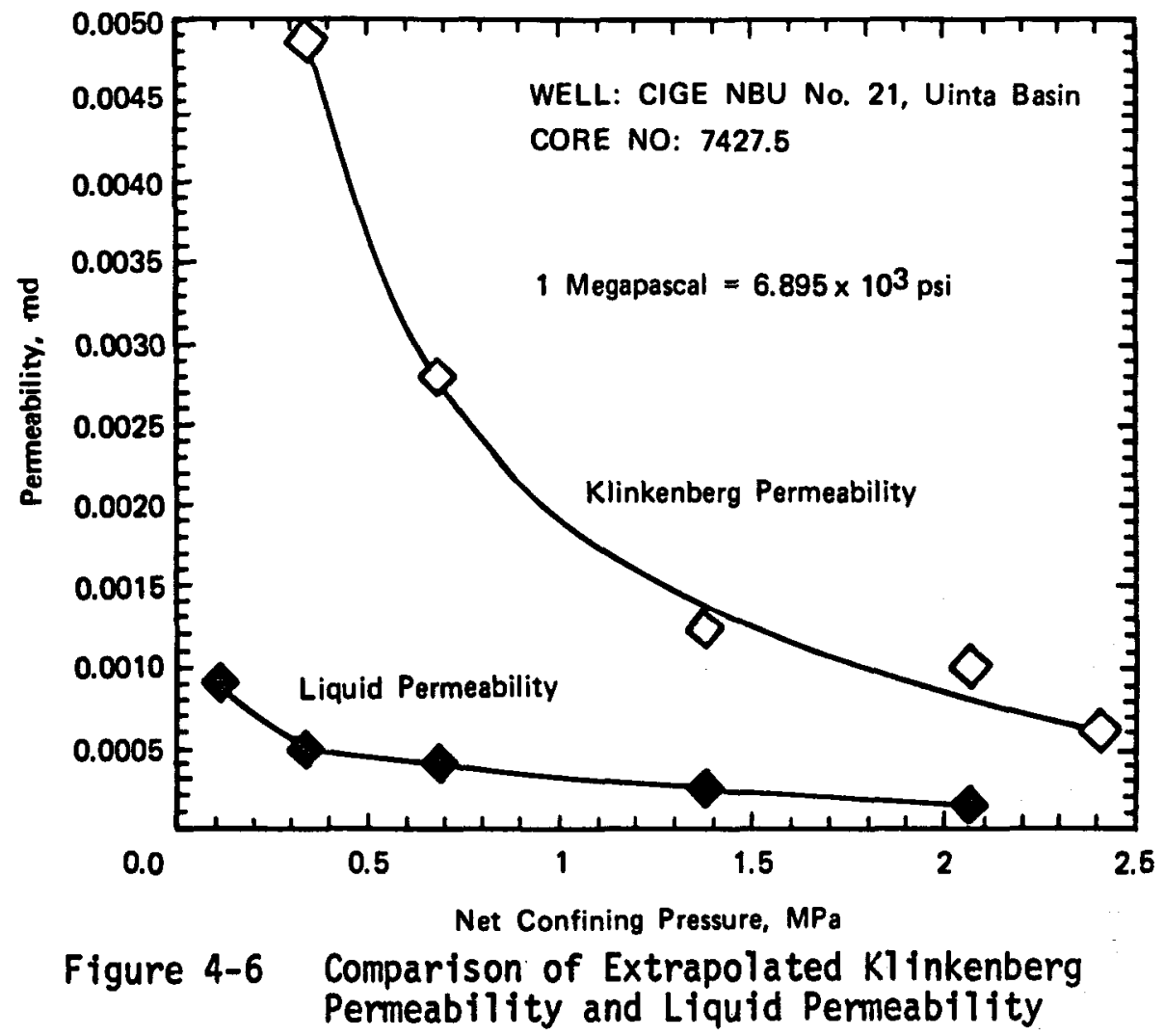

Study of Sonic, Neutron and Density Logging of Low Permeability Gas Sands - Texas A\&M University

The carbonate content of cores from the CIGE NBU No. 21 well was measured and the effect of the carbonate on the matrix density is shown in Figure 4-7.

Samples from the Mitchell Energy Muse-Duke No. 1 well, Limestone County, Texas, and Pacific Transmission Supply Company No. 24-19 Federal well, Sublette County. Wyoming, have been cut to lengths that can be used for travel time analysis. The results for porosities measured with the matrix volume cap are listed in Table 4-4.

Porosity, matrix densities and bulk densities have been calculated and recorded (Table 4-5) for the samples to be used in the travel-time. experiments.

The Mitchell No. 1 Muse-Duke samples have very little porosity and an almost constant matrix density. The PTS No. 24-19 Federal scomples have a wider range of porosities and a seemingly variable matrix density. Density logs from the Mitchell No. 1 Muse-Duke well could be easily interpreted using a constant matrix density of $2.69 \mathrm{gm} / \mathrm{cc}$. Further work is needed to best determine how to analyze the logs from the PTS No. 24-19 Federal well. 
(Italics denote changes since March 31, 1980.)

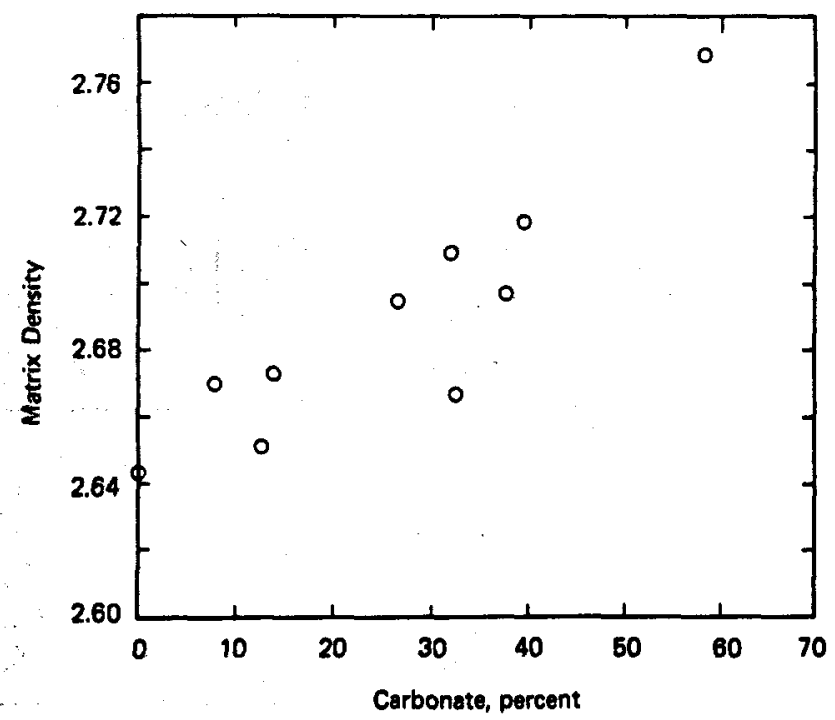

Figure 4-7 Matrix Density vs Percent

Carbonate, CIGE No. 20

The densities measured on the CIGE No. 21 samples are in accord with the results obtained from other CIGE core sections. The lower porosity samples have a matrix density of $2.66 \mathrm{gm} / \mathrm{cc}$ or greater. The higher porosity samples have a matrix density of $2.65 \mathrm{gm} / \mathrm{cc}$ or less.

USGS has studied thin sections of 38 Mesaverde somples from the Shell No. 7. Southman Canyon Field in the Uinta Basin. This well is approximately seven miles east of the CIGE No. 21 well and about $500 \mathrm{ft}$ upstructure. Their findings verify the data already collected on the CIGE No. 21.

An observation that should help log interpretation is the shale-sand contacts appear to be more heavily cemented thon other areas within the particulor sand body. This is illustrated in Figure 4-8, showing a section of the density log from CIGE No. 21. A well developed sand body is located between 4,545 ft and 4,590 ft (as defined by the garma ray section). Zones $A$ and $B$ indicate the increased bulk densities are due to the increased combonate which occurs at shale-sand contacts. Zone $C$ represents a thin shale section that appreciably alters the bulk density of the surpounding sand. Normally shales are expected to decrease the bulk density readings; here the bulk density increased. Normal logging techniques would interpret the high bulk densities of Zones $A, B$ and $C$ to have $a$ lower porosity than the rest of the sand body. Figure 4-9 illustrates that the presence of carbonate controls the matrix density of the formation. Shale-sand contacts have more carbonate present, thereby cousing the matrix density to be greater, which reads as a larger bulk density on the log. Thus, the causes of the density changes in Zones $A, B$ and $C$ have been identified, but $a$ eure method of correctly calculating porosity is not yet available. 
Table 4-4 Porosity Results Measured with Matrix Volume Cap

PTS No. 24-19 Federal

\begin{tabular}{ccr}
\hline Sample & Depth, ft & $\begin{array}{r}\text { Porosity, } \\
\text { Percent }\end{array}$ \\
\hline P1 & 5,120 & 12.4 \\
P2 & 5,173 & 11.9 \\
P3 & 5,193 & 5.6 \\
P4 & 5,206 & 13.5 \\
P5 & 5,210 & 13.4 \\
P6 & 5,222 & 14.0 \\
\hline
\end{tabular}

Muse-Duke No. 1 Well

\begin{tabular}{lcc}
\hline Sample & Depth, ft & $\begin{array}{c}\text { Porosity, } \\
\text { Percent }\end{array}$ \\
\hline M1 & 11,223 & 2.40 \\
M2 & 11,251 & 2.80 \\
M3 & 11,363 & 2.40 \\
M4 & 11,387 & 1.65 \\
M5 & 11,437 & 2.00 \\
M6 & 11,460 & 2.10 \\
M7 & 11,491 & 1.80 \\
M8 & 11,554 & 2.30 \\
M9 & 11,278 & 2.30 \\
M10 & 11,522 & 1.80 \\
\hline
\end{tabular}


Table 4-5 Laboratory Measured Densities

\begin{tabular}{|c|c|c|c|c|}
\hline & $\begin{array}{l}\text { Sample } \\
\text { No. }\end{array}$ & $\begin{array}{l}\text { Porosity, } \\
\text { Percent }\end{array}$ & $\begin{array}{l}\text { Bulk Density, } \\
\text { gm/cc }\end{array}$ & $\begin{array}{c}\text { Matrix Density, } \\
\text { gm/cc }\end{array}$ \\
\hline CIGE No. 21 & $\begin{array}{l}\text { A12 } \\
\text { A48 } \\
\text { A41 } \\
\text { A47 } \\
\text { A6 } \\
\text { A25 } \\
\text { A39 }\end{array}$ & $\begin{array}{r}3.2 \\
10.9 \\
9.8 \\
7.3 \\
4.4 \\
7.7 \\
10.3\end{array}$ & $\begin{array}{l}2.60 \\
2.46 \\
2.47 \\
2.53 \\
2.59 \\
2.57 \\
2.46\end{array}$ & $\begin{array}{l}2.66 \\
2.64 \\
2.63 \\
2.65 \\
2.67 \\
2.69 \\
2.63\end{array}$ \\
\hline PTS No. 24:19 Federal & $\begin{array}{l}\text { P1 } \\
\text { P2 } \\
\text { P3 } \\
\text { P4 } \\
\text { P5 } \\
\text { P6 }\end{array}$ & $\begin{array}{r}12.4 \\
11.9 \\
5.6 \\
13.6 \\
13.4 \\
14.1\end{array}$ & $\begin{array}{l}2.42 \\
2.49 \\
2.55 \\
2.44 \\
2.44 \\
2.42\end{array}$ & $\begin{array}{l}2.62 \\
2.69 \\
2.64 \\
2.67 \\
2.66 \\
2.68\end{array}$ \\
\hline Mitchell No. 1 Muse-Duke & $\begin{array}{l}\text { M1 } \\
\text { M2 } \\
\text { M3 } \\
\text { M4 } \\
\text { M5 } \\
\text { M6 } \\
\text { M7 } \\
\text { M8 } \\
\text { M9 } \\
\text { M10 }\end{array}$ & $\begin{array}{l}2.4 \\
2.8 \\
2.5 \\
1.7 \\
2.0 \\
2.1 \\
1.8 \\
2.3 \\
2.3 \\
1.8\end{array}$ & $\begin{array}{l}2.64 \\
2.64 \\
2.65 \\
2.67 \\
2.66 \\
2.66 \\
2.67 \\
2.72 \\
2.65 \\
2.66\end{array}$ & $\begin{array}{l}2.68 \\
2.69 \\
2.69 \\
2.69 \\
2.69 \\
2.69 \\
2.71 \\
2.76 \\
2.69 \\
2.69\end{array}$ \\
\hline
\end{tabular}

UGR SEMI-ANNUAL/September 1980 


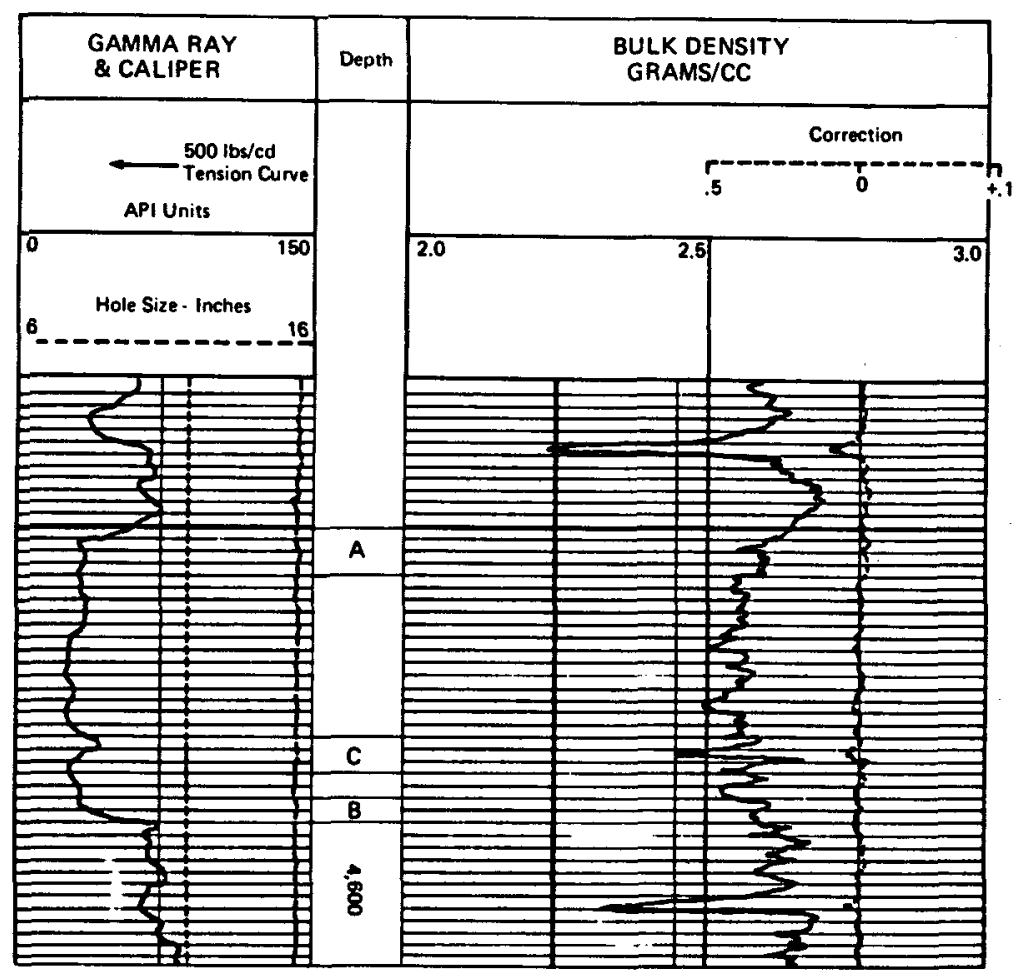

Figure 4-8 Log Section from CIGE NBU No. 21

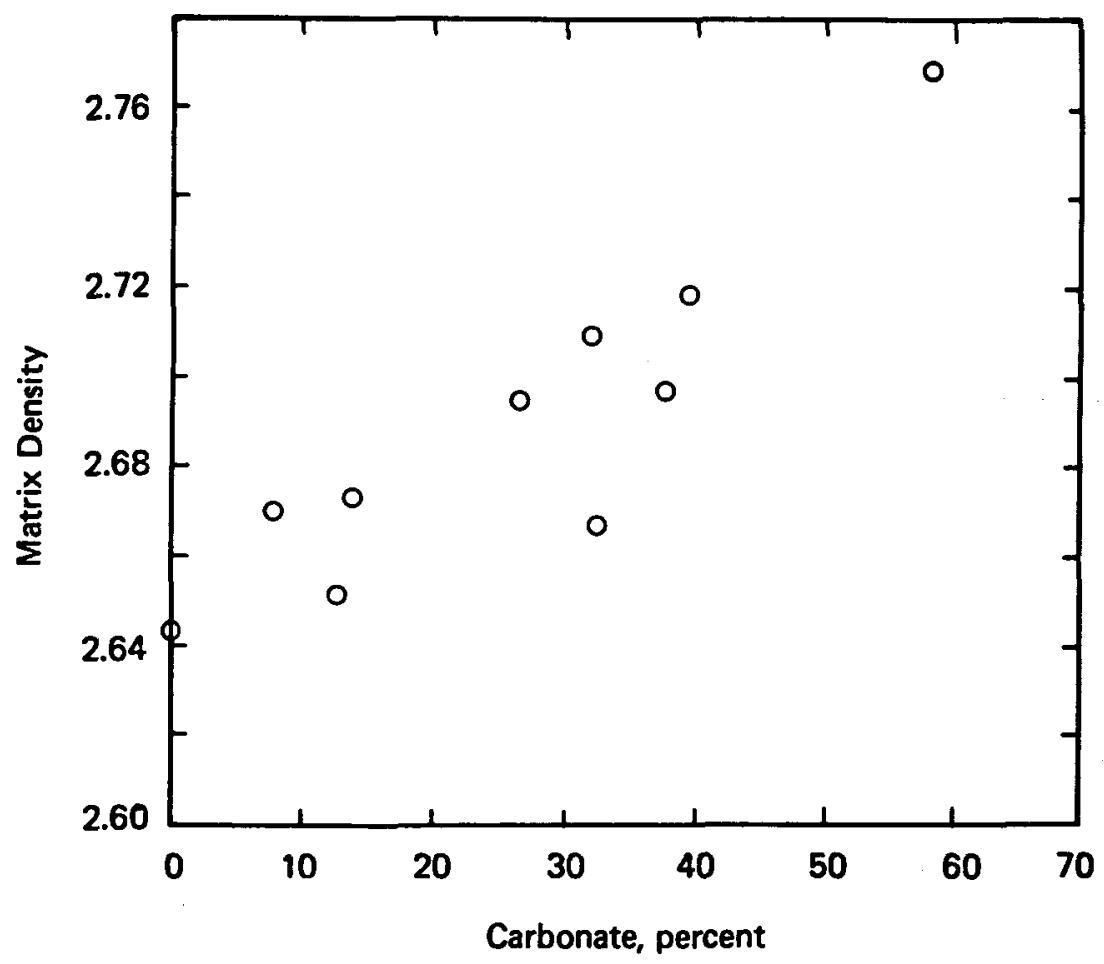

Figure 4-9 Matrix Density vs Percent Carbonate CIGE NBU No. 21 
(Italics denote changes since March 31, 1980.)

The porosity logs of the Mapco RBU No. 11-17F well, Uintah County, Utah, are being evaluated similarly to the evaluation of the CIGE NBU NO. 21 well, Uintah County. Core data includes porosity, permeability and matrix density. These properties were measured on 54 one-ft samples. Log depths were correlated to core depths, and corresponding readings from the density, sonic, neutron and gama ray logs were obtained for each scample.

Figure 4-10 is a plot of bulk density versus lab measured porosity. Bulk density was calculated from the porosity and matrix density of each sample and best fit least squares lines drown through the data. Although the data does not demonstrate a clearly variable matrix density, as did the same plot for the CIGE No. 21, the data does indicate that the best "average" value for matrix density is 2.665 or $2.67 \mathrm{gm} / \mathrm{cc}$. This is particularly apparent for porosities greater than 6 percent where the majority of the somples have a matrix density of $2.67 \mathrm{gm} / \mathrm{cc}$ or less.

Figure 4-11 is a plot of neutron porosity versus lab porosity. The scatm ter of the data about the matrix lines is due to the varying amounts of carbonate cement and shale.

Figure 4-12 is a plot of sonic porosity versus lab measured porosity. The sonic log indicates a porosity that is higher than the measured porosity. This indicates that the assumed matrix travel time of 52.6 micro-seconds per foot is too low. Figure 4-13 shows a plot of log travel-time versus lab porosity, while Figure 4-14 is a plot of calculated matrix travel-time versus lab porosity. The matrix travel-times have been calculated using the log travel-times and the lab porosities. For Figure 4-13 and 4-14, only those samples with a garma ray reading of less than 60 were plotted to evaluate cleaner, high porosity sands. In these figures, a least squares line was drown through the data.

\section{LOGGING STUDIES}

\section{Interface Conductivity Studies}

A semi-automated method for cation exchange capacity (CEC) determination has been developed. Up to 17 samples $(10 \mathrm{~g}$ per sample) can be acconmodated by the ion exchanger. The technique involves $\mathrm{Ba}^{++}$exchange at $9.2 \mathrm{pH}$.

After exchange ions on rock samples are replaced with barizm ions, the comount of barium on the clay is analyzed by conductometric titration with magnesirm sulfate $\left(\mathrm{MgSO}_{4}\right)$. In addition to the forward titration, the feasibility of adding an excess amount of $\mathrm{MgSO}_{4}$ and back tritrating with barium ions was investigated. The CEC of bentonite was measured as $.82 \mathrm{meq} / \mathrm{g}$. The forward and back tritration of one sample gave the same value. This CEC compares with .711 meq/g from Worthington and $.755 \mathrm{meq} / \mathrm{g}$ as measured in the lab using the commonium acetate method. 


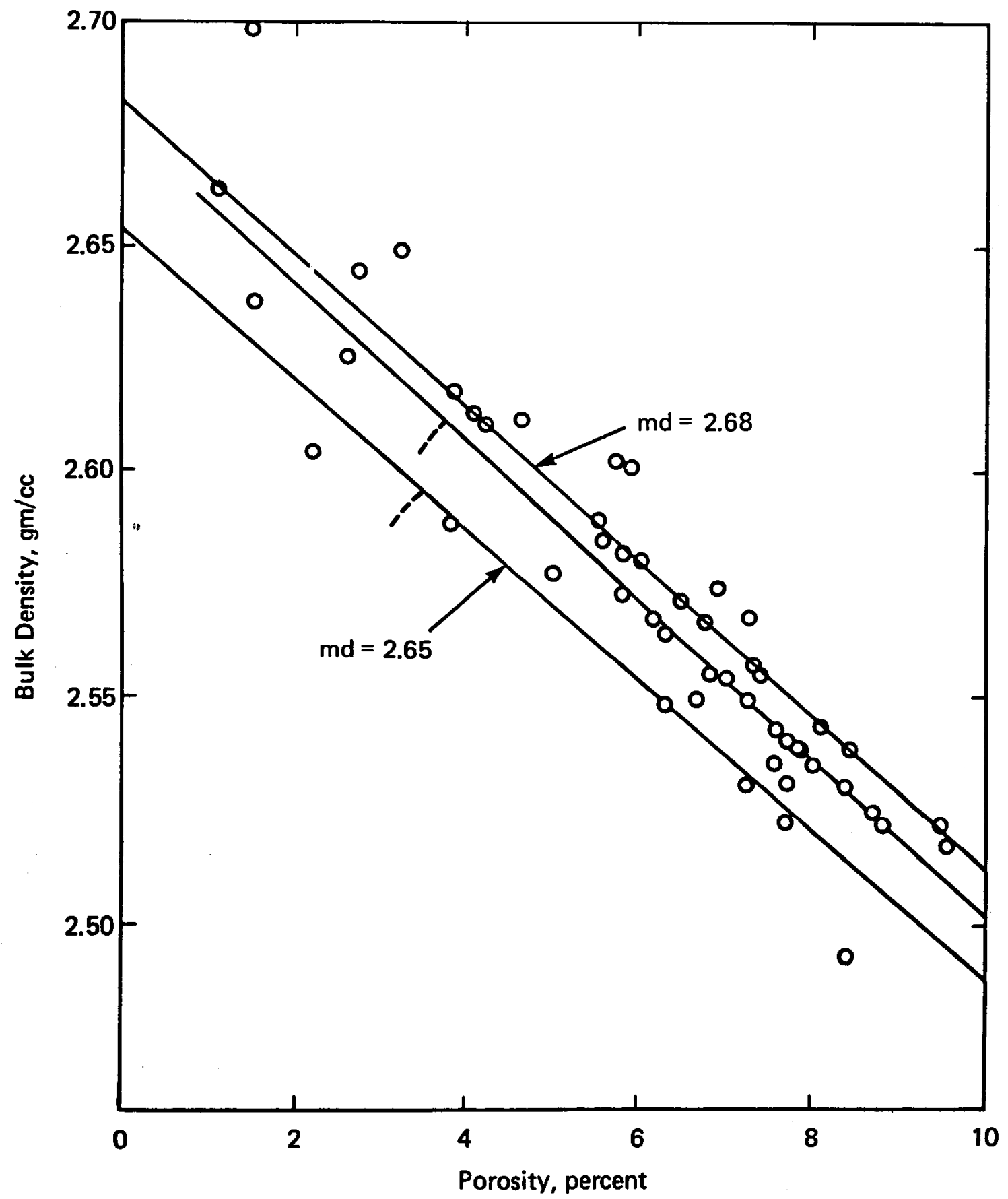

Figure-4-10 Bulk Density vs Laboratory Derived Porosity, Mapco RBU No. 11-17F 


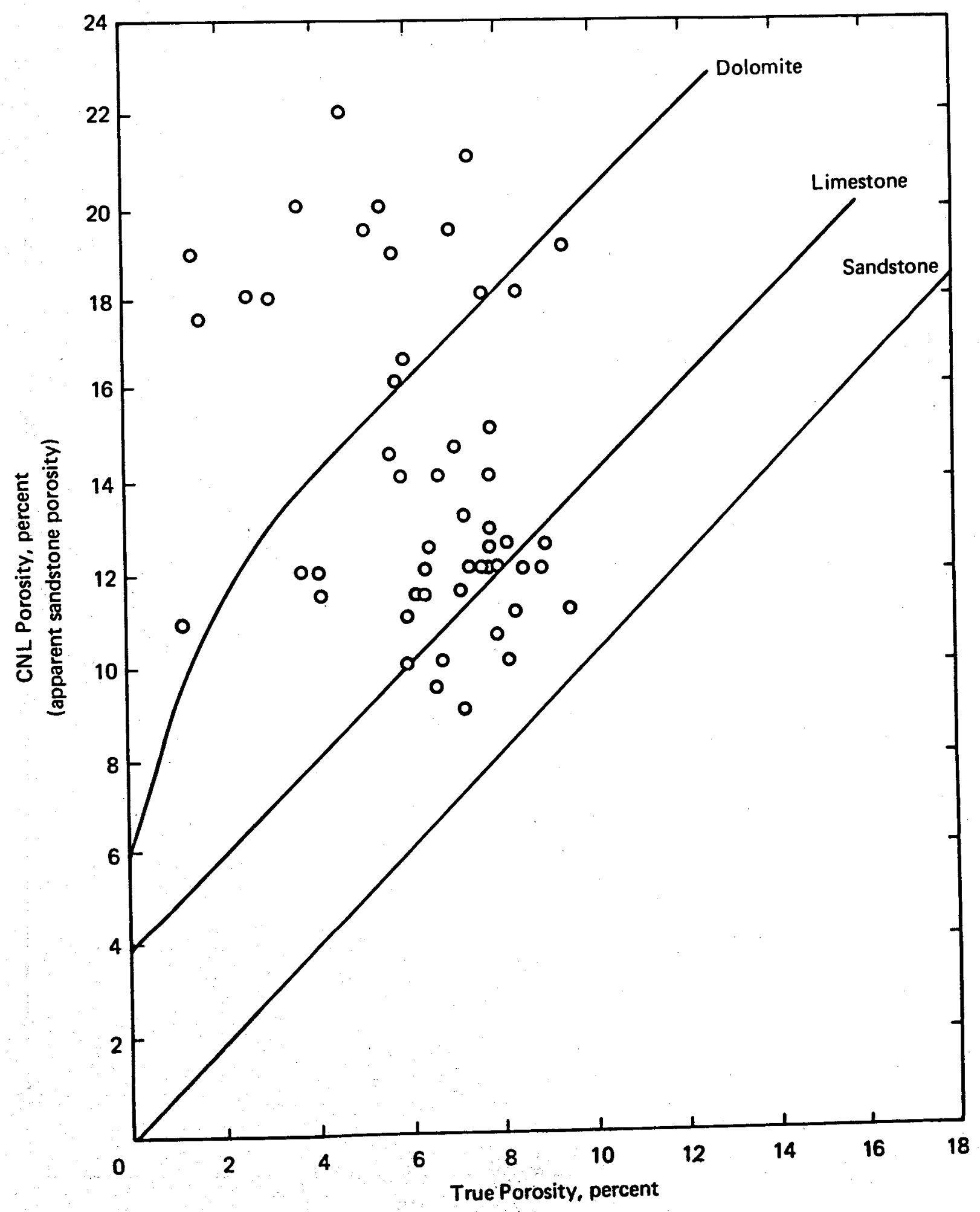

Figure 4-11. Neutron Log Porosity vs Laboratory Derived Porosity, Mapco RBU No. 11-17F 


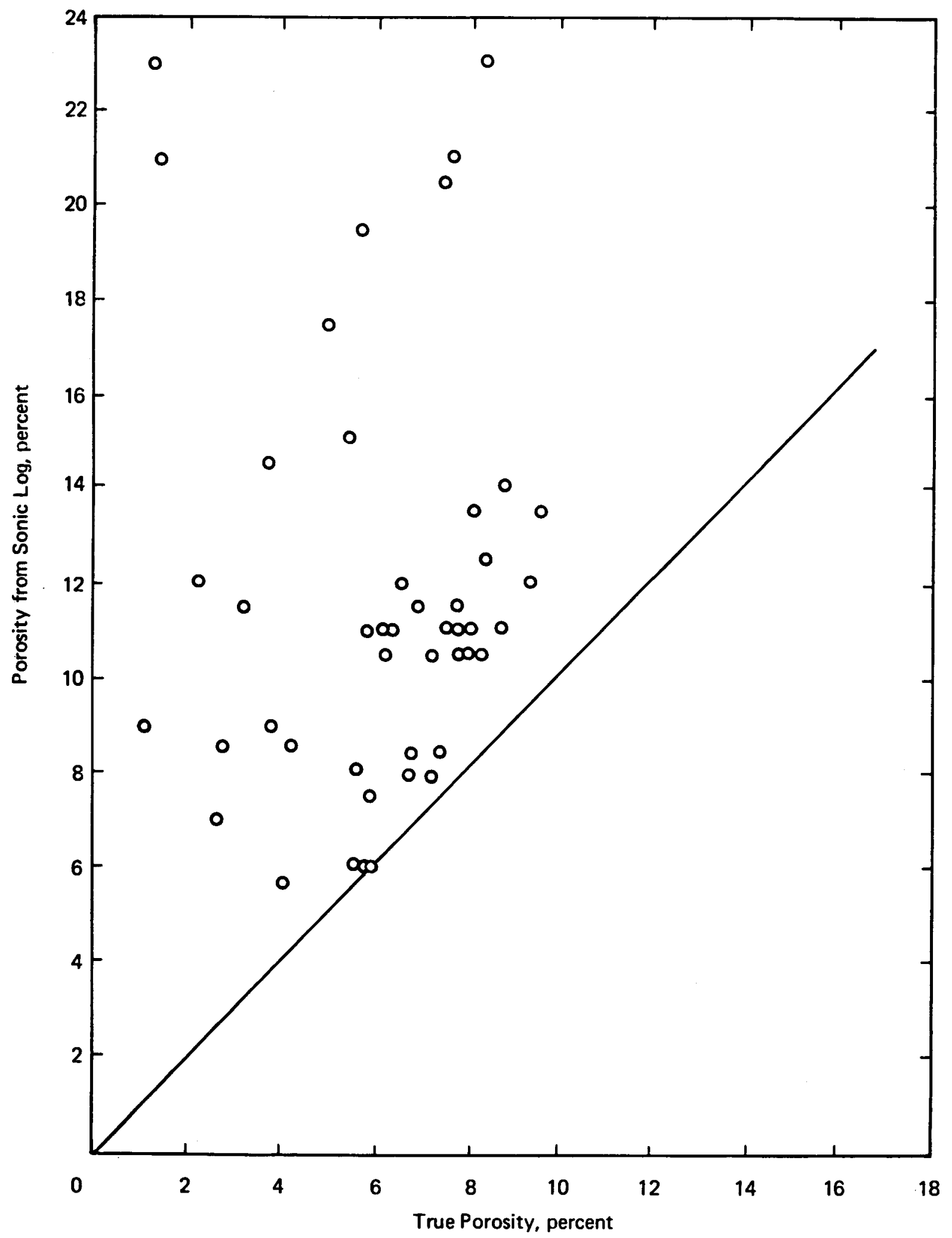

Figure 4-12 Porosity from Sonic Log vs Laboratory Derived Porosity, Mapco RBU No. 11-17F 


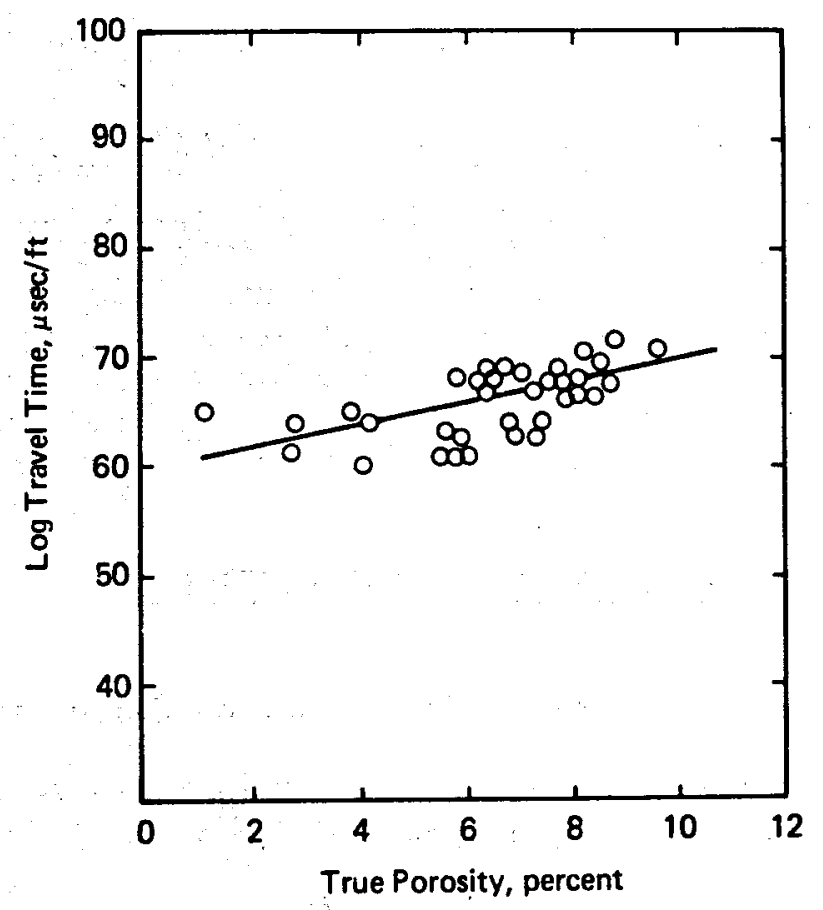

Figure 4-13 Sonic Log Travel Time, Mapco RBU No. 11-17F

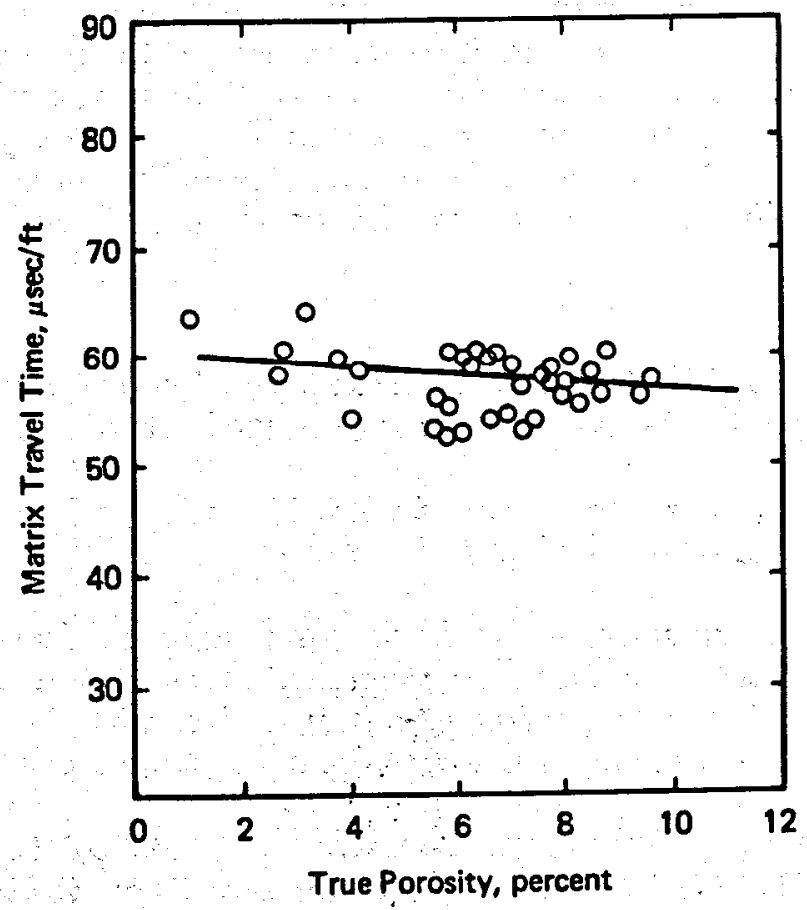

Figure 4-14 Calculated Matrix Travel Times, Mapco RBU No. 11-17F 
(Italics denote changes since March 31, 1980.)

In another study, Klinkenberg permeabilities of four Uinta Basin samples, measured at 1,000 psi, ranged from 15 to 200 microdarcies. Liquid permeability and resistivity were measured at confining pressures from 300 to 3,200 psi. The data were in agreement with the empirical model by Jones and owens. 1 The data were also used to evaluate a theoretical rock geometry model based on thick-wall capillary tubes. The data fit to this model appears to be marginal. A third permeability model was derived, based on rectangular slits or rectangularly-shaped capillaries. The permeability data fitted to the rectangular model show improvement over a thick-wall copillary tube model. The results indicate rock capillaries are not round but tend to be slits or rectangular.

\section{ADVANCED LOGGING TECHNIQUES AND INTERPRETATIONS}

\section{Dielectric Constant Measurement for Formation Evaluation}

The interaction between capacitance and inductance in the dielectric constant measurement system was studied during April.

The interaction is caused by the distributed parameter nature of the bridge circuit. Numerous modifications to minimize the effect have been tried and accurate results can now be obtained from $500 \mathrm{KHz}$ to 20 $\mathrm{MHz}$ at a specific point in the circuit.

The distributed transmission line correction which was required by the sample holder was eliminated. The sample holder was modified so the terminals of the measurement system were directly connected to the sample electrodes. The modified measurement system was tested on artificial somples. Results were accurate to +2 percent for $500 \mathrm{kHz}$ to 20 $\mathrm{MHz}$ and +5 percent for $30 \mathrm{MHz}$. The data measurements are reliable enough that a calibration curve can be used to achieve increased accuracy.

Developments and Applications of a Wide Band Laboratory Dielectric Constant Measurement System - Colorado School of Mines

Ten sandstone cores were prepared in April for the Zaser experiment and the dielectric experiment using bridges.

Dielectric constant measurements have been made at low frequenoies 1500 to $10 \mathrm{kHz}$ ) on 20 low-loss rock samples. Construction and testing has been completed on the saturation chamber and sample holder unit. Sandstone samples are now being ground to proper thickness for the holder.

1 Jones, F.O. and W.W. Owens, "A Laboratory Study of Low Permeability Sands," SPE 7551, 1979 SPE Symposizm on Low Permeability Gas Reservoirs, May 20-22, Denver, p. 325-334. 
(Italics denote changes since March 31, 1980.)

Thirteen sandstone reservoir samples $2.25 \mathrm{in}$. in dianeter and $.25 \mathrm{in}$. thick were prepared for the study. A similar number of synthetic sandstone samples were prepared for equipment testing.

Use of Sonic Techniques to Measure In Situ Stresses - Lawrence Livermore National Laboratory

The data acquisition and fast Fourier transform analysis programs for the LSI-11 computer were completed. These programs can provide an accurate analysis of the acoustic birefringence phenomenon. The programs have been successfully tested on Nugget sandstone and oil shale for the acoustic transmission mode. A theory for the borehole application of the technique has been developed. Work has begun to test the theory on Nugget sandstone and oil shale using a same face mode.

\section{Proppant Transport in Massive Hydraulic Fracturing - University of Tulsa}

The object of this contract is to study proppant transport during massive hydraulic fracturing, particularly, the settling of proppant particles in fracture fluids where the fluid viscosity has been enhanced by gelling agents. Primary considerations have been in developing a computational model and identifying the requirements for an economically feasible fracture treatment.

Three plexiglass vessels were constructed to measure the settling rates of sand particles in fracture fluids. Height and length were $12 \mathrm{in}$. and separation can be $1 / 2^{\circ} \mathrm{in} ., 1 / 4 \mathrm{in}$. or $1 / 8 \mathrm{in}$.

Ottowa sand of 20/40 mesh was selected as the proppant; however, because of the large size variation, further screening was necessary to obtain 28 to 35 mesh. Absolute density of the sand was measured using a pycnometer. Published values were used for both density and specific gravity. The densities of the hydroxypropyl guar solutions were measured by weighing. These values are listed in Section $A$ of the following Results.

A RVT Wells-Brookfield Micro viscometer was used to measure slurmy viscosity. Since non-Newtonian behavior was expected, viscosity measurements were made at different $\mathrm{rpm}$ and consequently at different shear stresses. Viscosity data were collected for two temperatures, $30^{\circ} \mathrm{C}$ and $35^{\circ} \mathrm{C}$, and the results are tabulated in section $B$ of the Results.

About 300 readings were taken to develop experimental techniques to measure single-particle settling time. Single particles would not submerge when dropped at the surface because of surface tension. Tweezers had to be used to immerse the particles below the surface of the liquid before releasing them. The time taken for the particle to settle between two lines 8 in. opart was recorded. The settling times were recorded not only in water but for different concentrations of the 
(Italics denote changes since March 31, 1980.)

hydroxypropyl guar in water. These settling times are given in Table 4-6. Table 4-7 shows the settling rates. The readings were taken for plate separations of $1 / 2$ in., $1 / 4$ in. and $1 / 8 \mathrm{in}$.

Horizontal lines at 1/2-in. intervals were etched on the front wall of the settling chambers to measure bulk settling rates in sand-water slurpies. In these settling studies, a homogeneous slurry of $1 \mathrm{lb}$ sand per gallon was prepared by placing the appropriate sand and water in the settling chomber (suitably covered) and vigorously shaking the chamber. The chamber was set abruptly upright on the bench and the time it took for the sand to fill the lower portion of the chamber between the bottom and the first horizontal mark was recorded.

A $1.2 \mathrm{gm} / \mathrm{liter}$ (corresponding to $10 \mathrm{Zb} / 1,000 \mathrm{gal}$ ) solution of hydroxypropyl guar in water was prepared in a blender. An anti-focmant was added. Different amounts of sand (28 to 35 mesh) were added to the solution and settling times were measured as previously described. A similar procedure was used for a $2.4 \mathrm{gm} / \mathrm{liter}$ solution $(20 \mathrm{lb} / 1,000 \mathrm{gal})$ and these results are tabulated in Table 4-8. Table 4-9 gives the times the sand took to settle to specific etch marks on the plexiglass vessels.

Results

A. Densities

1. Ottowa sand $20 / 40$ mesh

The following data were obtained from the literature:

Actual density $=21.929 \mathrm{Ib} / \mathrm{gal}$

Specific gravity $=2.63$

Absolute density was measured by pyonometer:

Absolute density $=2.645 \mathrm{gm} / \mathrm{ml}=22.02 \mathrm{Zb} / \mathrm{gal}$.

2. Solutions

Beccuse of the low concentrations used, the densities of the solutions were almost identical to those of water at the same temperatures.

B. Viscosities

$1.2 \mathrm{gm} /$ Liter Hydroxypropyl Guar

$\begin{array}{lll}30^{\circ} \mathrm{C} & \text { at } 20 \mathrm{rpm} & \mu=9.60 \mathrm{cp} \\ \text { at } 50 \mathrm{rpm} & \mu=7.55 \mathrm{cp} \\ \text { at } 100 \mathrm{rpm} & \mu=6.27 \mathrm{cp}\end{array}$


(Italics denote changes since March 31, 1980.)

$\begin{array}{rlr}350^{\circ} \mathrm{C} & \text { at } 20 \mathrm{mpm} & \mu=4.00 \mathrm{cp} \\ \text { at } 50 \mathrm{mpm} & \mu=7.87 \mathrm{cp} \\ \text { at } 100 \mathrm{cpm} & \mu=8.57 \mathrm{cp}\end{array}$

$2.4 \mathrm{gm} / \mathrm{liter}$ Hydroxypropyl Guar

$\begin{array}{lll}30^{\circ} \mathrm{C} & \text { at } 20 \mathrm{rpm} & \mu=14.72 \mathrm{cp} \\ & \text { at } 50 \mathrm{rpm} & \mu=10.32 \mathrm{cp} \\ \text { at } 100 \mathrm{rpm} & \mu=10.75 \mathrm{cp} \\ 35^{\circ} \mathrm{C} & \text { at } 20 \mathrm{rpm} & \mu=8.32 \mathrm{cp} \\ & \text { at } 50 \mathrm{rpm} & \mu=12.00 \mathrm{cp} \\ & \text { at } 100 \mathrm{rpm} & \mu=10.88 \mathrm{cp}\end{array}$

Mapping and Contouring Water Resistivities in Tight Western Gas Sands Texas A\&M University

Reliable water samples from Uinta Basin Upper Cretaceous formations are virtually nonexistent. This is primarily because water production from such formations is a rare occurrence and because fluids from multiple zones are conmingled routinely. As a result, no mathematical relationship between the SP log and the resistivity ratio, $R_{w} / R_{m F}$, has been established.

Feasibility of Fabricating Light Weight Proppants for Application in Gas and 011 Well Stimulation - Terra Tek, Inc.

The primary object of this contract is to determine the feasibility of fabricating light weight proppants for application in deep gas and oil well stimulations. This work includes the selection of viable materials and manufacturing techniques.

A theoretical comparison of solid, hollow and porous spheres is shown in Figure 4-15. Also shown are values for glass, sintered bauxite (using estimated properties), and a "design goal" of specific gravity of 2.0 with a fracture pressure of 20,000 psi. Several trends are apparent, the most obvious being the strength versus specific gravity tradeoff. However, the differences between materials is also striking. The advantages of using a high strength material such as the AD999 (99.9 percent pure) alumina is apparent. In general, the results appear to indicate that significant advances in proppant strengthdensity properties are possibie.

With the exception of the AD999 alumina, the hollow spheres are predicted to have an advantage over the porous spheres. However, as shown by the AD999 alumina, this is not a universal mule but depends on the modulus and bend strength of material. 
Table 4-6 Mean Single Particle Settling Times, secs.

\begin{tabular}{lccc}
\hline Fluid & \multicolumn{3}{c}{ Plate Separation } \\
& .125 in. & .25 in. & .50 in. \\
\hline Water & & & \\
Settling in sec & $3.4+0.2$ & $3.2+0.3$ & $3.0+0.3$ \\
No. of experiments & 30 & 50 & 130 \\
Temp. ( ${ }^{\circ}$ C) & 28 & 29 & 32
\end{tabular}

Hydroxypropyl Guar

Solution (1.2 gm/liter)

$\begin{array}{lccc}\text { Settling in sec } & 6.7+0.4 & 5.4+0.4 & 4.7+0.4 \\ \text { No. of experiments } & 20 & 20 & 20 \\ \text { Temp. }\left({ }^{\circ} \mathrm{C}\right) & 28 & 28 & 28\end{array}$

Hydroxypropyl Guar

Solution $(2.4 \mathrm{gm} / \mathrm{liter})$

$\begin{array}{lccc}\text { Settling in sec } & 18.12+0.6 & 13.54+1.0 & 9.9+1.5 \\ \text { No. of experiments } & 20 & 20 & 20 \\ \text { Temp. }\left({ }^{\circ} \mathrm{C}\right) & 30 & 30 & 30\end{array}$

Table 4-7 Mean Single Particle Settling Rates, $\mathrm{cm} / \mathrm{secs}$.

\begin{tabular}{lccc}
\hline Fluid & $.125 \mathrm{in}$ & $\begin{array}{c}\text { Plate Separation } \\
.25 \text { in. }\end{array}$ & $.50 \mathrm{in}$. \\
\hline Water & 6.01 & 6.37 & 6.73 \\
$\begin{array}{l}\text { Hydroxypropyl Guar } \\
\text { Solution (1.2 gm/liter) }\end{array}$ & 3.06 & 3.80 & 4.3 ' \\
$\begin{array}{l}\text { Hydroxypropyl Guar } \\
\text { Solution (2.4 gm/liter) }\end{array}$ & 2.06 & 1.50 & $1.1 \%$ \\
\hline
\end{tabular}


Table 4-8 Mean Single Particle Settling Times, secs.

\begin{tabular}{|c|c|c|c|c|c|c|}
\hline SOLUTION & $\begin{array}{c}\text { Solution } \\
\text { Height, } \\
\text { in. }\end{array}$ & $\begin{array}{c}\text { Sand Added } \\
\text { to Solution, } \\
\mathrm{gm} / \text { /iter of solution }\end{array}$ & $\begin{array}{l}\text { Total Height } \\
\text { Sand + Solution, } \\
\text { in. }\end{array}$ & $\begin{array}{l}\text { Temp. } \\
\left({ }^{\circ} \mathrm{C}\right)\end{array}$ & $\begin{array}{c}\text { Mean Time } \\
\text { for Sand } \\
\text { to Settle } \\
\text { Completely, } \\
\text { sec }\end{array}$ & $\begin{array}{l}\text { No. of } \\
\text { Observations }\end{array}$ \\
\hline Hydroxypropyl Guar & 10 & 120 & 10.4 & 37 & 6.46 & 15 \\
\hline \multirow[t]{2}{*}{$1.2 \mathrm{gm} / \mathrm{liter}$} & & 360 & 11.0 & 35 & 8.26 & 15 \\
\hline & & 720 & & 35 & 11.80 & 20 \\
\hline Hydroxypropyl Guar & 10 & 120 & 10.5 & 33 & 24.75 & 10 \\
\hline \multirow[t]{2}{*}{$24 \mathrm{gm} / \mathrm{liter}$} & & 360 & 11.1 & 33 & 26.00 & 20 \\
\hline & & 720 & & 33 & 28.50 & 10 \\
\hline
\end{tabular}

Table 4-9 Mean Single Particle Settling Rates, cm/secs.

Solution: Hydroxypropyl Guar, $2.4 \mathrm{gm} / \mathrm{liter}$

Sand: $120 \mathrm{gm} / \mathrm{liter}$ of Solution (Total height $10.5 \mathrm{in.})$

Time required for sand to settle to the first mark $(0.5 \mathrm{in.})$

$5.85 \mathrm{sec}$

Time required for sand to settle completely (1.6 marks; 0.8 in.) $24.75 \mathrm{sec}$

Sand: $360 \mathrm{gm} /$ /iter of Solution

Time required for sand to settle to the 3rd mark (1.5 in.)

$10.51 \mathrm{sec}$

Time required for sand to settle to the 4 th mark $(2.0 \mathrm{in}$.

$18.72 \mathrm{sec}$

Time required for sand to settle to the 5 th mark ( $2.5 \mathrm{in.})$

$26.00 \mathrm{sec}$ 


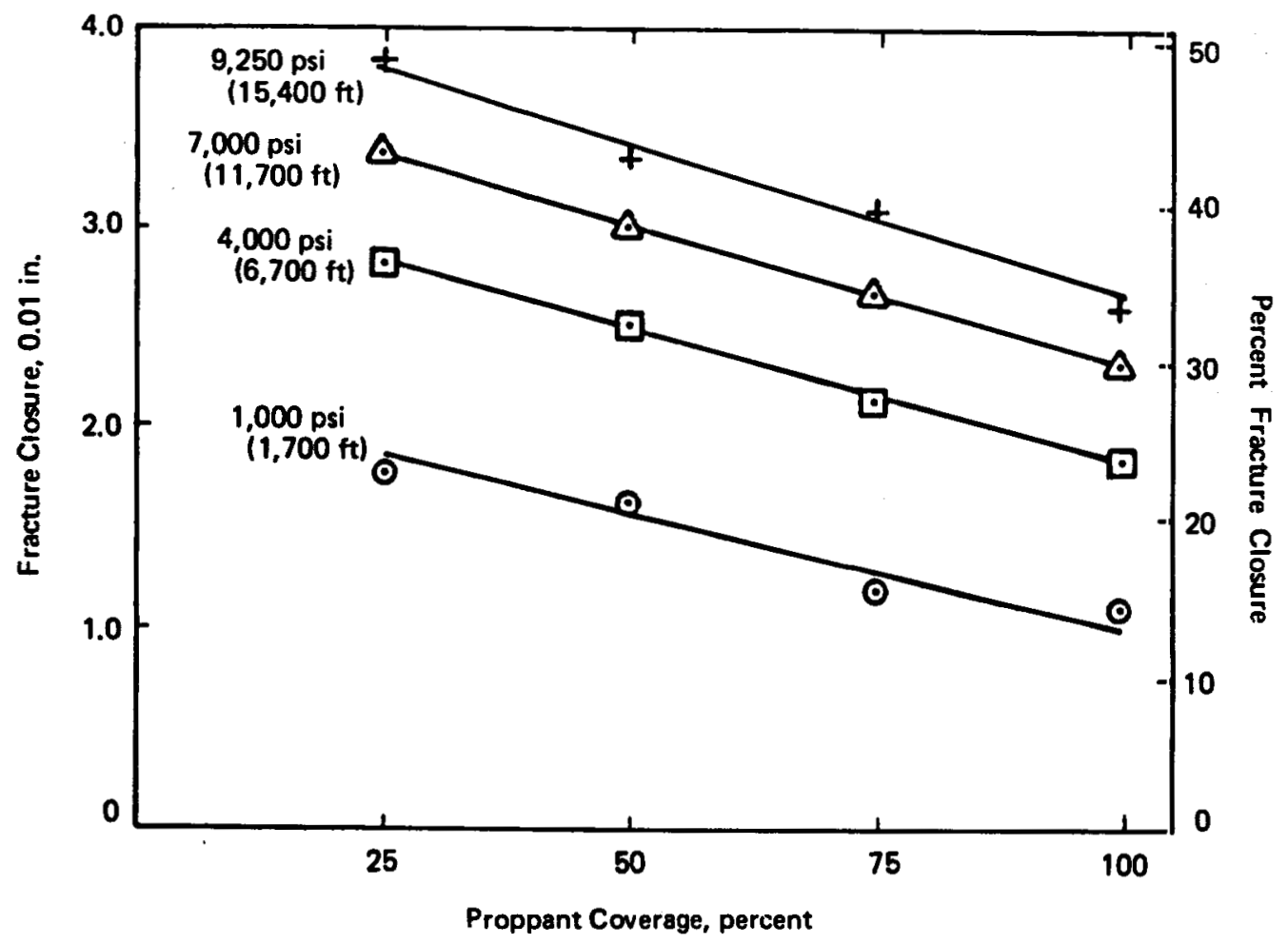

Figure 4-15 Fracture Closure vs Proppant Coverage Using 12/20 Mesh Sintered Bauxite and Grey Berea 
(Italics denote changes since March 31, 1980.)

HYDRAULIC FRACTURING AND FRACTURE CONDUCTIVITY

\section{ROCK-FLUID INTERACTION}

\section{Proppant Embedment Studies}

To establish a standard, work began on the embedment of sintered bauxite into Berea Sandstone. Replicate experiments with 12-20 mesh proppant have shown that the initial embednent (from 0 to 1,500 psi) is quite variable. This is probably due to the relatively small number of large proppant (0.6 percent of 12-14 mesh) in a sample. Consequently, unless the proppant is sorted by size and a sample is reconstructed in the exact quantity needed for each experiment, the random differences in grain distribution from one sample to the next will lead to variable percentages of the largest proppant. To overcome this problem, results were averaged from several identical experiments.

Embedment in one area of the Berea block may be greater than some other area (differential embedment) due to variations in rock hardness or random differences in the proppant size distribution. The new method for measuring embedment has allowed the differential embedment to be estimated. Occasionally, large differences have been noticed. Results from these experiments are discarded since they would not be representative of reservoir conditions where the two rock faces must be held basically paralzel.

\section{Proppant Embedment in Hydraulically Fractured Reservoirs}

One of the problems associated with hydraulic fracturing is fracture closure due to crushed proppant in deep reservoirs. A proppant of sintered bauxite was developed to alleviate this problem. However, in deep reservoirs, closure pressures can cause proppant embedment and result in 2088 of fracture conductivity.

Work has begun on the embedment of sintered bawrite into Berea as a standard. Replicate experiments with $12 / 20$ mesh proppant have shown that the initial embednent (from 0 to 1,500 psi) is quite variable. This is probably due to the relatively small number of large proppant (0.6 percent of $12 / 14$ mesh) in a somple.

Gray Berea Sandstone was used in a series of experiments designed to examine fracture closure and crushing strength of bauxite. Fracture closure or proppant embedment was excmined as a function of proppant coverage and fracture closure pressure. Bauxite proppant (12/20 mesh) was placed between two 4-in. square Berea Sandstone blocks (2 in. thick). The propped area was a 2-in. square area. Dial micrometers were used to measure fracture closure. 
(Italics denote changes since March 31, 1980.)

Figure 4-15 shows fracture closure as a function of proppant coverage at four closure pressures. Except for the 25 percent coverage data, the values shown in the figure are averages of multiple tests. Then coverage is reduced to 25 percent, the sandstone blocks tend to fracture with increased embedment. When rock fracturing occurred, the results were discarded because the data is not representative of reservoir conditions.

Formation depths were calculated using a gradient of $0.6 \mathrm{psi} / \mathrm{ft}$. These plots represent fracture closure pressures at depths of $1,700 \mathrm{ft}$ to 15,400 ft. Although the slopes at each pressure are linear, the slope increases indicate deeper proppant penetration at higher pressures. For fractures at greater depths, decreased proppant coverage will result in a corresponding greater loss of fracture conductivity. For a 25 percent proppant coverage, fracture closure was found to be approximately one-half at 15,400 ft. Although Berea Sandstone is softer and more porous than typical tight gas sand formations, initial results indicate that proppant embedment is greater into tight gas sand rocks than into the Berea. However, large quantities of homogeneous tight gas sand core were not available for repetitive embedment tests. Further tests are planned to correlate this work with typical tight sands.

Microscopic excminations of the stressed bauxite showed that part of the proppant cleaved or cracked, but did not shatter like sand propprnts. ongoing tests will determine the relative crushing strength of these two materials.

To further investigate the results of propping fractures in deep gas weils with sintered bouxite, the study has been extended to include embedment between fractured surfaces. Previous work has been concentrated on rocks with smooth (cut) surfaces. Figure 4-15 compares embedment in fractured grey Berea blocks and embedment in smooth grey Berea blocks using 12/20 mesh sintered bauxite. The rate of embedment for the fractured block is much more rapid at low closure pressures and is still somewhat faster at higher pressures. This is probably due to a reduced proppant-block contact and a less well supported embedment surface. However, the initial fracture width of the propped fractured blocks is much greater, and only at higher pressures does it opproach that of the smooth block case. It oppears that aithough smooth brocks may be useful in studying the effects of proppant coverage, mesh size, size distribution, etc., absolute estimates of fracture conductivity should be based on fractured rock.

Figure 4-16 shows the theoretical comparison of porous with hollow spheres. Figure 4-17 shows fracture closure compared to closure pressure. 


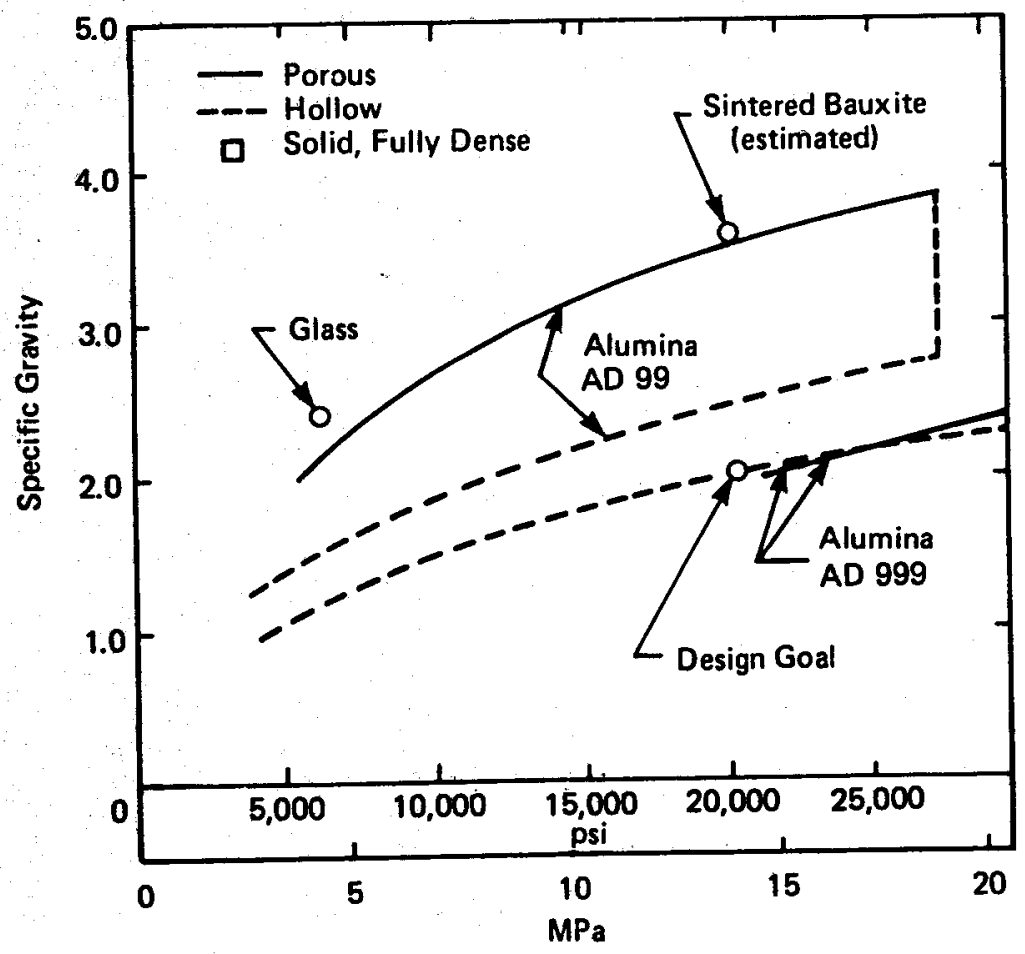

Fracture Pressure

Figure 4-16 Theoretical Comparison of Porous with Hollow Spheres, 20/40 Mesh 


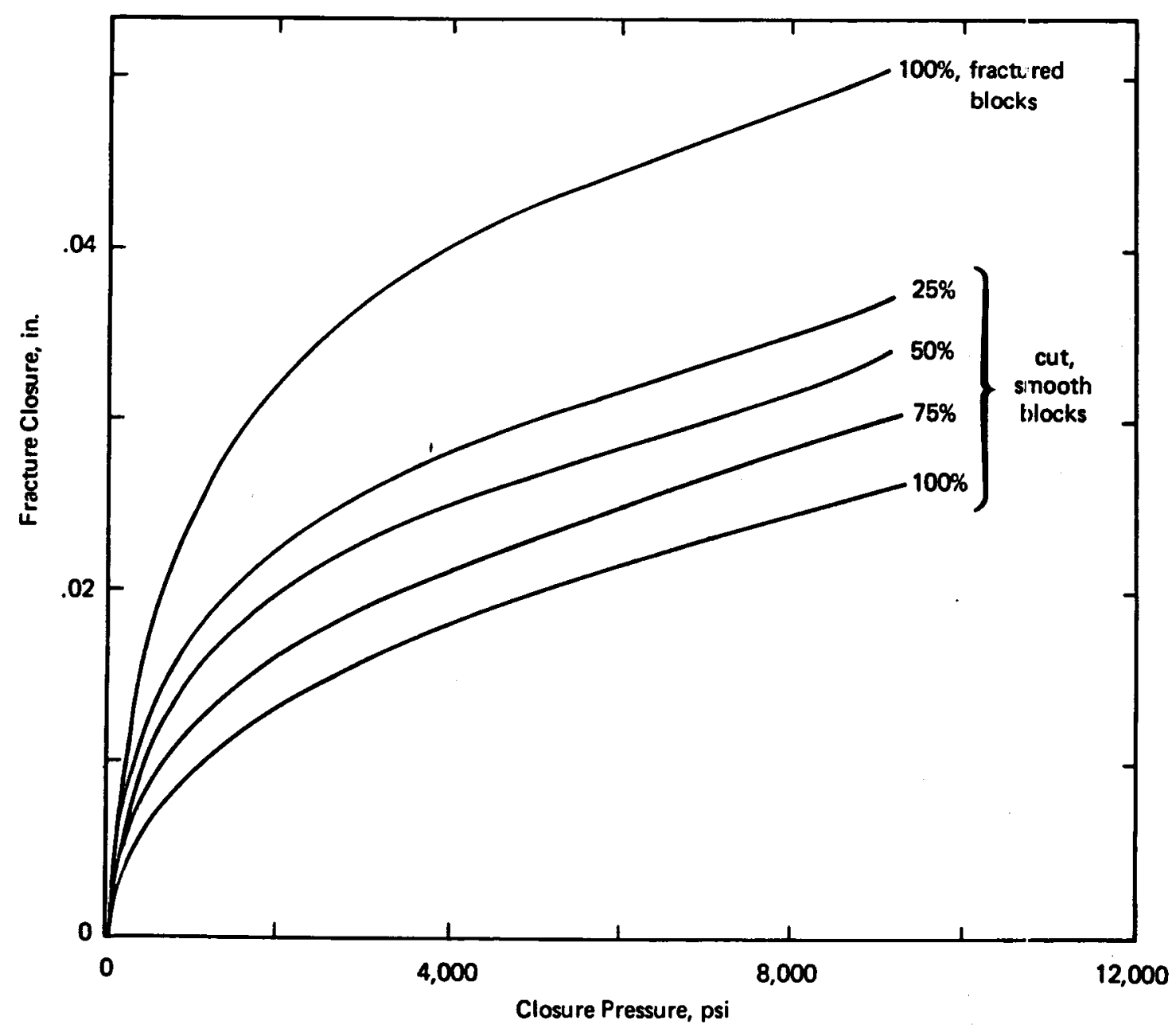

Figure 4-17 Fracture Closure vs Closure Pressure with Various Fractions of Monolayer Coverage Using 12/20 Mesh Sintered Bauxite Proppant Between Smooth and Fractured Berea Blocks 
(Italics denote changes since March 31, 1980.)

Simulated Fracture Conductivity

A long term flow through stressed-proppant experiment is in operation. A 2 percent KCl solution will flow through the simulated proppant-filled fracture at a flowrate of approximately 3 mls per minute. Periodic somples of the fracture effluent will be collected for 5 days to measure the change in size and quantity of particles generated from the simulated fracture.

A long term stressed-proppant experiment was completed during May. A 2 percent KCl solution was contimuously injected at a constant rate of 2 mls per minute into a simulated fracture between tight core halves packed with 40-60 mesh sand and subjected to a constant 5,000 psig overburden pressure. Effluent particle-liquid samples were collected periodically for analysis with a Model TA II Coulter Particle Counter. Samples collected were analyzed to determine their particle concentrations for the first 72 hours of the experiment.

It appeared that a large number of particles were created initially upon overburden pressure opplication. The number of particles per unit volume found in the effluent increased rapidly within the first few hours of the experiment, peaked and dropped off after the first 24 hours. After 48 hours particle concentration was down to $1 / 3$ of the peak concentration. The curve shape of a plot of particle concentration versus time indicates most of the particles were created initially as overburden pressure.

\section{RESERVOIR SIMULATION STUDIES}

\section{Parametric Analys is of MHF Test Data: An Engineering Study of Western Gas Sands}

Further study was conducted during the period of the uniqueness of reservoir and fracture parameters obtained from pressure transient analysis. Work also centered on the effect of fracture skin and wellbore storage on the pressure responses of wells.

The base case model used in the first uniqueness study consisted of two ten-ft producing zones with 5 percent hydrocarbon porosity and $.10 \mathrm{md}$ permeability. The top zone contained a fracture with a half-length of $100 \mathrm{ft}$ and fracture conductivity of $1.57 \times 10^{3} \mathrm{md}-\mathrm{ft}$. The bottom zone contained a 40-ft fracture with the same fracture conductivity. A match of the pressure transient response of the two-layer model was obtained with a model having a single 20-ft producing zone with $.097 \mathrm{md}$ permeability, 5 percent hydrocarbon porosity, and a single fracture conm ductivity equal to the base case. Drawdown and build-up curves of the two cases show agreement is very good with only slight discrepancies noted in the midale portions. A comparison of the production forecasts for the two models also shows very close agreement. 
(Italics denote changes since March 31, 1980.)

The second study used a base case model also containing two 10-ft zones with 5 percent hydrocarbon porosity. The upper zone had a permeability of $.10 \mathrm{md}$ and a single fracture with half-length of $100 \mathrm{ft}$ and a fracture conductivity of $1.57 \times 10^{3} \mathrm{md}-\mathrm{ft}$. The lower zone had a permeability of $.05 \mathrm{md}$ and a single fracture with half-length of $40 \mathrm{ft}$ and a fracture conductivity of $6.3 \times 10^{2} \mathrm{md}-\mathrm{ft}$. A match of the two-layer pressure transient response was obtained with a single 20-ft zone with $.0755 \mathrm{md}$ permeability, 5 percent hydrocarbon porosity, and a fracture with a half-length of $76 \mathrm{ft}$ and fracture conductivity of $1.57 \times 10^{3} \mathrm{md}-\mathrm{ft}$. Drawdown and build-up curves of the two cases show good agreement of the pressure response and production forecast curves.

An additional study was performed using the single layer model from the second uniqueness study to see if the production history could be matched with a model having enhanced permeability around the wellbore instead of a fracture. Cinco, Samaniego and Dominguez presented in their article on "Transient Pressure Behavior for a Well with a Finite-Conductivity Vertical Fracture" published in the August, 1978 SPE Journal, a relationship for a psuedo skin factor for a well having a finite conductivity fracture. A figure in the article showed a graph of $\left(s_{f}+\right.$ In $\left.x_{f} / x_{w}\right)$ vs $\left(W_{f D} K_{f p}\right)$. The fracture and reservoir characteristics used in the model placed $i t$ on the flat part of the curve where the quantity (sf + In $\left.x_{f} / r_{w}\right)$ was approximately equal to .70 . Using the following equation:

$$
s_{f}=\left(\begin{array}{l}
k \\
k_{s}
\end{array}\right.
$$

and substituting values of $r_{s}$ and solving for $k_{s}$, it was found that a negative skin factor of 4.75 would approximate the fractured well model.

Figure 4-18 shows a plot of the production forecasts from the fractured model and the enhanced permeability model. The forecasts of the two models are relatively close in early years but deviate in later years. This comparison shows that a fractured well could be simulated by a nonfractured well model if the simulator were based on the early production history.

The effects of fracture skin and wellbore storare on the pressure transient responses of a single layer model were also studied during the period. Figures.4-19 and 4-20 show the effect of fracture skin, "s", on the drawdown and build-up curves of a model having a 20-ft producing zone with .1 md permeability, 5 percent hydrocarbon porosity, and a single fracture of 100-ft half-length and fracture conductivity of 1.57 $x 10^{3} \mathrm{md}-\mathrm{ft}$. As shown, the jracture skin greatlu affects the drawdown curves but has no effect on the build-up curves. Wellbore storage was introduced into the model having a fracture skin of 1.0 . It can be seen that wellbore storage changes the shape of the early portion of both tile drowdoun and builii-up curves but the curves become concurrent later in time. Figures 4-21 and 4-22 show the pressure responses on an expanded scale of the model with a fracture skin of .10, with and without wellbore storage. It can be seen that the effect of wellbore storage becomes less noticable as the skin factor decreases. Figures 4-23 and 


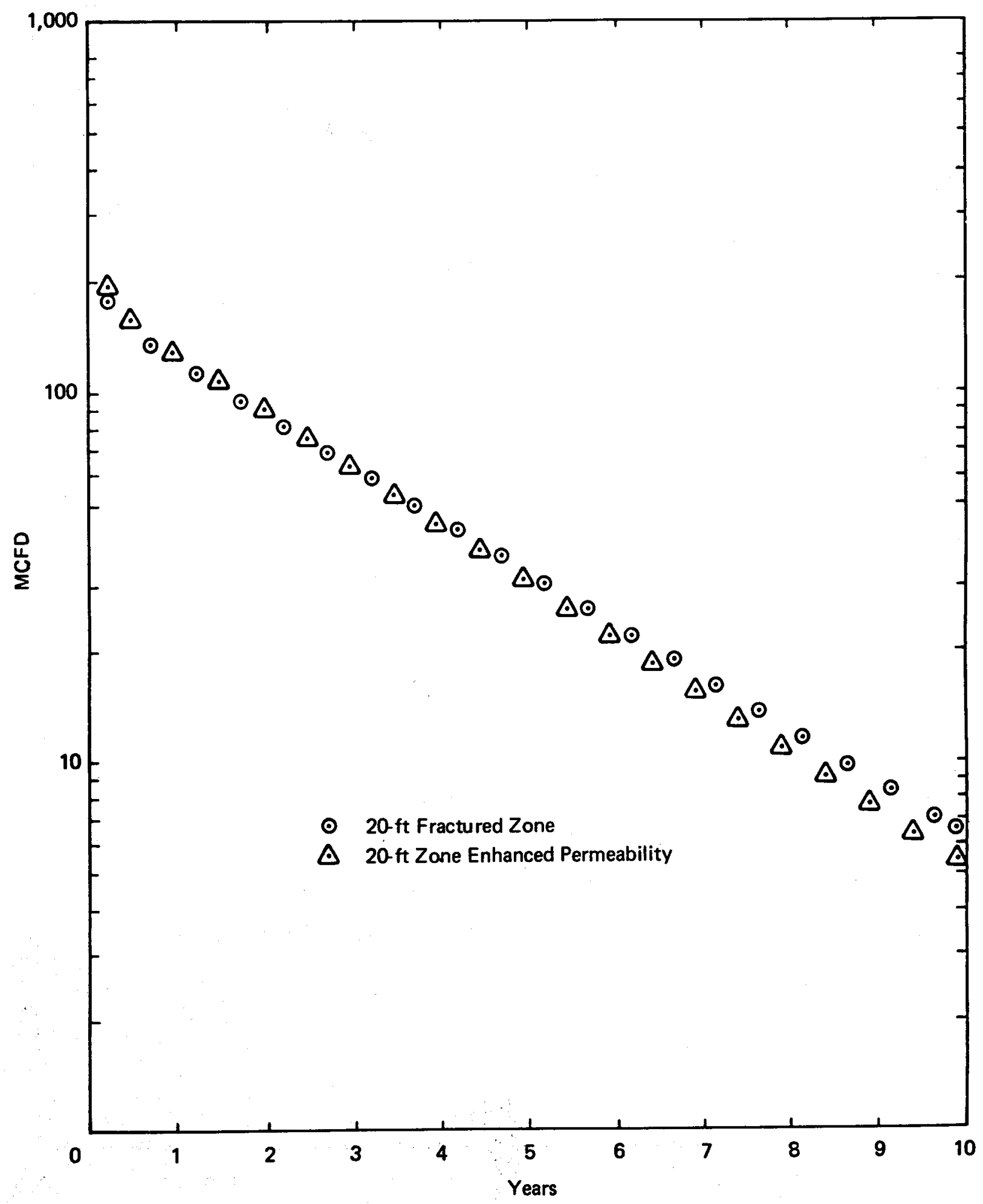

Figure 4-18 Production Forecast 


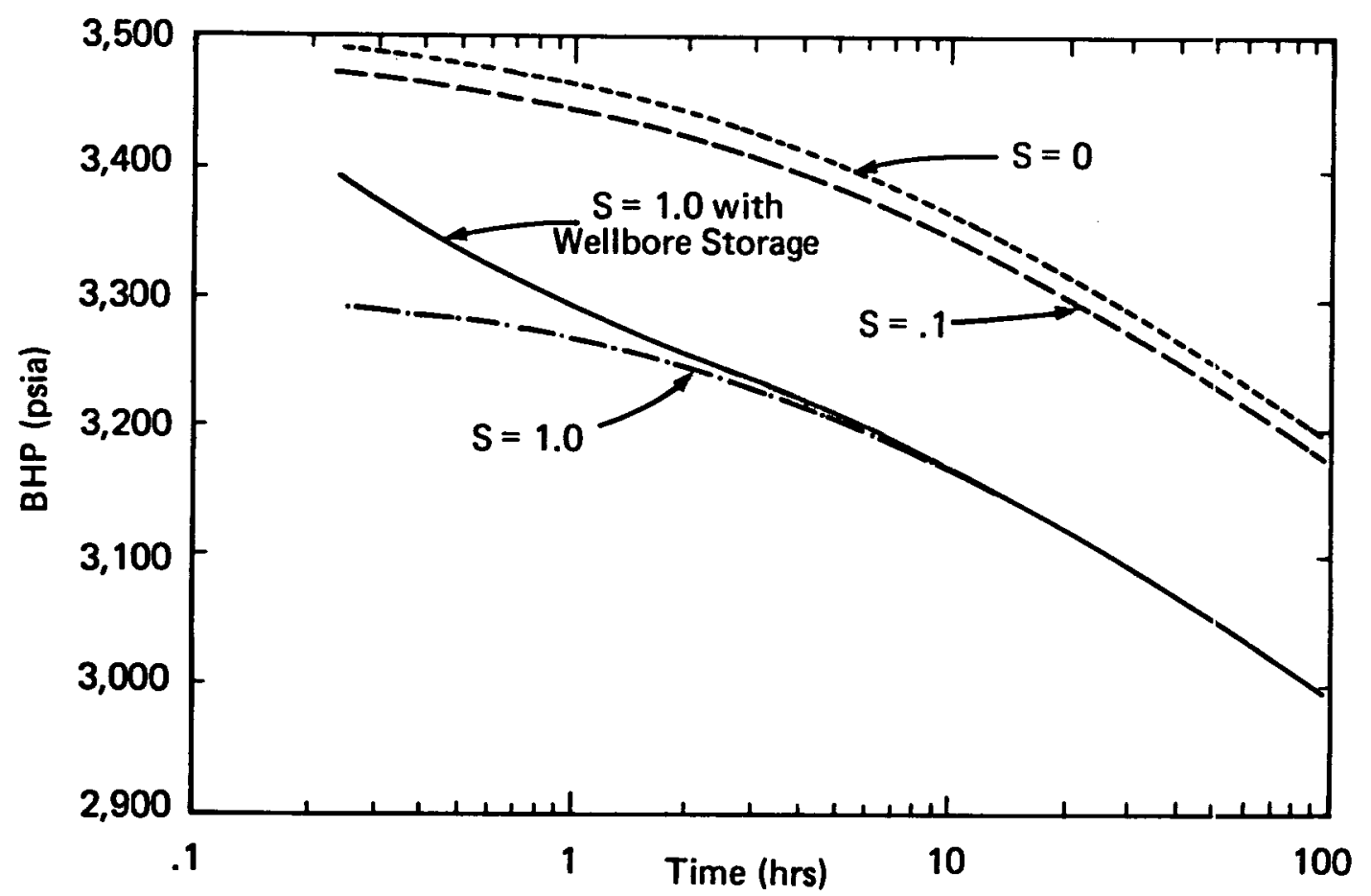

Figure 4-19 Effect of Fracture Skin on Drawdown with $0.1 \mathrm{md}$ Permeability

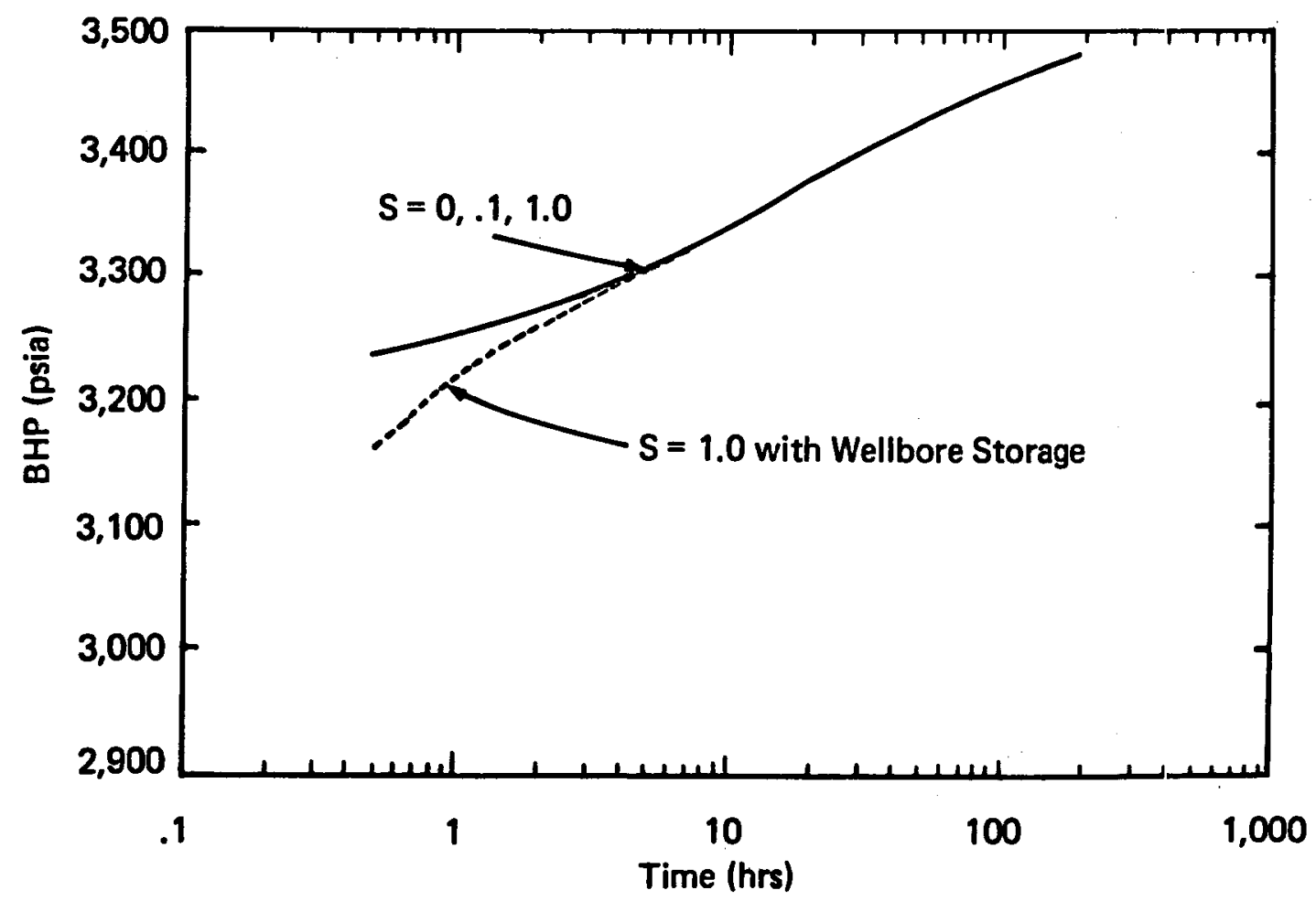

Figure 4-20 Effect of Fracture Skin on Build-up with 0.1 md Permeability 


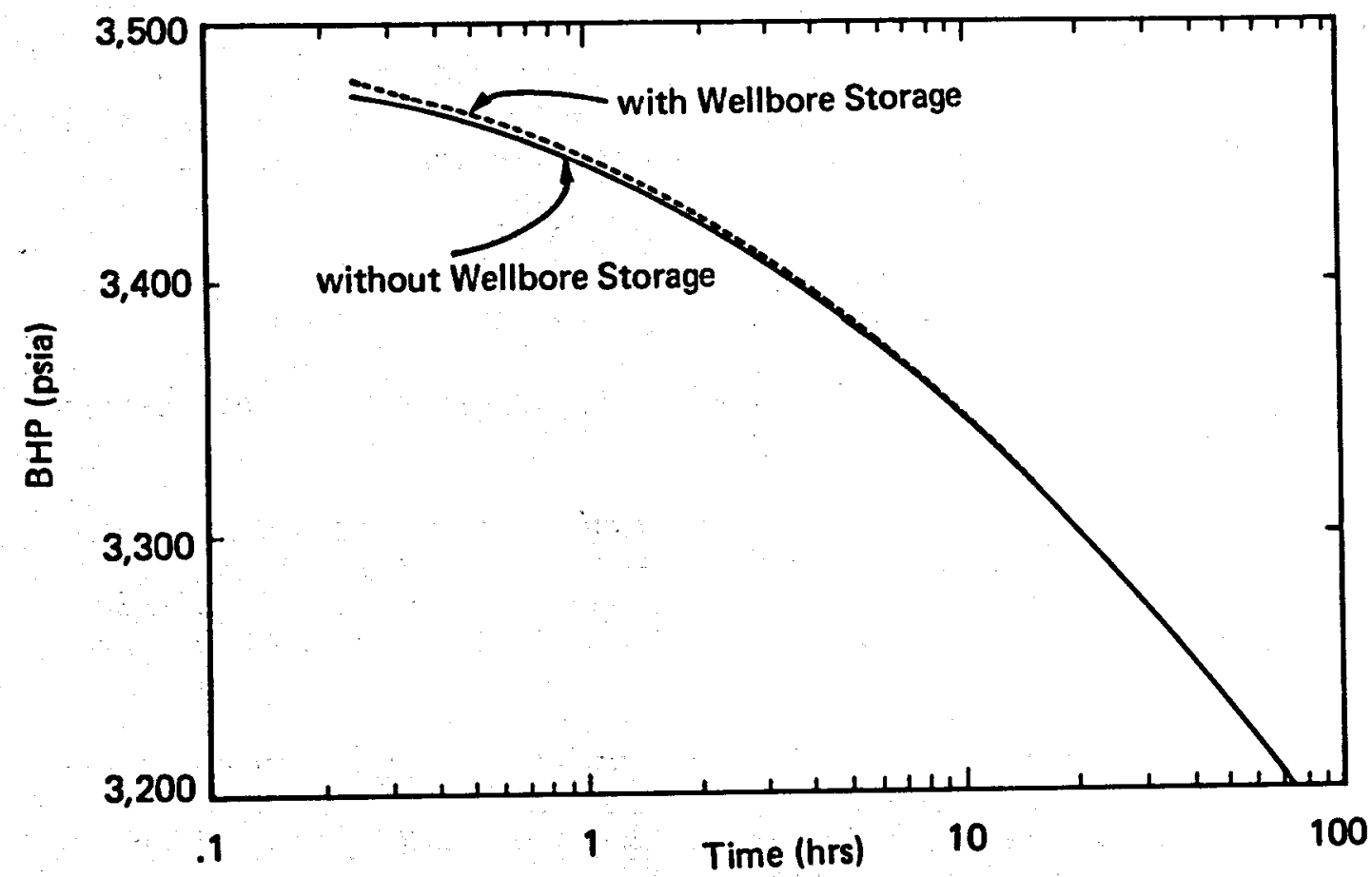

Figure 4-21 Effect of Wellbore Storage on Drawdown with Fracture Skin $0.1 \mathrm{md}$ and $0.1 \mathrm{md}$ Permeability

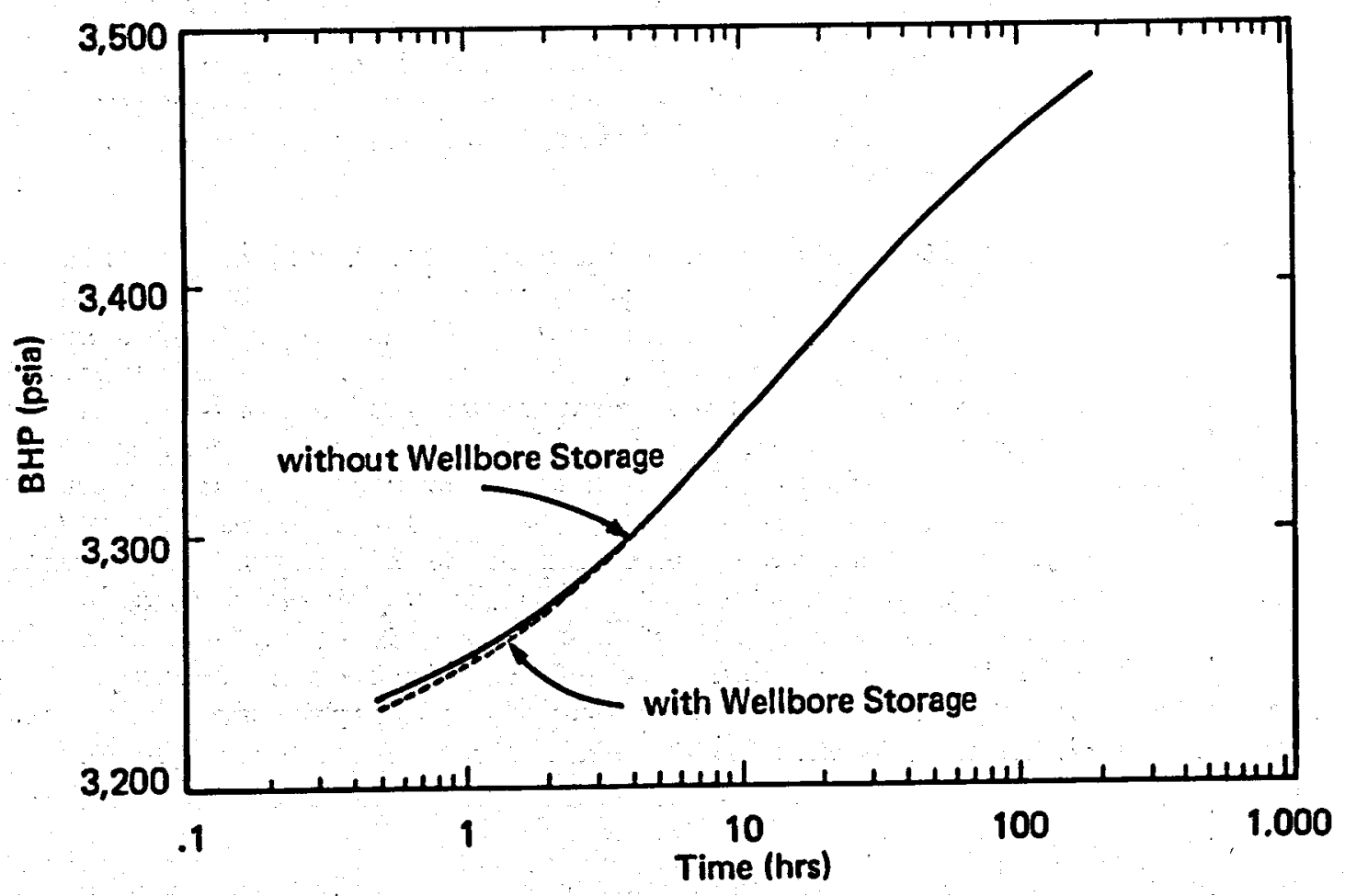

Figure 4-22 Effect of Wellbore Storage on Build-up with Fracture Skin of $0.1 \mathrm{md}$ and 0.1 md Permeability 
(Italics denote changes since March 31, 1980.)

4-24 show the effect of wellbore storage on the single layer model having a fracture skin of .10, but having a lower formation permeability of $.05 \mathrm{md}$. The effect of wellbore storage increases in the lower permeability reservoir as expected.

In the future, a two-phase simulation model will be used to study the ejfect of fracture face damage on well performance.

Parametric Analysis of MHF Test Data: An Engineering Study of Western Gas Sands - Intercomp, Inc.

During July, work was performed on the task determining how fracture fluid remaining around the fracture affects the post fracture test periods. To perform this study, it was necessary to use the single Well Radial F'low Simulator in conjunction with the new Two Phase Fracture Propagation Model.

Before beginning work with the fracture models, a nonfractured reservoir was simulated to determine whether the two models would calculate the some pressure transient responses to a given set of reservoir parameters. Although the parameters in both simulators were identical, it was not possible to match the transient responses. Further work on Task 2 will be delayed until the differences between the two models can be resolved and can match the pressure transient responses on a nonfractured reservoir.

Further study of the uniqueness of reservoir and fracture parometers continued as well as the effect of fracture geometry on the pressure transient response of a well. In addition, work was begun using the Two Phase Fracture Propagation Model.

The first uniqueness study consisted of a base case model having two 10-ft producing zones with 5 percent hydrocarbon porosity and $.10 \mathrm{md}$ permeability. The upper zone had a fracture with a 100-ft half-length and fracture conductivity of $2.6 \mathrm{md}-\mathrm{ft}$. The lower zone had a fracture with a 40-ft half-length and fracture conductivity of $1.1 \mathrm{md}-\mathrm{ft}$. A match of the pressure transient response of the two layer model was obtained with a single 20-ft producing zone and a single fracture with 76-ft half-length and $2.0 \mathrm{md}$-ft fracture conductivity. Drowdown wid build-up curves from the two cases showed agreement between the curves. Figure 4-25 is a comparison between the production forecasts obtained from the two models. It is noted that the single layer model has a slightly higher initial production rate and declines at a slightiy faster rate than the two layer model. Despite the difference in rates, the two wells had nearly identical cumulative productions at the end of the 10 years. 


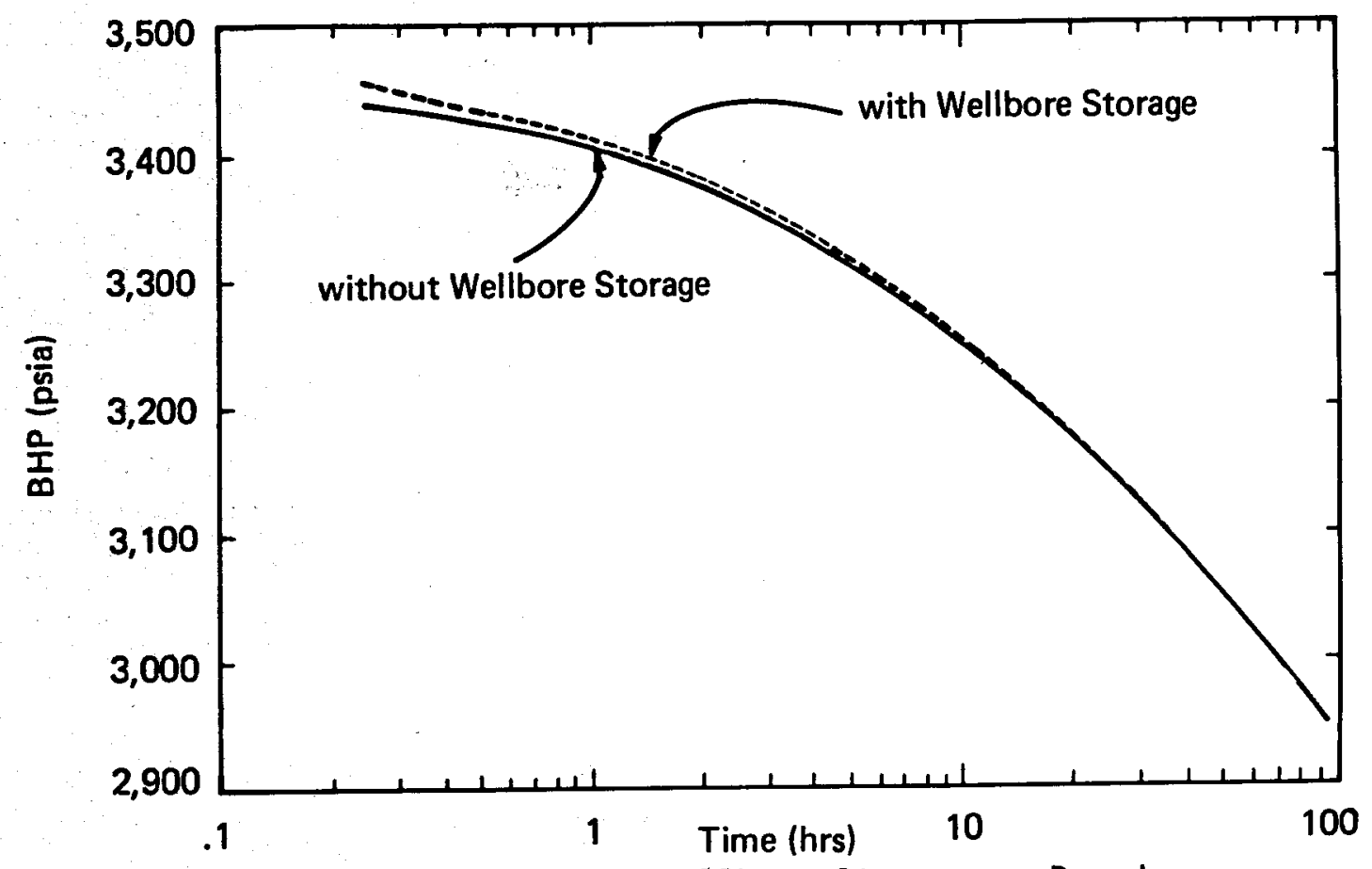

Figure 4-23 Effect of Wellbore Storage on Drawdown with Skin Factor of $0.1 \mathrm{md}$ and $0.05 \mathrm{md}$ Permeability

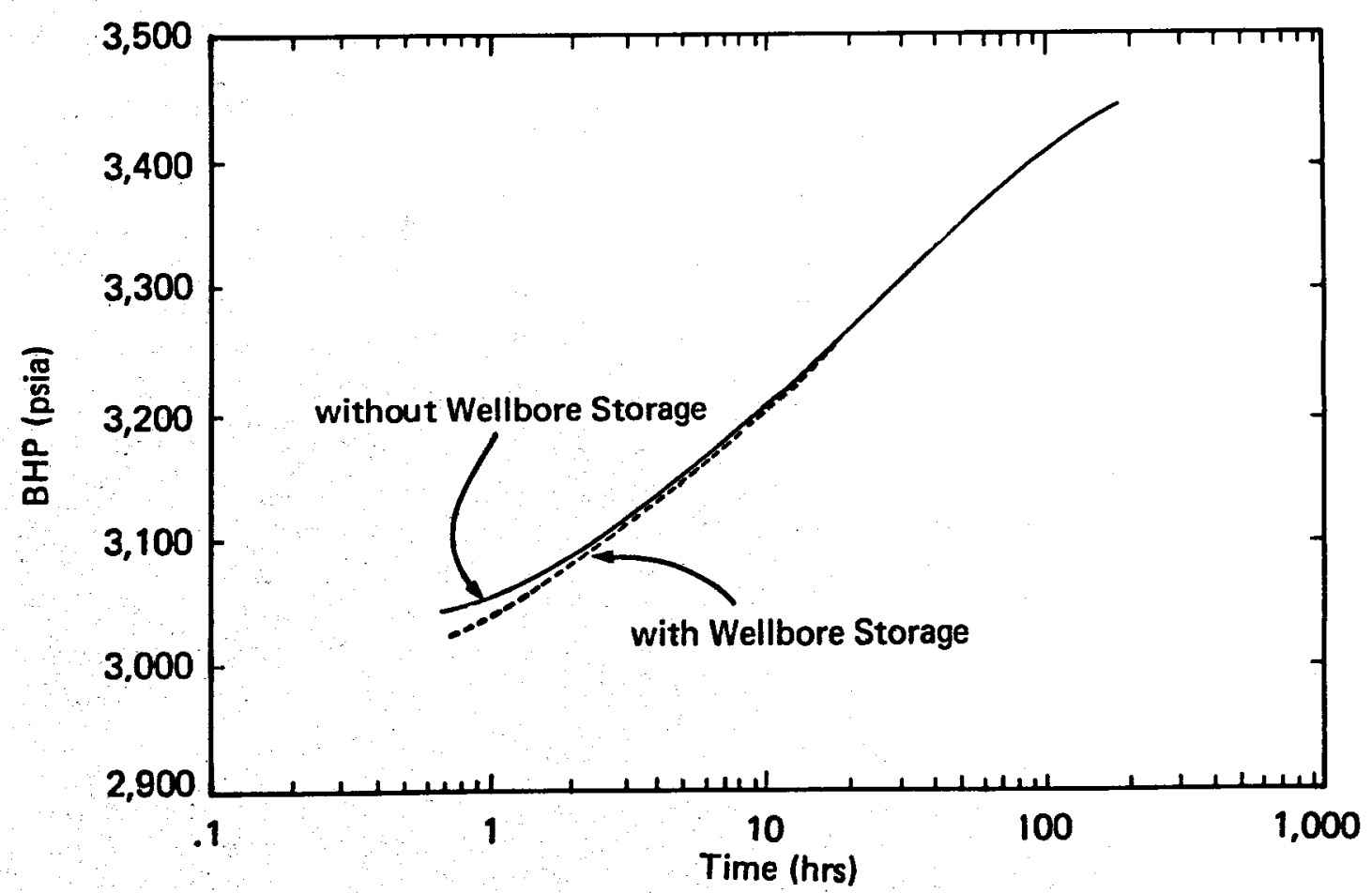

Figure 4-24 Effect of Wellbore Storage on Build-up with Skin Factor of 0.1 md and $0.05 \mathrm{md}$ Permeability 
(Italics denote changes since March 31, 1980.)

The second uniqueness study consisted of a two layer base case model having two 10-ft producing zones with $.10 \mathrm{md}$ permeability and 5 percent hydrocarbon porosity. The upper zone had a fracture with 624-ft halflength and fracture conductivity of $9.8 \times 10^{3} \mathrm{md}-\mathrm{ft}$. The lower zone had a fracture with 40-ft half-length and fracture conductivity of 6.3 $x 10^{2}$ md-ft. A match of the two layer model was obtained with a single 20-ft producing zone and a fracture with 344-ft half-length and fracture conductivity of $5.4 \times 10^{3} \mathrm{md}-\mathrm{ft}$. Drowdown and build-up curves of the two models showed very close agreement in their pressure responses. Figure 4-26 shows a comparison between the production forecasts obtained from the two models. There is quite a bit of discrepancy in the curves during the later production years. This could be explained by the fact that the lower zone in the two layer model produces at a much lower initial rate because it is not fractured as extensively. The lower zone then will not deplete as fast and therefore, sustains production for a longer period than the single layer model, which has a fairly large fracture.

The third uniqueness study was performed using two models that did not contain fractures but had producing zones with different permeabilities. The two layer model consisted of two 10-ft producing zones with 5 percent hydrocarbon porosity. The upper and lower zones had permeabilities of 1.0 and $.10 \mathrm{md}$, respectively. A match of the two layer model was obtained with a single layer model having a 20-ft producing zone with .535 md permeability. Drowdown and build-up curves from the two models were in close agreement. Figure 4-27 is a comparison of the production forecasts for the two models. It can be seen that there is quite a difference between the two production forecasts despite the fact that the pressure transient responses are nearly identical.

The fracture geometry study used a single 20-ft producing zone having 5 percent hydrocarbon porosity and permeability of $.10 \mathrm{md}$. Three different fracture geometries were studied. The first was a single wing fracture having a length of $100 \mathrm{ft}$. The second was a complex fracture having three fractures at $120^{\circ}$ angles, each having a length of $66.67 \mathrm{ft}$ (for a total fracture length of $200 \mathrm{ft}$ ). The third was two double winged, perpendicular fractures having half-lengths of $50 \mathrm{ft}$ (for a total of $200 \mathrm{ft}$ ). All of the fractures had conductivities of 103 md-ft. Figures 4-28 and 4-29 show the drowdown and build-up curves for the three different fracture geometries. Figure 4-30 is a plot of the production forecasts for the three fracture geometries. It can be seen that by increasing the number of fractures around the wellbore but still maintaining the same total fracture length, the long-term production characteristics of the well will be enhanced.

The Two Phase Fracture Propagation Model is now operational and is close to its final form. The two phase water, oil model can be used to simum late initiation, propagation and closure of a fracture along with flow and shut-in periods before and after fracture treatment. A stand-alone or simultaneous proppant progrom is also included to simulate the propping of the fracture created in the fracture model. An excomple model 


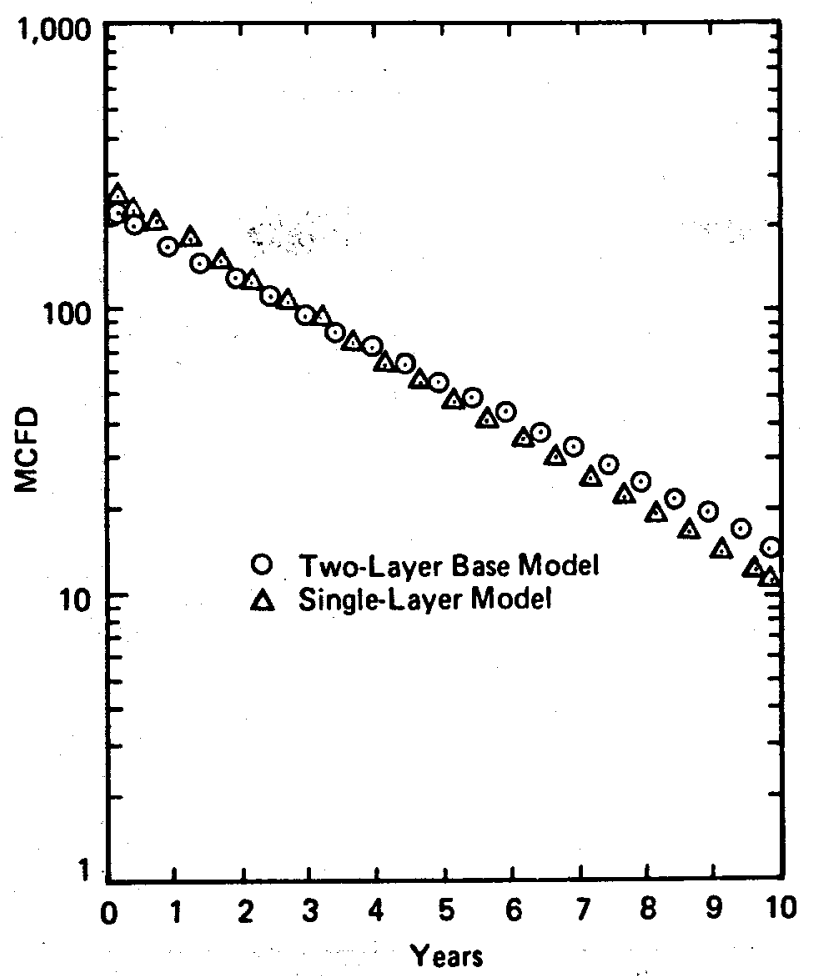

Figure 4-25 Comparison of Production Forecasts

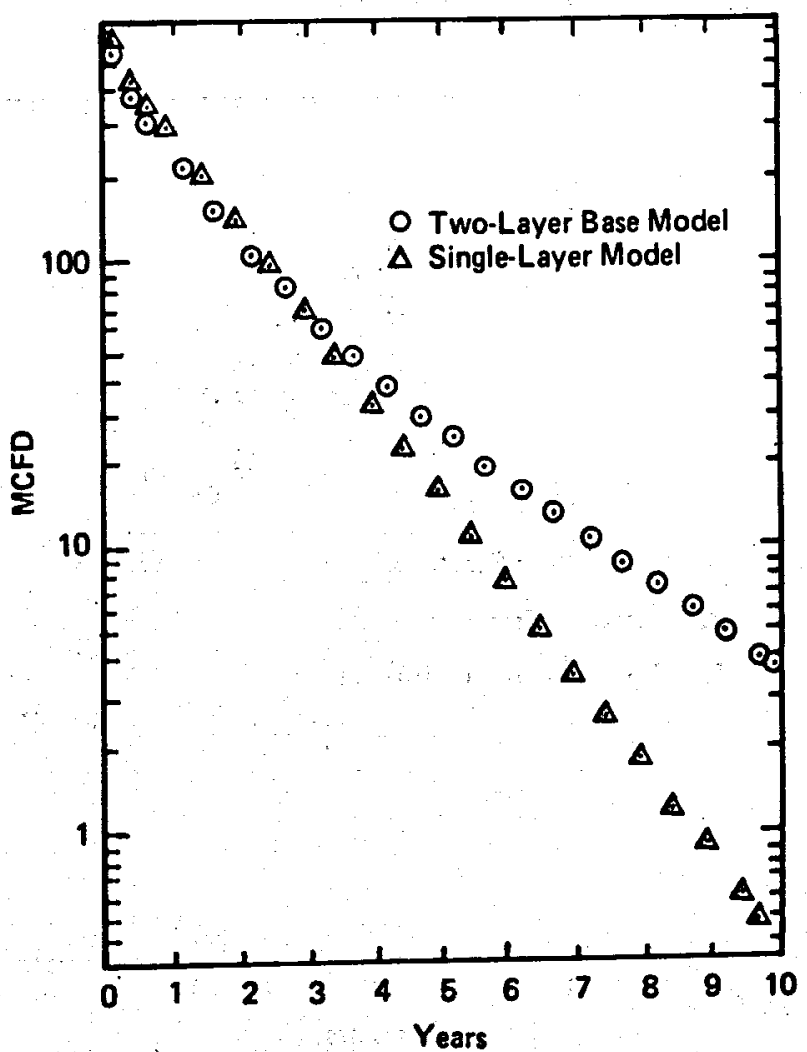

Figure 4-26 Comparison of Production Forecasts 


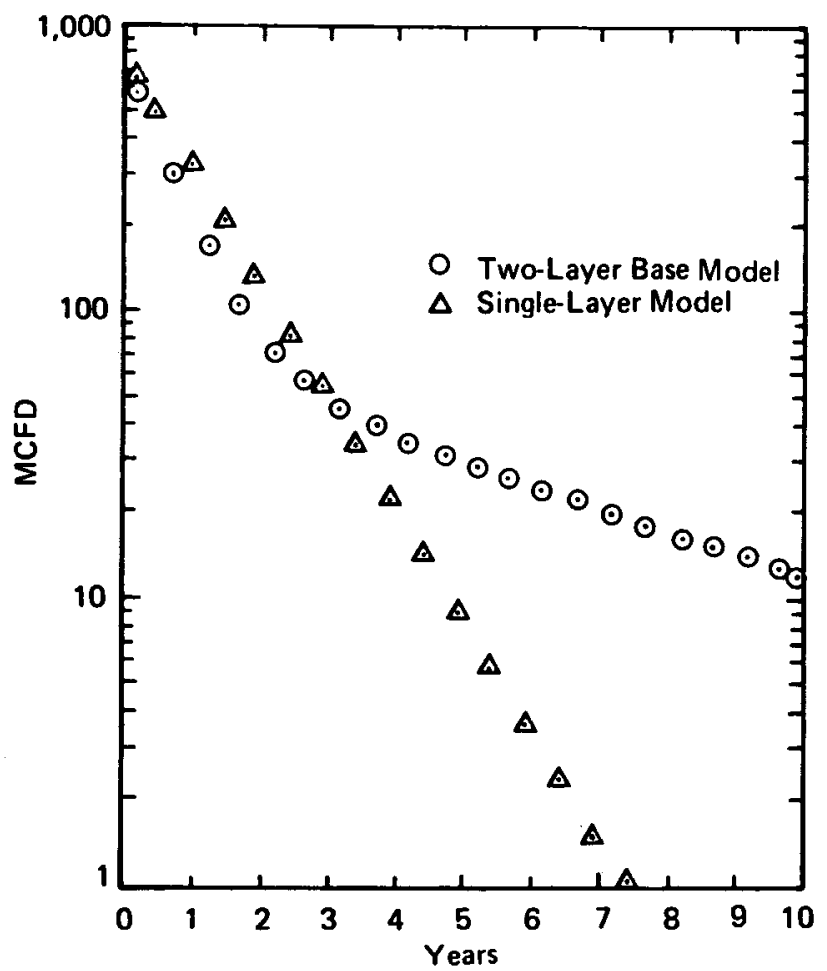

Figure 4-27 Comparison of Production Forecasts

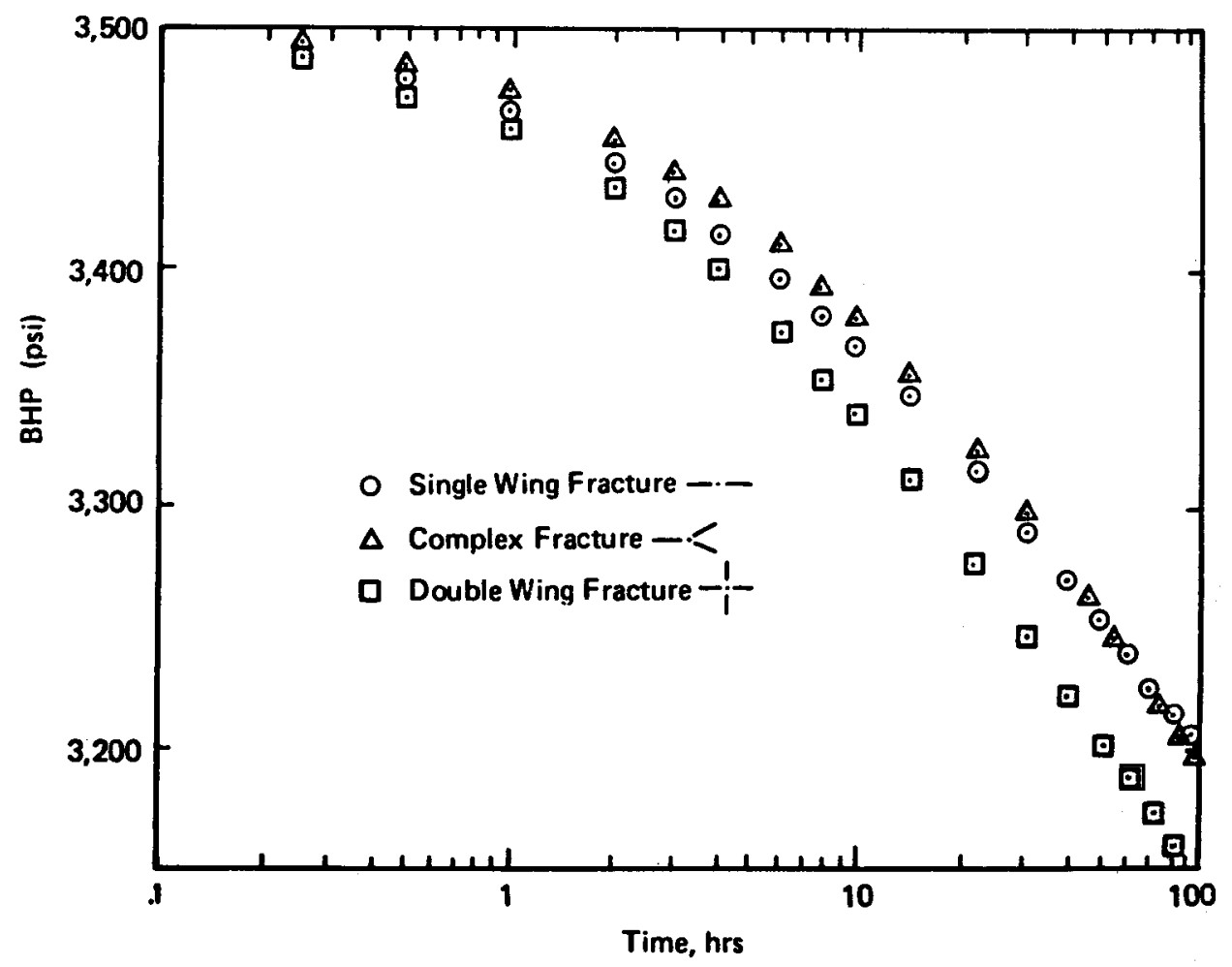

Figure 4-28 Drawdown Curves for Three Fracture Geometries 


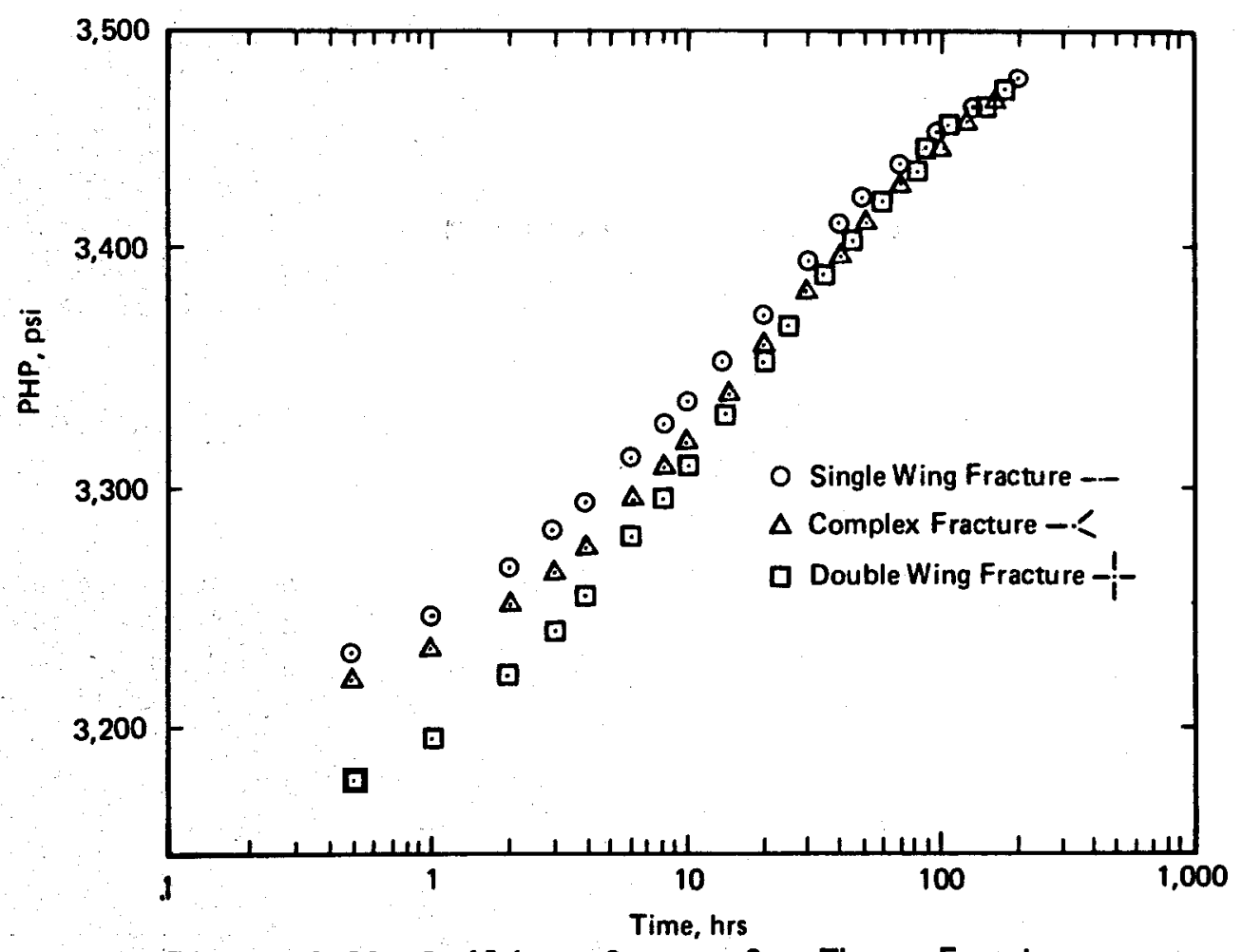

Figure 4-29 Build-up Curves for Three Fracture Geometries

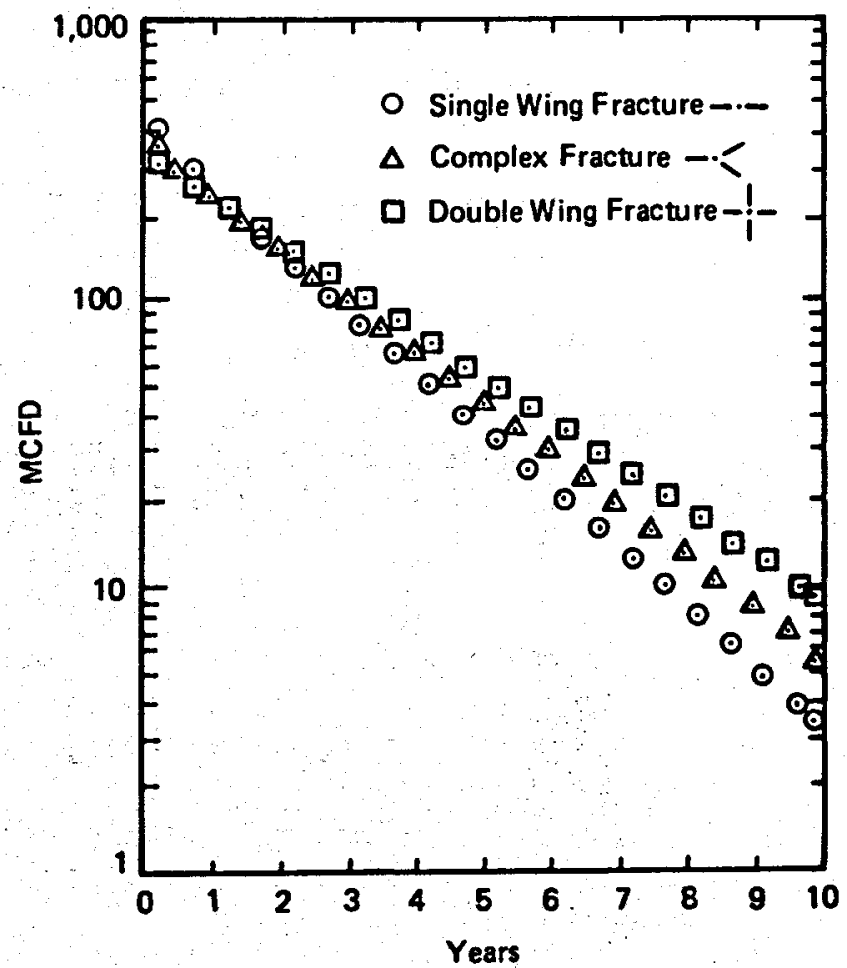

Figure 4-30 Production Forecasts for Three Fracture Geometries 
(Italics denote changes since March 31, 1980.)

will be used to study the effect of after-fracture flowback time on the build-up tests commonly mon after fracture treatment of a well. The radial gas model used in the previous studies will be used to determine if a well was tested too soon. If the fracturing fluid still fills some of the fracture as well as the ones a few inches into the fracture face or reservoir rock, this will indicate that a short ineffective fracture was formed, when in reality, a longer fracture was created.

Reservoir Simulation for Hydraulically Fractured Gas Wells in Lenticular Formations - University of Oklahoma

Work continued toward developing reservoir simulation techniques for analysis and evaluation of hydraulically fractured gas wells completed in noncontinuous lenticular formations. To mun the multi-dimensional gas well simulator, computer services were re-established with the University of Tulsa Computer Center. The copability of the existing two dimensional gas well simulators is being extended to include important effects such as non-Darcy flow in the reservoir and fracture, wellbore and fracture storage effects, and frictional pressure drop within the production string.

Development of the two dimensional gas reservoir simulator progressed. All additions to the progran have been completed which reflect the effects of non-continuous sand lenses, non-Darcy flow, wellbore and fracture storage and pressure drop in the production string. Considerable effort was expended in developing the computer logic associated with these additions in order to conserve computer storage.

\subsubsection{GAS RESEARCH INST I TUTE}

\section{GAS RESEARCH INSTITUTE SPONSORED PROJECTS}

Work continued on the development of a matrix or information model to identify the state-of-the-art in tight gas sands technology. Numerous departures from the matrix model proposed by the Project Advisors have been recommended.

\section{GAS RESEARCH INSTITUTE SPONSORED WORK}

A subcontract has been approved with M. D. Wood, Inc., to furmish FRACMAP services for two sites in the Wattenberg Field, Colorado. Amoco Production Company will provide the sites and certain required well stimulation data. The purpose of the subcontract is to obtain information on hydraulic fracture length. 
Literature review and a geologic background study continued on the combined Arkoma Basin/Ouachita Mountains Province of Oklahoma and Arkansas. A report is in preparation. Preliminary review continued on the Raton Basin of New Mexico and Colorado.

Preliminary background work has begun for the Anadarko Basin of Oklahoma and Texas, and the Wind River and Big Horn Basins of Wyoming.

\section{EVALUATION OF SEISMIC DATA FOR DETAILED STRATIGRAPHIC STUDIES IN LENTICULAR SANDS}

All processing of the Bryson Canyon seismic data has been completed and the final report is in preparation.
$4 \cdot 3 \cdot 3 \quad T R=$
WESTER N
G A S
S A N D S
$S \cup P P O R T$

\section{COMPUTERI ZED DATA BASE DEVELOPMENT}

An assessment has been made of using existing computer data base systems to establish a WGSP computerized data base and alternatives for developing that data base system have been evaluated. Two types of systems have been considered. The first contains only abstracts of WGSP-related documents and other information sources; a user would access the system with a keyword and the system would print out sources of information relating to that keyword. The second system which includes the first, would also contain geological and technological data relevant to the WGSP. The systems will be designed for access from remote locations by all project participants and other designated users.

\section{ECONOMIC ANALYSIS OF GAS PRODUCTION FROM TIGHT GAS SANDS}

Work continues on the development and application of an economic analysis methodology. A data base for over 900 gas wells in the Uinta, Greater Green River, Piceance, and Denver (Wattenberg Field) Basins has been developed. Most of this information was acquired in a previous data acquisition task. Subsequently, the data base has been augmented by filling data gaps and updating gas production information. The well data has been evaluated and a subset of wells, which have adequate data available for analysis, has been defined.

For various reasons, including data availability, gas production data are being used to measure the effectiveness of well performance. Four independent production decline progroms using least-squares curve-fit were developed/coded to determine the best (in the least-squares sense) exponential, harmonic, hyperbolic and generalized hyperbolic fit. 
(Italics denote changes since March 31, 1980.)

While all four progroms provide good fits of the measured data, the generalized hyperbolic model provides the most reasonable extropolation. An implementation disadvantage of this modei is that it incorporates a two dimensional iteration scheme; to obtain a converged solution requires trial and error selection of starting values for the interaction. Consideration was given to switching to exponential decline when the gas flow regime transforms from a linear to radial regime. However, calculations showed that in the tight reservoirs, linear or transitional flow exists through most of the expected life time of the well. The curvefit progroms can compute an extropolated decline curve and cumulative production for any desired time. To implement a statistical analysis of the well data, generalized hyperbolic production decline curve-fits have been obtained for several hundred wells from the Denver Basin (Wattenberg Field), Washakie (Greater Green River) Basin and Piceance Basin. A computer plot copability was developed which plots actual decline data and superimposes a plot of the computed curve fit. Such plots have been obtained for over a hundred weils.

A semies of modifications which address specific changes needed for analyses of the western basins was incorporated into a previously developed gas well economic model. Using the extrapolated curve-fits and cost data developed for the recent NPC evaluations, expected values of internal rates-of-return (DCF) are being calculated. In a given area, these calculations can be made as a function of economic factors, such as well head gas prices, and/or engineering parameters, such as fracture size. Since the decline curves are based on existing wells, this reflects existing state-of-the-art technology. The results wili show the effect of variations in stimulation and geologic parameters, and in gas price and well cost.

A more general opproach is to compute a simultaneous regression on all technical parameters that have a significant effect on well production. A computerized procedure to accomplish this was developed by TRW for another study, and is currently being utilized on the Wattenberg and washakie data sets.
$4 \cdot 3 \cdot 4$
LAWRENCE
L I V E R MOR E
LABORATORY

THEORETICAL ANALYSIS

\section{Crack Growth Across Frictional Interfaces}

To evaluate hydraulic fracture penetration across a frictional interface a set of calculations have been utilized to calculate the strain energy density, $e_{t}$, at the fracture tip and directly across the interface as a pressurized fracture approaches the interface. 
(Italics denote changes since March 31, 1980.)

Figure 4-31 displays the normalized strain energy density on a semilog plot as a function of crack position for several values of $B$, where $\beta$ is the ratio of the shear stress that the frictional interface can support in the absence of a pressurized crack to the pressure in the crack, $p_{c}$. The strain energy density is normalized by obtaining the ratio of $e_{t}$ with $P_{c} / E$ where $E$ is Young's modulus for the material. The crack tip position $\delta$, has been normalized with the crack length and the interface is located at $\delta=0.0$.

The frictional interface does not affect the pressurized fracture until the crack is less than one crack length from the interface. It is obvious that the crack has to be nearer to the interface before the strain energy density increases as $B$ is increased. The strain energy density appears to approach an asymptote as the fracture tip approaches the interface. These results show that fracture propagation is enhanced by frictional slippage along an interface as the tip approaches the interface.

Figure 4-32 shows the normalized strain energy density in the material opposite the fracture as a function of $B$. The strain energy density shown on this plot was the value in the material across the interface as the fracture reached the interface. These results show that for increasing $B$, higher frictional stress supported by the interface, the strain energy density increases rapidly across the interface. This increases the likelihood of fracture propagation across the interface. The results presented here are for values of frictional shear stress somewhat less than those which have been experimentally shown for interface penetration.

It should be noted that for these calculations the fluid pressure was assumed constant over the entire length of the crack. It is believed that the fluid does not penetrate the entire crack length and hence the load experienced by the crack would be somewhat less than predicted in these calculations.

Calculation to analyze the penetration of a pressure driven fracture across a frictional interface proceeded in June. It was previously noted that frictional slip tends to drow a fracture towards an interface and the results were presented in terms of the Mode 1 stress intensity factor. Stress intensity factors cannot be used to study penetration of a frictional interface because that factor does not correctly depict the state of stress across the interface. The strain energy density has been calculated in the vioinity of the fracture tip and just across the interface as the pressurized fracture approaches the interface. Strain energy behaves like the square of the Model 1 stress intensity factor in the vicinity of the fracture tip. 


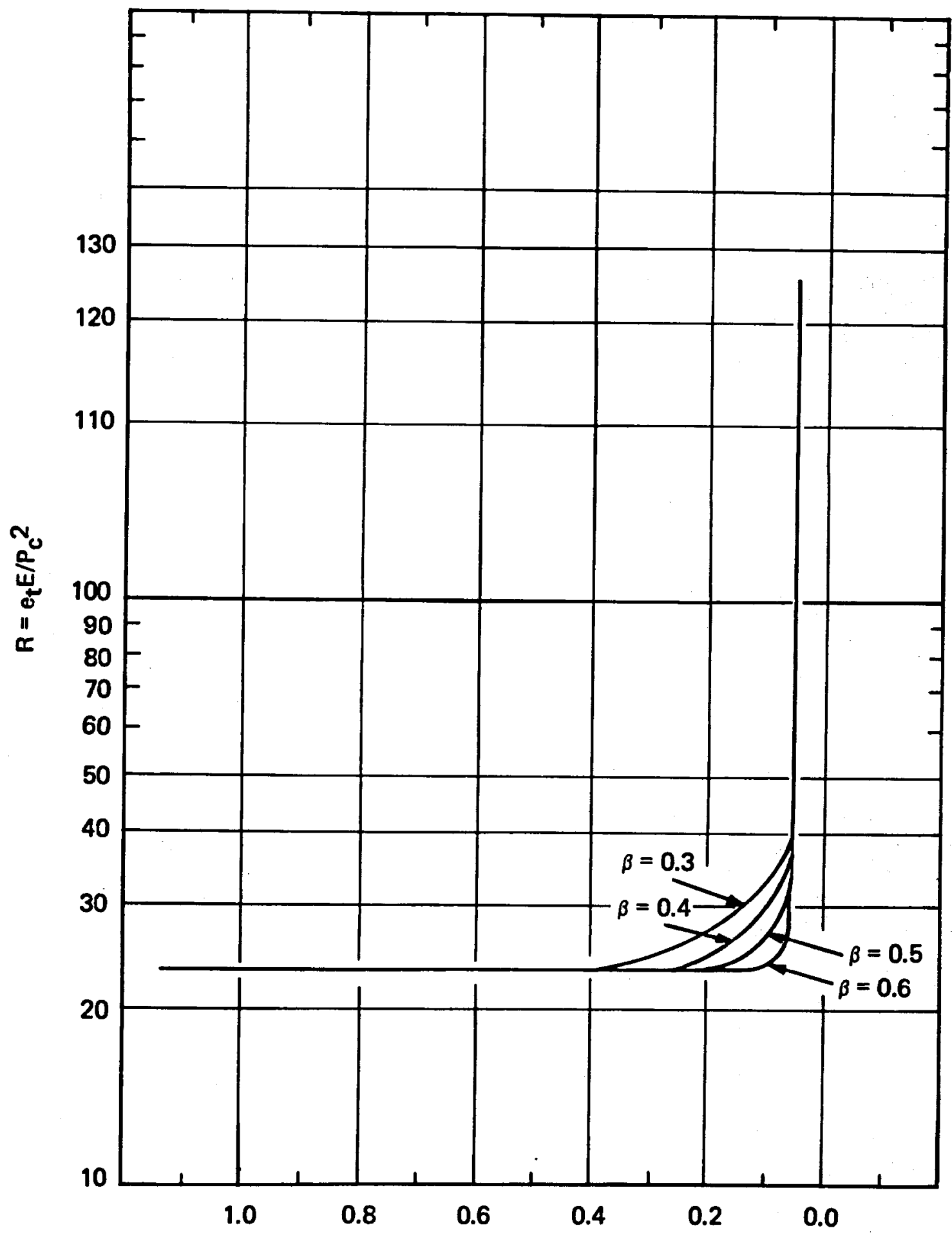

Figure 4-31 Normalized Strain Energy Density at the Crack Tip as a Function of Distance from the Interface for Several Values of $B$ 


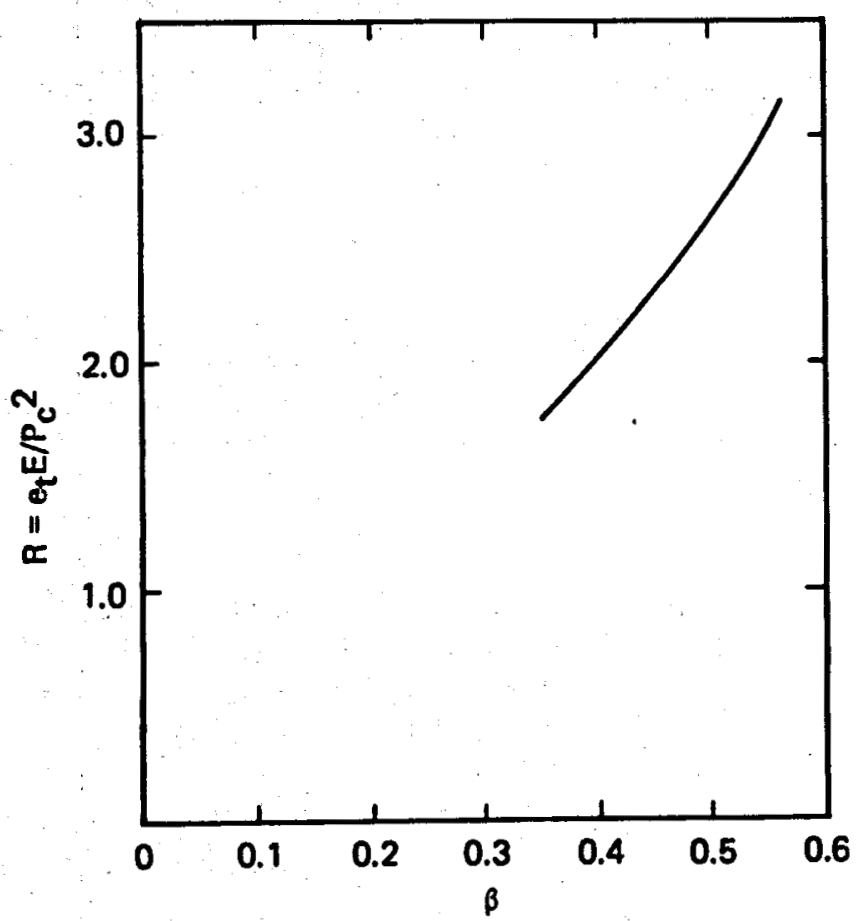

Figure 4-32 Normalized Strain Energy Density as a Function of $B$ in the Material Across the Interface from the Crack 
(Italics denote changes since March 31, 1980.)

Figure 4-33 shows the geometry of the problem. The materials on either side of the interface have the some mechanical properties with Young's modulus, $E=20$ GPa and Poisson's ratio, $=0.25$. Several calculations were performed to determine the strain energy density for a series of frictional stresses that the interface could support. Results of these calculations, shown in Figure 4-34, show a normalized strain energy density, $R_{e}$, as a function of normalized frictional shear stress $I_{e}$, that the interface can support. Normalized strain energy density is defined as where $e_{T}$ is the strain energy density, $P_{C}$ is the pressure in the

$$
R_{e}=\begin{array}{ll}
e T^{E} & n \\
P_{c} & \ell
\end{array}
$$

crack (constant over the length of the crack), $l$ is the length of the pressurized crack and $n$ is the characteristic dimension of the crack tip region over which the energy density, eT, is averaged. The normalized shear stress which the interface can support is defined as

$$
I_{e}=\tau{ }_{f}^{0} / P_{c} \text {, where } \tau{ }_{f}^{0} \text { is the frictional shear }
$$

stress the interface can support when the pressurized fracture is not present. (The normal load across the interface is modified and varies as the pressurized crack approaches the interface.) Except for the lawer end, the curve is linear over the range analyzed.

New time-efficient solution techniques are being developed for simulation models designed for a wider range of stimulation phenomena.

\section{Crack Growth Near An Unbonded Interface with Variable Coefficient of Friction}

Analyses have been completed of a pressure driven fracture intersecting a frictional interface with a varying coefficient of friction along the interface. The geometry of the problem is shown in Figure 4-35. Material on both sides of the interface was identical with Young's modulus of $20 \mathrm{GPa}$ and Poisson's ratio of 0.25 . The two dimensional calculations were performed in plane strain. Pressure in the crack was constant at a value of $6 \mathrm{MPa}$ and the frictional interface was held together by a normal stress of $3 \mathrm{MPa}$. The length of reduced friction along the interface was the same as the length of the pressurized crack.

Figure 4-36 shows the strain, $\varepsilon$, parallel to the interface on the side of the interface opposite the crack. Figure 4-37 shows the strain, $\varepsilon_{y}$, where the region of reduced friction had a frictional coefficient of 0.0 with the remainder of the interface having a frictional coefficient of 0.7. Figure 4-38 had the coefficients of friction at 0.1 and 0.7 for the region of reduced friction and the remainder of the interfaces, respectively. Figure 4-39 shows the strain, $\varepsilon_{y}$, for coefficients of friction of 0.1 and 0.7 , but the axis of the pressurized crack intersected the reduced frictional zones off center. 


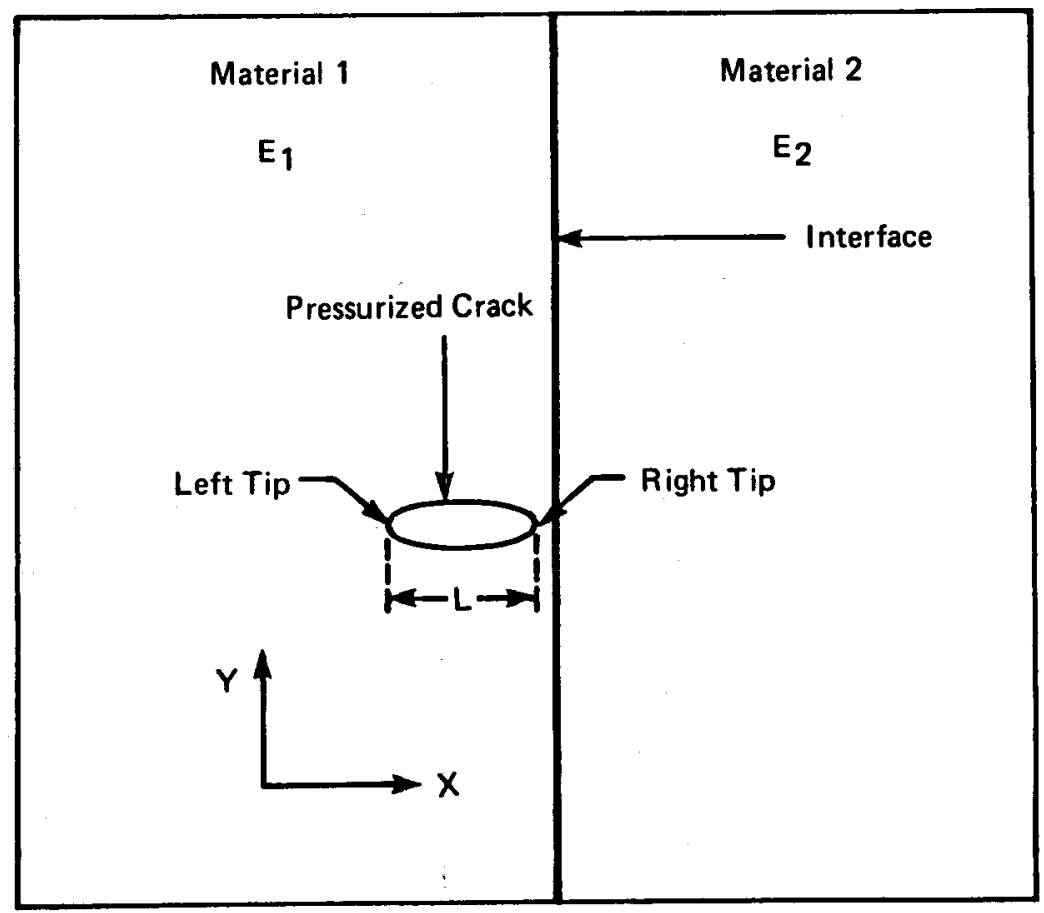

Figure 4-33 fracture Geometry 


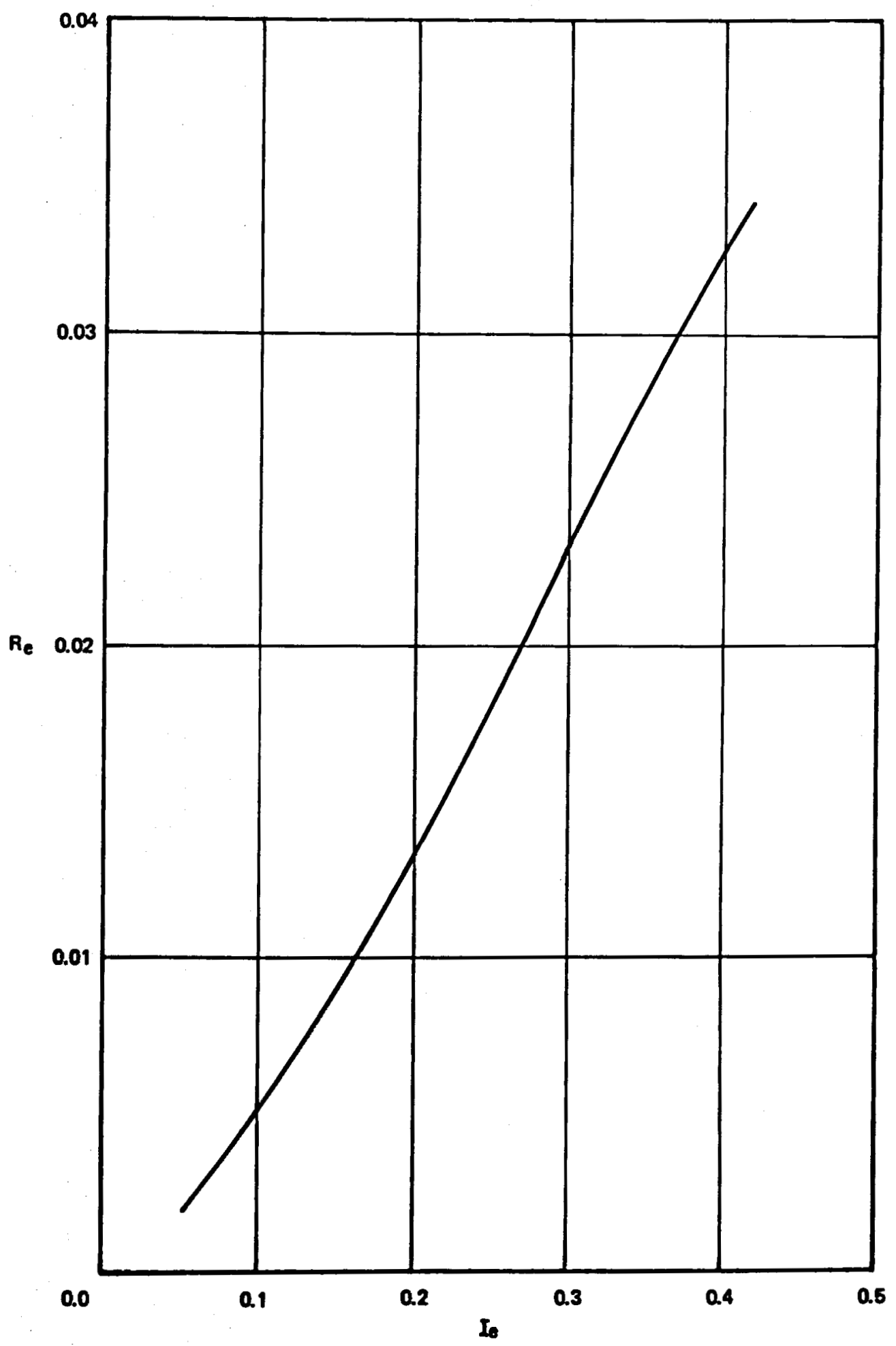

Figure 4-34 Normalized Strain Energy Density, Ke, as a Function of Frictional Sheer Stress, Ie 


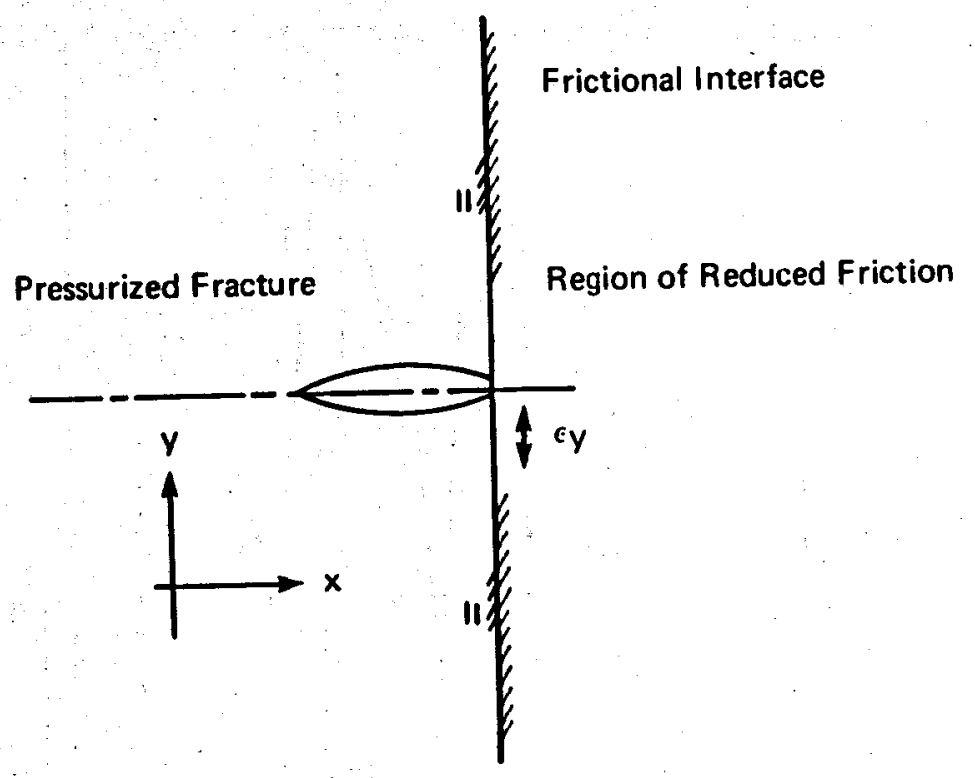

Figure 4-35 Frictional Prob. Geometry

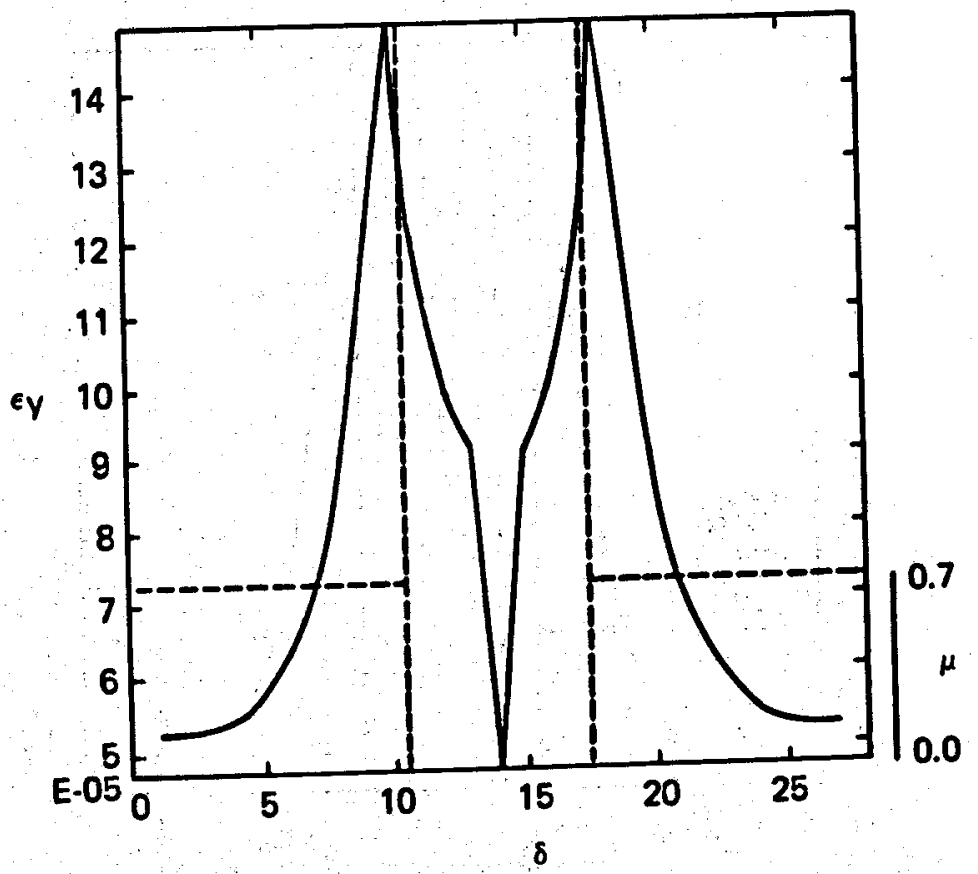

Figure 4-36 Parallel Strain Across Interface from Pressurized Fracture as a Function of Position Along Interface 


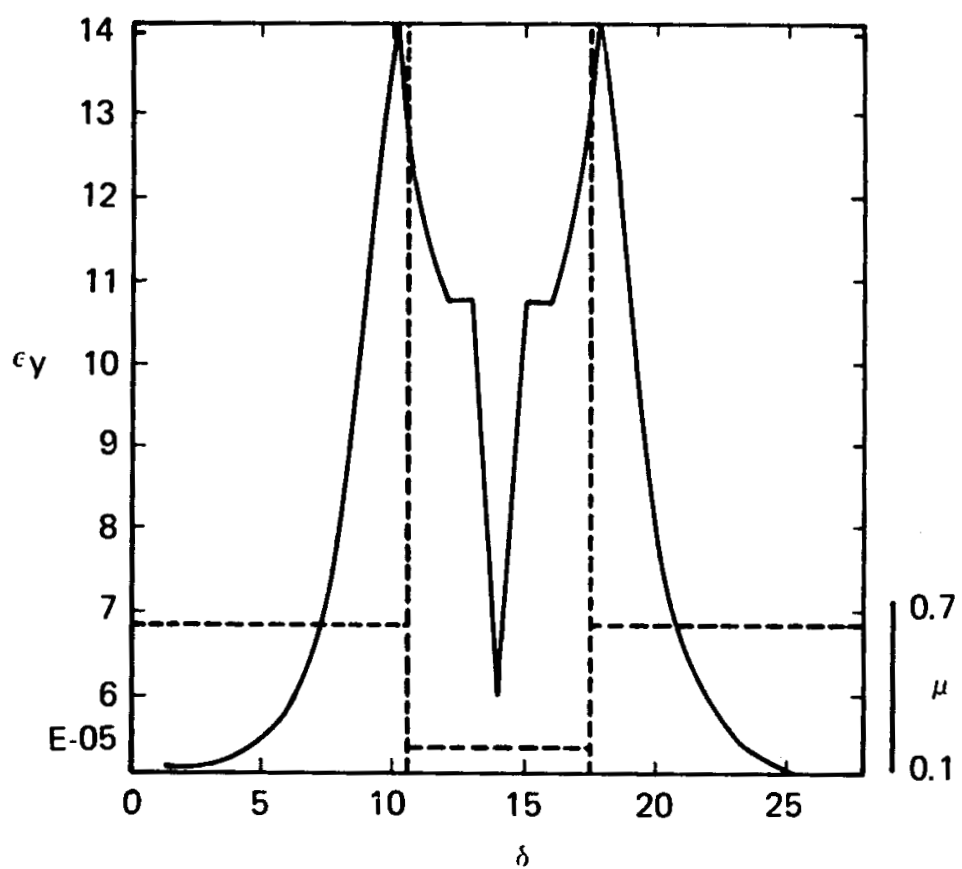

Figure 4-37 Parallel Strain Across Interface from Pressurized Fracture as a

Function of Position Along Interface

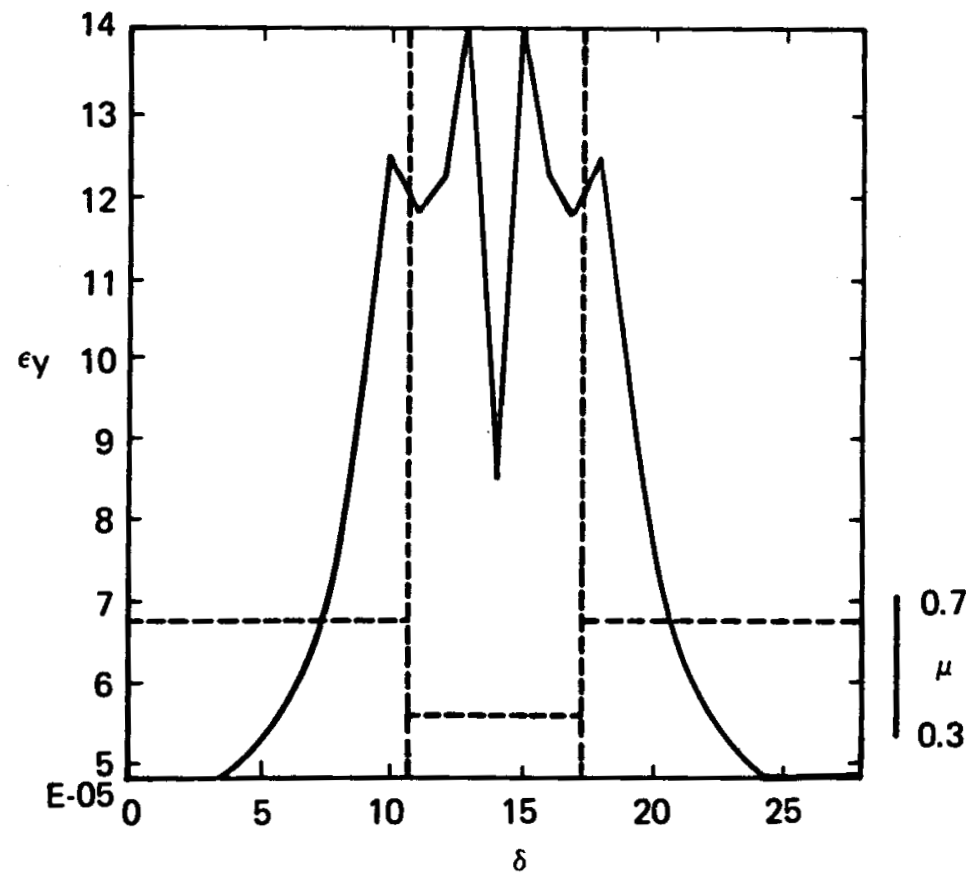

Figure 4-38 Parallel Strain Across Interface from Pressurized Fracture as a Function of Position Along Interface 


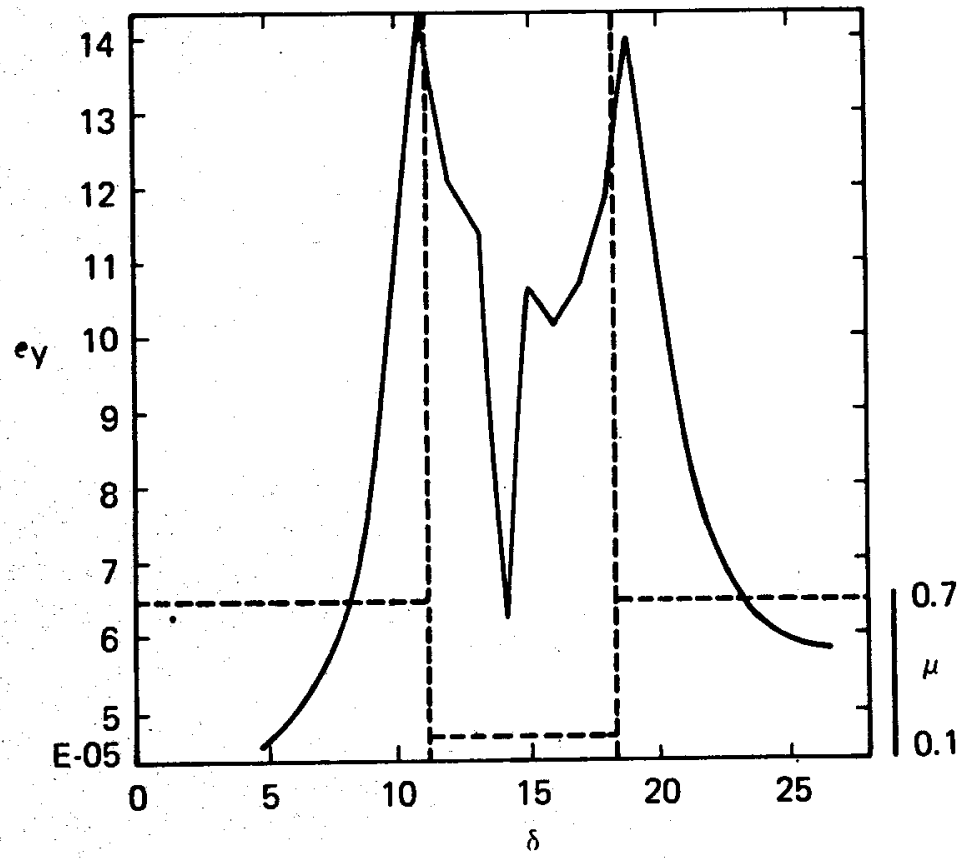

Figure 4-39 Parallel Strain Across Interface from Pressurized Fracture as a Function of Position Along Interface 
(ltalics denote changes since March 31, 1980.)

Figures 4-36 and 4-37 show significant tensile strain just outside the region of reduced fracture. Hence, the crack should reinitiate across the interface in one or both of these areas and result in an abrupt step in the fracture path. Figure 4-38 shows that smaller differences in the frictional characteristics along the interface result in a broader region of increased strain. Reinitiation of the fracture across the interface can be expected at some point of weakness. Hence, the fracture path offset could occur anywhere from just off the fracture axis to just outside of the region of reduced friction. Figure 4-39 displays an asymmetry in the strain pattern because the fracture intersected the reduced frictional region asymmetrically. Again, the higher strain regions are just outside the reduced frictional region of the interface and fracture initiation would be expected near the end of the reduced frictional region closest to the pressurized fracture tip. Previously reported experimental results show strong correlation to these theoretical results.

Abrupt changes in the fracture path that are observed from a mine back of the hydraulically fractured region could be caused by frictional effects.

\section{LABORATORY EXPERIMENTS}

During April some experiments on crack growth across partially lubricated interfaces in Indiana limestone were performed to check the repeatability of experiments performed earlier. Some preliminary experiments were begun on growing penny-shaped cracks between loaded interfaces in plexiglass. These experiments are similar to those performed by Papadopoulos and cleary at MIT. 1

Work continued on the apparatus for simultaneous ultrasonic velocity measurements in multiple directions. At a confining pressure of 0.8 $G P a$, the inner cylinder of the high pressure vessel failed. Construction of a new cylinder is expected to take about three months. Preparation of Mesaverde sandstone and shale samples from Colorado and of Mesaverde shale from sublette County. Wyoming, has been completed.

The PMMA blocks designed and constructed to study fluid flow in cracks were tested in July. The design appears satisfactory at low levels of closure stress ( 1,000 psi). Only preliminary experiments have been performed. Tests were also initiated to study crack growth across heterogeneous rock plates consisting of sandstone, limestone and dolomite.

1 Papadopoulos, J. M. and M. P. Cleary, "Laboratory Experiments on Bydraulic Fracture," Informal Report to LLNL, February 1980. 
(Italics denote changes since March 31, 1980.)

A set of Brazil tests for measurement of tensile strength of Mesaverde shale from Wyoming has been completed.

Measurements were completed of the failure envelope under triaxial compression of Mesaverde shale, as well as pressure-volume measurements of Mesaverde sandstone. The results will be documented later. Specimen preparations for pressure-volume and uniaxial strain measurements of Mesaverde shale were also completed.

\section{HYDRAULIC FRACTURE GROWTH}

During September exploration continued of the use of polycarbonate to study fluid flow in cracks. The surfaces of the samples obtained to date polish well but the material is quite dark. As compared to the clear PMMA, making visual observation of the fluid flow is more difficult. Experiments were begun to study the effect of a nonuniform stress field in crack growth. The experimental arrangement is shown in Figure 4-40. Either a cube or prism block of rock is subjected to an applied load in two perpendicular directions. A uniform load is applied over the faces whose normals are in the vertical direction. However, in one of the horizontal directions the platens of the press load four horizontal shims, as shown in Figure 4-40. The central region between the shims is unload. The third face of the block, through which the fluid injection tube passes, is unconfined. Only a few preliminary experiments have been performed and no conclusive results are available.

\section{MECHANICAL PROPERTIES}

Pressure-volume measurements on Mescverde shale up to a confining pressure of 0.7 GPa have been completed. Testing and calibration of the pressure vessel for ultrasonic measurements in multiple directions has continued. Specimen preparation of Mesaverde sandstone from Colorado at a depth of $1958 \mathrm{~m}$ has been completed.

\section{Fluid Motion in an Expanding Crack}

Work is progressing on the code to calculate the fluid motion in an expanding propagating crack. Presently the code calculates a moving fluid front down a channel, which can be done using two separate methods. The results of the two compare fairly well.

One code can calculate flow when the problem boundary does not align with zone boundaries, which is needed when the crack is allowed to expand in width. Presently, the crack face is not moved in time. 


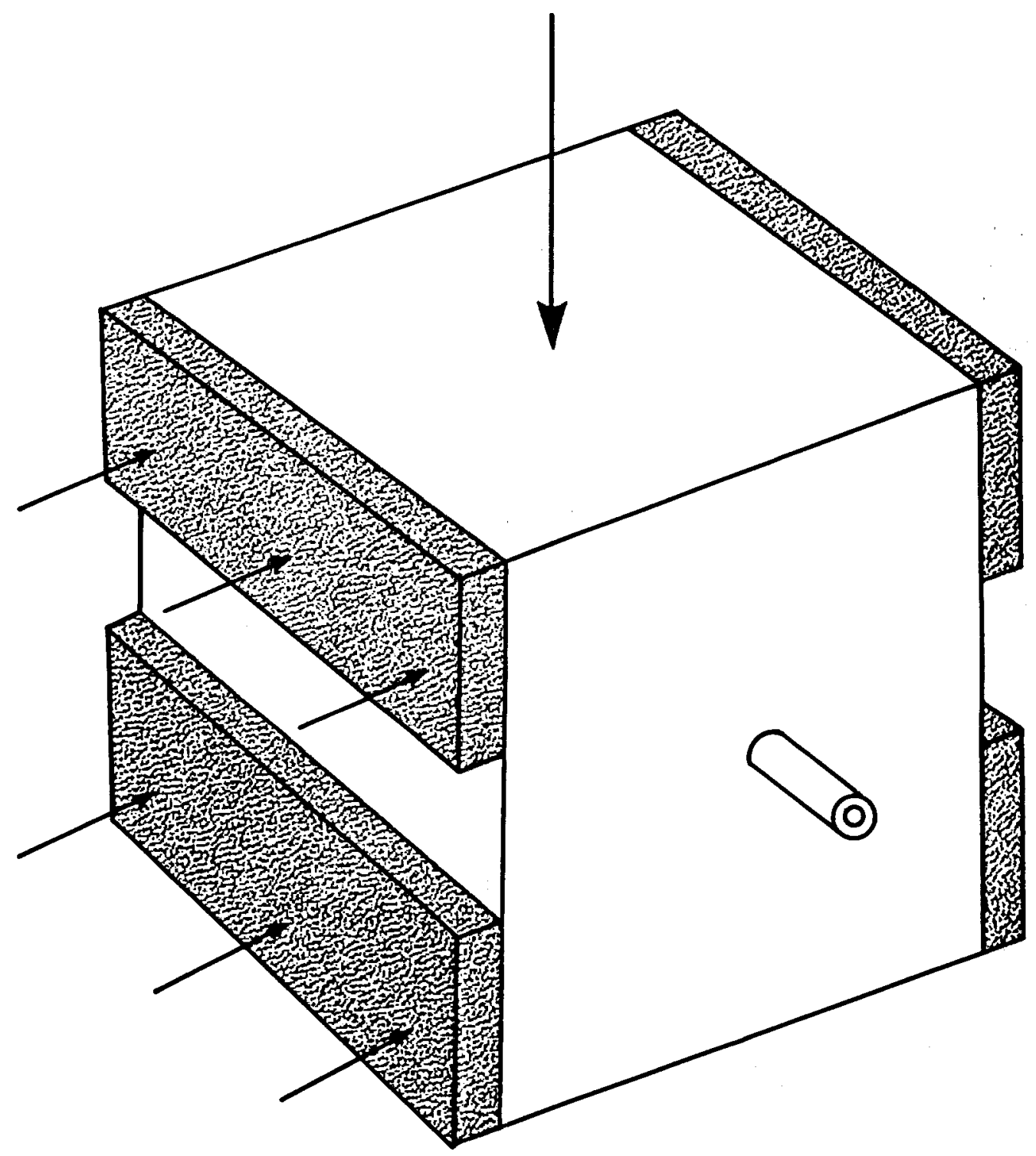

Figure 4-40 Experimental Arrangement to Study Effect of NonUniform Stress Field as Crack Growth 
(Italics denote changes since March 31, 1980.)

\section{GEOLOGY/GEOPHYSICS}

Work continued on compilation and comparison of subsurface structure, hydraulic fractures, surface joints and near-surface stress determinations from the Rangely oil field.

During July cores were excomined in the USGS core library. Critical parts of a core from the deep Mesaverde test. Inexco WASP No. A-1, Sec. 28, T36N, R112W, Sublette County, Wyoming, were observed.

Mineral-fizled (or partially filled) fractures have the geometry, offsets and terminations at and across beddings very similar to those predicted by computations. They appear to be natural hydraulic fractures. A large quantity of data from this well is now being reviewed.

Study continued of the time versus depth relationship for the burial of Mescuerde resemoirs and of the stress variations with time.

Work is continuing on compilation and interpretation of Uinta Basin and Rock Springs Uplift structural data.

\section{3 .5 LOS ALAMOS NATIONAL LABORATORY}

Measurement of water in the pore space of solid, porous samples continued using magnetic resonance techniques. The inverse geometry instrument was used. Nuclear spin-lattice $\left(T_{1}\right)$ and spin $\left(T_{2}\right)$ relaxation time measurements for water were determined in several samples. Three sample types were used: packed sea sand of different sieve sizes, sintered alumina $\left(\mathrm{Al}_{2} \mathrm{O}_{3}\right)$ solids and a western gas sands core.

AII measured $T_{2}$ 's showed a nonexponential decay. Although this could result from several factors, the deviation is most likely caused by improper magnetic field homogeneity over the somple. Different results are expected when improved magnets are available. Spin-lattice relaxation time ( $T_{7}$ 's) were described using a single exponential decay constant for the sea sand experiments. This uniformity could be the result of narrow pore size distribution used through this sample set. The sintered alumina ceramics demonstrated a $T_{1}$ with an exponential decay, which also suggests narrow pore size distribution. The pore size distribution was determined with mercury invasion with a peak of approximately 1 micron with 10 percent and 90 percent points at 0.5 and 2.0 micron, respectively. Initial results with the gas sands core showed a marked nonexponential $T_{1}$, which could be explained in part by a larger pore size distribution.

Work began on the mounting and aligrment system for the new permanent magnet pair. Improved instmonents for $R F$ pulse generation of RF transm mitting was located, and a $3 \mathrm{KW}$ pulse transmitter was acquired to improve the current measurement system. A new mount was constructed of non-magnetic materials for the permanent magnet pair. The mount 
(Italics denote changes since March 31, 1980.)

clamps the lower magnet in place while the upper magnet is held in a gimbal, permitting fine adjustments so the projected magnetic field can be optimized. Magnetic field mapping along the horizontal plane between the two magnets indicates that this new mount will be adequate for the next series of experiments. A digital pulsed spectrometer and a hiah powered $R F$ transmitter will improve the signal-to-noise ration of subsequent measurements.

A new NMR spectrometer permits $180^{\circ}$ pulsing measures at shorter times with greatly improved signal-to-noise ratios. This instmoment will allow more accurate NMR characterization of rock samples and ultimately result in better calibration of the downhole tool.

Preliminary data from the permanent magnet downhole tool indicates that a slight misalignment can be readily detected in the NMR signal. Enclosing the magnet and coil assembly in a Faraday cage reduced the electronic noise, and the dead time following the RF pulse was reduced by using a diode array to isolate the transmitter.

other studies have concentrated on defining the pore size distribution within tight gas sands core samples. This is necessary since the proton resonance reiaxation time might be an indication of the pore size distribution.

\subsubsection{SANDIA LABORATORIES}

\section{Hydraulic Fracture Characterization}

A breakdown and fracture experiment was performed on she zI oil Company's Big Mineral Creek "S" Sand Unit No. 343, Grayson County, Texas. The perforated zone was 5,823 to $5,835 \mathrm{ft}$.

Prior to the breakdown portion of the experiment, three 5-2b explosive charges were detonated at 5,700 ft from Unit No. 343 at S600 W, $5300 \mathrm{~W}$ and due south of Unit No. 343. The purpose of these detonations was to obtain the orientation of the seismic systems. For verification purposes, a gyro orientation unit was installed on the Unit 343 seismic system.

Prior to the explosive shots, a borehole seismic system was clamped at a depth of $5,862 \mathrm{ft}$ in Unit 343. A second seismic system was clamped at a depth of $5,765 \mathrm{ft}$ in Unit 309, an offset well approximately $580 \mathrm{ft}$ east of Unit No..343. During breakdown, Unit 343 was filled with 25 $B B L$ of clear water and the formation was treated in three stages.

During the main fracture experiment the seismic system in Unit 343 was removed and clamped at a depth of 5,330 ft in Unit No. 210, a second offset well opproximately $560 \mathrm{ft}$ south of Unit 343 . The seismic system in Unit 309 was not moved. Again for orientation purposes, three 5-lb 
(Italics denote changes since March 31, 1980.)

explosive charges were detonated within $10 \mathrm{ft}$ of the first orientation shots. No gyro backup was used. The systems in Units 210 and 309 were recorded for opproximately two hours while a 48,000 gal fracture treatment was performed on Unit 343.

The horizontal geophone signals were used to plot and excomine hodograms for direction (azimuth) to the event. With the explosive orientation shots, this produced the direction of alignment of the horizontal geophones.

Excmination of the orientation shots produced a direction for the reference geophone of N67OE for the system in Unit 343 with a spread of zero degrees on the three shots. The reference geophone direction in Unit 309 was determined to be $N 350 C$ with a spread of -14 to +9 for the six shots. The system in Unit 210 was oriented to be $N 50^{\circ} E$. The spread of the three shots for this well was also zero degrees. The gyro attached to the system in Unit 343 indicated a direction of $N 600^{\circ}$. The large spread of directions in Unit 309 was due to high background noise present in that well.

Of approximately 60 signals recorded during breakdown for the seismic system in Unit 343, 20 were useful in determining fracture direction. The other signals were eliminated from analysis because the direction could not be determined. These 20 signals are plotted in Figure 4-41.

During breakdown on the system in Unit 309, 31 (out of 50 total) usable seismic signals were recorded. These signals fell into two categories. These signals are plotted in Figure 4-42. Five of these signals occurred prior to any promping in Unit 343. Distances from Unit 309 were calculated using a compressional wave velocity of $13,700 \mathrm{ft}$ per second and assuming a Poisson ratio of 0.25 . A velocity of $13,700 \mathrm{ft}$ per second was obtained from the sonic log of Unit 343.

During the main fracture experiment, only two signals were received on the seismic system in Unit 309. Nine out of 15 signals could be used to determine source location in the Unit 210 system. The positions of the signals received in Unit 210 are also shown in Figure 4-42. No signals were received in Unit 210 other than during the promping in Unit 343.

It is speculated that the lack of signals in Unit 309 during the fracture is due to some part of the system deteriorating and the sensistivity being reduced. However, no verification could be made when the system was removed from the weil.

The surface electrical potential system (SEPS) was also fielded for this experiment. Forty-eight test probes were utilized at two potential probe locations around the fracture well No. 343: Radius $1(1,200 \mathrm{ft})$ and Radius $2(1,600 \mathrm{ft})$. Current was injected into the formation at 5,700 ft via the current injection probe and two current sinks. The first sink was another well located approximately 8,900 ft to the south- 


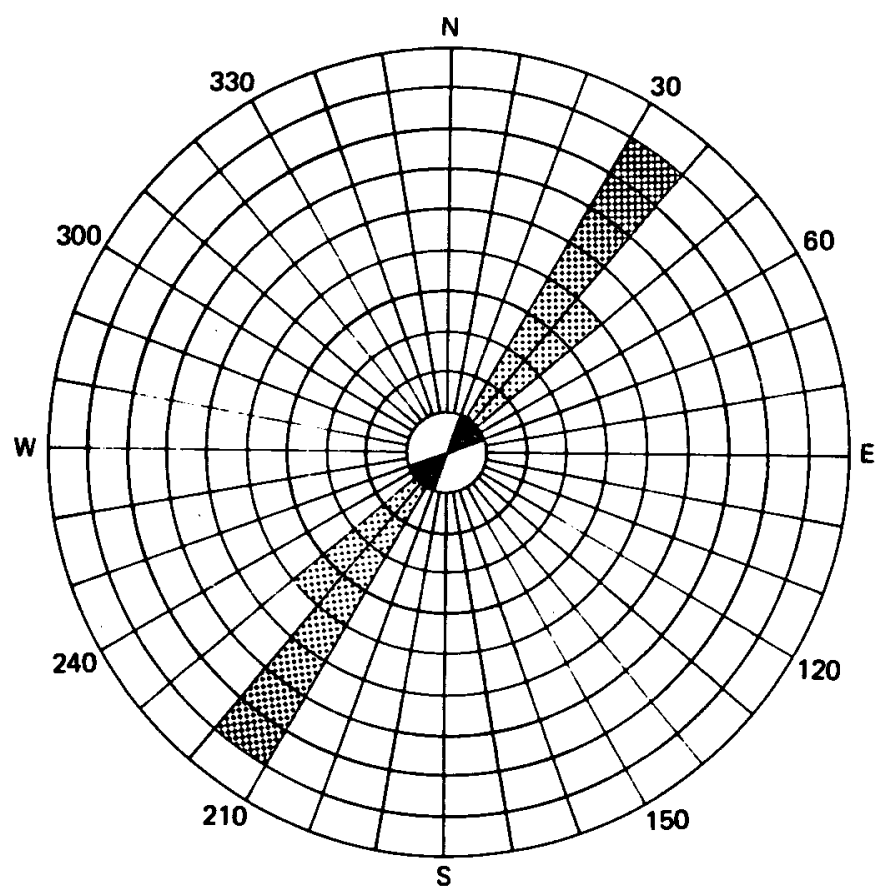

Unit 343

Figure 4-41 Shell Big Mineral Creek Breakdown Seismic Signals, February 26, 1980

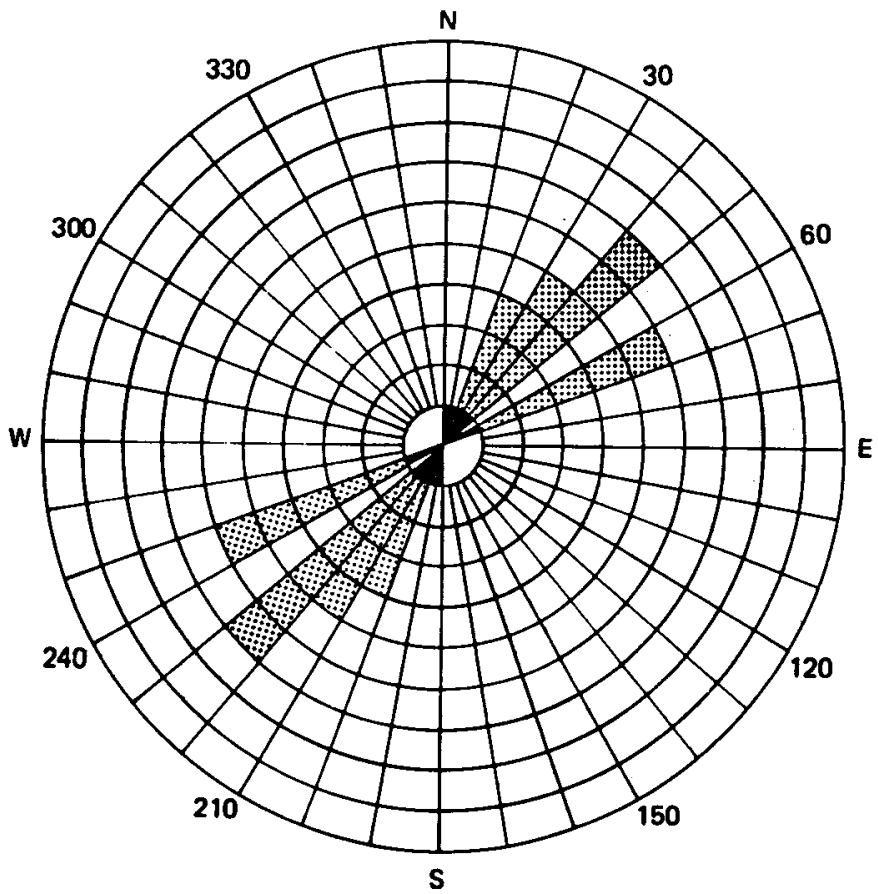

Unit 309

Figure 4-42 Shell Big Mineral Creek

Breakdown Seismic Signals,

February 16, 1980 
(Italics denote changes since March 31, 1980.)

southeast (Line 1) and the second was that of the fracture well casing (Line 2). Both methods produced signals of comparable strength. The fracture well casing, however, produced the best looking waveshapes. The potential measurement boxes (PMBs) which monitor the probe potentials were operated at a gain of $72 \mathrm{db}$. The risetime of the injected current pulse was increased. Shielded current wire was used throughout the PMB portion of the system crray.

The primary data analysis has been completed. The predominant direction indicated was between $50^{\circ}$ and $60^{\circ}$ (as shown in Figure 4-43).

Software changes have been campleted in the seismic data analysis program to investigate vertical angles to the seismic source. Applying this progran to the Shell Big Mineral Creek experiment indicates only a small rotation from the data previously reported.

Two downhole hydrophone systems, one using the Edo Westem transducers and the other using the ITC transducers, hove undergone a series of tests in the Sandia WHIPP No. 13 borehole at Carlsbad, New Mexico. The tests included a vibrator which produced ow audio signals at the surface from $30 \mathrm{~Hz}$ to $120 \mathrm{~Hz}$ and a series of surface explosive shots at distances of approximately $100 \mathrm{ft}$ to $500 \mathrm{ft}$ from the borehole. Data was collected using both systems at depths of $730 \mathrm{ft}, 830 \mathrm{ft}, 1,800 \mathrm{ft}$ and 3,200 ft from the surface. In addition, data was collected in the vibrator tests at 10-ft intervals from $1,650 \mathrm{ft}$ to $1,850 \mathrm{ft}$.

Analysis of the explosive shot data indicates that a difference is discernible in arrival times to the transducers and that determining the shot location is feasible. However, the accuracy of locating the shot position has not as yet been determined.

\section{BOREHOLE RESISTIVITY SYSTEM}

A parametric study was completed using the recently developed onedimensional solution. The study revealed:

- the sensistivity of probe measurements (potentials or equivalent apparent resistivities) to variations in the radial extent of the invaded zone, and

- the sensistivity of probe measurements to the structure and transition region when this region is moved to several different radial positions.

The conductivity profiles and predicted apparent resistivities at the probe are shown in Figures $4-44$ and 4-45. The apparent resistivities show sensistivity to large movements (meters) of the entire transition region, and also to transition region details when the transition region is close to the probe (< 4 meters). When the transition region is moved out to 8 meters, the sensistivity to its stmucture is degraded. 


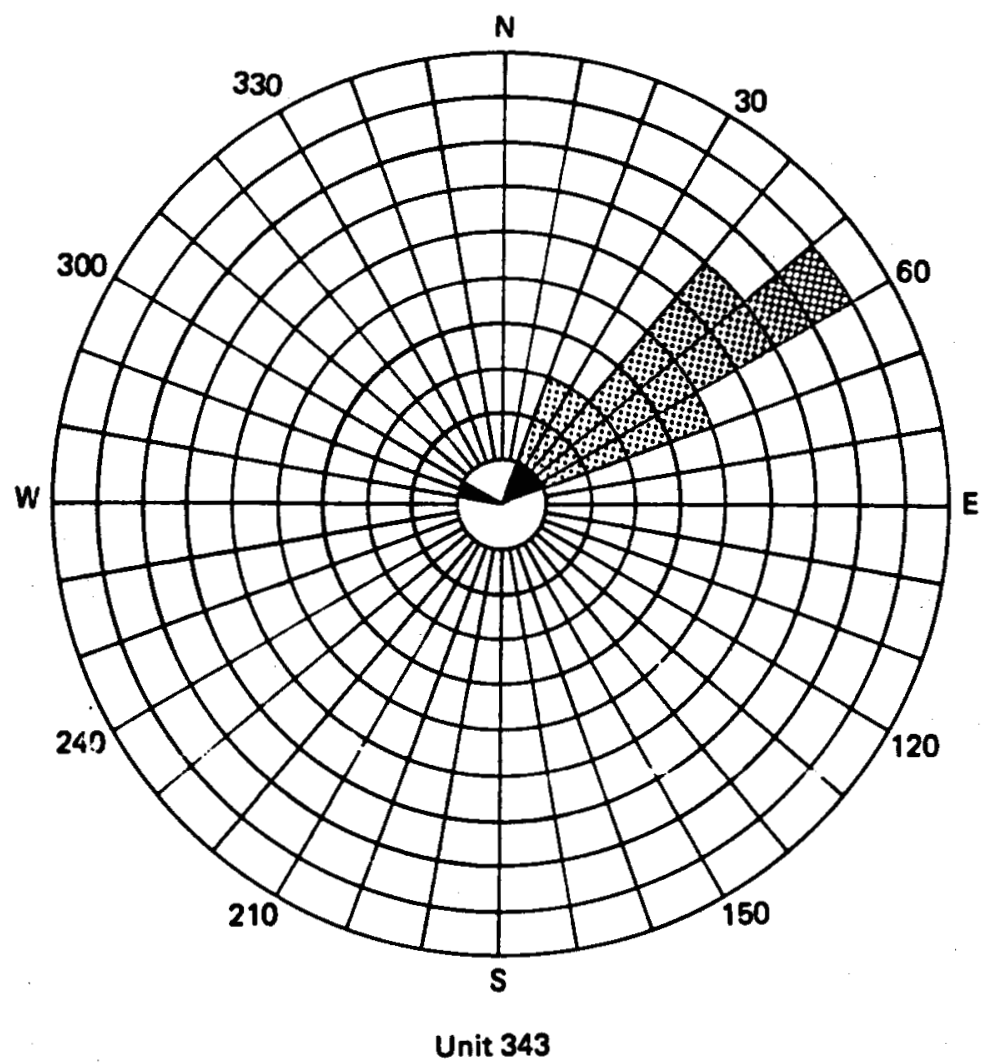

Figure 4-43 Shell Big Mineral Creek SEPS

Electrical Direction, February

17,1980 


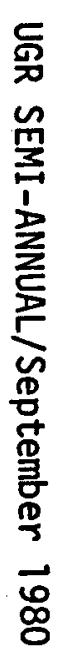

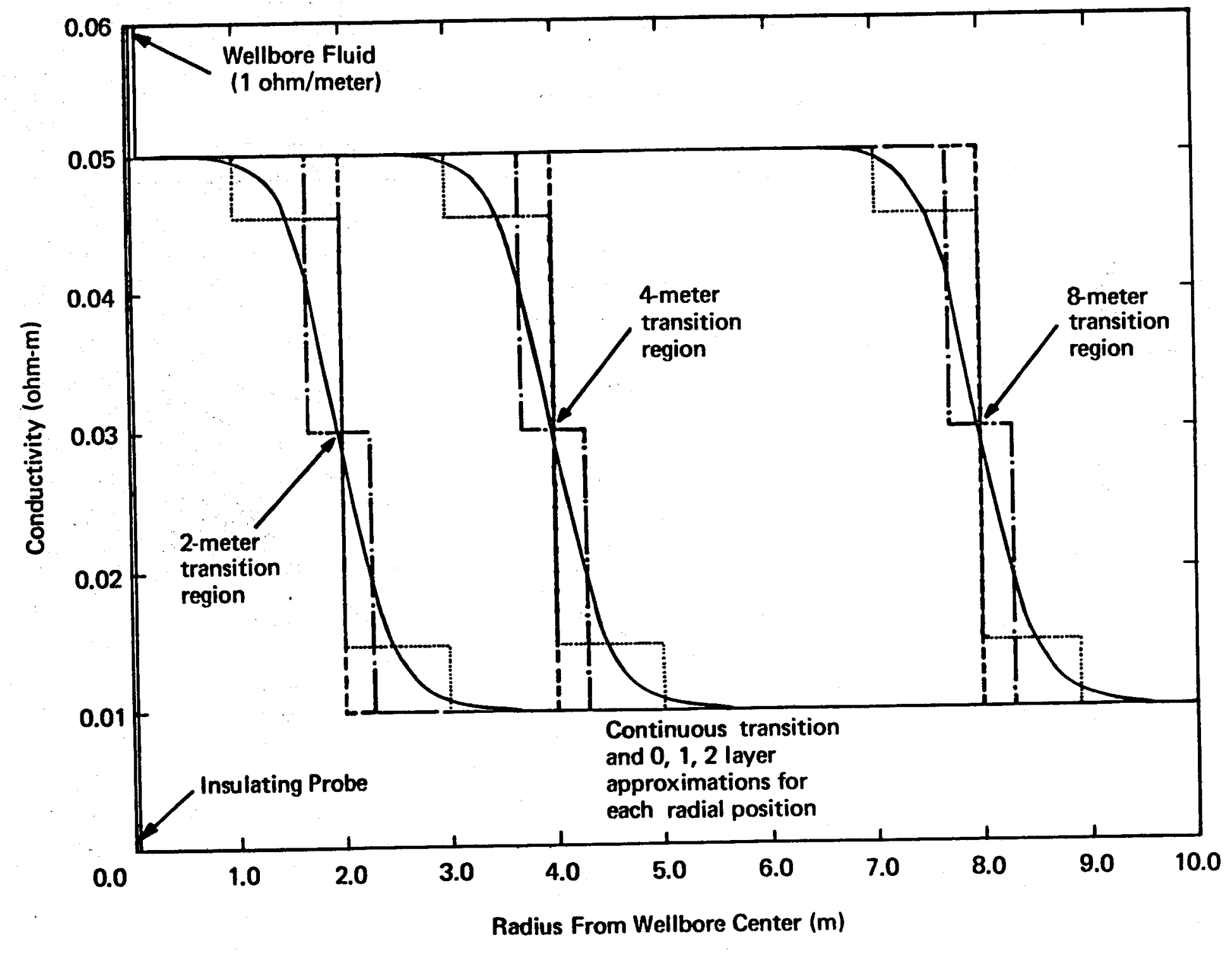

Figure 4-44 Conductivity Profile 


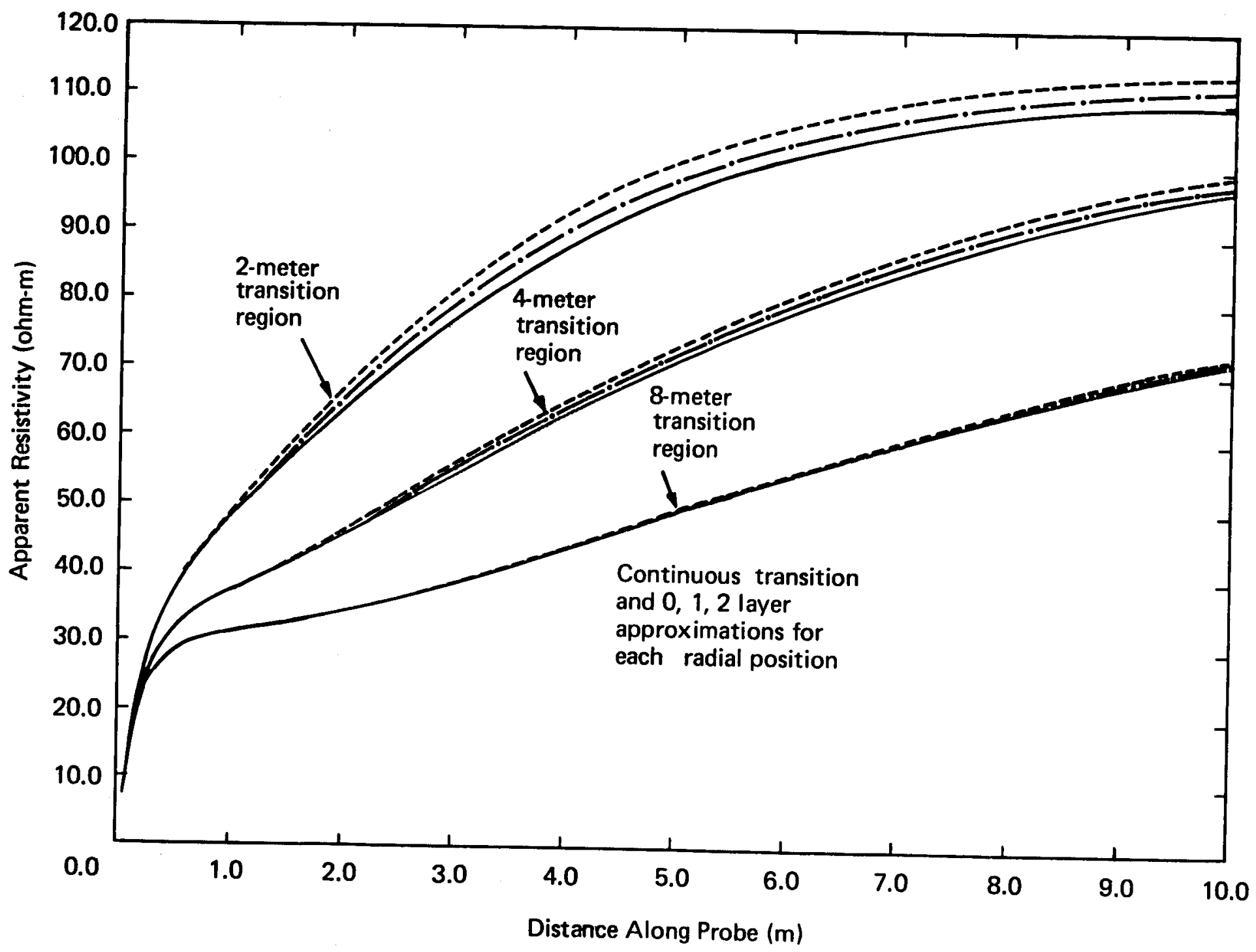

Figure 4-45 Predicted Apparent Resistivities at Probe 
(Italics denote changes since March 31, 1980.)

The width of the transition region remained constant throughout. The transition region might make a greater impact on probe measurements if it is of greater width.

The two dimensional finite element solution to the borehole resistivity problem become operational in June. The code was tested on a radially stratified resistivity profile which could then be compared with the previously developed one dimensional model. The physical model represents a $0.0381-m$ radius probe inside a $0.0762-m$ radius wellbore fluid. The wellbore fluid conductivity was taken to be $1 \mathrm{ohm} / \mathrm{m}$, the invaded zone conductivity $0.05 \mathrm{ohm} / \mathrm{m}$, and the virgin formation conductivity $0.01 \mathrm{ohm} / \mathrm{m}$. The invaded zone extended out to a radius of $2 \mathrm{~m}$. A comparison of the resulting potentials and apparent resistivities from the one and two dimensional models is given in Figure 4-46. The disorepancy in opparent resistivity at larger distances from the current source opparently results from having too few elements in the vicinity of the wellbore.

Increasing the number of elements along the two dimensional borehole model in the finite element code brought calculations into closer agreement with the one dimensional model, as shown in Figure 4-47. The remaining discrepancy may be due to the very large aspect ratio of elements near the borehole. These elements are a necessity if a rectangular mesh structure is maintained. Since the reverse problem will likely conform to this rectangular stmucture, the 2 to 3 percent error near ten meters will have to be tolerated. The ridge regression inversion algorithm (specifically Margvardt's method) is now being coded and wizl be used with both one and two dimensional models.

\section{ELECTROMAGNETIC IMPEDANCE SOURCE FOR THE EVALUATION OF TIGHT GAS RESERVOIRS}

\section{Dielectric Modeling}

The bulk dielectric properties of an inhomogeneous material are frequency dependent. This frequency dependence or dispersion has been observed by several investigators for systems comprised of sandstones saturated or partially saturated with saline water. In past work, such a system has been modeled as a nonconducting material with imbedded inclusions of conducting fluid. The shape of the inclusions is very important: long and thin inclusions cause more dispersion than spherically-shoped ones. In this model, distribution functions for the aspect ratios of pore structures are generated from the dielectric data. It is hoped that these distribution functions can be related to fluid and gas flow parameters. 

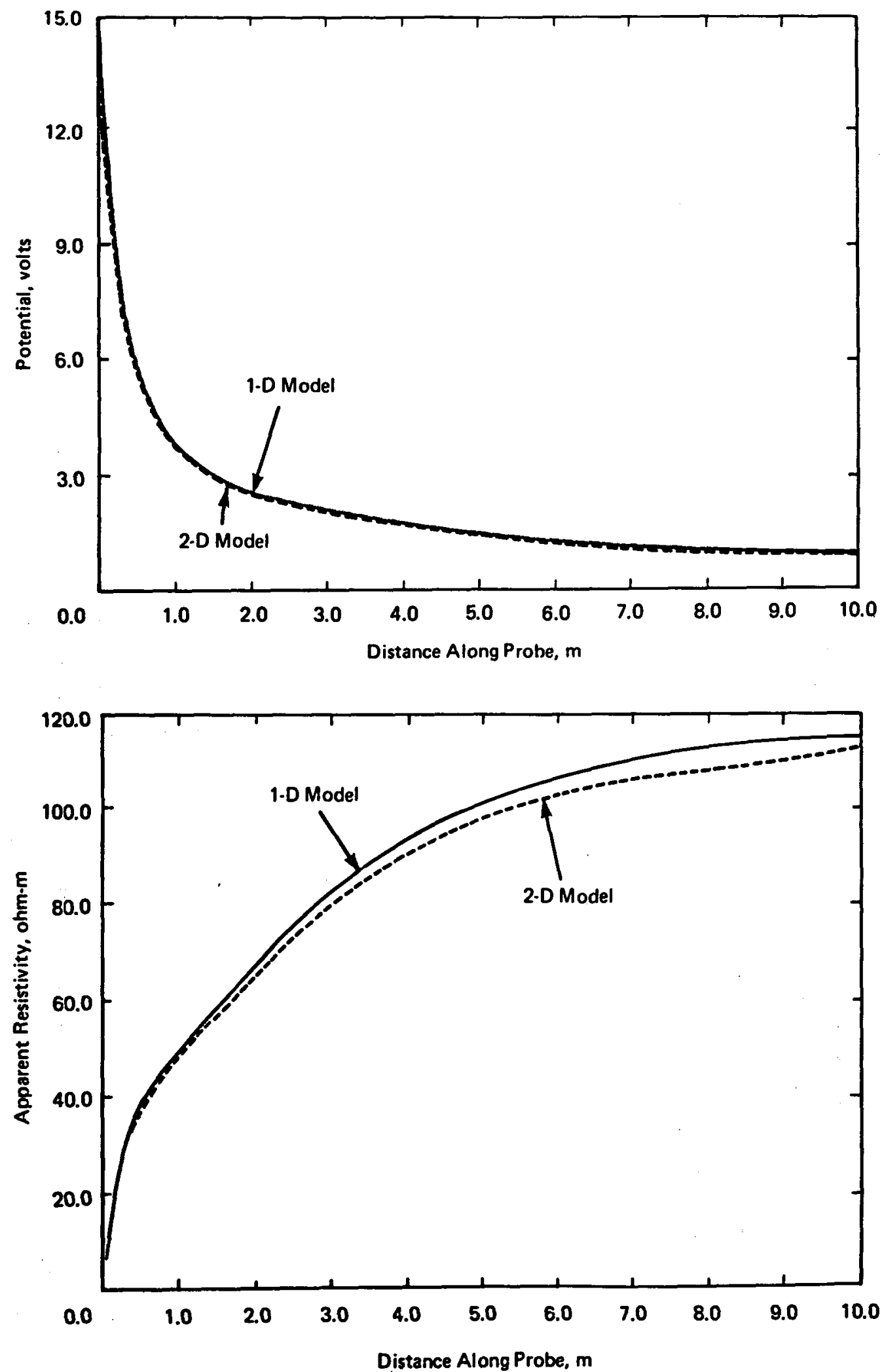

Figure 4-46 Comparison of Potentials and Apparent Resistivities from One and Two Dimensional Models 

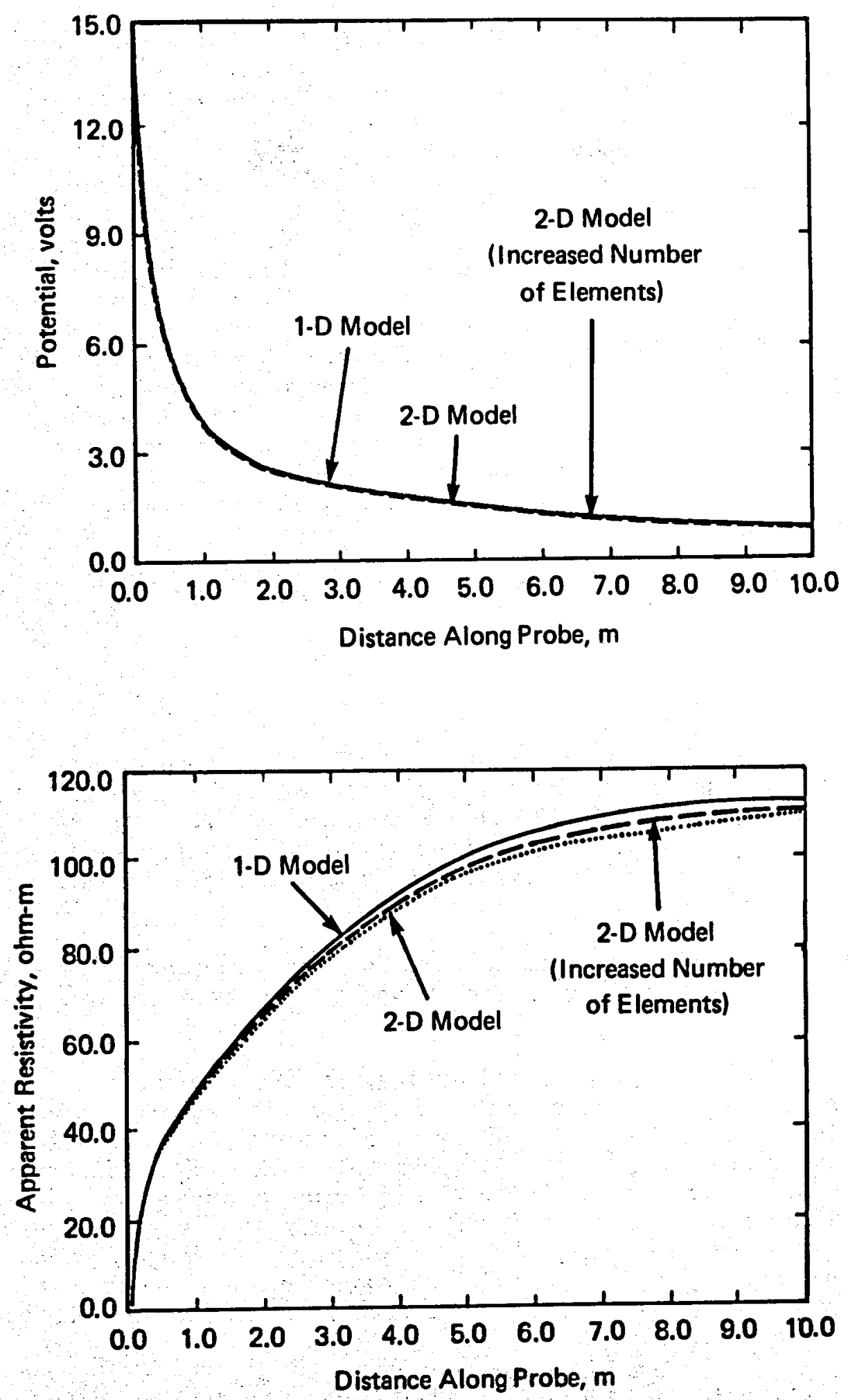

Figure 4-47 Comparison of 1-D and 2-D Mode1 Calculations 
(Italics denote changes since March 31, 1980.)

Work in July concentrated on digitizing optical pictures of rock scomples and trying different approaches to define parometers to suitably describe the observed pore structure. These pore structures will be placed into the dielectric models. Figure 4-48 shows the result of digitizing such a picture. The photograph is of sample No. 4403.8 from the CIGE No. 21 core which was permeated with blue-dyed epoxy allowing the connected pores to be located and their outline traced. Figure 4-49 shows the same picture after computer analysis. The individual line segments represent constant spacing. Finding mean and standard deviation of the segment lengths provides some indication of the pore shape. The line segments were drown using the picture frome as the principal axis. If, however, each pore has its own axis system defined simply by the longest dimension, then a measure of the anisotropy of the system can be obtained. Figure 4-50 shows such an analysis. The angle between the pore principal axis and the picture horizontal axis is plotted for each pore. The figure shows that a weak anisotropy might exist, but further work is necessary to determine the best method of defining the pore axis system and then the anisotropy.

\section{ELECTROMAGNETIC LOGGING}

\section{Laboratory Investigations}

To obtain accurate experimental data of the dielectric properties of rock scomples, past and present techniques must be understood. A method employed by G. $R$. Othoeft (USGS) compares the applied waveform to that passed through the sample and determines the attenuation and phase shift of the signal in the somple. From this the dielectric properties can be obtained.

A progran has begun at Sandia to attempt to produce synthetic rock samples to simulate rock properties such as pore geometry and fluid flow.

A procedure using only the small sphere size was implemented. Large dicometer (up to $2 \mathrm{in.}$ ) samples were made from the spheres at several temperatures. Then several smaller samples were cored from the large sample and a surface area analysis accomplished. This will not only provide surface area data, but will also give an average pore size distribution and the connected volume porosity. By taking several small samples from the large one, the homogeneity of the large samples can be determined. If it is possible to produce a homogeneous scomple, the next step would be to check the procedure to see if a reproducible porosity can be obtained.

The analytical solutions for homogeneous and two-zone cases have been computed this period for low frequency ( $20 \mathrm{kHz}$ and $2 \mathrm{MHz}$ ) interrogations. Results were mun to provide comparisons with those being obtained through the finite-difference-equation opproach. For $20 \mathrm{kHz}$ coupling 


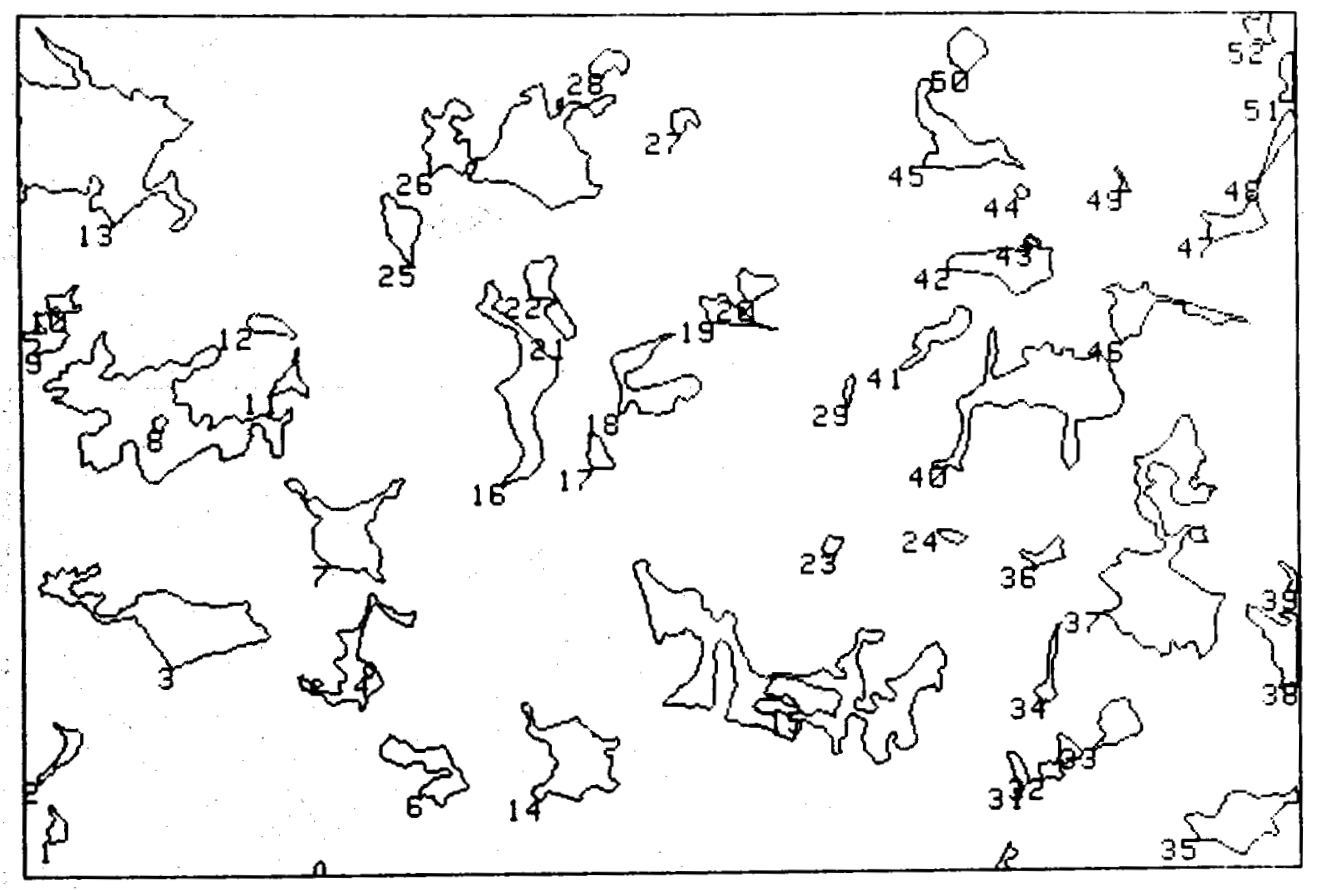

Figure 4-48 Digitization of Sample No. 4403.8 from CIGE No. 21 Core

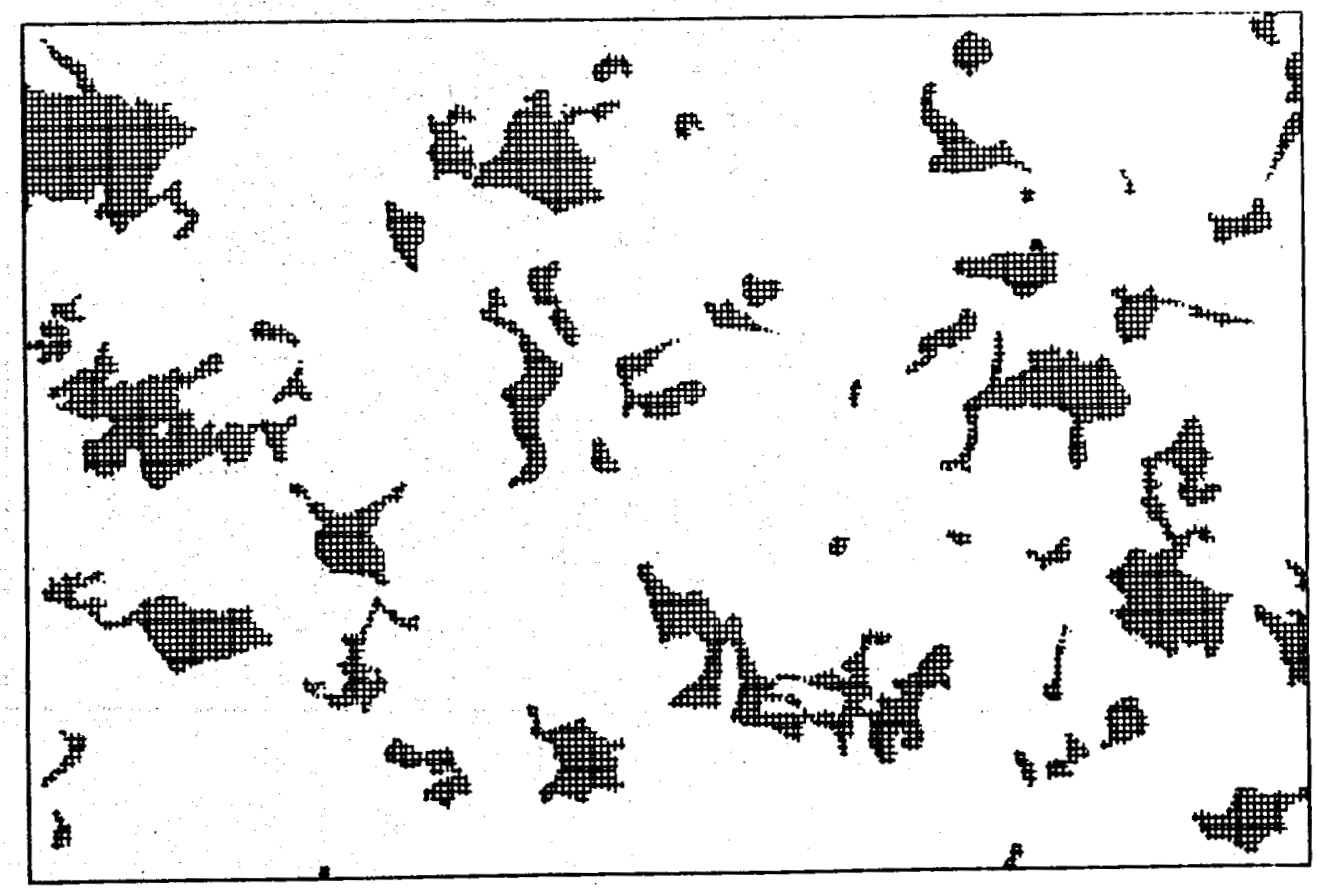

Figure 4-49 Computer Analysis of Digitized Sample No. 4403.8 

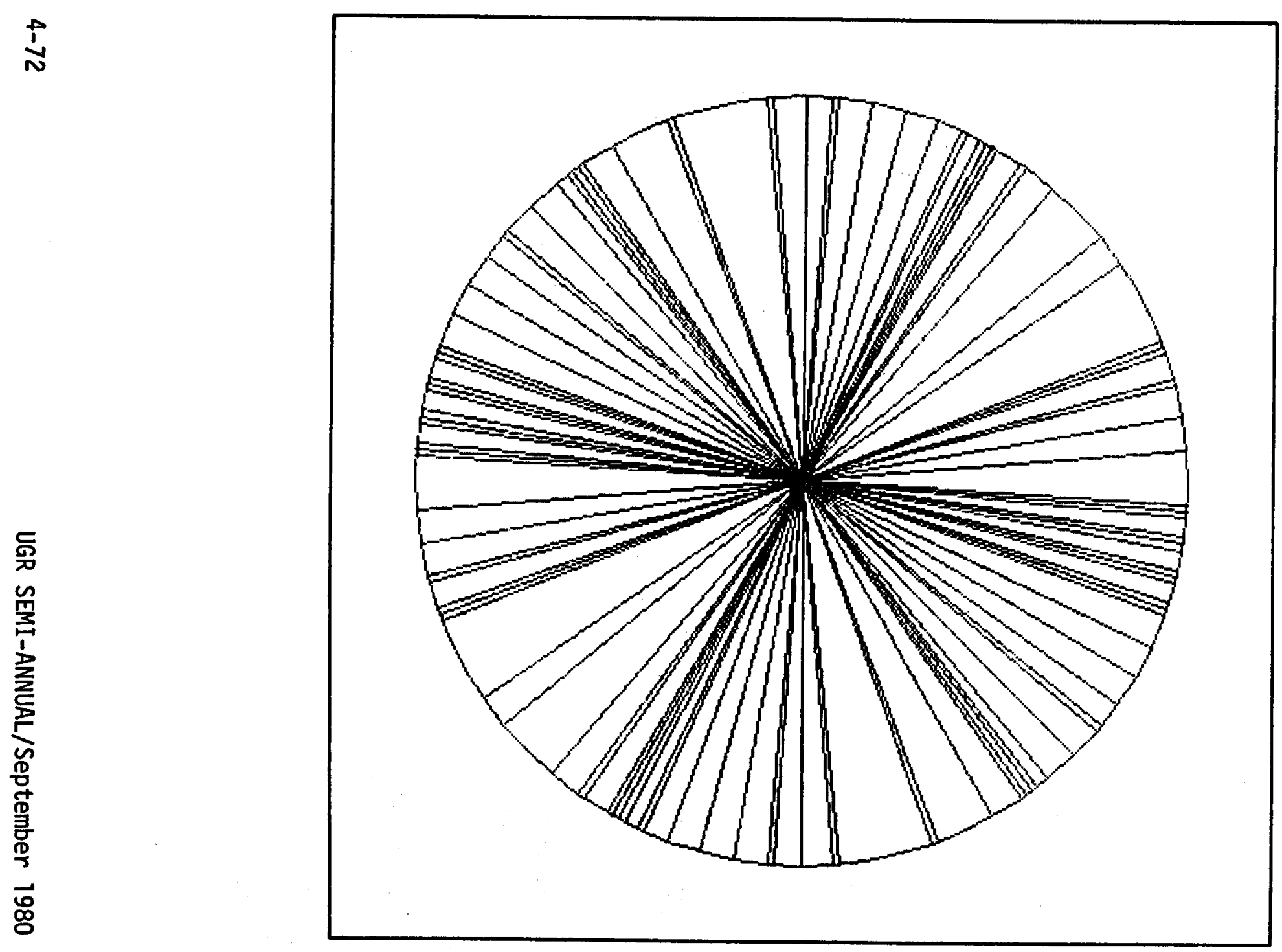

Figure 4-50 Principal Pore Axis Angles 
(Italics denote changes since March 31, 1980.)

with two coils spaced less than 3 coil-diameters, the results of two approaches agree to less than 1 percent of correct values. However, results for large coil springs and higher frequencies by the infinitedifference-equation opproach are not available.

The modeling of coaxial coils was completed for homogeneous formation interrogations. The transfer impedances of coupling coils have served as the measurable responses to evaluate the refractive index of an undetermined formation. The refractive index charts are now in use as a baseline for quantifying perturbutions due to borehole conditions and invasion profiles.

Drilling muds with law conductivities were found to have negligible effects, which is consistent with published results of other investigators. On the other hand, muds with high conductivities have significant effects for operating frequencies higher than $30 \mathrm{MHz}$. Inversion charts with borehole effects are being compiled for documentation.

The development of a generalized $\mathrm{N}$-Zone code has been undertaken to assure that a formation can be evaluated when a general invasion profile is specified. Extremely slow convergence of the simpler problems in the past has miled out the straight forward integration for the $N$-Zone case. The tedious analytical transformations for ropid convergence have been performed and coded for computations. Preliminary results for this generalized $N$-Zone code indicate an accuracy to the 12th digit when the physics and geometry were reduced to a homogeneous formation. Reductions to other configurations are in progress to check published results of other investigators.

\section{HIGH RESOLUTION SEISMIC FORMATION MAPPING}

Results of the 3-D seismic reflection sumvey at the Bryson Canyon site were interpreted.

Figures 4-51 and 4-52 reviev the typical results of modeling a sandstone channel. Figure $4-53$ shows a somple of a two dimensional, vertical slice of the actual field data. A reflection response showing similar characteristics to the model response is indicated. This and other channellike responses may be followed from this section to others across the site; in this way the channels may be mapped. An alternate method of viewing the data is a three dimensional time slice where the data presented are sliced horizontally at a given value of reflection time. A groy scale represents the peaks and troughs of the seismic data in this format. Figure 4-54 shows a time slice at 0.128 second. The unit labeled "C2" in the figure represents a channel trending to the upper right of the figure. The data from additional slices also show components of dip to the left and bottom which explains why the entire channel does not show on this single time slice. Projecting the trends and calculated dips of several different channel responses to the outcrop area at this site, candidate channels are found at those locations. 

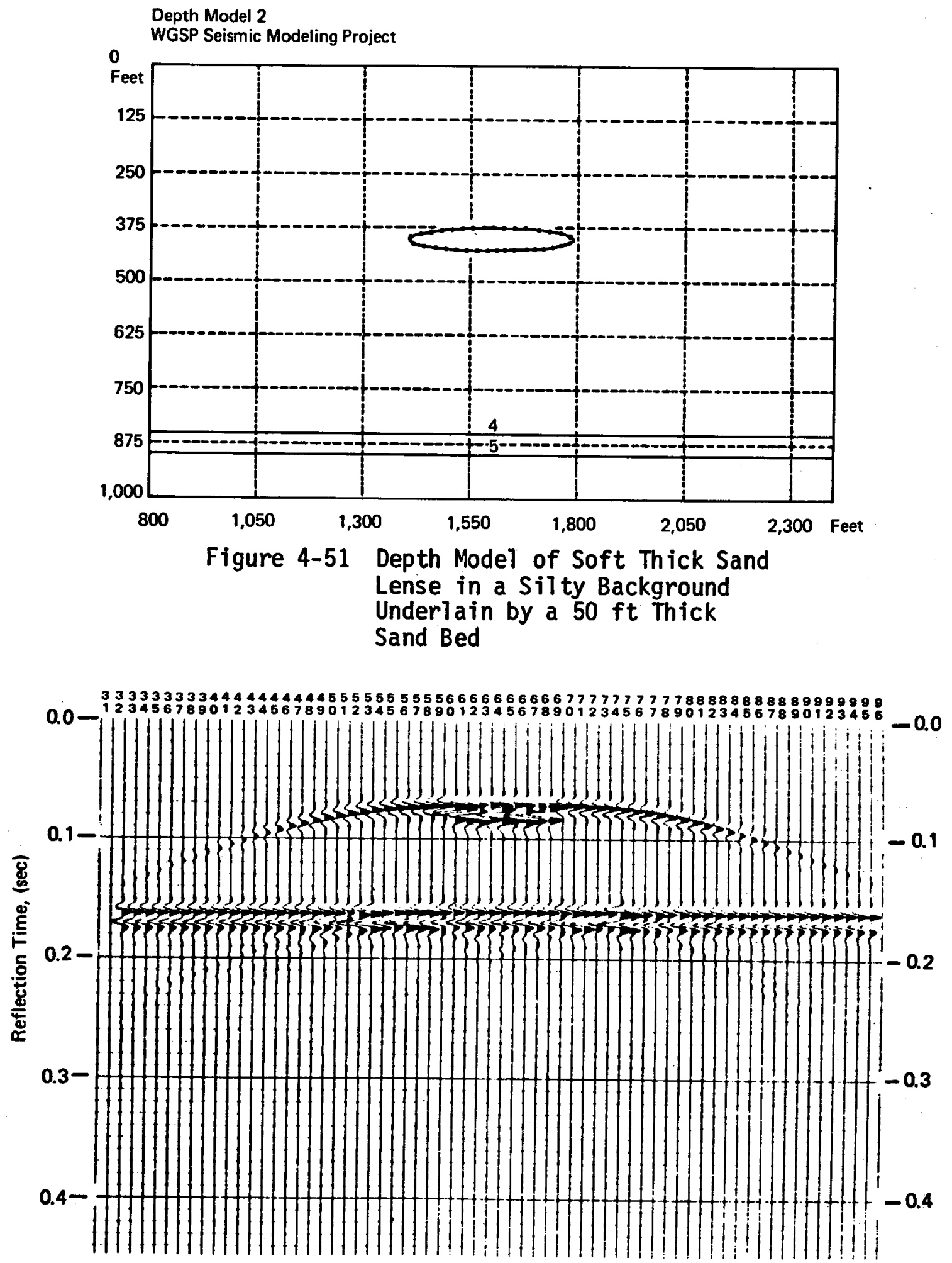

Figure 4-52 60-140 Hz Wavelet Record Section of Depth Mode1 


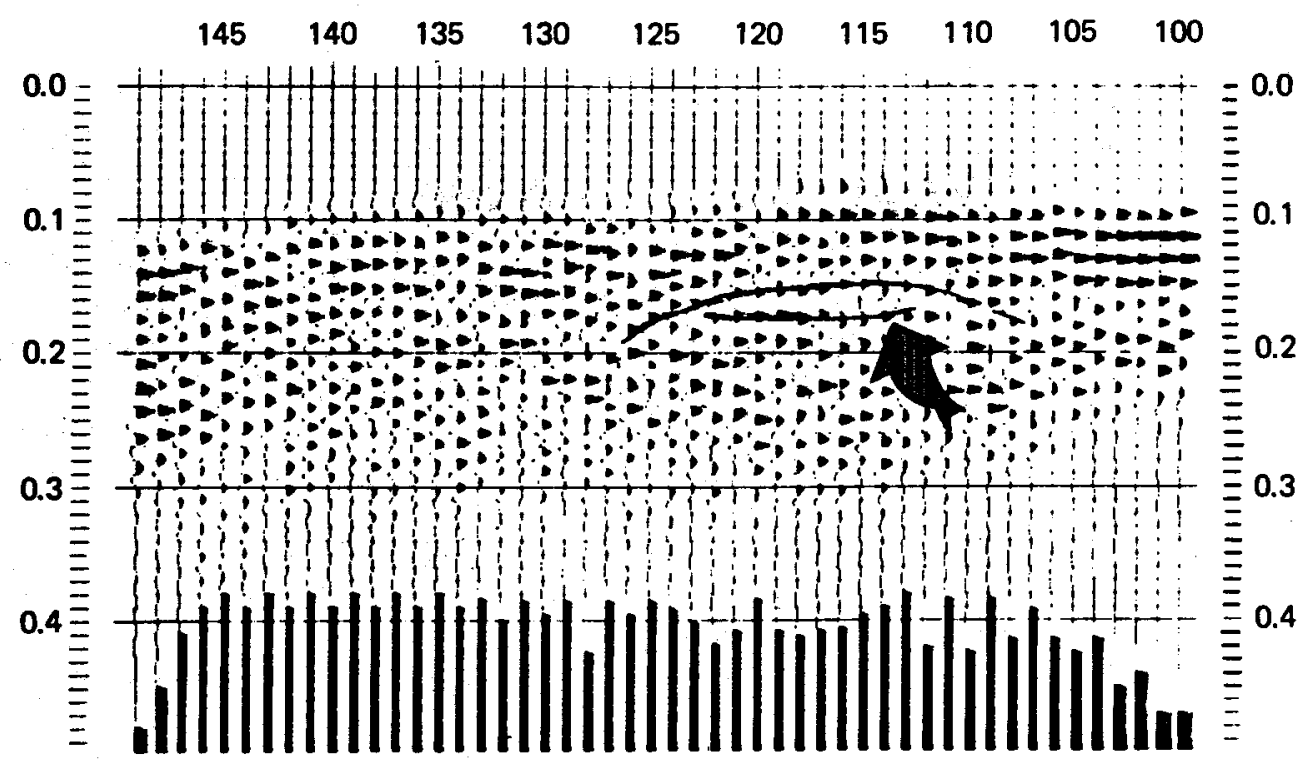

Traverse 1

(Arrow denotes lense type reflection)

Figure 4-53 Two Dimensional Record Section Taken at Bryson Canyon Site

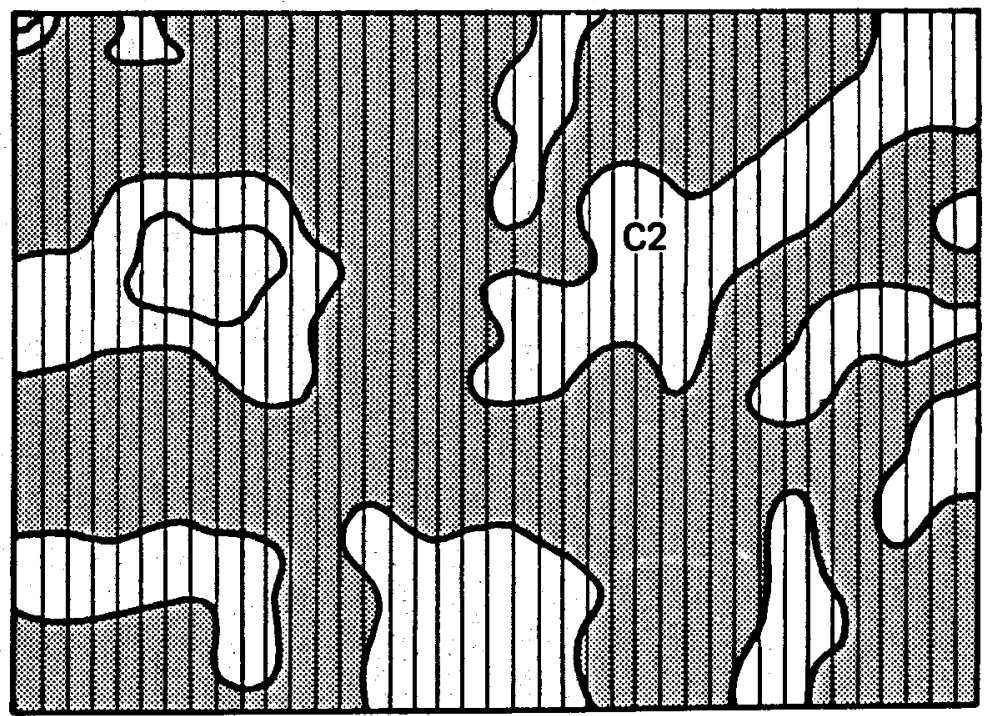

$$
T=0.128 \cdot \mathrm{sec}
$$

Figure 4-54 Three Dimensional Time Slice at $\mathrm{T}=0.128 \mathrm{sec}$. (Area labeled $\mathrm{C2}$ is interpreted as a channel) 
(Italics denote changes since March 31, 1980.)

The results of the seismic survey led to an interpretation of at least three sand channels trending across the survey area. These channels are referred to as " $A$," " $B$ " and "C." $C$ is intersected by $C K$ GeoEnergy well DOE-GC-1 as determined by logs from the well and a tie to the seismic data using a synthetic seismogram. The average trend of each channel is roughly $N 60^{\circ}$, although each meanders in the nature of river channels. To determine where these channels should crop out on the eastern cliff face of the site, the N600E bearing is projected up the measured dip from the known depth $(C)$ or estimated depth ( $A$ and $B$ ) at the survey area. Figure 4-55 shows the survey area, projected trends and estimated outcrop positions of channels $A, B$ and $C$. Also shown are existing channels measured in outcrop. Comparison of seismic projections with measured estimates of candidate channels is given in Table 4-10. Although not identical, the agreement between seismic and outcrop (excluding the bearings of $C$ and number 8) are quite good regarding position and bearing, especially when considering the seismic is extrapolated over 1,000 ft and the outcrop determinations are statistical in nature.

The overall result of the seismic model study and field experiment is in preparation.

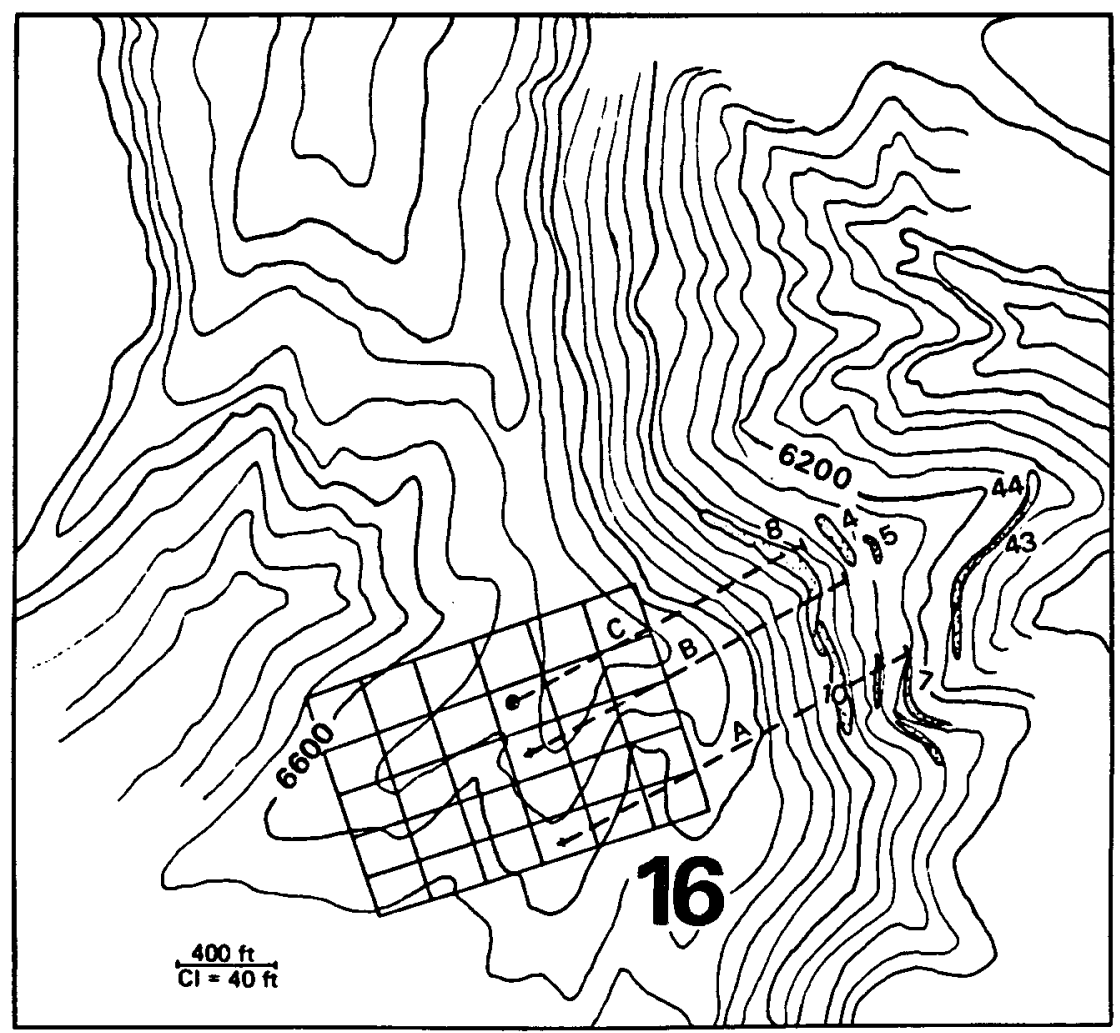

Figure 4-55 Map Showing Projected Trends of Channels A, B and C, Projected Outcrop and Positions of Mapped Outcropping Channels in Area 
Table 4-10 Comparison of Seismic and Outcrop Descriptions of Channel Sands tones

\begin{tabular}{|c|c|c|c|}
\hline Channel & $\begin{array}{c}\text { Elevation (top), } \\
\mathrm{ft}\end{array}$ & $\begin{array}{c}\text { Thickness, } \\
\mathbf{f t}\end{array}$ & Bearing \\
\hline A & 6,240 & $40(?)$ & $N 60 E^{1}, N 60 E^{2}$ \\
\hline 7 & 6,240 & 8 & $N 25 E^{3}$ \\
\hline B & 6,340 & $40(?)$ & $N 60 E^{1}, N 80 E^{2}$ \\
\hline 10 & 6,400 & 20 & $N 100 E^{3}$ \\
\hline 5 & 6,280 & 10 & N $25 E$ \\
\hline C & 6,370 & $40(?)$ & $N 60 E^{1}, N 110 E^{2}$ \\
\hline $\begin{array}{l}8 \\
4\end{array}$ & $\begin{array}{l}6,410-6,420 \\
6,310-6,320\end{array}$ & $\begin{array}{l}26 \\
25\end{array}$ & $\stackrel{N}{N} 20 E^{3}$ \\
\hline
\end{tabular}

1 - average channel trend

2- projected meander trend at outcrop

3 - statistical fit of meander trend at outcrop 
(Italics denote changes since March 31, 1980.)

4.4 FIELD TESTS AND DEMONSTRATIONS

4.4 .1 B ACK GROUND

Field tests are essential to verify the findings of laboratory tests and modeling studies. The field test and demonstration program involves cooperation between industry and goverrment and also interacts geologic studies with laboratory research and development. The following projects are in active status in WGSP:

- a dry gas injection experiment in the Wattenberg Field, Colorado, by Colorado Interstate Gas Company,

- MHF demonstrations by Gas Producing Enterpmises in the Uinta Basin, Utah,

- MHF treatment of the Cotton Valley Limestone Formation in Limestone County, Texas, by Mitchell Energy Corporation,

- MHF demonstration in the Piceance Basin, Colorado, by Mobil Research and Development Corporation, and

- a mineback testing program by Sandia Laboratories.

Table 4-11 summarizes completed and active WGSP MHF treatments. Progress of these projects is presented in the following sections.

The Western Gas Sands Project has initiated a major field experiment which will provide an opportunity for $R \& D$ in the tight gas reservoirs in the western United States. The experiment's overall objectives are (1) to obtain geologic characterization of low permeability, lenticular gas sands and (2) to evaluate state-of-the-art and developing technology to optimize gas recovery from these reservoirs.

The Multi-Well Experiment (MWX) consists of two phases. Phase 1 Drilling of the first well, a stress well and another offset well. Phase 2 - A series of well tests and stimulation tests with the attendant analyses and evaluation. The planning associated with Phase 1 is fairly well developed and some pre-drilling activities and studies are already underway. The planning associated with the second phase is also underway.

The cxperiment has six tasks: drilling and coring, laboratory testing, stimulation, production testing, field diagnostics and analysis and cvaluation. A variety of contractors and agencies are to be involved in the acquisition and analysis of the data. These analyses are 
Table 4-11 MHF Contract Location and Frac Data

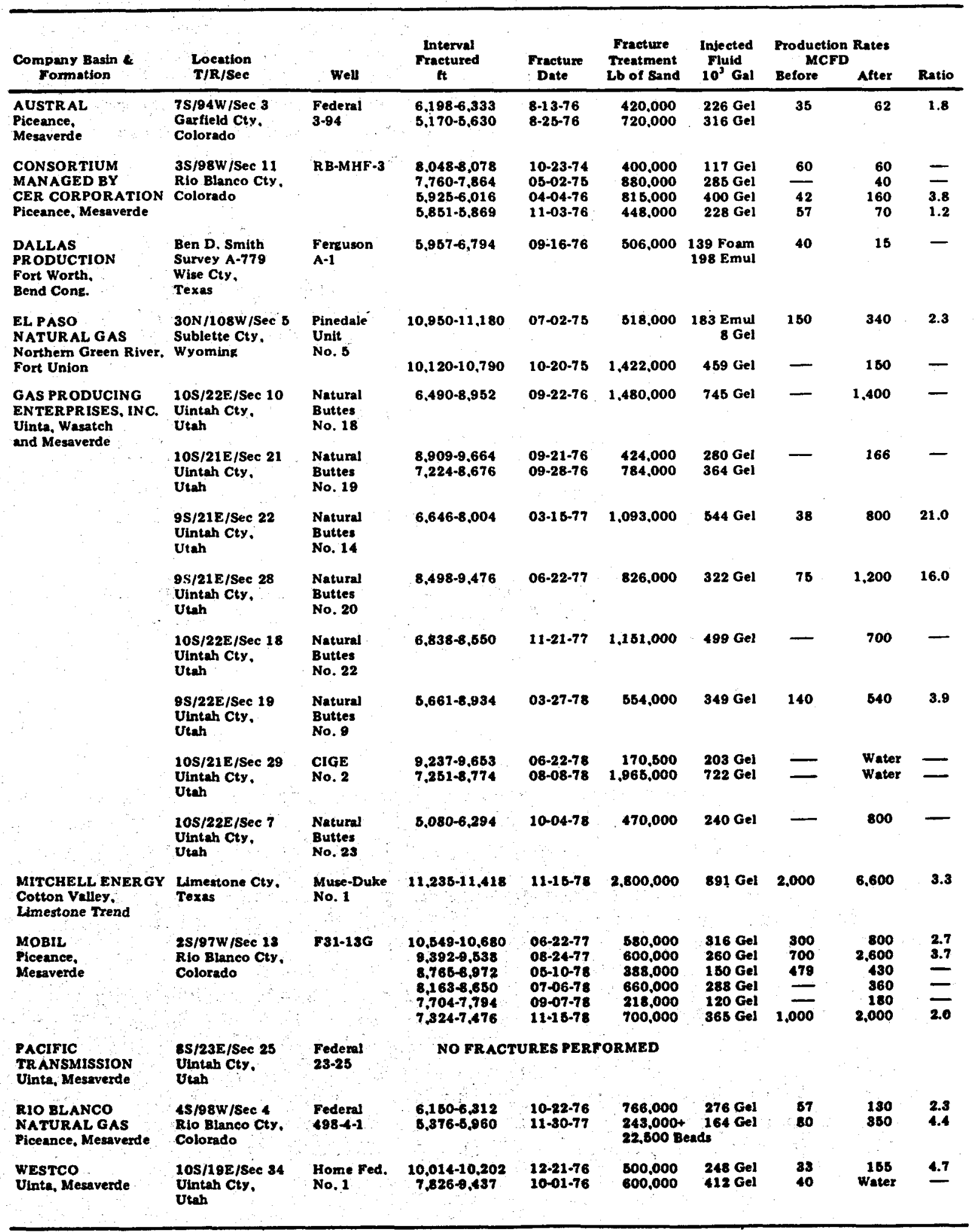


(Italics denote changes since March 31, 1980.)

expected a yield a geologic characterization of lenticular reservoirs, a reservoir model, hydraulic fracture stimulation model with resultant fracture geometries, core-log-well test correlations, technology assessments, economic evaluations, and recommendations for gas recovery from these reservoirs. Responsibility for the conduct of the experiment has been given to Sandia National Laboratories by the Department of Energy. CER Corporation is the primary subcontractor. A Technical Review Panel has been formed to meet at regular intervals to review plans. plans.

Negotiations are presently underway with superior oil Company for a site, Sec. 34. T65N, R94W in Garfield County, Colorado. The site, a few miles west of Rifle in the Colorado River Valley, has good weil control and access is mostly on a paved road. Preliminary work on obtaining permits, lease agreements and the formulation of site grading plans, etc., is complete.

Assuming present negotiations for a site are successful, drilling activities should commence in the spring of 1981. At this location the Mescuerde sequence, the prime target for the experiment, is 4,000 to $8,000 \mathrm{ft}$ deep. Lowrence Livermore National Laboratory has been provided data to prepare an environmental report and permits will be obtained by CER.

Preliminary work is underway in considering well spacing. Aspects being considered are operational, having the wells in the same lens as often as possible, probable direction of fractures and use of wells for fracture diagnostics.

\section{FIELD DRILLING}

Prospective subcontractors were contacted to provide services to Sandial CER in the activities associated with drilling the first well of the project, $M W X-1$. Updating is continuing on the MWX-1 drilling manual.

The Technical Review Panel arranged visits for project logging personnel to their respective logging groups. The Milti-Well Experiment logging plan was reviewed by each of these groups in turn.

In parallel with preparations to drill and core MWX-1, work continued in the effort to adapt the pressure coring system to tight sands. This included developing a noninvasive gel, extracting gas directly from the inner core barrel and assuring the polycrystaliine diamond bit is adequate for the hard sandstones in the Rocky Mountains. This bit is being considered for its improved "regular" coring rates and core quality. This bit will be utilized on MWX initially on a pilot basis. 


\section{LABORATORY TEST (CORE ANALYSIS)}

The taking and analysis of core will provide a key link in the determination of physical and engineering properties which serve as inputs to the problem of systematically optimizing the extraction of gas from the tight gas sands. The MWX core program is comprehensive.

An interagency Multi-Well Experiment Core Advisory Comittee has been formed and is responsible for the core handling and analysis plan. The Committee had its first meeting in April at BETC and a follow-up meeting at IGT in August. The first meeting considered the overall MWX core program. The second meeting considered synergisms involving stress effects and reservoir parameters (water saturation, capillary pressure and direational permeability in the MWX core program).

other noteworthy items in the MWX core progran in the second half of FY 1980 were:

- an agreement by the USGS to measure 15 to 20 gas samples from MWX, isotope and chromotography analysis,

- an agreement by METC, Sandia, TRW and the Colorado Geological Survey to let the Colorado GS perform the analyses of MWX coal sections,

- the USGS and Mountain Fuel provided core for MWX Zaboratory studies from tight gas sands and adjoining shales, and

- two prospective sites were visited for the MWX core library; Cleveland Cliffs Fuel Company, Rifle, Colorado, April, 1980, and the DOE/Bendix facility at Grand Junction, Colorado, July, 1980 .

A formation drilling fluid invasion study was designed during meetings between Sandia and CER. The first tests were to investigate invasion of various dry sandstones by oil-base drilling fluid at a 250 psi overbalance condition, at 1500F, no mud additives, for four hours. The dry sandstones are more prone to invasion, and thus provide a worst case test. These results should help indicate how extensive an experiment matrix in terms of rock saturations and use of filter cake is needed to put limits on the comount of invasion and to help provide data for use in log interpretation.

There appear to be 2 to 3 separate invasion zones in the rocks studied to date. A preliminary interpretation is that the innermost ane (greatest invasion) is water, the middle band is oil, and the outer band of the rock (least invasion) seems plugged with asphaltines or paraffin-like material. The oil-base mud which is being used is similar to what will be used on MWX and it has 10 percent water dispersed throughout. More cnalyses will be made on these zones. 
(Italics denote changes since March 31, 1980.)

Paleomagnetism is being considered as a possible means of orienting the core. A study on paleomagnetism by Sierra Geophysics in Mesaverde core was generally inconclusive, and indicated an inability to orient better than \pm 100 .

The MWX core program will require some special items. Design has proceeded on a core gamna apparatus to correlate log depth with the driller's depth of core taken. A simple tool was designed and fabricated which could determine the attitude of a natural fracture plane in a matter of seconds without removing the core from the logging table. The tool can determine the attitude of planar sedimentary structures as well. The strike and dip of crossbeds, for excomple, might be used in conjunction with a dipmeter wireline log to orient a core or to infer the paleo-flow direction and long axis of a fluvial channel deposit. A prototype gas canister for outgassing (desorption) has been designed and fabricated. It will be used to study outgassing of organic-rich shales, the sandstones adjacent to them, and other portion of the core.

A first step in setting up a data base is the ability to translate topes from service campanies participating in MWX. Software has been developed to enable storing log data from Schlumberger topes in a common file.

\section{PRODUCTION TESTING}

Preliminary versions of three computer subroutines, designed to predict gas production for various reservoir and fracture assumptions, have been written and debugged. These routines will become part of a engineeringeconomic systems model of gas production from tight sand lenses.

The production routines calculate gas production rates over time for three situations: 1) production from a massive hydraulic fractured (MHF) well in a sand lens with the fracture minning down the length of the lens and contained within the lens; 2) production from a MHF well with the fracture muning perpendicular to the lens axis breaking out of the lens and breaking back into neighboring sand lenses; and 3) production from a multiple radially fractured weil in a sand lens. A tentative sequence of testing is now under consideration.

\section{FIELD DIAGNOSTICS}

A 3-D seismic model has been developed to determine the trend and extent of the lenticular gas sands. Previously tested at 1,300 ft in the Uinta Basin, further testing will be on the Multi-Well Experiment.

A regional stress survey was initiated. Preliminary work was based in part on an éarlier USGS stress sumey. Early planning was conducted. for the MWX-2 well to determine in situ stresses throughout the vertical section for subsequent hydraulic fracture design. This design will implement the perforations and mini-fractures which are made along the length of this weil. 


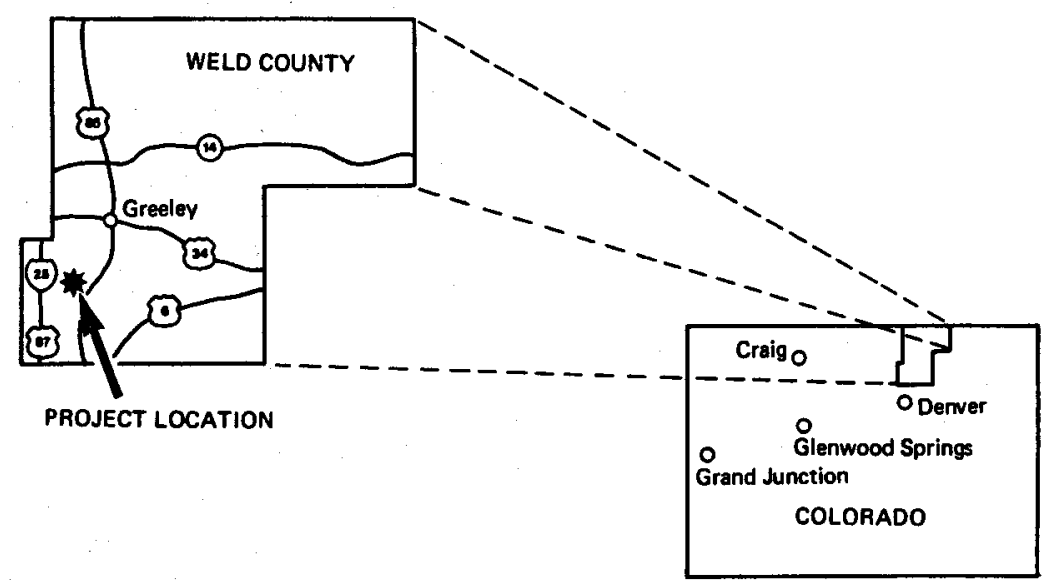

Contract Date:

Anticipated Completion Date:

Total Project Cost:
September 1, 1977

March 1, 1981

DOE $\ldots \ldots \ldots \ldots \ldots \ldots \ldots \ldots \ldots \ldots 75,000$

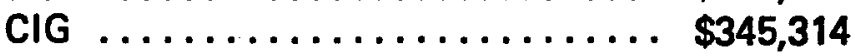

Total $\$ 420,314$

Principal Investigator:

David Wilson

Technical Project Officer for DOE:

C. H. Atkinson

\section{OBJECTIVE}

Cyclic injection of dry natural gas is the method to be used to increase production of tight gas sands. 
(Italics denote changes since March 31, 1980.)
$4 \cdot 4 \cdot 2$
COLORADO
I NTERSTATE
GAS
C O MPANY

Measurement of bottom-hole pressure at both the Miller No. 1 and the Sprague No. 1 wells was completed. The Rolo calcivon chloride dehydrators did not perform satisfactorily, and were replaced with a giycol dehydrator installed on the suction side of the compressor to allow operation in either direction. CIG tested a new pump on the glycol dehydrator. Since this new pump can operate down to 40 psi, it is operable at any pressure compatible with the compressor.

CER Corporation analyzed the BHP data for the Miller No. 1 well. The pressure data from Cable Inc. on the Sprague No. 1 well indicates that there has been some improvement in formation permeability. The Sprague No. 1 well began exhibiting radial flow after $500 \mathrm{hrs}$; previously this well had not reached radial flow after 1,100 hrs.

Production from Sprague No. 1 well and injection into the Miller No. 1 well began May 7 and continued until May 15. The direction of the cycle was reversed and production from the Miller and injection into the Sprague started May 15 and continued until June 5. This longer than normal cycle was an attempt to inject as much gas as possible into the Sprague. The injection and production cycles and the new ethylene glycol dehydrators worked well. The water content of the gas injected remained a constant $3.5 \mathrm{lb}$ of water per MMCF.

Figure 4-56 illustrates production and injection and associated pressures of these wells.

Production from the Miller No. 1 well and injection of dehydrated gas into the Sprague No. 1 well began May 15 and continued until June 5 . This cycle was longer than normal in an attempt to inject as much gas as possible. However, Miller No. 1 did not have sufficient deliverability to supply the injection for three weeks and additional gas was taken from the pipeline. Due to the increased cost, it was decided to return to the two-week production/injection schedule. 

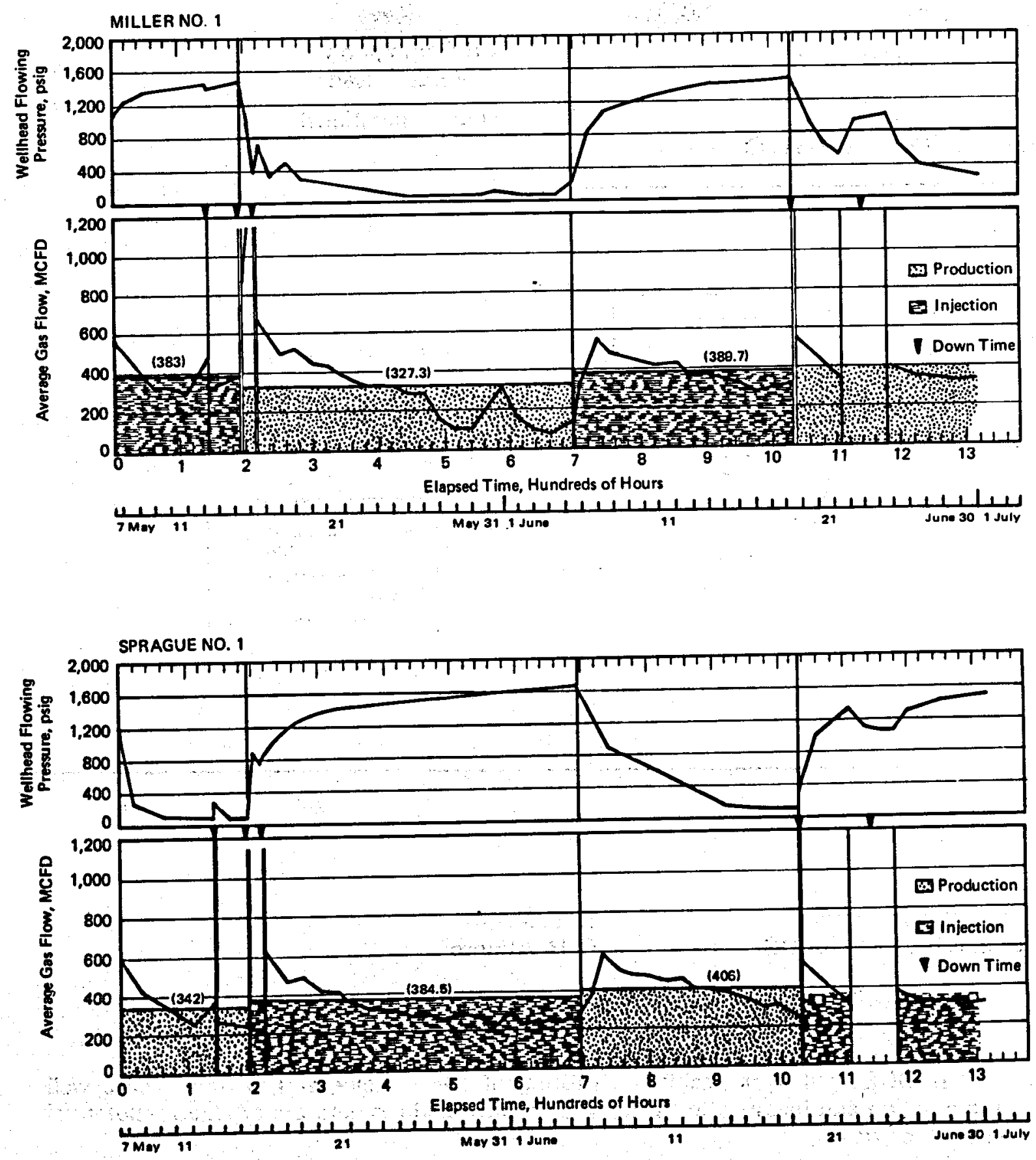

Figure 4-56 Production and Injection Volumes and Associated Pressures of CIGE Miller No. 1 and Sprague No. 1 Wells 
DOE WELL

\section{TEST FACILITY}

CER Corporation

Las Vegas, Nevada

DE-AC08-79-BGO1569

Status: Operational

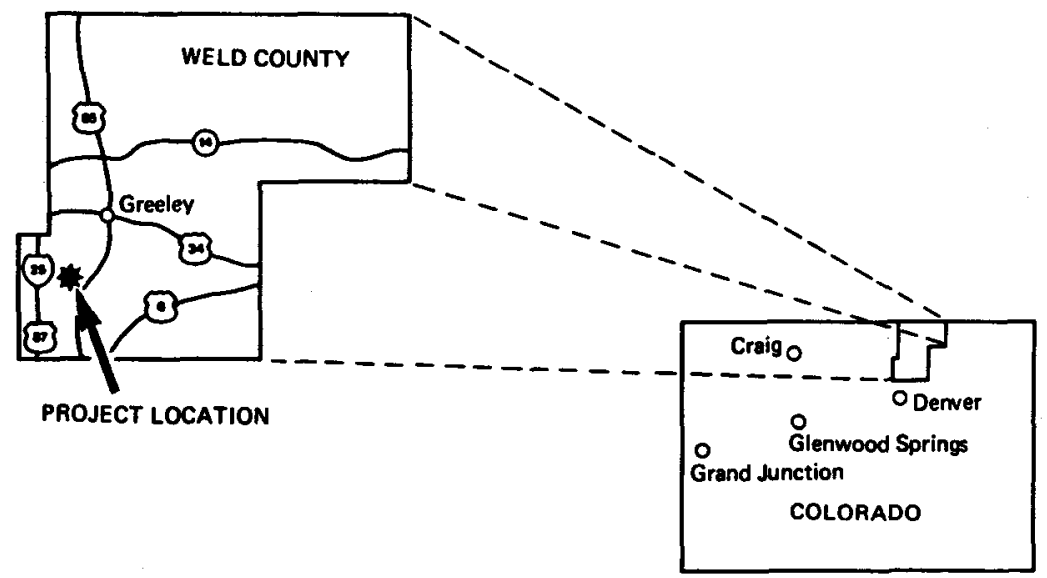

Principal Investigator:

R. L. Mann

Technical Advisor for DOE:

C. H. Atkinson

\section{OBJECTIVE}

The DOE Well Test Facility, consisting of two vehicles, will provide a deep well instrumentation and investigation system to monitor and evaluate the productive potential of all types of wells. 
(Italics denote changes since March 31, 1980.)

\subsubsection{DOE WELL TEST FACILITY}

In support of the joint DOE/CIG dry gas injection experiment, the DOE Well Test Facility was on site at Miller No. 1 in the Wattenberg Field, Colorado, duming April. The remaining portions of a modified isocronal test were campleted and analysis of the dry gas injection data gathered during April and previous months continued during May.

Bottom-hole pressure data gathered from the CIG Miller Do. 1 well, Wattenberg Field, Colorado, was analyzed. Preliminory results derived from the linear analysis indicated substantial improvement of the zone surpounding the fracture.

The well test facility underwent modifications in Las Vegas.

To enhance the ability to analyze well test data from the trailer, the development began of a three-dimensional, single-phase reservoir simulator. This model will have fracture analysis capabilities.

The analysis of the Miller No. 1 data was completed. A comparative analysis of the Sprague No. 1 data from this year with data obtained zast year will determine improvements as a result of cyclic injection. 
NATURAL BUTTES

UINTAH COUNTY, UTAH

DE-AC08-76 ET 12060
Massive Hydraulic Fracturing Demonstration

Gas Producing Enterprises, Inc.

Subsidiary of Coastal States Gas Co.

Houston, Texas

Status: Active

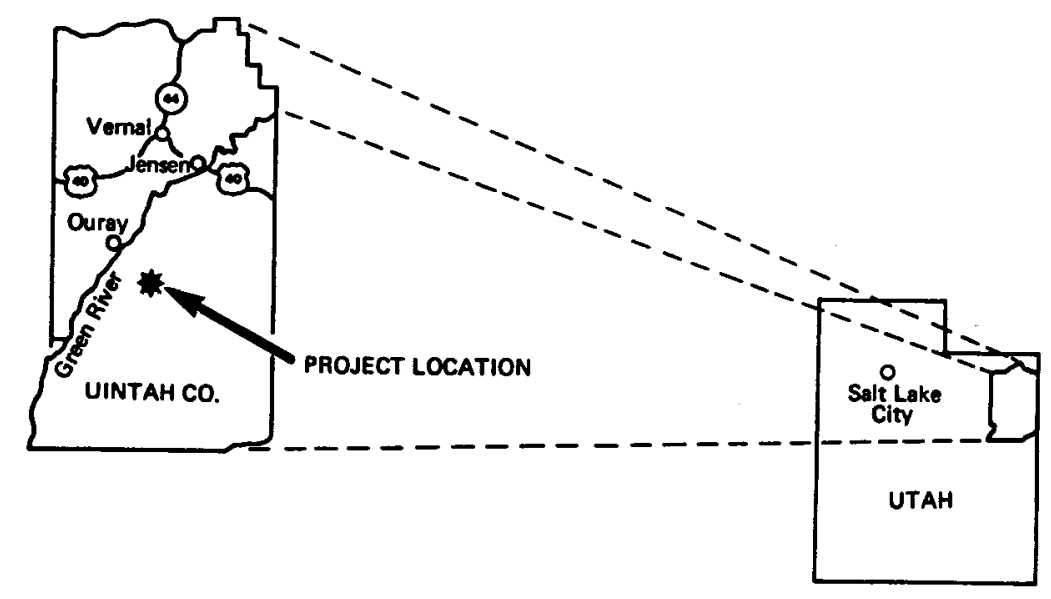

Contract Date:

Anticipated Completion:

Total Project Cost (estimated):
July 1,1976

March 31, 1980

DOE $\ldots \ldots \ldots \ldots \ldots \ldots \ldots \ldots \ldots \$ 2,827,000$

Industry (prior costs) . . . . . . . . 1,881,000

Industry (new costs) $\ldots \ldots \ldots \ldots \ldots, \quad 3,051,000$

Total $\$ 7,759,000$

Principal Investigator:

Technical Project Officer for DOE:

W. E. Spencer

C. H. Atkinson

\section{OBJECTIVE}

To evaluate the effectiveness of massive hydraulic fracturing for stimulating natural gas production from thick, deep sandstone reservoirs having low-permeability. 
(Italics denote changes since March 31, 1980.)

4.4 .4 GAS PRODUCING ENTERPRISES, INC.

Figures 4-57 through 4-62 show the production histories of wells fractured in this project. 


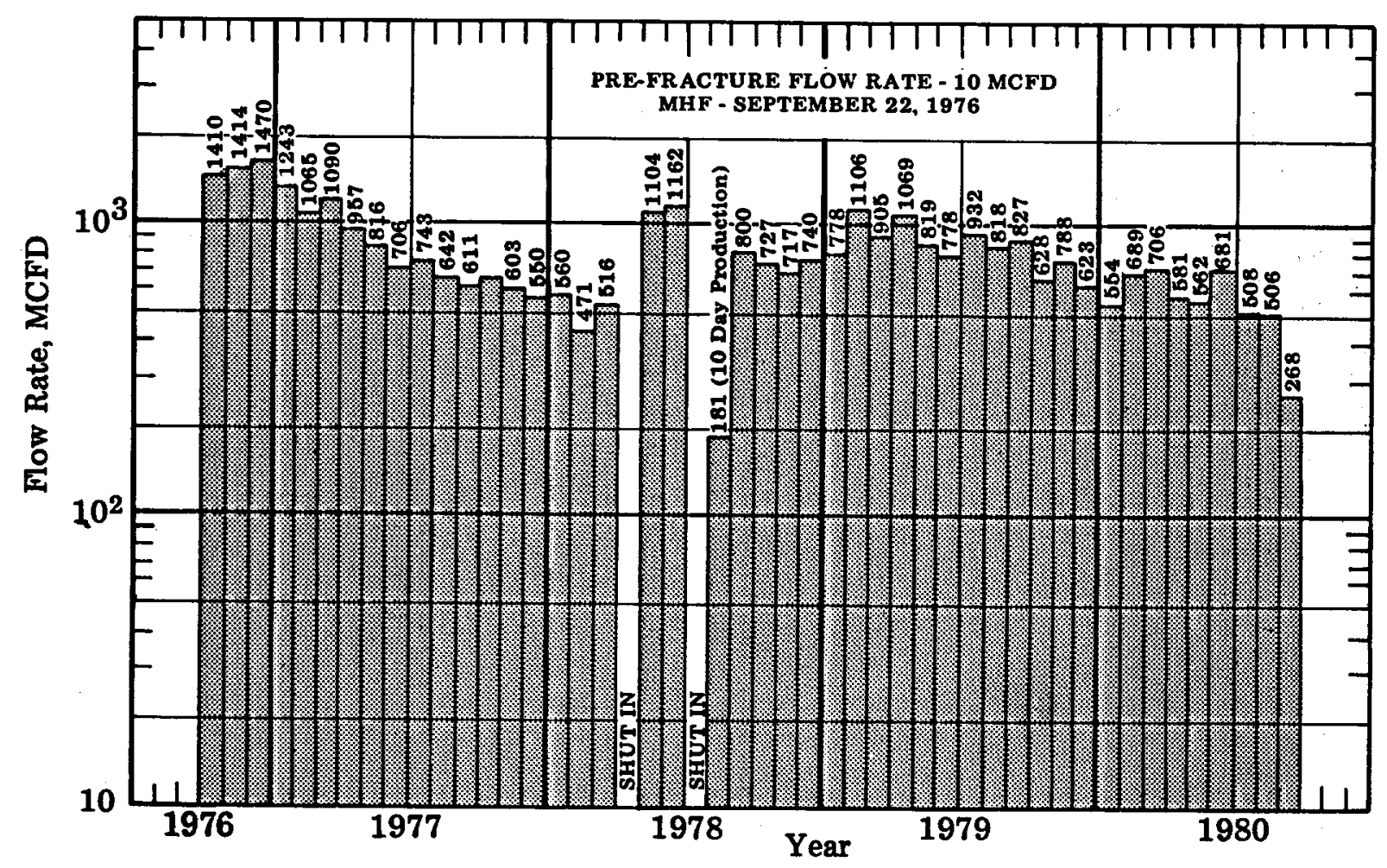

Figure 4-57 Natural Buttes No. 9 Well Flow Rate

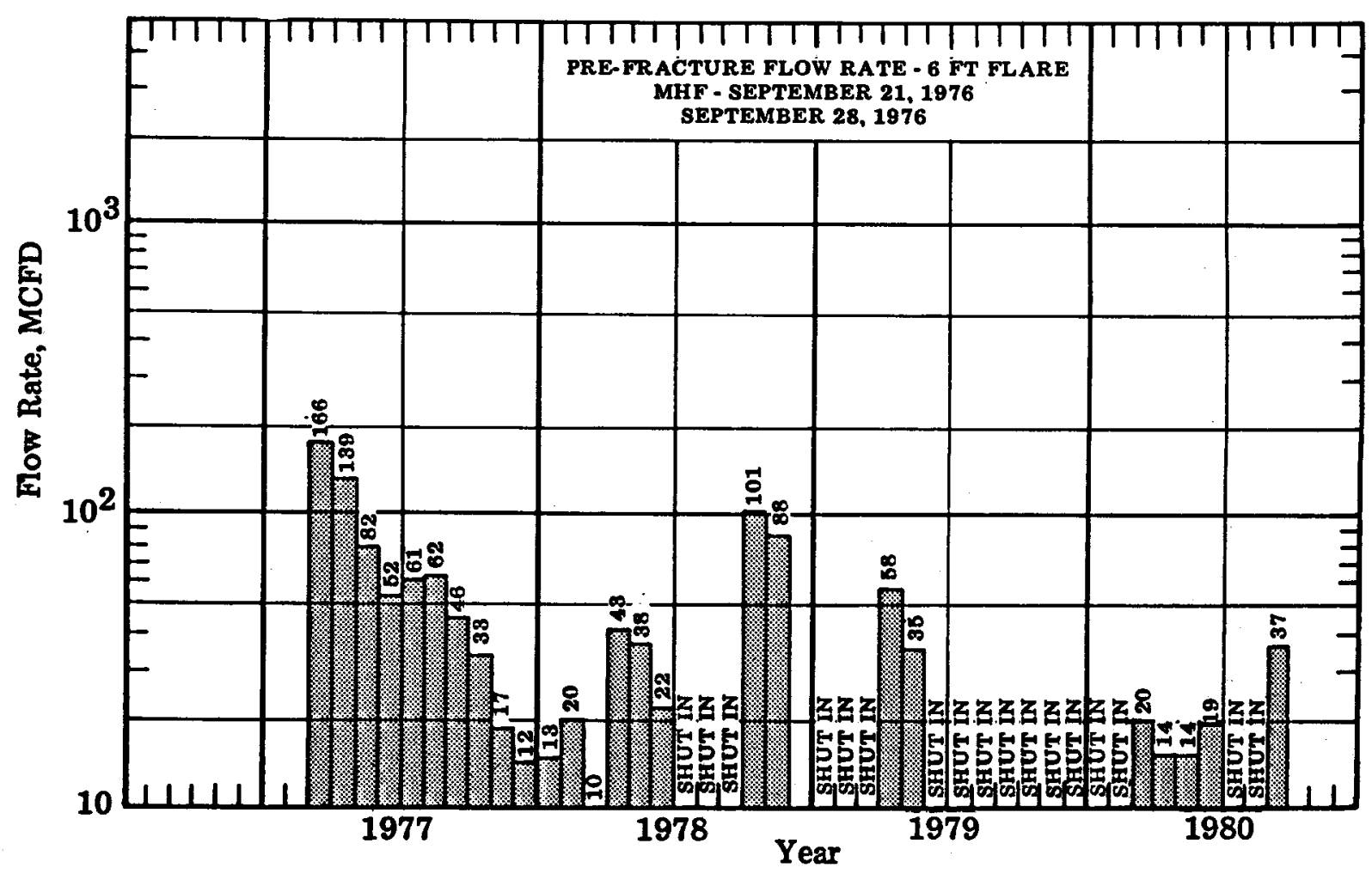

Figure 4-58 Natural Buttes No. 14 Well Flow Rate 


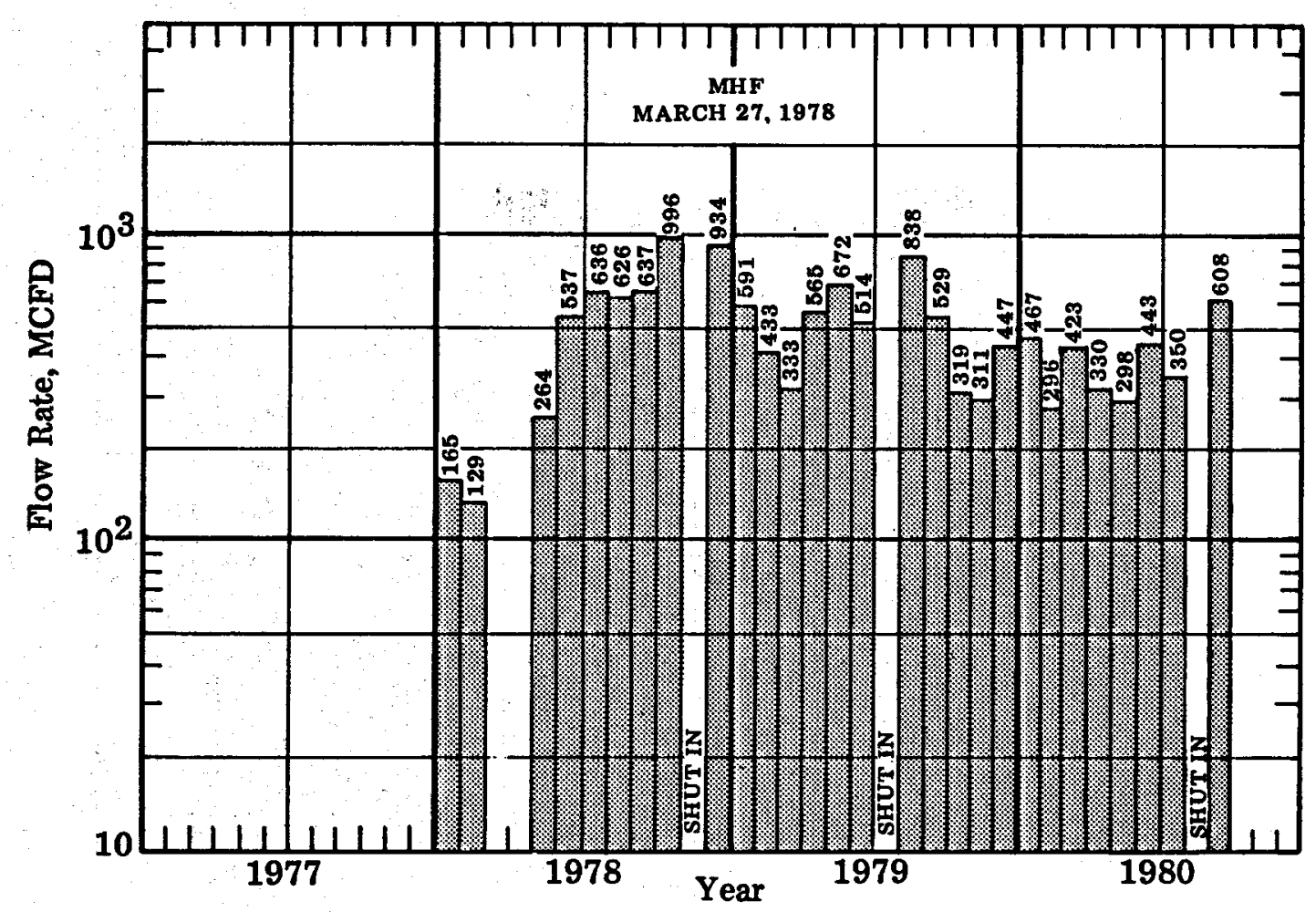

Figure 4-59 Natural Buttes No. 18 Well Flow Rate

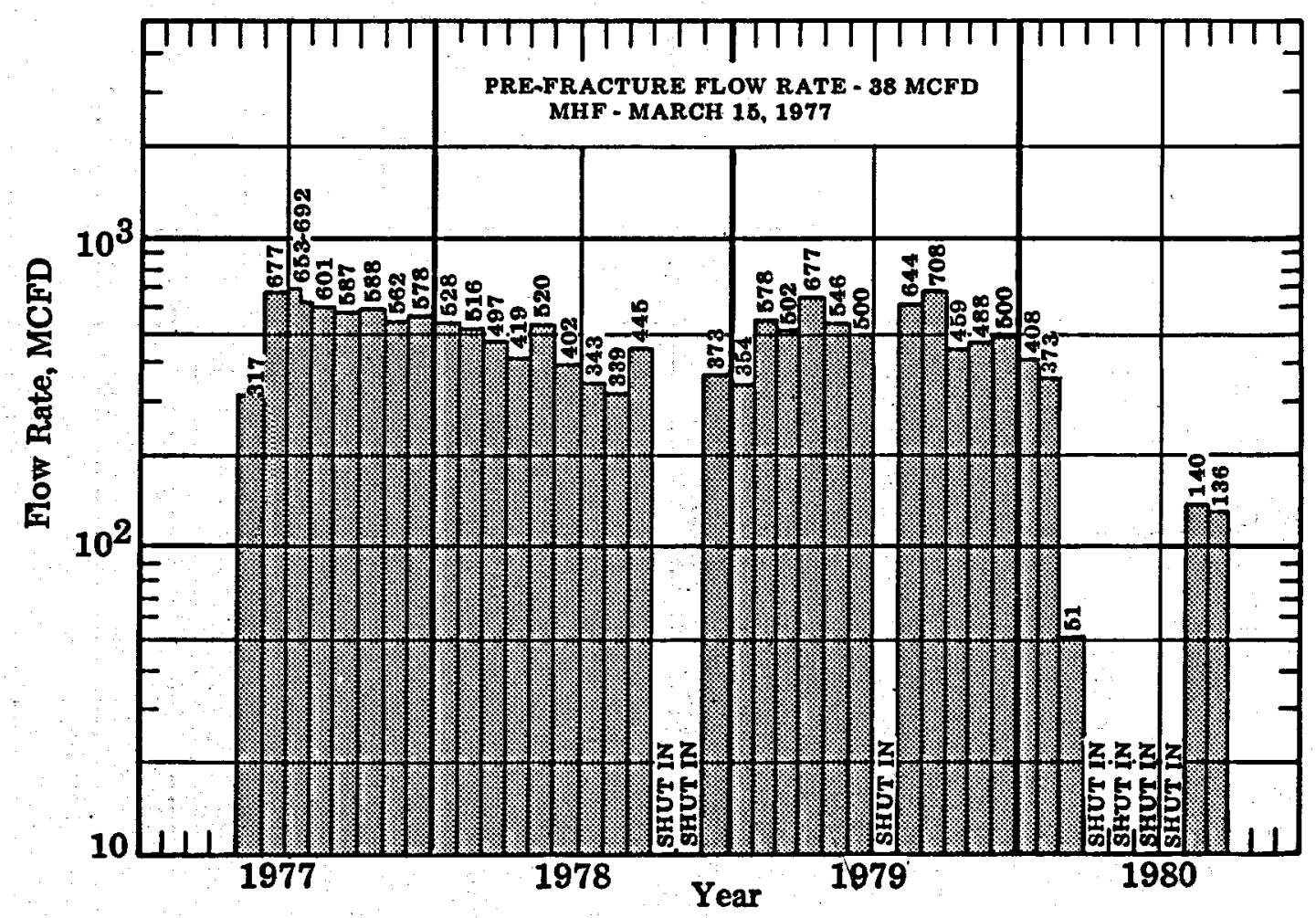

Figure 4-60 Natural Buttes No. 19 Well Flow Rate 


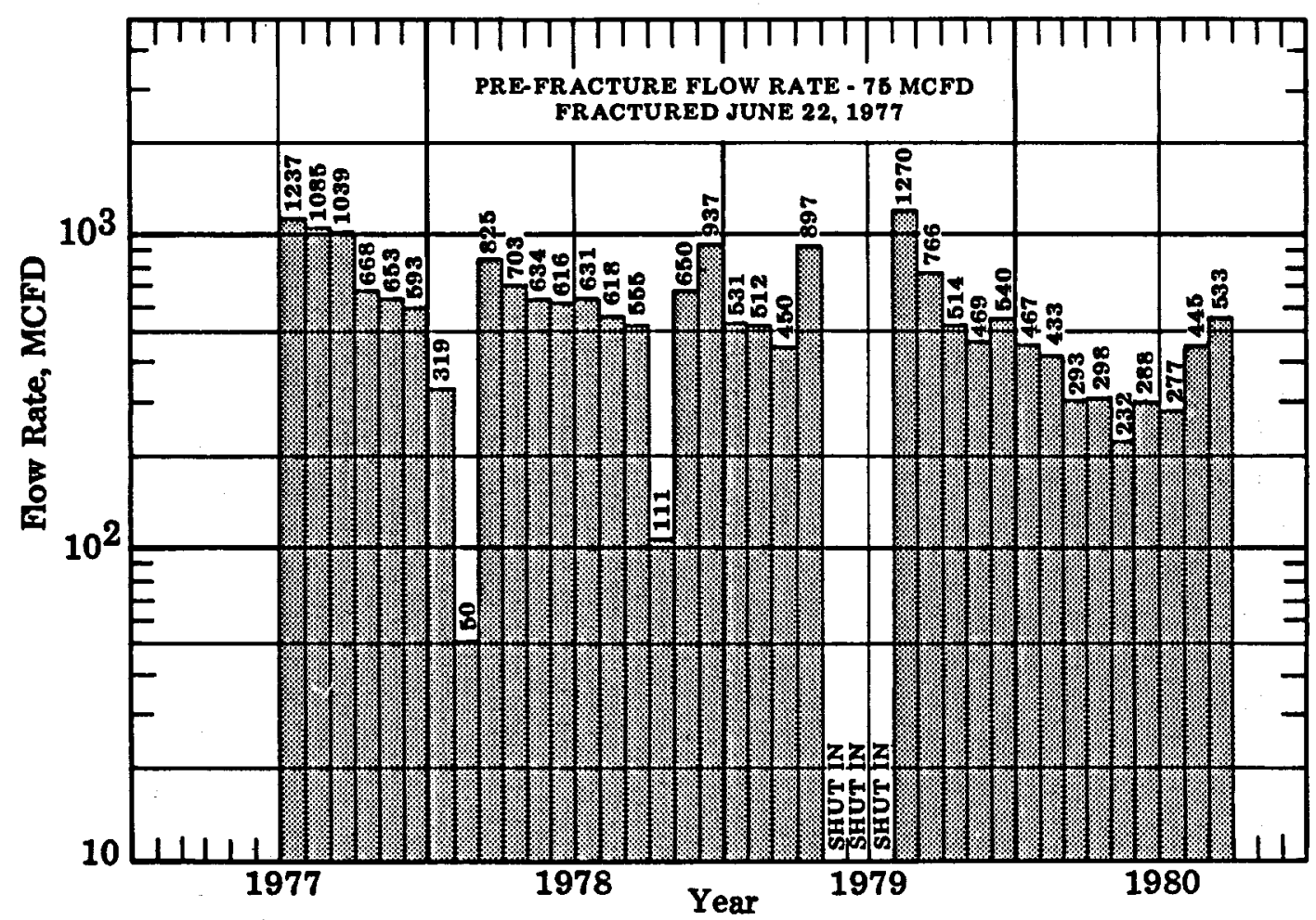

Figure 4-61 Natural Buttes No. 20 Well Flow Rate

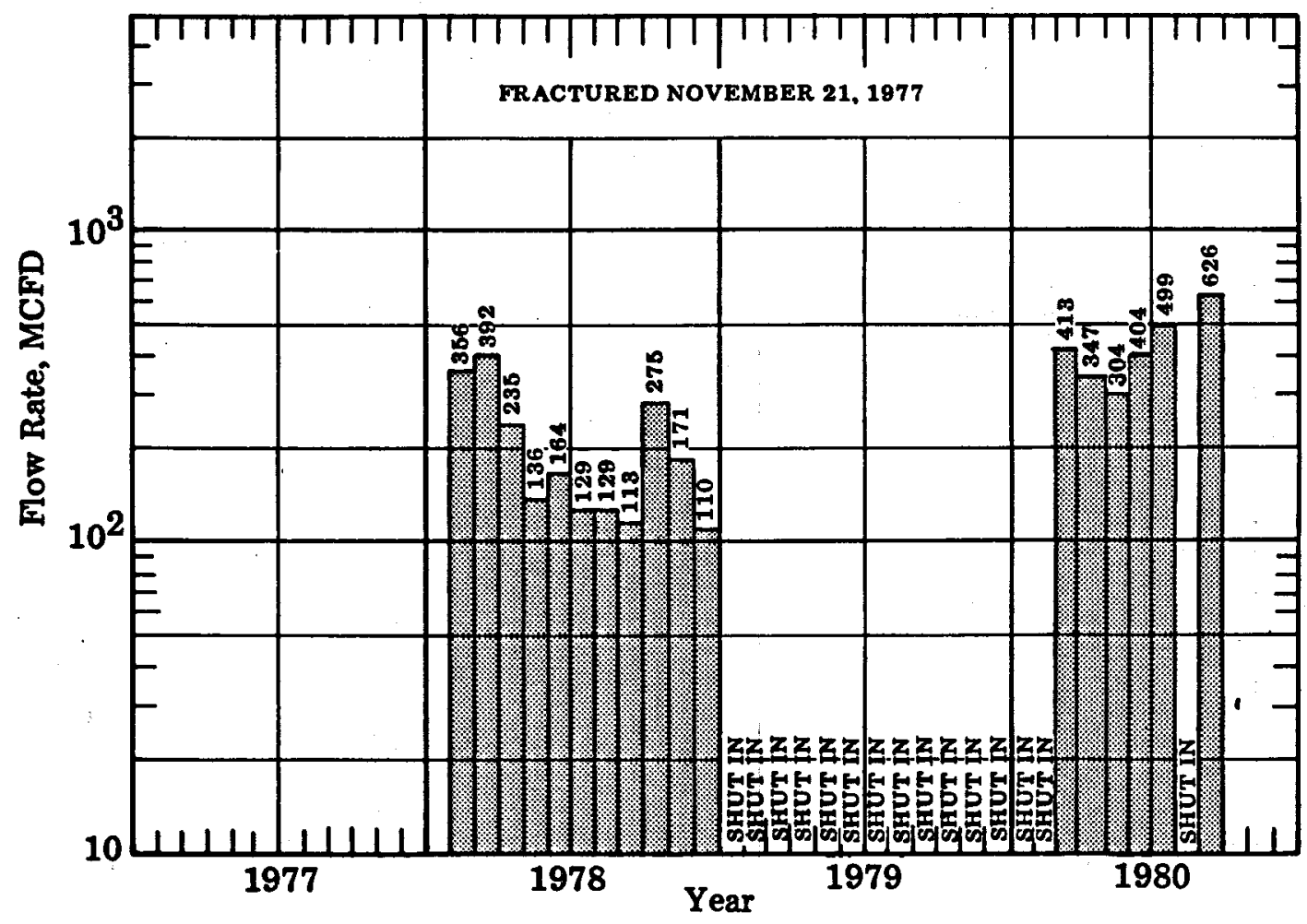

Figure 4-62 Natural Buttes No. 22 Well Flow Rate 
FALLON-NORTH

PERSONVILLE FIELD, TEXAS

DE-AC08-78ET 12160
Massive Hydraulic Fracturing Demonstration

Mitchell Energy Corporation

Houston, Texas

Status: Active

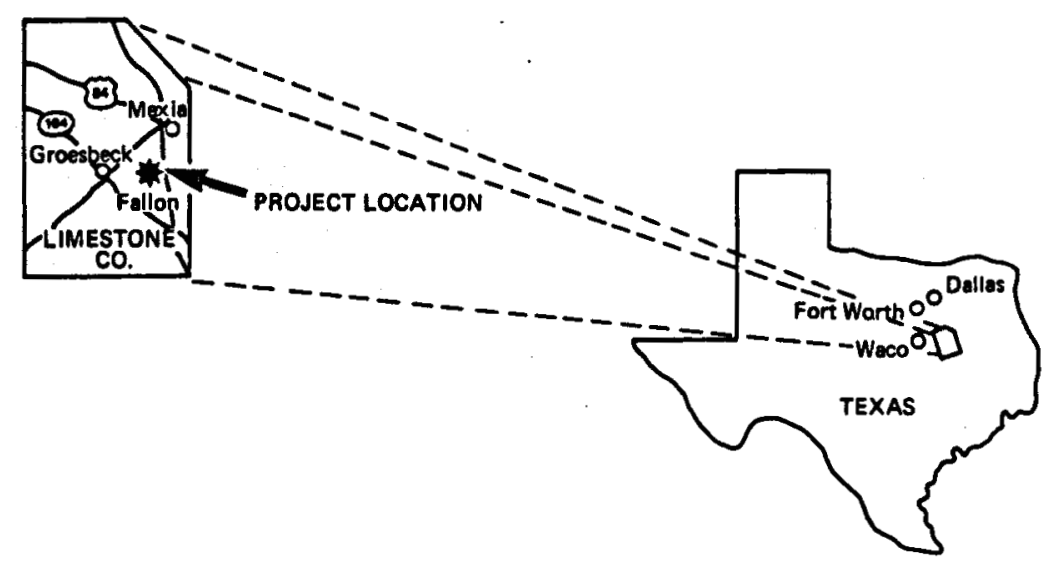

Contract Date:

Anticipated Completion:

Total Project Cost (estimated):
March 15, 1978

Project completed, waiting on final report.

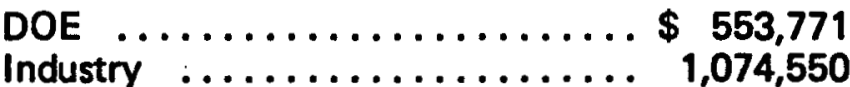

Total

$\$ 1,628,321$

Principal Investigator:

F. D. Covey

Technical Project Officer for DOE:

C. H. Atkinson

\section{OBJECTIVE}

To test massive hydraulic fracturing in the Cotton Valley Limestone Formation. 
(Italics denote changes since March 31, 1980.)

4.4 .5 MITCHELL ENERGY CORPORATION

$A$ draft of the final report has been reviewed and retumed for finalization. 
NEVADA TEST SITE

NYE COUNTY, NEVADA
Mineback Testing

Sandia Laboratories

Albuquerque, New Mexico

Status: Active

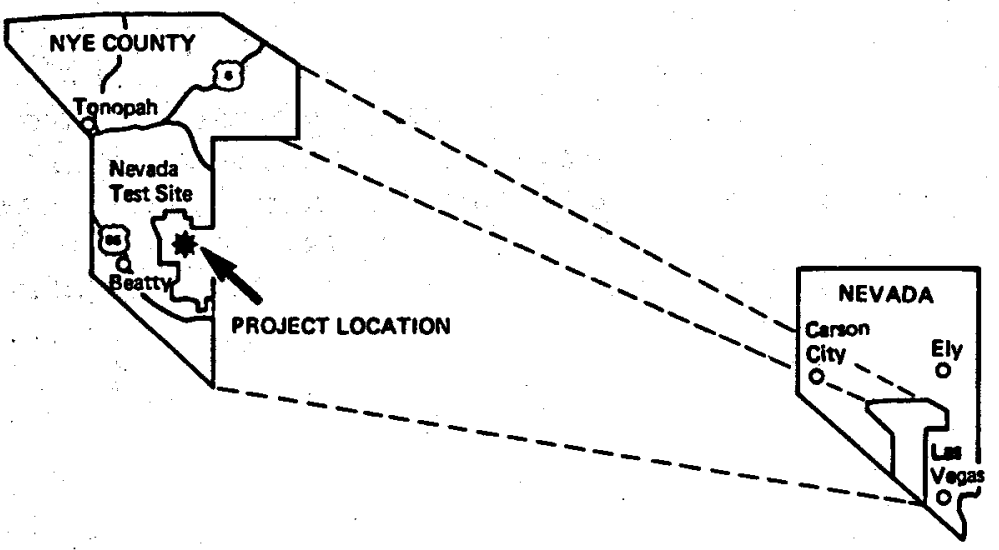

Principal Investigator:

D. A. Northrop

\section{OBJECTIVE}

To develop an understanding of the fracturing process for stimulation and thereby improve the production of natural gas from low-permeability reservoirs. This will be accomplished by conducting controlled fracture experiments which are accessible by mineback for direct observation and evaluation. 
(Italics denote changes since March 31, 1980.)

4.4 .6 S A N I A NATIONAL LABORATORIES S T IMULATION RESEARCH

HYDRAULIC FRACTURING

Formation Interface Fracture Experiment

The exploratory coring program to determine the overall shape of the fractures was completed. The data have been used to drow width contours of the combined Hole No. 6 fractures. The fractures are of relatively uniform width in the center and rapidly toper to zero near the crack tip. Section A-A' (Figure 4-63) has the most abundant fracture tip width data showing the steepest tapering at the fracture tip. Because

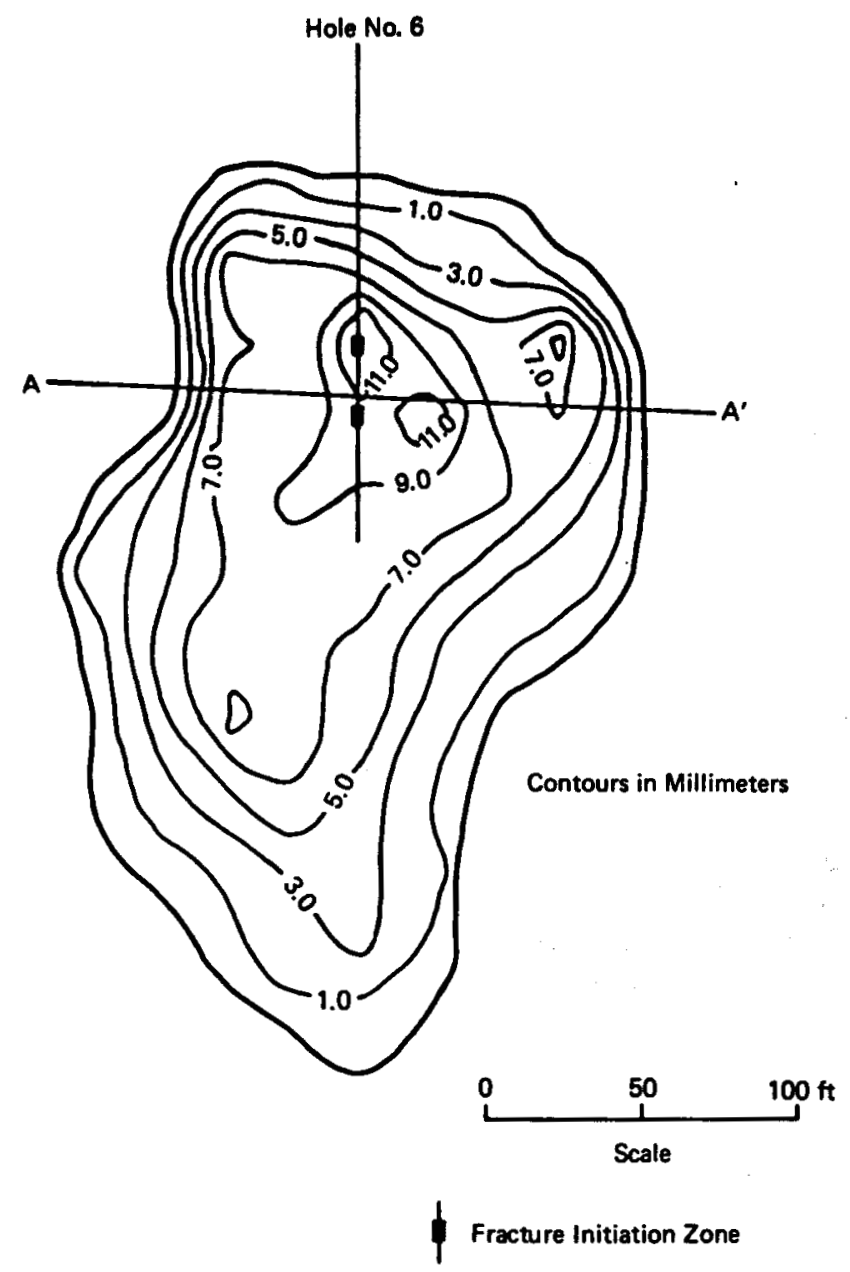

Figure 4-63 width of Fracture Through Section A-A (Mineback Data) 
(Italics denote changes since March 31, 1980.)

of limited data in most other areas, the contouring routine probably smooths out the steep gradients probably existing on all edges of the fracture. The relatively flat center and steep gradients at the tip with the fracture width varying markedly in the center may be associated with the stranding that is observed throughout the fracture.

\section{Fluid Mechanics/Proppant Transport Experiments}

The process of hydroulic fracturing is recognized to be a complex interaction between rock mechanics and fluid mechanics considerations. However, the fluid mechanics aspeats of fracturing are generally less understood than the global rock mechanics considerations, such as crack dilation under a pressure load. The important fluid mechanics processes associated with fracturing can be broadly divided into two categories. The first is basic phenomena, such as the pressure distribution and the width in a propagating fracture. Experiments to measure the pressure and width at various locations in a fracture during propagation are presently being planned. The second area is proppant transport and the resultant conductivity.

Two types of instmontation packages are being designed for these experiments. The first is a displacement transducer/pressure transducer package which will be used to measure the width and pressure at various locations in a fracture. The second is a fracture detection device which will be emplaced ahead of the fracture so that the length of the fracture as a function of time can be correzated with width and pressure data. In situ stress measurements were made in the region where tests will be conducted to determine site suitability. It was found that the minimom in situ stress is quite uniform with a magnitude of about 525 psi. Mineback of the created fractures is now underway to determine the orientation of the stress field and to provide an experiment access drift.

In Situ Stress Measurement by Hydraulic Fracturing Through Perforations

Mineback experiments have shown that the most important factor governing containment of hydraulic fractures is differences in the minimom principal in situ stress. In the Piceance Basin Multi-Well 1 Experiment, the distribution of minimu in situ stress will be measured through the Mesaverde horizon. Minifracs will be conducted through perforations to obtain pertinent measurements. To be certain that performing tests through perforations will yield accurate and reliable data, an experiment is being conducted in G-tunnel to compare the fracturing through perforations to open hole fracturing.

In the first test, PERF 1, a horizontal hole was drilled from the tunnel to a total depth of $65 \mathrm{ft}$ and was cased and perforated in five zones $(60,48,36,24$ and $12 \mathrm{ft})$. The 60-ft zone had four perforations, and the other zones had two perforations each, aligned at different 
(Italics denote changes since March 31, 1980.)

orientations with respect to the principal in situ stresses directions. These zones were fractured with small volumes $(<10 \mathrm{gal})$ of dyed water at flow rates of 4 to $8 \mathrm{gpm}$. However, only the 60-ft zone behaved normally. The fracturing pressure was 1,300 to 1,400 psi with instantaneous shut-in pressure (ISIP) of approximately 900 psi, which is typical of the minimum in situ stress in this area. In the 48-ft zone, the fracturing pressure rose to approximately 2,200 psi, and it was obvious that the perforations were very small (most likely only a muptured casing). However, the ISIP was 900 to 1,000 psi, which is normal. The other three zones were also not perforated well, exhibiting fracturing pressures of $>2,400 \mathrm{psi}$, no obvious ISIP, and leaks around the casing. Clearly, adequate perforation size is imperative for a valid test.

Five zones in a second cased hole (PERF 2, located $3 \mathrm{ft}$ above PERF 1) have been perforated with four perforations in the farthest zone and two perforations in each of the other four zones. Orientations of the perforations are staggered horizontally and vertically.

\section{Laboratory In Situ Stress Experiments}

Laboratory experiments conducted on $8 \mathrm{in}$. diometer samples show and quantify the importance of in situ stress differences on the direction of fracture propagation. The specimens are subjected to overburden stresses and confining stresses are applied to one-half of the sample. Fractures are then initiated in the samples and the effect of the confining stresses are observed. These tests are currently being conducted with Nevada tuff samples. Preliminary experiments show that 300 psi difference in pressure is sufficient to keep a fracture from propagating into the stressed area.

\section{In Situ and Regional Stress Measurements}

To determine the influence of in situ and residual stresses on fracture containment, in situ strain measurements in ashfall tuff had previously been made. Three horizons were instrumented. The lowest bedding horizon corresponded to the horizon in which a mined-back hydraulic fracture terminated abruptly and where a peak in the minimom principal in situ stress, $\sigma_{3}$, was measured by small hydraulic fractures.

Unconfined conpression tests on specimens parallel and perpendicular to bedding were completed. This was to calculate stresses from the measured strains using elastic properties of the ashfall tuff from three horizons. Significant differences in the elastic modulus were found. In the upper horizon, the tuff was highly anisotropic with a modulus of about 3.52 GPa perpendicular to bedding and about 6.54 GPa parallel to bedding. In the middle layer, the tuff was less anisotropic with a modulus of about $2.45 \mathrm{GPa}$ and $3.15 \mathrm{GPa}$ parallel and perpendicular to bedding, respectively. In the lowest horizon, the tuff was isotropic 
(Italics denote changes since March 31, 1980.)

with a modulus of about 1.76 GPa. The leastic anisotropy in the upper horizon can be correlated to a strong dimensional grain fabric in the tuff. This fabric was not found in the lowest horizon.

Calculations of the minimum principal stress, $\sigma_{3}$, using elastic properties and measured strains, showed a consistent increase in 03 . It ranged from $0.56 \mathrm{MPa}$ in the upper horizon, to $0.64 \mathrm{MPa}$ in the midale horizon, to 1.66 $M P a$ in the lower horizons. AlZ stresses were compressive. The large abrupt increase in $\sigma_{3}$ in the lower horizon provided an independent measure of the stress peak. The result confirms that an increase in $\sigma_{3}$ can control the vertical growth of hydraulic fractures. Thus, while in situ stress state directly affects the growth of hydraulic fractures, elastic moduli (variations due to fabric within the rock) can affect the stress state.

\section{Crack Tip Process Zone Study}

The mechanism of crack growth determines the extent of the near crack surface domage produced as the crack propagates. The extent of this process zone domage is one of the factors that determines the permeability of the fracture surface. Thus, it has a direct bearing on the sizing of a hydrofracture to achieve the desired production rate. In addition, the damaged zone near the crack surface affects the closure rate of the fracture and may reduce the effectiveness of the proppant.

In a joint study with the University of Maryland, the process zone is being examined to determine its size and shape under simple loading conditions. In this study, the crack tip region is examined under load, using a surface replicating technique. At various stages of the loading history, an acetate film replica is made of the polished surface of the fracture specimen in the region where the crack intersects the surface. The replicas are then examined by. the SEM to determine the size and shope of the cracktip process zone. Three experiments have been mon. In two of these, the cracked specimen was monotonically loaded until the crack advanced. In the third, a crack was propagated under cyclic loading. The replicas from these experiments are being prepared for SEM study.

\section{Fracture Criterion Development}

The stress field has been numerically calculated for an internally pressurized and finite crack near a material interface. The solution process requires two steps. The first involves the numerical solution of a singular integral equation which equates the stress field on the crack boundary to the arbitrary, but specified, internal pressure distribution of the crack. The second step convolves this solution with an appropriate Green's function to obtain the stress field beyond the crack tip. The stress intensity factor, $K_{1}$, is also determined. This calculation is more accurate and much less cumbersome and time- 
(Italics denote changes since March 31, 1980.)

consuming than standard finite element crack codes. Unlike finite element calculations, solutions can be found when the crack tip is extremely close to the interface.

For the crack/interface geometry illustrated in Figure 4-64 the change in stress intensity factor, $K_{1}$, as the crack approaches the interface, is given in Figure 4-65. It is commonly believed that $K_{1}$ approaches zero as the crack tip drows closer to the interface, but the zero value is probably never attained. The decrease in $K_{1}$ as the crack approaches the interface suggests that fracture propagation might terminate near the interface. However, Figure 4-66 indicates that as the tensile stresses near the crack tip decrease with decreasing $K_{1}$, the load is transferred across the interface into the higher modulus material. Because of these large discontinuous stress variations, it is likely that use of $K_{1}$ alone as a fracture propagation criterion is inappropriate. Fracturing may therefore occur in the high modulus material if this stress load becomes sufficiently large, but a suitable criterion for fracture growth at an interface remains unknown.

Feasibility Study for the Prediction of In Situ Stress and Hydraulic Fracture Orientation by Strain Relaxation Measurements

Knowledge of the state-of-stress is particularly important for accurate prediction of the shope and orientation of massive hydroulic fractures that stimulate gas production in low permeability reservoirs. Accordingly, a feasibility study has been conducted in tuff at the $G$ tunnel (NTS) to determine the state-of-stress form time-dependent strain relaxation of over sored specimens. Two techniques were used: a strain gauge rosette on the surface of the core and disc gauges attached to the circromference of the core. The strain gauge rosette was mounted prior to overcoring and measured both the elastic and time-dependent strain relaxation of the core. After overcoring and the removal of core from the tunnel wall, the disc gauge was attached and measured only the time-dependent relaxation.

Preliminary analysis of the data indicated that the tuff behaved as linear viscoelastic with the cores releasing asympototically to a final permanent strain within 36 hours. Both techniques produced similar results which suggests that the orientation of the principal strain is identical for the instantaneous elastic strain and the time-dependent relaxation strain. The principal stresses and their directions can be estimated from these strain determinations using the appropriate elastic constants.

This study suggests that both techniques for strain-relaxation measurements of oriented core at depth may indicate the orientation of the principal strains and stresses and thus, accurately predict the orientation of subsequent hydraulic fractures. Additional studies in the Piceance and Vinta Basins are planned. 
(Italics denote changes since March 31, 1980.)

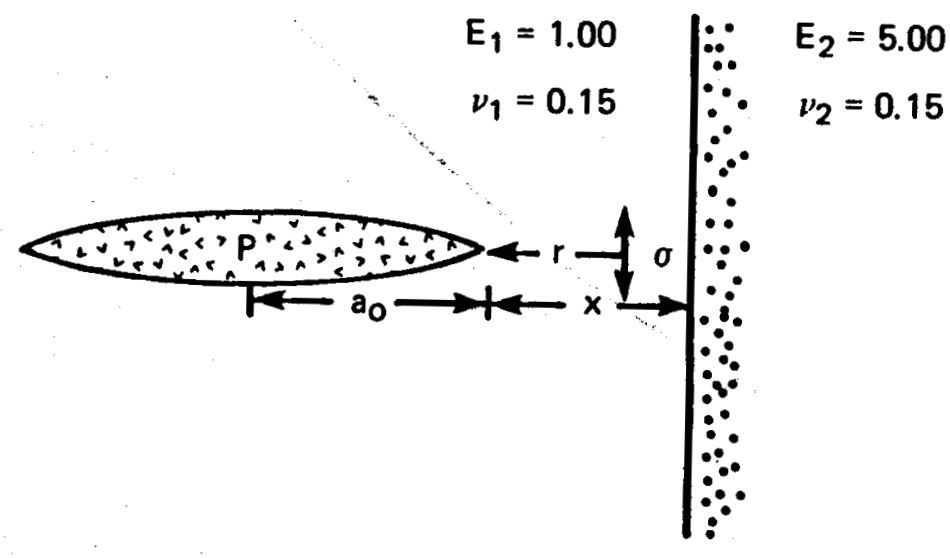

Figure 4-64 Geometrical Relationships

Between Crack and Interface

Petrological and Geochemical Effects on Hydraulic Fracture Behavior

A comprehensive investigation is being conducted of the "hard bands" observed in the WIS Tunnel Bed No. 5 formation. These bands have been associated with measured high minimum streseses and thus have affected hydraulic fracture behavior. The objectives of this study are:

- a detailed mineralogical analysis of these layers, using optical microscopy, SEM and $x$-ray diffraction;

- an interpretation of their origin; and

- to determine what relationship exists between the distribution of the hard bands, elastic moduli changes and in situ stress.

To date, the petrographic information shows the bands to be composed of intensely zeolitized tuff, whereas the adjacent material is not zeolite-cemented. The most abundant zeolite phase is calcirm-rich clinoptilolite; in addition, low-cristobalite appeans frequently in both the hard bands and unaltered tuff. A diagenetic origin for these features has been proposed which involves zeolite precipitation from silica-rich groundwater where the bands possibly mock former positions of the water table. 


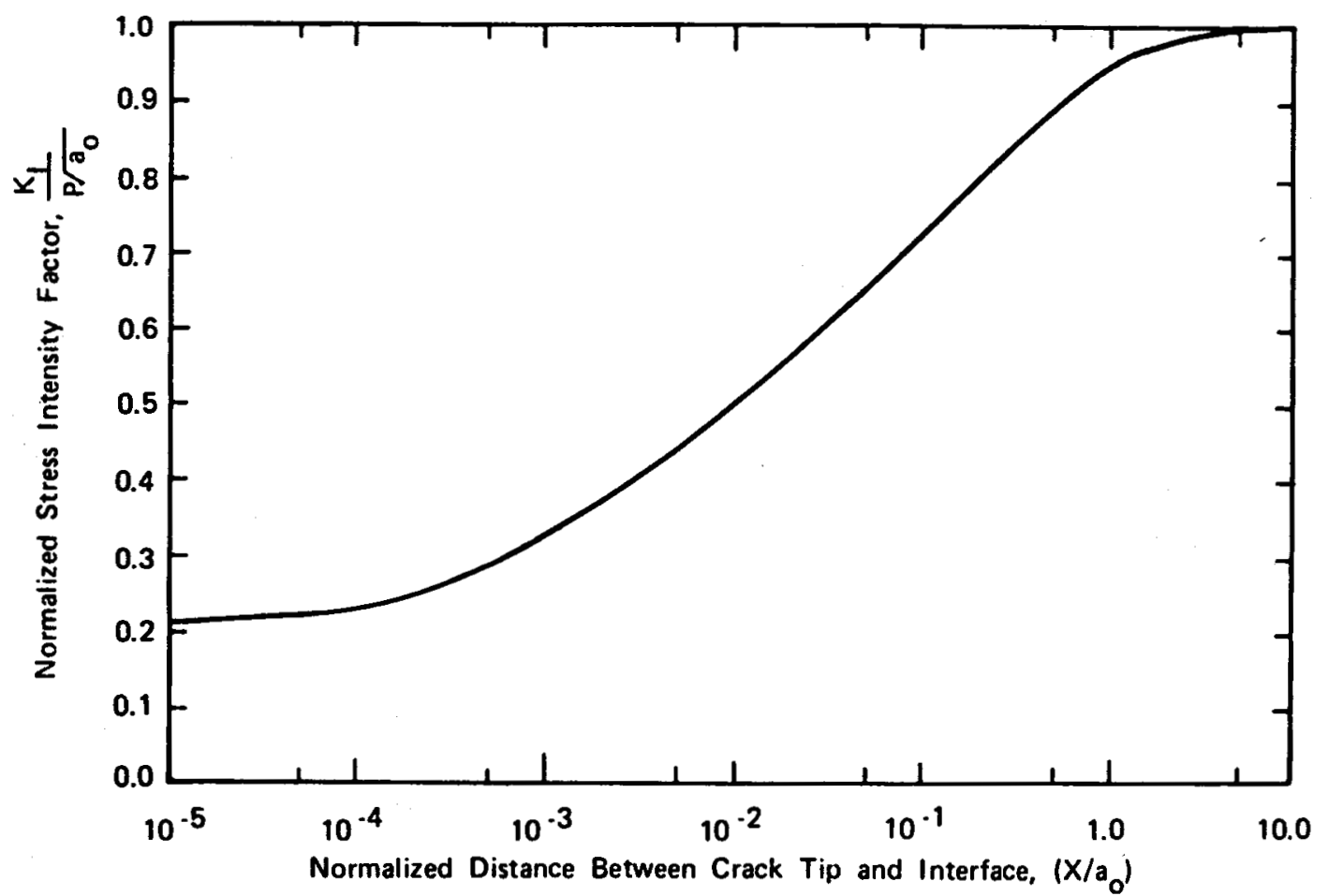

Figure 4-65 Variation in Stress Intensity Factor as a Crack Approaches an Interface

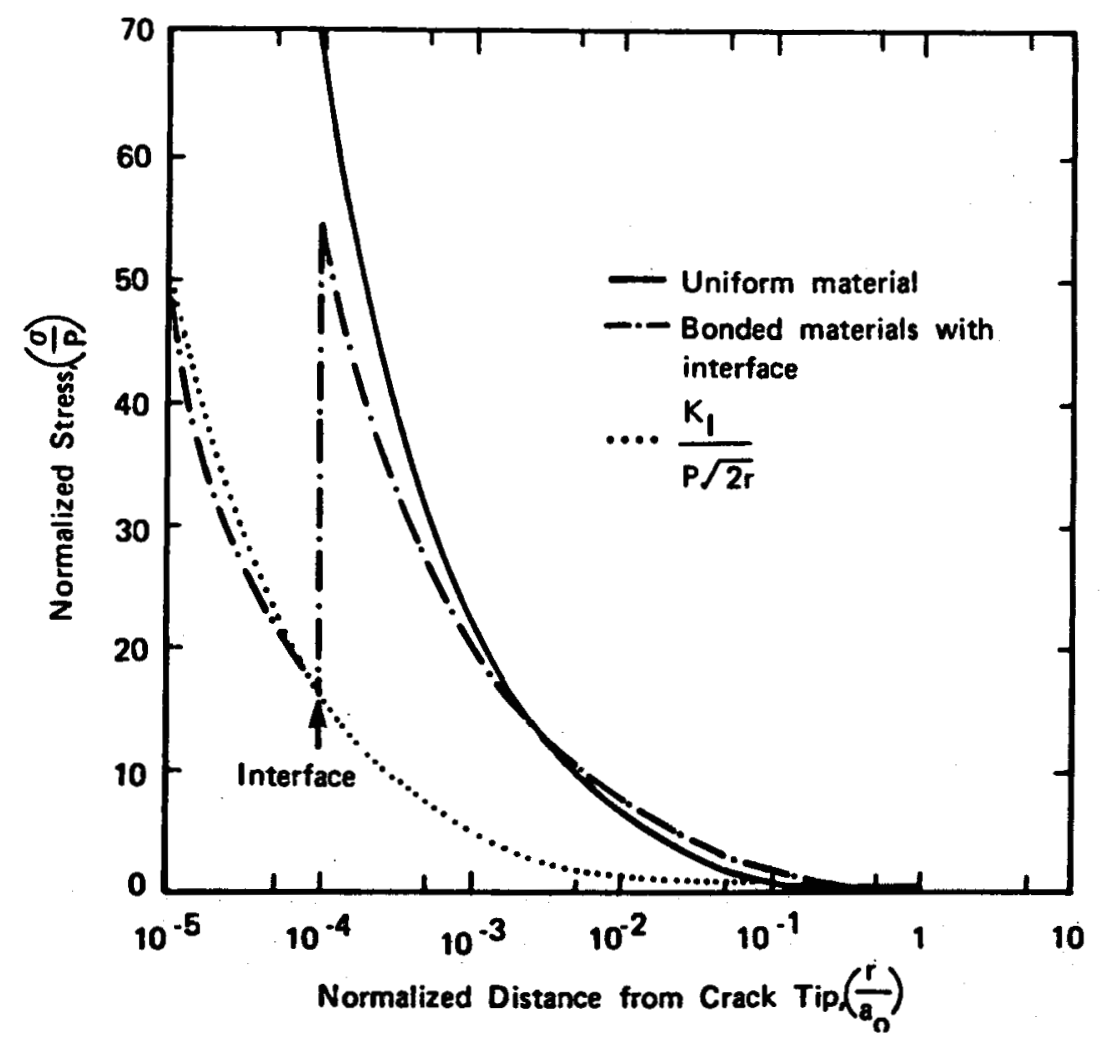

Figure 4-66 Tensile Stress as a Function of Distance from Crack Tip 
(Italics denote changes since March 31, 1980.)

This work may make it possible to relate the hard bands to changes in moduli and/or in situ stress. A possible analog in the tight gas sands may be silica diagenesis occurring where upward-diffusing groundwater meets an impermeable barrier. 
(Italics denote changes since March 31, 1980.)

\subsection{PROJECT MANAGEMENT}

\section{TECHNOLOGY TRANSFER DOCUMENTATION REPORTS}

During the reporting period, the Western Gas Sands Project Quarterly Basin Activities Report, January 1-March 31, 1980 and the Westem Gas Sands Project Quarterly Basin Activities Report, April 1 - July 31 , 1980 were released. The WGSP financial supplements for the months of March, April, May, June, July and August, 1980, were released to a limited distribution. Project status reports for March, April, May, June, July and August, 1980, the Project Plan Document for FY 1981 and WGSP Logging Report were released.

The DOE Well Test Facility Manual was updated as equipment was added or modified.

\section{PROJECT DATA BANK}

The following maps have been added to the WGSP project data bank:

"Subsurface and Surface Correlation of Some Upper Cretaceous and Tertiary Rocks, Northern Green River Basin, Wyoming, Section $A-A$ ', $B-B^{\prime}$," by B. E. Low, USGS, 1979;

"Mop Showing Appraisal of Mineral Resource Potential of Rare 11 Proposed Roadless Areas in National Forests, Montana (Exclusive of Coal, Oil, Gas and Constmuction Materials)," compiled by M. R. Mudge, R. L. Earhart and D. D. Rice, USGS, 1978; and

"Landsat Lineaments in Western South Dakota," G. W. Shurs, USGS, 1978.

\section{ARTICLES AND PUBLICATIONS RELATING TO THE WGSP INCLUDE:}

"Development in Hydrocarbon Fluids for High-Temperature Fracturing," by J.W. Burhan, L. E. Hariss and B.W. Daniel, Haliburton Services;

"Some Relations Between Diagenesis and Porosity (Real and Imagined), Sandstones of Mesaverde Group, Uinta Basin, Utah," by C. W. Keighin, USGS; 
(Italics denote changes since March 31, 1980.)

"Bowdoin Dome Area, North-Central Montana-Example of Shallow Biogenic Gas Production fram Lower-Permeability Reservoirs," by G. L. Nydegger, D. D. Rice and C. A. Brown, USGS; and

"Coastal and Deltaic Sedimentation of Upper Cretaceous Eagle Sandstone: Relation to Shallow Gas Accumulations, North-Central Montana," by D. D. Rice, USGS. 


\subsection{METHANE RECOVERY FROM GEOPRESSURED AQUIFERS}

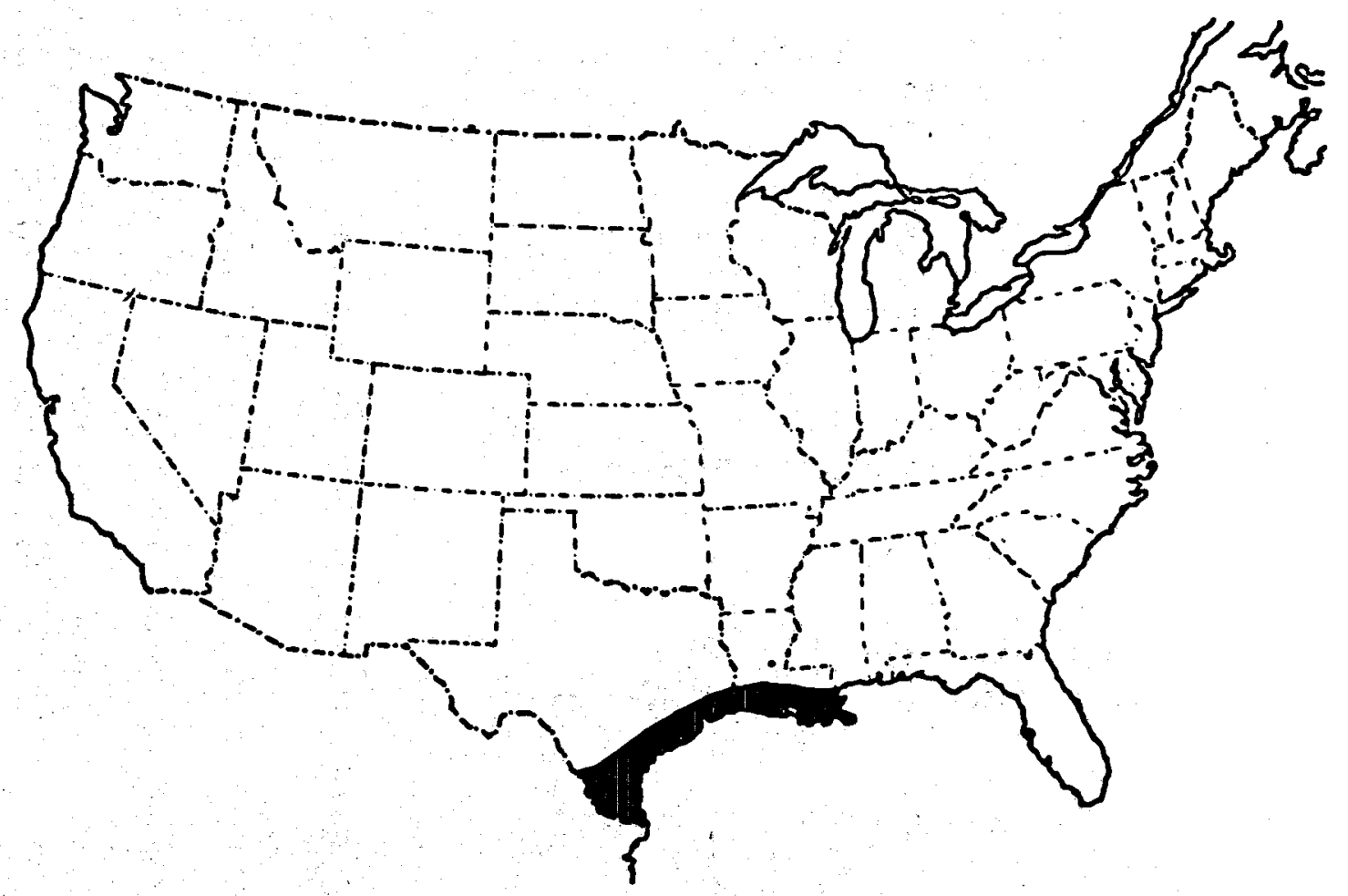


5.1 INTRODUCTION 5-3

5.1.1 Background 5-3

5.1.2 Methane From Geopressured Aquifers Project 5-4

5.2 RESOURCE ASSESSMENT $5-8$

5.2.1 General 5-8

5.2.2 Texas Resource Assessment 5-8

5.2.3 Louistana Resource Assessment $5-9$

5.2.4 Identification of Other Potential Areas 5-10

5.3 SUPPORTING RESEARCH 5-11

5.3.1 General 5-11

5.3.2 Aquifer Fluid Characterization 5-11

5.3.3 Data Processing 5-12

5.3.4 Lega 1, Institutiona 1, and Operations
Research

5.3.5 Environmental Research 5-15

5.3.6 Expansion of Area of Study 5-18

5.4 FIELD TESTS AND DEMONSTRATIONS 5-19

5.4.1 General 5-19

5.4.2 Design Well Program 5-21

5.4.3 Wells of Opportunity Program 5-24

5.5 TECHNOLOGY TRANSFER $5-29$

5.5.1 General 5-29

5.5.2 Forum Meetings 5-29

5.5.3 Geopressured Geothermal Symposia 5-29 


\subsubsection{BACKGROUND}

Methane, the major constituent of natural gas, is slightly soluble in water at standard conditions; however, solubility increases rapidly with pressure and temperature (above $82^{\circ}$ C.). High-pressured subsurface zones (known as geopressured zones in the petroleum industry) containing water and its dissolved methane thus represent a potential resource base for natural gas. Geopressured zones are found in only a few coastal areas of the world. One of the largest of these zones underlies a large portion of the northern shoreline of the Gulf of Mexico, in a strip 200 to 300 miles wide slightly off the coast of Texas and Louisiana. Here, sedimentary deposits exhibit a maximum thickness of some 50,000 feet in some areas, with the upper 25,000 feet primarily composed of alternating series of rock layers which may be broadly classified as sandstones and shales, and the lower layers consisting almost entirely of shales, which are believed to be the origin of the methane in the geopressure formations.

There are indications that dissolved methane may exist in geopressured aquifers in areas other than the Gulf Coast. A study is currently under way to research avallable data to identify areas outside the Gulf Coast probable of containing this resource.

Because of the many unknowns associated with this resource, quantitative estimates are difficult to make. This uncertainty is reflected in the current in-place-resource estimates which vary widely from a low of 984 trillion standard cubic feet (TCf) to a high of 50,000 Tcf. Not enough is known at this time to estimate how much of this resource can be economically exploited. Since the geopressured aquifers contain water under high pressure and temperature, additional energy may be extracted in the form of useful heat and hydraulic energy.

The economics of natural gas production from geopressured aquifers depend on many factors, such as:

- The prevailing price for natural gas.

- The cost of drilling and equipping deep wells for production.

- The ability of these wells to produce large volumes $(40,000$ barrels per day) of water over a lifetime of at least 20 years. 
The absence of significant environmental impact, through proper mitigation, at such production levels.

Private industry has not investigated this potentially large resource so far because of the above uncertainties and, therefore, it is logical that the Federal government provide the initial effort to a point where such doubts are substantially removed for the private sector to take over further research and development.

\subsubsection{METHANE FROM GEOPRESSURED} AQUIFERS PROJECT

The Department of Energy (DOE), through its predecessor agencies, has been involved in geopressured aquifer research since 1974. Currently, this program is being carried out by DOE's Division of Geothermal Energy at the headquarters level, with implementation of various projects being handled by the Geopressure Projects Office, Houston, and the Geothermal Branch, both of the Nevada Operations Office in Las Vegas, Nevada.

The goal of the program is to stimulate commercial development, by the private sector, of the geopressured-geothermal resource as an economical, reliable, safe, and environmentally acceptable energy source. In order to achieve this goal, DOE is evaluating production strategies for the recovery of methane from the shallower geopressured reservoirs and for "total energy recovery" (i.e., recovery of methane, production of electric power, and direct heat utilization) from the deeper, higher-temperature reservoirs. Major program activities are aimed at improved understanding of the resource, including the confirmation of optimum reservoirs and the identification and resolution of key engineering, environmental, and institutional problems. If successful, the program will provide the information required by the industry to develop geopressured energy resources beginning in the mid-1980s.

To date, the DOE-R\&D program has concentrated on resource characterization. These efforts have resulted in the identification of optimum prospects for reservoir confirmation drilling and testing. On the basis of these accomplishments, a long-term R\&D strategy has been developed, in cooperation with industry and state and local government agencies, which is aimed at bringing geopressured-geothermal resources "on line" in a planned and phased manner. This long-term program will cover the following five key areas, which are discussed in depth in the continuation of this section:

\footnotetext{
- Regional Planning

- Resource Definition
} 
- Technology Development

- Environmental Control

- Facilities

\section{REGIONAL PLANNING}

Work in this area provides for the analysis of the economic, institutiona 1, legal, and technological framework for geopressured-geothermal energy exploration, development, and utilization; and the identification and assessment of policy options and technical programs to encourage and expedite its development according to the intended schedule.

The major component of this effort is the regional operations research conducted by the Louisiana Department of Natural Resources and the University of Texas at Austin, in cooperation with appropriate organizations within the region; i.e., federal, state, and local government agencies; industries; utilities; field developers; and public interest groups. These regional organizations are expected to play important roles in the identification of prospects for detailed evaluation.

This regional operations research program will be supplemented by other regional and national policy programs. On the regional level, DOE will work with cities, counties, and state governments, as well as the private sector, to assess the legal and institutional barriers to the desired development objectives. On the national level, studies are directed toward determining the federal incentives which would most effectively accelerate commercial development of the resources. Incentives in the form of depletion allowances, investment tax credits, production tax credits, and price regulations have recently been enacted as part of the tax and price provisions of the National Energy Act.

\section{RESOURCE DEFINITION}

The work in this area is directed at resolving two major reservoir uncertainties; one, the number, location, characteristics, and producibility of individual geopressured aquifers; and two, the amount of recoverable methane, a key factor in the economics of the utilization of geopressured resources. To this end, the assessment of all known onshore geopressured formations in Texas (Frio, Vicksburg, and Wilcox) and Louisiana (Miocene, oligocene, and Tuscaloosa) is being conducted by the Texas Bureau of Economic Geology and Louisiana State University, respectively, in order to delineate optimum resource areas for reservoir confirmation drilling and testing. During the period 1979 to 1984, the reservoir confirmation program will consist of drilling and testing approximately four new wells a year specifically designed for long-term reservoir testing in the optimum resource areas delineated 
in the resource assessment studies. In addition, the program will include testing in up to four existing wells a year to obtain additional data on fluid and reservoir characteristics.

The reservoir confirmation program was initiated in 1977 with the recompletion and testing of the Edna Delcambre No. 1 well, an abandoned gas well in Vermilion Parish, Louisiana. Results of testing of two geopressured aquifers at 12,900 and 12,600 feet at rates up to 12,000 barrels a day indicated average gas production up to 80 standard cubic feet per barrel (scf/bbl), although recombined samples yielded solubilities of approximately $20 \mathrm{scf} / \mathrm{bbl}$. Data from the Fairfax Foster Sutter No. 2, Beulah Simon No. 2, and Pleasant Bayou No. 2 indicate gas production of 20 to $25 \mathrm{scf} / \mathrm{bbl}$ and recombination sample data indicate the water is saturated with gas at reservoir conditions.

\section{TECHNOLOGY DEVELOPMENT}

Efforts in this area are directed toward reducing the cost of developing and using geopressured resources. Some research projects address critical problems that must be solved if exploitation of the resource is ever to support a significant industry. The technology development program is conducted under the following basic categories: direct heat utilization, well drilling and completion, geochemical engineering, advancing heat exchanger development, and advanced energy conversion systems.

Based on the results of the operations research and systems analysis work, which will identify energy narkets in the region, a number of engineering and economic studies of nonelectric applications will be initiated. In addition, site-specific application studies will be conducted for those areas selected in the resource definition studies for confirmation drilling and testing. Nonelectric application experiments covering residential/commercial space heating and cooling, industrial processing, and agricultural uses will also be initiated to obtain site-specific and application-specific engineering and economic information.

The other technology development program categories include geopressured-specific as well as broadly applicable (e.g., hydrothermal, hot dry rock) elements. The geopressured-specific elements address problems associated with high pressures, sand production, and fluid chemistry. Broadly applicable elements include, for example, development of hightemperature drill bits, more efficient and low-cost energy conversion systems, and materials research.

ENVIRONMENTAL CONTROL

The geopressured-geothermal environmental control program is conducted under two basic categories: one, programs associated with specific 
geopressured development sites or prospect-specific programs; and two, programs aimed at resolving generic geopressured resource development concerns.

\section{Prospect-Specific Programs}

Four types of programs directly affecting the development of geopressured prospects or sites will be conducted in conjunction with well site selections resulting from the resource assessment studies. These programs include: regional baseline studies; environmental data collection and analyses associated with site selections; environmental impact analyses, including preparation of impact assessments and statements; and environmental monitoring.

\section{Generic Programs}

Environmental concerns associated with geopressured resources are similar to those identified with hydrothermal resources. These concerns include subsidence, induced seismicity, toxic gas release, well blowout, noise, and waste fluid disposal. The research and development activities will be directed to assess which of the concerns are justified and what, if any, mitigating procedures exist to minimize environmental impacts of full-scale development.

\section{FACILITIES}

Results of the reservoir definition studies, together with the information obtained from the operations research activities, will provide the necessary information to enable a decision on whether to proceed with the design and construction of pilot-scale or commercial-sized demonstration plant(s). If the conditions are favorable, it is anticipated that the pilot/demonstration plant(s) will be designed to produce and market electric power, separate the methane, and utilize the remaining heat in the geothermal fluids for direct heat applications. Specifically, the plant(s) will be designed to: demonstrate state-ofthe-art technologies; obtain realistic cost data from which operating, maintenance, and production costs can be extrapolated with confidence; provide adequate instrumentation to obtain engineering data; and demonstrate reservoir deliverability and longevity. Efforts leading to the pilot/demonstration plant(s) will involve conceptual design, site evaluation, additional reservoir testing, and environmental. studies and assessments. 


\subsubsection{GENERAL}

Current resource assessment activity is focused on the onshore portion of the Texas-Louisiana Gulf Coast. As a result of the high level of exploration and development effort related to oil and natural gas production, a large amount of information already exists concerning the subsurface geology of this area. Starting with this data base, a major effort is under way, principally at the University of Texas and the Louisiana State University, to prepare a regional assessment of the geopressured resources of the Gulf coast.

\subsubsection{TEXAS RESOURCE ASSESSMENT}

Two organizations associated with the University of Texas at Austin-Bureau of Economic Geology (BEG) and Center for Energy Studies (CES)-have performed most of the resource assessment work for the Texas Gulf Coast. The primary objectives of this assessment are to define the geopressure "fairways" in the Texas Gulf Coast and to delineate optimum areas which can be developed as test sites for long-duration testing. In the course of this study, well log information, geological data, well production information, and seismic survey results have been integrated to define geopressured fairways based on criteria such as minimum volume, temperature, pressure, porosity, and permeability. The primary areas of study have been in the Frio, Wilcox, and Vicksburg formations along the Gulf Coast.

Initial work resulted in choosing the optimum test well sites in Brazoria County, Texas (Section 5.4). Continuing work centers around high-resolution studies of other prospective sites in the Frio Fairway and using the same techniques in studying the Wilcox and Vicksburg fairways. To date, a total of five sites have been delineated in the Frio and four sites have been located on the Wilcox fairway.

In addition to the resource assessment, the following research is being carried out to define specific reservoir properties which will provide a major improvement in quantitative estimates of the resource in place:

\section{COMPACTION MEASUREMENTS}

The objective of this study is to determine the compaction mechanics of geopressured reservoirs. This information will help determine the 
(Italics denote changes since March 31, 1980.)

drive mechanisms and reservoir physical properties that affect production and potential for subsidence. Existing core testing equipment is being modified and plans are to add capability for elevated temperature and long-term creep testing. Theories will be developed and validated for observed rock behavior. Data resulting from this research will be used for computer simulations of production performance and subsidence prediction.

To date, cores from the Pleasant Bayou No. 1 and No. 2 wells have been tested and data are available.

SANDSTONE CONSOLIDATION ANALYSIS

This work will identify factors controlling reservoir quality in Tertiary sandstones and will evaluate their significance to geopressured aquifer production. The research program is focused on the delineation of the origin of porosity with emphasis on secondary leached porosity; definition of the relationship between porosity, permeability, and mineralogy and to relate the effects of diagenetic mineralogy to acoustic log response; and delineation of the effects of concomitant shale diagenesis on cementation and leaching in adjacent sandstones. It is possibie that these studies will lead to a predictive technique for determining reservoir quality.

To date, the sandstone consolidation sequences for the Frio, Vicksburg, and Wilcox formations have been documented.

FORMATION VELOCITY STUDIES

The objective of this project is to determine the elastic properties of hydropressured and geopressured formations encountered in test wells. Compressional and shear wave data will be obtained from using Schlumberger long-spaced sonic $10 \mathrm{~g}$ and Birdwell clamped geophones. Correlations with 1 ithology and well logs will be made. Data obtained from this project will be used to determine permeability and porosity.

To date, the long-spaced sonic log has been run in the Pleasant Bayou test wells and results have been analyzed.

\subsubsection{LOUISIANA RESOURCE ASSESSMENT}

As in the Texas studies, the objectives of this project are to define geopressured fairways and delineate optimum resource areas which can be developed for long-term testing. The analysis and interpretation of well $l o g$ data, geologic information, and seismic surveys have resulted in a list of 63 candidate areas. Further refinement has narrowed this list to ten sites; of which five sites have been classified as primary sites for further investigation. The above work has been performed by the Louisiana State University (LSU). 
(Italics denote changes since March 31, 1980.)

The primary sites resulting from the above study (Atchafalaya Bay, LaFourche Crossing, Southeast Pecan Island, Johnson Bayou, and Rockefeller Refuge) are being further studied in detail to determine optimum well sites. This research will concentrate on:

- Analysis and interpretation of regional structural-stratigraphic framework of southern Louisiana;

- Detailed geologic and geophysical studies;

- Development and application of geophysical techniques, particularly seismic reflection and gravity, to resource prospect evaluation; and

- Geochemical studies of diagenetic changes in the prospect areas.

The remaining five sites or prospective areas will be investigated in a similar manner in the near future.

\subsubsection{DENTIFICATION OF OTHER} POTENTIAL AREAS

Science Applications, Inc., has been awarded Contract DE-AC08-80NV10133 for the purpose of researching avallable information from areas outside the Gulf Coast to identify other potential areas of occurrence of the resource. Their initial study or Phase I has been completed and delineate several other areas within the continental U.S. that exhibit geopressure potential. 
(Italics denote changes since March 31, 1980.)

5.3

SUPPORTING RESEARCH

5.3 .1

GEN ER A L

Resource assessment activities described in 5.2 will provide an estimate of the amount of gas-bearing water in place in geopressured aquifers. How much of this resource can be produced is influenced by many factors, such as the amount of gas in solution, economics of production, environmental considerations, and legal and institutional barriers. To resolve some of these problems, research is being carried out in diverse areas affecting geopressured aquifer production.

\subsubsection{AQUIFER FLUID CHARACTERIZATION}

Three projects are under way which, when completed, will contribute significantly to the understanding of the nature of methane production from geopressured aquifers.

\section{IDAHO STATE UNIVERSITY (DE-ASO8-78ET12145)}

One of the most important factors concerning geopressured aquifers that is not accurately known is the amount of methane that is contained in the water. This contract with Idaho State calls for a laboratory study to determine the solubility of methane in water at varying conditions of salinity, temperature, pressure, carbon dioxide, and higher hydrocarbon content.

Methane solubilities in aqueous $\mathrm{NaCl}$ solutions of 5 to 20 percent have been determined for temperatures of 100 to $240^{\circ} \mathrm{C}$ and pressures of 2,000 to 22,500 psi. Solubilities of methane-carbon dioxide systems and methane-liquid hydrocarbon systems are being studied. Additional laboratory equipment is being assembled for solubility studies of these systems in actual field somples of produced brines from geopressured geothermal aquifers.

\section{UNIVERSITY OF SOUTHERN CALIFORNIA (DE-ASO8-78ETI1396)}

The basic purpose of this laboratory study is to ascerta in whether methane can be produced from geopressured aquifers at gas-water ratios which exceed the theoretical gas-water ratios in undisturbed aquifers: As fluid is withdrawn from an aquifer reservoir, pressure will decrease, resulting in liberation of gas from solution. If the gas saturation within the aquifer builds up fast enough, a point may be reached when 
(ltalics denote changes since March 31, 1980.)

the gas will be able to flow as free gas through the reservoir. In such a case, it may be possible to increase and accelerate the methane recovery from aquifers.

To accomplish this project, simulated geopressured aquifers have been constructed to represent consolidated (Berea sandstone) and unconsolidated (graded loose sand) reservoirs. In situ conditions have been created by using methane-saturated water and brine under high pressures. These "aquifers" have been be produced and the rate of methane and brine production carefully monitored. The resulting data, including pressure and production history and fluids production, will indicate the nature of production, i.e., whether more gas is produced than the theoretical ratio.

The project has been completed and the final report is in preparation.

\subsubsection{DATA PROCESS ING}

The data processing support is provided in three major categories: computer simulation of production and economics, interpretation of test data resulting from field activities, and creation of a data bank and information distribution.

INSTITUTE OF GAS TECHNOLOGY (DE-ACO8-78ET27098)

The Institute of Gas Technology (IGT) will provide computer programs to determine production economic sensitivity to:

- relative permeability,

- cost of water disposed,

- reduction of permeability from production,

- changes in reservoir drive, and

- effect of two-phase flow.

Reservoir engineering studies on recent wells of opportumity tests are being conducted at the present time.

INTERCOMP, INC. (DE-AC08-78ET11395) AND IGT

Interpretation of field test data is very vital to the accurate definition of the resource. Data to be analyzed include: 
(Italics denote changes since March 31, 1980.)

- well logs,

- core analyses,

- drill stem tests,

- production and injection tests, and

- pressure buildup, drawdown, and interference tests.

As field test data become available from the activities described in Section 5.4, both IGT and Intercomp, Inc., will perform the computer calculations and provide interpretations. In addition, Intercomp will simulate the reservoirs under production conditions to provide projections of long-term production potential. These simulations will be used to pinpoint those reservoir parameters which exhibit the greatest influence on the production behavior of the aquifer. Parameters considered will include reservoir temperature, pressure, porosity, permeability, thickness, and areal extent. Also examined will be the variation of permeability with pressure.

Analysis of data from the Fairfax Foster Sutter No. 2 and the Pleasant Bayou wells have been completed. Computerized analysis of flow tests hove been submitted.

\section{UNIVERSITY OF TEXAS (DE-AC08-79ET27018)}

This is a continuation of work previously funded under Contract No. EY-76-S-05-5243 and provides for the establishment of an automated information system containing available information in the geopressured aquifer research areas.

Known as the Geopressured Geothermal Information System (GGIS), the various tasks include the following:

- A library of digitized well logs from known geopressured areas. Logs from geopressured wells will be digitized, processed, and interpreted to gain a regional and local understanding of the petrophysical and fluid properties of the reservoirs.

- Preparation and distribution of bibliographic information.

Development and refinement of the thesaurus for use by researchers.

- Preparation and distribution of information on geopressured resources to users at cost.

- Quarterly newsletter preparation and distribution. 
(Italics denote changes since March 31, 1980.)

- Development of computer software for log analysis, file management, plotting, and automated data entry.

Approximately eight million curve-feet of data have been verified and stored in tape files. Most of these logs are of wells in the Brazoria Geopressured Fairway. Work under this contract will be continued under a master contract to incorporate various contracts.

\subsubsection{LEGAL, INSTITUTIONAL, AND} OPERATIONS RESEARCH

Since geopressured aquifer methane production is a totally new and untried concept, many nontechnical factors that affect exploitation need to be identified and resolved. Legal issues such as definition, ownership, and leasing will directly impact on the future of the resource. To resolve such issues concurrently with technological development, several research projects have been funded to clearly identify the issues and propose possible solutions to alleviate any problems.

\section{OPERATIONS RESEARCH}

The overall objective of this work is to produce a recommended development plan for geopressured aquifer production. Currentiy, two projects are funded--one at the University of Texas (DE-AS08-78ET27087) and the other at Louisiana Department of Natural Resources (DE-FG08-78ET27085). Together, these two projects will cover the entire area of interest along the U.S. Gulf Coast. Detailed objectives for these projects are as follows:

- Characterize the resource: review and assemble existing data that describe the resource base.

- Identify impediments to geopressured energy development: environmental constraints, gas prices, resource ownership, field unitization, etc., will be analyzed.

- Preparation and analysis of development scenarios: information obtained from the above two tasks will be used to develop a time-oriented schedule for energy production. The likely effects of tax policies, production tax credits, gas prices, depletion, and intangibie drilling allowances will be analyzed. Attention will be given to social and institutional factors that may affect development, such as expected employment levels; and impacts on schools, roads, and other public services will be analyzed. Any action that is required by federal, state, and local governments to help development will be identified. 
- Cost-benefit analysis for above development scenarios will be prepared.

- These scenarios will be reviewed with locally interested parties to aid in the promotion of regional planning efforts.

Work on these two contracts has been complezed and final reports are in preparation.

In addition to the overall effort as described above, local studies will be carried out in areas recommended for testing. One such project is already under way in connection with the Brazoria County site (see Section 5.4). The Alvin Community College has been funded (DE-AS0878ET27032) to establish an information network and data base for socioeconomic planning assistance in the county to educate the public, industry, and governmental entities in the geopressured aquifer development program.

LEGAL ISSUES

As already mentioned, legal issues may create a possible hindrance to geopressured aquifer development... Under an ERDA contract (No. E(40-1)5257), the Law School of Louistana State University was asked to review this problem. The final report, covering the State of Louisiana, basically included the following tasks:

- Review the legal framework within which the geopressured resource will have to be developed and identify those problems which may be created by its development within that framework.

- Offer possible solutions to these problems or at least indicate techniques which might be considered in their resolution.

- Assemble a compendium of those statutory or regulatory provisions which may regulate or affect resource development.

\subsubsection{ENVIRONMENTAL RESEARCH}

Production of large quantities of fluids from geopressured aquifers has potential environmental impact on air, water, and land use. Prel iminary investigations indicate that the areas of major concern are subsidence and water disposal. Impact on air quality and surface waters will be minimal. It is planned to prepare a generic impact assessment and sitespecific environmental impact assessments for each test well.

OAK RIDGE NATIONAL LABORATORY (ORNL)

The ORNL is responstble for the preparation of generic and sitespecific environmental assessment reports in support of the geopressured 
(Italics denote changes since March 31, 1980.)

test well program. Both in-house expertise and subcontractors are used to accomplish this task. Current activity is as follows:

- Generic assessment completed for the Wells of Opportunity Program (see Section 5.4) for the Frio formation.

- Work has been initiated on the generic assessment to cover the entire well test program.

- Site-specific assessments are under way for Southeast Pecan Island and Gladys McCall sites in Louisiana.

\section{LOUISIANA GULF COAST STUDY}

The Institute for Environmental Studies at Louisiana State University was contracted to environmentally qualify potential well sites in six areas of the Gulf Coast. The objective was to compare high-priority prospect areas on the basis of potential environmental impacts. The assessment was made on the basis of the nature and extent of the proposed testing activities and how they affect land use, geology, air quality, water resources, ecological systems, and natural hazards. The following prospect areas were studied:

- South Johnson's Bayou

- Sweet Lake

- Rockefeller Refuge

- Southeast Pecan Island

- Atchafalaya Bay

- LaFourche Crossing

Final report (10/15/78) entitled "A Preliminary Environmental Assessment of Selected Geopressured-Geothermal Prospect Areas: Louisiana Gulf Coast Region--Volumes I and I," has been issued and the information from this report will be used as background data for future site-specific impact assessment reports.

\section{TEXAS GULF COAST STUDY}

Similar efforts are under way in Texas to environmentally qualify potential well sites for geopressured aquifer development.

- The Bureau of Economic Geology (BEG) at the University of Texas was contracted to study the geopressured fairway areas in Brazoria, Kenedy, and Dewitt counties to study the following parameters: 
--active geologic processes,

--current land use,

--air and water quality baseline data, and

--current flora and fauna.

- The final report is to be used in preparing environmental assessment reports for test well activity in these two counties.

- The Bureau of Economic Geology has started similar work for the areas overlying the Wilcox formation geopressured aquifer resources.

- Site-specific monitoring: The BEG is also conducting environmental studies at the DOE test well in Brazoria County, Texas (see Section 5.4). The objective of this program is twofold: to provide baseline environmental data and to continue monitoring during the testing phase. A number of surveys will be performed prior to, during, and after wells have produced large amounts of fluids. These include:

--air quality monitoring,

--water quality monitoring,

--microseismic surveys,

- -leveling surveys,

--disposal well monitoring, and

--noise impact surveys.

The approximate data collection frequency is: air quality-daily, water quality--monthly, ground stability--semiannually, and microseismicity--continuousiy.

- The Lawrence Berkeley Laboratory (LBL) has been funded (a) to develop techniques for distinguishing naturally occurring subsidence from that which may be caused by fluid withdrawal from geothermal wells and (b) to develop techniques for operating geothermal fields in a manner that will prevent or minimize adverse effects due to subsidence.

Five major areas will be covered by this research, namely:

--characterization of subsidence,

--physical theory of subsidence,

--properties of materials,

--simulation of subsidence, and

--subsidence control.

Most of the data generated from this study will be directly applicable to geopressured aquifer development.

- To provide first-order releveling of an area along the Texas Gulf coast that contains potential geopressured resources, the 
(Italics denote changes since March 31, 1980.)

National Geodetic Survey (NGS) has been funded to perform $3,200 \mathrm{~km}$ of vertical control releveling in east Texas. The first survey was completed in August 1978, and future surveys will be performed as needed.

\section{3 .6 \\ EXPANSION OF \\ A R E A \\ OF \\ ST U D Y}

SCIENCE APPLICATIONS, INC. (Contract No. DE-ACO8-80NV10133)

This contract has recently been awarded to SAI for the purpose of investigating areas outside of the Gulf Coast where geopressured aquifers containing methane may occur. A search has been completed to determine occurrence of the resource mentioned in literature. This will be followed by a field study to verify such occurrences and estimate their magnitude. 
(Italics denote changes since March 31, 1980.)

$5.4 \quad \frac{\text { FIELD TESTS AND }}{\text { DEMONSTRATIONS }}$

5.4.1 GENERAL

The field testing program consists of both long- and short-term tests. The long-term tests under the Designed Well Program are based on resource assessment studies which identify optimum sites suitable for such testing. The estimated duration of these tests is from 18 to 24 months, during which all aspects of geopressured geothermal research will be investigated, including production testing, reservoir evaluation, and environmental impact evaluation.

In contrast, the short-term tests under the Wells of Opportunity Program are mainly designed for quick production tests and reservoir evaluation. Estimated duration of these projects is one to three months. The tests under this program are carried out on wells drilled by the industry that were found to be nonproductive, but they penetrated good geopressured aquifers (as indicated by local geology and well logs). Other wells which have depleted their productive oil and gas reservoirs and are to be abandoned are also included in these prospects. Such well(s) are being acquired from the original operator for the express purpose of short-term tests and are being plugged and abandoned after the tests.

At the start of the Wells of Opportunity Program, it was difficult to locate appropriate wells for testing and it was decided to attempt reentry into plugged and abandoned well, 10ated in p.omising are.s. recause of the difficulties encountered in these operations, any further attempts to reenter plugged and abandoned wells will be researched to the point where the probability of success is high or funding exposure is strictly limited.

It is expected that data obtained from both testing programs will allow a detailed characterization of the production potential of geopressured aquifers to be made and provide recommendations for optimum ways of exploiting this resource.

BACKGROUND

As a result of resource assessment studies performed by the Bureau of Economic Geology of the University of Texas, an optimum site was selected near Alvin, Texas. This site was chosen in accordance with the following criteria which define an "ideal" reservoir for commercial production: 
- reservoir volume--at least three cubic miles

- fluid temperature--greater than $300^{\circ} \mathrm{F}$.

- minimum permeability--20 millidarcys

- water salinity--up to $80,000 \mathrm{ppm}$

- initial bottom-hole pressure--greater than 10,000 psia

- production rate--20,000 to 40,000 barrels of water per day.

The test well is located on a five-acre site in Brazoria County (40 miles south of Houston) on the east bank of the Chocolate Bayou on General Crude 0il Company's Martin Ranch property.

\section{PROGRAM OBJECTIVES}

The objectives of the well drilling and testing program are to determine the following parameters:

- Reservoir permeability, porosity, thickness, rock material properties, depth, temperature, and pressure

- Reservoir fluid content, specific gravity, resistivity, viscosity, and hydrocarbons in solutions

- Reservoir fluid production rates, pressure, temperature, production decline, and pressure decline

- Geopressured well and surface equipment design requirements for high-volume production and possible sand production

- Specific equipment design for surface operations, hydrocarbons distribution, and effluent disposal

- Possibilities of reservoir compaction and/or surface subsidence.

\subsubsection{DES I GN WELLS}

SUMMARY OF PROGRESS

Drilling was started on the GCO-DOE Pleasant Bayou No. 1 in July 1978. By November 1978, the well had reached 15,675 feet. A total of nine cores were taken and full suites of well logs were run. While attempting to take core No. 10, the core barrel stuck at 10,505 feet. All efforts to recover the drill pipe and resume drilling operations falled, 
(Italics denote changes since March 31, 1980.)

5.4.2 DESIGN WELLS PROGRAM--TEXAS

Fenix \& Scisson, Inc.

Status: Active

Las Vegas, Nevada

Contract:

Contract Date:

Contract Completion Date:

DE-AC08-76ND00038

November 1977

Apri1 1, 1981

Principal Investigator:

Ken Ortego (Fenix \& Scisson, Las Vegas)

DOE Project Engineer, Testing:

F. L. Goldsberry (Houston)

DOE Project Engineer, Drilling:

R. D. Clarke (Las Vegas)

\section{OBJECTIVE}

To drill, complete, and test a well on a site in Brazoria County, Texas.

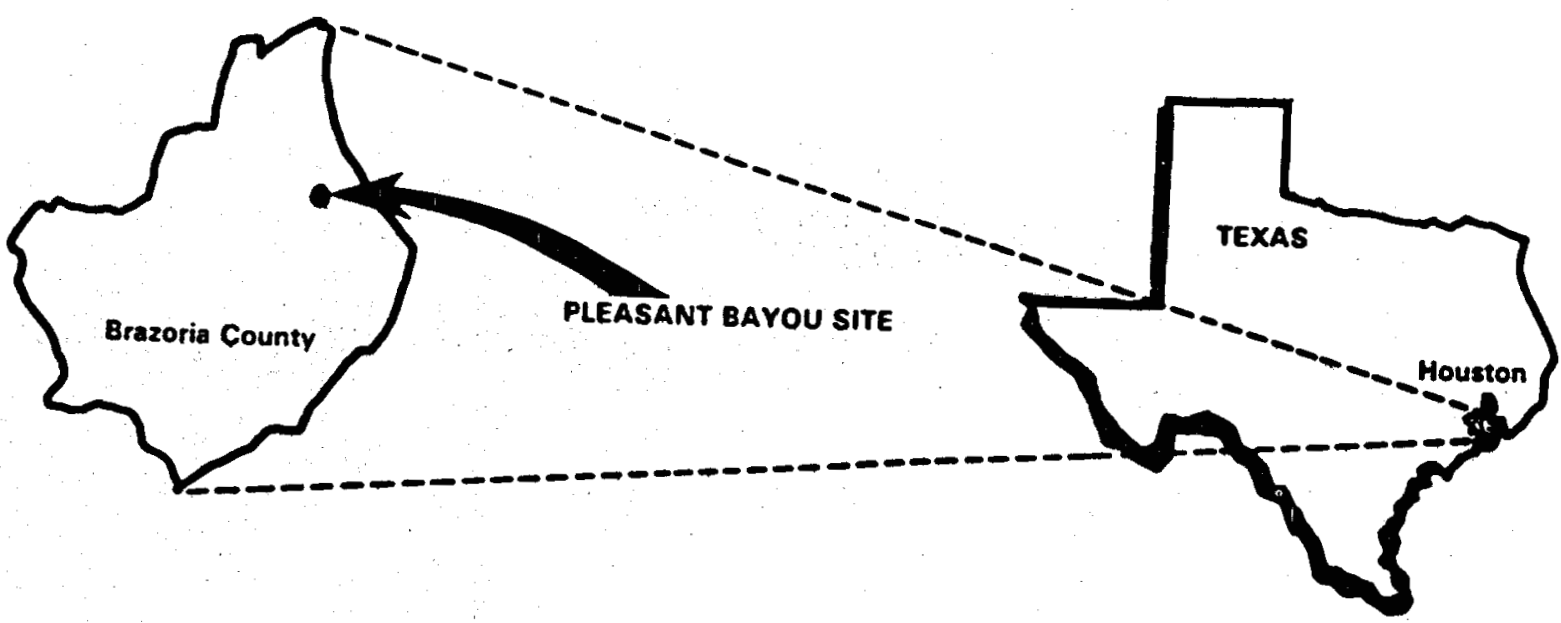


(Italics denote changes since March 31, 1980.)

and it was decided to plug this well and select a new location 500 feet away. This move was preferred over sidetracking because of the poor condition of 13 3/8-inch protection casing and the possibility of complications in reservoir testing due to influence of the existing hole. Pleasant Bayou No. 1 was plugged in January 1979. This well was recompleted as an injection well in November 1979.

The GCO-DOE Pleasant Bayou No. 2 was spudded 500 feet southeast of well No. 1 in January 1979. Drilling proceeded according to plan to 16,500 feet, at which point the well was completed as follows:

20-inch casing at 1,395 feet--cemented to surface.

$133 / 8$-inch casing at 8,488 feet--cemented to surface.

9 5/8-inch casing at 14,284 feet--cement top at 13,800 feet.

7-inch liner set from 13,992 feet to 16,500 feet.

The zones 15,988 feet-16,006 feet, 16,038 feet-16,046 feet, 15,576 feet-15,586 feet, and 15,580 feet-15,590 feet were perforated and drill stem tested. Production from these zones varied from $3 \mathrm{BWPH}$ to $14 \mathrm{BWPH}$. The zone from 14,644 feet-14,704 feet was perforated to test. The No. 1 well was completed as a disposal well and a 10-day flow test was completed on December 13, 1978. A 45-day flow test was started on September 16, 1980, and completed on October 31, 1980. Early results of this test are as follows:

Static bottom-hole pressure: 11,275 psi

Static surface pressure: 4,391 psi

Bottom-hole temperature: $301 \mathrm{~F}$.

Surface flowing temperature: $279^{\circ} \mathrm{F}$.

Crm. flow comount: $577,161 \mathrm{BW}$

Flowing BHP after 45 days: 10,389 psi

Flowing surface pressure: 3,567 psi

Gas/water ratio: Avg. $20.28 \mathrm{cu}$. ft./BW

Cum. gas produced: 11,707 MCF

On October 31, 1980, the well was shut in and the 60- to 120-day pressure buildup was started. 


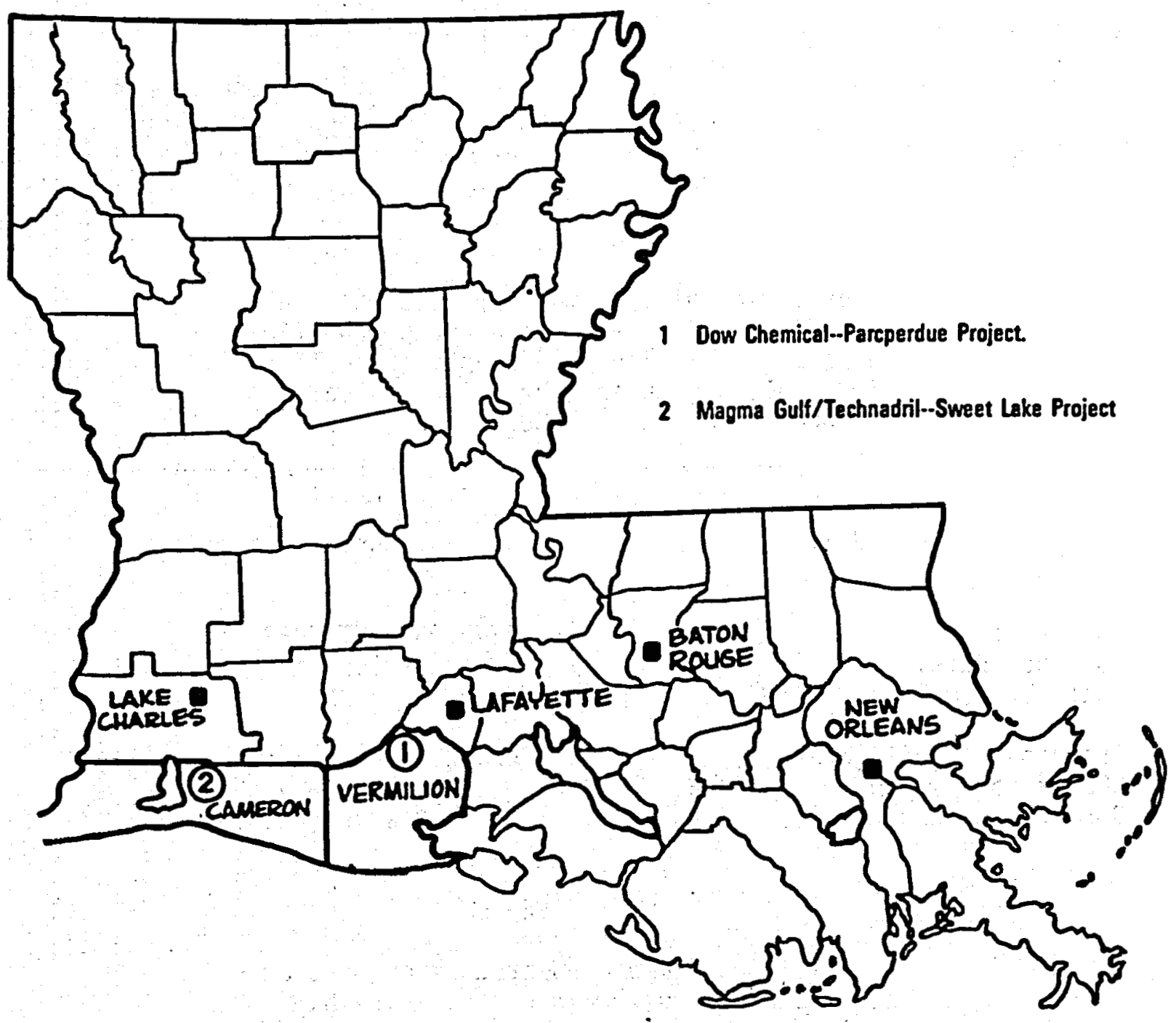


5.4.2 DESIGN WELLS PROGRAM--LOUISIANA

Dow Chemical, U.S.A.

Status: Active

Midland, Michigan

Contract:

Contract Date:

DE-AC08-79ET27255

Contract Completion Date:

September 1979

September 1982

Principal Investigator:

DOE Project Engineer, Testing:

Dr. John Wilson (Dow Chemical)

DOE Project Engineer, Drilling:

F. L. Goldsberry (Houston)

D. J. Steinnead (Las Vegas)

\section{OBJECTIVE}

To drill, complete, and production test a geopressured aquifer in the Parcperdue field in Vermilion Parish, Louisiana. Long lead time items have been ordered. Spud date is planned for December 1980.

Magma Gulf/Technadril

Houston, Texas

Contract:

Contract Date:

Contract Completion Date:

Principal Investigator:

DOE Project Engineer, Testing:

DOE Project Engineer, Drilling:
Status: Active

DE-AC08-78ET27082

December 1979

November 1982

Dr. Clay Durham (Magma Gulf)

F. L. Goldsbermy (Houston)

R. D. Clarke (Las Vegas)

\section{OBJECTIVE}

To drill, complete, and production test a geopressured aquifer in Cameron Parish, Louisiana.

STATUS: Long lead time items have been received. The well was spudded in mid-August, 1980. The 13 3/8-inch surface pipe was set at 4,047 feet and the 9 5/8-inch intermediate casing was set at 10,230 feet. On November 20, 1980, the well was drilling ahead at 11,000 feet. The disposal was drilled and completed in October 1980. 
H. J. GRUY \& ASSOCIATES (Contract DE-AC08-77ET28460)

Because of the unavailability of good candidate wells for this program, it was decided to attempt reentry into old, abandoned wells. Two such attempts were made without success. Of three other attempts, three were made on newly drilled wells. Two of these were successful. A brief account of each attempt is given below.

ALICE C. PLANTATION WELL NO. 2

The Alice C. Plantation No. 2 was selected as the first test well from among a number of reentry candidates. This well was originally drilled in 1964 to a total depth of 19,000 feet and was plugged and abandoned because it was nonproductive of oil or gas in commercial quantities.

Reentry operations began in July 1978, and the well was cleaned out to a depth of 18,000 feet. While the drill pipe was being pulled out in preparation for running 7-inch casing, the well began to flow uncontrolled. Efforts to bring the flow under control were unsuccessful; however, the hole bridged over and the flow stopped. After installing proper equipment, the well was reentered, and it was found that the 9 5/8-inch casing had apparently collapsed beginning at the depth of 5,053 feet. At this point, it was concluded that it would be imprudent, both technicaily and financially, to continue operations and the well was plugged.

GLADYS MCCALL WELL NO. 1

This well was originally drilled in 1965 to a depth of 15,598 feet and subsequently plugged and abandoned as a dry hole. The well was selected for reentry since no adequate well of opportunity (i.e., the ones that were currently being drilled) was being offered by industry for testing.

The reentry and testing plan called for running a 7-inch tieback string, equipping the well with $31 / 2$-inch tubing, and flow testing the geopressured sands. Operations began in October 1978. Upon reentry, it was found that the casing in the hole was badly damaged and the location and condition of tubulars were quite different from those anticipated, based on the plugging and abandonment records. After exhaustive and unsuccessful attempts at reentry at approximately 3,500 feet, it was decided to cease operations and to plug and abandon this well.

FAIRFAX FOSTER SUTTER WELL NO. 2

This is the first well of opportunity that was offered for testing right after the original operator determined it to be nonproductive of oil or gas in commercial quantities at the objective completion depth. This well was drilled by Neuhoff 0 il and Gas Company to 16,340 feet. 
Eaton Operating Co. Houston, Texas

Contract:

Contract Date:

Contract Completion Date:

Principal Investigator:

DOE Project Engineer, Testing:

DOE Project Engineer, Drilling:
Status: Active

$D E-A C 08-80 E T 27081$

December 1979

December 1981

Dr. Ben A. Eaton (Eaton)

F. L. Goldeberry (Houston)

E. X. Zuniga (Las Vegas)

\section{OBJECTIVE}

To acquire, complete, and production test geopressured acquifer wells of opportunity in the U.S. Gulf Coast.

H. J. Gruy \& Associates

Houston, Texas

Contract:

Contract Date:

Contract Completion Date:

Principal Investigator:

DOE Project Engineer, Testing:

DOE Project Engineer, Drilling:
Status: Program

Complete

DE-AC08-77ET28460

September 1977

November 1980

R. J. Dobson (Gruy)

F. L. Goldsbermy (Houston)

E. X. Zuniga (Las Vegas)

\section{OBJECTIVE}

To acquire, complete, and production test geopressured aquifer wells of opportunity in the U.S. Gulf Coast. 


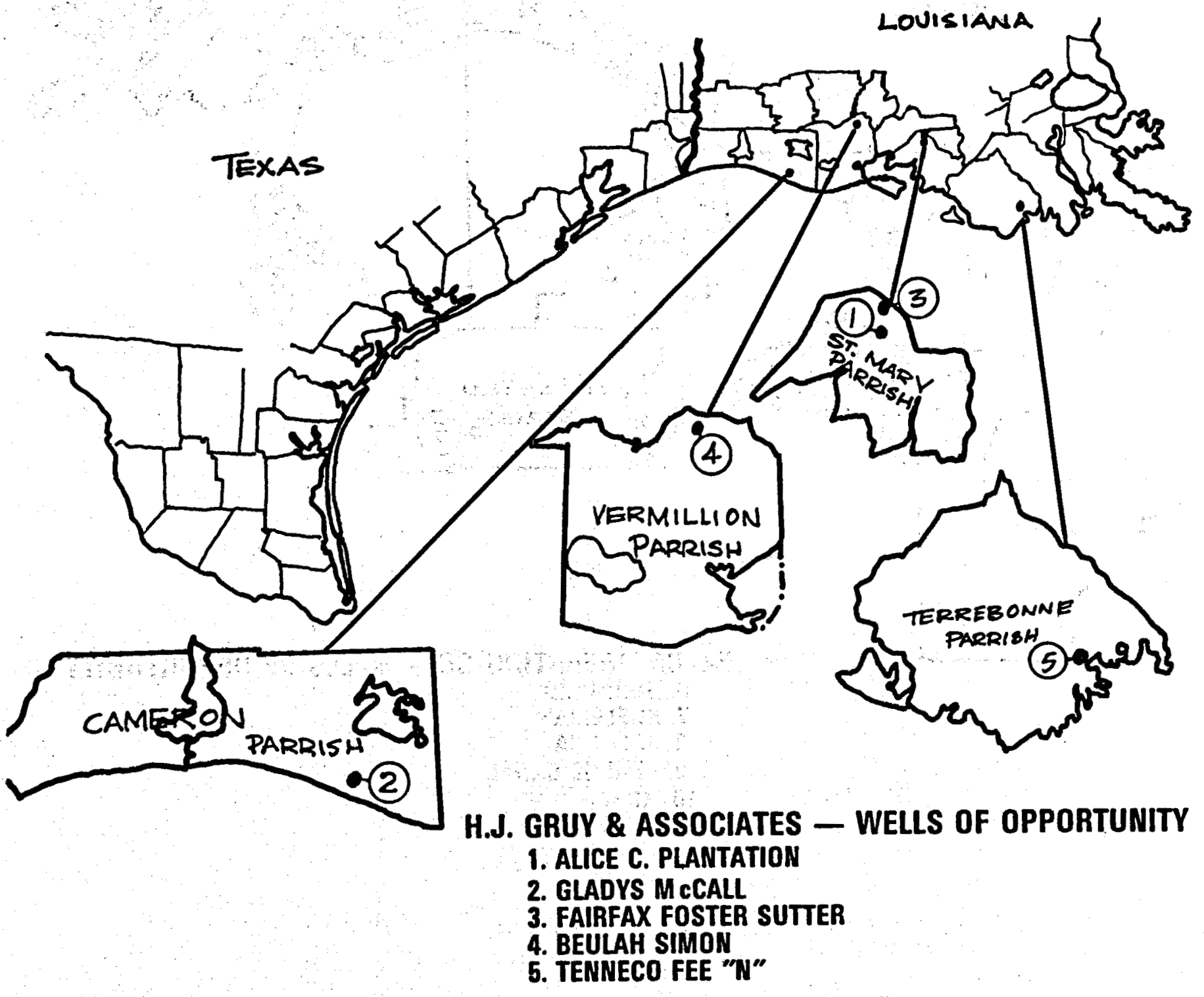




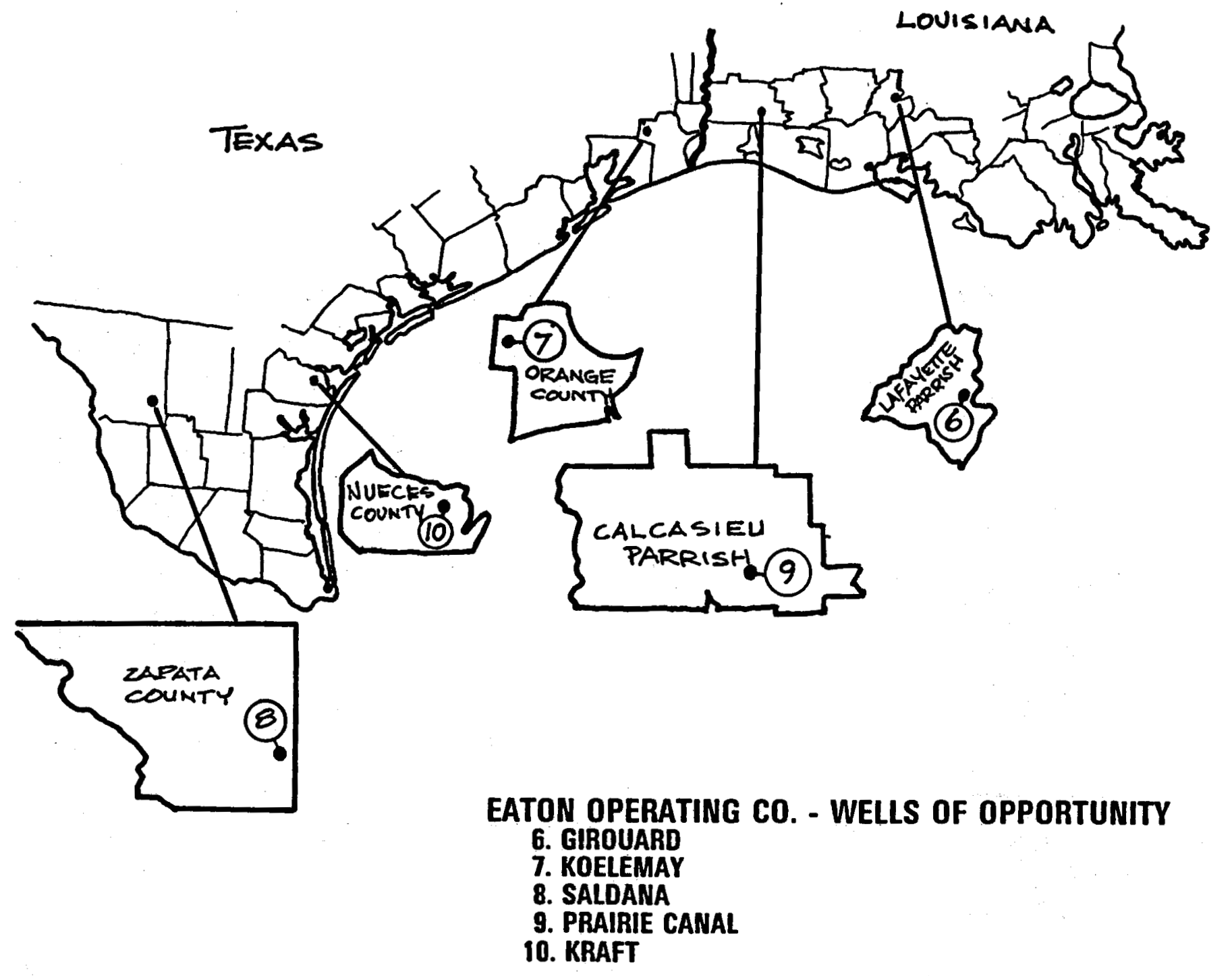


Completion operations began in March 1979. A 5 1/2-inch liner was run from 14,130 feet to the total depth of 16,340 feet. A section of the MA-6 sand of lower Miocene age was perforated from 15,780 feet to 15,930 feet. Production tubing consisting of $31 / 3-$ inch tubing from surface to 13,947 feet and $27 / 8$-inch tubing from 13,947 feet to 15,573 feet was installed. A saltwater disposal well was drilled and cased with 5-inch casing to 3,962 feet, cemented to surface, and perforated from 3,609 feet to 3,669 feet. Production equipment was installed and the well was tested. Both production well and disposal well were returned to Neuhoff on August 20,1979 , after removing the production tubing and plugging the well back to 14,935 feet.

The testing consisted of two flow rates and two pressure buildups. Initial reservoir pressure was observed to be 12,200 psi and the initial reservoir temperature $270 \mathrm{~F}$. The brine contained an average of 190,904 $\mathrm{mg} / \mathrm{liter}$ of total dissolved solids and the salinity expressed in equivalent $\mathrm{NaCl}$ concentration was $160,000 \mathrm{mg} / 1$ iter. The average dissolved gas content was 22.8 standard cubic feet per stock tank barrel of water. The gas consisted of 89.57 mol percent methane and 7.85 mol percent $\mathrm{CO}_{2}$ and had a specific gravity of .6447 and a heating value of 948 Btu per cubic foot.

The maximum flow rate measured from the well was approximately 7,747 barrels per day, but this rate could not be sustained due to the low permeability of the reservoir, estimated at $14 \mathrm{md}$. Analys is of the drawdown and buildup data indicate two reservoir boundaries interpreted as parallel faults approximately 1,800 feet apart, with the well approximately midway between the faults.

BEULAH SIMON WELL NO. 2

This well was drilled by Southport Exploration, Inc., to 15,265 feet, found nonproductive of oil or gas in commercial quantities, and offered for testing of the geopressured sands which had been penetrated. Completion operations commenced in September 1979. A 5 1/2-inch liner was run from 11,556 feet to 15,234 feet and tied back to surface with 7 -inch casing. A string of $31 / 2$-inch tubing was installed from surface to 14,224 feet and a section of the Lower Camerina sand was perforated from 14,674 feet to 14,770 feet. A saltwater disposal well was drilled and cased with 5 1/2-inch casing to 2,702 feet, cemented to surface, and perforated from 2,464 feet to 2,524 feet. Production equipment was installed and testing operations were commenced in October 1979 and completed in December 1979.

The reservoir pressure measured with a Hewl itt-Packard downhole gauge was 13,015 psia at 14,722 feet (midpoint of the perforations). The well flowed at a rate of approximately 8,000 barrels per day during initial cleanup flow. Bottom hole temperature was measured at $266^{\circ} \mathrm{F}$ prior to starting a test flow. Surface flowing temperature was $220^{\circ} \mathrm{F}$. A flow test of approximately 7,000 barrels per day was started but was discontinued when the Hewlitt-Packard gauge was pushed up the tubing by the 
(Italics denote changes since March 31, 1980.)

flowing brine and became lodged in the production string. The well was killed and the tubing pulled to recover the gauge and tangled cable.

A final flow test for 10 days was accomplished with the HewlittPackard gauge out of the hole. The rate of flow was measured starting at 11,200 barrels per day and ending at 10,780 barrels per day. The surface pressures were measured starting at 5,210 psia and ending at 4,658 psia on the casing, and starting at 4,300 psia and ending at 3,221 on the tubing. Flowing temperatures measured at surface ranged from $256^{\circ} \mathrm{F}$ to $269^{\circ} \mathrm{F}$, and gas/water ratios ranged from 21.85 cubic feet per barrel to 22.69 cubic feet per barrel.

The well was shut in for 20 days and the pressure buildup recorded with a Hewlitt-Packard gauge at bottom hole and with dead weight gauges at surface.

\section{TENNECO FEE "N" WELL NO. 1}

This well was completed as a dry hole by Tenneco 0 il Company in January 1979, and cased to a total depth of 17,276 feet. It was offered for testing of two geopressured sands occurring from 16,906 to 17,005 feet, and from 17,098 to 17,185 feet, respectively. The wel1 was acquired by DOE and completion operations began in January 1980. The well location was at an inland water site and operations had to be conducted from barges. The well was cleaned out to 13,148 feet and a 5-inch tieback casing string was set and cemented from 13,148 to 12,270 feet. A 7-inch casing string was set from the crossover at 12,270 feet to surface. The well was then cleaned out to a total depth of 17,226 feet. A cement bond $\log$ was run which indicated questionable cement bonding behind the $41 / 2-$ inch liner which was in the well from total depth of 17,242 to 13,148 feet. Several unsuccessful attempts were made to effectively recement the 4 1/2-inch liner. Evidence of a hole in the $41 / 2$-inch liner was detected and it was concluded that it would be impossible to complete the well in the target sands. The well was plugged and abandoned.

\section{EATON OPERATING COMPANY (Contract. DE-AC08-80ET27081)}

Under this contract, four nowly drilled wells have been acquired and operated on. Two of these wells have been successfully completed and tested. One of these wells has been plugged and abandoned after completion of the test. The other well has been returned to the original operator as a producer of oil and gas in commercial quantities. As of this date, the other two wells have been successfully completed and one is in the process of testing, while the other is cwaiting the drilling of the disposal well for testing to proceed. One other well will be aoquired and tested if reentry and cleanout of a plugged well by a third party is successful. A brief account of these operations is given bezow. 
(Italics denote changes since March 31, 1980.)

GIROUARD WELL NO. 1

This well, located approximately 10 miles southeast of Lafayette, Louisiona, was drilled and cased by Wainoco Oil and Gas Corporation and abandoned as a dry hole in April 1980. The weil was reentered by the DOE contractor, Eaton Operating Company. Inc., in May 1980, and completed as a geothermal-geopressured well-of-opportunity test well in June 1980. A new disposal well was drilied nearby and completed in July 1980. The interval tested was the Oligocene Marginulina Texana No. 1 sand of the Upper Frio age from 14,744 to 14,819 feet in depth. The disposal we $2 z$ was perforated in the interval from 2,870 to 3,000 feet in depth in a Miocene saltwater sand.

During the test, the well was flowed at rates varying from 2,400 to 18,460 borrels of brine per day through 3 1/2-inch tubing. Observed data were:

Original reservoir pressure: 13,203 psia

Original reservoir temperature: $274^{\circ}$

Bighest surface temperature: $255^{\circ} \mathrm{F}$

Gas/liquid ratio: 37 SCF/bbZ

Water analysis: $23,500 \mathrm{ppm}$ total dissolved solids

$13,300 \mathrm{ppm}$ chlorides

Gas analysis (mole percent): 91.3 methane

Gas heating value: $970 \mathrm{BTU} / \mathrm{SCF}$

$6.0 \mathrm{CO}_{2}$

2.5 heavier hydrocarbons

0.2 mole percent

Lowest flowing bottom hole pressure: 11,242 psia

No comosion observed and light scaling effects.

Sand production: 0.5 to 1.7 pounds per $1,000 \mathrm{bbls}$.

Reservoir data interpretation resulte:

Maximom explored volumes of brine: greater than

5.2 million bbls.

Maximum radial distance explored: 1,540 feet

Test well productivity index: 3.0 to $4.0 \mathrm{BPD} / \mathrm{p} 8 \mathrm{i}$

Reservoir: Very restricted: lenticular with a permeability range of 200 to 240 millidarcies and a flow angle of less than 50 degrees.

No major problems were encountered with the drilling, completion, or testing of this site. Both wells have been plugged and abandoned after the conclusion of the tests. The Contractor has prepared a detailed draft final report at this time.

KOELEMAY WELL NO. 1

This well, located approximately 10 miles west of Becumont, Texas, was drilled by Lear Petroleum Exploration Inc., to a depth of 14,885 feet and cased with 9 5/8-inch intermediate casing set at 10,031 feet, and 5 1/2-inch casing to 13,925 feet. Several intervals were perforated by 
(Italics denote changes since March 31, 1980.)

Lear and found not productive of oil or gas in commercial quantities. One of these intervals from 11,645 to 11,665 feet proved to be productive of saline water with a salinity of 16,500 ppm at a reservoir pressure of $9,440 \mathrm{psi}$ and a temperature of $240^{\circ} \mathrm{F}$. The well was acquired in May 1980 under a standard agreement for testing the geopressured geothermal aquifer.

The well was reentered in Jume 1980 and completed in July by drilling cement plugs and cleaning the well bore to 12,599 feet, setting $23 / 8$-inch tubing at 11,550 feet, and perforating from 11,641 to 11,780 feet. The 2 3/8-inch tubing was installed to accommodate bottom-hole pressure and temperature measuring instruments while flowing through the annulus between the 51/2-inch casing and the 23/8-inch tubing. A saltwater disposal well was drilled, test equipment was installed, and the well was tested in September 1980. Operations were intermpted by torrential rains from tropical storm "Daniel" in early September.

Drowdown data was obtained by flowing at a rate of opproximately 2,400 barrels per day and gas-to-water ratio of 30 cubic feet per barrel for 24 hours. The well was then shut in for 24 hours to obtain buildup data.

A second flow test was commenced on September 16, 1980, attempting to maintain a sustained flow of 5,000 barrels per day. The flow rate could not be maintained and dropped to 3,722 barrels per day when the well was shut in due to disposal problems. The disposal well pressure had built up to above 400 psi and the flow was diverted to the reserve pits in order to rework the disposal well. When the reserve pits filled to copacity, the well was shut in. The disposal well was reperforated and treated with acid.

A third flow was conmenced on September 19, 1980. Initial flow was 7,000 borrels per day which declined ropidly to 3,751 borrels per day. At the same time, the production of gas was increasing and oil was being produced. On September 25, 1980, the well was producing at a rate of $3,42.0$ barrels of water per day, 919 MCF of gas per day, and 100 barrels of oil per day. At midnight on September 25, 1980, custody of the well was transferred back to Lear Petroleum Exploration. Inc. As of this date, Lear was reportedly producing at a rate of 140 barrels of oil per day and 1.5 million cubic feet of gas per day with opproximately 2,000 barrels of water per day and the disposal well was accepting the disposed brine without any problems.

SALDANA NO. 1 AND 2 WELLS

These wells, located approximately 35 miles southwest of Laredo, Texas, were drilled and cased by Riddle oil Company. The No. 1 well was drilled to 11,385 feet and cased to total depth. The No. 2 well was drilled to 11,171 feet and cased to 10,655 feet. A fish consisting of 5-inch liner and drill pipe which became stuck were left in the bottom, uncemented, with the top at 9,830 feet and a bridge plug at 9,822 feet. The wells 
(Italics denote changes since March 31, 1980.)

are located less than 2,000 feet apart. Riddle tested various intervals in both wells without encountering conmercial quantities of oil and gas. Well No. 2 tested an interval at 9,745 to 9,835 feet which proved to be productive of water at a reservoir pressure of 6,750 psi, salinity of $11,121 \mathrm{ppm}$, and temperature of $256^{\circ} \mathrm{F}$.

The wells were acquired by Eaton and operated on in early October, 1980. WeIZ No. 1 was reworked and plugged back to 4,000 feet for use as the disposal well. Well No. 2 was reworked and completed with perforations at 9,745 to 9,820 feet in the First Hinnant Sand of the Upper Wizcox Group of late Eocene age. As of this date, the test of this well is near completion.

PRAIRIE CANAL WELL NO. 1

This well, Zocated 7 miles south of Lake Charles, Louisiana, was drilled by Houston Oil and Minerals Corporation to 15,636 feet, cased to 14,171 feet, abandoned as a dry hole, and offered for geopressured geothermal testing. The Hackbermy Sand of the Upper Frio formation of the Catahoula Series had been encountered at the interval from 14,976 to 15,024 feet, and indicated water existed with pressure of 13,516 psi, temperature of $304^{\circ} \mathrm{F}$, and salinity of $27,000 \mathrm{ppm}$.

The well was acquired and completed by installing 5 1/2-inch production casing from 15,630 feet to surface, and 2 3/8-inch tubing to accomodate downhole measuring instruments while flowing through the annulus between 5 1/2-inch casing and 2 3/8-inch tubing.

At this time, the rig has been moved nearby to drill a disposal well prior to testing. Testing is scheduled for December 1980.

KRAFT WELL NO. 1

This well is the second well proposed for test by Don Ross of Ross-Pope Drilling Equipment Company. Mr. Ross is interested in finding a possible energy source in a proposed project for production of alcohol from sugar cane for a gasohol project using an unconventional energy source. An agreement with Mr. Ross had been executed in May 1980, for testing another well, the Bevly No. 1, in the scome area which had been drilled by Getty oil Company and plugged and abandoned in 1968. The agreement provided for Mr. Ross to reenter the well and, if reentry, cleonout to bottom, and tie-back 7 5/8-inch casing were successful, the well would be acquired by DOE/Eaton for completion and test. The reentry attempt was not successful and the acquisition was aborted.

Mr. Ross has now acquired the Kraft No. 1 well in the same area and structure, and a similar agreement has been executed. The Kraft well was drilled by Coastal States Petroleum Corporation and plugged and abandoned as nonproductive of oil or gas in commercial quantities. Data from available logs indicate that the Frio-Anderson Sand at a depth of 
(Italics denote changes since March 31, 1980.)

12,750 to 12,860 feet contains water at reservoir pressure of 10,986

psi, temperature of $290^{\circ} \mathrm{F}$, and estimated salinity of $14,000 \mathrm{ppm}$. As of this time, Mr. Ross has obtained a rig for the attempted reentry. 
(Italics denote changes since March 31, 1980.)

5.5 TECHNOLOGY TRANSFER

5.5.1 GENERAL

It. is expected that the data from research described in the preceding sections will stimulate industry interest and result in participation by the private sector in the development of this resource. The DOE policy, from the very beginning, has been to involve the industry and the public in every stage of the research effort. There are two ways this is accomplished, namely through $\mathrm{DOE} /$ Industry forum meetings and through large-scale symposia.

\subsubsection{FORUM MEETINGS}

These meetings are designed to bring together people doing research on geopressured aquifers and industrial participants who are interested in this resource development. Meetings are divided along the lines of interest in the following working subgroups:

- $\quad$ site selection

- drilling and testing

- environmental/lab research/legal

- technology overview

Meetings are held fairly regularly (one- to three-month intervals), at which results of ongoing research are presented, usually by the principal investigators so that information can be exchanged on a firsthand basis. Active participation is continually sought from industry, government entities, and the public.

The first meeting was held in September 1977, and to date, numerous such meetings have been held. Two meetings were held during CY 1980.

\subsubsection{GE OPRESSURED--GEOTHERMAL. SYMPOSIA}

Four symposia have been held, with the last one being in Austin, Texas, in October 1979. The fifth symposium is planned after the results from the design wells and some additional wells of opportunity become available. 
(Italics denote changes since March 31, 1980.)

Results from ongoing or completed projects are presented formally at these symposia. The meetings are open to all interested parties and excellent participation has been obtained in the past. Proceedings are published after each symposium. The fifth geopressured conference is scheduled to be held at LSU in Baton Rouge, Louisiana, in October 1981. 